tesi doctoral

\title{
Metodologia de recerca per a la definició del repte de disseny i les seves premisses basada en l'anàlisi ergonòmica i les eines del disseny
}

presentada per

Mireia Puig-Poch

dirigida per

Dra. Julia Galán Serrano

Dr. Francisco Felip Miralles

Octubre 2020

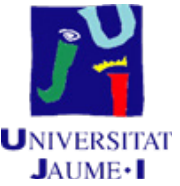





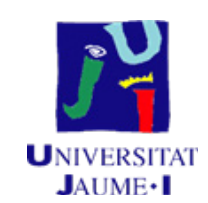

Programa de Doctorat

en Tecnologies Industrials i Materials

Programa de Doctorado

en Tecnologías Industriales y Materiales

Escola de Doctorat de la Universitat Jaume I

Escuela de Doctorado de la Universitat Jaume I

\section{Metodologia de recerca per a la definició del repte de disseny i les seves premisses basada en l'anàlisi ergonòmica i les eines del disseny}

\footnotetext{
Memòria presentada per Mireia Puig-Poch per a optar al grau de doctora per la Universitat Jaume I

Memoria presentada por Mireia Puig-Poch para optar al grado de doctora por la Universitat Jaume I
}

Doctoranda:

Mireia Puig-Poch

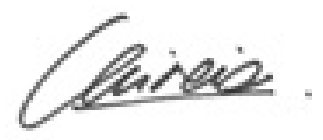

Directora:

Dra. Julia Galán Serrano

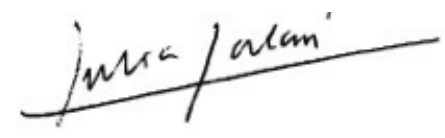

Director:

Dr. Francisco Felip Miralles

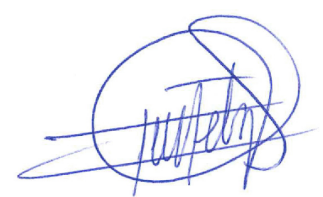





\section{Resum}

El disseny de producte configura els artefactes del dia a dia de les persones intentant respondre a les necessitats, desitjos i problemàtiques d'aquestes persones. Aquesta és una tasca enorme i amb una gran responsabilitat ja que per davant de tot ha de prevaldre, precisament, el benestar de la persona. La varietat de resultats possibles en un procés de disseny és immensa i, per tant, més enllà d'aquests resultats que es concreten en objectes, el disseny comparteix un mètode de treball que atorga als dissenyadors certes habilitats que els permeten trobar solucions per cada un dels reptes que apareixen al llarg del recorregut projectual.

La metodologia del projecte no és fixa ni estàtica, sinó que s'adapta a les diverses circumstàncies, envergadures, tipologies i enfocaments que pugui tenir el projecte. Tot i així, hi ha certes característiques que es mantenen en cada un dels processos projectuals i que es descriuen en les diverses propostes metodològiques, habitualment, a través d'unes fases que recorre el dissenyador, des de la idea, a la configuració i desenvolupament de l'objecte. Tanmateix, en les últimes dues dècades s'ha posat especial èmfasi en una etapa prèvia al procés de disseny en sí mateix. Es tracta d'una etapa que pretén formular bones preguntes per poder trobar bones respostes i que es basa en l'observació de la quotidianitat i l'empatia en una àmplia fase de recerca que en moltes ocasions inclou la participació de l'usuari com a membre de l'equip. Una de les principals metodologies que aposta per aquesta aproximació prèvia al context real de les persones i que busca reptes rics i conceptualment adequats és el Design Thinking, i les seves metodologies afins, que procuren posar a la persona com a centre de la reflexió projectual, que aposten per un llenguatge proper i visual, que pretenen innovació, creativitat, i pensament lateral, i que treballen a través de fases iteratives amb el prototipatge per assegurar un producte final ajustat a les necessitats de les persones. Aquest tipus de processos projectuals utilitzen una sèrie d'eines i mètodes que guien al llarg del procés de disseny, ajuden a estructurar aquest procés i en faciliten la seva comunicació. És 
a dir, els esquemes visuals i els reculls d'eines creatives democratitzen una disciplina que mai es cansa d'explicar-se a sí mateixa.

Resulta especialment interessant per aquest treball aquesta fase de recerca prèvia que ha de desembocar en un repte de disseny que vulgui millorar en algun aspecte la vida de les persones. Un dels principals objectius d'aquest treball és contribuir que aquesta recerca inicial del projecte de disseny es desenvolupi de manera eficaç i satisfactòria; i per aconseguir-ho, es pretén aportar una estructura metodològica per a la recerca i anàlisi en la fase inicial del projecte de disseny.

Conceptualment, els pilars que sustenten aquesta fase de recerca i que han de fer possible la bona relació entre la persona, l'entorn i l'artefacte són bàsicament tres. Per una banda, el convenciment que cal entendre a la persona i com aquesta es relaciona amb el món que l'envolta per poder formular bones preguntes, i que, per tant, és indispensable enfocar la recerca a partir de l'experiència d'usuari i la usabilitat, ja que precisament es preocupen de la bona relació entre la persona, l'artefacte i l'entorn. Per una altra banda, la capacitat d'anàlisi que té l'ergonomia en una visió de la realitat holística i sistèmica que permet observar la realitat des d'una perspectiva humanista i científica en pro al benestar de la persona. Aquí s'entén l'ergonomia com una disciplina prospectiva capaç de plantejar reptes de futur, de la mateixa manera que el disseny, i es recull el sistema persona/màquina com a eina vàlida per a estructurar una recerca exhaustiva. I finalment, la capacitat del disseny de conceptualitzar el projecte, les seves fases i les seves eines, així com d'estructurar processos creatius complexes i comunicar-ho de manera eficaç i comprensible.

Tots aquests ingredients es mesclen per a desenvolupar una metodologia de recerca enfocada a la definició de reptes de disseny fruit de l'observació i l'anàlisi de la quotidianitat que es basa en l'anàlisi ergonòmica i que fa ús de les eines i mètodes del disseny, així com de la seva base metodològica en relació al projecte, que en aquest cas, es converteix en una fase de recerca. És a dir, que la fase de recerca pròpia de tot projecte de disseny, en aquest treball, es converteix en el projecte en sí.

La proposta per a una metodologia de recerca ofereix una estructura de cinc fases seqüencials (organitzar, buscar, analitzar, definir i comunicar) que avancen sobre un esquema que 
distribueix la quotidianitat en cinc àmbits (persona, acció, artefacte, entorn i finalitat), de manera que la metodologia es converteix en un quadre de doble entrada. L'esquema convida a reflexionar sobre cada uns dels àmbits a cada fase, per tant, ja des del principi quan s'organitza la recerca es té en compte la realitat de forma global. Es recull informació i s'analitza sobre cada un dels àmbits, i es defineixen reptes de disseny i premisses projectuals també sobre l'estructura d'aquests mateixos cinc àmbits. Finalment, un brief de disseny és l'eina que es considera adequada per a comunicar el resultat de la recerca a través d'un repte fruit de la reflexió i unes premisses de disseny per a cada un dels àmbits. Tot i tenir un plantejament seqüencial, la proposta permet processos iteratius, així com la repetició d'alguna de les fases, sense que això afecti el seu desenvolupament. Per acompanyar aquest procés, la metodologia ofereix algunes eines que es consideren adequades per a cada una de les fases, per exemple, l'entrevista, l'observació etnogràfica o el mapa d'accions de l'usuari, que contribueixen en fer més àgil i comprensible la proposta.

La metodologia que es presenta, doncs, no pretén acompanyar el projecte fins al final, sinó acompanyar la recerca inicial per a la detecció de reptes de disseny que millorin la vida de les persones.

Per tal de testejar-la i perfeccionar-la, la metodologia s'ha aplicat en l'àmbit docent en diverses assignatures de caràcter projectual, a través d'un cas pràctic amb el qual els estudiants, assumint el rol de dissenyadors, havien de detectar necessitats de la realitat que els envolta amb el propòsit de plantejar un repte de disseny. Gràcies a aquesta aplicació, s'ha pogut reformular l'estructura fins a definir les cinc fases que es comenten més amunt aconseguint que l'aparent estructura rígida de fases i àmbits, sigui en realitat adaptable a les diverses necessitats de recerca del projecte de disseny, així com a les necessitats prospectives del projecte ergonòmic.

En resum, la proposta per a una metodologia de recerca que es presenta en aquest treball recull la visió de l'ergonomia i la seva capacitat d'anàlisi sistèmica, així com la capacitat del disseny d'organitzar el projecte i comunicar-lo, és a dir, les virtuts d'ambdues disciplines, per a l'anàlisi de la relació de la persona amb l'entorn i els artefactes que l'envolten. 
Gràcies a aquesta anàlisi, es pretén col·laborar en la definició d'un tipus de repte de disseny centrat en les persones que col·labori en el benestar comú i es pretén que el dissenyador, abans de posar-se a aportar solucions, es plantegi de forma exhaustiva i raonada quins són els problemes.

\section{Abstract}

Product design develops the artifacts used by people on a daily basis in an attempt to respond to their needs, desires and problems. This involves a lot of work with plenty of responsibility because people's well-being must prevail over everything else. The variety of the possible outcomes that can be obtained with a design process is vast. Therefore, beyond the outcomes that become a specific object, design follows a working method that confers designers certain skills to allow them to find solutions for every single challenge that can emerge throughout the design process.

The project methodology is neither fixed nor static, and adjusts to the project's possible circumstances, sizes, types and approaches. In any case, some common characteristics are described in most methodological proposals that all designers go through in any design process, such as the product idea, configuration and development. However in the last two decades, a preliminary stage to the design process has become especially relevant. It is based on empathically observing everyday life in the research phase in order to be able to raise good questions to find the right answers. In many cases, it includes the end user's participation as a team member. Design Thinking, as well as other related methodologies, are the main ones that opt for this preliminary approach to the real context, and to search for rich and conceptual appropriate challenges. They place the person at the centre of the project reflection and pursue innovation, creativity and lateral thinking. With close visual language, they work through iterative phases with prototyping to ensure a final product that adjusts to people's needs. Such a project process uses different tools and methods during 
the design process to structure it and make its communication easier. In other words, visual diagrams and creative tools democratise a discipline that never tires of explaining itself over and over again.

The preliminary research phase in this $\mathrm{PhD}$ thesis is especially interesting because it will become a design challenge to improve some aspects of people's lives. One of the main goals is to help to efficiently and satisfactorily develop this initial project design phase and, to do so, the intention is to provide a methodological structure for research and analyses in the preliminary design project phase.

Conceptually, there are basically three pillars that support the research phase and enable a good relationship to link the person, the environment and the artifact:

The first one is the idea that it is important to understand the way that a person interacts with the world around him/her in order to ask the right questions. Therefore, it is essential to start research from user experience and usability as both are concerned about the good relationship among the individual, the environment and the artifact.

Secondly, the analytical capacity of ergonomics, with a holistic and systemic vision of reality, allows us to observe reality from the humanistic and scientific perspectives in order to take care of someone's well-being. So ergonomics is understood as a prospective discipline capable of posing future challenges in the same way as design does, and it uses the human-machine system as a valid tool to structure exhaustive research.

Finally, there is design availability that conceptualises the project, its phases and tools, and organises complex creative processes and communicates them effectively and understandably. All these characteristics help to put together and develop a research process that focuses on finding design challenges as a result of analysing everyday life from an ergonomic viewpoint by using, on the one hand, the tools and methods that design proposes and, on the other hand, its methodological approach in a relation with the project. Hence this methodological approach becomes a research phase. In other words, the research process of any design project in this $\mathrm{PhD}$ thesis becomes the project itself. 
This research methodology proposal is arranged as five sequential phases (organise, search for, analyse, define, communicate), combined with five areas of everyday life (person, action, artifact, environment, finality). In this way, the methodology evolves to a double entry table that invites to reflect on every single area in each phase. Therefore, reality is globally considered when the research project is organised. Information is collected and analysed in each area, and the resulting design challenges and project premises are also defined according to these five areas. Lastly, a design brief is written. This is the document used to properly inform about the research outcomes, and is based on the reflection and the design premises in every single area. Although this proposal takes a sequential approach, it permits both iterative processes and the repetition of some phases without affecting its development. In order to support the process, this methodology offers some tools for each phase; e.g., interview, ethnographic observation or user journey mapping, which help to make the proposal easier and understandable.

The presented methodology does not intend to form part of the project until the end, but in its initial phase, to detect design challenges that improve people's lives.

To date, this proposal has been presented as a research exercise in the teaching sphere in some subjects with a project nature. Thanks to this exercise, it has been possible to define the five above-described phases, which take the apparent rigid structure of phases and areas that are adaptable to not only different design project needs, but also to the prospective ergonomic project needs.

Briefly, the proposal for an analysis methodology presented in this $\mathrm{PhD}$ thesis includes both the vision of ergonomics and its capacity for systematic analyses, and the design capacity to organise and communicate the project. This means that it contains the virtues of both disciplines to analyse the relationship between the person with the environment and the artifacts around it. This analysis intends to work on the definition of a design challenge that focuses on the person and his/her common well-being. Its intention is for the designer to consider existing problems in an exhaustive and reasoned way before providing solutions. 


\section{Resumen}

El diseño de producto configura los artefactos del día a día de las personas intentando responder a las necesidades, deseos y problemáticas de estas personas. Ésta es una tarea enorme y de gran responsabilidad ya que por encima de todo debe prevalecer, precisamente, el bienestar de la persona. La variedad de resultados posibles en un proceso de diseño es inmensa y, por ello, el diseño comparte un método de trabajo que otorga a los diseñadores ciertas habilidades que les permiten encontrar soluciones para cada uno de los retos que van apareciendo a lo largo del recorrido proyectual.

La metodología del proyecto no es fija ni estática, sino que se adapta a las distintas circunstancias, envergaduras, tipologías y enfoques que pueda tener el proyecto. Aun así, existen ciertas características que se mantienen en cada uno de los procesos proyectuales y que se describen en las distintas propuestas metodológicas, habitualmente, a través de unas fases que recorre el diseñador, desde la idea a la configuración y desarrollo del objeto. Sin embargo, en las dos últimas décadas se hace especial énfasis en una etapa previa al proceso de diseño en sí. Se trata de una etapa que pretende formular buenas preguntas para encontrar buenas respuestas, y que se basa en la observación de la cotidianidad y la empatía en una amplia fase de investigación que en muchas ocasiones incluye la participación del usuario como miembro del equipo. Una de las principales metodologías que apuesta por esta aproximación previa al contexto real y que busca retos ricos y conceptualmente adecuados es el Design Thinking, y sus metodologías afines, que procuran colocar a la persona en el centro de la reflexión proyectual, que apuestan por un lenguaje cercano y visual, que pretenden innovación, creatividad, y pensamiento lateral, y que trabajan a través de fases iterativas con el prototipaje para asegurar un producto final ajustado a las necesidades de las personas. Este tipo de procesos proyectuales utilizan una serie de herramientas y métodos que guían a lo largo del proceso de diseño, ayudan a estructurar este proceso y facilitan su comunicación. Es decir, los esquemas visuales y el conjunto de herramientas creativas democratizan una disciplina que nunca se cansa de explicarse a sí misma. 
Resulta especialmente interesante para este trabajo esta fase de investigación previa que debe desembocar en un reto de diseño que quiera mejorar en algún aspecto la vida de las personas. Uno de los principales objetivos de este trabajo es contribuir en un desarrollo eficaz y satisfactorio de esta investigación inicial del proyecto de diseño; y para conseguirlo, se pretende aportar una estructura metodológica para la investigación y análisis en la fase inicial del proyecto de diseño.

Conceptualmente, los pilares que sustentan esta fase de investigación y que deben hacer posible una buena relación entre la persona, el entorno y el artefacto, son básicamente tres. Por un lado, el convencimiento que hay que comprender a la persona y cómo ésta se relaciona con el mundo que le rodea para poder formular buenas preguntas, y que, por lo tanto, es imprescindible enfocar la investigación a partir de la experiencia de usuario y la usabilidad, ya que, precisamente, son dos conceptos que se preocupan por la buena relación entre la persona, el artefacto y el entorno. Otro pilar es la capacidad de análisis que tiene la ergonomía en su visión de la realidad holística y sistémica que permite observar la realidad desde una perspectiva humanista y científica en pro del bienestar de la persona. Aquí se entiende la ergonomía como una disciplina prospectiva capaz de plantear retos de futuro, de la misma forma que lo hace el diseño, y se recoge el sistema persona/máquina como una herramienta válida para estructurar una investigación exhaustiva. Y finalmente, el tercer pilar es la capacidad del diseño por conceptualizar el proyecto, sus fases y sus herramientas, así como de estructurar procesos creativos complejos y comunicarlos de forma eficaz y comprensible.

Todos estos ingredientes se mezclan para desarrollar una metodología de investigación enfocada a la definición de retos de diseño fruto de la observación y el análisis de la cotidianidad que se basa en el análisis ergonómico y que utiliza las herramientas y métodos del diseño, así como su base metodológica en relación con el proyecto, que, en este caso, se convierte en una fase de investigación. Es decir, la fase de investigación propia de cualquier proyecto de diseño, en este trabajo, se convierte en el proyecto en sí.

La propuesta de una metodología de investigación ofrece una estructura de cinco fases secuenciales (organizar, buscar, analizar, definir y comunicar) que avanzan a lo largo de un esquema 
quedistribuyelacotidianidaden cincoámbitos(persona, acción, artefacto, entornoyfinalidad), de forma que la metodología se convierte en un cuadro de doble entrada. El esquema invita a reflexionar sobre cada uno de los ámbitos en cada fase, por lo tanto, ya desde un principio cuando se está organizando la investigación, se tiene en cuenta la realidad de forma global. Se recoge información y se analiza en relación con cada uno de los ámbitos, y se definen retos de diseño y premisas proyectuales también sobre la estructura de estos mismos cinco ámbitos. Finalmente, un brief de diseño es la herramienta que se considera adecuada para comunicar el resultado de la investigación a través de un reto fruto de la reflexión, y unas premisas de diseño para cada uno de los ámbitos. Cabe decir que, aunque el planteamiento es secuencial, la propuesta permite procesos iterativos, así como la reformulación de alguna de sus fases, sin que este hecho afecte su desarrollo. Para acompañar este proceso, la metodología ofrece algunas herramientas que se consideran adecuadas para cada una de las fases, por ejemplo, la entrevista, la observación etnográfica o el mapa de acción de usuario, que contribuyen en hacer más ágil y comprensible la propuesta.

La metodología que se presenta no pretende acompañar el proyecto hasta el final, sino acompañar la investigación inicial para la detección de retos de diseño que mejoren la vida de las personas.

Con el fin de testearla y perfeccionarla, la metodología se ha aplicado en el ámbito docente en distintas asignatu $\neg$ ras de carácter proyectual, a través de un caso práctico en el que los estudiantes, asumiendo el rol de diseñadores, tenían que detectar necesidades en la realidad que les rodea con el fin de plantear un reto de diseño. Gracias a esta aplicación, ha sido posible reformular la estructura hasta la definición de las cinco fases que se comentan más arriba consiguiendo que la aparente estructura rígida de fases y ámbitos sea en realidad una estructura adaptable a las distintas necesidades de investigación del proyecto de diseño, así como a las necesidades prospectivas del proyecto ergonómico.

En resumen, la propuesta para una metodología de investigación que se presenta en este trabajo recoge la visión de la ergonomía y su capacidad de análisis sistémico, así como la capacidad del desiño de organizar el proyecto y comunicarlo; es decir, este trabajo recoge 
las virtudes de ambas disciplinas para el análisis de la relación de la persona con el entorno y los artefactos que le rodean. Gracias a este análisis, se pretende colaborar en la definición de un tipo de reto de diseño centrado en las personas que colabore en el bienestar común, y se pretende que el diseñador, antes de empezar a aportar soluciones, se plantee de forma exhaustiva y razonada cuáles son los problemas existentes. 


\section{CAPÍTOL I · INTRODUCCIÓ}

1.1 Motivació de la investigació 20

$\begin{array}{lll}1.2 & \text { Plantejament de la investigació } & 21\end{array}$

1.3 Definició del problema 22

1.4 Objectius de la investigació 26

1.4.1 Objectiu principal 26

1.4.2 Objectius de l'aproximació als principals conceptes 26

1.4.3 Objectius per a la metodologia de recerca 26

1.5 Tasques per a la investigació i estructura de la tesi 27

1.6 Delimitació i abast de la investigació 30

1.7 Hipòtesi 31

$\begin{array}{lll}1.8 & \text { Metodologia } & 31\end{array}$

\section{CAPÍTOL II · REVISIÓ GENERAL DE LA RECERCA EN} EL PROJECTE DE DISSENY

2.1 Introducció 36

2.2 Delimitació de termes i metodologies. Usabilitat i experiència d'usuari

2.2.1 Observar el disseny a partir de la Usabilitat i l'Experiència d'Usuari 39

2.2.2 Enfocament des de l'Ergonomia 41

2.2.2.1 Sistema Persona/Màquina 43

2.2.2.2 Usabilitat i Experiència d'Usuari 51

2.2.2.3 Ergonomia Prospectiva 57

2.2.2.4 Ergonomia Participativa 62

2.2.2.5 Ergonomia Cognitiva 66

2.2.2.6 Estudis de cas $\quad 74$

2.2.2.7 Conclusions $\quad 78$

2.2.3 Enfocament des del Disseny UI-UX. Disseny d'Interficies i Experiència d'Usuari

2.2.3.1 Heurístics de Jakob Nielsen. Usabilitat $i$

Experiènci d'Usuari 
2.2.4 Enfocament des del Disseny de Producte

2.2.4.1 Experiència d'Usuari. Metodologia sorgida a la Universitat Tècnica TUDelft 89

2.2.4.2 La visió d'Elizabeth Sanders 92

2.2.4.3 Estudis de cas 94

2.2.5 Enfocament des del Disseny de serveis 95

2.2.5.1 Service Design Thinking 96

2.2.5.2 Jams de Creativitat 101

2.2.5.3 Estudis de cas 103

2.2.6 Conclusions 105

$\begin{array}{lll}2.3 & \text { Mètodes i eines } & 107\end{array}$

2.3.1 Design Thinking 108

2.3.2 Doble Diamant 116

2.3.3 Manual Thinking 119

2.3.4 El Disseny Generatiu 121

2.3.5 Mètode Kaospilot 126

2.3.6 Eines 128

2.3.7 Conclusions 137

2.4 La base analítica del disseny 139

2.4.1 El procés projectual 141

2.4.2 Les fases d'anàlisi 152

2.4.2.1 Recol·lecció de dades pel projecte de disseny $\quad 158$

2.4.2.2 Antropologia, etnografia i enfocaments afins aplicats al disseny 164

2.4.2.3 Conclusions 177

2.4.3 Les fases argumentatives 178

2.4.3.1 Extracció de conclusions. Els insights 184

2.4.3.2 El repte de disseny 190

2.4.4 Elaboració d'un brief de disseny 198

2.4.5 Conclusions 203 


\section{CAPÍTOL III · PROPOSTA PER A UNA METODOLO-} GIA DE RECERCA

$\begin{array}{lll}3.1 & \text { Introducció } & 206\end{array}$

3.2 Àmbits d'aplicació i idoneïtat $\quad 214$

$\begin{array}{lll}3.3 & \text { Objectius } & 221\end{array}$

3.4 Esquelet de la proposta $\quad 223$

3.5 Les dimensions de l'artefacte 231

3.6 Fases de divergència 251

3.6.1 Fase Organitzar 251

3.6.2 Fase Buscar 258

3.7 Pont entre divergència i convergència: fase Analitzar 270

$3.8 \quad$ Fases de convergència 279

3.8.1 Fase Definir 279

3.8.2 Fase Comunicar 285

$\begin{array}{lll}3.9 & \text { Esquema general de la proposta } & 291\end{array}$

CAPÍTOL IV · APLICACIÓ DE LA METODOLOGIA (CAS PRÀCTIC) 295

4.1 Planificació i temporització 296

$\begin{array}{lll}\text { 4.1.1 Objectius } & 298\end{array}$

4.1.2 Definició del projecte 300

4.1.3 Avaluació de la metodologia 304

$\begin{array}{lll}4.2 & \text { Treball de camp } & 305\end{array}$

4.2.1 Sessió 1: Observació i mapa d'accions d'usuari 308

4.2.2 Sessió 2: Hipòtesi i entrevistes 313

4.2.3 Sessió 3: Dimensions $i$ insights 317

4.2.4 Sessió 4: Repte de disseny i projecció de futur 318

4.2.5 Sessió 5 (confinada): Premisses de disseny prioritzades 322

4.2.6 Comunicació 322 
CAPÍTOL V $\cdot$ RESULTATS

5.1 Introducció

5.2 Desenvolupament de l'exercici i reptes 327

5.3 Anàlisi de l'aplicabilitat de la metodologia 333

5.3.1 La caracterització del repte de disseny 333

5.3.2 Les enquestes 337

5.3.3 Els briefs resultants $\quad 340$

$\begin{array}{lll}5.4 & \text { Reflexions finals } & 349\end{array}$

CAPÍTOL VI · CONCLUSIONS

6.1 Punts crítics i encerts $\quad 354$

6.2 Limitacions de la metodologia 358

$\begin{array}{lll}6.3 & \text { Futures línies de treball } & 361\end{array}$

BIBLIOGRAFIA $\quad 363$

ÍNDEXS DE TAULES I FGURES 371

Taules $\quad 372$

$\begin{array}{ll}\text { Figures } & 372\end{array}$ 


\section{CAPÍTOL I}

\section{INTRODUCCIÓ}




\subsection{Motivació de la investigació}

Des de la tasca docent en ergonomia aplicada al disseny de producte es planteja una problemàtica en l'enfocament de la disciplina i com aquesta dona suport al projecte de disseny, ja que tradicionalment es planteja com un punt més a tenir en compte en el desenvolupament del projecte. L'enfocament tradicional de l'ergonomia està estretament lligat al món laboral, seguretat i higiene en el treball, amb un caràcter preventiu i correctiu. Però des del projecte de disseny resulta molt més interessant una altra part de l'ergonomia, relacionada amb la seva capacitat d'observació i anàlisi, amb un caràcter prospectiu.

Per altra banda, existeix un interès propi relacionat amb la fase inicial del projecte de disseny: la recerca, la detecció de necessitats, el plantejament d'un repte de disseny, que és recolzat per l'aparició definitiva del Design Thinking en el panorama creatiu i metodologies afins com a metodologies pròpies del disseny. Tot i cert escepticisme inicial en referència a les virtuts d'aquesta metodologia, sí que se li reconeixen certes aportacions que faciliten el camí a una nova manera de fer més estructurada i recolzada per eines dinàmiques i aparentment senzilles. Una estructura que es pot transmetre de forma eficaç a gent poc avesada en processos projectuals.

A poc a poc, s'observa la proximitat entre les dues disciplines, ergonomia i disseny de producte, que a la vegada poden semblar tant allunyades, sobretot perquè tant l'una com l'altra es preocupen bàsicament del mateix: de la configuració dels objectes i entorns que envolten la persona. Així, la motivació per a la realització d'aquesta tesi doctoral té l'origen en dues mirades paral·leles d'una mateixa problemàtica: la relació de la persona amb el món que l'envolta. I l'observació de com les dues disciplines treballen en paral·lel, quan podrien nodrir-se una de l'altra.

A més a més, s'entén que aquesta investigació —en relació a una recerca nodrida per principis ergonòmics i de disseny- pot millorar la proposta docent tant d'assignatures d'ergonomia, com d'assignatures de projectes, ja que pot ajudar a explicar una fase bàsica 
per tot projecte: la recerca. Així es planteja la possibilitat que la pròpia dinàmica del projecte es beneficiï de la introducció d'una metodologia enfocada clarament a la prospecció i al treball en comú amb els diversos actors que participen de la temàtica que desencadena un projecte; amb el desig, que la metodologia surti de l'aula i es desenvolupi també en l'àmbit professional.

Existeix, a més a més, un interès general pels processos creatius col·laboratius, així com pel treball multidisciplinari i transversal, entenent que és un enfocament enriquidor per al projecte, ja que permet observar els fenòmens des de diverses perspectives. Un tipus d'enfocament necessari per la complexitat del món actual i per la intenció de col·locar els desitjos i necessitats de la persona en primer terme.

Resumint, aquesta tesi està motivada per quatre interessos genèrics:

1. Interès per l'estructuració d'anàlisi de l'ergonomia i la seva capacitat prospectiva

2. Interès per la fase inicial del projecte de disseny: recerca, detecció de necessitats, i definició d'un repte de disseny

3. Interès per metodologies de treball multidisciplinari i col·laboratiu

4. Interès per a la millora docent de la metodologia del projecte i de l'ergonomia aplicada al disseny

\subsection{Plantejament de la investigació}

Aquest treball es planteja des del concepte que comparteixen disseny i ergonomia com a element propi de recerca de la disciplina: la usabilitat i l'experiència d'usuari. Es realitza una aproximació sobre com cada disciplina enfoca la relació de la persona amb l'artefacte i s'analitzen els models, mètodes i metodologies més rellevants i més enfocades a prioritzar l'experiència d'usuari. Es posa especial èmfasi en models actuals que s'aparten de la funcionalitat 
clàssica del disseny de producte $\mathrm{i}$ aposten per la persona com a eix vertebrador del projecte. A més a més, es fa una aproximació a la capacitat analítica i de recerca d'ambdues disciplines.

És a dir, en una primera fase de la tesi, es planteja un reconeixement genèric d'una sèrie d'elements que giren al voltant de la interacció entre la persona i el producte:

1. L'ergonomia proposa el sistema persona/màquina per a configurar la interacció entre la persona i el producte

2. L'ergonomia té una visió pròpia de la usabilitat i l'experiència d'usuari

3. L'ergonomia té capacitat prospectiva i participativa

4. El disseny UI-UX no té el monopoli sobre el concepte experiència d'usuari

5. El disseny de producte es pot enfocar des de punts de vista alternatius a la funcionalitat

6. El disseny té una gran capacitat analítica

7. El disseny disposa d'eines i tècniques per a desenvolupar la recerca i l'anàlisi

8. L'ergonomia té una gran capacitat analítica

9. L'ergonomia disposa d'eines i tècniques que li permeten valorar l'anàlisi

Tal i com es pot veure a la figura 1, es planteja un recorregut al llarg d'aquestes temàtiques per concloure en una metodologia de recerca comuna, que tingui com a prioritat a la persona i l'experiència d'usuari.

\subsection{Definició del problema}

Habitualment l'ergonomia apareix dins del projecte de disseny a través d'un apartat que es titula antropometria, relegant aquesta disciplina a una qüestió de dimensions. En canvi, la disciplina té molt més a oferir al projecte de disseny. Per la seva banda, sovint el disseny focalitza els seus esforços analítics sobre elements propis de l'àmbit del disseny, és a dir, el disseny de producte tendeix a l'enginyeria o el disseny d'interiors tendeix a l'arquitectura. 


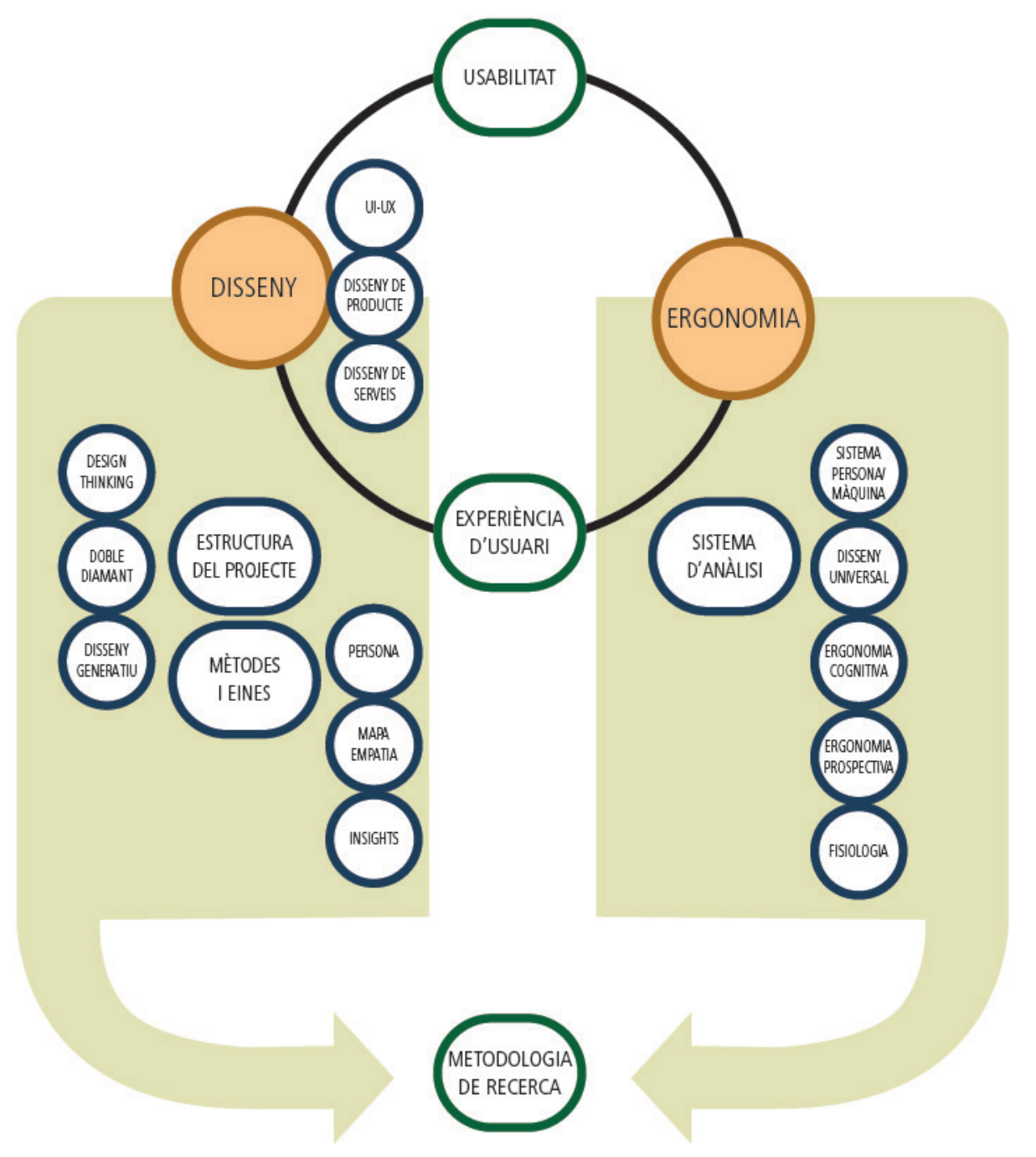

Fig. 1 Plantejament inicial de la recerca

En aquest sentit, és interessant com l'ergonomia pot aportar una visió global centrada en la relació entre l'usuari i l'artefacte, més enllà de qüestions més tècniques.

Per la seva banda, l'ergonomia també és una disciplina tècnica i especialment enfocada a la revisió de la seguretat laboral a través de protocols i normatives. Tot i els seus esforços per obrir-se cap a processos més participatius, encara està lluny del disseny. Per tant, el disseny pot aportar el seu coneixement de tècniques i eines creatives per ajudar a l'ergonomia en el seu procés cap a la participació prospectiva. 
Així doncs, el principal problema que es planteja és com es poden aproximar dues disciplines que comparteixen gran part de la seva preocupació, però que poden aparèixer tant distants, i com poden millorar-se una a l'altra.

Es pretén aprofitar allò que tenen de bo una i altra disciplina per millorar-ho i proposar una estructura de recerca que uneixi les estratègies metodològiques de l'ergonomia i el disseny; es tracta d'establir una estratègia comuna d'anàlisi per a qualsevol tipus de projecte. Per una banda, l'ergonomia ofereix un mètode d'anàlisi molt ampli i sobretot aborda els problemes des de molts punts de vista diferents. Pel disseny, aquesta visió àmplia és un avantatge que pot ser molt profitós. Tot i així, és comú enfocar l'ergonomia en l'àmbit laboral per a la millora de la higiene i la salut del treballador, on fa una tasca inqüestionable normativitzant aspectes laborals per a la protecció del treballador. Però en aquest sentit, l'ergonomia s'allunya de les necessitats ergonòmiques del disseny, és a dir, deixa de ser tan útil com podria al dissenyador, ja que les normatives i protocols que proposa tenen una intenció laboral, preventiva i correctiva. El dissenyador necessita entendre els principis ergonòmics per poder-los aplicar en un producte que encaixi en un moment futur. És a dir, necessita entendre l'antropometria i les seves taules organitzades per percentils per afinar en la presa de decisions dimensionals. En el desenvolupament del projecte, el dissenyador cal que es qüestioni les dimensions proposades normativament per corroborar-les a través de l'anàlisi buscant la màxima resposta a nivell d'usabilitat. I, efectivament, també l'ergonomia s'esforça perquè a través de la seva anàlisi, els processos que han sigut revisats gaudeixin de bona usabilitat. Per tant, s'entén com a problemàtic que dues disciplines, des d'enfocament diferents, pretenguin el mateix. Tot i que encara és més problemàtic observar, que si una no fa la feina correctament, la segona hi serà per corregir-ho. Per tant, sembla lògic pensar que és molt més interessant tenir en compte una sèrie de qüestions des del principi del projecte de disseny, quan encara no s'ha iniciat la configuració de l'artefacte.

Així doncs, instintivament s'observa que fa falta apropar l'ergonomia a l'àmbit del disseny, a la vegada que el disseny es pot beneficiar de l'abast de l'ergonomia i de la seva 
anàlisi. Seria beneficiós pels dissenyadors introduir eines i mètodes basats en l'ergonomia però fent ús de les tècniques del disseny, molt més avançades en l'àmbit de la cocreació i la interacció i participació de l'usuari durant el mateix procés de disseny. Unes tècniques relativament noves — pròpies del segle XXI- que provenen, entre d'altres, del Design Thinking i van evolucionant ràpidament, sobretot a través d'àmbits del disseny més nous com el disseny de serveis o el disseny d'interacció (UI-UX).

Així doncs, es tenen en compte dues disciplines que treballen paral·lelament la relació de la persona amb el món artificial que crea i configura constantment aquesta mateixa persona. Una relació que s'anomena usabilitat, i que valora, de forma genèrica, la facilitat d'ús dels productes.

El terme usabilitat el treballa cadascú des del seu àmbit, amb característiques pròpies, i d'un temps ençà, habitualment lligat a un altre concepte l'experiència d'usuari, que es podria definir de forma genèrica com la percepció de la usabilitat en un recorregut d'ús més ampli, abans, durant i després de fer servir el producte.

La usabilitat i l'experiència d'usuari es consideren conceptes clau per a la definició de reptes de disseny que es preocupin principalment de la relació de la persona amb l'entorn i els productes que el configuren. Per això, es considera necessari, entendre com s'enfoquen aquests dos conceptes des de les dues disciplines, i així poder unificar una visió que desemboqui en una anàlisi profunda de la relació de la persona amb el món, que permeti plantejar reptes de disseny que es concretin en propostes de disseny que solucionin les problemàtiques, els desitjos i les necessitats d'aquesta persona.

Per altra banda, és necessari fer una aproximació a la pròpia base analítica del disseny en els sectors especialment preocupats per la comprensió de la persona, per entendre com es comporta a nivell de metodologia projectual i dibuixar en quin moment es troba actualment, ja que el disseny és una disciplina en constant reformulació. 


\subsection{Objectius de la investigació}

\subsubsection{Objectiu principal}

Configuració d'una metodologia de recerca i anàlisi aplicable a projectes de producte, espais o serveis fent ús de l'estructuració i visió general i sistèmica de l'ergonomia, a la vegada que de les tècniques i mètodes del disseny col-laboratiu.

\subsubsection{Objectius de l'aproximació als principals conceptes}

Aquesta recerca ha de proporcionar recursos i coneixements per a la posterior elaboració d'una metodologia de recerca:

- Contextualitzar la base analítica i la metodologia de recerca del disseny i l'ergonomia

- Contextualitzar com el disseny i l'ergonomia es comporten al voltant de l'usuari i les seves necessitats

- Contextualitzar els conceptes compartits entre ambdues disciplines

\subsubsection{Objectius per a la metodologia de recerca}

Aquesta metodologia ha de permetre seguir un procés guiat i participatiu per poder plantejar espais, o objectes, que siguin eficients, eficaços i que satisfacin l'usuari:

- Possibilitar el desenvolupament d'un procés guiat i participatiu de la fase de recerca del projecte de disseny i del projecte ergonòmic 
- Afavorir un procés de recerca exhaustiu, amb una visió global i sistèmica de les diverses dimensions i variables que configuren la interacció entre persona i artefacte

- Definir una metodologia de recerca que presenti les diverses visions del projecte i com es relacionen entre elles

- Definir una metodologia de recerca que guiï al dissenyador en la detecció denecessitats, problemàtiques i desitjos que es puguin convertir en reptes de disseny $i$ afavorir que aquests reptes encaixin amb les necessitats, desitjos i problemàtiques de les persones

- Definir característiques valorables per les variables establertes

- Proposar tècniques i eines que ajudin en la recol·lecció de dades, en l'anàlisi d'aquestes dades, en l'extracció de conclusions vàlides per a la definició de necessitats, problemàtiques i desitjos, i en la proposta d'un repte de disseny vàlid i amb vocació innovadora

- Traslladar els conceptes d'usabilitat i experiència d'usuari a valors que es puguin qualificar i convertir-se en premissa projectual

- Proposar una metodologia que estructuri la recerca i es pugui traslladar de forma senzilla a qui l'ha de fer servir

- Proposar una metodologia dinàmica, comprensible i fàcil d'aplicar

\subsection{Tasques per a la investigació i estructura de la tesi}

Per dur-ho a terme, aquesta investigació es planteja a través de cinc tasques que, majoritàriament, s'esdevenen de forma paral·lela en el temps.

Tasques d'exploració · Es plantegen una sèrie de tasques d'apropament a la literatura existent per a la revisió de conceptes clau relacionats amb les metodologies de recerca de disseny i ergonomia, així com amb els conceptes d'usabilitat i experiència d'usuari, amb la intenció d'aclarir quines definicions existeixen i quines, d'entre aquestes, es consideren 
més encertades. És necessari revisar les necessitats de recerca de la fase inicial del projecte. Formen part de la revisió bibliogràfica el concepte de variables ergonòmiques aplicades al projecte, així com els principis metodològics que estructuren el projecte ergonòmic.

També formen part d'aquesta revisió bibliogràfica les tècniques de cocreació i el disseny generatiu, que dibuixen un rol al dissenyador que s'aparta del rol clàssic. En la mateixa direcció, es planteja una revisió dels nous rols de l'ergonomista en processos d'ergonomia prospectiva.

La pròpia etapa de recerca es valida a través de processos d'anàlisi pròxims al disseny i fent ús de les pròpies eines utilitzades, de manera que se'n pugui extreure conclusions útils per a la elaboració de la proposta. És a dir, que el procés avalua el propi procés.

Aquesta recerca també inclou activitats experiencials amb les quals es realitzen testos parcials d'aplicació de la metodologia i s'observa com reaccionen els estudiants davant les tasques proposades. S'observa també el seu nivell de comprensió de la proposta i quins resultats s'aconsegueixen. Aquesta etapa és dilatada en el temps, i es considera necessària per a definir les necessitats de recerca bibliogràfica, ja que cal contextualitzar la proposta. Per tant, l'aplicació nodreix la recerca, i la recerca nodreix l'aplicació.

Tasques de concreció · Fruit de les tasques d'exploració i de les seves conclusions es dona cos a una metodologia per a la recerca i l'anàlisi del projecte de disseny. S'aprofiten les virtuts metodològiques del disseny i l'ergonomia per plantejar una metodologia que guiï en la recerca.

Tasques d'avaluació · Es posa en pràctica la metodologia en un ambient controlat amb un grup d'alumnes i s'avaluen els principals aspectes de la proposta, sobretot el seu grau de comprensió, el seu acolliment i la sensació per part de l'estudiant que l'estructura d'anàlisi proposada pot contribuir en el bon desenvolupament en la definició del repte de disseny.

Tasques de revisió $\cdot$ Es revisen certs aspectes que s'han detectat conflictius durant l'apli- 
cació de la metodologia, i es millora la proposta perquè resulti més comprensible. Es dona valor als aspectes que s'han detectat positius.

Tasques de comunicació - Es trasllada el recorregut realitzat en format escrit, s'elabora material per al seguiment de la metodologia.

Aquests cinc grups de tasques es traslladen a la tesi a través de sis capítols:

Capítol I · Introducció que situa la recerca i els conceptes principals que es tenen en compte en el desenvolupament de la tesi

Capítol II · Aproximació als conceptes i temàtiques pertinents per al desenvolupament de la proposta. Avalua els conceptes que s'introduiran a la proposta

Capítol III - Introdueix la proposta de metodologia de recerca per a les fases inicials del projecte de disseny. En descriu l'estructura i com es vinculen els conceptes de l'ergonomia i el disseny per a una proposta comuna. Proposa una execució a través de fitxes de treball que ajuden en el seu desenvolupament. Aquesta proposta inclou les millores pertinents realitzades a través de les diverses avaluacions, és a dir, agrupa les tasques de concreció, avaluació i revisió.

Capítol IV · Exemplifica la posada en pràctica de la metodologia en una classe de projectes. S'expliquen les diverses tècniques utilitzades i el desenvolupament de l'exercici.

Capítol V · Explica el resultat projectual. Exemplifica les limitacions d'aplicabilitat de la metodologia, així com el grau de satisfacció dels estudiants que han participat en l'exercici.

Capítol VI - Realitza una valoració global de la metodologia, planteja punts crítics i millores, així com els seus punts forts. Realitza una reflexió general sobre la tesi i planteja possibles línies futures de desenvolupament i aplicació. 


\subsection{Delimitació i abast de la investigació}

El resultat d'aquesta investigació pretén ser una metodologia de recerca i anàlisi en les fases inicials del projecte de disseny que conclou amb l'elaboració d'un repte de disseny i unes premisses projectuals explícites que formen part del brief inicial, document que dona pas al desenvolupament del projecte.

La intenció és que la metodologia sigui utilitzada per aquelles persones que s'enfronten al disseny d'un producte o servei. Es tracta d'una proposta metodològica que hauria de permetre seguir un procés guiat i participatiu, ja que la proposta planteja una estructura adaptable a diferents necessitats.

La investigació pretén proposar una nova metodologia i aplicar-la per poder extreure conclusions de la seva funcionalitat. La metodologia està destinada a la fase d'anàlisi del projecte, en una fase prèvia al desenvolupament de la proposta, i per tant, acaba amb un brief que inicia el projecte de disseny. És a dir, tracta la part inicial que dona arguments pel plantejament d'un repte de disseny ben enfocat i que respon a necessitats, problemes i desitjos de les persones.

Aquesta investigació no pretén desenvolupar cap projecte fins al final, sinó elaborar una metodologia que permeti identificar les problemàtiques d'un espai respecte el servei que s'hi du a terme, els productes que s'hi veuen involucrats o la configuració dels entorns que l'acullen.

La metodologia es vol utilitzar inicialment en un àmbit docent per a traslladar l'ergonomia al projecte de disseny i afavorir-ne el seu tractament. També es vol traslladar en processos creatius per al desenvolupament de conceptes de disseny que desemboquin en reptes. En fases més avançades, es pretén traslladar la metodologia a àmbits professionals. 


\subsection{Hipòtesi}

La recerca al voltant de les activitats de les persones i la seva experiència en l'ús d'artefactes, entorns i serveis, pot desembocar en la revelació d'evidències que es transformin en reptes de disseny basats en les necessitats, problemàtiques i desitjos de les persones. Per estructurar aquesta recerca, ergonomia i disseny poden aportar elements propis de cada disciplina que s'uneixin per a l'elaboració d'una metodologia de recerca i anàlisi adaptable, àmplia i eficaç, amb l'objectiu de definir reptes de disseny innovadors i una sèrie de premisses projectuals que emmarquin aquest repte de forma argumentada.

\section{Preguntes d'investigació:}

- L'estructura d'anàlisi ergonòmica a través del sistema persona/màquina pot contribuir positivament en les fases de recerca del projecte de disseny?

- L'ergonomia pot beneficiar-se d'eines, tècniques i mètodes del disseny?

- És possible estructurar una metodologia de recerca amb la intenció que detecti reptes de disseny innovadors i beneficiosos per la persona?

- D'una metodologia de recerca, se'n pot valorar l'eficàcia, l'eficiència i la satisfacció?

\subsection{Metodologia}

Aquesta tesi es basa en dos grans blocs: per una banda, la revisió de literatura on es tracten els conceptes de forma teòrica, i per altra banda, la posada en pràctica d'eines i recursos, on es tracten els conceptes de forma aplicada. Aquestes dues activitats es realitzen en paral·lel per construir un mapa genèric de l'estat de la qüestió en relació a la recerca del projecte de disseny, així com l'enfocament al voltant de la usabilitat i l'experiència d'usuari. Cal tenir 
en compte, que aquests dos conceptes, no només formen part del disseny i l'ergonomia, sinó que actualment, sobretot el terme experiència forma part del dia a dia més comú.

La revisió de la literatura pretén trobar els principals actors actuals de cada àmbit, sempre, però, amb una mirada a l'origen del concepte per poder entendre'n el seu abast. Per exemple, es recorre al naixement de la usabilitat, a través de Nielsen i la seva obra Usability engineering de 1993, però es contrasta amb altres aportacions més actuals, com per exemple, des de la Universitat Tècnica de Delft a través d'autors com Hekkert i van Dijk, que l'any 2011 presenten Vision in Product Design: Handbook for Innovators.

Amb la revisió de la literatura també es busquen patrons compartits entre disciplines i es procuren delimitar els termes i conceptes de cada una, tot i així, la seva capacitat de relació és immensa i els límits, habitualment, es presenten difosos. Una altra preocupació de la revisió de literatura és poder definir la base metodològica, eines i mètodes que s'utilitzen en els diversos àmbits. En aquest sentit, es revisen visions més tradicionals com la de Jones, que presenta el 1972 el seu Design Methods, la visió de Martí Font, que presenta el 1999 Introducció a la metodologia del disseny; o de Cross que presenta el 2003 Métodos de diseño: Estrategias para el diseño de productos. També es busca l'origen del Design Thinking $\mathrm{i}$ els principis que guien aquesta metodologia des d'un àmbit empresarial amb l'obra de Brown (2009) Change by design, així com la seva evolució cap al disseny generatiu a través de Sanders i Stappers (2012) amb el Convivial Toolbox, i altres articles que presenten la seva visió de la metodologia pel disseny. També, la visió des del disseny de serveis amb Stickdorn i Schneider (2011) amb la seva obra pionera This is Service Design Thinking. Basics-Tools-Cases.

A nivell ergonòmic es realitza un escaneig genèric, començant per una obra normativista presentada pel Ministeri de Treball, amb Nogareda (5a ed. 2008), com a coordinadora, titulada Ergonomía. Passant per obres cabdals dels factors humans com Sanders i McCormick (7a ed. 1993) Human Factors in Enginnering and Design o Tillman, Fitts, Woodson, Rose-Sundholm i Tillman (3a ed. 2016) amb Human factors and Ergonomics Design Handbook. També es revisen altres visions, com per exemple, l'ergonomia pros- 
pectiva que presenten Robert i Brangier (2012) a Prospective ergonomics: origin, goal and prospects, i temàtiques més específiques com Laplace (1995) La psicologia ergonòmica, o Hollnagel (1997) amb la seva obra Cognitive ergonomics: it's all in the mind, que contribueix a dibuixar una visió més àmplia de l'abast ergonòmic.

A nivell de recerca, es localitzen obres que es preocupen específicament de la recerca en disseny, com Craouch i Pearce (2012) amb Doing Research in Design o Milton i Rodgers (2013) amb Métodos de investigación para el diseño de producto, i això s'acompanya de literatura d'altres disciplines com Monaghan i Just (2000) Social \& Cultural Antropology o Harper (2018) Best practices for ethnographic research, lessons learned in the wild.

Paral-lelament, es fa recerca de casos aplicats i es tenen converses amb persones de diversos àmbits que permeten focalitzar la recerca de literatura pertinent, per exemple, es parla amb Jose Guimerà, ergonomista, que trasllada la visió de la relativament nova ergonomia participativa, això obra la mirada cap a noves visions, i així s'arriba a Garcia (febrer 2011) Ergonomía participativa: metodologia, una ponència presentada en una jornada tècnica sobre trastorns musculoesquelètics. També es parla amb Abel de Benito, dissenyador gràfic i ex president de l'Associació de Dissenyadors Professionals ADP, que obre la mirada, sobretot, en l'elaboració del brief professional i facilita a Phillips (2005) (cómo crear) el brief de diseño perfecto. $\mathrm{O}$ amb Coral Martínez, dissenyadora especialista en gestió del disseny, que obra la porta als mètodes del Manual Thinking de Luki Huber.

L'altre gran bloc té una base aplicada, és a dir, forma part de la tasca docent de comunicació i posada en pràctica de processos de recerca, tant des de l'ergonomia com des del disseny de producte, que comença com a deixeble de Jordi Mañà i Juan Alberto Favaro. D'aquests dos ergonomistes dissenyadors, se'n recull la intenció constant d'afavorir el disseny amb les bondats de l'ergonomia, i el desig de traslladar als estudiants els conceptes ergonòmics de forma estructurada i precisa.

Des de 2013 s'imparteix l'assignatura d'Ergonomia a l'Escola Superior de Disseny, ESDi, de Sabadell, i des de 2016 l'assignatura d'Anàlisi de Projectes: Producte, impartida a la mateixa escola. També s'imparteix des del curs 19/20 la fase inicial del projecte final de 
grau de producte — és a dir, la part de recerca-, a l'escola LCI de Barcelona, així com l'assignatura de Ciència i Tecnologia II als alumnes de primer del Títol Superior Oficial en Disseny d'Interiors i del Títol Superior Oficial en Disseny de Producte, on es treballa l'ergonomia. I finalment, l'assignatura Mètodes i Processos d'Investigació Aplicats al Disseny Industrial de Productes del màster universitari en Estudis Avançats en Disseny-Barcelona que ofereixen conjuntament la Universitat Politècnica de Catalunya, UPC, i la Universitat de Barcelona, UB. Aquesta experiència, fa possible desenvolupar exercicis de classe per valorar l'aplicabilitat d'una estructura d'anàlisi eficaç i fàcil de traslladar a l'alumnat, que es pugui convertir en una proposta més genèrica i de major abast. Per a una avaluació més global, es realitza un test final, amb alumnes aliens a una estructura similar, ja que no cursen una assignatura on es puguin anar introduint conceptes a poc a poc i que, per tant, permet valorar el grau d'independència de la proposta, verificar-ne l'estructura i les eines utilitzades. Aquest exercici, es realitza a l'assignatura de Disseny per a l'Entorn i l'Hàbitat del grau en Enginyeria en Disseny Industrial i Desenvolupament de Productes de la Universitat Jaume I de Castelló de la Plana, UJI, durant els mesos de febrer i març de 2020. Un cop acabat l'exercici, troncat per l'aparició del Covid-19 i el confinament de la població, es realitza una enquesta per avaluar la satisfacció dels alumnes després d'haver utilitzat la metodologia i per contrastar la seva opinió envers, també, a altres tècniques i mètodes als quals poden estar més acostumats.

De manera que a partir de tota la informació generada al llarg dels anys, i la recerca realitzada amb més profunditat al llarg d'aquests últims tres anys, es presenta una proposta de recerca pel projecte de disseny que s'alimenta de l'ergonomia i del propi disseny i que inclou un esquelet estructural i unes eines per ajudar en el desenvolupament de la metodologia. 


\section{CAPÍTOL II}

\section{REVISIÓ GENERAL \\ DE LA RECERCA EN EL PROJECTE DE DISSENY}




\subsection{Introducció}

Que la recerca forma part del disseny sembla inevitable i necessari si es té en compte la complexitat del món que ens envolta i el fet que qualsevol artefacte creat per l'ésser humà es pot considerar dissenyat, tant l'objecte, com el sistema, com el servei, o l'aplicació digital. És fàcil pensar que el dissenyador no pot saber-ho tot i que, per tant, davant d'un repte de disseny necessita una fase de recerca que assenti unes premisses projectuals que caldrà respectar al llarg del procés de disseny. Idealment, com més acurada, precisa i coherent sigui aquesta recerca, millor base tindrà el projecte per avançar. Però no només, tal com es veurà al llarg d'aquest capítol, la recerca també pot ser prèvia al repte de disseny. Des de l'àmbit ergonòmic també es té en compte la complexitat del món, per exemple autors com Antonio Bustamante comenten el fet que la complexitat i l'alta especialització actual amplien els coneixements universals necessaris per a les bones pràctiques ergonòmiques (Bustamante 2008, p. 7). Tot és benvingut amb pro d'ordenar la complexitat. Com diu Donald Norman, el problema no és la complexitat en sí, sinó la complexitat desordenada, i el disseny, com a pensador del món, té un paper fonamental en l'ordenació d'aquesta complexitat (Norman 2010, pp. 2-31). És per aquest fet que sembla necessari estructurar la recerca de manera que el dissenyador tingui en compte tot allò cabdal pel projecte.

A més a més, si es té en compte el motiu final de qualsevol projecte de disseny, es pot prendre com a vàlida l'afirmació de Crouch i Pearce quan escriuen que "la principal preocupació del disseny és la transformació del món"1 (Crouch i Pearce 2012, p. 15) i en general s'hi pot afegir, el bé comú i la millora de la qualitat de vida de les persones en qualsevol dels múltiples àmbits que actualment ens envolten. Es pren com a premissa que els projectes, en qualsevol cas, no han de ser perjudicials ni per la persona ni per l'entorn; aquesta n'ha de ser la intenció.

Crouch i Pearce (2012) reflexionen sobre la recerca que es realitza relacionada amb el

1 Traducció pròpia d'aquesta i de totes les altres cites que apareixen al llarg d'aquest treball i que el seu idioma original difereix del català 
disseny, tant des de dins el disseny mateix com en relació al disseny. La seva reflexió serveix, entre d'altres coses, per afirmar que el disseny no es pot concebre sense recerca. Tal com escriuen a la introducció de Doing Research in Design, la "recerca requereix estratègies que permetin als dissenyadors explorar els contextos més amplis en què es concep, produeix i consumeix un objecte" (Crouch i Pearce 2012, p. IX). Els autors justifiquen la necessitat de fer recerca en el moment que "els objectes i els usuaris interactuen entre ells de diferents maneres en diferents circumstàncies" (Crouch i Pearce 2012, p. X), per això consideren que és necessari no només investigar l'usuari final i els materials o processos productius, sinó que cal afegir un coneixement cultural i ideològic relacionat amb l'ús i les actituds del consumidor, de manera que la recerca s'amplia i es fa en el seu nivell més fonamental, a la vegada que posen el focus sobre l'experiència d'usuari. Crouch i Pearce consideren que "el nostre entorn intel·lectual, emocional i físic està modelat per processos i objectes de disseny" (Crouch i Pearce 2012, p. X) i que, per tant, el dissenyador ha de ser conscient de la seva tasca i de la seva contribució en la construcció del món.

\footnotetext{
"La transformació del món que es produeix a través del disseny és material i conceptual. Els materials es transformen en objectes que provoquen canvis en el nostre món i en modifiquen com es pensa. Noves reflexions sobre el món alteren la manera com es percep i com es gestiona a través dels sistemes organitzatius. El món material i el món de les idees són els regnes investigats i gestionats pels dissenyadors." Crouch i Pearce, 2012, p. XI
}

Així doncs, per justificar la recerca en el món del disseny, aquests autors atorguen una gran responsabilitat al dissenyador, que passa per la responsabilitat respecte al propi ésser humà i a l'entorn. Per tant, de la mateixa manera que es pot afirmar que la recerca és fonamental en un projecte de disseny, també es pot afirmar que ho és l'Ergonomia, ja que els seus àmbits d'acció passen pel profund coneixement, precisament, de la persona i l'entorn amb la intenció de respectar-los i d'impedir-ne el dany, en el moment que s'estableix la relació entre ells quan s'hi suma un artefacte necessari per a realitzar les tasques que permetran assolir els objectius proposats. 
D'alguna manera s'ha tornat al principi, i la recerca es dirigeix a la relació, o altrament dit a la interacció, d'una persona amb algun objecte, sistema o servei dissenyat. De manera que les tasques necessàries per a aconseguir uns objectius es puguin dur a terme sense errors $\mathrm{i}$ de forma saludable (no nociva) per la persona i per l'entorn. Sembla doncs, que la recerca en disseny també gira entorn dels tres pilars de la usabilitat que van descriure en el seu moment Adolphe Chapanis (1991) a Evaluating Usability i Jakob Nielsen (1993) a Usability Engineering: persona, tasca i entorn.

Segons aquests pioners, la usabilitat és una manera de definir la facilitat d'ús. I aquesta facilitat d'ús passa pel mesurament de tres supòsits: (1) la persona que fa ús de l'objecte, (2) la tasca que realitza aquesta persona i (3) el context en el qual es realitza, o ambient, com també apareix referenciat. De la interacció d'aquests tres elements neix la usabilitat, per tant, quan es parla d'un objecte utilitzable i comprensible, ens trobem davant d'un objecte amb unes tasques definides, el qual és utilitzat per una persona en un context determinat.

També cal fer esment de l'experiència d'usuari, és a dir tot allò que afecta, sent, observa i pensa l'usuari en l'ús del producte, així com l'abans i el després. De manera que es defineixen diferents àrees de coneixement que fan esment sobre la mateixa problemàtica: la relació de la persona amb el món dissenyat i el seu entorn. Actualment el terme experiència és un concepte clau en molt àmbits, des d'Airbnb oferint experiències, enlloc d'habitacions, el Seat León X-PERIENCE o el "Viu l'hivern més intens de la teva vida", espot publicitari per la temporada d'hivern 2018-2019 del govern andorrà, tot passa per l'experiència, i ni el disseny ni l'ergonomia queden fora d'aquesta tendència.

En aquest capítol es pretén revisar una mateixa problemàtica (la relació de la persona amb el món dissenyat) a través de la mirada de dues disciplines diferents (l'ergonomia i el disseny) i extreure'n de cada una els elements més significatius per poder estructurar al seu voltant la inevitable fase de recerca del projecte, buscant la fórmula per tal que a través d'una recerca guiada i estructurada sigui més efectiu, tant extreure conclusions projectuals, com detectar problemàtiques que es converteixin en repte de disseny. 
Des d'aquesta recerca es considera, però, que per fer aquesta revisió cal conèixer també les eines i els mètodes que cada una d'aquestes disciplines utilitza per arribar, en principi, a un mateix lloc. És per això que dedica un punt dins del capítol a la revisió d'alguns d'aquests mètodes que destaquen, per exemple, per la seva originalitat, eficàcia, o renom.

El capítol conclou amb una reflexió sobre la base analítica del projecte de disseny, aquella que assenta les bases projectuals, per desgranar per quines fases passa i quin és el seu objectiu final. Tota aquesta recerca al voltant de diversos temes relacionats, guien aquest treball a través del projecte de disseny, entès com a una sèrie de presa de decisions que té lloc al llarg del projecte, sense especificar en un principi quin ha de ser el resultat final: un objecte, una aplicació, un servei, un espai, entre d'altres.

\subsection{Delimitació de termes i metodologies. Usabilitat i experiència d'usuari}

\subsubsection{Observar el disseny a partir de la Usabilitat i l'Experiència d'Usuari}

Com es pot llegir a la introducció d'aquest capítol, es pretén revisar com des de diverses disciplines i diversos àmbits s'enfoca i s'analitza la relació de la persona i l'objecte amb el propòsit de millorar el disseny del món. És a dir, com l'anàlisi de la relació de la persona i l'objecte pot ajudar a prendre decisions de disseny encertades, de manera que els objectius i tasques definides es puguin realitzar de manera eficaç, eficient i satisfactòria.

El diversos àmbits analitzats es troben, per una banda dins del propi món del disseny; i per l'altra, dins del món de l'ergonomia.

Des de la recerca ergonòmica es poden trobar afirmacions com que "els mètodes ergonòmics estan dissenyats per millorar el disseny de producte a través de la comprensió, o la predicció, de la interacció humana amb els seus aparells"'(Stanton, Young, i Harvey, 2a ed. 2014, p. 1). Amb una afirmació com aquesta es veu clar, que el dissenyador i l'ergonomista tenen en 
comú la recerca de solucions de la relació entre l'ésser humà i el seu món dissenyat. I, també, des de l'àmbit de l'ergonomia l'èmfasi recau sobre la relació, és a dir, sobre la interacció. Com l'ergonomia enfoca l'anàlisi d'aquesta relació es veurà, en primer lloc, a través de la definició del sistema persona/màquina que guia el projecte ergonòmic; i en segon lloc, com aquesta disciplina introdueix la usabilitat com a factor clau de la seva anàlisi.

Alessandra Rinaldi (2016) explica, per altra banda, com el concepte d'experiència d'usuari (UX), tot i ser difícil de definir per la gran varietat d'àmbits i disciplines que hi fan referència, sembla ser una clara evolució del concepte, també ergonòmic, d'usabilitat vinculat tant a la interacció amb interfícies digitals com no digitals. Agafa com a referència la ISO 9241-201:2010, com a norma en relació a l'experiència d'usuari, precisament una ISO que parla de "l'ergonomia de la interacció de la persona amb la màquina". L'autora fa un interessant recorregut per diversos autors reflexionant sobre els factors que poden influir en l'experiència d'usuari en la interacció de productes o sistemes, i com el fet de tenir en compte aquesta experiència pot modificar o no el disseny d'artefactes. De manera que, a grans trets, la usabilitat quedaria definida en el moment d'interacció; i l'experiència d'usuari, faria un pas més cap a les sensacions, emocions i pensaments de l'usuari, no només durant l'ús de l'artefacte, sinó també abans i després.

Per altra banda, en aquesta aproximació de la visió ergonòmica, també es posa èmfasi en l'ergonomia cognitiva i l'ergonomia participativa, ja que són dos vessants interessants pel projecte de disseny, que parlen de percepció i comprensió de l'objecte, el primer; i de metodologia col·laborativa, el segon. A l'altre extrem, queda fora de l'anàlisi d'aquesta recerca, tot allò relacionat amb l'ergonomia enfocada estrictament al món laboral.

Des d'una visió francòfona, Jean-Marc Robert i Eric Brangier (2009) classifiquen tres àmbits d'acció de l'ergonomia: correctiva, preventiva i prospectiva. Els dos primers els relacionen més aviat en un àmbit laboral, i el tercer, l'ergonomia prospectiva, la presenten com una nova manera d'entendre l'ergonomia que obra la porta a nous camps i que sobretot, n'amplia l'abast. Aquests autors, desenvolupen el concepte d'ergonomia prospectiva i descriuen en els seus articles característiques, objectius i significats molt pròxims a les teories 
que desenvolupen Elizabeth Sanders i Pieter Jan Stappers (2012) amb la descripció del fuzzy front end del futur projecte de disseny, precisament la fase del projecte on es detecten necessitats.

A través de la teoria sobre l'ergonomia prospectiva de Robert i Brangier, es pot detectar la fina línia que separa, si és que realment ho fa, el disseny i l'ergonomia. Les dues disciplines tenen una part de desenvolupament compartida i per tant, tot i orígens diferents, poden arribar al mateix lloc, i a més a més, nodrir-se i gaudir dels encerts de cada una.

Des del disseny, aquest treball s'aproxima a la usabilitat i l'experiència d'usuari des de diversos àmbits. Per començar, des del disseny UI-UX, que sembla haver-se erigit com a propietari d'aquests dos conceptes, com demostra el seu propi nom, i s'esforça en explicar la usabilitat i l'experiència d'usuari amb Jakob Nielsen al capdavant. Però no només es reflexiona sobre com la persona interactua des d'un àmbit digital, per exemple Paul Hekkert i Matthijs Van Dijk (2011) ofereixen una interessant visió amb clara intenció prospectiva, des de la Universitat Tècnica de Delft (Països Baixos), a través de la qual es reflexiona de la interacció amb l'objecte físic, més enllà de les interfícies o aplicacions.

Resumint, aquest capítol pretén desgranar les visions respecte la interacció de la persona amb el món dissenyat que tenen diferents disciplines, i dins d'aquestes disciplines des de diversos àmbits.

\subsubsection{Enfocament des de l'Ergonomia}

El terme ergonomia és relativament nou. Tot i que certs autors afirmen que és tant antic com la relació de l'ésser humà i els útils que ell mateix desenvolupa, la veritat és que no és fins el 1949, després de la II Guerra Mundial, que es funda l'Ergonomics Research Society a Cambridge, $\mathrm{i}$ es desenvolupa com a ciència multidisciplinària més enllà dels instints per al bé propi que podien existir en un passat prehistòric. Dins del manual Ergonomía (Nogareda (coor.) 5a ed. 2008) de l'Institut Nacional de Seguretat i Higiene en el Treball (INSHT), es considera el britànic K.F. Hywell Murrell l'artífex del terme ergonomics que 
en el seu moment va definir com "el conjunt d'investigacions científiques de la interacció de l'home i l'entorn de treball' (pag. 12). A Estats Units, l'estudi d'aquesta interacció pren el nom de human engineering i aquest és el nom que pren la institució que vetllarà pel seu desenvolupament quan es funda el 1957 la Human Factors Engineering Society. El 1961, es funda també l'Associació Internacional d'Ergonomia (IEA). Més endavant, el 1988 es constitueix l'Associació Espanyola d'Ergonomia (AEE).

Tal i com descriuen diversos autors, entre ells Erik Hollnagel (1997), la II Guerra Mundial es presenta com a punt d'inflexió dins de la incipient disciplina ergonòmica ja que apareixen una nova categoria de màquines que no es caracteritzen només per una demanda de força muscular, sinó per l'ús de capacitats sensorials, perceptives, de judici i de presa de decisions, sobretot en el camp de l'aviació on se superen velocitats i acceleracions mai vistes fins al moment, de manera que certes operacions arriben a ser tant complexes que els límits de les condicions humanes provoquen errors imprevistos. En conseqüència, entre altres coses, es veu necessari estudiar aquestes capacitats en relació al comandament dels aparells.

Un cop acabada la guerra, aquests estudis es dirigeixen cap a la vida laboral, en quan les hores que passa el treballador realitzant les seves tasques no li poden resultar nocives. L'ergonomia defineix uns intervals de condicions òptimes per al desenvolupament del treball, des d'un vessant físic (les condicions materials), mental (el contingut del treball) i social (l'organització del treball). Així doncs, relacionat amb el treball, la disciplina es desenvolupa al voltant de termes com salut i seguretat, productivitat i eficàcia, fiabilitat i qualitat, i satisfacció i desenvolupament personal.

Per altra banda, aquest enfocament laboral pren el sistema persona/màquina com a unitat d'estudi, ja que l'anàlisi d'un sistema amb factors variables permet encarar situacions complexes. S'estableix un sistema de treball que engloba unes tasques a realitzar, en un espai, amb un entorn físic i organitzatiu concret, i això afecta a les persones i als mitjans i processos de treball ${ }^{2}$.

2 De Ergonomía (Nogareda (coor.) 5a ed. 2008) de l'Institut Nacional de Seguretat i Higiene en el Treball, p.11-18 
L'àmbit laboral s'erigeix com l'àmbit tradicional de l'ergonomia, és a dir, la higiene i la seguretat laboral, emmarcat tot plegat dins del món dels Riscos Laborals. Però des d'aquesta recerca es considera que l'ergonomia és molt més que això ja que la seva visió sistèmica $\mathrm{i}$ global d'allò que analitza la porten a ser un element imprescindible en l'àmbit del disseny. Segons Antonio Bustamante el concepte que engloba la paraula ergonomia s'ha anat ampliant al llarg dels anys. Aquest arquitecte i ergonomista considera que amb l'entrada del segle XXI l'ergonomia ja "no es refereix únicament al treball, no es cenyeix a la relació home/ màquina, sinó que s'estén al context més ampli de la relació entre l'home i el medi artificial creat pel propi home" (Bustamante, 2008, p.15). Bustamante ja està posant les bases per un sistema home/màquina/entorn. De fet, Bustamante proposa una definició d'ergonomia que ell mateix considera molt més útil per al dissenyador: “l'ergonomia és una disciplina la finalitat de la qual és adaptar l'entorn habitable a l'habitant de l'entorn" (Bustamante, 2008, p.15), entenent que adaptar fa referència a "millorar les característiques per a l'ús del ser viu que l'habita" (Bustamante, 2008, p.7) i amb aquesta definició obre la porta a l'acció de l'ésser humà sobre altres elements fora de l'àmbit laboral. A la vegada, posa la disciplina al servei d'aquest ésser humà, i sempre el col·loca per davant de la màquina, element que forma part del binomi sistèmic que organitza l'entorn.

\subsubsection{Sistema Persona/Màquina}

L'Ergonomia, habitualment, treballa des del concepte de sistema persona/màquina que és la manera que ha desenvolupat per ordenar la relació de l'ésser humà amb allò que l'envolta, el món artificial creat pel propi ésser humà. La idea bàsica que persegueix aquesta disciplina és adaptar el món artificial (dissenyat) a la persona, de manera que les tasques d'aquesta última es realitzin de forma eficaç, segura i confortable, en un món on es tenen en compte les característiques, les limitacions i les necessitats d'aquesta persona ${ }^{3}$. Cal afe-

3 De la definició d'ergonomia facilitada per l'Associació Espanyola d'Ergonomia AEE · http://ergonomos.es/ 
gir, també, que l'ergonomia “sempre és còmplice de l'home [persona] enfront del sistema home/màquina" (Bustamante, 2008, p.16), és a dir, que en aquest binomi, les reflexions sempre aniran en direcció al bé de la persona, i adaptarà la màquina; sense oblidar, tal i com ens recorden Mark Sanders i Ernest McCormick, que "la majoria de «coses» que fa servir la gent, són coses construïdes per la mateixa gent”'(Sanders i McCormick, 7a ed. 1993, p. 3). A través d'una sèrie de variables, el sistema persona/màquina analitza aquesta relació per poder descriure quines són les característiques, limitacions i necessitats a tenir en compte en cada cas concret. Com que es parla de sistema, inevitablement entra en joc una relació de causa/efecte entre les accions d'una i altra part del sistema.

El sistema persona/màquina que descriu el manual Ergonomía publicat per l'INSHT, el defineix com a "conjunt format per la persona i el seu lloc de treball, la unitat dins la qual s'estableix una relació mútua entre els dos elements" (Nogareda (coor.), 5a ed. 2008, p.15). Segons el manual, el sistema es descriu i s'estructura per poder encarar, un cop més, la complexitat de tasques i funcions, tot i que en aquest cas en l'àmbit laboral. Es defineix l'objecte de l'ergonomia com 'l'activitat concreta de la persona (grup de persones) que utilitza les màquines (mitjans tècnics)"; de la mateixa manera que defineix l'objecte d'investigació com "el sistema" que es forma entre ells. Afegeix que l'optimització del sistema només podrà tenir lloc si se'n té una visió global, i perquè aquesta visió global sigui real cal afegir-hi l'ambient (entorn físic i organitzatiu), de manera que "la persona, la màquina i l'ambient formen un complex funcional en el qual el paper rector correspon a la persona" (Nogareda (coor.), 5a ed. 2008, p.15). Més endavant afegeix la necessitat de definir funcions i objectius a aconseguir per poder acabar de definir el sistema. Acaba fent esment del disseny també de la comunicació entre la persona i la màquina, és a dir part l'ergonomia cognitiva — vegeu apartat 2.2.2.5 Ergonomia Cognitiva—, amb especial interès sobre el grau de participació de la persona per a què la tasca es desenvolupi correctament (Nogareda (coor.), 5a ed. 2008, pp.16-17).

Aquesta obra posa sobre la taula els diversos elements a tenir en compte per a l'anàlisi de la relació entre la persona i la màquina: la persona, la màquina, l'entorn, l'objectiu o fina- 
litat, i la pròpia acció. Aquests elements, amb més o menys complexitat permetran definir el sistema de forma global.

Part imprescindible del sistema és la persona. Aquí l'ergonomia pot definir les variables humanes a tenir en compte. Aquestes variables poden ser tant fisiològiques, com biomecàniques, com psicològiques. Cada projecte, amb les seves característiques, reclama una informació o una altra. Està clar, però, que sempre hi haurà una part d'antropometria, de biomecànica o de percepció. Les variables humanes, doncs, passen per fer un repàs de tots els elements a tenir en compte relacionats directament amb la persona.

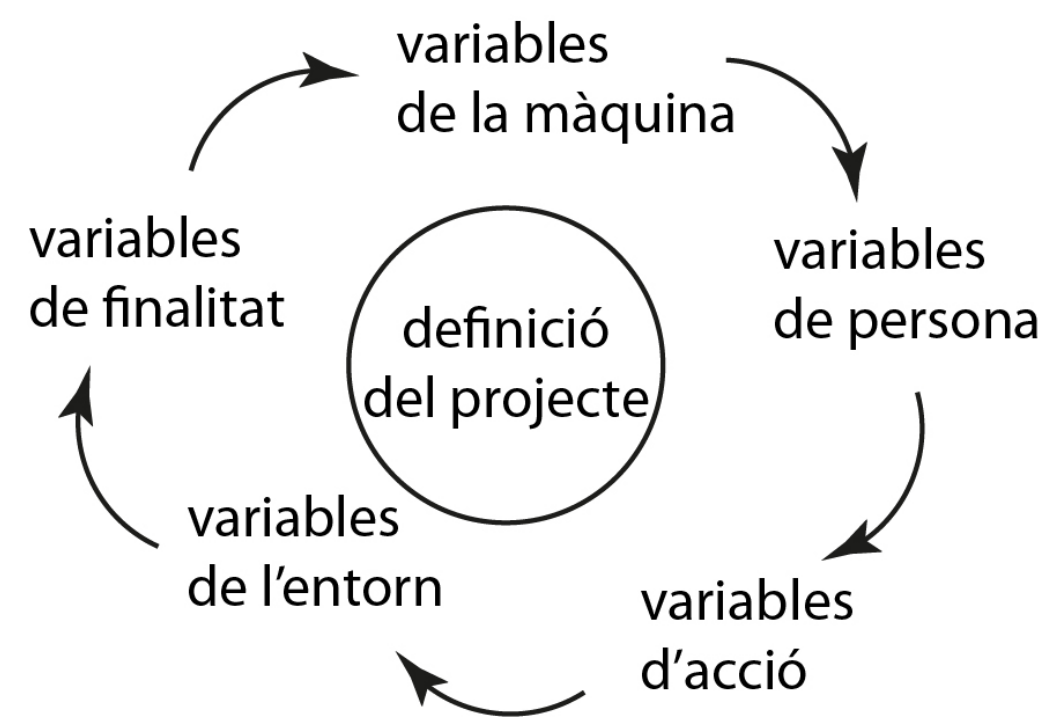

Fig. 2 Variables del sistema persona/màquina.

L'altra part del binomi està format per la màquina, entès aquí en el seu sentit més ampli. Definir les variables de la màquina a tenir en compte ajudarà a definir-ne les funcions tècniques, actives i passives, i les diferents tipologies. Per exemple, en el cas que la màquina sigui una bicicleta, aquesta pot ser una bici de muntanya, de càrrega, de passeig, de trial, infantil, etc. La definició de la màquina, està estretament lligada amb la seva finalitat i objectius. Amb aquesta connexió directa ens endinsem en una nova part del sistema compost per les variables de finalitat. Per descomptat, aquesta finalitat, així com les característiques de la màquina i la persona, desencadenen en una sèrie d'accions a executar. La definició 
d'aquestes accions ens porta a les variables d'acció. I finalment, tot plegat té lloc en un entorn. Aquest entorn es definirà segons el cinquè grup de variables: les variables d'entorn. La definició dels cinc grups de variables permeten dibuixar un mapa precís de les característiques per analitzar, tant d'un producte o servei existent, com d'un repte de disseny inicial. Aquesta és una de les principals aportacions de l'ergonomia en l'organització de l'anàlisi del projecte de disseny.

Des de la visió de Mark S. Sanders i Ernest J. McCormick, el desenvolupament tècnic i tecnològic de la societat és el fet clau que fa necessària una revisió ergonòmica sistemàtica i en les fases inicials del procés de disseny. Per ells, aquesta revisió ergonòmica, permet prevenir modificacions un cop el producte ja ha sigut fabricat. Segons aquests autors, la base de l'anàlisi ergonòmica és precisament el sistema; en recullen la definició de Bayley (1982): "un sistema és una entitat que existeix amb la finalitat de dur a terme algun propòsit. Un sistema està compost per humans, màquines o altres elements que treballen conjuntament (interactuen) per acomplir algun objectiu que aquests mateixos components no serien capaços d'acomplir per separat" (Bayley, 1982, a Sanders i McCormick, 7a ed. 1993, pp.13-14)

En aquesta definició es detecten 4 de les 5 variables del sistema d'anàlisi que es proposa: el sistema està compost per humans —(1) les variables humanes—, i màquines —(2) les variables de màquina-, o altres elements que treballen conjuntament -(3) variables d'acció- per acomplir algun objectiu —(4) variables de finalitat— que aquests mateixos components no serien capaços d'acomplir per separat. S'hi troben a faltar (5) les variables d'entorn, que aquests autors no inclouen en la definició del sistema, sinó com a una de les seves característiques.

Per entendre aquesta classificació, cal tenir en compte que per ells és essencial el nivell de complexitat del sistema, ja que des del sistema més simple, com pot ser una persona amb un martell, com el més complex, un servei de salut com un hospital, són considerats sistemes susceptibles d'anàlisi de l'ergonomia. Per ells és clau el paper actiu de la persona dins del binomi amb la màquina, ja que és la persona qui desencadena la voluntat d'acom- 
plir un objectiu. Aquí coincideix amb la importància que l'INSHT a través del seu manual Ergonomía (Nogareda (coor.) 5a ed. 2008) quan mostra especial interès sobre el grau de participació de la persona en el sistema persona/màquina.

La classificació que proposen és la següent (Sanders i McCormick, 7a ed. 1993, p.15):

- Sistemes manuals. Eines manuals associades a un operador humà, on per tant, l'energia necessària per activar-la és la força física de la persona

- Sistemes mecànics. També anomenats sistemes semiautomàtics, format per les eines motoritzades. En aquest cas, l'energia ve proporcionada per la màquina, i la persona té una tasca de control o comandament.

- Sistemes automatitzats. Quan el sistema és completament automàtic i no és necessària la participació de la persona, o hi participa molt poc, ni com a font d'energia, ni pel control. Sanders i McCormick encerten en indicar que tot i la baixa participació de la persona, el sistema continua sent susceptible de respectar les premisses ergonòmiques, ja que igualment necessitarà ser instal·lat, un manteniment o una reprogramació, que executaran persones.

Sanders i McCormick també desenvolupen les propietats genèriques que caracteritzen els sistemes, començant pel fet que es consideren sistemes perquè tenen una intenció, un propòsit. Sense un objectiu (o més d'un) deixarien de ser sistemes, i es convertirien en un conjunt d'elements un al costat de l'altre. (Sanders i McCormick, 7a ed. 1993, p. 16)

Una altra característica és que els sistemes es relacionen amb altres sistemes formant sistemes superiors, i convertint-se a la vegada en subsistemes d'aquest sistema superior. Qualsevol organització es pot anar desgranant fins a arribar als components. Tot i així, els autors adverteixen que la definició de sistemes i subsistemes no és única sinó que depèn de la intenció d'aquell que dur a terme l'anàlisi, i mentre tingui lògica i coherència, qualsevol divisió és acceptable. S'extreu d'aquesta característica que es defineixen 3 elements propis del conjunt sistema: (1) el sistema, (2) el o els subsistemes i (3) els components.

També és propi del sistema el fet d'actuar en un entorn; entorn que té la capacitat, segons 
les seves característiques, de modificar el propi sistema. Aquí s'identifiquen les variables d'entorn que es trobaven a faltar en la definició. Per a Sanders i McCormick l'entorn és tot allò que queda fora dels límits del sistema, des del seu entorn més immediat, fins a un entorn més global relacionat per exemple, amb les condicions ambientals de temperatura i humitat. Per a aquests autors, a més a més, l'entorn es pot definir segons unes característiques naturals les quals no es poden modificar, però respecte les quals es pot protegir la persona, com per exemple el fred o la calor. I unes característiques del propi sistema que el limita i que habitualment "imposa certes restriccions en el comportament (com per exemple la limitació del rang de moviment o la limitació del camp de visió) o predetermina certs aspectes del comportament (com per exemple mirar un moble d'arxius, passejar pel laberint d'un supermercat fins a trobar el pa, o intentar veure la vora de la carretera en una nit plujosa)" (Sanders i McCormick, 7a ed. 1993, p. 16).

Finalment, cal tenir en compte la fiabilitat global del sistema, que dependrà de la fiabilitat de cada un dels seus components i subsistemes, i de la relació que s'estableix entre ells, és a dir, com estan organitzades les diverses parts i com depenen unes de les altres, o si existeixen sistemes de suport que poden accionar-se en cas d'error. A nivell d'ergonomia, es pot limitar el concepte de fiabilitat del sistema a la probabilitat d'assolir les funcions amb èxit (Sanders i McCormick, 7a ed. 1993, p. 19).

Sanders i McCormick aconsegueixen dibuixar el sistema persona/màquina de forma senzilla sobretot posant èmfasi sobre qui fa què: ja des de la classificació inicial entre sistemes manuals, mecànics o automatitzats, on la classificació es basa en qui exerceix la força i qui exerceix el control, distingint així la funció bàsica de cada part del sistema. Per aquests autors, de la mateixa manera que per Tillman et al. (3a ed. 2016), és essencial en qualsevol sistema decidir qui realitzarà les accions que fan acomplir la funció.

La mirada de Sanders i McCormick també és especialment interessant en el moment que es pregunten com pot encaixar l'ergonomia (o factors humans) en les diverses fases del procés de disseny i desenvolupament, ja que precisament aquesta és la pregunta que desencadena aquest treball i la seva recerca en una metodologia per l'anàlisi: com encaixa l'ergonomia 
dins del projecte de disseny. Per a aquests autors, l'ergonomia juga un paper transcendent en dos moments: en la fase inicial com a base per al disseny, i en la fase final, com a mètodes d'avaluació i millora del disseny realitzat. En aquest treball, es pretén centrar l'èmfasi en la part inicial del procés de disseny, quan es delimiten les premisses i es defineix el repte de disseny.

Des de la tradició anglosaxona Wesley Woodson, president de Man Factors Associates (consultoria d'ergonomia a El Cajon, USA), va ser l'autor de la primera edició de Human Factors and Ergonomics Design Handbook l'any 1981. Woodson destaca per la seva sobrada experiència en l'anàlisi de sistemes i disseny de producte en àmbits molt diversos. En la tercera edició d'aquesta obra datada el 2016, amb Barry Tillman al capdavant, aquests autors aporten la seva visió del sistema i el defineixen com a un grup d'elements integrats en un tot funcional que té una missió concreta, és relativament gran i complex, i es pot dividir en subsistemes o components (Tillman et al., 3a ed. 2016, p. 3), distribució que també s'ha vist proposada per Sanders i McCormick. Per a poder-lo analitzar, Tillman comença per especificar els factors humans (nom que pren l'ergonomia als EUA) però que aquí serveix per desenvolupar les característiques de la persona, i per tant, fent referència al sistema $\mathrm{P} / \mathrm{M}$, a (1) les variables humanes. Per a Tillman, és important definir les diverses funcions del sistema, que ens permetran conèixer els objectius generals i els objectius secundaris del sistema, per tant, les (2) variables de finalitat, que guiaran en el recorregut del què Tillman anomena missió, que es tradueixen en (3) les variables d'acció. Finalment, té en consideració les característiques ambientals, que fan referència a (4) les variables d'entorn. Per completar els cinc tipus de variables, falten (5) les variables de màquina. En aquest sentit, Tillman elabora unes consideracions prèvies per definir els agents que han de dur a terme les diverses accions. Tillman convida a definir les accions sense especificar si se'n farà càrrec la màquina o la persona, i de la persona encara n'especifica el rol que tindrà. És a dir, que no només es preocupa de la persona-usuari, sinó també de la persona-tècnic de manteniment o de la persona-responsable de neteja. Sense especificar-ho, Tillman engloba un sistema molt més ampli, i s'aproxima a la visió més àmplia de l'experiència d'usuari, que implica més actors en la vida del producte. A més a més, frena la reproducció de sistemes 
coneguts, i fa reflexionar a l'ergonomista sobre les capacitats, virtuts i limitacions tant de la màquina, com de la persona, abans de prendre la decisió sobre qui s'ha d'encarregar de fer què. Es pot dir, que hi ha una sèrie de variables de màquina o persona que no distribueix fins al final, un cop les variables d'acció i de finalitat estan ben definides. Aquí coincideixen amb Sanders i McCormick (7a ed. 1993) quan es plantegen com l'ergonomista ha de prendre la decisió sobre si serà la persona o la màquina (o el software) qui executarà certes accions per aconseguir l'objectiu. Aquests autors, recullen les possibles funcions a realitzar en quatre de diferents: (1) la detecció, és a dir, la recepció de la informació; (2) l'emmagatzematge de la informació, que si se n'encarrega la persona es parlarà de memòria i aprenentatge; (3) el processament de la informació i presa de decisions, que predisposa a l'acció o no acció, i que si se n'encarrega la màquina caldrà que estigui programada per a respondre de forma adequada. I (4) les funcions d'acció, aquelles que ocorren en conseqüència de les decisions preses, per exemple un senyal sonor, o l'activació d'algun control (Sanders i McCormick, 7a ed. 1993, pp. 17-18). Sanders i McCormick estan descrivint aquí diferents funcions de la ment que es comentaran més endavant a l'apartat 2.2.2.5 Ergonomia Cognitiva, però amb el plantejament sobre les capacitats avançades de la màquina respecte la persona, o les capacitat cognitives i de comprensió, més enllà de la lògica i la programació de la persona respecte la màquina.

D'una manera o d'una altra, l'ergonomia, com també fan altres disciplines, estructura la realitat a través de sistemes, subsistemes i components que li permetin observar, analitzar i prendre decisions pel bé de la persona en relació a la seva activitat, entorn i eines utilitzades. Els cinc grups de variables que es proposen (finalitat, acció, persona, màquina i entorn) són una manera de recórrer els sistemes sense deixar-se cap element, sempre tenint en compte que estan relacionades entre sí i que una depèn de l'altra. La principal diferència de les diverses propostes és el punt d'origen, la variable que marcarà el recorregut d'anàlisi respecte les altres.

Per exemple, Tillman et al.(3a ed. 2016) organitzen el sistema començant per les variables de finalitat, és a dir, per definir clarament els objectius del sistema, tant els primaris com els secundaris. En canvi, Sanders i McCormick (7a ed. 1993), organitzen el sistema en primer 
moment segons l'actor principal del sistema, és a dir, qui aporta l'energia i qui aporta el control. Per a l'INSHT, el punt de partida de la caracterització del sistema és la relació que s'estableix entre la persona i la màquina, és a dir, que el punt de partida són les variables d'acció. Aquestes diferències es recullen en la proposta d'estructura per a la metodologia de recerca que es desenvoluparà en el capítol III.

\subsubsection{Usabilitat i Experiència d'Usuari}

Dins de l'ergonomia, tradicionalment es parla d'usabilitat sobretot fent referència a la seva anàlisi a través de testos i protocols. Aquest terme queda recollit a les diverses normatives ISO, però des de l'entrada del segle XXI també s'hi afegeix l'experiència d'usuari, terme cada vegada més estès en tots els àmbits, no només en l'ergonomia. Des d'Itàlia, Alessandra Rinaldi reflexiona sobre la verdadera capacitat de dissenyar experiències o simplement "per” una experiència concreta. Des de la banda francòfona, trobem a Eric Brangier (França) i a Jean-Marc Robert (Canadà) que reflexionen precisament sobre la inclusió de l'experiència d'usuari a través de la seva proposta d'ergonomia prospectiva. Al llarg d'aquest apartat es fa un repàs d'aquestes dues mirades.

Habitualment la usabilitat va lligada a l'existència de comandaments o aplicacions digitals, però per exemple, si es vol escriure amb una ploma estilogràfica cal tenir en compte una sèrie de qüestions sobre la posició del plomí i la pressió que faran possible l'escriptura de forma eficaç; aquí no hi ha comandaments pròpiament dits, però tot i això es poden aplicar les variables del sistema persona/màquina per analitzar l'ús de la ploma, ja que segons es moguin la mà $\mathrm{i}$ els dits, la ploma reaccionarà d'una manera o d'una altra, o més concretament, la tinta sortirà d'una manera o d'una altra. I en l'anàlisi d'aquest instant, és quan es parla d'anàlisi d'usabilitat, en el precís moment en qual té lloc la tasca, seguint amb l'exemple de la ploma, en el moment que s'està escrivint. Com es veurà seguidament a 
través de la Norma, els testos d'usabilitat analitzen diverses característiques amb l'objectiu de verificar que l'acció transcorre de forma eficaç, eficient i satisfactòria.

Donald Norman (1990) i Jakob Nielsen (1994) pretenen facilitar les accions de la persona a través d'una bona seqüència d'ús, i la comprensió de l'objecte — com es veurà més endavant en l'apartat 2.2.2.5 Ergonomia Cognitiva — per un millor ús de l'objecte, per tant una millor usabilitat. Els dos autors tenen una forta relació entre ells que s'anirà veient al llarg d'aquest treball, sobretot per la seva capacitat d'ordenar premisses pel bon disseny, entre elles els heurístics de Nielsen (1994) que fan referència al disseny digital, i que es veuran a l'apartat 2.2.3.1 Heurístics de Jakob Nielsen. Usabilitat i Experiència d'Usuari.

En referència a la usabilitat el principal problema és com valorar de forma objectiva aquest bon ús del producte. Els protocols ergonòmics pretenen aquesta objectivitat i proposen més enllà dels tres ítems principals (eficàcia, eficiència i satisfacció), una sèrie més llarga de característiques a tenir en compte, i que haurien de guiar en l'anàlisi objectiva de la usabilitat. Encara que diferent, la relació entre els principis del bon disseny de Norman — apartat 3.2.5 — i els heurístics de Nielsen — apartat 3.3.1—i aquestes característiques llistades a continuació, hi ha una preocupació inicial per a una bona usabilitat.

- Efectivitat · aconseguir els objectius desitjats

- Eficiència $\cdot$ aconseguir els objectius desitjats amb el mínim esforç

- Satisfacció · absència de molèstia

- Facilitat d'aprenentatge $\cdot$ nivell de propedèutica adequat

- Facilitat de memorització · simplicitat, intuïció, analogia

- Error · minimització dels errors i la seva reparació

- Rendiment - quantitat de treball realitzat

- Flexibilitat · capacitat d'adaptació

Aquestes característiques han de ser quantificables (caldrà definir-ne la quantitat per poder-les valorar) i pretenen objectivitat. Són fruit de l'observació directa, del registre de les accions, de l'anàlisi biomecànica, o del recompte d'encerts i errors, informació recopilada a través de l'observació en el moment d'execució de la tasca, com per valoració de certes condicions psicofisiològiques, com per exemple, el grau d'exactitud de l'execució, el temps 
empleat per a realitzar una tasca, el número d'errors, el consum metabòlic, entre d'altres. Totes elles característiques relacionades amb la investigació de dades quantitatives.

Per altra banda, les característiques subjectives estan relacionades amb qüestionaris d'opinió i actitud, entrevistes, observació, focus groups i un altre tipus de recopilació d'informació relacionada amb les eines pròpies de l'etnografia i l'antropologia, que pretén definir característiques com el confort, l'acceptació del producte, l'esforç, la percepció de qualitat. Totes elles característiques relacionades amb dades qualitatives i molt més pròximes a l'experiència d'usuari.

Ernest McCormick fa una aportació interessant a la usabilitat tot just a finals dels anys 70 del segle $\mathrm{XX}$, sense que el concepte usabilitat estigui ja definit i globalitzat com passarà més endavant. McCormick (1980), descriu quatre principis a tenir en compte per a la distribució i estructuració d'elements que en millorarà el seu ús. Tot i que un cop més, es pot tenir en compte per a la distribució de displays i comandaments, són quatre principis útils per a la distribució de components a nivell genèric, des d'aquests controls, passant per la distribució d'una cuina, fins a l'envergadura d'una zona residencial i l'organització de serveis. Segons aquest autor, "serveix com a hipòtesi raonable el fet que qualsevol component té, per norma general, una situació 'òptima' des de la qual dur a terme la seva finalitat" (McCormick, 1980, p. 259). Si es recull aquesta hipòtesi, el dissenyador ergonomista ha de poder definir aquesta posició òptima, $\mathrm{i}$ ho ha de fer seguint premisses ergonòmiques antropomètriques, de postura, esforç i cognició humanes. Lamentablement, les decisions de disseny no només es prenen tenint en compte qüestions humanes, així McCormick (1980) proposa quatre principis per ajudar a la presa de decisions en referència al bon ús del components que formen el sistema, i que en l'actualitat, es pot afirmar que contribueixen a la definició d'una bona usabilitat:

- Principi d'importància. Fa referència a aquells components essencials per dur a terme l'activitat. És a dir, per complir amb l'objectiu principal, per tant, cal fer una jerarquització de tasques i prioritzar components essencials per aconseguir l'objectiu

- Principis de frequiència d'ús. Fa referència a la intervenció temporal dels components 
- Principi funcional. Útil per a classificar les funcions dels components i agrupar-los o distribuir-los per unitats funcionals o objectius afins. És a dir, segons la relació funcional que tenen entre ells.

- Principi de seqüència d'ús. En relació a les diverses fases o etapes que tenen cada una de les accions, de manera que es poden establir criteris de relació segons aquestes relacions.

McCormick (1980) afegeix, que els principis d'importància i freqüència són aplicables a les fases més bàsiques de situar, mentre que els principis funcional i de seqüència, són més aviat aplicables a la distribució dels components dins de l'àrea general (McCormick, 1980, p. 260).

Més enllà de la definició d'usabilitat estricte, l'experiència d'usuari inclou no només el moment d'ús, de manera que les característiques a tenir en compte també són més àmplies. Tornant a l'exemple de la ploma, el simple fet d'escollir-la, i no un bolígraf per exemple, ja implica una sèrie de qüestions que van més enllà de la simple acció d'escriure; inclou, entre d'altres, una sèrie de qüestions socioculturals que queden fora de l'anàlisi d'usabilitat més estricte. El concepte d'experiència, més recent, queda fora de l'àmbit ergonòmic més tradicional, però el tenen en compte autors com Robert i Brangier en la seva descripció de l'ergonomia prospectiva, tal i com es veurà més endavant, ja que proveir d'una bona experiència d'usuari ho consideren el fi últim de l'artefacte (Robert i Brangier, 2009, pp. 162-169).

Segons l'ergonomia, la usabilitat pretén definir una tasca o acció com a eficient, eficaç i satisfactòria, en la intersecció entre la tasca, la persona i l'entorn. És a dir, en un primer moment, la usabilitat descriu el grau de facilitat d'ús d'un producte o sistema de complexitat diversa. Aquesta avaluació es produeix mitjançant l'anàlisi de la interacció entre usuari i producte per poder identificar defectes o deficiències derivades de la seva conceptualització o disseny. La Norma ISO 13407:1999 (revisada posteriorment amb la ISO 9241-210 i confirmada el 2015) descriu el què en castellà denomina "utilizabilidad" com el "grau amb el qual un producte pot ser utilitzat per usuaris específics per aconseguir uns objectius 
concrets amb eficàcia, eficiència i satisfacció, en un determinat context d'utilització". La norma revisada, expandeix el producte, a "sistema producte o servei". També descriu eficàcia com 'l'exactitud i grau de consecució amb els quals els usuaris assoleixen els objectius establerts". L'eficiència la descriu, com la "relació entre els recursos empleats i l'exactitud i grau de consecució amb els quals els usuaris assoleixen els objectius establerts". I la $s a-$ tisfacció, la defineix com 'l'absència d'incomoditat i existència d'actituds positives cap a la utilització del producte". Descriu també el context d'utilització, com "el conjunt d'usuaris, tasques, equipament (equip, programes i documents) i entorn físic i social en el qual s'utilitza un producte".

Aquesta Norma descriu l'ús dels sistemes interactius, i els defineix com "la combinació de components d'equips i programes, que reben o subministren dades procedents o destinades a un usuari humà, amb l'objectiu d'ajudar-lo a complir una tasca"; aquí la revisió torna a incloure els serveis que no apareixien en la versió antiga. La descripció del sistema interactiu és extrapolable a la interacció de l'ésser humà amb qualsevol producte, també el producte físic més enllà de la comunicació a nivell d'aplicacions digitals, la norma revisada afegeix com a nota que els sistemes interactius també inclouen packaging, branding, documentació per l'usuari, ajuda en línia, suport i formació, però no afegeix producte físic en sí.

La Norma revisada ISO 9241:210 descriu concretament l'ergonomia de la interacció persona sistema, concretant en la seva part 210, el Disseny centrat en l'Usuari per als Sistemes Interactius en una pretesa intenció de mantenir-se en el món digital. Tal i com es pot llegir, la Norma pretén ser útil com a "marc pels professionals relacionats amb els factors humans i la usabilitat que treballen en el disseny centrat en la persona." En el seu article, Rinaldi (2016) fa notar el canvi d'user-centred design a human-centred design, que hi ha entre l'antiga i la nova versió, que la pròpia Norma justifica a la Nota 1 com a necessitat d'emfatitzar que la Norma va dirigida no només a aquells actors classificats normalment com a "usuaris", sinó a una quantitat d'actors major, tot i admetre que les dues nomenclatures s'utilitzen sovint com a sinònims. 
Tal i com seguidament descriu Rinaldi (2016), la Norma parla de l'experiència d'usuari (UX) i la descriu com el "conjunt de percepcions de la persona i els resultats derivats de l'ús i/o expectativa d'ús d'un producte, sistema o servei." Aquí, les paraules clau són percepció i expectativa. La primera lligada a l'ergonomia cognitiva, entesa també com la capacitat de l'usuari d'entendre un producte; la segona, lligada inevitablement a l'experiència d'usuari. La Norma, tal com indica el seu títol, fa referència a la interacció entre la persona i sistemes que passen principalment per un software $\mathrm{i}$ un hardware, però tal i com afirma Rinaldi, la interacció apareix quan s'estableix una relació recíproca entre dos o més elements i per tant, és adequat també parlar d'interacció entre la persona i qualsevol altre producte físic (i no digital). (Rinaldi, 2016, p.17).

Rinaldi dona la responsabilitat a l'especialista en ergonomia per a "garantir la maximització de l'experiència d'usuari durant l'ús del producte" al considerar que hi intervenen altres factors més enllà de la usabilitat (Rinaldi, 2016, p.18). Factors, per altra banda, amb possibilitats de ser valorats de forma objectiva, tal i com es descriu a la Norma. En canvi, alguns factors, com la satisfacció, formen part de la subjectivitat de l'usuari i per tant, en principi, més difícils de valorar de forma objectiva, o si més no, molt més lligats a les circumstàncies d'ús.

Rinaldi guia la recerca sobre diferents autors a través de la concepció que no és possible dissenyar l'experiència d'usuari, ja que es descriu a través de característiques subjectives, i que per tant, el què es pot fer és dissenyar per una experiència concreta. És a dir, preparar l'objecte esperant que la reacció de l'usuari sigui la prevista. Citant a Giulio Ceppi, Rinaldi afirma que "cada procés o producte de disseny pretén generar comportament i, per tant, una experiència en el seu usuari, però està fora de lloc pensar que ontològicament existeix un disseny d'experiència. És una forma de definir una filosofia de disseny, una manera d'apropar-se al disseny, des d'un punt de vista relacional, holístic, evolutiu i complex." (Rinaldi, 2016, p.21). 


\subsubsection{Ergonomia Prospectiva}

Per la seva banda, Robert i Brangier (2009) fan una proposta molt interessant des del món de l'ergonomia. La proposta és molt pròxima a certes metodologies de disseny que aboquen els seus esforços en la recerca de nous reptes basats en l'experiència, les necessitats, els desitjos i les problemàtiques de l'usuari, com per exemple el disseny generatiu que proposen autors com l'Elizabeth Sanders, o el mateix Design Thinking. En aquest cas, Robert i Brangier no ho anomenen disseny, sinó ergonomia prospectiva, però com es pot veure a continuació els punts de contacte són molt clars.

Robert i Brangier (2009, pp. 162-168) proposen una nova classificació dels diversos enfocaments de l'ergonomia a la vegada que en proposen un de nou. Aquests autors defineixen tres enfocaments: ergonomia correctiva, preventiva i prospectiva.

Accepten la definició d'ergonomia correctiva, com un tipus d'ergonomia dedicada a esmenar errors. També accepten la definició d'ergonomia prospectiva que fan altres autors, però l'anomenen diferent, li donen el nom d'ergonomia preventiva, ja que reserven el qualificatiu prospectiva per a la seva proposta enfocada a la innovació. Per exemple, Bustamante, també l'anomena ergonomia preventiva, i la compara amb un instrument de la medicina preventiva, ja que considera que "anàlogament, l'ergonomia preventiva s'ocuparà de preveure les conseqüències negatives que pugui tenir l'ús d'un instrument per a la salut de l'usuari, i modificar aquest instrument per eliminar les seves possibilitats patògenes." (Bustamente, 2008, p. 17).

Robert i Brangier (2009) consideren que el qualificatiu prospectiu no és adequat tal i com s'ha utilitzat tradicionalment, perquè en realitat està descrivint un fet preventiu. Per una banda, les discrepàncies comencen en relació al moment d'ús de l'hipotètic producte. Robert i Brangier consideren que fins al moment, tot i parlar d'ergonomia prospectiva, altres autors, com per exemple Laurig o Montmollin, referents en dècades anteriors, es mante- 
nen dins del que Robert i Brangier anomenen el "futur definit"; en canvi, la seva proposta d'ergonomia prospectiva està enfocada cap un "futur indefinit".

La definició de Robert i Brangier per l'ergonomia prospectiva és la següent: "Es pot definir una ergonomia prospectiva com la part de l'ergonomia que intenta anticipar les necessitats i activitats humanes per crear nous artefactes que siguin útils i proporcionin experiències d'usuari positives." (Robert i Brangier 2009, p. 165). Aquests autors, doncs, reserven per a l'ergonomia prospectiva la recerca al voltant de "l'anticipació de les necessitats i activitats humanes" (Robert i Brangier 2009, p. 165) i afirmen que la base metodològica per aconseguir-ho és l'anàlisi de les persones en el seu entorn, on poder-les observar i entrevistar, així com recollir dades de diversos tipus. En aquest sentit hi ha una clara similitud amb les premisses metodològiques del Design Thinking — vegeu apartat 2.3.1 DesignThinking-, o del disseny generatiu que proposa Elizabeth Sanders — vegeu apartat 2.3.4 Disseny generatiu - , que pretenen construir a partir de la profunda comprensió de l'usuari en el seu entorn propi.

Per tant, parant un moment en l'argumentació, val la pena afegir que la proposta de Robert i Brangier té una visió reduccionista de les competències del disseny, ja que considera que aquesta disciplina es limita a perseguir idees i conceptes d'un futur immediat i té un enfocament diferent. Per aquests autors, les tasques del disseny caminen paral·leles amb les tasques de l'ergonomia preventiva, a través de les quals es treballa sobre projectes ja definits prèviament. Fins i tot en articles posteriors (Robert i Brangier, 2012) anomenen aquest enfocament directament disseny, ja que consideren que el terme ergonomia preventiva té connotacions negatives i és massa limitada. La visió del disseny d'aquesta investigació és molt més àmplia i, en conseqüència, molt més pròxima a la teoria d'ergonomia prospectiva que plantegen Robert i Brangier.

Resumint, Robert i Brangier (2009) caracteritzen l'ergonomia prospectiva a través de cinc eixos. El primer és precisament aquest enfocament basat en l'experiència d'usuari. El segon és la multidisciplinarietat, entenent que fa ús de pràctiques i eines pròpies d'altres disciplines humanistes com l'etnografia, la psicologia o l'antropologia; així com de la 
informàtica o l'enginyeria que han de ser capaces de donar resposta tecnològica a les necessitats. El tercer eix fa referència precisament a la relació que estableix l'ergonomia amb la tecnologia, que segons l'autor tant pot ser technology-pull com technology-push. En el primer cas, serien les necessitats i desitjos de les persones que empenyerien la innovació tecnològica; i en el segon cas, la tecnologia oferiria solucions sense aplicació, de manera que l'ergonomia prospectiva ajudaria a trobar aquestes aplicacions. Posteriorment, Robert i Brangier (2012) afinen aquest eix, i consideren que a causa de l'enfocament centrat en l'usuari, rarament es donaran casos de technology-push. El quart eix de l'ergonomia prospectiva és el seu caràcter enfocat a la innovació. I el cinquè eix, fruit de l'experiència acadèmica dels autors, està relacionat amb la possibilitat que ofereix la disciplina de sumar els factors humans a disciplines com el disseny industrial, l'enginyeria o la informàtica.

Per a què sigui possible el canvi de classificació dels diversos enfocaments de l'ergonomia, Robert i Brangier (2009) observen com el rol de l'ergonomista evoluciona cap a un paper de gestor, gerent o estratega dins de l'organització i amplien així l'abast de la disciplina, fet que segons els autors obliga, a part d'ampliar la pròpia definició d'ergonomia, a revisar-ne els programes acadèmics. Com es veurà més endavant —apartat 2.2.5.1 Elizabeth Sanders. El fuzzy front end-, Sanders i Stappers (2012), des del món del disseny, també descriuen uns canvis molt similars en el paper de dissenyador, que anomenaran facilitador, fins i tot el Design Thinking — apartat 2.3.1 - dona un tomb al paper del dissenyador pròxim al paper de l'ergonomista prospectiu d'aquests autors. Robert i Brangier (2009) no discrepen del punt de vista clàssic de l'ergonomia on les seves diverses mirades es divideixen entre l'ergonomia correctiva o preventiva (en ocasions també anomenada prospectiva); la primera revisant i modificant artefactes existents, i la segona treballant durant les fases de disseny i desenvolupament del projecte, sinó que n'afegeix una tercera que difereix de les dues anteriors.

Robert i Brangier (2009) proposen la següent taula que estructura les diferències dels tres possibles enfocaments de la disciplina: 
Taula 1. Comparativa entre ergonomia correctiva, preventiva i prospectiva

\begin{tabular}{|c|c|c|c|}
\hline & $\begin{array}{l}\text { Ergonomia } \\
\text { correctiva }\end{array}$ & $\begin{array}{l}\text { Ergonomia } \\
\text { preventiva }\end{array}$ & $\begin{array}{l}\text { Ergonomia } \\
\text { prospectiva }\end{array}$ \\
\hline Temporalitat & Passat & Present & Futur \\
\hline Naturalesa de la tasca & Corregir & Dissenyar & Anticipar \\
\hline Punt inicial & $\begin{array}{l}\text { Requeriment d'un } \\
\text { client (un problema } \\
\text { a corregir) }\end{array}$ & $\begin{array}{l}\text { Un artefacte a } \\
\text { dissenyar }\end{array}$ & $\begin{array}{l}\text { La iniciativa de } \\
\text { l'ergonomista } \\
\text { (objecte a crear) }\end{array}$ \\
\hline Focus principal & $\begin{array}{l}\text { El problema } \\
\text { per corregir }\end{array}$ & $\begin{array}{l}\text { L'artefacte per } \\
\text { dissenyar }\end{array}$ & $\begin{array}{l}\text { Necessitats } \mathrm{i} \\
\text { activitats per definir }\end{array}$ \\
\hline Disciplines associades & $\begin{array}{c}\text { Antropometria, bio- } \\
\text { mecànica, fisiologia, } \\
\text { psicologia, enginyeria, } \\
\text { informàtica, disseny }\end{array}$ & $\begin{array}{l}\text { Les mateixes }+ \\
\text { antropologia, } \\
\text { etnografia, } \\
\text { sociologia, art }\end{array}$ & $\begin{array}{l}\text { Les mateixes que les } \\
\text { anteriors + direcció, } \\
\text { gestió i màrqueting }\end{array}$ \\
\hline $\begin{array}{l}\text { Focus de la } \\
\text { recol-lecció de dades }\end{array}$ & $\begin{array}{l}\text { Causes de pèrdues } \\
\text { com accidents, } \\
\text { incidents, errors, } \\
\text { sobrecàrregues }\end{array}$ & $\begin{array}{l}\text { Respostes de l'usuari } \\
\text { respecte prototips i } \\
\text { altres simulacions }\end{array}$ & $\begin{array}{l}\text { Les queixes, neces- } \\
\text { sitats, expectatives } \\
\text { de les persones, i les } \\
\text { respostes respecte } \\
\text { les simulacions }\end{array}$ \\
\hline $\begin{array}{l}\text { Status dels } \\
\text { factors humans }\end{array}$ & Factors de recuperació & Factors d'integració & Factors d'innovació \\
\hline $\begin{array}{l}\text { Naturalesa de } \\
\text { la intervenció }\end{array}$ & Reactiva & Activa & Anticipativa \\
\hline Producció de riquesa & $\begin{array}{l}\text { En la reducció o } \\
\text { eliminació de } \\
\text { les pèrdues }\end{array}$ & $\begin{array}{l}\text { En l'optimització del } \\
\text { rendiment i } \\
\text { l'experiència d'usuari }\end{array}$ & $\begin{array}{c}\text { En la creació de nous } \\
\text { productes i serveis }\end{array}$ \\
\hline $\begin{array}{l}\text { Possibilitat } \\
\text { d'ingressos }\end{array}$ & Baixa & Mitjana & Alta \\
\hline
\end{tabular}

Font: Robert i Brangier (2009, p. 167)

Recorrent diversos articles de Robert i Brangier es pot dibuixar com aquests autors enfoquen l'ergonomia prospectiva a través de l'usuari i la seva experiència, això sumat a altres característiques que van enumerant (per exemple, la necessitat de pensar de forma visual, o la preferència per parlar d'activitats amb les persones, més que directament de necessitats), mostren l'elevat paral·lelisme entre les premisses d'una metodologia com el Design Thinking (disseny centrat en les persones, enfocat al futur i basat en la detecció de necessitats i desitjos) i l'ergonomia prospectiva de Robert i Brangier. Fins i tot a nivell de disciplines associades, o que hi concorren, es manté el paral·lelisme entre el Design Thinking i l'ergonomia prospectiva, ja que les dues parlen de l'estructuració d'equips del projecte, de 
gestió i de comunicació. Robert i Brangier (2009) estan proposant el nou ergonomista que pot molt ben ser el nou dissenyador.

Per altra banda, dins de la mateixa evolució de la definició d'ergonomia prospectiva assenten les bases per a una bona fase de recerca inicial, de la mateixa manera que fa el disseny prospectiu. Els autors afirmen que l'ergonomia prospectiva “observa amb profunditat per trobar els factors i les tendències que realment cal tenir en compte [...]. Requereix la capacitat de recollir i analitzar gran quantitat d'informació de diverses fonts, l'habilitat de percebre nous fenòmens i d'avaluar la seva importància, i la capacitat d'anticipar-ne les conseqüències". A més a més, afegeixen "els factors en joc són els clàssics: les persones, les seves activitats, la tecnologia i el context." (Robert i Brangier 2012, p. 5238). En aquest sentit, la metodologia de l'ergonomia prospectiva passa per una bona fase d'anàlisi, que es podria organitzar un cop més (tal com fa l'ergonomia preventiva, o el disseny) a través del sistema persona/màquina: (1) variables de persona, (2) variables de màquina (aquí anomenat tecnologia), (3) variables d'acció (aquí anomenat activitats), (4) variables d'entorn (aquí anomenat context). Només falten (5) les variables de finalitat, lligades als objectius i necessitats i que, potser precisament, és el què pretén identificar l'ergonomia prospectiva que proposen Robert i Brangier en la seva anàlisi.

Finalment, per a Robert i Brangier (2012) el principal impacte de la seva proposta ha de ser dins de la pròpia ergonomia, ja que segons aquests autors obre un camp immens de possibilitats, a la vegada que dona una nova dimensió a l'ergonomista, al oferir-li la possibilitat de liderar projectes, investigació i en conseqüència la innovació, i deixar de ser només consultor durant el desenvolupament del projecte. Com escriuen els mateixos autors, l'ergonomia prospectiva "implica una ampliació i un enriquiment significatiu de la missió de l'ergonomia" que ha de portar a l'ergonomista a ser proactiu i liderar equips amb un objectiu major "la participació activa en la definició i organització del futur per poder millorar o canviar el món”. (Robert i Brangier 2015, p. 1). 


\subsubsection{Ergonomia Participativa}

L'ergonomia tradicional observa, aplica protocols per analitzar de forma el més objectiva possible i proposa solucions de millora. De fet, es podria afirmar que la persona és la raó de ser de l'ergonomia, ja que la disciplina persegueix el seu benestar en tots els sentits. Bustamante (2008) parla d'una relació intel·ligent amb els objectes que ens envolten com a premissa a perseguir per tots aquells que es dediquen a pensar els espais, objectes i artefactes que ens envolten, és a dir, que d'alguna manera reclama l'ergonomia en tots els processos de disseny. Bustamante (2008) considera que tenir en compte a la Persona és tant bàsic que d'alguna manera hauria d'estar inclòs a l'escola el fet de saber llegir i entendre la complexitat del món que ens envolta, perquè així tothom seria capaç de prendre decisions adequades en referència a la relació persona/màquina, és a dir en relació a l'antropometria, la postura, la fisiologia, etc. Amb les seves paraules Bustamante no parla pròpiament de l'ergonomia participativa, però d'alguna manera n'assenta les bases, ja que posa sobre la taula el coneixement propi de la persona (o usuari) del seu propi entorn, del seu propi comportament, i de la relació que s'estableix entre ell mateix i la resta d'elements. No només es limita a observar l'usuari i a aportar solucions per al seu benestar, sinó que el fa directament partícip del seu benestar. Aquest precisament, és el motiu principal del desenvolupament de l'ergonomia participativa que ha anat agafant força l'última dècada i que, segons Garcia et al. (2009), arriba al nostre territori provinent de països com Canadà, Gran Bretanya, Holanda o Finlàndia.

L'ergonomia participativa forma part de la tendència creixent d'incloure la persona sota el focus d'estudi (en aquest cas el treballador) en un marc concret (en aquest cas la prevenció dels riscos en l'àmbit laboral). Més enllà de l'ergonomia passiva, que inclou totes aquelles accions i presa de decisions que afecten al disseny del lloc de treball, avaluació de processos i riscos, equips de protecció individual (EPI), etc., l'ergonomia participativa, així com l'ergonomia activa, pretén fer partícip al propi treballador de les accions i actituds que poden ser nocives per ell mateix. És una visió de l'ergonomia que entén que el treballador 
també ha de ser coneixedor de tot allò que no ha de fer i evitar-ho, de la mateixa manera que ha de promocionar tot allò que li resulta beneficiós o neutre. Com descriu Garcia "el principi bàsic de l'ergonomia participativa és la capacitació dels treballadors perquè participin tant en la identificació dels riscos i danys derivats de les exposicions a càrrega física en el treball, com en la proposta i avaluació de les mesures de correcció adequades a cada situació” (Garcia et al. 2009, p. 509). I afegeix que “l'ergonomia ha d'actuar de diferent manera a cada situació específica, avaluant l'efectivitat de les intervencions i adaptant-se als canvis de factors determinats a través de l'assaig de noves accions" (Garcia et al. 2009, p. 510). Un exemple de posar en pràctica l'ergonomia participativa, és el mètode ERGOPAR, desenvolupat per ISTAS-CCOO "a partir del coneixement, experiència i resultats obtinguts en programes d'ergonomia participativa d'altres països, adaptant-ne mètodes i eines al context espanyol" (Garcia, febrer 2011), que proposa un procediment de millora contínua de les condicions laborals, així com la participació del treballador per aconseguir-ho. Aquest mètode inclou la formació d'un equip dins de la pròpia organització que anomena Ergo Grup i està compost per treballadors amb competències i punts de vista diferents sobre els llocs de treball. Aquest equip serà l'encarregat d'estudiar els llocs de treball, aportar propostes de modificació i supervisar la implementació de les millores.

Segons el manual desenvolupat per María José Sevilla Zapater (2014, p.12), els avantatges que proposa aquest mètode són els següents:

- Promou la participació dels diversos actors de l'empresa per a la millora de les condicions de feina

- Aborda una de les categories de riscos laborals —els trastorns musculoesquelèticsamb més impacte sobre la salut i el benestar dels treballadors i en preveu l'exposició

- Permet identificar i tractar moltes situacions de risc sense necessitat de fer servir complicats protocols tècnics

- Potencia la integració de la prevenció a l'empresa, i facilita la creació d'una cultura sòlida de prevenció 
Aquesta visió resulta interessant perquè explica com els temes ergonòmics no són estàtics, ni tan sols en un lloc de treball aparentment estàtic. Segons Garcia, es pot afirmar que "la participació de les persones afectades per la solució dels problemes es considera no només un dret sinó una necessitat per a la millora de les condicions de vida i de feina" (Garcia et al. 2009, p. 511). Quan canvia la persona, canvien les seves característiques i per tant cal redefinir elements a nivell d'antropometria i biomecànica. L'ergonomia participativa, desvirtua els esquemes estàtics de bones pràctiques entenent que l'ésser humà s'ha de moure i que rarament existeixen les situacions ideals, i per tant estàtiques. I aposta perquè la persona sigui conscient de tot allò que li és nociu, postures, esforços, càrregues, repeticions, etc.

L'ergonomia participativa vol arribar a diferents nivells de complexitat en relació a la seva anàlisi i a la seva proposta de millora. Per aconseguir-ho, Sevilla Zapater proposa una sèrie de preguntes que emmarquen inicialment l'abast del protocol: "Què volem aconseguir amb el mètode? El mètode continuarà més enllà de la seva aplicació inicial? Com participa el treballador i la direcció de l'empresa? I els seus representants? Quins mecanismes participatius es creen per a la implantació? La participació és voluntària o obligatòria? Qui pren les decisions?" (Sevilla Zapater 2014, p. 12). Aquest plantejament inicial per emmarcar el projecte ergonòmic s'aproxima a la necessitat del projecte de disseny d'emmarcar també el seu abast, com es veurà més endavant — vegeu Capítol III · Proposta per a una Metodologia de Recerca-, a través de premisses de disseny.

També es desprèn d'aquesta visió que el treballador cal observar-lo treballant, no només per adaptar-ne el lloc de treball, sinó també per fer-lo partícip dels canvis en la seves accions i actituds, i educar-lo en el seu propi cos. Els professionals que transmeten l'ergonomia activa i participativa volen canviar la visió existent que l'ergonomia posa barreres al treball amb llibertat, per fer entendre que l'ergonomia pretén promoure bones pràctiques, és a dir, accions beneficioses per a la pròpia persona. En aquest sentit, es busca la participació dels treballadors també en el diagnòstic de les problemàtiques i en la recerca de solucions, i no només es comuniquen els resultats i per a la realització dels canvis pertinents, sinó que es realitza formació per als treballadors. Aquesta formació inclou per una banda la transmis- 
sió de coneixements del propi cos humà, i per l'altra, l'anàlisi crítica dels llocs de treball i de les pràctiques habituals dels treballadors. Transmetre els termes i consells ergonòmics d'aquesta manera, permet arribar a consensos i assegurar-se un major compliment de les bases per a la higiene i seguretat laboral. Com explica Garcia, dels diversos agents que participen en el marc d'una estratègia d'ergonomia participativa (directius, especialistes, treballadors, tècnics, etc.), són precisament els treballadors que intervenen en més fases: anàlisi, propostes, priorització, assaig, implementació i avaluació (Garcia et al. 2009, p. 511). Com més coneixement té el propi treballador, més és capaç de prevenir per si sol les males pràctiques abans que succeeixin, de manera que la paraula prevenció, pren valor.

Per a aquesta recerca, l'ergonomia participativa resulta rellevant sobretot per dues qüestions:

1. Comprendre que la interacció entre la màquina i la persona no és estàtica, per tant cal fugir a nivell de disseny de la presa de decisions que guiïn cap a productes que obliguen a posicionaments estàtics

2. Que l'usuari és part fonamental en la presa de decisions.

Aquesta revisió s'allunya de la visió presentada en l'apartat anterior en relació a Robert i Brangier, ja que es troba a cavall entre l'ergonomia correctiva i preventiva, tot i així es considera que és interessant recollir-la tant pels dos punts citats més amunt, com pel fet que a través d'una bona anàlisi és possible desencadenar un procés d'ergonomia prospectiva lligada a escenaris futurs i a la innovació. A més a més, s'emmarca en la tendència que dona valor a l'usuari i a la pròpia persona, apoderant-la per prendre decisions sobre el seu propi benestar. El mètode ERGOPAR, per exemple, considera com a base fundacional que "les persones que desenvolupen el lloc de feina a analitzar són aquelles que millor el coneixen. Posseeixen la informació i l'experiència necessària per a abordar les situacions de risc ergonòmic des de la perspectiva d'activitat real a la feina" (Sevilla Zapater 2014, p. 21). Com es veurà més endavant, el Design Thinking — apartat 2.3.1— també dona valor al coneixement del treballador (anomenat usuari o persona en el món del disseny) i el posa com a una de les principals fonts d'informació. 
Sevilla Zapater (2014) també avisa de certes problemàtiques que es poden donar a l'hora d'aplicar el mètode. Aquí coincideix Carmen Mora en declaracions realitzades respecte el treball relacionat amb innovació empresarial in company a l'hora d'aplicar tècniques del Design Thinking (C. Mora en comunicació personal, 2 de juliol de 2015). Per exemple, Sevilla Zapater escriu que la motivació és clau per a la participació fluïda del treballador, així com que cal estar atent d'incloure tots els col·lectius de l'empresa necessaris perquè ningú es pugui sentir exclòs del procés de millora ergonòmica. Finalment, expressa la necessitat de ser clar amb els objectius del procés i donar-los a conèixer, de manera que ningú es pugui sentir frustrat o desmotivat perquè no s'estan complint les expectatives. A més a més, Sevilla Zapater afegeix que dins la pròpia organització que viu el procés de millora, tothom ha d'estar alineat, no només el treballador ha de participar convençut del procés, sinó que aquells amb capacitat de prendre decisions i aplicar-les han de tenir-ne la voluntat (Sevilla Zapater 2014, p. 21-23).

En resum, l'ergonomia participativa és la manera que l'ergonomia tradicional enfocada al món laboral ha trobat d'actualitzar-se. Afegint-se a la tendència general de fer partícip de qualsevol canvi als actors que hi tenen un paper, per aconseguir que els canvis siguin més fluids, consensuats i positius; a la vegada que busca fer conscient a cada persona de les coses nocives, i de les coses beneficioses.

\subsubsection{Ergonomia Cognitiva}

L'Associació Internacional d'Ergonomia ${ }^{4}$, IAE, divideix la disciplina en tres grans blocs: ergonomia física, ergonomia organitzacional i ergonomia cognitiva. La primera, i tal com en fa referència Erik Hollnagel és l'ergonomia tradicional amb una preocupació de "naturalesa tangible" relacionada amb l'anatomia, les característiques fisiològiques i biomecàni-

4 Per més informació, visitar el web de l'IAE https://www.iea.cc/whats/ 
ques, i que té com a principals objectius "reduir les lesions i malalties laborals, millorar la productivitat, i millorar la qualitat laboral" (Hollnagel, 1997, p. 1176). Com afirma l'IAE, l'ergonomia física es preocupa de temes com la postura, la càrrega de material, els moviments repetitius, etc.

Per altra banda, l'ergonomia organitzacional és aquella branca de l'ergonomia que es preocupa de l'optimització de les estructures, polítiques i processos, i que treballa al voltant de temes com la comunicació, la temporització de les tasques, el treball en equip, la qualitat o la gestió. És a dir, temes pròxims al disseny de serveis i a la gestió del disseny.

Finalment, l'IAE en el seu portal web (www.iea.cc) defineix l'ergonomia cognitiva com aquella branca de l'ergonomia que "fa referència als processos mentals com ara la percepció, la memòria, el raonament i la resposta motriu, que afecten a les interaccions entre humans i altres elements d'un sistema". Com es llegeix en el seu portal web (www.iea.cc), les principals preocupacions giren al voltant de "la càrrega de treball mental, la presa de decisions, el rendiment qualificat, la interacció humà/ordinador, la fiabilitat humana, l'estrès laboral i la formació". Per a Hollnagel, la veritable diferència radica en què "l'ergonomia cognitiva posa el focus en la manera com pensem, enlloc de en la manera com actuem, i més concretament en com les persones mantenen el control de la seva feina" (Hollnagel, 1997, p. 1173).

Per altra banda, es pot afirmar que l'ergonomia cognitiva fa referència a com la persona és capaç d'entendre el món que l'envolta i en conseqüència els artefactes que hi cohabiten. També en aquest punt cal parlar de complexitat, per aproximar-nos a la comprensió d'aquests artefactes, així com del coneixement tàcit que ens permet afrontar novetats sense massa problemes. Com també comenta Bustamante (2008), la intel-ligència ben dotada de Leonardo da Vinci (1452-1519) i de Miguel Angel (1475-1564), els va permetre englobar tot el coneixement i la cultura del Renaixement (Bustamante, 2008, p. 8). Actualment, degut a l'avanç en totes les disciplines i en totes les ciències, un coneixement comparable en una sola persona és inabastable. El món és senzillament massa complex. Per tant, cal 
dissenyar en concordança amb el coneixement tàcit i amb les capacitats cognitives de les persones, cal que es conegui quin és aquest coneixement i quines són aquestes capacitats, així com també comprendre com es percep, es processa i s'entén la informació que arriba al cervell a través del múltiples sensors distribuïts pel cos, exteroceptors que detecten estímuls procedents de l'entorn, i propioceptors, que transmeten estímuls del propi cos, per exemple de músculs, lligaments i tendons sobre la posició del cos. El coneixement conscient de l'entorn és molt reduït en comparació amb el coneixement inconscient. Aquesta afirmació és un dels principals arguments de la teoria del coneixement de Michael Polanyi, quan pretén reconsiderar el coneixement humà "començant pel fet que podem saber molt més del què podem explicar" (Polanyi, 1966, p. 4). Segons aquest autor, per exemple, som capaços de reconèixer se nse problemes centenars de fisonomies, però resulta molt complicat especificar amb paraules quins trets veiem per reconèixer-ne la diferència, i encara més complicat si es parla de fisonomies desconegudes. Polanyi afegeix, però, que si enlloc de descriure les faccions d'una cara, s'han de triar entre diverses opcions, la persona és molt més capaç en reconèixer i comunicar el seu coneixement. En aquest sentit, la descripció de Polanyi concorda amb un dels principis del Design Thinking, pel qual s'afirma que el dissenyador (o facilitador) ha de ser capaç de preparar les sessions creatives de manera que tothom pugui expressar el coneixement que té en relació a la temàtica tractada aportant eines que li facilitin la comunicació d'allò que sap, temes sobre els quals és expert, però que potser li resulta difícil comunicar o traslladar de forma comprensible per persones alienes al tema, o també, que com a expert, no és conscient del propi coneixement existent.

L'ergonomia cognitiva s'ha de preocupar, per exemple, de definir com es percep millor un senyal de velocitat, si amb un dial semicircular, amb un de lineal o amb informació numèrica digital, i on cal col·locar els controladors de velocitat respecte els seus indicadors. És a dir que s'ajuda de la psicologia per tractar sis funcions de la ment: (1) la percepció d'estímuls, (2) la selecció i la interpretació d'aquests estímuls, (3) la seva transformació i la resposta associada, (4) l'emmagatzematge d'informació i la memòria, (5) el raonament i el pensament reflexiu, i tot plegat per acabar desembocant en (6) l'acció, que fa referència 
a la predisposició, la conducta i el comportament, que ha de permetre a la Persona entendre i relacionar-se amb el món que l'envolta.

L'ergonomia es preocupa de la percepció d'estímuls a través dels cinc sentits: què és capaç de veure l'ull humà i com, quins angles de visió són adequats, què podem sentir o què és el soroll. Aquestes capacitats i viabilitats dels sentits es tradueixen en premisses projectuals que cal respectar, tant a nivell de disseny com a nivell ergonòmic.

També les emocions com a conjunt de respostes químiques i neuronals, produïdes pel cervell quan detecta un estímul i que desencadenen una emoció i una resposta automàtica corresponent formen part de les qüestions a tenir en compte ja que afecten a la Persona i a com aquesta s'enfronta als seus objectius i a l'entorn. Les reaccions afectives, més o menys espontànies que impliquen una avaluació personal que predisposa a l'acció. Les emocions s'associen a comportaments bàsics, de caràcter dual: premi o càstig, amor o odi, alegria o tristesa, etc. Les emocions duren poc i es converteixen en sentiment, que sí que perdura en el temps. Els dos termes, emoció i sentiment, són conceptes interrelacionats. En el moment que prenem consciència de les alteracions del nostre cos, l'emoció es converteix en sentiment. Els sentiments són l'avaluació conscient i subjectiva que fem de la percepció del nostre estat corporal durant una resposta emocional. A diferència de les emocions, els sentiments són sensacions de moderada intensitat i prolongades en el temps.

Els estímuls i la informació que rep el cervell es processa de maneres diverses, hi ha una part que rep una resposta intuïtiva associada a la resposta automàtica, i una part de resposta voluntària i reflexiva. La llum que arriba els ulls, els fa aclucar si és massa forta, aquesta acció és automàtica, però quan es fa conscient ens posem les ulleres de sol.

Per altra banda, la memòria com a procés complex que permet la codificació, emmagatzematge i recuperació de la informació, juga un paper bàsic i fonamental en la comprensió del món. Es pot parlar de dos tipus de memòria: (1) una memòria declarativa (explícita), que recull episodis viscuts i pensats de forma conscient, sobre els quals un mateix en pot parlar, i (2) una memòria no declarativa (tàcita), que recull tots els coneixements adquirits mitjan- 
çant la comprensió, durant l'aprenentatge i l'experiència. Tal com afirmen Henao-Cálad, Uribe Ochoa i Diez Gaviria (2016) el coneixement tàcit “s'adquireix a través de l'experiència, és personal, difícil d'expressar o capturar en paraules, s'aprèn a través de l'exemple i la pràctica quotidiana, es troba incorporat i es fa evident en el fer" (Henao-Cálad et al., 2016, p. 450). Aquest tipus de coneixement es contraposa al coneixement explícit, que es caracteritza per ser "objectiu, racional, seqüencial i teòric" (Henao-Cálad et al., 2016, p. 452).

Per a Michael Polanyi (1966) l'estructura bàsica del coneixement tàcit està formada per dos tipus d'elements que tenen una relació lògica entre ells: "s'arriben a conèixer els detalls dels elements, sense arribar a ser capaços d'identificar-los. Aquesta és la relació funcional entre els dos termes de coneixement tàcit: només coneixem el primer element confiant en la nostra consciència per assistir al segon” (Polanyi, 1966, p. 10). És a dir, que som capaços de descriure el primer element, i és aquest que ens guiarà a deduir el segon, encara que no es pugui descriure de forma conscient.

El raonament i el pensament reflexiu formen part de la zona més evolucionada del cervell i permeten a l'ésser humà formar-se opinions a partir de la informació de la qual disposa. És aquesta capacitat d'anàlisi i raonament que permetrà a un treballador formar part de l'Ergo Grup, que s'ha vist en l'apartat anterior, i prendre decisions adequades per al seu benestar i el de la comunitat. Entendre de forma bàsica els processos mentals que guien en aquest camí, així com els processos relacionats amb les relacions humanes estudiats per altres ciències com la sociologia o l'antropologia, ajuden a l'ergonomista en el seu treball d'anàlisi i diagnosi. L'última funció de la ment plantejada, és aquella que predisposa a l'acció, és a dir, una funció de la ment que implica el comportament, l'actitud i la predisposició de la persona. En resum, l'ésser humà és complex i així ho és també la seva capacitat de percebre, entendre i transformar el món. "Molts artefactes industrials contemporanis ens ofereixen una munió de possibilitats de realitzar les seves utilitats sense precedents en la història. [...] El que sens dubte hagués meravellat un home del segle passat és per a nosaltres un fet quotidià" (Martí Font, 1999, p.36). Cal tendir present, que la complexitat no només és tecnològica, "cal analitzar en profunditat les diversificacions funcionals i ser 
capaços d'inventariar-les, per tal d'arribar a comprendre amb la màxima eficàcia possible els complicats fonaments de la nostra cultura material" (Martí Font, 1999, p.38).

Donald Norman és un gran ordenador de la complexitat. Dues dècades abans de Living with complexity (2010), ja en parlava en una de les seves obres cabdals The Design of Everyday Things (1990), a través de la qual presenta cinc principis pel bon disseny relacionats amb la interacció entre la persona i el producte, aquest últim entès de forma àmplia. Norman (1990) analitza com la configuració dels objectes es fa comprensible a la persona i ajuda o entorpeix la comprensió del seu ús. És a dir, que forma i configuració no poden ser plasmats de qualsevol manera ja que d'ells en depèn la usabilitat i la comprensió de l'objecte.

Els principis pel bon disseny que proposa Norman (1990) són els següents:

- Visibilitat - Aquí fa referència a la necessitat que els elements indispensables per l'ús siguin visibles per la persona. Norman posa com a exemple el disseny de certes portes de vidre que no expliquen quina és la seva direcció d'obertura, ja que no tenen pom o cap altre tipus d'identificador, o fins i tot parets envidriades que no expliquen quina de les seccions és la porta. Els dos exemples poden provocar desconcert a la persona que ha de passar cap a l'altra banda. Com es veurà més endavant — vegeu apartat 2.2.1 Enfocament des del Disseny UI-UX. Disseny d'Interfícies i Experiència d'Usuari-, aquest principi es pot relacionar amb un dels heurístics de Jakob Nielsen que aposta per la visualització dels elements necessaris per a la navegació de la web abans que fer recordar una seqüència de comandaments a l'usuari, es tracta del principi reconèixer, abans que recordar. Ajudar a entendre com funciona la porta a través de la visualització dels elements imprescindibles pel seu ús (tot i que molt probablement ja s'hauria après al passar una segona vegada pel mateix lloc) i per tant evitar l'aprenentatge o memorització del funcionament, és precisament allò que busca aquest principi del bon disseny.

Martí Font (1999) explica molt bé el tema de la visibilitat en els objectes tecnològics. Aquest autor parla de pistes i també afegeix la característica cultural que participa de la pròpia comprensió de l'artefacte: 
"Per més amagat, per més emmascarat que quedi el funcionament real, cal garantir sempre la deducció de les operacions necessàries que estan en correlació directa amb aquell. [...] Aquesta necessitat és quelcom inherent a la cultura material humana moderna. Són necessàries pistes que han d'aparèixer en els nostres artefactes de tal manera que mostrin el seu funcionament al marge de les explicacions i les guies d'instruccions d'ús. Altrament no quedaria garantida l'eficàcia de l'ús i, el que és més important, l'aprenentatge d'aquest en els processos d'enculturació i en la vida quotidiana i en el sí de les institucions educatives." (Martí Font, 1999, p. 60)

- $\quad$ Limitacions - En aquest cas, Norman fa referència a la necessitat que el propi objecte impedeixi l'error humà. Per exemple, si dues peces només poden encaixar en una direcció, la forma i configuració d'aquestes peces han d'impedir que es puguin encaixar de cap altra manera que no sigui la correcta. En relació a l'error humà, bàsicament es pot parlar de dos tipus d'error, (1) l'error inconscient, en el qual la persona creu que ho està fent bé, encara que no sigui així, i executa amb destresa les accions que vol realitzar; i (2) l'error per falta de destresa, en el qual la persona pretén fer una acció correcta però per alguna raó no ho aconsegueix. El primer és més difícil de prevenir, però el segon cal dissenyar per evitar-lo.

- Prestacions - L'afany d'incloure el màxim de possibilitats no sempre és positiu, té un límit. L'autor posa com a exemple els telèfons centraleta, que tenen múltiples botons que no s'arribaran a fer servir mai i que, a més a més, en compliquen l'ús, ja que són susceptibles de ser premuts per error. A part, la gran quantitat de possibilitats es mostren a través de codis que cal memoritzar sense una lògica intuïtiva per a l'usuari. De manera, que al final, la gran quantitat de prestacions enlloc de ser una virtut, és un defecte.

- Topografia natural · És el nom que Donald Norman dona a la relació entre els comandaments i les accions comandades. Per exemple, l'accionament d'una palanca que farà aixecar un braç mecànic, ha de seguir la direcció del braç, és a dir, si s’aixeca la palanca, s'aixeca el braç, ja que d'aquesta manera la seva comprensió i ús és molt més intuïtiva. De la mateixa manera, que els comandaments d'una vitroceràmica han d'estar col·locats segons un esquema similar per a què es pugui identificar fàcilment el foc amb el seu accionador. 
També la norma tècnica NTP226: Mandos: Ergonomía de diseño y accesibilidad enumera algunes recomanacions per a la col·locació de comandaments respecte a allò que comanden. Per exemple, la reproducció de posicionament entre comandament i indicador quan estan en panells diferents, el respecte dels estereotips de conducta dels interruptors, o la seqüenciació temporal dels comandaments, en el cas que s'hagin d'accionar segons una seqüència concreta. I com s'ha vist anteriorment, McCormick (1980) i els seus principis per a la distribució del elements —vegeu 2.2.2.2 Usabilitat i Experiència d'Usuari-.

- Retroalimentació $\cdot$ L'usuari ha de veure, escoltar o sentir que les seves accions obtenen un resultat, per exemple, quan es prem un timbre, cal que la persona sàpiga que funciona, encara que s'estigui trucant uns quants pisos més amunt, l'aparell del carrer informa a través del so que efectivament s'està trucant. En el mateix sentit, si un botó té una acció retardada, cal que la màquina indiqui que hi està treballant.

Per a Martí Font (1999) la complexitat de l'artefacte — terme que aquest autor utilitza per parlar de l'objecte-, està relacionada amb "les deduccions que cal fer per determinar l'aprenentatge de la seva utilitat i del seu ús quotidià, sense recórrer a les sempre necessàries instruccions d'utilització que sovint acompanyen l'artefacte industrial" (Martí Font, 1999 , p. 57). Per a aquest autor, el canvi de paradigma en relació a la complexitat es basa sobretot en dues qüestions. Per una banda, l'objecte artesanal es podia llegir i entendre a través de la seva estructura material, que permetia a partir de la prova i error deduir-ne funcionament i ús. I per altra banda, aquesta estructura era evident a simple vista. És a dir, que visibilitat mecànica i deducció de funcionament eren conseqüència una de l'altra. En canvi, l'objecte actual no gaudeix d'aquestes característiques ja que l'evolució tecnològica i científica modifiquen aquest equilibri; al llarg de la història té lloc "la progressiva eliminació visual del moviment mecànic o energètic en els artefactes d'alta complexitat tecnològica" (Martí Font, 1999, p. 57). Un bon exemple d'aquesta evolució són els telèfons mòbils, que passen de tenir botons i tecles, a tenir una superfície plana i tàctil; amb paraules de Martí Font, amaga les seves "funcions operatives". "El moviment real mecànic i els tractaments formals inesperables que garantien la deducció de l'ús tendeixen a una progressiva separa- 
ció. El primer queda tancat a l'interior de l'artefacte, cada vegada més amagat per carcasses que l'envolten, mentre que el segon tendeix a la desaparició i queda sense objectiu, sense funció" (Martí Font , 1999, p. 57). Aquest autor escriu acabant el segle XX, la depuració de formes que tindrà lloc en els següents anys amb els objectes tecnològics, els mòbils, però també els petits electrodomèstics, reproductors de música, i en general tot els aparells tecnològics.

Per altra banda, l'ergonomia també es preocupa de la càrrega i l'esforç mental, i sobretot en un món cada vegada més tecnificat on la tendència continua sent la disminució de la càrrega i esforç físic i l'augment de la càrrega i esforç mental; i, en un context laboral aquesta càrrega mental es converteix en un dels factors més importants d'estrès laboral. Per això, en qualsevol disseny cal preveure la utilització adequada de les capacitats humanes i tenir en compte que les funcions cognitives no es poden analitzar només des d'un punt de vista quantitatiu (per exemple, quantitat d'informació donada); sinó que també cal analitzar-les des del punt de vista qualitatiu (relacionat amb la complexitat).

En definitiva, l'ergonomia cognitiva és també un apartat important de la reflexió ergonòmica; en aquest cas, per fer èmfasi en la interacció entre la persona i l'artefacte. L'ergonomia cognitiva es preocupa de la comprensió dels objectes per part de la persona, i ofereix recursos a l'hora de prendre decisions amb la finalitat que aquesta comprensió es faci de manera fluïda.

\subsubsection{Estudis de cas}

En el marc de l'assignatura d'Ergonomia de l'Escola Superior de Disseny, ESDi, de Sabadell, els alumnes desenvolupen un treball relacionat amb la usabilitat que pretén optimitzar l'ús d'un dispositiu interactiu, en aquest exemple, l'alumne rep l'encàrrec de redissenyar un comandament a distància. Aquest exercici es du a terme durant 4 setmanes (del 17 de març al 14 d'abril de 2020, en ple confinament per covid-19). Les dues primeres setmanes 
es destinen a les anàlisis, i les dues segones a l'elaboració, avaluació i comunicació de la proposta. Hi participen un total de 10 alumnes de 3r del Grau Oficial de Disseny, menció en Producte.

Per començar, l'alumne ha de realitzar una anàlisi del dispositiu fruit d'una observació objectiva. En aquesta anàlisi, ha de definir la finalitat de l'objecte, així com les seves característiques materials, formals, estètiques, funcionals i interactives a través de la definició de la relació entre components, la seva col·locació i estructura funcional. Seguidament, ha de realitzar una anàlisi contextual a través de l'observació de l'usuari fent servir el comandament. Per fer-ho, necessita conèixer les seqüències d'accions més i menys habituals i posar a prova l'usuari en l'execució d'aquestes accions. Aquesta observació, no és altra cosa que un anàlisi d'usabilitat en context d'ús. Un cop ha realitzat les dues anàlisis, ha d'extreure unes conclusions que definiran el seu redisseny convertint-se en premisses projectuals. Un dels principals temes a tenir en compte, a part de l'antropometria, és l'ergonomia cognitiva que descriu la capacitat d'interacció i comprensió que té l'usuari respecte un comandament a distància que probablement fa servir gairebé cada dia.

Es recomana als alumnes tenir en compte els principis pel bon disseny de Norman (1990) —vegeu 2.2.2.5 Ergonomia cognitiva一, els principis de distribució i col·locació de McCormick (1980) —vegeu 2.2.2.2 Usabilitat i experiència d'usuari-, així com els principis del disseny universal que vetlla per la bona usabilitat dels productes pel màxim d'usuaris possibles sense haver de tenir una adaptació o un disseny especial ${ }^{5}$. En aquest cas, l'alumne té llibertat total per modificar el comandament tant com consideri oportú sense tenir en compte altres tipus de restriccions econòmiques o tecnològiques. Tot i així, la proposta ha de ser plausible.

Fruit de les anàlisis, els 10 alumnes arriben a conclusions força similars, principalment relacionades amb l'antropometria de la mà i l'ergonomia cognitiva.

5 Podeu veure més informació sobre els principis del disseny universal tal i com es descriuen des de la facultat de disseny de la NC State University en el següent link: https://projects.ncsu.edu/ncsu/ design/cud/pubs_p/docs/poster.pdf 
Relacionada amb l'antropometria de la mà consideren que el comandament és massa gran per a un ús eficient de les diverses accions que es poden combinar, que cal anar desplaçant la mà amunt $\mathrm{i}$ avall per arribar a tots els botons. Dos alumnes observen diferències per dretans i esquerrans.

La segona conclusió és que el comandament no està cognitivament optimitzat, té molts botons que no es fan servir, i d'aquests, molts d'ells no es fan servir per desconeixement de la seva funció. Per altra banda, i només en 8 dels exercicis, els alumnes consideren que les necessitats actuals de visualització de la televisió ha canviat suficient com per necessitar un canvi radical en el comandament. De fet, un canvi que ja es pot observar, per exemple, en el control remot de l'AppleTV, o en d'altres dispositius de gama alta.

En relació al disseny universal, 7 dels alumnes inclouen a la seva proposta qüestions d'activació de funcions per veu o escriptura Braille.

A continuació es presenta una taula - vegeu taula 2- amb algunes de les propostes dels alumnes. Les imatges de l'esquerre corresponen al comandament a distància original, i les imatges de la dreta a la seva proposta, realitzada a través d'esbós o maqueta.

Taula 2: Mostra del resultat de l'exercici de redisseny d'un comandament a distància aplicant principis ergonòmics. (Fotos i esbossos realitzats pels alumnes de tercer del Grau Oficial de Disseny, menció en Producte, de l'Escola Superior de Disseny, ESDi, de Sabadell, en el marc de l'assignatura d'Ergonomia durant el curs 19/20)

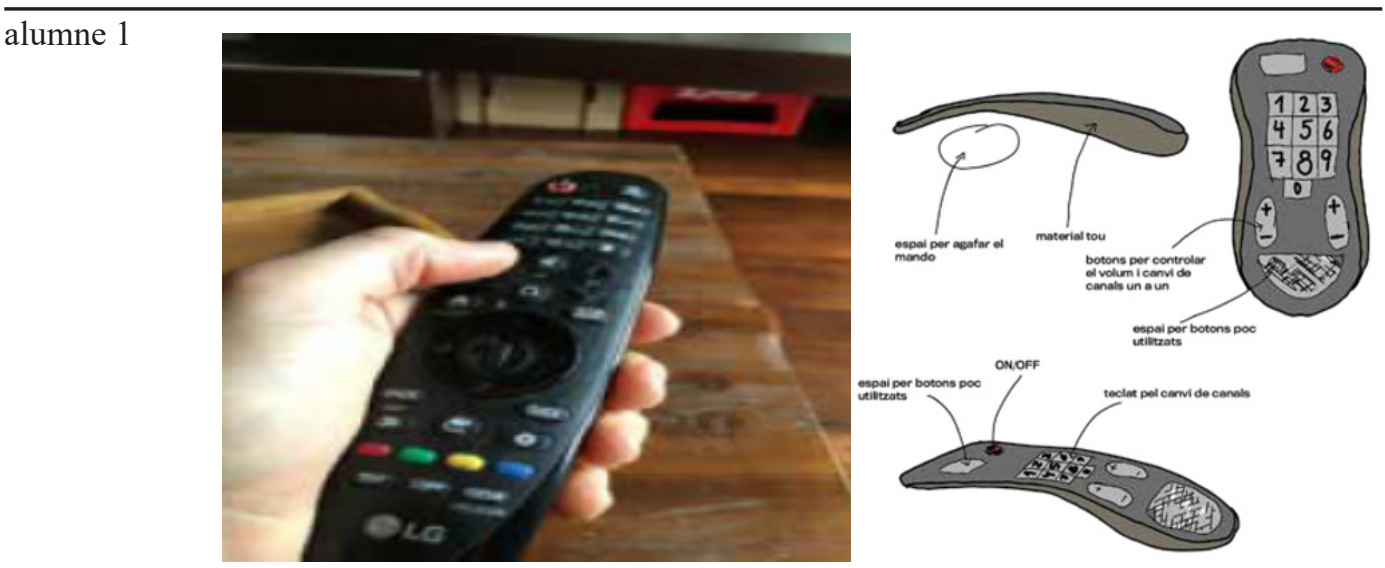


Aquest alumne no arrisca massa en la seva proposta, redueix mides, i treu botons, però encara manté els botons numèrics i deixa un espai per botons d'ús poc habitual. La seva proposta es basa, també, en un canvi de materials i de forma que millorin la presa manual

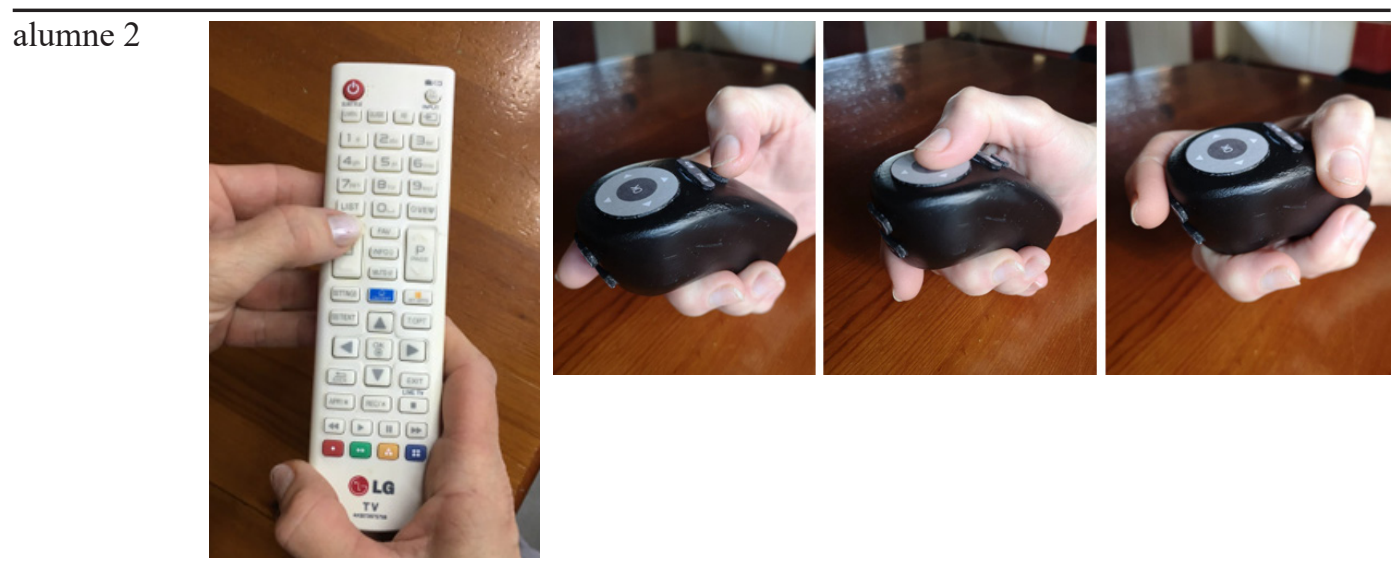

En aquest cas, l'alumne sí que arrisca i proposa un comandament on només hi tenen cabuda els botons amb les funcions més importants, a més a més, fent ús dels principis de McCormick distribueix les funcions a les diverses parts del seu comandament que passa a ser pròxim a un joystick. Aplicant els principis d'ergonomia cognitiva, optimitza el dispositiu per a una usabilitat molt més eficient i eficaç (un cop l'usuari s’ha familiaritzat amb el dispositiu). A més a més, té en compte la presa manual per a la configuració de la forma.

alumna 3
L'alumna se centra en l'optimització del comandament a través de l'ergonomia cogni-
sidera principals en un món d'smart TV. Per altra banda, inclou un sistema braile per a
la comunicació amb persones invidents. Manté en gran mesura les dimensions originals
del comandament, raó per la qual, no tots els botons que hi distribueix són accessibles
sense desplaçar la mà. En aquest sentit, caldria revisar les seqüències d'ús i els principis
funcionals per assegurar que la distribució s'hi ajusta de forma còmode i intuïtiva.


S'inclou aquest exercici docent com a exemple d'aplicació de diversos principis projectuals vistos al llarg d'aquest capítol. A més a més, serveix com a exemple d'ergonomia prospectiva, ja que a través de criteris ergonòmics és possible redissenyar un objecte de forma conceptual i tenint en compte aspectes d'usabilitat i experiència d'usuari. És un exemple de com l'ergonomia pot servir com a base per a replantejar objectes, sortint de la seva faceta preventiva relacionada amb la seguretat laboral. En els tres exemples mostrats, el grau de modificació i proposta innovadora és molt diferent, es podria afirmar que l'alumne 2 respon de forma més encertada en relació als principis prospectius en un replantejament de l'objecte.

\subsubsection{Conclusions}

Aquest treball s'estructura al voltant de la relació que s'estableix entre la persona i el món dissenyat, o l'artefacte — tal i com l'anomena Martí Font (1999)—, ja que es considera que a partir de l'anàlisi d'aquesta relació es podran desenvolupar unes premisses de projecte que respectin a la persona.

Concretament en aquest apartat, es fa una revisió sobre com l'ergonomia enfoca aquesta relació, i apareix en primer terme perquè precisament la manera com aquesta relació es desenvolupa és la raó de ser de l'ergonomia. Es presenta com a disciplina sistèmica i global que aborda la relació de la persona amb tot allò que l'envolta des de diversos punts de vista: físic, mental i organitzatiu. La funció bàsica de l'ergonomia des del punt de vista tradicional és establir premisses pel projecte que ajudin a totes aquelles persones responsables del disseny i desenvolupament d'un artefacte a respectar la persona per sobre d'altres prioritats. En un altre estadi, s'encarregarà també de la revisió i la millora dels artefactes existents.

L'ergonomia és una disciplina que es nodreix del coneixement d'altres ciències com la sociologia, la psicologia, la medicina, la física, la biologia, entre d'altres, i n'extreu de cada 
una la informació necessària per a recolzar les premisses projectuals. L'ergonomista treballa amb la persona com a centre de la seva tasca i té la ferma intenció de facilitar-li la vida, millorar-ne la comoditat i el benestar, i evitar-li qualsevol aspecte nociu. Aquesta immensa tasca, a més a més, ha de poder ser valorada i per això també cal definir quins són els límits acceptables sobre els quals es treballa: aquí entra en joc la usabilitat i la seva valoració del bon ús, tant de forma objectiva, com subjectiva.

Per altra banda, l'ergonomia estructura el seu coneixement a través del sistema persona/ màquina, que ordena la realitat $\mathrm{i}$ ajuda a l'investigador a no deixar de banda cap element important; això inclou des de les dimensions antropomètriques i la capacitat d'esforç, passant per detecció de necessitats de l'ergonomia prospectiva que defensen Robert i Brangier - vegeu apartat 2.2.2.3 Ergonomia Prospectiva一, fins a la comprensió de l'objecte i l'entorn que defensa l'ergonomia cognitiva —vegeu apartat 2.2.2.5-. A través del sistema persona/màquina, l'ergonomia defineix (1) qui fa què, (2) com ho fa, (3) què necessita per fer-ho, (4) on ho fa i (5) què vol aconseguir.

Aquesta mirada sistèmica i global, és útil tant a la visió més tradicional de l'ergonomia, com a mirades més pròximes al disseny, com l'ergonomia prospectiva que defensen Robert i Brangier des d'una tradició francòfona. Aquests autors centren la seva recerca en la definició d'un repte de disseny basat en l'experiència, les necessitats, els desitjos o problemàtiques de la persona, de manera molt similar a com ho desenvolupa la disciplina del disseny. És amb aquests autors que es fa clarament visible la relació profunda entre l'ergonomia i el disseny a través de l'eix central que guia ambdues disciplines i que és la seva raó de ser: la persona.

Al llarg dels seus articles, Robert i Brangier parlen de l'ergonomia prospectiva com una disciplina multidisciplinària, que es basa en l'experiència d'usuari, està relacionada amb la tecnologia i enfocada a la innovació. Unes característiques clarament extrapolables al disseny, tal i com es veurà en els propers apartats.

Per la seva banda, l'ergonomia més tradicional s'actualitza a través de l'anomenada ergonomia participativa que busca fer partícip a l'usuari del coneixement del seu propi cos i 
capacitats, així com de la presa de decisions que afectaran al seu lloc de treball, de manera que sigui més fàcil arribar a consensos i es faci conscient de tot allò que li pot resultat nociu (per evitar-ho), o profitós (per promocionar-ho).

Finalment, en aquest apartat es fa una revisió del què significa l'ergonomia cognitiva. Com tenir en compte les capacitats de percepció, comprensió, resposta i maneig de la Persona, així com la relació entre la memòria i el coneixement tàcit, amb la presa de decisions respecte el comandament de l'artefacte. Cal saber en quin món vivim, respectar els estereotips de conducta i abordar la complexitat tècnica i tecnològica actual i del futur que es preveu, per establir premisses projectuals adequades.

En resum, aquest apartat aporta eines ergonòmiques per a l'estructuració d'una anàlisi sistèmica i global del projecte de disseny.

\subsubsection{Enfocament des del Disseny UI-UX. Disseny d'Interficies $i$ Experiència d'Usuari}

Com s'ha vist en l'apartat anterior, usabilitat i experiència d'usuari són termes propis de l'ergonomia, però d'alguna manera, el disseny d'interfícies i aplicacions digitals se n'ha apoderat. Actualment, aquests dos conceptes estan àmpliament descrits dins d'aquest àmbit del disseny i han quedat camuflats en àmbits més tradicionals com el disseny de producte i el disseny d'espais que ho tracten de forma diferent, no tant com a raó de ser sinó com a part a tenir en compte. La tendència cap a l'experiència és clara, però els àmbits del disseny més tradicionals i més assentats segurament són més lents, o poc àgils, a l'hora d'adaptar-se a metodologies col-laboratives com el Design Thinking, el co-design, ja que la seva base tradicional és molt més àmplia i està més assentada, $\mathrm{i}$ encara que siguin conceptes que li són propis els introdueix de forma paral·lela sense modificar la metodologia del projecte des de la base. 
A l'altre extrem, l'anomenat disseny UI-UX, precisament acrònims per denominar UI com a interfície d'usuari (de l'anglès User Interface) i UX, com l'experiència (de l'anglès User eXperience), s'apodera dels dos termes. Recull usabilitat descrita com a un atribut d'una bona experiència d'usuari; és a dir, com un atribut de qualitat. I recull experiència com al disseny centrat en l'usuari, que es preocupa més enllà de l'estricte moment d'ús. El disseny UI-UX és una disciplina relativament nova, si més no en creixent importància, de la mateixa manera que el disseny de serveis, les dues disciplines molt més dinàmiques i àgils en adaptar-se als nous enfocaments del disseny, entre altres raons perquè neixen i evolucionen al mateix temps que aquests conceptes. Acullen l'experiència i la usabilitat com a raó de ser de la seva metodologia projectual. És per aquest motiu que, tot i apartar-se de l'àmbit d'aquest treball, es considera important acostar-s'hi per desxifrar-ne els seus principis i conceptes troncals.

\subsubsection{Heurístics de Jakob Nielsen. Usabilitat i experiència d'usuari}

Jakob Nielsen s'erigeix com el gran guru de la usabilitat i l'experiència d'usuari descrita des de la comprensió de la interacció en el món digital. La seva aportació més reconeguda són les regles heurístiques d'usabilitat que permeten definir aquest terme més enllà d'un atribut de qualitat. Amb el coetani Adolphe Chapanis van assentar les bases de la usabilitat a principi dels anys 90, referint-se a usabilitat com la facilitat d'ús d'un producte o sistema, en el moment que interactuen tres supòsits: persona, tasca i entorn, descripció coincident amb la Usabilitat descrita des de l'Ergonomia.

Actualment, Jakob Nielsen continua descrivint la usabilitat a partir del disseny UI-UX, a través dels cinc components que atribueixen qualitat a una interfície (Nielsen, 2012):

1. Capacitat d'aprenentatge: com l'usuari és capaç de moure's per una pàgina el primer cop que la visita. 
2. Eficiència: un cop que l'usuari coneix el disseny, amb quina rapidesa pot realitzar tasques?

3. Capacitat de memorització: quan l'usuari torna a una pàgina, amb quina facilitat és capaç de dominar-la de nou?

4. Grau d'error: quants errors comet l'usuari? Com de greus són aquests errors? Amb quina facilitat es poden corregir?

5. Nivell de satisfacció: és agradable visitar la pàgina?

Aquí doncs es recuperen part de les característiques a tenir en compte per al bon desenvolupament de la usabilitat, que s'han vist a l'apartat 2.2.2.2 Usabilitat i Experiència d'Usuari, però aquí aplicats exclusivament a la navegació de les interfícies i als portals i pàgines web. La clau de la usabilitat, com sempre, i des de qualsevol enfocament, és intentar valorar-la de forma objectiva, per poder extreure conclusions comparables que permetin definir si el nivell d'usabilitat és alt o baix respecte similars. Segons Nielsen, només es pot descriure la usabilitat a través d'atributs mesurables que permetin analitzar-la de forma sistemàtica (Nielsen, 1993, p. 26). També en aquest sentit Nielsen coincideix amb l'ergonomia, que pretén establir protocols per una anàlisi objectiva de la usabilitat tal i com descriu la norma ISO 9241-210 per els sistemes interactius. Un cop més, ergonomia i disseny comparteixen la matèria d'estudi.

Per altra banda, el mateix Nielsen (2012) justifica la importància de la usabilitat amb el fet que es tracta d'un element imprescindible per a la "supervivència" de la pàgina o aplicació. Si una web és difícil de fer servir, la gent no hi tornarà, o fins i tot la tancarà abans d'aconseguir allò que vol. En aquest mateix article introductori, Nielsen argumenta que realitzar un test d'usabilitat és la millor manera d'assegurar la qualitat d'un producte. També argumenta que en cada fase del disseny la usabilitat juga el seu paper i que per tant caldrà testar-la tantes vegades com es consideri oportú. Com ja apunta a Usability Engineering (1993) el disseny és un procés iteratiu i cal redefinir les idees a través del prototipat i el test en múltiples iteracions, fins al test de la proposta final. És a dir, que Nielsen ja proposa el 1993 
una de les bases projectuals que recull el Desing Thinking, la iteració — vegeu apartat 2.3.1 Design Thinking-. Entre les diverses eines per a mesurar la usabilitat que proposa Jakob Nielsen, es troba l'anàlisi heurístic, l'objectiu principal del qual és "trobar els problemes d'usabilitat en un disseny d'interfície d'usuari perquè puguin ser atesos com a part d'un procés de disseny iteratiu" (Nielsen, 1993, p. 155).

Jakob Nielsen (1994) presenta 10 principis generals per al disseny d'interacció en una altra de les seves obres cabdals, els anomena principis heurístics ja que són regles generals:

1. Visibilitat de l'estat del sistema - El sistema ha de mantenir l'usuari informat sobre què està passant, això inclou per exemple qualsevol estratègia per mostrar com es carrega una pàgina, $\mathrm{o}$ la barra que mostra el procés de descàrrega

2. Concordança entre el sistema i el món real · La interfície ha de parlar un llenguatge que pugui comprendre l'usuari de forma natural i lògica, i per tant en concordança amb el món real. Això està relacionat tant amb el vocabulari i les explicacions, com amb les icones o altra informació gràfica del sistema

3. Control de l'usuari i llibertat - Aposta perquè l'usuari sempre tingui la possibilitat de tornar enrere si s'ha equivocat, és a dir, que mantingui el control de la navegació, a la vegada que se senti amb llibertat suficient per escollir allò que vol veure

4. Consistència i estàndards - Aposta per mantenir les convencions, de manera que a l'usuari no li faci falta preguntar-se què significa un concepte, o que no dubti preguntant-se a quin apartat correspon allò que està buscant

5. Prevenció de l'error · Tot i que, tal com diu l'heurístic de concordança amb la realitat, els missatges d'error han ser entenedors i concrets, previ a l'aparició de l'error s'aposta per preveure'l i prevenir aquest error, de manera que el missatge ja no faci falta

6. Reconèixer millor que recordar - Aposta per fer visible tot allò necessari per a la navegació i evitar que l'usuari hagi de recordar on eren les coses perquè tenen una ruta d'accés complicada. És a dir, les diverses funcions han d'estar a la vista, o s'han de poder recuperar amb facilitat 
7. Flexibilitat i eficiència d'ús · La flexibilitat permet configurar el sistema de manera que l'usuari expert pugui crear dreceres impossibles d'entendre per l'usuari novell i així optimitzar-ne l'ús, és a dir adaptar la configuració per a usos freqüents

8. Estètica i disseny minimalista $\cdot$ Els diàlegs han de ser precisos i concisos, i evitar informació irrellevant o poc utilitzada. Tota informació que està de més impedeix una navegació fluïda i augmenta el risc d'error i confusió

9. Ajudar als usuaris a reconèixer, diagnosticar i recuperar-se dels errors · Un cop l'error ha tingut lloc, el missatge que l'acompanya ha de ser explicatiu del per què i oferir solucions constructives per solucionar el problema

10. Ajuda i documentació · Encara que la interfície pugui funcionar sense ajuda ni explicacions, la seva documentació hauria de ser fàcil de localitzar i hauria d'oferir informació respecte les tasques de l'usuari i les accions a realitzar

Si recollim els cinc principis pel bon disseny que proposa Donald Norman — vegeu apartat 2.2.2.5 Ergonomia Cognitiva- es pot veure la correspondència amb els heurístics que proposa Jakob Nielsen. En primer lloc, l'heurístic de Visibilitat del sistema de Nielsen és paral·lel a la Retroalimentació de Norman, tant un com altre principi pretén que l'usuari no es pensi que alguna cosa no funciona adequadament perquè no obté una resposta immediata del sistema, Norman posa l'exemple del timbre, Nielsen la barra de càrrega i el percentatge d'execució. Pel què fa a l'heurístic de Concordança entre el sistema i el món real és paral·lel al concepte de Topografia natural de Norman, els dos aposten per afavorir una concordança i lògica de posició i direcció, també relacionat amb convencions gràfiques i culturals, com per exemple el color blau per l'aigua freda i el vermell, per l'aigua calenta. En tercer lloc, l'heurístic Reconèixer millor que recordar és paral·lel al principi de Visibilitat de Norman. Els dos aposten per a la bona visibilitat de tot allò necessari per ajudar a l'eficiència i eficàcia en l'execució d'accions. En quart lloc, el principi projectual de Prestacions està repartit per diversos heurístics, per exemple Flexibilitat i eficiència d'ús és paral·lel en el sentit que l'afany d'incloure el màxim de prestacions no sempre és po- 
sitiu. Però també és paral·lel amb l'heurístic Estètica i disseny minimalista, ja que els dos principis aposten per incloure només allò necessari que ajudi a evitar errors, de manera que també forma part de l'heurístic de Prevenció de l'error. Tot plegat relacionat amb l'intent de simplicitat com a ajuda al bon ús. Finalment, en cinquè lloc el principi Limitacions de Norman, que es pot reconèixer també en l'heurístic Estètica i disseny minimalista per la recerca dels dos d'una configuració d'acord amb la usabilitat, que simplifiqui les accions i el camí per aconseguir un objectiu.

Els heurístics només són, però, una de les principals tècniques que presenta Nielsen (1993) per a l'anàlisi d'usabilitat. Altres tècniques cabdals i, a més a més, profundament relacionades amb les idees del Design Thinking — vegeu apartat 2.3.1 Design Thinking-, són l'observació de l'usuari mentre interactua amb la interfície i el què Nielsen anomena scenarios. En aquest cas, es tracta de prototipar la interfície de manera que es pugui testar de forma més senzilla, o més barata, una part concreta de la pàgina o l'aplicació, sense haver d'esperar a tenir-la completa.

La quarta tècnica que considera cabdal és el test d'usuari en el qual aquest últim explica en veu alta allò que va fent. Aquesta tècnica, que també inclou l'observació, afegeix el raonament de l'usuari a l'equació i permet recol·lectar els perquès de les accions que realitza, és a dir, quina intenció té quan executa una acció. Això permet, entre altre coses, veure el tipus d'error que ha comès l'usuari, si és inconscient (per tant l'usuari ha pres una mala decisió) o per falta de destresa (l'usuari a pres una bona decisió però no ha aconseguit executar-la adequadament).

Actualment, el fet de testar la usabilitat durant el procés de disseny és un imprescindible per a aplicacions i webs. Jakob Nielsen i Donald Norman tenen un portal web que dona veu a la investigació relacionada amb l'experiència d'usuari anomenat Nielsen Norman Group (www.nngroup.com). En aquesta plataforma, s'hi troba, per exemple, un article de Hoa Loranger (2018) titulat Usability Test, Even When You Know the Answer, que serveix com a exemple per visualitzar la importància que se li dona al test d'usabilitat. Segons Loranger 
"el benefici més obvi [del test] és descobrir la millor manera d'abordar les necessitats de l'usuari, identificant els elements de disseny que funcionen o no"6. En aquest article, l'autora no només argumenta la bondat del test per a la pròpia usabilitat, sinó que també afirma que el simple fet de realitzar-lo i obtenir resultats, és una manera de convèncer el client com a proba de bon funcionament.

Loranger (2018) posa sobra la taula un dels punts habitualment conflictius duran el procés de disseny: es tracta del moment quan, després d'una fase de divergència on apareixen múltiples idees possibles, cal convergir i prendre decisions — vegeu apartat 2.3.2 Doble Diamant—. L'autora argumenta que el test d'usabilitat és una bona manera de mesurar quines propostes (encara que totes siguin bones) funcionen millor, obtenint la resposta directament de l'usuari. De la mateixa manera, si alguna proposta no fos encertada i l'usuari no respongués com s'espera, el test d'usabilitat també ho detectaria.

Resumint, i tal com explica el propi títol de l'article de Loranger, “testar la usabilitat mai és una pèrdua de temps, encara que creguis saber-ne la resposta" (2018).

Tornant a l'Experiència d'Usuari, Nielsen afirma en el seu article "A 100-year view of User Experience" (2017) que és Donald Norman qui encunya el terme experiència d'usuari pel seu grup de treball a Apple Computer al voltant de 1993. Seguidament, però, també afirma que el camp és més antic que el terme, tal i com demostra en el títol de l'article. Nielsen i Norman col·laboren constantment i per això les seves teories, tot i que diversificades en l'objecte de recerca, coincideixen en les observacions i les premisses projectuals i es presenten com a principis heurístics o com a principis per la bona pràctica del disseny.

En aquest article, Nielsen presenta la dificultat de "traçar la línia entre els factors humans tradicionals i allò que podríem anomenar l'experiència d'usuari, dirigit al disseny centrat

6 Article recuperat a https://www.nngroup.com/articles/test-when-you-know-answer/. (Consultat el $02 / 02 / 2018)$

7 Article recuperat a https://www.nngroup.com/articles/100-years-ux/?lm=the-design-of-everyday-things\&pt=book. (Última consulta 27/02/2018) 
en l'ésser humà dels sistemes interactius"8 (2017). Quan escriu "factors humans", Nielsen fa referència al que des d'aquest costat de l'Atlàntic entenem com a "característiques ergonòmiques" i quan les descriu com a "tradicionals" està fent referència al fet que obvien precisament l'experiència d'usuari. Al mateix temps, Nielsen també està traçant una línia entre l'experiència d'usuari en referència als sistemes interactius, i la resta de sistemes, que podem anomenar, per exemple, analògics.

De totes maneres, Nielsen se situa, com també fa Donald Norman, sota el plantejament que l'experiència d'usuari no es limita als sistemes interactius, sinó que engloba un període més llarg de temps; és a dir, que també engloba abans i després del moment concret d'ús.

Donald Norman ho explica de manera molt clara en el vídeo "Don Norman: The Term UX"9 . Norman afirma que l'experiència d'usuari ho és tot: des del moment que es decideix comprar un producte. En aquest vídeo, posa com a exemple la compra d'un paquet i afirma que també és experiència d'usuari quan la caixa no cap al cotxe, quan s'arriba a casa carregat, quan s'obre el paquet, etc. En aquest vídeo, qui va encunyar el terme experiència d'usuari, afirma que en moltes ocasions se'n perverteix el significat. S'entén aquí que es perverteix des de la seva comprensió reduccionista, és a dir, a referir-se únicament a interfícies d'interacció d'aplicacions i webs.

Nielsen (2017), per la seva banda, procura aprofundir en les raons que han portat a la generalització del terme i enumera tres factors. Per començar, fa referència a la revolució informàtica de final dels anys 80 del segle XX que va posar especial pressió a la indústria informàtica perquè millorés la usabilitat dels seus productes. En segon lloc, fa referència a la revolució web dels anys 90 i 2000, que va posar especial pressió sobre la indústria perquè millorés el seu disseny d'interacció. I finalment, fa referència a la cobertura dels mitjans, especialment durant la bombolla de les empreses denominades puntcom. Segons

8 Article recuperat a https://www.nngroup.com/articles/100-years-ux/?lm=the-design-of-everyday-things\&pt=book. (Última consulta 27/02/2018)

9 Consultat per últim cop a NNGroup el 28 de febrer de 2018.

https://www.nngroup.com/articles/definition-user-experience/ 
Nielsen, aquests tres factors són clau per entendre com el món digital s’apodera del concepte experiència d'usuari.

En resum, no s'entén el disseny d'interfícies sense el concepte d'experiència d'usuari, així com tampoc és possible deixar fora la usabilitat. Els dos conceptes són la base per al desenvolupament del producte digital, i treballen guiats tant pels principis heurístics com pels principis que marquen els diversos processos i testos d'anàlisi de la usabilitat. El punt de contacte entre el món digital i el món físic o analògic es troba, en aquest cas, a través de les teories paral·leles, i en molts casos compartides de Donald Norman i Jakob Nielsen.

\subsubsection{Enfocament des del Disseny de Producte}

El disseny de producte és l'àmbit del disseny que per tradició li ha donat nom i n'ha configurat el marc d'aplicació i desenvolupament, sobretot si entenem que tot allò que ens envolta és un producte. Tot i així, aquesta afirmació segur que desperta grans discrepàncies, començant per enginyers i arquitectes que s'han dedicat a desenvolupar producte, i acabant per dissenyadors gràfics i de moda que tenen el mateix llarg recorregut que el disseny de producte. Tot i així, emmarcat en la reflexió i l'estructura metodològica del projecte, el disseny de producte ha tingut una tradició basada en l'experiència i en les maneres de fer dels propis dissenyadors que es traslladaven a les escoles de disseny any rere any. Amb l'arribada del segle XXI i la proliferació del món digital, així com de visions més experiencials relacionades amb la interacció, el disseny de producte s'ha hagut de reubicar per introduir nocions d'experiència d'usuari i usabilitat, que ja li eren pròpies, però no des d'un punt de vista central i metodològic. És a dir, el producte i la persona sempre han tingut interacció, ja que això és la seva raó de ser, però en el moment que el disseny digital pren la iniciativa del disseny d'interacció, el disseny de producte ha de reivindicar-se com a interacció tangible tant important com la intangible, i, en certa manera, amb les mateixes característiques. 
En aquest sentit, en aquest apartat es veuen dues visions del disseny de producte enfocades clarament cap al disseny de la interacció que portarà a definir un producte que li doni resposta a través de l'experiència d'usuari.

\subsubsection{Experiència d'Usuari. Metodologia sorgida a la Universitat Tècnica TUDelft}

Des de la Universitat de Delft, Paul Hekkert i Matthijs van Dijk, amb la seva obra Vision in Product Design: Handbook for Innovators (ViP) publicada el 2011 parlen de l'experiència d'usuari des de la visió del disseny de producte i de manera clarament prospectiva. Ja en la introducció afirmen que "és crucial observar a les persones que interactuen amb un producte per poder veure el seu significat real, ja que precisament durant la interacció és quan els productes revelen i absorbeixen significat" (Hekkert i van Dijk, 2011 p.15). Per a aquests autors, el context és un element clau que va més enllà dels aspectes físics ja que afirmen que també està compost per la part sociocultural, econòmica i tecnològica.

La interacció és la clau del canvi d'enfocament: dissenyar d'acord amb els principis de ViP significa "explorar allò que serà possible demà en comptes de solucionar els problemes d'avui”". I això bàsicament significa que cal "canviar la manera amb la qual la gent interactua amb els productes", aquest canvi només serà possible si "el dissenyador desitja canviar el significat de la relació entre l'usuari i el producte" (Hekkert i van Dijk, 2011 p. 16).

Hekkert i van Dijk (2011) revolucionen l'ordre natural de la metodologia projectual i afirmen que els productes són el mitjà per aconseguir interaccions (relacions) apropiades, ja que és així com obtenen significat. D'aquesta manera, els autors afirmen que el seu mètode està centrat en la interacció (no en l'usuari). A part, tal i com es comenta al paràgraf anterior, un dels altres punts claus és el context. Quan aquest context és el futur, pot ser que reclami nous comportaments $\mathrm{i}$ experiències, d'aquí que afirmen que $\mathrm{ViP}$ "està guiat pel context". El fet d'unificar els dos punts clau fa possible que es pugui afirmar que "l'element central de l'experiència en el disseny ViP consisteix en comprendre quin tipus de relació, 
o interacció, s'ajusta a un context específic" (Hekkert i van Dijk, 2011 p. 120). Segons van avançant en la descripció de la metodologia, els autors guien al dissenyador en aquest nou enfocament: no es tracta de desenvolupar una idea de producte que doni resposta a algun problema, es tracta de visualitzar la relació entre l'usuari i el producte sense saber allò que es dissenyarà, sobretot enfocat en les possibilitats i les oportunitats, posant èmfasi sobre els somnis, desitjos i hàbits de les persones. La interacció és el punt de contacte entre el context i el producte, la interacció defineix com el producte s'utilitza i s'experimenta. Segons els autors, el profund coneixement de les relacions entre cada element (context, interacció i producte) és l'element que ajuda al dissenyador a desenvolupar productes més efectius.

Aquesta visió innovadora en el desenvolupament metodològic del disseny de producte resulta interessant per aquesta recerca no només per donar una visió des del disseny de l'objecte, sinó també perquè descriu una manera diferent d'enfocar la interacció fora del món digital. Es tracta d'una visió clarament enfocada a la innovació i al disseny de producte nou, que es podria lligar també amb la descripció de l'ergonomia prospectiva de Robert i Brangier — vegeu subapartat 2.2.2.3 Ergonomia Prospectiva—.

L'esquema projectual que proposen Hekkert i van Dijk es pot veure a la figura 3, és un recorregut dividit verticalment en el costat esquerre (la desconstrucció i moment actual) i el costat dret (el disseny i el moment futur). Un recorregut que primer puja i després baixa, marca el transcurs del projecte i va passant a través de 3 nivells diferents que es repeteixen a un i altre costat. Els nivells són: nivell de producte, nivell d'interacció i nivell de context. Aquest esquema dibuixa la metodologia del projecte basada, precisament, en la interacció i el context. El futur, que queda emmarcat a la dreta, és l'aportació que dona resposta als desitjos de les persones. La pregunta bàsica per poder avançar i fer propostes prospectives és l'anàlisi del per què? i no com és habitual, l'anàlisi del què? (Hekkert i van Dijk, 2011, pp. 119-137).

La fase de desconstrucció és la que interessa en aquest treball, ja que és la fase que posa les bases, és a dir, les premisses projectuals, per al desenvolupament del projecte. Per a Hekkert i van Dijk, l'acció clau en aquesta fase és la mirada. En el nivell Producte: aprendre a mirar 


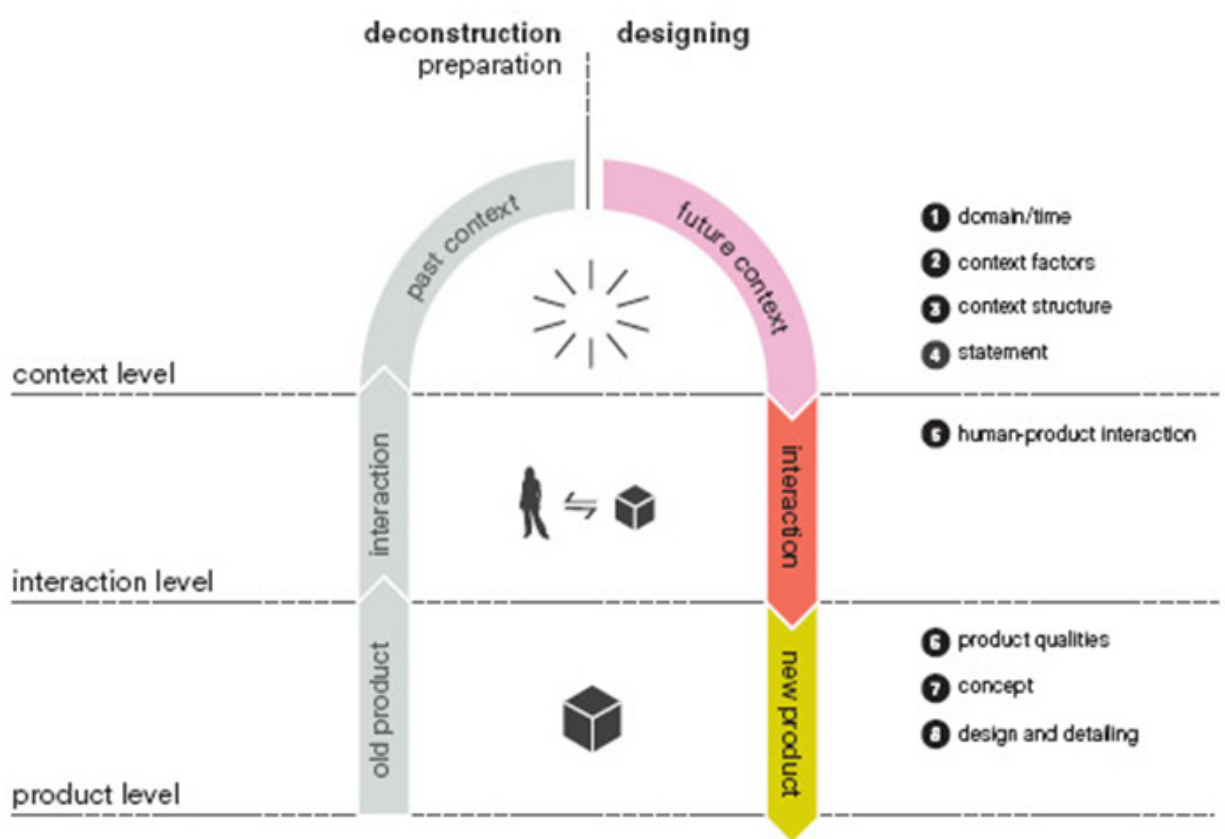

Fig. 3 Esquema metodològic a ViP, Hekkert i van Dijk, 2011, p. 119

i veure més enllà de la descripció del què veus, fins i tot aprehendre allò que no veus, és clau per assentar unes bases, i per oblidar que el producte, no té perquè ser un producte, també pot ser una aplicació, un servei, o una estratègia. En el nivell Interacció: allò que s'observa ja no és estàtic, cal la voluntat de caracteritzar la interacció i atorgar-li qualitats. El perill en aquest nivell, és qualificar la interacció caracteritzant la persona o l'artefacte, i el repte és caracteritzar la interacció ${ }^{10}$. Finalment la mirada en el nivell Context, ha d'estar enfocada cap a les tendències, les circumstàncies del moment o les problemàtiques que motiven el producte, la solució proporcionada. La clau d'aquest procés projectual és com “els principis i altres consideracions que es tenen en compte per conèixer per què la interacció observada té les qualitats que té i, conseqüentment, per què el producte és com és. Agafant

10 Aquest és un punt complicat de dur a terme si no es té pràctica en l'exercici de definir la interacció, ja que tradicionalment, el disseny de producte tendeix a definir la persona i l'artefacte 
aquestes reflexions, es formen les condicions possibles que han donat lloc a l'existència d'aquest producte" (Hekkert i van Dijk, 2011, pp. 126).

La fase de disseny, la que apareix a la dreta, transcorre de forma inversa i el què es proposa és tenir en compte el Context en primer lloc, després el nivell Interacció i per últim el nivell Producte. "En primer lloc, el dissenyador preveu un nou context; a continuació, es pregunta quina mena d'interacció resultarà i, finalment, dissenya un producte que fa possible la interacció desitjada." (Hekkert i van Dijk, 2011, pp. 134). Aquest és l'esquema bàsic, a partir d'aquí cada nivell es subdivideix en fases que ajuden al dissenyador a passar d'un nivell a l'altre.

En resum, aquesta metodologia és un bon exemple per l'èmfasi que posa en la interacció i la voluntat explícita de deixar pel final (o com més enllà millor) la pròpia essència del producte a dissenyar; és a dir l'artefacte final. De manera que sigui quin sigui aquest artefacte, realment encaixi amb les premisses projectuals establertes prèviament.

\subsubsection{La visió d'Elizabeth Sanders}

Elizabeth Sanders és de formació psicòloga i antropòloga. La seva relació amb el disseny comença els anys 80 del segle XX quan entra a formar part d'un equip de treball en disseny. En aquell moment la seva tasca és conèixer l'usuari i traduir aquest coneixement en principis i prescripcions que puguin entendre els dissenyadors de l'equip. D'alguna manera, s'estan posant les bases per un disseny humanista, que s'anomenarà centrat en l'usuari. A part, Sanders també s'interessa en aquell moment, pels mateixos dissenyadors, i de quina manera es comuniquen de forma visual els uns amb els altres.

La seva investigació culmina en el Convivial Toolbox (2012), que publica juntament amb Pieter Jan Stappers. Una de les seves principals aportacions en la recerca en disseny és el fet de tenir una visió global dels diversos camps on actua la disciplina i dibuixar de manera 
coherent i comprensiva el procés d'importància que viu el concepte d'experiència d'usuari. Sanders afirma que l'enfocament centrat en l'usuari iniciat els anys 70, i que havia agafat embranzida durant els anys 90, deixa de ser suficient en ple segle XXI, ja que aquest enfocament per si sol no pot afrontar la creixent complexitat ni els reptes de l'actualitat. Anys abans, Sanders i Stappers (2008) afirmen que ja no només es dissenyen productes per a usuaris, sinó que es dissenyen futures experiències de les persones, les comunitats i les cultures que estan connectades entre elles a través de la xarxa. Com a resum, Sanders i Stappers (2012) proposa un quadre - vegeu figura 4- on s'identifica l'evolució del disseny que es basa en els productes, amb el disseny que es basa en el propòsit de la persona i se centra en les seves necessitats, tant a nivell personal com a nivell de societat.

\begin{tabular}{|l|l|l|l|}
\hline $\begin{array}{l}\text { OLD } \\
\text { DESIGN THE TRADITIONAL }\end{array}$ & \multicolumn{3}{l}{ NEW > THE EMERGING } \\
\hline visual communication design & & & \\
\hline DESIGN DISCIPLINES
\end{tabular}

Fig. 4 Evolució de les disciplines en disseny. Sanders i Stappers (2012, p. 17)

Les disciplines tradicionals es basen en tangibles que descriuen el producte final: producte, espai interior, etc. En canvi, les noves metodologies es basen en intangibles com l'experiència o la innovació, intangibles que cal omplir de significat i atorgar-li l'artefacte. És a dir, que el producte final es manté com a incògnita mentre no es desenvolupa el projecte. En aquest sentit, Sanders i Stappers (2012) coincideixen amb la visió innovadora de Hekkert i van Dijk (2011), que a través del context també deixen oberta la concreció de l'artefacte. 
Tot i que Elizabeth Sanders forma part de la Universitat d'Ohio, gran part del seu treball està realitzat des de la TUDelft, com demostra la proximitat amb les teories metodològiques de Hekkert i van Dijk sobretot en l'èmfasi col·locat sobre la recerca prèvia, sense haver definit quin serà l'artefacte resultant del procés.

\subsubsection{Estudis de cas}

Per exemplificar com el disseny de producte treballa des de l'experiència d'usuari, es presenta el programa Moebio promocionat per Biocat, “organització que promou l'ecosistema sanitari i de ciències de la salut a Catalunya", tal com es pot llegir a la seva web (www.moebio.org última visita 25/07/2020). Aquesta organització, que promou projectes sanitaris des de 2008, llença el programa Moebio l'any 2013: “una iniciativa de desenvolupament de talent disruptiu que consta de diversos programes de formació per promoure la innovació i l'emprenedoria en la conjunció de tecnologia, ciències de la salut i empresa". Aquesta iniciativa formativa serveix com a exemple per a aquest treball per la metodologia que fan servir en el seu programa d.HEALTH basat en la immersió en el context i en el treball multidisciplinari. El d.HEALTH Barcelona és un programa de 6 mesos durant el qual es treballa en equips multidisciplinaris que conviuen en un dels hospitals amb conveni (Hospital Sant Joan de Déu, Hospital de Bellvitge, Institut Guttmann i Hospital Vall d'Hebron, de Barcelona, i Hospital Germans Trias i Pujol de Badalona). Els participants tenen 250 hores d'immersió clínica per a l'observació de pacients, familiars i personal hospitalari que ha de permetre la detecció de necessitats i problemàtiques reals, així com desitjos o expectatives no satisfetes que es puguin convertir en reptes de disseny que permetin desenvolupar solucions a través de nous productes. A més a més, s'ofereix formació per aquest tipus d'immersió etnogràfica en un ambient on les persones es troben en situacions delicades i on la millora tant de l'experiència de les persones, com del artefactes que s'utilitzen, així com espais i les seves dinàmiques, tenen un llarg recorregut. 
L'objectiu és el desenvolupament de producte fins a la seva fase de desenvolupament, moment en el qual els equips presenten els projectes i prototips a grups inversors amb la intenció de portar les propostes a mercat. Per tant, és un programa que també té una forta intenció empresarial unint el punt de partida basat en l'experiència amb la viabilitat econòmica. Sanders i Stappers (2008) presenten en el seu article sobre els nous mètodes de disseny, la seva experiència en àmbit hospitalari. Com a consultora per NBBJ, important firma d'arquitectura amb seu a diverses ciutats entre elles Boston, Hong Kong, Nova York o Los Angeles, treballa en la projectació de les habitacions dels pacients a partir d'un procés de disseny generatiu amb el personal sanitari. A través d'aquest treball col-laboratiu i d'immersió en el context, es defineixen les necessitats i problemàtiques de les persones que habiten l'espai per aconseguir solucions encertades — vegeu figura 5-.
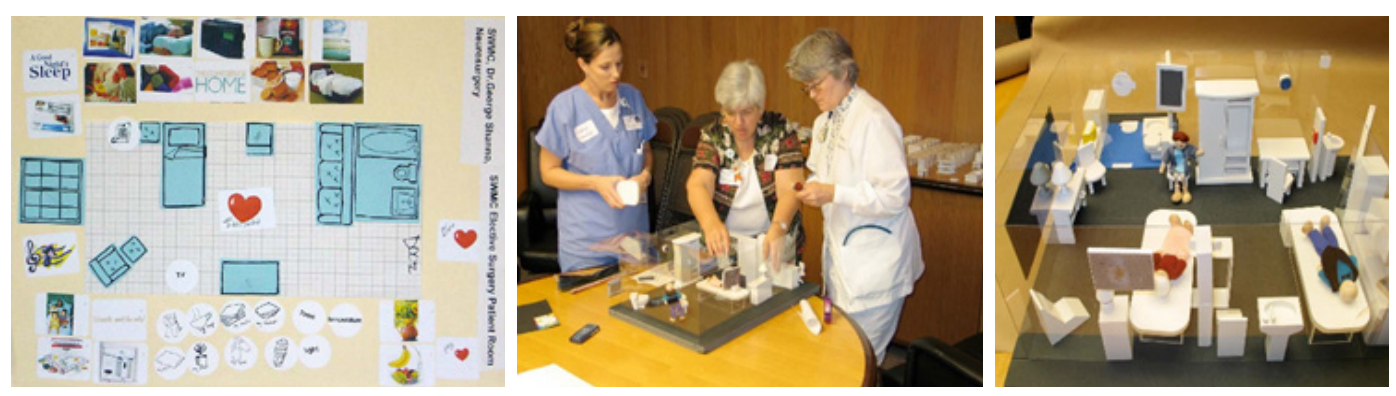

Fig. 5 Treball amb el personal d'infermeria i prototipatge 2D i 3D de les habitacions. (TUDelft Collegerama, 2009)

\subsubsection{Enfocament des del Disseny de serveis}

El disseny de serveis s'inclou com a apartat en aquest treball per la seva creixent importància en el món actual i en un moment, on es pot considerar com a especialitat amb suficient entitat com per a tenir característiques pròpies que el fan valuós, entre d'altres coses, per la seva visió de l'experiència d'usuari i per la seva capacitat de coordinar equips de disseny més amplis que inclouen altres àmbits. 


\subsubsection{Service Design Thinking}

L'any 2011 Marc Stickdorn i Jakob Schneider publiquen This is Service Design Thinking, una prolongació de les obres al voltant del Design Thinking, però amb la clara intenció de donar entitat a una tendència en importància creixent com és el disseny de serveis. Aquests autors reivindiquen amb la seva obra unes característiques concretes que permeten comprendre millor aquest àmbit del disseny. En aquesta obra pretenen explicar què és el disseny de serveis, com s'hi treballa, i quines eines es fan servir. Des d'aquest treball, és interessant observar el seu posicionament en relació a l'experiència d'usuari, ja que és un dels seus puntals, i gairebé la seva raó de ser.

Tot i expressar la impossibilitat de definir el disseny de serveis de forma concreta, Stickdorn i Schneider (2011) proposen una sèrie de característiques que l'emmarquen. El disseny de serveis "està centrat en la creació d'experiències ben pensades mitjançant una combinació de mitjans intangibles i tangibles" que busquen "nombrosos beneficis per a l'experiència de l'usuari final"' (Stickdorn i Schneider, 2011, p. 30). És a dir, que el disseny de serveis des de la seva essència es preocupa de tot el marc de l'usuari, de l'abans, el durant i el després de l'ús, per tant, es pot caracteritzar com a una pràctica focalitzada en el disseny de "sistemes i processos destinats a proporcionar un servei integral a l'usuari" (Stickdorn i Schneider, 2011, p. 30). Per fer-ho, necessita combinar habilitats del disseny tradicional, de la gestió i dels processos de l'enginyeria, en un moment que la disciplina s'ha fet conscient de la seva aportació per a la persona i ha incorporat "nous models de negoci que empatitzen amb les necessitats dels usuaris i intenta crear nous valors socioeconòmics dins la societat" (Stickdorn i Schneider, 2011, p. 30). Una tasca compromesa per "ajudar a la innovació (crear-ne de nous) o millorar serveis (existents) per fer-los més útils, usables, desitjables pels clients, i eficients i efectius per les organitzacions. Un nou camp holístic, multidisciplinari i integrador" (Moritz, 2005 a Stickdorn i Schneider, 2011, p. 31).

Així doncs, el disseny de serveis neix de la necessitat d'ampliar la mirada sobre el producte i focalitzar-la sobre l'usuari i la seva experiència quan fa servir el producte (entenent aquí 
el producte de forma àmplia). Una de les principals característiques del disseny de serveis és el seu enfocament cap a la persona, per tant "és fonamental comprendre els hàbits, la cultura, el context social i la motivació dels usuaris". [...] “Tots som clients, encara que amb diferents necessitats i ments. La comprensió i divulgació d'aquestes mentalitats dispars és on comença el pensament del disseny del servei". [...] "Un enfocament centrat en l'usuari ofereix un llenguatge comú que tots parlem, el llenguatge de l'usuari del servei" (Stickdorn i Schneider, 2011, pp. 36-37).

Una altra característica del disseny de serveis és la seva clara intenció de compartir els processos creatius, és a dir, la co-creació. En aquest punt coincideix amb la visió del disseny generatiu de l'Elizabeth Sanders que es tractarà més endavant — vegeu apartat 2.3.4 Disseny generatiu- Tant una com els altres aposten per incloure des de la fase de recerca a tots els actors implicats, en aquest cas, en un servei, caracteritzats pels stakholders que representen els diversos grups d'interès. En aquest sentit, la tasca del dissenyador de servies és facilitar un entorn on es puguin generar i avaluar les idees de grups d'interès heterogenis, per ampliar la visió del servei des de punts de vista aparentment distants. Tenir aquesta visió diferenciada de les diverses experiències, és un punt clau perquè el servei pugui ser útil, usable i desitjable pel major número de clients possibles. A més a més, i lligat a l'empatia del Design Thinking — vegeu apartat 2.3.1 Design Thinking - i lligat a les fases de recerca etnogràfiques — vegeu subapartat 2.4.2.2 Antropologia, etnografia i enfocaments afins aplicats al disseny-, el disseny de serveis aposta per l'anàlisi de les accions del client, com afirmen Stickdorn i Schneider, "per valorar el client, haureu de passar un temps entenent les interaccions que tenen amb servei, i això significa dues coses: en primer lloc, visualitzar el vostre servei a través dels ulls del client $i$, en segon lloc, dissenyar de manera que els clients rebin experiències coherents" (Stickdorn i Schneider, 2011, p. 80).

Una part molt interessant que proposa el disseny de serveis, sobretot, deguda a la seva alta complexitat, és la necessitat de dividir l'experiència en seqüències. El servei és complex perquè engloba un espai i temps important i variable, i per tant, és dificultós abastar-lo com un tot. Dividir l'experiència d'usuari en seqüències i marcar els punts claus d'interacció 
permet al dissenyador tenir una visió per peces encaixables que es poden tractar de forma individualitzada per el bé del servei en global. D'aquesta manera, es detecten punts conflictius dins de l'experiència de l'usuari que empobreixen l'experiència global i que, en canvi, probablement es poden solucionar de forma dirigida. De la mateixa manera, es detecten encerts en el servei, que es poden reforçar o reproduir per la seva bona acollida per part de l'usuari. El disseny de serveis “desconstrueix els processos de servei en punts d'interacció i interaccions úniques. Aquests, quan es combinen, creen moments de servei” (Stickdorn i Schneider, 2011, p. 40). Per a desenvolupar aquest procés, el disseny de serveis treballa amb eines visuals que estructuren el servei i aporten informació de l'experiència del client, per tant, aporten informació dels seus pensaments i sensacions, per exemple el Service Blueprint —vegeu figura 6-, o altres mapes seqüencials com l'user journey map.

La bona experiència d'usuari està lligada a les expectatives i a la satisfacció del client i aquesta satisfacció parla "sobre com la solució completa [el servei en general] et fa sentir, fa referència a una suma de detalls del servei i també ho relaciona amb la cultura del món exterior" (Stickdorn i Schneider, 2011, p. 85). Per això és tant important entendre el servei en el seu recorregut, sumant les diverses fases, per complir amb un servei complet.

Com s'apuntava a l'inici d'aquest subapartat, el disseny de serveis és tangible i intangible, ja que inclou una part organitzativa i una part directament relacionada amb el producte. En aquest sentit, no es tracta d'oblidar el cor del servei, sinó d'ampliar la visió reduccionista de l'ús del producte, Stickdorn i Schneider ho expliquen de la següent manera:

"El disseny del producte està sempre vinculat a un procés de fabricació.

En general, hi ha una gran quantitat de processos d'enginyeria que s'han d'integrar per donar suport a la producció d'un producte complet. Considerant el disseny del producte de manera integral com a servei, es pot considerar com tots els processos estan connectats al negoci d'intercanvi de mercaderies i màrqueting. El disseny del producte pot, i ha de, ajudar en el compliment de les exigències dels processos de lliurament i manteniment, així com l'experiència de l'usuari d'un servei“. (Stickdorn i Schneider, 2011, p. 40) 


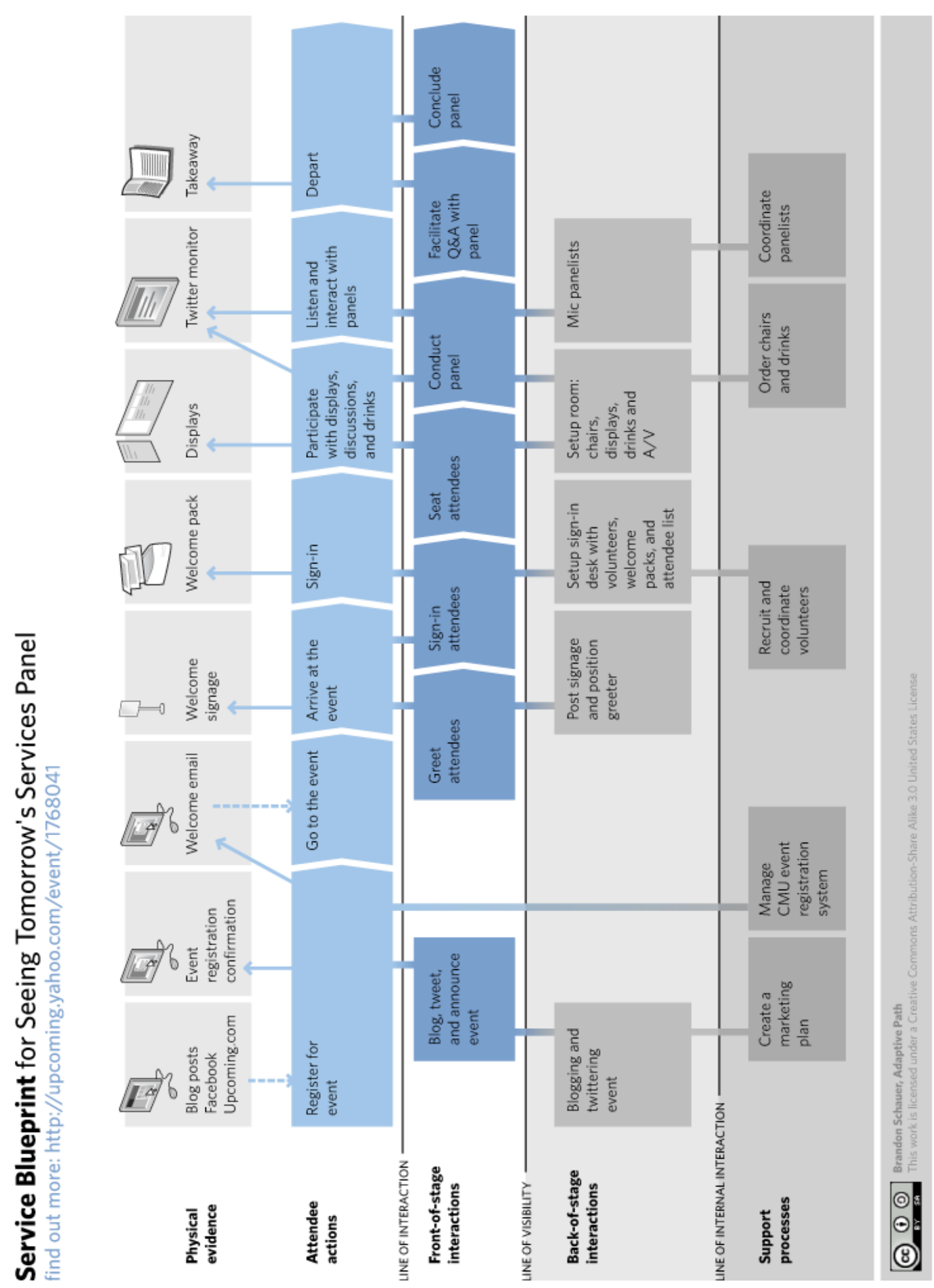

Fig. 6 Mostra d'un service blueprint. Autor Brandon Schauer. Copyright i termes de llicència CC BYSA 2.0. Recueperat de https://designforservice.wordpress.com/2009/03/17/service-panel-blueprint/ 
A més a més, per la seva alta complexitat i per la gran diversitat de projectes possibles el disseny de serveis necessita fer un pas previ a l'inici de la recerca, "el primer pas d'un procés de disseny de serveis és dissenyar el procés en sí, ja que el procés depèn en última instància del context del servei que s'està dissenyant i, per tant, varia de projecte a projecte" (Stickdorn i Schneider, 2011, p. 126). Aquesta afirmació és molt útil per estructurar la metodologia de recerca que es proposa en aquest treball, tal i com es veurà al capítol III, ja que s'aposta per una reflexió prèvia sobre les necessitats de la recerca, de manera que les dades que es recullin siguin pertinents pel projecte.

En resum, el disseny de serveis és, en essència, el disseny d'experiència d'usuari i, com a tal, és interessant conèixer-ne les característiques implícites tal i com descriuen Stickdorn i Schneider en una de les obres de referència d'aquest àmbit. A més a més, la visió d'aquests dos autors està estretament lligada al Design Thinking i a les teories de l'Elizabeth Sanders, de manera que dibuixa unes característiques comuns aprofitables en la intenció de crear una metodologia de recerca per al disseny. Aquests característiques són bàsicament, el seu enfocament centrat en l'usuari, la intenció de fer partícip als diversos actors del servei, la necessitat (i capacitat) per dividir el servei en punts clau importants que permetin evidenciar els pensaments i la satisfacció de l'usuari en cada un dels moments del servei, la necessitat de visualitzar el servei en un producte (no tot pot ser intangible), i finalment, i compartint característica amb l'ergonomia, una forta intensió holística, és a dir, que cal tenir en compte el context global on se situa el servei, igual que l'ergonomia pretén dibuixar el context global on se situa el projecte.

En paraules d' Stickdorn i Schneider:

"El disseny del servei consisteix en triar els punts clau més rellevants per a la prestació del servei i dissenyar una experiència de client consistent en aquests diversos punts clau. Es busquen oportunitats per introduir punts clau potencialment nous i més eficaços, així com eliminar punts clau febles, per coordinar l'experiència de l'usuari a través de punts clau en relació amb les necessitats dels usuaris i de la marca" (Stickdorn i Schneider, 2011, p. 138). 


\subsubsection{Jams de Creativitat}

Aquest apartat fa referència a un esdeveniment anual relacionat amb els tallers de creativitat, que s'autoanomenen "jam”, emulant les jams musicals on l'intèrpret (guitarrista, cantant, baterista,...) puja a l'escenari amb altres músics sense assaig previ, i sense que sigui necessari conèixer la resta de persones que compartiran una, o diverses cançons. En aquesta ocasió, la jam és de disseny de serveis i s'organitza simultàniament i de forma altruista arreu del món.

Tal i com es pot llegir a la seva web (http://planet.globalservicejam.org), la primera Global Service Jam va tenir lloc el març de 2011. En aquella ocasió, uns 1200 participants repartits per aproximadament 50 ciutats van coincidir en un mateix cap de setmana per desenvolupar projectes de serveis en el transcurs de 48 hores sota el lema "Super(heroes)". Uns mesos més tard, al novembre de 2011, va tenir lloc la primera Sustainability Jam; en aquesta ocasió secundada per 800 persones repartides per 40 ciutats, on van desenvolupar propostes en relació al concepte "Playgrounds". Finalment, el 2013 començava la GovJam, destinada al desenvolupament de serveis públics.

Tot plegat una iniciativa començada per Markus Hormess i Adam Lawrence, fundadors de WorkPlayExperience, consultoria per a l'experiència d'usuari i el desenvolupament de serveis. Des del seu naixement, les tres jams tenen lloc anualment, i és el punt de trobada per a reflexionar sobre reptes de disseny que apareixen a partir d'un tema proposat. Durant 48 hores, $\mathrm{i}$ fent ús de tècniques afins al Design Thinking, els participants segueixen els passos de descoberta, ideació, prototipatge, testeig i comunicació. El març de 2019 unes 100 ciutats han participat a la Service Jam sota els mateixos principis que la van fer néixer: reunir sense ànim de lucre persones d'àmbits diversos, arreu del món, durant el mateix cap de setmana, per participar en unes jornades de creativitat i desenvolupar propostes de serveis tant viables com sigui possible, a la vegada que s'aprenen dinàmiques de treball i s'entra en contacte amb el disseny centrat en les persones, l'experiència d'usuari, el prototipat, i en definitiva, el desenvolupament del projecte articulat des de la persona. 
Finalment, quan acaben les 48 hores, diumenge a las 15.00 , tots els equips participants han d'haver penjat les seves propostes a la mateixa plataforma online ${ }^{11}$.

Aquest experiència es recull com a mostra metodològica del disseny de serveis. Un dels elements més interessants d'aquest tipus d'esdeveniment és el "petit test metodològic per al desenvolupament de projectes. Una manera d'aproximar unes eines i uns mètodes a persones que poden no venir de l'àmbit creatiu i que els pot obrir un món de possibilitats." (Itziar Pobes en comunicació personal el 17/06/2015).

En una jam els temps són ajustats —vegeu figura 7- i això obliga als participants a estar actius en tot moment. Es promociona el prototipat de manera que es pugui testejar en diverses ocasions les hipòtesis plantejades per a solucionar el repte. L'objectiu és acabar el cap de setmana amb un projecte mínimament viable, factible i desitjable; és a dir, que es consideri plausible i que pugui interessar a algú.

Una altra de les qüestions clau és el treball en equip. Les persones que arriben a la jam venen de diversos àmbits i en general no es coneixen entre elles. El desenvolupament de les propostes s'organitza a través de petits equips de 5 o 6 persones que treballaran juntes durant el cap de setmana. És interessant que provinguin d'àmbits diversos per tenir una visió també diversa de la temàtica a tractar. Per a cada equip, el repte és la capacitat de prendre decisions de forma activa, sense discussions eternes que no aporten solucions.

L'últim punt de la jam és la comunicació. Durant les 48 hores en diversos moments es posen en comú les propostes dels diversos equips. És una forma de competència sana, i una manera d'introduir tècniques per a la crítica constructiva. Al final de tot, cada equip ha de buscar la millor manera de comunicar la seva solució al problema plantejat de forma autònoma i universal, és a dir, un vídeo, un cartell o algun altre tipus de solució visual i el

11 Es poden consultar els projectes realitzats des de totes les jams mundials a la plataforma web http://planet.globalservicejam.org/gsj18/submissions.

Altres webs de referència per a més informació:

Comunitat general $\cdot$ http://planet.globalsustainabilityjam.org/

Sustainability Jam Barcelona $\cdot$ https://barcelonasustainabilityjam.wordpress.com/

Sustainability Jam London · https://vimeo.com/82000335 
màxim entenedora possible, sense que l'acompanyi una explicació de la persona que ho ha pensat.

En definitiva, les jams de creativitat, són una posada en escena de les eines més dinàmiques utilitzades en el desenvolupament creatiu del projecte. Una mostra interessant sobre com enfocar un projecte des del disseny de serveis posant la persona com a punt clau del desenvolupament. La solució comença sempre per al plantejament de l'experiència d'usuari en relació al tema plantejat. Reflexionant com viu, sent, pensa i explica la persona la seva experiència, es busquen reptes de disseny des d'on construir aquesta solució plausible.

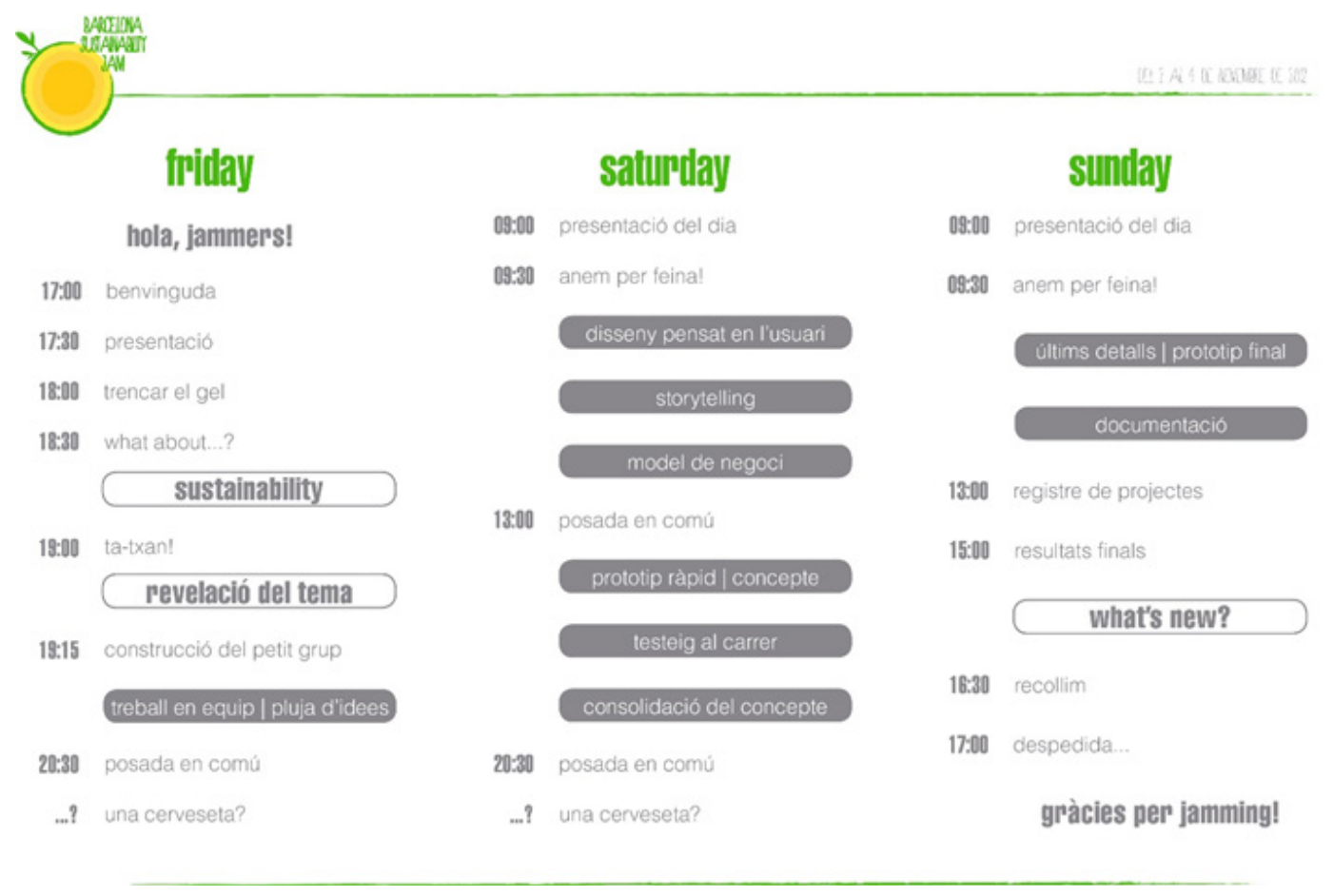

Fig. 7 Horaris Sustainability Jam Barcelona 2012 · Drassana Studio i Claro Partners

\subsubsection{Estudis de cas}

Com a exemple d'èxit del disseny de serveis aplicat a l'àmbit públic i desenvolupat a través d'eines col-laboratives, es vol presentar el projecte realitzat per l'empresa We Question 
Our Project ${ }^{12}$, amb seu a Barcelona. Com es pot llegir al seu perfil de LinkedIn, es dediquen a ajudar institucions per "entendre el que els ciutadans, usuaris finals o clients necessiten, esperen i volen d'ells", desenvolupen el projecte conjuntament amb els treballadors, buscant serveis "més eficients i satisfactoris, tant per als clients com per als equips interns".

L'any 2014 duen a terme la modificació el servei d'atenció ciutadana de l'ajuntament de Sant Quirze del Vallès, amb l'objectiu principal d'introduir els processos en xarxa i la comunicació online. No es tracta de de fer una web que funcioni, sinó de veure quins tràmits poden passar a ser virtuals i com afecta aquest canvi a l'atenció al públic presencial. Es realitza un escaneig dels procediments i del funcionament de l'equip d'Atenció Ciutadana i de l'equip de Comunicació, ja que la proposta és unir els dos departaments, per veure que cal un canvi de cultura i de pensament de manera que la introducció de les noves tecnologies no es percebi com una amenaça pels llocs de feina. A més a més, es fa palès que cal una modificació de l'espai físic perquè està dissenyat exclusivament per a l'atenció presencial. Per la fase de recerca, es fan servir eines de disseny generatiu — vegeu apartat 2.3.4- que impliquen la participació en el seu desenvolupament de treballadors i ciutadans que fan ús del servei. A més a més, es posen en pràctica el prototipat ràpid per validar propostes, com per exemple la modificació de l'espai a partir de cartrons que els permet assajar configuracions possibles, buscant en tot moment la satisfacció i comoditat dels usuaris. Amb el treball conjunt aconsegueixen trencar reticències al canvi, els treballadors es fan seu el projecte i entre tots, es proposen opcions per oferir un nou servei adaptat al servei en línia. Serveix, a més a més, com a exemple per mostrar que el disseny de serveis té una visió molt àmplia del problema plantejat, ja que un servei acostuma a incloure elements molt diversos. És a dir, en aquest cas, s'uneixen deferents perfils laborals d'un ajuntament, un espai físic i un espai virtual. Tot plegat ha de funcionar perquè l'atenció al públic, però

12 Per conèixer millor aquest estudi de disseny, veure com treballen, així com imatges del desenvolupament del projecte a l'ajuntament de Sant Quirze, visitar el seu perfil a http://www.wequestionourproject.com/WQOP_studio_profile.pdf, el se espai a LinkedIn https://www.linkedin.com/company/we-question-our-project/, o la seva web a http://wequestionourproject.com/ 
també els serveis tresoreria i comptabilitat o serveis informàtics, assimilin els nous canvis de procediments. El serveis, són múltiples peces que han d'encaixar i per això, aquesta disciplina s'esforça en desenvolupar eines que dibuixin aquesta complexitat, com per exemple el service blueprint, per relacionar aquestes peces, o l'user journey map, per tenir una visió precisa de la versió de l'usuari en els diversos punts de contacte amb el servei.

\subsubsection{Conclusions}

En aquest apartat, es parla de l'observació del disseny a partir de la usabilitat i l'experiència d'usuari. S'observa des d'aquest punt de vista perquè es considera que és una forma adequada d'argumentar i sustentar conceptualment el projecte. Al llarg de l'apartat es va veient com tant des de l'ergonomia, com des de diversos àmbits del disseny, es posa èmfasi en la relació de la persona i el món dissenyat, és a dir, en la interacció entre els dos ítems del binomi bàsic que descriu l'ergonomia: persona i màquina. Un dels principals objectius de l'ergonomia i el disseny és que aquesta interacció es realitzi de forma sana i efectiva i, naturalment, que s'acompleixin els objectius establerts, és a dir intenció, fi, finalitat i metes, la raó de ser d'aquesta interacció.

Tal i com argumenten Hekkert i Van Dijk (2011) des de la TUDelft, el fet d'enfocar l'anàlisi en la interacció (les relacions) fa possible una major gama de possibilitats de solució. Es tracta de definir un context futur per poder establir quina relació tindrà lloc entre persona i artefacte, i així poder elaborar les solucions que ho faran possible. Un futur que també pretenen dibuixar Robert i Brangier (2009) des de la seva ergonomia prospectiva - com s'ha vist a l'apartat corresponent 2.2.2.3-.

També des de l'ergonomia, el sistema persona/màquina organitza la relació d'ambdós a partir de 5 variables diferents — vegeu 2.2.2.1 Sistema persona/màquina—. El fet de començar per una o una altra variable, influeix en el posicionament de l'anàlisi. En un artefacte existent, és positiu començar l'anàlisi amb les variables d'acció, és a dir, caracteritzant 
la interacció, perquè és una manera excel·lent de detectar aspectes conflictius, nocius o problemàtics de l'ús del producte. Al sumar-hi les variables de finalitat, es desgranen les intencions, objectius i metes de les diferents accions. Un cop es tenen clares aquestes dues variables, es decideixen les variables de persona que són pertinents i que han de guiar per la presa de decisions de les variables de màquina. Finalment, les variables d'entorn han de contextualitzar la interacció i caracteritzar-la. Per altra banda, per al desenvolupament d'un artefacte inexistent, segurament és més pertinent començar des de les variables de finalitat, per establir una base sobre la qual construir l'artefacte, i a partir d'aquí caracteritzar la relació entre la persona i l'artefacte, és a dir, les accions. Aquestes diferències d'estructura de les variables es veuran més endavant al capítol III, Proposta per a una metodologia de recerca.

Elizabeth Sanders i Pieter J. Stappers recullen a través de la seva obra Convivial Toolbox (2012) un apunt més sobre els actors d'aquesta relació ampliant-ne l'abast. Qualsevol que té alguna relació amb l'artefacte, forma part del projecte. I a més a més, en forma part com a expert i de forma activa. Sanders i Stappers expliquen el canvi de papers que implica aquesta participació, per exemple, com el dissenyador esdevé facilitador. Aquesta aportació és interessant perquè ajuda a vestir l'abast de l'experiència d'usuari i amplia el valor de qualsevol artefacte, que ha de respondre amb qualitat a qualsevol dels actors que el visqui.

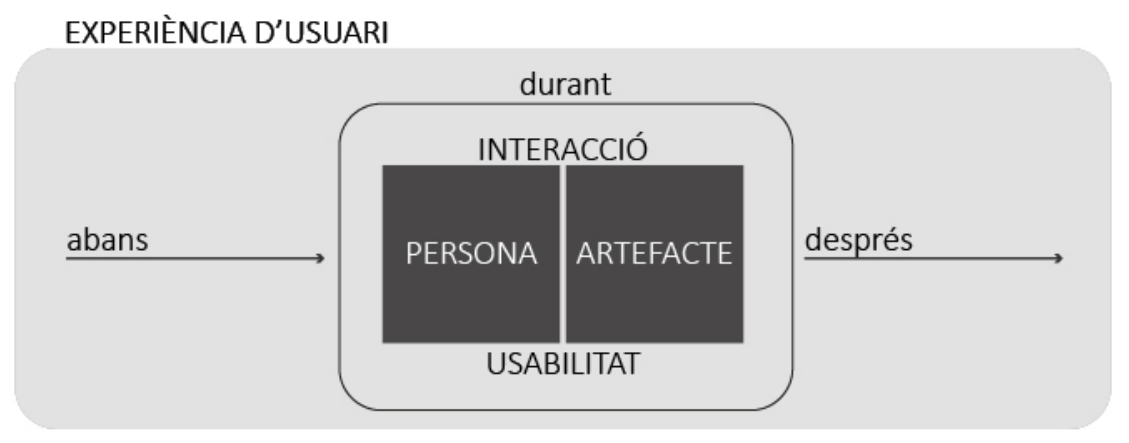

Fig. 8 Esquema sobre la relació entre la persona i l'artefacte 
Des de l'ergonomia també arriba la preocupació per a valorar la usabilitat a través de protocols que defineixen uns ideals desitjables, tant si són objectius (quantificables) o subjectius (fruit de l'apreciació d'un usuari o de l'analista). Dins de l'esquema global de l'experiència d'usuari - vegeu figura 8-, usabilitat i interacció són conceptes paral·lels que caracteritzen la relació entre la persona i l'artefacte. Així doncs, la usabilitat s'engloba dins d'aquesta mirada a partir de la interacció (relació). Aquest esquema, també dibuixa l'experiència d'usuari com un concepte que engloba diverses fases de la relació de la Persona i l'artefacte, inclou la part d'interacció i d'usabilitat, però també un espai previ i un de posterior que han d'acabar de caracteritzar l'artefacte, i que formen part del context.

Un cop plantejat aquest esquema bàsic, en l'apartat següent es fa una mirada sobre quins mètodes i quines eines ajuden a caracteritzar aquesta relació. Sobretot, com el disseny s'ajuda d'eines i mètodes per anar avançant en el procés de projectació.

\subsection{Mètodes i eines}

En els últims anys s'han desenvolupat una sèrie d'eines creatives, que precisament per creatives, s'associen al disseny. Encara que segurament no es poden considerar pròpiament disseny, sí que aquesta disciplina les fa servir en el desenvolupament del seu projecte, ja que totes elles procuren ordenar la realitat i el procés creatiu a través d'unes fases iteratives i estructurades que guiïn en aquest procés. Ara mateix, tocant la segona dècada del s.XXI, es pot viure com un procés natural d'abstracció i organització del projecte basat, entre altres coses, en l'experiència d'usuari, i en el convenciment que el disseny afavoreix els resultats. En aquest sentit, en aquest apartat es presenten una sèrie de mètodes i eines de recorregut divers que organitzen el procés creatiu.

Per començar es fa un revisió del Design Thinking intentant explicar com s'estructura a través d'unes fases que ni són fixes, ni estàtiques. Les seves virtuts i els seus defectes. Provinent de la consultoria Ideo recolzant-se en com els dissenyadors enfoquen el projecte, 
s'ha vestit el Design Thinking. El resultat és un vestit ben estructurat, fàcil d'explicar i d'entendre, $i$ amb una sèrie de virtuts vistoses que en algun moment han convençut a molta gent. Quan el 2009 Tim Brown publica Change by design, la metodologia s'expandeix en molts àmbits diferents, entre els quals en l'àmbit educatiu perquè l'estructuració del procés de disseny ofereix eines a l'aula per introduir els alumnes en el món de la projectació. Amb els anys, la metodologia com a tal perd força però els seus principis bàsics es mantenen i són aquests els que es revisen a continuació, així com la seva distribució en fases iteratives. Provinent del Design Thinking, apareixen metodologies afins, com per exemple el Doble Diamant, presentat pel Design Council britànic, que s'alimenta dels mateixos principis però que estructura les fases de manera diferent. A més a més, es presenta com a metodologia específica pel disseny de serveis. També com a metodologia afí, Elizabeth Sanders i Pieter J. Stappers (2012) presenten la seva visió projectual i posen l'èmfasi sobretot en la persona que participa com a actor en la relació amb l'artefacte a través del què ells mateixos anomenen disseny generatiu. Finalment, des de Dinamarca, es troba l'exemple de Kaospilot, una forma diferent d'entendre la metodologia projectual també lligada a l'acció i a la multidisciplinarietat.

Finalment, en aquest apartat, es poden veure també una sèrie d'eines que de manera molt més concreta es fan servir en el desenvolupament del projecte. Algunes d'elles com l'user journey o el service blueprint, o el brainstorming cada vagada formen més part del coneixement comú de la metodologia projectual, des de la tendència actual de portar el treball per projectes a qualsevol àmbit, educatiu, laboral, social, o cultural.

\subsubsection{Design Thinking}

El Design Thinking és actualment una metodologia creativa força estesa, que durant el segle XXI ha servit de base per a altres metodologies similars, que busquen el pensament disruptiu i la creativitat per a poder desembocar en la innovació. És una metodologia amb 
moltes virtuts, entre les quals es troba la capacitat que ha tingut per saber explicar-se a sí mateixa, i per vestir-se de quantitat d'eines visuals i ordenades (tant de noves, com de recuperades d'altres disciplines) que acompanyen la persona que desenvolupa un projecte amb Design Thinking al llarg de tot el recorregut, però que com a eines, són reutilitzables en molts altres àmbits fora del Design Thinking. Idris Mootee (2014) afirma que és una metodologia que se centra en una aplicació antropocèntrica per poder identificar problemes, que a continuació es plasmen en prototips tangibles o models no funcionals que ajudaran a solucionar aquests problemes. Mootee, afegeix que la tendència és simplificar el Design Thinking fins a convertir-lo "en un conjunt d'eines de fàcil accés que pot fer servir tothom [...] però que els Design Thinking és molt més que això" (Mootee, 2014, p. 30).

Precisament, en aquest apartat es procura fer un resum de les principals característiques del Design Thinking, que es repeteixen en els diversos models existents, més enllà de les seves eines concretes:

\section{Desenvolupar el projecte centrat en l'usuari}

Tenir empatia per les persones per les quals s'està dissenyant, i buscar la retroalimentació d'aquests usuaris. Segons Brown (2009) per al Design Thinking és cabdal el fet d'aprehendre com els usuaris fan servir els artefactes. Per fer-ho, la metodologia s'apropia de tècniques d'observació etnogràfiques i les aplica per generar solucions pràctiques. En la seva crítica, Kimbell (2011) puntualitza que tot i parlar-se d'un procés centrat en l'usuari, en realitat es continua emfatitzant al dissenyador com a principal agent del disseny. Aquesta és també una crítica que sorgeix en el pensament d'Elizabeth Sanders i les teories de cocreació, — vegeu 2.3.4 El Disseny Generatiu—, és el punt clau que porta a fer un pas més en el desenvolupament d'estratègies que posin realment a la persona i no només a l'usuari al centre de tot el procés. La consultoria Ideo també evoluciona en aquest sentit i proposa formes col·laboratives de treball, sobretot en el seu model HCD (Hear, Create, Deliver) ${ }^{13}$.

13 "HDC" mètode que proposa Ideo · Human-centered Design (per ampliar informació, visiteu www.designkit.org/human-centered-design). 
De moment, però, es pot afirmar que el Design Thinking promou el contacte iteratiu amb l'usuari, que permet verificar els diversos passos que es van duent a terme, en contrast amb altres recerques de solucions que se centren en la tecnologia o en la mateixa organització. Tim Brown (2009) explicita que l'aproximació centrada en la persona permet a les empreses lidiar millor amb l'espai que queda entre el producte i el servei, i el productor i el consumidor.

Per altra banda, el concepte de centrat en l'usuari també inclou una part d'empatia que se li reclama al dissenyador, així com la necessitat de tenir en compte emocions i sentiments, que se suma a la part de satisfer la part funcional. Per això, és comú sentir que el Design Thinking és disseny i psicologia.

Tim Brown (2009) té molt clar que la innovació s'ha de dirigir en dissenyar també l'experiència emocional de l'usuari. Així, l'observació, la comprensió i la capacitat de percepció en el seu sentit més ampli, es consideren habilitats bàsiques necessàries per a la creació de noves realitats i nous artefactes. En aquesta línia i fent referència al camp educatiu, Tschimmel (2012) defensa que l'entrenament de la percepció conscient i dirigida, i la recerca de nous matisos hauria de ser la part principal de l'ensenyament del disseny.

\section{Mostrar resultats de manera gràfica i visual}

Comunicar les idees de forma breu, esquemàtica i comprensible; tan visual com sigui possible. En aquest sentit, els documents elaborats per donar a conèixer les diverses propostes, prediquen amb l'exemple, ja que gairebé sempre es tracta de documents molt visuals. Segons Brown (2009), les representacions visuals creen nous insights ${ }^{14}$, en forma de mapes mentals que mostren connexions multidireccionals, que per altra banda, les descripcions verbals de forma lineal podrien ofuscar.

14 Sobre el concepte d'insight es parla més extensament en l'apartat corresponent — vegeu subapartat 2.4.3.1 Extracció de conclusions. Els insights- 


\section{Multidisciplinari i col·laboratiu}

El Design Thinking entén que el treball en equip sempre serà més fort a l'hora de resoldre reptes que una única ment pensant i que, sobretot, és beneficiosa una visió des de múltiples perspectives.

Hi ha moltes situacions de desenvolupament creatiu on es fa servir el Design Thinking i totes diferents, perquè hi entren en joc molts elements, per tant és difícil dibuixar una situació habitual. Tot i així, es pot afirmar que les diverses eines i activitats que es proposen al llarg del projecte, en la seva gran majoria, són per a realitzar a partir de grups de treball. Per una banda es promociona el treball en petit grup (de 4 a 6 persones) i per l'altra, que aquest grup estigui format per persones d'àmbits o disciplines diferents, per assegurar diversos punts de vista. En les fases de divergència ${ }^{15}$, que hi hagi gent amb una base de coneixement diversa facilita l'obertura de l'espai on es desenvolupa el projecte. Per altra banda, durant les fases de convergència, el fet de tenir diverses perspectives ajuda a establir relacions més riques i diferents.

\section{Ser conscient del procés}

Quan es realitza per primera vegada un procés de generació d'idees o d'innovació o de disseny, tant en tallers de curta durada com en processos de desenvolupament llarg, és fàcil que la gent que hi participa vagi una mica perduda. Per això, es recomana als organitzadors o responsables del desenvolupament que sempre s'expliquin les diverses fases que es realitzaran, així com en quin punt s'està en cada moment i quines eines i tècniques es faran servir. És positiu que el dissenyador sàpiga en quin punt del projecte es troba per poder prendre les decisions metodològiques més encertades.

15 Les fases de divergència i convergència formen part del procés projectual en qualsevol de les seves metodologies de disseny aplicades. Són fases de recollida de informació i fases de presa de decisions sobre les quals gira el procés de definició del projecte. Al llarg d'aquest treball, es fa referència a aquestes fases des de diversos punts de vista aportats pels diferents autors. Es considera que la proposta del Doble Diamant del Design Council les explica i se'n serveix de forma clara, per tant, s'expliquen amb més profunditat en aquest apartat — vegeu 2.3.2 Doble Diamant- 


\section{Prototipar}

Per al Design Thinking, fer prototips és una manera de validar idees, i també una part integrant del procés d'innovació. Aquí el terme prototip s'ha d'entendre de la manera més àmplia possible, engloba des d'un primer esbós, fins a la construcció d'un artefacte funcional realitzat amb peces fabricades, per exemple, per rapid prototyping, passant per les maquetes de treball en 2D o 3D que es considerin oportunes. Per una banda, prototipar és una manera de visualitzar els pensaments, així com de provar noves solucions. Per exemple, Cross (2001) afirma que pensar en múltiples perspectives sobre les futures possibilitats es difícil de dur-ho a terme a un nivell purament intern i mental, per això el dissenyador necessita interactuar amb alguna representació externa, sobre el paper o amb volum, segons sigui necessari en cada cas, i en cada estadi del procés de desenvolupament. Per altra banda, i com ja comenta Jones en el seu llibre "Design Methods" el fet de dibuixar també ajuda a explorar a la vegada el problema i la solució del projecte, una dualitat del procés de disseny que surt en diversos autors, com Dorst (2003) on cita el concepte de "coevolució" com a característica del procés de disseny pel qual es fa evolucionar el problema a resoldre i la seva solució a la vegada.

Per altra banda, el prototip no només és útil com a exploració pròpia del dissenyador, sinó que es converteix en una eina bàsica per a la comunicació de les idees i propostes, així com una ajuda per als diversos testos d'ús o de concepte que es puguin dur a terme.

\section{Incitar a l'acció}

En general el procés de Design Thinking convida a passar a l'acció. Es tracta de fer, no de pensar; no de crear idees aïllades, en abstracte o només descriure-les amb paraules, cal fer servir altres mètodes per fer-les visibles. Kimbell (2011) parla sobre el dualisme entre el "fer" i el "pensar", i sobre la importància d'entendre que el disseny es mou en l'àmbit de l'acció. Naturalment, el fet que predomini l'acció no vol dir que no s'hagi de pensar, o reflexionar, sinó que es tracta d'un procés pràctic, d'assaig i error, de prototip, de dibuix, d'entrevista, d'observació, etc. 


\section{Procés iteratiu}

E1 Design Thinking descriu un procés iteratiu on les diverses fases van endavant i endarrere segons va avançant. Al parlar d'un procés iteratiu, enlloc de lineal, és posa l'èmfasi en les relacions entre les coses, més que no pas en les seqüències de les coses. Com considera Jones (2a ed. 1992), el dissenyador fa una "predicció de futur" sobre unes premisses que considera certes. Aquestes característiques sumades a un procés de divergència i convergència, converteixen el procés de disseny en un procés iteratiu, no lineal. En aquest sentit, l'error i les fallades, formen part també del procés de disseny. Per a Tschimmel (2012) el fets de la incertesa i haver d'acceptar l'error com a part del procés són dos dels temes que més costen quan el Design Thinking es desenvolupa a nivell d'empresa, acostumada a un tipus de funcionament molt més planificat que s'aparta de les situacions ambigües i els fets impredictibles

Ser optimista ja que treballa sota la premissa que les persones creuen en el canvi i creuen en el procés

Com a exemple model de Design Thinking s'escull el model de l'Institut Hasso-Plattner. És un model desenvolupat en un àmbit educatiu, l'escola de disseny de l'Insitut Hasso-Plattner associat a la Universitat de Potsdam a Alemanya, coneguda amb el nom de d.school. Aquest institut està fortament lligat a la Universitat d'Stanford i a la consultora Ideo, nascuda a Palo Alto (USA), però actualment amb seus repartides per tot el món.

Com es veu a la figura 9, aquest model visualitza el procés de disseny en 6 passos connectats per unes línies que volen fer èmfasi en el caràcter iteratiu del procés. Els passos són (1) entendre, on es realitza una recerca d'informació de fonts secundàries; (2) observar, on es realitza recerca qualitativa a través d'observació directa, entrevistes, etc. (3) definir, que explicita el procés pel qual es fa una aproximació al projecte des del perspectiva de l'usuari; 


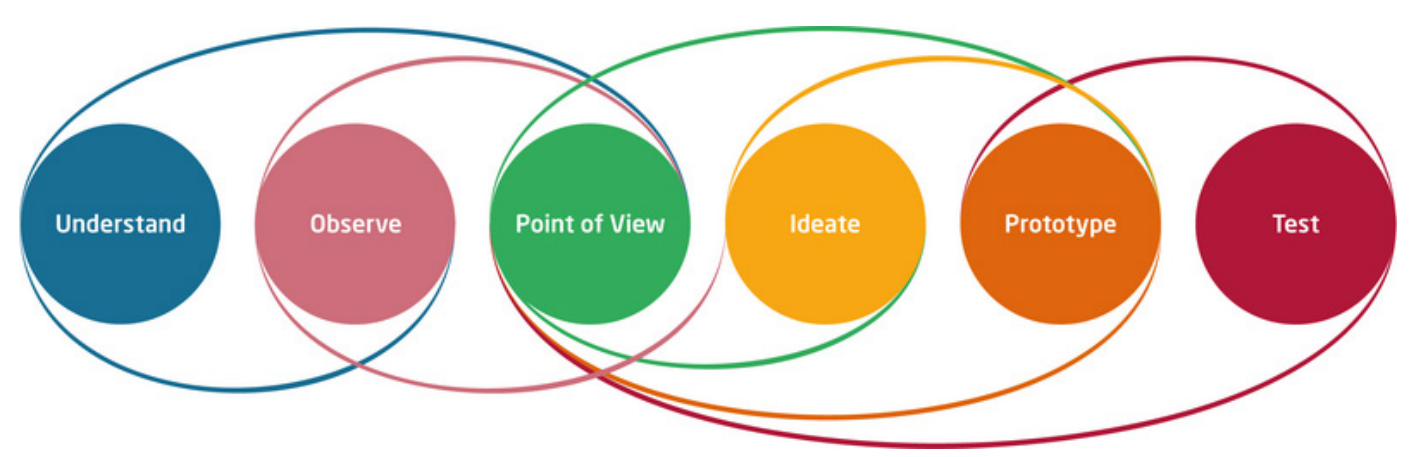

Fig. 9 Design Thinking per la d.school, Institut Hasso-Plattner. Model de 6 fases

(4) idear, on es realitza un procés de síntesi sobre tot allò après en les fases precedents, i on s'arriba a la conclusió d'una sèrie de conceptes o revelacions sobre els quals s'assentarà el projecte; (5) prototipar, on es realitzen proves de materials, formes, funcions, etc.; i finalment, (6) testejar, on es posen a prova les decisions preses. Tot això entès d'una forma lineal però amb capacitat per anar endavant $i$ endarrere com sigui convenient.

Des de la mateixa d.school també es proposa un altre model que només inclou 5 fases, ja que ajunta la primera entendre i observar en una fase que anomenen empatitzar - vegeu figura 10-.

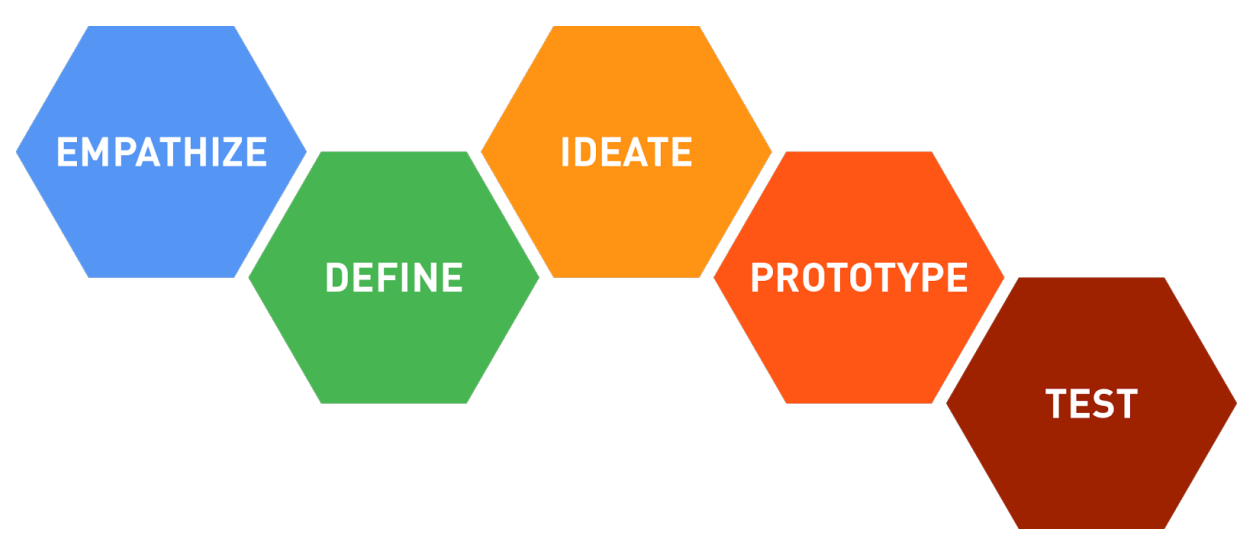

Fig. 10 Design Thinking per la d.school. Model de 5 fases 
En la seva capacitat d'adaptació, s'elaboren manuals de Design Thinking específics per certs sectors, per exemple per a educadors. Ideo des del Design Thinking for Educators (2012) disponible online ${ }^{16}$ de forma oberta proposa un procés de 5 fases: Descobrir, Interpretar, Idear, Experimentar i Evolucionar — vegeu figura 11-. És un esquema més evolucionat que ja que inclou gràficament les fases de convergència i divergència. A diferència del Doble Diamant, que es veu en l'apartat següent, aquest esquema divergeix i convergeix però també va estrenyent l'abast. Visualment, és molt explicatiu. També, en el propi esquema, inclou les accions clau a utilitzar en cada fase.

En aquest cas, el model convida a aquells que l'utilitzin a desenvolupar capacitats intuïtives per a la comprensió a través de l'observació i, sobretot, a desenvolupar idees amb sentit emocional. És a dir, que demanen posar especial èmfasi en les persones, què pensen i com se senten, per poder oferir respostes als seus desitjos.

En definitiva, el Design Thinking s'ha convertit al llarg dels anys en la guia principal de la metodologia creativa, $\mathrm{i}$ ha viscut, gràcies al seu propi èxit, infinitat de reformulacions, concrecions i revisions de l'esquema metodològic inicial. La pròpia metodologia s'ha revisat a través d'uns dels seus principis, la iteració, i així, ha sabut adaptar-se a àmbits diferents, des del món empresarial sota la promesa d'innovació, passant pel món del disseny sota la promesa d'efectivitat, i acabant en el món educatiu sota la promesa de claredat metodològica. El Design Thinking, amb les seves virtuts i defectes, ha encapçalat una revolució metodològica i d'enfocament del món creatiu, que ha permès, entre d'altres, centrar els esforços en les necessitats, desitjos i problemàtiques de la persona, $\mathrm{i}$ introduir mètodes $\mathrm{i}$ eines creatives en el desenvolupament del projecte de qualsevol àmbit. A la vegada que ha contribuït en el canvi que estem vivint en el món educatiu basat en projectes.

16 Vegeu https://designthinkingforeducators.com/ 


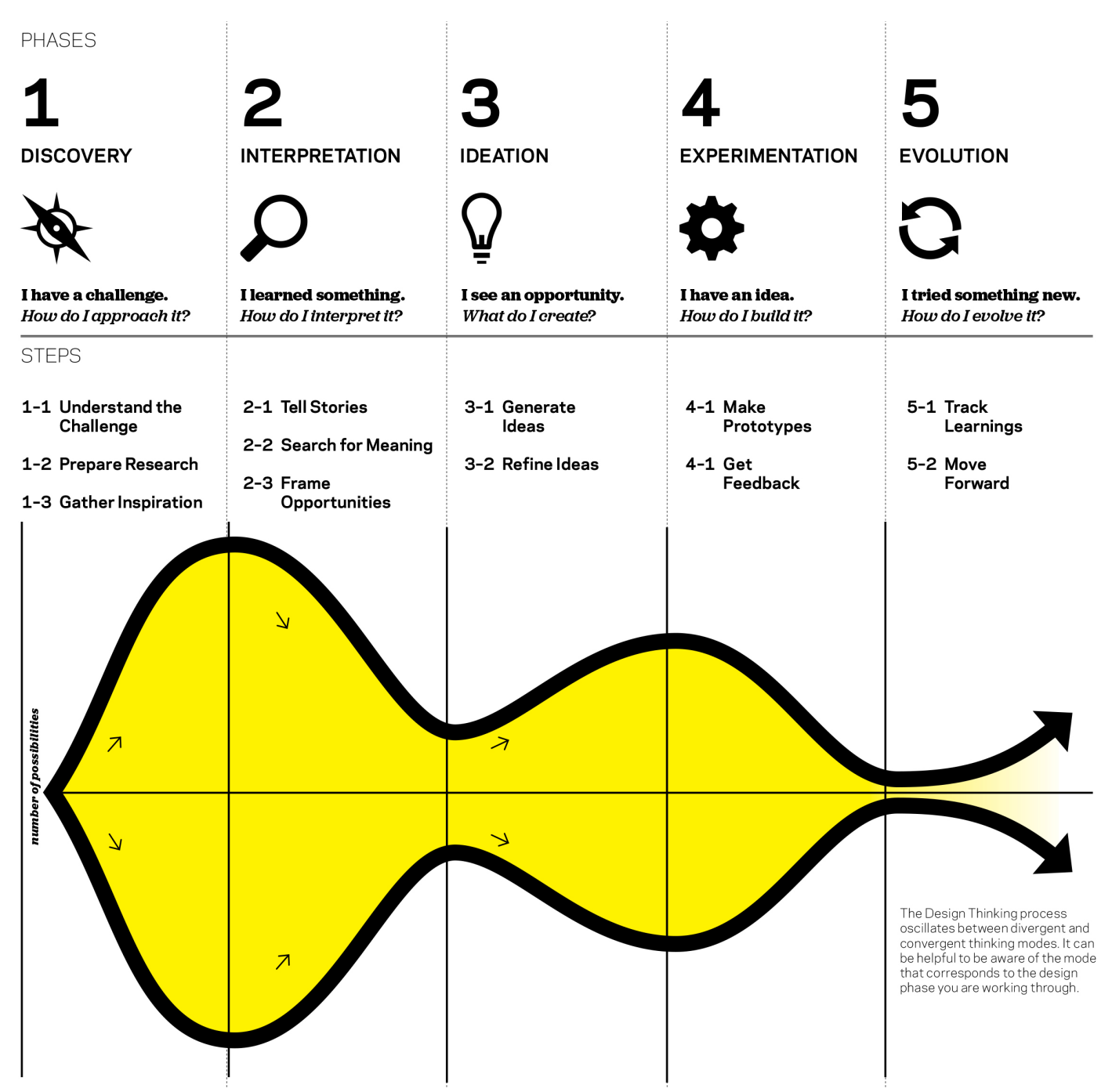

Fig. 11 Design Thinking for Educators (2012) p. 15

\subsubsection{Doble Diamant}

El Design Council neix el 1944 per donar suport a la recuperació econòmica de Gran Bretanya després de la II Guerra Mundial, amb la intenció de millorar el disseny dels productes de la indústria britànica. Actualment, el seu objectiu es concreta, de forma genèrica, en millorar la vida mitjançant el disseny. En aquest sentit, i més enllà de reconèixer i pro- 
moure el paper del disseny en la creació de valor i en el seu esforç per millorar la vida de les persones, el Design Council té una proposta metodològica que es concreta a través del Doble Diamant.

El model de doble diamant va ser desenvolupat l'any $2004^{17}$ — vegeu figura 12 - Gràficament mostra els processos de divergència i convergència que té lloc en el desenvolupament del projecte de disseny. El dibuix final queda en forma d'un diamant doble on conflueixen tres punts. La primera part del diamant, on les línies se separen, representa el primer pas de divergència, la fase de descoberta, en la qual es fa una recerca d'oportunitats. La segona part que tanca el diamant, coincideix amb la fase de definició, en la qual es realitza un primer filtrat de la informació recopilada, i que acaba amb l'elaboració del brief de disseny. A continuació arriba una nova fase de divergència, la fase de desenvolupament, en la qual es desenvolupa el projecte a través d'eines de Design Thinking, prototipat i testos. Finalment, s'arriba a una última fase de convergència que rep el nom de lliurament, amb una solució definida que passa per un test final, la producció i el llançament.

Segons explica Tschimmel (2012), aquest és l'únic model descrit per ser utilitzat per dissenyadors, els models que s'han vist a l'apartat anterior han sigut desenvolupats per ser utilitzats dins l'empresa i la gestió. Per aquesta raó, tot i considerar el Doble Diamant el model més complet, també considera que és el més difícil de fer servir en situacions on la gent no té experiència en processos d'aquest tipus, és a dir, fora de l'àmbit del disseny. L'any 2019, el Design Council presenta una revisió del seu model — vegeu figura 13 Doble Diamant 2019-, on introdueix més informació al model bàsic. A més a més, i de forma significativa, introdueix unes fletxes que trenquen la linealitat habitual del model, i el converteixen en un model iteratiu.

17 Així ho expliquen des de la seva plataforma web, on també expliquen com pretenen "donar suport a les organitzacions públiques, privades i del tercer sector que treballen transformant la forma de desenvolupar i prestar els seus serveis" https://www.designcouncil.org.uk/. (Última visita $1 / 06 / 2020)$ 
Uns diamants més petits informen dels principis de disseny que regeixen el model, així com del banc de mètodes (i eines) que acompanya qualsevol proposta metodològica creativa. Finalment, el model queda emmarcat per una declaració de principis a través del compromís (engagement) i el lideratge (leadership).

El punt d'inici i el punt final, deixen de ser un problema (problem) i una solució (solution), i passen a ser un repte (challenge) i un desenllaç (outcome). És una manera d'obrir la possibilitat de propostes durant el desenvolupament del projecte, com demostra la declaració d'intencions inclosa sota el títol de lideratge “creació de condicions que permetin la innovació, incloent-hi el canvi cultural, les habilitats i la mentalitat”. És a dir, atorguen al disseny el paper de configurar el món, i no només a l'aportació de solucions com en el primer model. El 2019 el disseny guia la innovació, no només soluciona problemes existents. En aquest sentit, és un canvi de visió important.

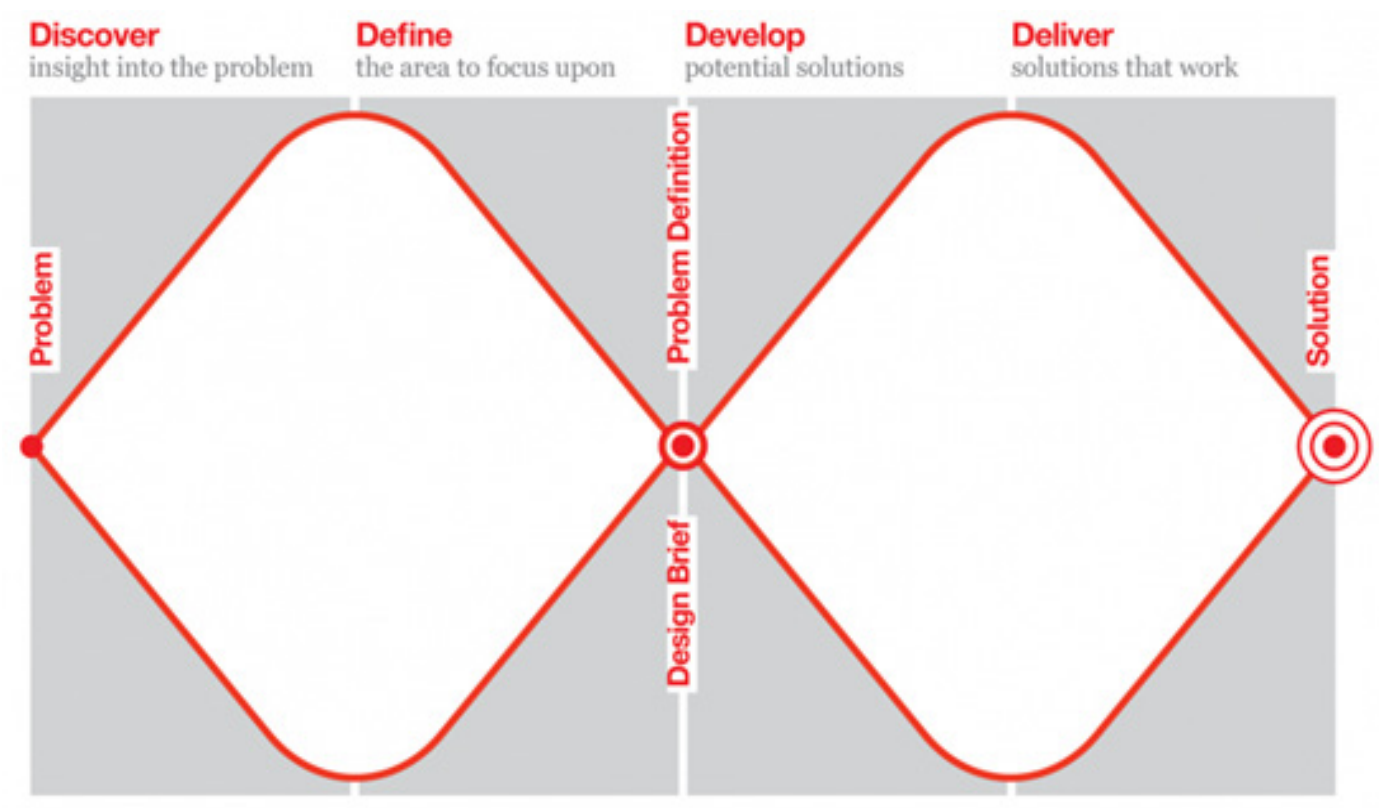

Fig. 12 Doble Diamant (2004) del Design Council 


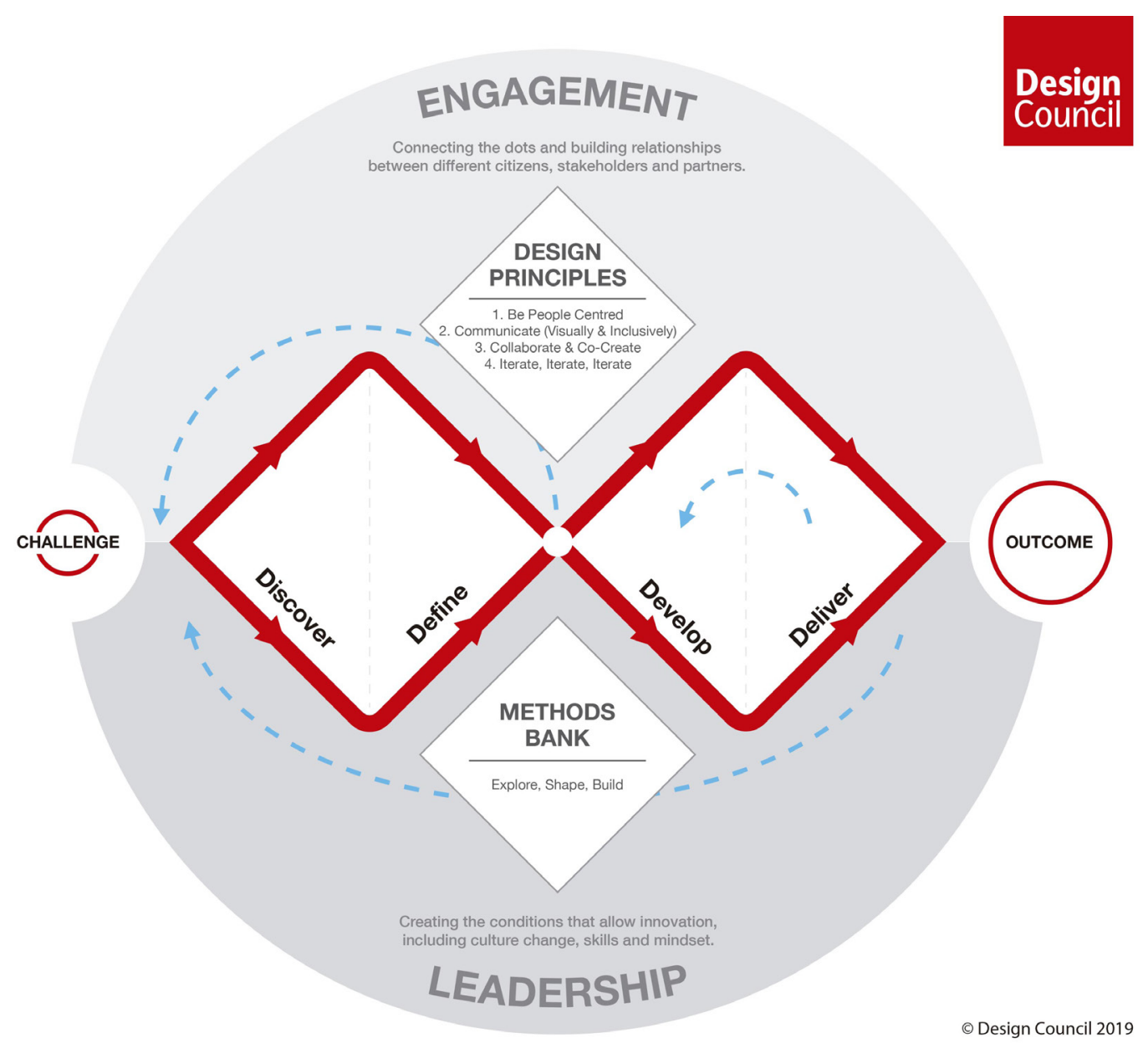

Fig. 13 Doble Diamant del Design Council · Revisió 2019

\subsubsection{Manual Thinking}

El Manual Thinking desenvolupat per Luki Huber i Gerrit Jan Veldman es presenta com una eina per a la gestió del treball creatiu en equip. Tal com expliquen els seus autors, el manual neix de la necessitat d'ordenar el procés creatiu, concretament durant la col·laboració de Luki Huber, dissenyador industrial, i Ferran Adrià, xef de cuina d'avantguarda, entre els anys 2001 i 2007. Fruit de la col·laboració neixen des de nous conceptes per servir el menjar, fins a noves eines per a la cocció, passant per eines per a les diferents preparacions de les creacions culinàries. 
Segons els seus autors, el Manual Thinking "ofereix un format eficient i agradable que ens permet afrontar diferents fases de creativitat, exploració, priorització i organització de manera dinàmica i estructurada.” (Huber i Jan Veldman, 2015, p. 38). La principal virtut del Manual Thinking és que es tracta d'una eina física, és a dir que consta d'un mapa (un full de paper mil·limetrat de 100x70 cm plegable, com els mapes) i unes etiquetes amovibles de diferents formes, colors i mides —vegeu figura 14-. El concepte bàsic, segons Coral Martínez, formadora de Manual Thinking, és "la millora de la usabilitat del paper craft fixat a la paret i els postits, elements típics dels processos creatius" (en comunicació personal 17/05/2019). És a dir, el Manual Thinking recupera metodologies per a la creativitat, com els mapes mentals, l'storytelling, l'atles d'idees o l'avaluació per eixos ${ }^{18}$, i els plasma en el seu propi format fent ús de les etiquetes i els mapes. Com diu Ferran Adrià en el pròleg del manual "per obtenir un resultat creatiu, hi ha d'haver una certa quantitat de caos, però cal començar des de l'ordre. En aquest sentit, els mapes de Luki són eines insubstituïbles." (Huber i Jan Veldman, 2015, p.8).

El Manual Thinking permet crear els mapes generatius de conceptualització i desenvolupament d'idees, i un cop acabats es poden guardar de forma còmoda i ordenada, de manera que en qualsevol moment es poden recuperar.

Com en altres processos creatius, també en metodologies pròximes al Design Thinking, es promou una actitud participativa i democràtica, i s'evita la jerarquització dels participants. Es treballa de forma visual i esquemàtica, recolzant-se en el pensament latera ${ }^{19}$, i s'eviten les llargues discussions que no arriben a cap consens. També es promou el treball en equip

18 Eines que surten explicades pas a pas en el llibre imprès de Manual Thinking (2015) de Luki Huber i Gerrit Jan Veldman. De cada eina es fa una breu explicació: per què serveix, què aporta, per què implica una millora en el desenvolupament del projecte. També explica pas a pas com dur-lo a terme, quins materials del Manual Thinking són necessaris i un exemple visual del mapa sorgint.

19 Pensament lateral, concepte creat per Edward de Bono, que es defineix com "una aproximació sistemàtica al pensament creatiu mitjançant tècniques formals que poden fer-se servir deliberadament" (De Bono, 1992, p. 10). Aquest esquema sistemàtic s'estructura al voltant de 3 principis: el qüestionament, les alternatives i la provocació. 


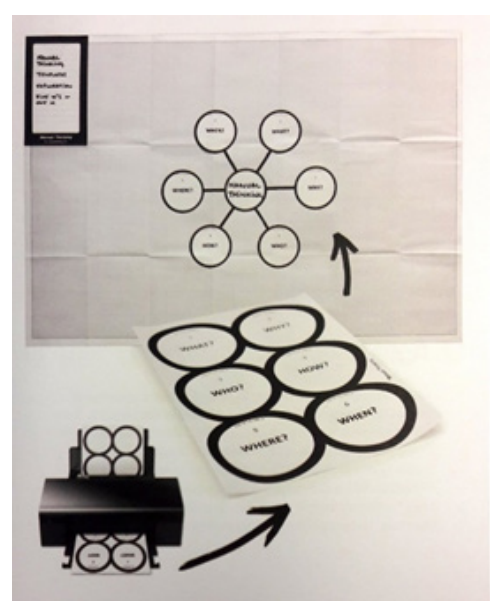

Fig. 14 Mostra del mapa i les etiquetes autoimprimibles (Huber i Jan Veldman, 2015, p.152) ajudant els participants a col·laborar en un únic mapa, per tant, amb objectius comuns, i oferint la possibilitat d'explorar de forma eficient múltiples possibilitats al voltant dels diversos tòpics. L'organització que facilita el Manual Thinking converteix l'execució d'aquest tipus d'activitats creatives en una activitat metòdica $\mathrm{i}$ palpable, i sobretot, fàcilment comprensible per a tots els participants.

Es considera interessant la inclusió d'aquesta eina com a mostra de la capacitat del disseny d'autodissenyar-se per a un bon desenvolupament del projecte. És a dir,

com uns dissenyadors, s'esforcen per millorar les seves pròpies eines, i convertir-ho, més enllà del negoci, en eines universals útils per a qualsevol procés creatiu. També en aquest cas, una de les intencions és facilitar, dinamitzar i afavorir els processos creatius a persones fora de l'àmbit del disseny, i segurament poc avesades a participar de pluges d'idees avançades.

\subsubsection{El Disseny Generatiu}

Un altre enfocament a tenir en compte és la visió d'Elizabeth Sanders i Pieter Jan Stappers que culmina amb el llibre Convivial Toolbox (2012).

Ja des del principi de la seva recerca, Sanders treballa sobre la idea que el disseny no ha de dissenyar pels usuaris, sinó amb els usuaris. L'any 2002 publica "From User Centered to Participatory Design Approaches" on considera que s'ha desenvolupat un nou moviment de disseny. Decideix anomenar-lo Postdesign (Sanders, 2002), un terme que no tindrà més recorregut però que mostra l'inici d'un nou paradigma en disseny que portarà una sèrie de canvis en la metodologia del projecte: noves maneres de raonar, sentir i treballar. Sanders 
veu molt clar que l'experiència participativa no només és un conjunt de metodologies, sinó que és una mentalitat i una actitud en relació a les persones, com per exemple la creença que tothom té alguna cosa per oferir en un procés de disseny i que amb les eines adequades tothom pot ser creatiu i capaç d'expressar opinions.

Quan l'any 2002 Sanders explica el procés de disseny centrat en l'usuari, comenta com de bones a primeres s'incloïa un investigador social que feia d'intermediari entre l'usuari i el dissenyador elaborant criteris de disseny a partir de les dades recollides de l'observació directe i d'altres fonts secundàries, de fet, aquest era precisament el seu paper. Aquests criteris, els utilitzava posteriorment el dissenyador per a desenvolupar el producte a través d'esbossos conceptuals. Segons Sanders (2002) una de les qüestions clau és que amb el temps els rols de dissenyador i investigador es fusionen (el dissenyador aprèn tècniques etnogràfiques i antropològiques, i l'investigador aprèn el llenguatge del disseny). Aquesta tendència que descrivia Sanders, a principi de segle XXI, s'ha mantingut i ha agafat força, en la recerca d'un disseny que s'autodefineix com a humanista. Una altra qüestió clau en tot aquest procés és que l'usuari passa a participar activament durant tot el procés de disseny, i que passa a ser imprescindible l'experiència d'usuari per a la presa de decisions del projecte. Sanders (2002) percep aquest gran canvi en el procés de disseny, el fet de fixar-se en l'experiència humana i en la intenció d'entendre el rol de les emocions fins al punt que l'experiència d'usuari es pugui convertir en una font d'inspiració i ideació del disseny —vegeu apartat 2.2.4.2 Visió d'Elizabeth Sanders-. Sanders, sumant-se a treballs d'altres autors, construeix les bases que considera necessàries per aproximar-se al coneixement d'aquesta experiència afirmant que cal apropar-se a l'usuari des de tres perspectives diferents: allò que la gent diu (pensa), allò que la gent fa (utilitza) i allò que la gent construeix (somia). Explorant aquestes tres perspectives simultàniament, Sanders considera que és l'única manera d'establir l'empatia necessària amb les persones que fan servir els productes.

Això que Sanders està descrivint a principi de segle XXI són les bases per l'experiència d'usuari actual. La importància que actualment s'atorga a l'usuari, als seus desitjos, 
problemàtiques i necessitats, així com als seus sentiments respecte l'ús de qualsevol producte o servei, comença com a observació de l'usuari en context a través d'estudis desenvolupats per especialistes en etnografia o antropologia.

Amb la intenció d'ajudar en aquesta recerca de l'usuari, Sanders crea el MakeTools (www. maketools.com), com a zona de trobada entre els pensaments i les idees de les persones de diferents disciplines i perspectives. El MakeTools permet tenir un nou llenguatge pel què actualment s'anomena codisseny, que no deixa de ser el disseny col-laboratiu. Aquest llenguatge passa per l'elaboració d'unes eines projectuals tant de tipus emocional com cognitiu, sobretot per la fase generativa del procés de disseny. Amb l'ús d'aquest tipus d'eines, el rol del dissenyador encara evoluciona més, i les seves tasques passen a incloure participar en la creació d'eines i en l'expansió del llenguatge de disseny per a usuaris, observar en persona les experiències i les eines que permeten l'expressió creativa d'usuaris i altres interessats, formar part de l'equip responsable de l'anàlisi i interpretació de les dades i dels artefactes i models generats pels usuaris, i fer ús de les idees generades pels usuaris com a font per a la inspiració i la innovació en disseny.

Així doncs, l'usuari queda inclòs en el propi projecte, no com a element observat, sinó com a part integrant de l'equip. Aquest fet implica una sèrie d'ajustos i canvis que Sanders i Stappers (2012) descriuen atorgant un nou nom al dissenyador, que passa a ser el facilitador, algú que ajuda als usuaris aportant recursos per expressar les seves opinions, necessitats i somnis, i deixa de ser el dissenyador, qui observa, proposa i decideix. Sanders i Stappers (2012) està apoderant a la persona perquè sigui capaç de generar i promoure alternatives a una situació present.

Les característiques bàsiques del disseny que descriu Elizabeth Sanders el 2002 són les que es llisten a continuació, i com es pot veure, guien el procés de disseny cap al desenvolupament $\mathrm{col} \cdot$ lectiu i l'experiència:

- Una nova mentalitat o enfocament. Es parla d'experiència i no d'artefactes, interfícies, sistemes o espais 
- No es tracta de mètodes específics, eines o processos, es parla d'un llenguatge visual emergent que tothom pot fer servir per expressar i interpretar les idees i sentiments que sovint són difícils d'expressar amb paraules

- És una actitud envers la gent, el fet de reconèixer que tothom té alguna cosa per oferir

- És contextual. Entendre i tenir empatia amb aquelles persones que viuen l'experiència amb els artefactes, interfícies, sistemes o espais

- És participatiu. Emfatitza la participació directa i activa de tots els interessats en el procés de desenvolupament de disseny

- És codisseny. Gent dissenyant junta

- És un procés en marxa. No es parla d'un procés lineal, sinó de la intersecció contínua de perspectives canviants.

Un altra part bàsica de la proposta de Sanders i Stappers (2008) és el què anomena fuzzy front end. L'autora considera que la representació del procés de disseny ha d'incloure una part molt important a l'inici, abans que comenci el procés de disseny pròpiament dit, l'anomenat front end, que és on tenen lloc les activitats destinades a informar i inspirar l'exploració de totes aquelles qüestions que estan sobre la taula. El fet que aquesta part del disseny sigui més caòtica li aporta el qualificatiu de fuzzy, que es pot traduir per 'embrollat'.

Durant la part d'exploració del front end la virtut és que encara està per definir el projecte

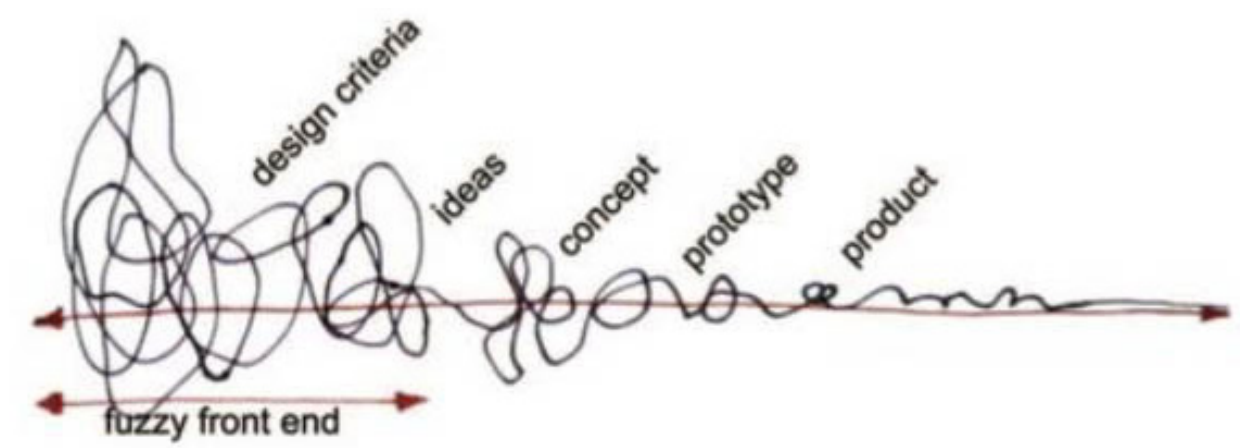

co-designing

Fig. 15 Representació del procés de codisseny. Sanders i Stappers (2008) 
en sí, un producte, un servei, una interfície,... i per tant no es focalitza en aquest resultat, sinó en l'exploració de l'experiència ¿com millorar l'ús de places i jardins d'una ciutat?, ¿com afavorir una dieta saludable? L'objectiu principal d'aquesta exploració és determinar què es podria dissenyar i, també en algunes ocasions, què no s'hauria de dissenyar.

També posteriorment i fent referència al fuzzy front end, Sanders i Stappers (2012) parlen de la conceptualització del projecte des del no res, ja que fan especial èmfasi en la detecció de noves necessitats, i no en una revisió de producte existent. La visió d'aquests autors és interessant per aquesta mirada prèvia exploratòria per a la definició de reptes de disseny basats en l'experiència.

Aquest esquema del gargot embrollat també forma part d'altres autors, Damien Newman, presenta el Design Squiggle ${ }^{20}$, precisament per explicar als seus clients, la dificultat de les primeres fases del procés de disseny.

Un cop superada aquesta part de recerca inicial, Sanders i Stappers (2012) presenten un procés de disseny de caire més tradicional, on les idees per un producte, servei o interfície es desenvolupen en conceptes, passen fases de prototip i validació en base a l'opinió dels futurs usuaris, fins que el producte es considera acabat. Per aquesta part exploratòria inicial, tal i com es veurà més endavant —vegeu 2.4.2 Les fases d'anàlisi-, són especialment importants les eines d'observació etnogràfica, i de selecció, classificació i codificació antropològica. El disseny recull les eines d'aquestes altres disciplines en el moment que col·loca l'usuari per davant d'altres consideracions, i pretén no només donar respostes a les seves necessitats físiques (en referència a una ergonomia reduccionista, qüestions d'antropometria, biomecànica i fisiologia), sinó també donar respostes a necessitats psíquiques i culturals (incloent, per tant, l'ergonomia cognitiva).

Per altra banda, cal tenir en compte que les noves disciplines de disseny, emergents en ple canvi metodològic, recullen els principis de l'experiència d'usuari amb molta més

20 Per més informació sobre la proposta d'aquest autor i sobre com desenvolupa el gargot: The Process of Design Squiggle de Damien Newman, thedesignsquiggle.com 
convicció. El disseny tradicional ho ha anat introduint a poc a poc, fins a arribar un punt, ja en ple segle XXI, que no es pot dissenyar sense tenir en compte el concepte d'experiència d'usuari.

En resum, Elizabeth Sanders és una pionera en el camp de la metodologia del disseny, posant les bases de certes característiques que s'han vist en aquest apartat, per un disseny que és actual: iteratiu, centrat en la persona fent-la partícip del procés i buscant l'experiència.

\subsubsection{Mètode Kaospilot}

Kaospilot s'autodefineix a la seva web (www.kaospilot.dk) com a una "escola de disseny i negocis híbrida, una formació multidisciplinària en lideratge i emprenedoria". Apareix en aquest treball com a exemple de metodologia docent pròpia i innovadora, que treballa de forma projectual, detectant reptes als quals aportar solucions. És interessant revisar quines estratègies segueixen per a la detecció d'aquests reptes en una metodologia afí al Design Thinking, amb la qual comparteix l'enfocament centrat en les persones i enfocat a l'acció, on s'educa a persones capaces de tenir idees i portar-les a la pràctica, la multidisciplinarietat, amb una forta consciència social i posant especial èmfasi en la solució de problemes del món real. També, molt d'acord amb les idees metodològiques del disseny, Uffe Elbæk, fundador de l'escola declara que "existeix la necessitat d'una educació que entreni la gent jove a navegar en temps de turbulències" (Brent, 2005, p. 52), aquí clarament alineat amb el tractament dels problemes mal definits del qual es parla en les teories de desenvolupament del propi disseny i de la complexitat del món actual. Precisament d'aquí és d'on neix el nom: els pilots capaços de governar el caos.

Segons Patrick Brent “l’enfocament educatiu de l'escola és la combinació de la formació en emprenedoria i la gestió de projectes amb la voluntat de fer una diferència positiva a la societat" (Brent, 2005, p. 9). Una de les característiques més inusuals de l'escola és que en 
el moment de la seva fundació, el $1991^{21}$, i durant molts anys, el seu currículum no ha estat lligat a cap ofici ni a cap disciplina concreta, sinó que la seva intenció és educar els alumnes amb "habilitats professionals perquè puguin treballar en qualsevol entorn professional basat en projectes" (Brent, 2005, p. 9). Aquesta intenció converteix l'escola en visionària, i la col-loca a tocar del 2020, en una escola de l'avantguarda educativa, completament alineada amb la tendència global del treball per projectes en tots els àmbits, tant educatius com laborals. Segons Brent (2005), aquesta organització educativa sense arrels acadèmiques, procura combinar dues direccions aparentment oposades: uns valors socials molt elevats $\mathrm{i}$ una orientació molt forta cap al mercat.

De manera similar, així com Ideo promou la seva metodologia i la posa a l'abast de tothom, Kaospilot pretén traslladar la seva metodologia docent com a mètode per a regenerar altres projectes educatius. Plantegen, per exemple, un format de formació per a desenvolupadors del pla eductiu d'un centre acadèmic. En aquesta formació es treballa a partir de la pròpia metodologia de Kaospilot, però destinat a un objectiu concret i en format concentrat. En aquest sentit es fan servir eines per estructurar la creativitat i desenvolupar el pensament lateral

Entre d'altres, una de les eines pròpies és l'anomenada I DO ARRT, què és una manera d'emmarcar el projecte a realitzar, és a dir, una eina que pretén alinear tothom que participa en un procés de desenvolupament projectual per posar-se d'acord en les expectatives i en un resultat final comú, tant en projectes d'envergadura, com en una simple reunió — vegeu apartat 2.3.6 Eines-.

Kaospilot apareix en aquest treball per la seva capacitat de recollir estratègies de diverses disciplines i aplicar-les en el desenvolupament del projecte, aportant així, una visió diferent i fresca del procés. També perquè l'estructuració del projecte, es du a terme a través d'esquemes visuals que permeten tenir en un sol cop d'ull el procés de projectació, és a dir,

21 Comparteix any de fundació amb la consultoria Ideo, amb Tim Brown al capdavant, propulsora del Design Thinking 
la seva estructura i ítems més importants. Val a dir però, que de la mateixa manera que les jornades creatives guiades pel Design Thinking, són un simulacre de la realitat, els tallers de desenvolupament creatiu de Kaospilot també són un simulacre del procés que ells mateixos segueixen en els seus estudis regulars.

L'esquema de desenvolupament de Kaospilot aplicat al disseny d'una "educació transformacional" es pot veure a la figura 16.

\subsubsection{Eines}

Al llarg del treball es fa referència a eines que acompanyen les diverses metodologies d'anàlisi. S'anomenen eines perquè organitzen i estructuren les activitats que van desenvolupant-se al llarg del procés de projectació. No són úniques, ni estàtiques, ni serveixen per qualsevol projecte, sinó que cal aplicar-les amb coneixement per aconseguir-ne el màxim rendiment. Cada eina o tècnica és adequada segons el context, el projecte o el temps que s'hi pot dedicar; no és per tant, una llista tancada d'eines que s'ha d'aplicar una rere l'altra. Metodologies com el Design Thinking n'han popularitzat unes de concretes, però la veritat és que les eines que fa servir el disseny són moltes i variades, i n'apareixen de noves constantment. El disseny, com a disciplina multidisciplinària, s'alimenta d'eines de l'antropologia o la psicologia, fa ús d'estudis d'interacció, d'experiència d'usuari i d'usabilitat; exprimeix altres eines visuals com l'esbós, els mapes o els prototips. També agafa tècniques de l'art o de l'enginyeria, i, en general, eines per potenciar la creativitat, ja que al disseny se li suposa un alt grau de creativitat i innovació. Com afirma De Bono, aquest tipus d'eines creatives, i altres tipus de recursos creatius, “no són crosses per aquells que no poden caminar sols, sinó tècniques útils per a les persones altament creatives" (De Bono, 1992, p. 32). Aquest autor, guru de la creativitat dels anys 90, defensa processos creatius estructurats i sistemàtics, i s'aparta de la creativitat fruit de la inspiració. Així, considera que l'ús i la pràctica d'aquest tipus d'eines, potencia la creativitat amb esforç i dedicació. 
VISIÓN BACKCASTING

Cómo diseñar una educación transformacional

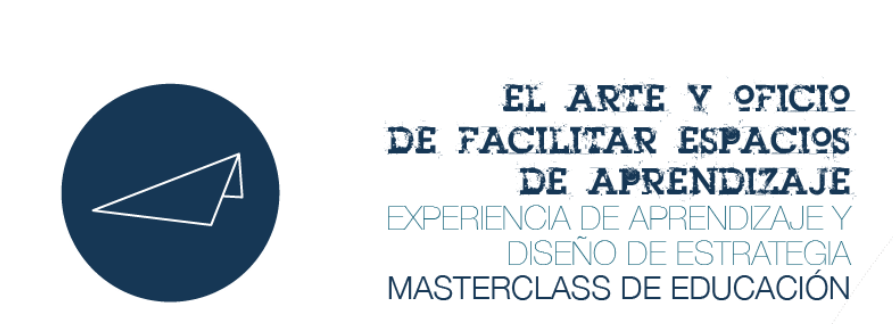

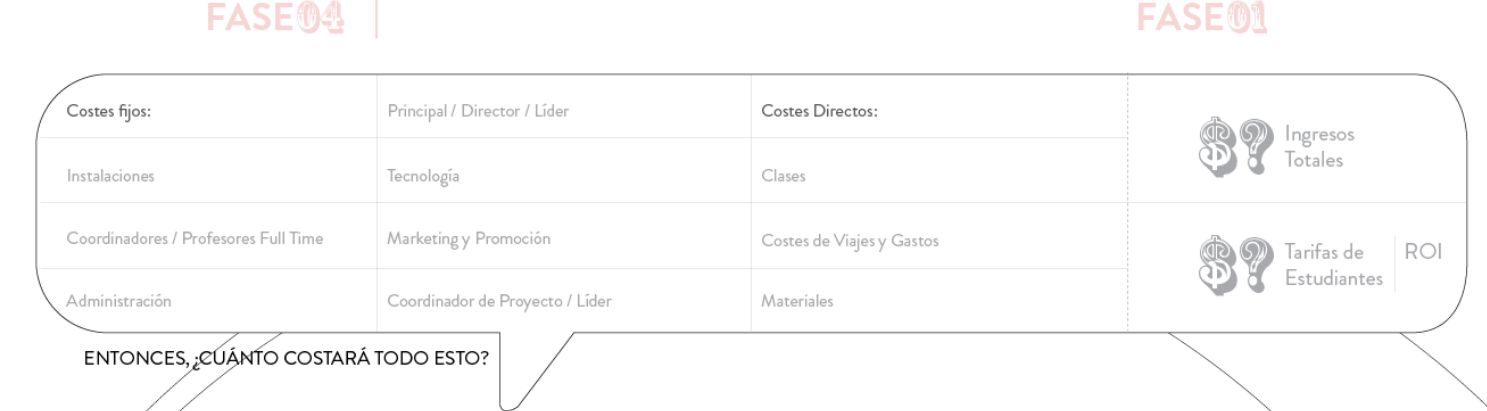

¿PARA QUIÉN ES?
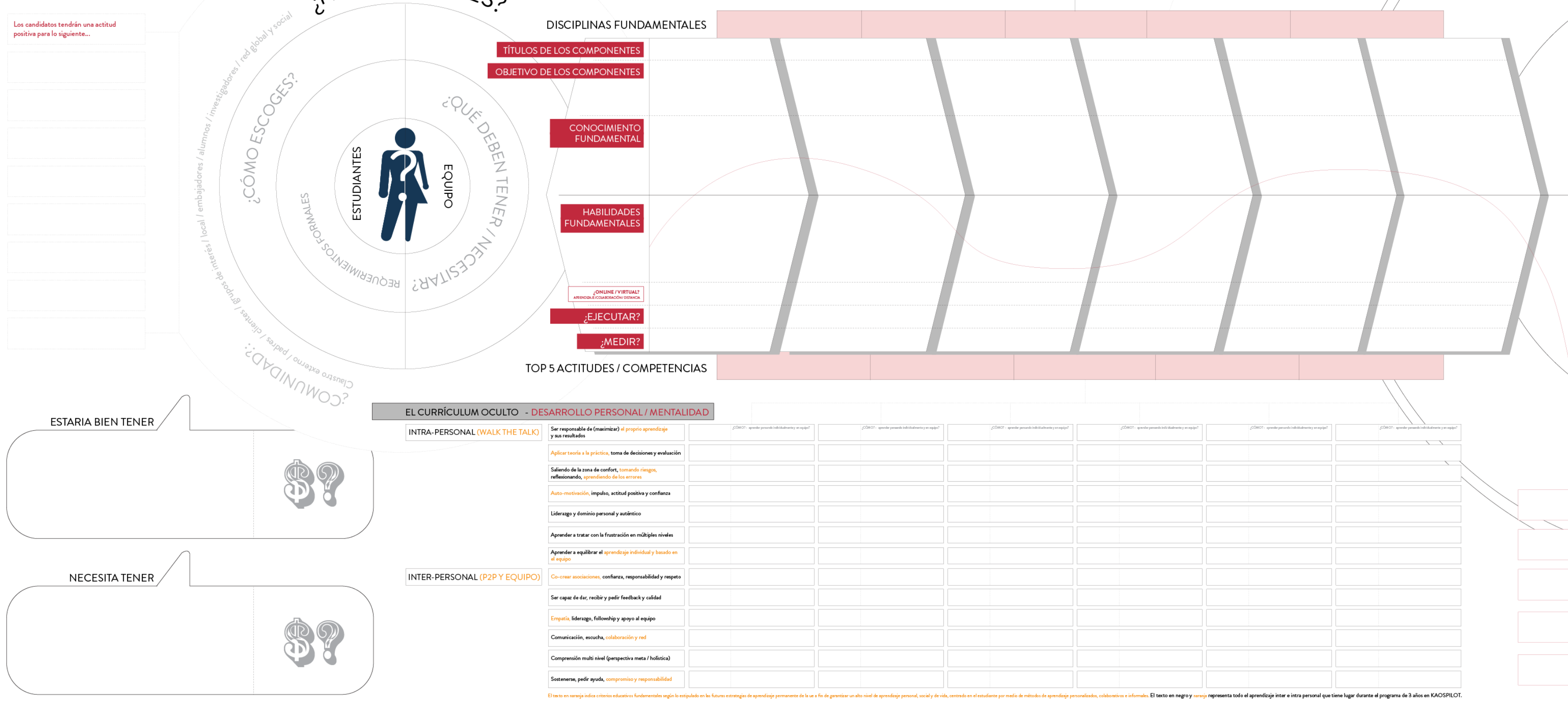

Per exemple, el Manual Thinking de Luki Huber — vegeu apartat 2.3.3 Manual Thinking— és una eina física que ajuda a dur a terme processos creatius, i a conservar-ne ben endreçat el seu resultat. Aquesta eina, neix de la necessitat de facilitar el treball creatiu estructurat i visual, típic del Design Thinking i altres metodologies afins, pròximes, també, al pensament lateral que descriu De Bono (1992). En el seu moment, no estaven popularitzats com ara, processos creatius visuals com el treball en grup a partir de mapes visuals, pissarres verticals de Post'it, o prototipatge bàsic, i aquestes eines organitzen la informació, la democratitzen, la fan més visible, i en faciliten el tractament —vegeu figures 17 i 18 -

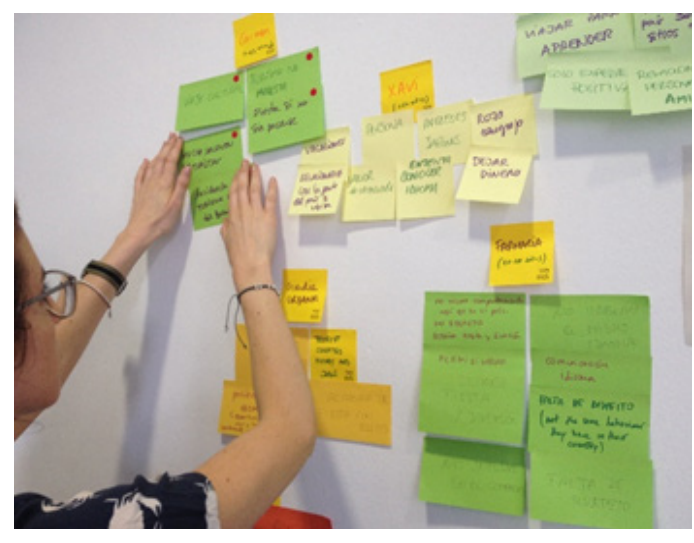

Fig.17 Fase d'ideació, GovJam 2015 Barcelona

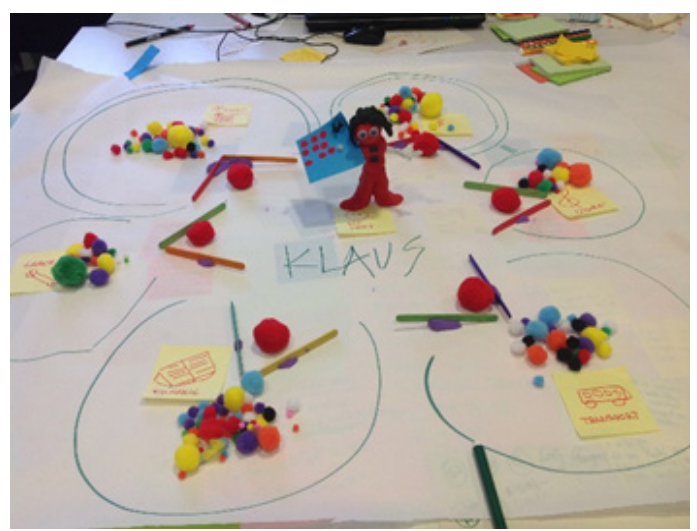

Fig.18 Fase de prototipat, GovJam 2015 Barcelona

Per exemple, una de les virtuts que es comenten del Design Thinking, és precisament la capacitat que ha demostrat aquesta metodologia per ordenar les eines i presentar-les de forma versàtil i àgil. A més a més, com explica Tschimmel (2012), les eines ajuden a fer el traspàs de les idees abstractes i poc madurades cap a algun concepte sobre el qual construir i discutir; precisament un dels moments més crítics del procés de disseny, a la vegada que el moment que marca la diferència entre un projecte avançat $\mathrm{i}$ innovador, o no.

Tot i així, una possible classificació d'aquestes eines és segons la fase projectual on encaixen millor. Al llarg de l'apartat 2.3 Mètodes i Eines, s'ha pogut veure com s'estructura la fase projectual des de diverses metodologies, $\mathrm{i}$ com de forma genèrica es pot dividir aquest procés en les fases de descoberta i divergència, i les fases de decisió i convergència. Tot $\mathrm{i}$ 
que les eines no són pròpies de cap de les fases, és a dir, que poden ser adequades per una o diverses, es poden classificar segons aquests dos grans moments.

Hi ha una eina molt útil que facilita Kaospilot, l'anomenat I DO ARRT per a l'inici de qualsevol projecte. Es tracta d'una eina per acordar tasques, normes i objectius abans de començar una reunió, unes jornades creatives, o un projecte en general. Es tracta d'acordar una sèrie de qüestions que guiaran el grup per treballar a la una. Les sigles I DO ARRT responen a les paraules següents:

- I intention - Per assegurar que tothom sap per què és membre del grup, quin és el seu valor principal, i quin és l'objectiu del projecte

- DO desired outcome - Per assegurar que tothom contribueix de forma efectiva en la direcció acordada, és a dir, que tothom coneix on es vol arribar

- A agenda $\cdot$ És l'espai reservat per a discutir i posar-se d'acord en els temes a tractar, les normes i els rols de les persones implicades. L'objectiu és establir un consens, i per tant el compromís de tothom, de respectar les decisions organitzatives prèvies.

- $\mathrm{R}$ roles $\cdot \mathrm{S}$ 'estableixen rols, com per exemple el conductor/facilitador de la reunió o procés projectual, els portaveus o els secretaris

- $\mathrm{R}$ rules $\cdot$ Les normes poden ser molt variades però sempre tindran la intenció d'aconseguir els objectius amb més eficàcia.

- T timeframe $\cdot$ Per posar-se d'acord amb la temporització

A continuació, es llisten una sèrie d'eines que s'han extret de diverses fonts ${ }^{22}$. En general fonts relacionades amb el disseny, que de forma altruista i democratitzadora es recullen tant en obra impresa, com a través de recursos online. Són eines comuns i en general molt utilitzades en l'àmbit del disseny. Per altra banda, aquest tipus de recursos adaptats a la dis-

22 Jones, JC (2a ed. 1992) El Design methods; Sanders, E. i Stappers, P.J. (2012) Convivial Toolbox; Stickdorn, M. i Schneider, J. (2011) This is Service Design Thinking. També de pàgines web com la www.designkit.org de Ideo, o la www.servicedesigntoolkit.org, amb plantilles d'ús 
ciplina ergonòmica en les seves fases de recerca i desenvolupament projectual serien útils per fer un pas endavant cap a l'ergonomia més prospectiva, alineada amb la descripció de Robert i Brangier (2009). En aquest sentit, l'ús d'eines per a la creativitat projectual és un punt de distanciament entre ergonomia i disseny, i un dels motius d'aquesta recerca, que pretén enriquir l'anàlisi ergonòmic a través de processos creatius, deixant enrere una visió basada en protocols d'avaluació i una ergonomia només preventiva i correctora.

Agafant com a exemple per a la classificació de les fases el Doble Diamant, per la fase de descoberta (divergent) les eines que es proposen són formes d'aproximació a l'usuari per identificar quines coses són importants per ell, què el motiva, quines emocions té, què no li agradarà, quina solució s'imagina, eines relacionades amb l'experiència d'usuari... Són eines d'aproximació al problema, o a la qüestió que es vol tractar, són eines de recerca i descoberta, tant in situ en forma d'experiència pròpia, com a través de recerca de literatura i referents. Es tracta d'aprendre i cal fer un registre de tot perquè serveixi posteriorment per a la generació d'idees.

- Observació in situ i registre de tot allò observat de forma sistemàtica, a través d'un diari de camp o de qualsevol altre mètode

- Recerca de literatura referents i antecedents

- Entrevista amb usuaris per empatitzar, buscar històries, entendre les decisions que prenen; així com investigar el comportament de les persones

- Enquestes, per recollir informació útil de persones com a mostra d'un conjunt de població molt més ampli

- Recerca d'inconsistències visuals, per trobar direccions sobre les quals fer recerca en relació a millores del disseny

- Testos sistemàtics, per identificar accions que són capaces d'aportar modificacions en situacions que són massa complicades per entendre

- Selecció d'escales de mesurament, taules per ordenar el contingut, i per poder-lo mesurar o calcular 
- Quadres de recepció d'informació, per ordenar el material recol·lectat

- Saturar i agrupar. A través d'idees escrites en Post-it es poden traduir pensaments i experiències en peces visuals. Primer s'agrupen tots, i llavors es classifiquen.

- Mind maps de tot tipus per ajudar a registrar la informació. Els mapes són clau per visualitzar les relacions i connexions dels diversos elements.

- Mapa d'empatia, on es classifica en quadrants diferents allò que diu, fa, pensa, i sent l'usuari

La fase definir (convergent) del doble diamant és una fase on s'especifica l'espai de definició de les premisses de disseny i el marc de treball, és a dir l'abast del problema. La clau d'aquest procés és determinar de forma precisa el reptes del disseny a través de treballar la informació recopilada i el coneixement adquirit en la fase anterior, és necessari crear coherència en tot el material recollit. Per aconseguir-ho, es proposen diverses eines que ajuden a desvelar els insights o revelacions, i a escollir un camí que acabarà amb la definició del problema a treballar o del brief de disseny, és a dir, unes eines que ajuden a buscar respostes i a prendre decisions.

- Brainstorming o pluja d'idees, sessió participativa de generació d'idees

- Storytelling. Per Brown (2009) aquesta és una eina relacionada amb el mapa de l'experiència d'usuari. Les històries posen les idees en context i els aporten significat. A més a més, les històries tenen la virtut de definir un espai temporal, ja que es construeix sobre una línia de temps.

- User Journey. Propi del disseny de serveis. Amb aquesta eina es pretén identificar tot allò que fa un usuari del servei des que sorgeix la necessitat de fer-lo servir, fins que acaba la relació.

- Persona. Una representació de l'usuari que ens ajuda a dibuixar un personatge arquetip que serveixi d'exemple d'un grup de persones més gran.

- Modificació de blocs mentals, per trobar noves direccions on buscar quan la recerca 
aparentment no ha trobat cap solució acceptable a través de preguntes que pretenen canviar el punt de vista: altres usos?, adaptacions?, modificacions?, ampliacions?, substitucions?...

- Diagrames morfològics, per ampliar l'àrea de recerca de solucions

La fase de desenvolupar és el què també es pot definir com l'inici del procés de disseny, que comença per la generació de múltiples idees que aportin possibles solucions. En aquest moment, la pluja d'idees torna a ser una eina pertinent, així com els croquis, els mind maps, els prototips i totes aquelles eines que ajuden a crear alternatives. Es tracta d'una nova fase de divergència.

- Taula de Com podríem...?, en la qual es plantegen frases subjectives sobre la temàtica que s'està tractant. Taules interrogatives: Què? Com? Per què?

- Elaboració de prototips de diversos tipus, d'empatia, d'avaluació, etc. Des del prototip més simple, que pot ser un esbós per explicar una idea, permet començar a treballar sobre fets i no sobre paraules que descriuen coses. El fet de prototipar, obliga a prendre decisions i descobreix nous temes que no havien sorgit fins al moment

- Matrius i xarxes d'interacció. Expressions visuals per veure com les diverses accions o punts concrets del projecte es relacionen amb d'altres. Per fer-ho, ajudar-se de matrius i xarxes facilita la classificació i l'obertura de ment

Per la fase de lliurament, les eines busquen, per una banda, confirmar i avaluar les decisions preses i, de l'altra, comunicar la proposta i lliurar el projecte per a la següent fase. També hi entren eines de validació del projecte i de revisió.

- Prototips molt més elaborats i fidels al producte final, tant en 2D com en 3D que permetin exàmens d'usabilitat més estrictes

- Sistemes d'enginyeria. Per aconseguir compatibilitat interna entre components del sistema i compatibilitat entre el sistema i el seu entorn

- Checklists per fer visibles els requeriments que han guiat el procés de disseny i es 
puguin reconèixer els diversos passos seguits, així com verificar que s'han respectat els requeriments imposats. També per enregistrar i poder-ne fer ús en altres ocasions similars.

- Elaboració de criteris de selecció. Definir clarament què es considera un disseny acceptable

Es pot trobar a internet amb facilitat reculls d'eines amb explicacions sobre com utilitzar-les i amb exemples concrets d'aplicació. Per exemple, des de Ideo es crea la www. designkit.org on es troben descripcions de les diverses eines, vídeos de gent que explica la mentalitat que guia aquesta metodologia i casos d'estudi.

A www.servicedesigntoolkit.org es poden descarregar plantilles que guien durant les diverses fases del procés de disseny. Des la mateixa pàgina es pot accedir a un manual, però ja no de forma gratuïta.

Des de la d.school i el Hasso Plattner Institut ofereixen també els seus recursos de forma gratuïta online a http://dschool.stanford.edu/use-our-methods. La Universitat Oberta de Catalunya, UOC, té també un portal de recursos en obert a http://design-toolkit-test.uoc. edu/ agrupats en el què anomenen Design Toolkit.

A www.designthinkingforeducators.com es poden veure una sèrie de vídeos que expliquen com fer ús de les eines. La pàgina, relacionada amb Ideo, serveix per explicar què és el manual Design Thinking for Educators.

La consultora Frog Design, no ofereix les seves eines en línia a www.frogdesign.com, però sí que té publicat un llibre publicat amb el títol "Frogthink Workbook" on apareixen explicades amb detall.

A part de les eines online que es poden descarregar de forma gratuïta, trobem diversos manuals entre ells Convivial Toolbox de E. Sanders i P.J. Stappers. O el manual publicat per Lucy Kimbell amb el títol The Service Innovation Handbook. Action-oriented creative thinking tool kit for service organisations en clara relació amb el disseny de serveis; igual 
que el manual de M. Stickdorn i J. Schneider amb l'obra pionera en el disseny de serveis This is Service Design Thinking. I com a obra pionera no podem oblidar el Design Methods de J.C. Jones.

Resumint, d'eines n'hi ha moltes i cadascú ha de saber triar segons les necessitats del projecte i adaptar-les. L'experiència en el propi desenvolupament del projecte serà clau per saber aplicar cada eina de la millor manera possible i treure'n el màxim profit.

És envejable la capacitat del disseny d'estructurar-se dins del seu propi sistema en una estructura dinàmica i adaptable a les infinites situacions de disseny que poden produir-se. L'abast del disseny arriba allà on arriba la ideació humana, per tant és infinit, i cada situació o cada projecte és únic. L'única possibilitat d'estructurar una disciplina tant diferent dins la pròpia disciplina, és a través d'un mètode projectual acompanyat de recursos adaptables.

\subsubsection{Conclusions}

El què es troba en l'apartat d'Eines i Mètodes està relacionat amb la posada en escena del desenvolupament del projecte. És a dir, per una banda la seva estructuració en general a través de fases; i per l'altra, eines concretes que acompanyen en el procés de realització del projecte.

Els mètodes són les diverses propostes que formen l'estructura; un esquelet que sustenta el procés projectual. Totes elles són propostes de fases molt genèriques, a part d'iteratives, o sigui que tot i estructurar, són àgils i adaptables a les diverses necessitats dels projectes. Es considera la premissa de convergència i divergència una de les més interessants, també per la base projectual que ocupa aquest treball. Ja en l'obra de 1970, Design Methods, de John C. Jones, posa nom a les diverses fases projectuals a través d'aquests conceptes: divergència, transformació, convergència. La seva proposta encara es manté en una sola iteració; és a dir, un procés de recerca —-divergència— on s'amplia el coneixement, una 
fase de transformació, i un procés de presa de decisió — convergència-, on es seleccionen i es trien les opcions pertinents. Més endavant, tant a la proposta del Doble Diamant, com a les propostes basades en els principis del Design Thinking, les fases de divergència $i$ convergència són iteratives i acompanyen el projecte tantes vegades com sigui necessari.

En definitiva, aquesta estructuració és molt positiva per entendre el desenvolupament del projecte de disseny, però no únicament, en realitat és aplicable a qualsevol altre procés projectual. El fet de fer entenedor aquest procés, el democratitza, de manera que s'expandeix cap a àmbits on no era usual el treball per projectes; una bona mostra d'això és l'expansió del Design Thinking a nivell empresarial. També, com que es deixa explicar de forma clara, resulta molt útil per les pròpies escoles de disseny, ja que posa noms i cognoms a un procés preexistent, però més difícil d'explicar sense aquesta posada en escena visual i explicativa. Per altra banda, aquests mètodes posen èmfasi en la Persona, posicionen la Persona com a premissa projectual a respectar, satisfer i ajudar, així com millorar-li l'entorn en general; i en aquesta línia són les eines més comuns, buscant la comprensió de l'usuari. La ferma intenció de benefici per la persona d'aquest tipus de mètode projectual, conflueix perfectament amb els principis bàsics de l'ergonomia i del disseny, i d'aquí que es consideri que són dues disciplines paral·leles.

Pel què fa a les eines, es consideren ajudes. És a dir, tècniques que ajuden a aconseguir un fi. A través d'unes instruccions senzilles, completant mapes o responent preguntes, es duen a terme una sèrie d'activitats que ajuden a recollir informació, a classificar-la, a analitzar-la, a treure conclusions, a prendre decisions, a aprofundir en algun tema, a llegir entre línies, a descartar, a prioritzar, etc. Les eines són infinites i s'utilitzen segons necessitat. Tot i així n'hi ha algunes que formen part de l'esquelet projectual, com per exemple el Service Blueprint o l'User Journey Map, com s'ha comentat al subapartat 2.2.5.1 Service Design Thinking, ja que són eines que ajuden a tenir una visió global del projecte, convertint-se en un tipus d'eina fonamental que es pot fer servir en tots els projectes, sigui quina sigui la seva envergadura. 
En resum, aquest és un apartat d'aplicació, una aproximació als mètodes i les eines que es fan servir actualment en el projecte de disseny, que no pretén fer-ne un resum extensiu, sinó fer visible la gran quantitat de possibilitats estructurals i de recursos disponibles.

\subsection{La base analítica del disseny}

Es pot afirmar amb rotunditat que el disseny es desenvolupa a través de projectes. Naturalment, no és l'única disciplina que ho fa, però potser sí que és una de les disciplines que més s'esforça per explicar com funciona el projecte, sense oblidar els esforços destinats a explicar el propi procés de dissenyar. Queda fora de l'abast d'aquest treball, tot i que en alguna ocasió s'hi fa referència, allò que està relacionat amb les bases del pensament que fan possible el projecte de disseny, és a dir, una recerca més profunda relacionada amb les bases cognitives, o amb el raonament, que per exemple, permeten al dissenyador treballar a partir de problemes mal definits com a base del projecte. Temàtica que van posar sobre la taula des de la Universitat Tècnica de Delft, en el primer simposi sobre recerca en disseny l'any 1991. Tal com diu Katja Tschimmel (2012), resulta especialment interessant perquè en aquell moment posen les bases d'una nova visió per analitzar el pensament en disseny. Aquest treball, però, s'allunya d'aquesta reflexió i se centra en el propi projecte, en el desenvolupament del projecte que avança pas a pas per acabar definint un artefacte que formarà part en menor o major mesura del món que ens envolta. Concretament, se centra en una fase de recerca que, a grans trets, ha de desembocar en la definició de les premisses que emmarquen i sustenten el projecte, la plasmació de reptes de disseny i la possible projecció d'hipòtesis.

La metodologia del projecte, tot i les seves diferències, és allò que marca el pas del disseny; i és a la vegada, allò que fa possible que es pugui parlar de disseny d'una campanya, de disseny d'un cotxe o de disseny d'un artefacte per servir la sopa, ja que de manera genèrica 
i cadascú amb les seves particularitats, envergadura o exigències tecnològiques, comparteixen la base projectual del seu fer. Entendre la metodologia del projecte, fa possible afrontar els reptes, encara que siguin molt dispars, sobretot a les persones que s'inicien en la disciplina.

Aquestes afirmacions sobre la disparitat dels reptes i per tant sobre la gran capacitat d'abast del disseny, són possibles en el moment que el projecte se sustenta sobre una forta capacitat d'anàlisi, de presa de decisions i d'establiment de premisses que han de marcar el desenvolupament de l'artefacte. L'argumentació respecte la presa de decisions durant el projecte, és el que en aquest treball s'anomena la base analítica del disseny. Al seu torn, aquesta base analítica se sustenta sobre els principis de recerca i investigació, tal i com es veurà més endavant.

S'agafa com a referència per a aquest apartat l'estructura projectual del disseny que descriu Josep Maria Martí Font a través de la seva obra Introducció a la metodologia del disseny (1999). Tot i que és una estructuració clàssica, es considera rellevant per a la seva profunditat d'anàlisi, i per la seva proximitat. És interessant la seva visió perquè defineix el disseny a través de la seva metodologia del projecte i d'aquesta manera aconsegueix ampliar l'abast de la disciplina més enllà de la concreció final de l'artefacte. Així doncs, es recullen de la seva obra aquelles reflexions que fan referència precisament a característiques del mètode i del model projectual del disseny.

Aquest apartat es divideix en quatre subapartats. El primer -2.4.1 El procés projectual一, pretén ser una aproximació a les generalitats del procés projectual, de manera que s'explica la necessitat del projecte de tenir una estructura i una organització de tasques i tempos. És una caracterització genèrica que es pot concretar de formes diverses, pretén fixar el mètode projectual com a raó de ser del procés de dissenyar, però entenent que segons les intencions o necessitats del propi projecte, entre d'altres característiques, es pot concretar diferent.

El segon i tercer subapartats - 2.4.2 Les fases d'anàlisi, i 2.4.3 Les fases argumentatives del projecte-, s'endinsen en el cor d'aquest treball, ja que exposen el procés projectual de 
recerca: l'obtenció de dades, el seu tractament i com convertir-ho en informació pertinent pel projecte. I posteriorment, com aquesta informació pertinent es converteix en premisses de disseny. Ambdós subapartats corresponen a la primera iteració de divergència i convergència del projecte; és a dir, una fase de recerca i aproximació empàtica a un tema, i l'extracció d'evidències i reptes de disseny.

Finalment, l'últim subapartat -2.4.4 Elaboració d'un brief de disseny-, correspon a l'elaboració d'una guia projectual de premisses a respectar per al desenvolupament del projecte. És el punt de partida per al desenvolupament del projecte i el document que en fixa les bases. Com es veurà en el subapartat corresponent, les dues fases d'anàlisi i d'argumentació són les que sustenten conceptualment la presa de decisions respecte les premisses projectuals. Aquest treball, pretén endinsar-se en el procés projectual fins a aquest punt, és a dir, fins a l'elaboració del brief, ajudar en el mètode de manera que aquest procés sigui estructurat, àgil, complet i, per davant de tot, basat en les persones. Queda fora del seu abast les següents fases de desenvolupament, formalització, producció, etc. que convertiran la idea en artefacte físic real.

\subsubsection{El procés projectual}

Josep Maria Martí Font (1999) pretén construir un model del procés projectual del disseny perquè considera que és l'única manera de descriure'l, precisament degut a la gran varietat de possibilitats existents. Segons el propi autor, el model que proposa mostra "amb el major grau de simplicitat, claredat i generalitat, la complexitat del propi procés projectual real" (Martí Font, 1999, p. 100). Aquesta és també la intenció dels models vistos en apartats anteriors com les diverses fases del Design Thinking o el Doble Diamant, que també presenten models projectuals simples, que guien al llarg de la complexitat del projecte vegeu 2.3 Mètodes i Eines-. De totes maneres, en aquest apartat no interessa tant el model que proposa Martí Font, molt més complex que la resta, sinó la seva aportació sobre les 
constants projectuals, és a dir, sobre algunes característiques del projecte de disseny, que en formen part de forma implícita (Martí Font, 1999, p. 101-103), i que permeten caracteritzar el projecte de forma genèrica.

Per exemple, l'autor considera que "tota producció d'artefactes és el resultat i la conseqüència de necessitats humanes de tot ordre i/o pot generar també noves necessitats no existents amb anterioritat” (Martí Font, 1999, p. 101). El tema del disseny al voltant de

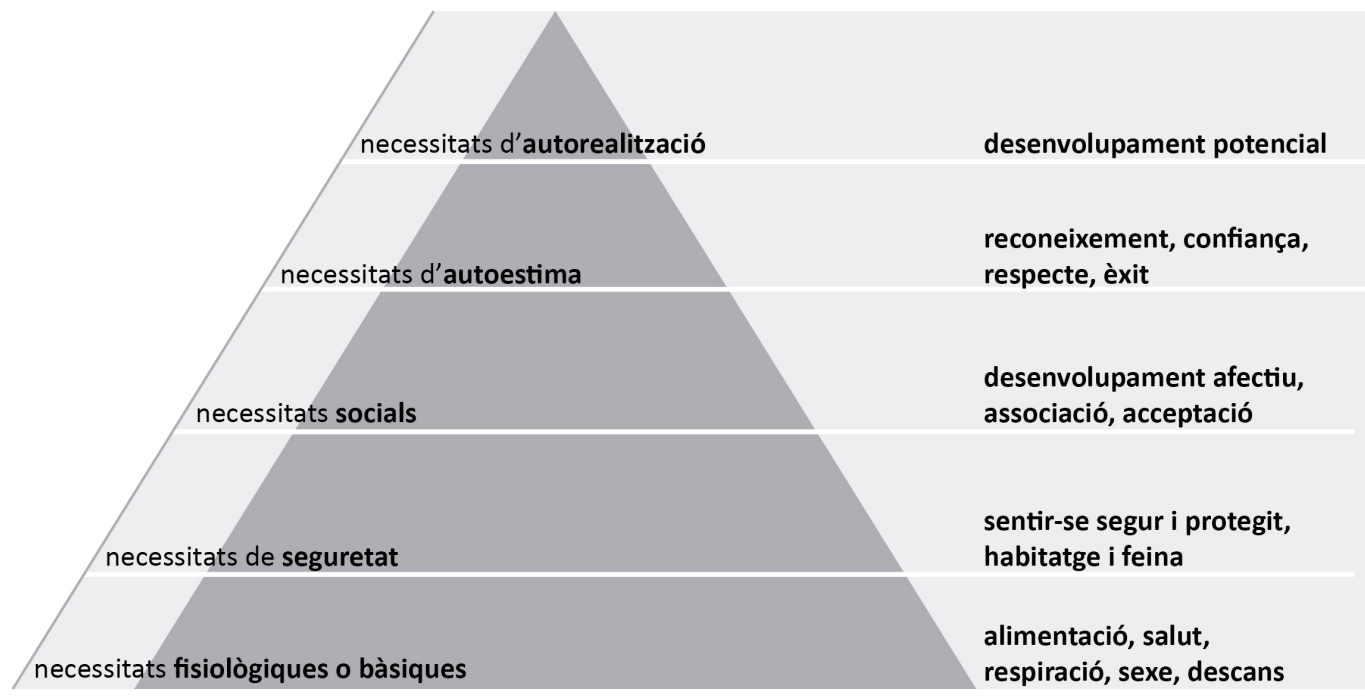

Fig. 19 Piràmide de Maslow segons Turienzo (2016)

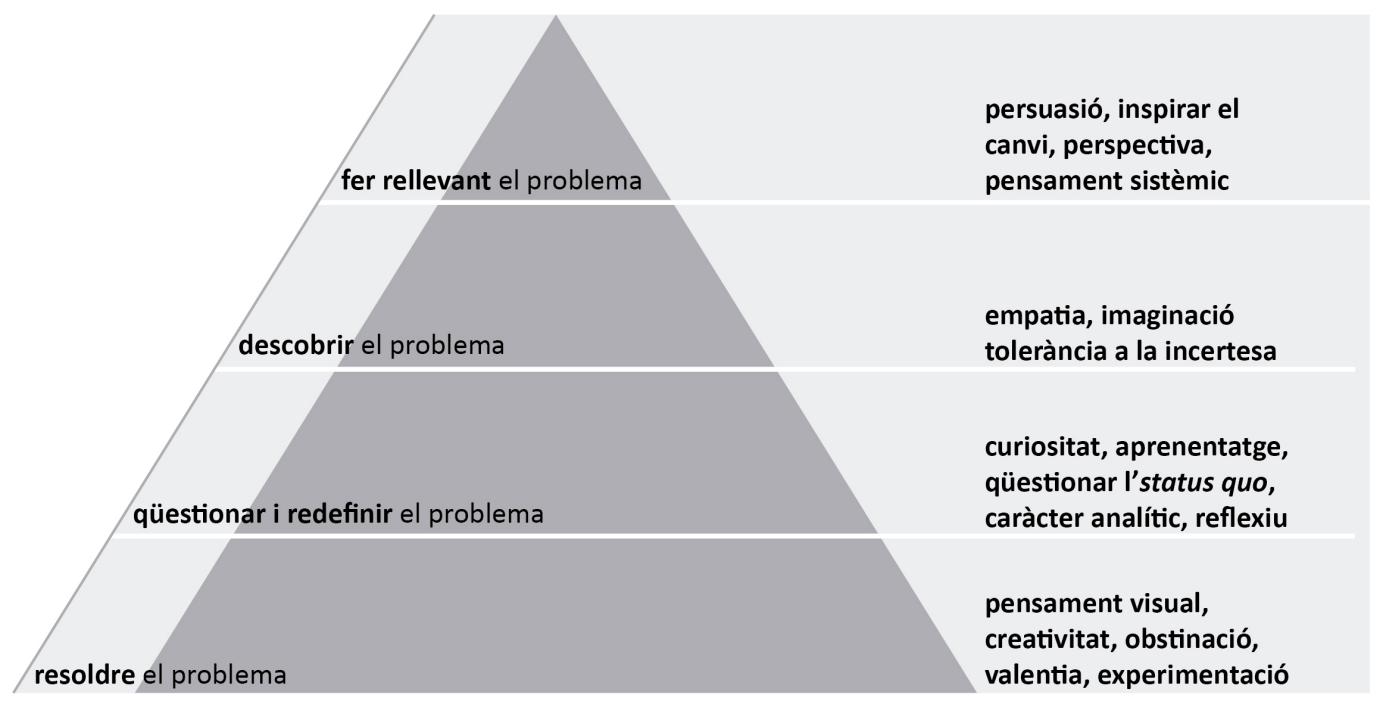

Fig. 20 Piràmide d'habilitats segons Luis Arnal (2017), d'Insitum 
les necessitats humanes, és un tema recorrent, sovint el seu punt de partida teòric, i segur conflictiu com a base del projecte. Per exemple, si es pren com a referència la piràmide de necessitats que va presentar el psicòleg nord-americà Abraham Maslow el 1943, les necessitats humanes són moltes i molt variades, de manera que el projecte es podria situar en qualsevol punt de la piràmide, on les necessitats apareixen diferenciades per nivells. La piràmide exemplifica com la persona pretén cobrir cada nivell de necessitats; amb l'assoliment de cada nivell, es passa al nivell directament superior, en un recorregut que suposadament puja cap a la felicitat — vegeu figura 19-, i on, si no estan cobertes les necessitats d'un nivell, no té sentit fixar-se en el següent. Tot i així, i en referència al disseny, el propi Martí Font, citant a Ortega i Gasset, afirma que existeix la paradoxa quan "allò que és superflu és el més necessari i primordial per a l'home. Segons Ortega, l'home no només vol viure, sinó que en realitat vol viure bé. No vol l'estar, vol el benestar. En aquest sentit, l'autèntica necessitat de l'home no és el que els antropòlegs han anomenat sovint necessitats primàries, sinó tot allò que sobrepassa aquest estadi” (Martí Font, 1999, p. 64). Sota aquest punt de vista, el punt de partida del projecte també és un punt conflictiu, ja que ràpidament es pot caure en estereotips superflus relacionats amb el disseny, per exemple l'estètica com a raó de ser, o la creació voluntària de necessitats inexistents fins al moment, temàtica molt actual relacionada amb la tecnologia. La complexitat de la formalització de l'artefacte és immensa, i no forma part de l'abast d'aquest treball, tot i així, es considera pertinent fer-hi esment perquè sí que es considera important que el dissenyador sigui conscient del punt de partida del seu projecte, que també inclou on se situa social, econòmica i culturalment. En aquest sentit i per al projecte de disseny, resulta molt interessant la piràmide d'habilitats que presenta Luis Arnal, membre fundador d'Insitum ${ }^{23}$, consultoria de disseny amb seu a diversos països del continent americà i a Espanya (Barcelona), a les jornades de disseny organitzades pel FAD (Foment de les Arts i el Disseny, Barcelona) el juny de 2017. Arnal presenta una piràmide que dibuixa la diferència de problemes, que un dissenyador afronta.

23 Per més informació, visitar la seva pàgina web www.insitum.com 
Arnal parla de problemes i no de necessitats, en una actualització de la piràmide de Maslow i fent referència al disseny. La piràmide és útil per entendre on es col·loca el repte, com respon així a les diverses necessitats i, a més a més, aprofita per a caracteritzar les habilitats del dissenyador - vegeu figura 20-.

En aquesta piràmide es poden veure les diverses oportunitats del repte de disseny. Si es pren com a exemple el repte de l'elaboració del cafè, al nivell inferior, el concepte resoldre el problema, fa referència al moment inicial de la resolució del problema, la configuració d'una cafetera i la solució tècnica i de materials que ho fan possible, per exemple, les cafeteres de cafè espresso italianes de principi de segle XX com la de l'empresa La Pavoni — vegeu figura 21-; cafeteres de bar, grosses i complicades. Amb el mateix repte de fer el cafè, el 1933 Luigi de Ponti amb la col·laboració d'Alfonso Bialetti, presenten la petita Moka Express — vegeu figura 22-, fruit del segon nivell de la piràmide qüestionar i redefinir el problema. La premissa projectual que redefineix el problema és que Bialetti vol una solució per a fer el cafè a casa, per tant ha de ser un artefacte, petit i senzill, precisament el què aconsegueix amb la Moka Express a principis dels anys 30. En el tercer nivell de la piràmide, es troba descobrir el problema. Aquí el nou repte és "professionalitzar" el cafè a casa i poder-lo fer de manera més àgil, més ràpida i més precisa, és a dir, sempre igual, sense perill de sobreeixir o que es cremi, entre d'altres,

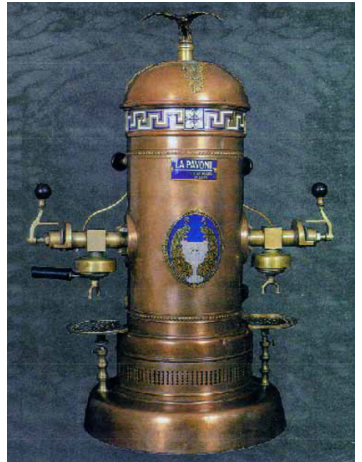

Fig. 21 Model "Ideale" versió "Gigante Lusso", 1930

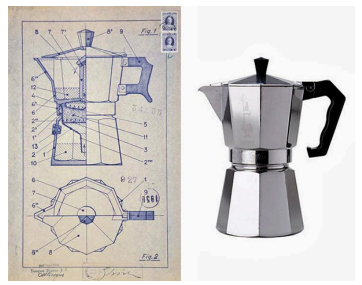

Fig. 22 A l'esquerre, esbós per a la cafetera original; a la dreta, una cafetera actual de la marca. Comparant-les es veu amb claredat les poques modificacions viscudes.

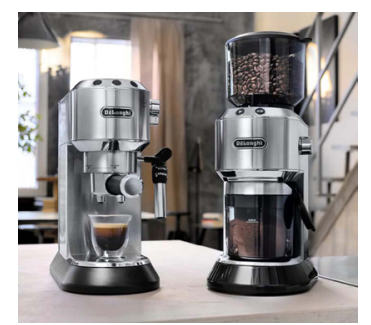

Fig. 23 Model "Dedica EC 685.M" i molinet de cafè, de DêLonghi

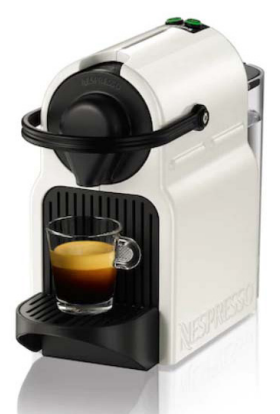

Fig. 24 Model "INICIA" de Krups per a Nespresso 
és a dir, que es descobreixen problemàtiques. Diverses marques presenten els seus models, DêLonghi - vegeu figura 23-, Saeco, Krups, etc., en format de cafetera de bar en versió reduïda, i cafè espresso manual. Finalment, s'arriba a la cúspide de la piràmide fer rellevant el problema, i aquí, naturalment, es troba el cas Nespresso — vegeu figura 24-, que aporta una solució per a fer cafè que es converteix en un servei global i, aparentment, amb molta més qualitat que la resta de solucions, fins al punt de convertir el fet de prendre un cafè en un plaer ineludible.

Aquesta piràmide serveix per veure la importància de les premisses projectuals, ja que són precisament aquestes que emmarcaran el projecte, i per tant les resolucions finals. Es tracta d'emmarcar el projecte per ser conscient on se situa el producte en societat

En segon lloc, Martí Font considera que la producció de tot artefacte o bé és una iniciativa pròpia, o bé és una iniciativa aliena que arriba en forma d'encàrrec (Martí Font, 1999, p. 101). Ambdues situacions funcionen com a punt de partida del projecte. Però cal especificar, que pel bé de la innovació, i en pro dels processos metodològics descrits amb anterioritat — vegeu per exemple 2.3.5 Kaospilot— aquest encàrrec no hauria de ser amb format final, a amb la proposta de l'artefacte, sinó que hauria de partir de la necessitat, del problema, del desig, o de l'anàlisi de l'experiència. Aquest últim exemple, un punt clau en la societat d'avui dia, no només en el món del disseny, sinó en general com a terme que justifica la presa de decisions en moltes altres disciplines; i, en ocasions, amb un ús abusiu traslladat a la vivència esporàdica. En relació a aquest punt, la tesi doctoral de Froukje Sleeswijk Visser (2009) des de la TÜDelft aporta una visió interessant quan aproxima l'experiència d'usuari des de la quotidianitat de la rutina i des del disseny de producte, de servei i de la combinació dels dos. És així com la fase analítica del disseny pren sentit i es predisposa a definir reptes que caldrà desenvolupar. De tot això se'n farà especial èmfasi en el proper subapartat — vegeu 2.4.2 Les fases d'anàlisi —.

Martí Font proposa la hipòtesi com el punt transcendent on el dissenyador amb més o menys precisió visualitza una solució al repte i és capaç de definir una o diverses hipòtesis. Per aquest autor, "una d'aquestes possibles hipòtesis o qualsevol combinació entre elles i 
algunes de les seves parts, es converteix en l'autèntic punt de partida del procés projectual, més enllà de l'encàrrec" (Martí Font, 1999, p. 101). Per a Kumar (3a ed. 2011), des de conceptes de recerca en sí, alienes al disseny, "les hipòtesis aporten claredat, especificitat i enfocament a un problema de recerca, però no són essencials per a un estudi" (Kumar, 3a ed. 2011, p. 86), aquestes paraules ajuden a contextualitzar les fases d'anàlisis sense la definició de la hipòtesi, sinó des de la recerca del repte. Així doncs, es podria dir que el repte de disseny és el punt que clausura l'anàlisi de la informació, i la hipòtesi el punt de partida per a les primeres propostes de projecte, en un estat molt incipient, però que segons el projecte ja pot començar a concretar si es treballarà un objecte, un servei, la configuració d'un espai, etc., o fins i tot es pot caracteritzar el projecte de forma més concreta ${ }^{24}$. Com ja s'ha dit repetidament, és en aquest punt on acaba l'abast d'aquest treball, i deixa a fora les diverses fases de desenvolupament de l'artefacte, així com tot allò que té a veure amb processos productius. Relacionat amb la hipòtesi, Martí Font afegeix que "tota informació potencial prèvia a un procés projectual tendeix a ser infinita o almenys inabordable en el temps finit del procés. Això planteja la necessitat d'acceptar el fet que tota elecció d'una hipòtesi de treball es fa a partir d'informació incompleta" (Martí Font, 1999, p. 101). Com ja van dibuixar en el seu moment Cross, Dorst i Roozenburg, (1992) quan afirmen que el dissenyador assumeix que el punt de partida del disseny sempre és un problema mal definit, però que la preocupació del dissenyador no és la comprensió del problema, sinó la seva solució i per això, fent ús del raonament abductiu caracteritzat per Charles Sanders Peirce, enfoca els esforços cap al futur i s'ajuda del coneixement, tant tècnic com productiu del moment actual. Per a Martí Font, la manera de superar aquesta incertesa és precisament a través de la metodologia del projecte. Per a aquest autor "partirem sempre de situacions

\footnotetext{
24 Aquesta concreció, per exemple, es podria definir a través de l'eina I Do Arrt de Kaospilot que $\mathrm{s}$ 'ha vist en el seu apartat corresponent - 2.3.6 Eines-. És a dir, es concreta de forma genèrica on es posiciona el projecte i què es vol aconseguir, de manera que l'equip de treball té clar una base que l'ajuda a descartar o acceptar opcions. Per exemple, si s'acorden principis de sostenibilitat com a premissa indiscutible del projecte, tota decisió presa haurà de respectar aquest principi. Si l'equip està alineat en aquest sentit, s'estalviaran discussions ja que les bases projectuals defineixen el marc de treball.
} 
d'informació imperfecta i incompleta i així i tot, caldrà establir estratègies que responguin amb la màxima eficàcia possible a les nostres necessitats de transformació. De tot això es pot deduir la importància que cal donar a la temàtica metodològica" (Martí Font, 1999, p. 145).

Per altra banda, l'afirmació anterior també amaga una problemàtica relacionada amb el temps, o la temporització, i mostra així un altre aspecte transversal que proposa Martí Font. La recerca "tendeix a ser infinita i inabordable" també a nivell temporal, per tant obliga a plantejar molt bé què es vol saber, com i sobretot, quan. Encara que sembli una obvietat, “tota producció d'artefactes, donada la preexistència de la idea sobre l'existència d'un artifici, implica temps de treball i un conjunt finit de decisions humanes" (Martí Font, 1999, p. 101). És obvi que el projecte necessita dedicació i temps de treball, i per tant, es converteix en una necessitat bàsica del procés projectual el fet de temporitzar tasques. Tornant per un moment a les crítiques que rep el Design Thinking, és el punt de la necessitat temporal de dedicació i treball de qualsevol projecte, que converteix les jornades creatives en simulacre o joc. El Design Thiking es reivindica per no caure a la temptació de considerar-se un mètode sense esforç i treball.

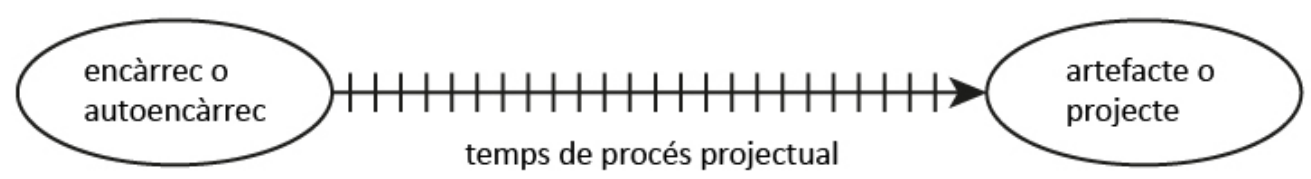

Fig.25 Esquema del procés projectual amb punt d'inici i punt final.

(Martí Font, 1999, p. 102)

Resumint, l'esquema bàsic per a la realització del projecte, segons Martí Font (1999) parteix d'un encàrrec o autoencàrrec, i desemboca en un artefacte o projecte. Ambdós extrems queden separats pel temps necessari per al procés projectual — vegeu figura 25- Com s'ompli l'espai temporal del procés, depèn dels diversos models projectuals. 
Sigui quin sigui el model, ha de ser clar i ha d'estar estructurat des del principi, ja que la complexitat del procés és elevada i, per tant, fa necessària una estructuració tant temporal, com d'accions a realitzar. Segons Martí Font, per arribar a l'artefacte i a la seva producció, és necessària "no només l'existència de projecte sinó també que aquest sigui totalment explicitat i objectivat" (Martí Font, 1999, p. 96), és a dir, ben explicat, referenciat, raonat, prototipat.

Segons Martí Font, el projecte de disseny està format bàsicament per a dues vessants projectuals. Per una banda, "els conjunts instrumentals", un tipus d'aspecte projectual que permet "garantir el control dels aspectes quantificables del procés", per exemple, el tipus de premisses projectuals que aporta fonamentalment l'ergonomia física. Per altra banda, hi ha un altre tipus d'aspectes que Martí Font anomena "variables lliures" que fan referència a la sensibilitat artística i que permeten "un control relatiu sobre aquells aspectes no quantificables"; a part que aporten "un major grau d'incertesa i d'inseguretat" (Martí Font, 1999, pp. 148-149) i que es podrien incloure en aspectes d'usabilitat subjectiva, entre els quals es troba l'estètica, així com el confort o les expectatives d'ús.

Les dimensions del producte són múltiples i es poden caracteritzar de formes molt diferents. Sí que cal tenir en compte, però, que precisament com que les dimensions són múltiples, el disseny també és l'art de l'equilibri. Per exemple, de forma similar a Martí Font, es poden dividir les dimensions del producte entre aquelles que responen a funcions d'ús o lògiques, i aquelles que responen a funcions d'estima o psicològiques. Les primeres, són aquelles que relacionen l'objecte amb l'usuari i la utilitat que li proporciona el seu ús. Les segones, responen a valors individuals dels usuaris, per exemple s'identifiquen amb el contingut estètic, i s'ajusten al què Martí Font anomena "variables lliures". Un altre grup de dimensions a tenir en compte pot ser la dimensió del valor que s'atorga a l'artefacte, valors d'ús, d'estima, de canvi, de mercat, etc. Aquest grup, també divisible entre el valor que respon a funcions d'ús i el valor que respon a funcions d'estima; però sobretot l'artefacte es caracteritza per la seva capacitat de respondre a les expectatives de l'usuari en les diverses dimensions. Com més encaixi amb les expectatives, més valor tindrà. 
El paper del dissenyador és un altre tema a tenir en compte durant el procés projectual. Com hem vist en apartats anteriors - vegeu apartat 2.3.4 sobre el disseny generatiu, en referència a la visió d'Elizabeth Sanders i Pieter Jan Stappers-, el paper del dissenyador canvia per convertir-se en facilitador, en el moment que el procés projectual conviu amb els actors que formen part del context que s'està investigant. Aquest paper entra en joc sobretot en processos de disseny participatiu, i especialment en fases de recerca inicial com explica la mateixa Elizabeth Sanders o Froukje Sleeswijk Visser, que comparteixen la visió del projecte des del fuzzy front end. Al Design Thinking, tal i com el presenta Tim Brown (2009), també li interessa parlar de la dissolució del paper clàssic del dissenyador; per una banda perquè això li permet ampliar el seu abast cap a tasques de gestió, i per l'altra, perquè pot convertir en dissenyador a tot aquell que adquireixi la manera de fer i de raonar del disseny. Tal i com afirma aquest autor "El disseny és massa important ara per deixar-lo a mans dels dissenyadors" (Brown, 2009, p.37). En definitiva, el paper de facilitador, és un paper de guia per acompanyar a la resta d'actors (en principi poc avesats en processos projectuals de disseny) en les diverses fases del projecte. Per a Martí Font, en una visió més clàssica del paper del dissenyador, afirma que "el dissenyador no és l'autor únic de l'artefacte, però és l'especialista que té en compte tots els problemes de la interacció amb el seu usuari i amb la indústria productiva i, per tant, és qui ha de preveure el comportament que l'usuari potencial —és cert que desconegut, a diferència del que passava en la producció artesanal— haurà de descobrir i aplicar" (Martí Font, 1999, p. 72). Amb aquestes paraules, Martí Font demostra que el concepte que recull el terme experiència d'usuari té llarg recorregut i que forma part de la comprensió global de l'artefacte.

Per acabar aquests comentaris genèrics respecte al procés projectual afegir que cap mètode és definitiu o perfecte, sinó que estan en constant evolució i són adequats o inadequats segons el projecte. En paraules de Martí Font “molt sovint l'adequació d'un mètode pot variar segons el moment de la seva aplicació i, donada aquesta circumstància, no hem d'avaluar el mètode com a bo o dolent sinó com a oportú o inoportú” (Martí Font, 1999, p. 72). Per aquest fet, quan es vol avaluar el procés projectual "cal fer sempre una doble avalu- 
ació: avaluació constant del procés i avaluació individual dels mètodes aplicats —com a instruments de presa de decisió- en aquell. Així es fa evident en la seva importància la necessària distinció entre els mètodes concrets i les seves situacions concretes d'aplicació i la metodologia com a ciència del mètode" (Martí Font, 1999, p. 150).

Finalment, com a conclusions metodològiques en relació al procés projectual, es llisten cinc característiques que han d'ajudar en la definició de la metodologia projectual, però que la caracteritzen com a inconcreta i inexacta, com a procés obert que ha de marcar un camí però que ha de deixar llibertat d'adaptació a cada circumstància:

1. Cap mètode és infal-lible en termes absoluts, si més no en un procés de tipus heurístic com és el del disseny

2. Un mateix mètode pot ser correcte en unes condicions i incorrecte en altres

3. Els mètodes ja experimentats en altres situacions processuals poden ser reutilitzats en una de nova, a condició de ser avaluats positivament en funció d'aquesta nova situació.

4. L'inventari acumulat de mètodes mai garantirà l'exhaustivitat ni l'eficàcia; altrament dit, qualsevol inventari pot ser enriquit en qualsevol moment amb nous mètodes inventats de bell nou

5. Podem també incrementar l'inventari a partir de modificacions i recombinacions d'antics mètodes

(Martí Font, 1999, p. 151)

A part de marcar la necessitat de mètode i la temporització, Martí Font deixa oberta la porta a la constant modificació del mateix mètode, perquè s'adapti completament a les circumstàncies. Aquí serveix la metàfora que el mètode, en disseny, també és fluid, com la cultura, tal i com descriu Zygmund Bauman.

Fins aquí les reflexions genèriques del procés projectual, és a dir, reflexions relacionades amb el posicionament del mètode i de la seva necessitat com a estructura de desenvolupament projectual. El mateix Martí Font resumeix la seva idea de projecte a través de tres 
fases diferenciades, que casen amb les fases que en el seu moment descriu J.C. Jones en el seu Design Methods (2a ed. 1992). J.C. Jones les anomena fases de divergència, transformació i convergència, i es repeteixen progressivament augmentant el nivell de concreció. Per la seva banda, Martí Font defineix les seves fases com es pot llegir a continuació:

“[...] el procés de disseny que proposo està estructurat de la següent manera: període projectual en què la informació i l'anàlisi predominen sobre la síntesi funcional i formal; període projectual en què es constitueix una, o unes, hipòtesis de treball destinades a convertir-se en la base de la nova configuració material i finalment període de fixació i progressiva configuració material de la hipòtesi projectual escollida"

(Martí Font, 1999, p. 228)

Tot i així, Martí Font va més enllà i reconeix que el projecte no acaba aquí, sinó que continua durant tot el procés productiu, i no només en aquest moment, sinó també posteriorment quan l'artefacte ja està al mercat i la recollida d'informació pot continuar, per a la millora del mateix artefacte, o l'aparició de reptes nous. És a dir, que el projecte pot viure permanentment.

La intenció d'aquest subapartat és tenir una visió més àmplia del procés projectual que defineix el disseny de forma completa, abans de parlar de forma més concreta de les tres fases del procés que interessen per a aquest treball i que es concreten al llarg dels tres subapartats següents. Es tracta de les tres fases que avancen des de l'aparició de l'encàrrec (o autoencàrrec) si es recull el punt d'inici de Martí Font (1999), fins a la detecció del repte de disseny, que pot desembocar o no en una hipòtesi de treball, però que irremeiablement ha d'acabar en un brief de projecte que marqui les premisses a tenir en compte. Els següents subapartats es divideixen en aquests tres moments: (1) les anomenades fases d'anàlisi, que inclouen la recerca i recol·lecció d'informació i el seu tractament; (2) les anomenades fases argumentatives, que inclouen l'extracció de conclusions i la selecció de premisses; i (3) l'elaboració d'un brief, com a document que recull tot allò que es considera bàsic i pertinent per al desenvolupament del projecte. 


\subsubsection{Les fases d'anàlisi}

En el moment que el dissenyador encara un projecte, la primera tasca hauria de ser sempre de recerca. Encara que el punt de partida projectual sigui definit, el procés començarà per un posicionament del repte de disseny, en relació als materials, els usos, les formes, el procés productiu, l'estètica, la persona, etc. en cada una de les dimensions del producte, inclòs un estudi de mercat. En aquest treball, quan es parla de les fases d'anàlisis es fa referència a un tipus de recerca més fonamental, en un moment del projecte més inicial, i que s'aproxima en les seves formes als mètodes de recerca de les ciències socials, fixant-se sobretot en la persona i la seva quotidianitat. En aquest treball, el repte és que l'estructura d'anàlisi de l'ergonomia en el moment que posa atenció sobre la interacció de la persona amb el món que l'envolta, entri a formar part del mètode d'aquesta recerca; això, però, es veurà en el capítol III, amb la proposta per a una metodologia de recerca. De moment, i en aquest subapartat, es pretén fer una revisió sobre com el disseny enfoca la recerca en les aquí anomenades fases d'anàlisi.

Des de la Universitat Tècnica de Delft, Froukje Sleeswijk Visser (2009) publica la tesi Bringing the Everyday Life of People into Design on es fa especial èmfasi sobre les fases inicials d'anàlisi en el projecte de disseny de producte o serveis. Els tutors de la tesi són Elizabeth Sanders i Pieter Jan Stappers, per tant, segueix la mateixa línia que aquests investigadors. Concretament, la tesi versa sobre la recol·lecció d'informació en relació a l'experiència d'usuari en les fases inicials del projecte, l'anomenat fuzzy front end, i sobre com aquesta informació es trasllada de forma útil al procés de disseny. Per tant, resulta una obra de referència en el sentit que es preocupa de la mateixa fase que aquest treball. Sleeswijk Visser (2009) també raona la importància d'una bona recol·lecció de dades com a punt clau que s'ha de traslladar amb un missatge clar i entenedor pel dissenyador, de manera que li permeti comprendre a l'usuari de forma profunda. Aquest moment del projecte, quan es tracta de traslladar la informació en premisses tangibles i intel·ligibles pel disseny, és un moment especialment crític al qual cal dedicar-li atenció, ja que és el moment on es comencen a posicionar les bases del 
projecte. Aquest moment crític s'abordarà a l'apartat següent 2.4.3 Les fases argumentatives. Les fases d'anàlisi s'emmarquen com a fases de recerca, per això és útil recórrer a eines de recerca aplicada en el camp de les humanitats, que ajudaran al dissenyador a obtenir la informació que necessita per a desenvolupar les premisses de disseny, per això es presenta un subapartat dedicat a l'antropologia i l'etnografia aplicada al disseny —vegeu 2.4.2.2-. Recollint les paraules de Ranjit Kumar, la recerca és "un hàbit de qüestionar-se què es fa $\mathrm{i}$ fer un examen sistemàtic d'observacions clíniques per explicar i trobar respostes per allò que es percep, amb l'objectiu d'iniciar canvis adequats per a un servei professional més eficaç" (Kumar, 3a ed. 2011, pàg. 22). Aquest autor, considera que la recerca és una manera de "recopilar informació precisa i fiable en relació a l'efectivitat de les diverses intervencions per poder proporcionar així proves per confirmar aquesta efectivitat” (Kumar, 3a ed. 2011, p. 25). En definitiva, la recerca és una disciplina en sí mateixa, amb característiques ben definides; però a la vegada, no s'hauria d'entendre el procés projectual del disseny sense una fase de recerca. Per tant, es considera imprescindible que aquesta fase es dugui a terme de la millor manera possible, de forma estructurada, organitzada i definida amb l'objectiu de trobar informació útil pel procés de disseny.

Per a Blessing i Chakrabarti (2009), la recerca en disseny ha passat per tres fases que se superposen entre elles: una fase experiencial, una intel·lectual i una experimental (Wallace i Blessing, 2000, a Blessing i Chakrabarti, 2009). La primera, que s'allarga fins passat els anys 50 del segle XX, està basada en l'experiència dels dissenyadors sèniors que expliquen els seus processos de disseny i els productes resultants. Més que recerca en sí, són reflexions personals sense cap marc teòric concret $i$, en general, tècnicament molt específiques (Blessing i Chakrabarti, 2009, p. 3). Actualment, aquest tipus de recerca experiencial també continua a través de reculls de productes icònics amb els seus encerts i virtuts, o també reculls de productes explicats pels sues autors ${ }^{25}$.

25 Entre moltes altres possibles, obres com:

Design Museum (2010). Cómo diseñar una silla. Barcelona: Editorial Gustavo Gili.

Ricard, A. (2012). Casos de diseño. Barcelona: Ariel

Mortero, E. (2008). Diseño, desde 1850 hasta la actualidad. Barcelona: Random House Mondadori. 
La fase intel·lectual comença al voltant dels anys 60 del segle XX. "Durant aquesta fase es crea una base lògica i coherent pel disseny, i es comencen a proposar metodologies, principis i mètodes" (Blessing i Chakrabarti, 2009, p. 3). Aquí es pot incloure, per exemple, l'obra de J.C. Jones Design Methods publicada per primer cop el 1970, i que ha sortit citada en diverses ocasions al llarg d'aquest treball per la seva visió innovadora. Durant aquests dos períodes, la recerca és més aviat escassa i, en general, faltada de cohesió entre autors.

Finalment, a partir dels anys 80 , i agafant força al llarg dels anys 90 , s'inicia la fase experimental. Durant aquests anys, els esforços giren entorn de la comprensió de la feina del dissenyador, com dissenya, com és el moment creatiu, quins recursos utilitza, però la diferència principal és que s'esforça en explicar-ho de forma genèrica —no individual de forma experiencial com a la primera fase descrita一, és a dir, que s'estructura un marc teòric i s'esforça per emmarcar-se en un context de recerca científica. Com expliquen Blessing i Chakrabarti (2009), “es van fer estudis empírics per a la recollida de dades, tant al laboratori com a la pràctica, per entendre més globalment com dissenyen els dissenyadors i els equips de disseny i quin impacte van tenir els nous mètodes i eines en el procés de disseny” (Blessing i Chakrabarti, 2009, p. 3). Fruit d'aquesta recerca, s'estructura el Design Thinking que apareix per primera vegada a mitjan anys 90 del segle passat. Actualment, es podria dir que encara vivim d'aquesta empenta de final de segle ja que el disseny ha aconseguit assentar-se com a disciplina necessària per al desenvolupament i la innovació, de manera que des d'àmbits molt diversos s'apliquen eines i mètodes del disseny. El mercat està ple d'obres en format manual que ajuden al dissenyador novell a introduir-se en el món creatiu a través, precisament, de la recerca inicial del projecte que observa la quotidianitat. Per altra banda, Blessing i Chakrabarti (2009) fan una distinció molt interessant relacionada amb el propòsit d'aquesta recerca dividint-la en dos grans blocs: una intenció enfocada en entendre el producte basada en el coneixement, les eines i els mètodes. I una altra intenció enfocada a donar suport al procés de disseny, és a dir enfocada en millorar el disseny en general, tant el producte com el procés de dissenyar i que té a les persones com a referència clau. També és interessant com aquests autors plantegen la discrepància del terme recerca 
en l'àmbit del disseny, ja no observant la disciplina, sinó des de dins del propi projecte: "Cal destacar que el terme "investigació en disseny" i termes relacionats com "mètode de recerca de disseny" i "metodologia de recerca de disseny" també s'utilitzen en el context de la pràctica de disseny per referir-se a enfocaments i mètodes per a dissenyadors, més que a investigadors, per adquirir coneixements per millorar el seu treball fent recerca, per exemple, com a part de l'etapa d'aclariment de tasques d'un projecte de disseny particular" Chakrabarti, 2009, p. 6).

En realitat, quan es parla de recerca i disseny es pot estar parlant de coses diferents. Per una banda, trobem la recerca sobre el disseny; és a dir, recerca sobre objectes, processos, actors o el seu significat i importància, el disseny com a objecte d'estudi. Aquesta seria la recerca més consolidada i comú, que habitualment fa servir mètodes d'investigació crítics per avaluar i interpretar els objectes i les seves circumstàncies. Com escriuen Milton i Rodgers (2013, pp.11-19), és un tipus de recerca que té una perspectiva teòrica, fora del procés creatiu i que la gran majoria de vegades no ho duen a terme dissenyadors, sinó antropòlegs, historiadors o psicòlegs, entre d'altres. A més a més, el resultat de la recerca no té perquè ser coneixement útil pel disseny, sinó que es pretén respondre a uns estàndards científics de recerca amb el corresponent rigor metodològic. En certa manera, aquest enfocament també tracta la investigació sobre metodologia de disseny, aquí és on es podria col·locar part d'aquest treball d'investigació, ja que es reflexiona sobre la metodologia del disseny, i de l'ergonomia. Tanmateix, s'aparta d'aquesta línia d'investigació en el sentit que aquí sí que es pretén ser útil pel propi disseny, aportant un mètode d'anàlisi i recerca útil en el propi desenvolupament del projecte. Així és com arribem una segona manera d'enfocar la recerca: la recerca pel disseny.

La recerca pel disseny busca obtenir, al final de la investigació, un artefacte o objecte dissenyat. És a dir, la recerca en aquest cas treballa per nodrir al projecte d'informació vàlida al voltant dels factors condicionants del disseny (tecnològics, ergonòmics, estètics, entre d'altres). Per tant, s'allunya de la recerca científica, ja que no busca veritats universals, sinó que està relacionat amb aconseguir propostes adequades. Milton i Rodgers (2013) consideren 
que és un tipus de recerca que es basa en el coneixement ja disponible i que el seu interès principal és millorar la pràctica del disseny, és a dir, millorar el projecte, i en aquesta tasca, millorar l'artefacte resultant, sense preocupar-se de contribuir de forma original al coneixement general. En aquest sentit, s'estaria parlant del propi procés de disseny entès com una recerca, on el dissenyador és l'investigador i on el focus principal de la recerca està sobre "allò que hauria d'existir". Aquesta és, doncs, una visió de la recerca que casa sobradament, amb la visió de la recerca dins del projecte que es té en aquest treball.

Segons afirma Herrera Batista (2010), dins d'aquesta opció, la recerca es pot dividir en dos grans blocs. Per una banda, la recerca centrada en el producte, on es realitzen anàlisis i avaluacions de les característiques i propietats dels objectes, així com estudis d'usabilitat, per al desenvolupament de nous objectes i noves formes d'ús. I per l'altra, la recerca centrada en l'usuari, on es tenen en compte aspectes humans com a motor de la investigació: ergonomia, anatomia, psicologia, així com l'experiència d'usuari. En aquest sentit, s'entén que el dissenyador no pot obviar en la seva recerca cap del dos blocs, perquè només estant atens a les qüestions objectives i funcionals, i a les qüestions subjectives i d'estima, les premisses projectuals seran suficientment coherents per desembocar en un bon producte. A més a més, en aquest treball es té una visió de l'ergonomia molt més àmplia, que també inclou, per exemple, la usabilitat i l'ergonomia cognitiva, així com una fase de recerca prospectiva inicial.

La recerca pel disseny es basa, doncs, en investigar la quotidianitat per detectar evidències que es converteixin en reptes de disseny, una opció que es veurà àmpliament descrita al llarg d'aquest apartat.

Finalment, una tercer enfocament de la recerca és la recerca a través del disseny. Milton i Rodgers (2011) descriuen aquest enfocament com a una pràctica experimental on el subjecte i l'objecte de la recerca són el disseny mateix. És a dir, a partir de l'objecte de disseny es genera coneixement sobre el disseny. Segons aquests autors, aquest enfocament se centra en el prototipat com a instrument d'investigació i anul·la la divisió entre la teoria i la pràctica, ja que aposta per un treball transdisciplinari que genera coneixement útil pel disseny 
a partir de procediments sistemàtics i rigorosos en relació a les propietats dels materials, la personalització del producte o l'adaptació a l'usuari, entre d'altres.

En resum, tres enfocaments que relacionen la recerca amb el disseny: sobre el disseny, pel disseny i a través del disseny. Gràcies a la recerca realitzada per a l'elaboració d'aquest treball, té lloc una recerca sobre el disseny, que vol desencadenar en una millora de la recerca pel disseny. La divisió d'enfocaments, que s'acosta i s'allunya de la recerca científica clàssica, és un dels principals conflictes de la recerca relacionada amb el disseny, i s'espera, amb aquest treball contribuir en el bon desenvolupament del projecte, és a dir, contribuir en el bon desenvolupament de la recerca pel disseny.

Retornant a les fases d'anàlisi, que tenen lloc durant la recerca pel disseny, es poden descriure diverses activitats a tenir en compte que es distribueixen en diverses fases. Les fases d'anàlisi inclouen la recol·lecció de dades, el tractament, ordenació i anàlisi d'aquestes dades, que es veurà en el punt següent — subapartat 2.4.2.1 Recol·lecció de dades pel projecte de disseny-. En referència al procés projectual, es considera que el Doble Diamant del British Council — vegeu 2.3.2 Doble Diamant— és una proposta molt pragmàtica, ben estructurada i de fàcil comprensió. Aquest treball se centra en el primer diamant, on es troben les fases de descoberta i de definició. És visualment tangible com aquestes fases es corresponen també a una fase de divergència i a una de convergència, respectivament. És a dir, una fase de recol·lecció d'informació, i una altra de presa de decisions, que es corresponen en aquest treball amb les anomenades fases d'anàlisis i fases argumentatives —aquestes segones, es veuran en el punt 2.4.3 Les fases argumentatives-. És a dir, per a Martí Font, el primer diamant correspon al "període projectual en què la informació i l'anàlisi predominen sobre la síntesi funcional i formal" (Martí Font, 1999, p. 228).

En tota aquesta fase de recerca les intencions són bàsicament dues: per una banda, (1) entendre la persona amb les seves capacitats i limitacions, en el seu context i en la interacció amb els artefactes que l'envolten, per fer visible problemes, desitjos i necessitats del futur (proper o llunyà) on el disseny, en els seus múltiples àmbits, pot aportar millores; és a dir, definir reptes de disseny. I per l'altra, (2) abastir al dissenyador d'una base conceptual que 
li permeti prendre decisions de forma argumentada, basant-se en les informacions obtingudes durant la recerca.

Amb aquestes dues intencions sempre presents, en els següents subapartats es fa una revisió sobre com es pot dur a terme aquesta recerca.

\subsubsection{Recol·lecció de dades pel projecte de disseny}

El dissenyador constantment es nodreix de dades que utilitza per vestir el projecte de contingut. Es pot afirmar que qualsevol projecte de disseny té una o diverses fases de recol·lecció de dades, des del moment més inicial del projecte quan encara no està definit el repte de disseny fins quan el producte està en ús i se'n continua revisant l'experiència. En paraules de Martí Font, "a partir del moment en què es produeix un encàrrec i s'inicia un procés de disseny, les estratègies inicials del dissenyador han de contemplar un conjunt d'activitats que són sobretot de caràcter informatiu" (Martí Font, 1999, p. 229). És, però, en aquest moment inicial, fora del projecte en sí, que resulta especialment interessant la recerca que es du a terme, ja que treballa a partir de la quotidianitat, el coneixement, les pràctiques i usos de les persones. Es tracta d'una fase de recerca i de recol-lecció de dades que posteriorment caldrà organitzar i analitzar per extreure'n informació útil per al projecte de disseny. Quan Sanders i Stappers (2012) parlen del fuzzy front end fan referència a aquesta recerca inicial on a través de la persona i la seva experiència amb els artefactes i l'entorn es podran desvelar reptes de disseny, tot i que aquests autors, a diferència de Martí Font, no situen l'inici del procés amb l'encàrrec (o autoencàrrec), sinó en la recerca per arribar a definir aquest encàrrec.

A mesura que el projecte avança, les necessitats d'investigació i recerca van canviant, però hi són sempre presents: en fases inicials, sobretot en aspectes de descobriment (per definir un bon repte), en fases intermèdies sobretot en aspectes d'ampliació de coneixement (per 
tenir recursos per plantejar bones hipòtesis i propostes), i en fases més avançades sobretot en aspectes de validació, (per prendre decisions verificades).

Per a tot aquest procés de recerca en cada una de les fases, el disseny utilitza una sèrie d'eines i mètodes que recull d'altres disciplines, com per exemple l'antropologia, l'etnografia, la sociologia o el màrqueting. Des de l'aparició del Design Thinking i la seva virtut per explicar el mètode, així com la proliferació del disseny de serveis, proliferen manuals i reculls d'eines que ajuden a desenvolupar les diverses fases del projecte, entre elles, també les diverses fases de recerca que es troben en cada projecte. En aquest treball, se'n comenten algunes, però no és la seva intenció fer-ne un recull exhaustiu; i s'escullen aquelles que dirigeixin al projecte de disseny centrat en la persona, de manera que la seva experiència quotidiana sigui font d'inspiració pel repte de disseny. De fet, com escriuen Crouch i Pearce (2012) és la pròpia metodologia que està formada per elements combinats, aquests elements són precisament els diversos mètodes utilitzats, però, per sobre d'aquests, dominen la intenció de la recerca i "la lent teòrica o conceptual a través de la qual es veuen els fenòmens que estem estudiant”. (Crouch i Pearce, 2012, p. 53). És a dir, amb la intenció fonamental del projecte, com ja s'ha comentat al principi d'aquest apartat — vegeu 2.4.1 El procés projectual-.

Així doncs, serà la intenció, el per què s'està duent a terme la recerca, que farà escollir entre la llarga llista de mètodes i eines possibles. Per exemple, Sleeswijk Visser (2009) proposa el mapa de context — vegeu figura 26- com a eina essencial on bolcar la informació recollida en la recerca etnogràfica de l'experiència quotidiana; que es basa, entre d'altres, en que cada usuari és un expert en la matèria en qüestió.

Sleeswijk Visser aposta per la recerca generativa (Sanders i Stappers, 2012). Amb l'ajuda d'aquest tipus de mapa es "produeixen dades i informació que aborden els aspectes funcionals, personals, culturals i socials de les seves experiències en la vida quotidiana. Els resultats són plens d'anècdotes, que contenen els sentiments, valors, necessitats i somnis de les persones" (Sleeswijk Visser, 2009, p. 5). En el mapa, els diversos elements es posicionen a diferents nivells, ordenant així l'experiència segons característiques del context més o 


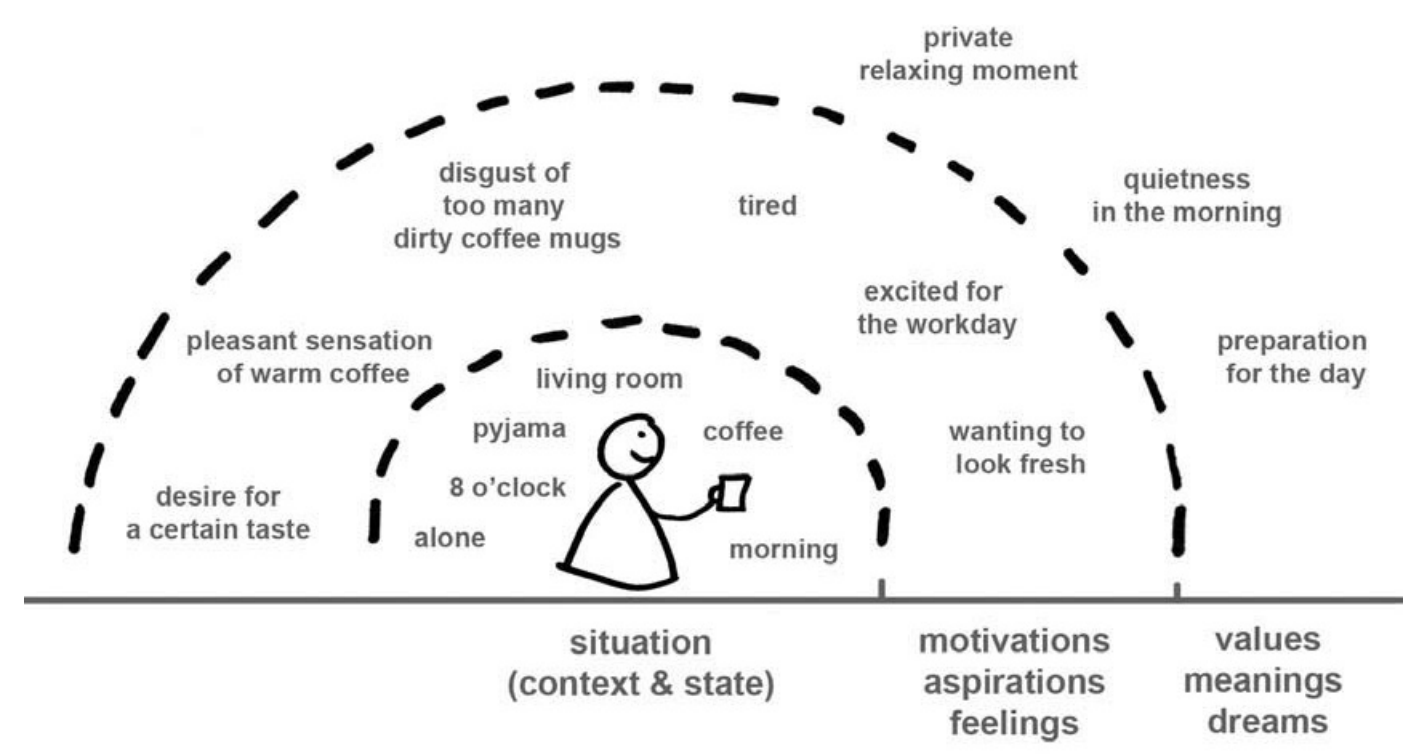

Fig. 26 Mapa de context (Sleeswijk Visser, 2009, p. 16). En el mapa es descriu la recerca realitzada sobre prendre cafè al matí.

menys objectives, les diverses motivacions, aspiracions o sentiments que pugui tenir l'usuari; finalment, un tercer nivell que aporta informació sobre valors, somnis o significats. Per a aquesta autora, el contacte amb l'usuari és bàsic ja que considera que el dissenyador mai tindrà el mateix recorregut vital, ni d'experiència, ni memòria, ni somnis, com tampoc coneixements tècnics o culturals. Cada persona és diferent i, per tant, és necessari recórrer als veritables usuaris. Aquest punt permet visualitzar una de les primeres característiques de la recol·lecció de dades en una fase de recerca del projecte de disseny: les dades s'extreuen en el context real, i aquesta és la forma més directe que té el dissenyador d'entrar en contacte amb la persona, el seu entorn material i cultural, i no menys important, establir-hi empatia. L'altra gran preocupació de la tesi doctoral de Sleeswijk Visser (2009) és com la informació recollida es converteix en informació que el dissenyador pugui interpretar i li sigui útil. Es preocupa especialment de la comunicació entre els recol·lectors de dades i els dissenyadors, ja que considera que en la majoria de casos es tracta de persones diferents. Aquesta autora llista una sèrie de característiques que considera importants per a la posada en escena de la informació: (1) material visual, que inclou fotos, esbossos, vídeos i pot transmetre molts nivells d'informació; (2) informació subjectiva, i de qualitat, més que no pas descripcions 
amb molt detall, fins i tot l'ambigüitat pot obligar al dissenyador a omplir buits, activant així la creativitat; (3) informació sense filtrar, és a dir, mostrar el món de forma real, en situacions reals i no simulades; i (4) històries, gràcies a la capacitat que té una història de transmetre experiències a diversos nivells i contextos. (Sleeswijk Visser, 2009, pp. 34-35).

Per establir el contacte amb la persona, empatitzar-hi i entendre-la bé, acostumen a ser més útils eines de recol·lecció de dades qualitatives, que permeten emfatitzar el per què de les accions realitzades o les decisions preses, així com recórrer a sentiments i emocions de forma més profunda. Algunes d'aquestes eines són, per exemple, l'entrevista, l'observació de camp, els focus group, o, més directament, els processos de co-creació, on usuaris i dissenyadors o investigadors comparteixen espai. Passar de la recerca teòrica a l'aprenentatge en context i estudiar els fenòmens en situacions reals del món real, és una part que el dissenyador no hauria de deixar de banda. Des del disseny, la recerca holística i l'experimentació són essencials.

En aquesta línia, les dades de recerca qualitatives permeten conèixer les raons i els motius de les diverses accions, actituds o comportaments de l'usuari, així com la seva complexitat i la gran varietat de matisos possibles. L'entrevista i l'observació són dues eines bàsiques per a la recol·lecció d'aquest tipus de dades; amb la primera, es podrà aprofundir en el per què, i en la segona, més aviat en el què i el com. Tres dimensions de les dades que poden aportar molta informació al dissenyador. Crouch i Pearce fan una caracterització molt hàbil sobre el tipus de dades recollides, per aquests autors les dades qualitatives "responen a la intenció d'entendre el detall de les experiències individuals i mostrar que 'les coses com aquesta passen'; en canvi, les dades quantitatives, intenten generalitzar i així demostrar que 'les coses passen així'.” (Pasqualini, en comunicació personal, 2003, a Crouch i Pearce, 2012, p.69). Aquestes últimes, les dades quantitatives, es basen en la recol·lecta numèrica d'informació i caldrà analitzar-les, sobretot, de forma estadística.

El punt clau és que també cal dissenyar les entrevistes i les observacions, o en definitiva qualsevol acció de recerca. Aquí entra en joc el paper de dissenyador com a facilitador, ja que és responsabilitat seva abastir-se de les eines necessàries per a què les persones objecte 
de la seva recerca siguin capaces de comunicar informació pertinent. La preocupació expressada per Sleeswijk Visser (2009) sobre com es comuniquen les dades obtingudes per a què puguin tenir sentit pel dissenyador forma part també d'aquest procés: el contingut cal que sigui pertinent. Per tant, és també indispensable elaborar un pla de recerca general. Cal definir, fins allà on es pugui, quines són les dades (o la informació) que es vol obtenir i en quin format. Depenent de la fase del projecte, si està més o menys avançat, es podrà ser més o menys precís, però totalment a cegues no acostuma a ser profitós. Per altra banda, a part de definir quines dades són necessàries, també caldrà definir on trobar aquestes dades, on anar-les a buscar, i definir com es guardaran. Tot aquest procés, forma part de la recollecció de dades, definir bé tots els passos hauria d'assegurar que les dades recollides siguin traslladables al projecte. I per poder-ho dur a terme, el dissenyador o l'equip de disseny, hauria de conèixer eines i mètodes i quan fer-ne ús per treure'n el màxim profit. Per tant, el fet que el mateix dissenyador sigui coneixedor de metodologies, del procés de disseny, de les seves fases, de les intencions de cada una i de quines eines disposa, és molt beneficiós pel propi procés de disseny. Segons Martí Font, per “establir el conjunt d'operacions necessàries per projectar cal constituir models per sistematitzar i racionalitzar el caos informatiu que ens apareix en les etapes inicials del procés" (Martí Font, 1999, p. 229), és a dir, calen models que estructurin el procés i guiïn a través del mètode per ser capaços de processar grans quantitats d'informació fruit de la recerca.

Més enllà de les diverses capes d'experiència en la interacció amb algun artefacte per part de la persona, tal i com es descriu des del disseny, en aquest cas les aportacions de Sleeswijk Visser (2009), o de Sanders i Stappers (2012), la interacció es veu condicionada per molts aspectes de la realitat. L'experiència de la quotidianitat és una font d'informació molt valuosa i pot ser un punt de partida des d'on començar a construir el mapa de les diverses dimensions de la interacció de la persona amb l'artefacte, és a dir, un punt de partida per complimentar un mapa de projecte estructurat i inspirat des del sistema persona/màquina que descriu l'ergonomia. L'oportunitat que brinda aquest sistema és que és holístic $i$, per exemple, també té en compte aspectes de la màquina, que quedaran supeditats als aspectes 
de la persona. Així és com es podrà aconseguir posicionar la persona per davant d'altres dimensions del projecte i brindarà al disseny la possibilitat d'oferir solucions basades en premisses que respectin a l'ésser humà i a l'entorn natural. Aquestes qüestions, es veuran amb més profunditat en el capítol III.

Per la seva banda, Martí Font també fa referència als models de la vida quotidiana, en aquest cas, però, en el sentit que signifiquen un filtre per a la visió que el mateix dissenyador en té. Això és recull en les tesis de la segona cibernètica de Maturana i Varela (1972), quan posen sobre la taula la importància de l'observador com a individu que, mentre observa, forma part d'allò observat. En paraules de Martí Font, "l'ús de models de la vida quotidiana és quelcom que ens condiciona — per bé o per mal- en la nostra apreciació de les coses. Es tracta de models establerts pel costum, per les modes, per les nostres capacitats mimètiques o per les imposicions d'altri”" (Martí Font, 1999, p. 210). Un mateix no es pot escapar de sí mateix, i aquest és un altre punt a tenir en compte en la recerca inicial d'usos, costums i quotidianitat. En aquest sentit, Crouch i Pearce - d'igual manera que han fet altres autors vistos en apartats anteriors - adverteixen de la importància de definir el posicionament de la recerca des del principi, quan s'està planificant. Per aquests autors, la posició de l'investigador es basa en una combinació de les seves experiències prèvies, el posicionament cultural i social (informat per ideologies), la seva particular visió del món i l'hàbitat (Crouch i Pearce, 2012, p.56).

En un altre sentit, però de forma no menys important, cal tenir en compte que la recol·lecció de dades també inclou les tasques de fixació i emmagatzematge d'aquestes dades. Això és un procés llarg i que pot ser molt farragós, però imprescindible pel posterior tractament de les dades, així com la seva fàcil consulta futura. Per exemple, cal transcriure les entrevistes i cal codificar-ne els continguts, de la mateixa manera que cal codificar els continguts d'una observació de camp. Cada peça informativa ha de quedar perfectament etiquetada, com a mínim amb informació sobre qui ha dut a terme la recol·lecció de dades, on i quan s'ha dut a terme, i qui en són els participants. Aquestes tasques es veuran en els subapartats posteriors ja que formen part de les eines bàsiques de recol·lecció de dades. El tractament de 
la informació i les dades són clau per a la seva utilitat en el projecte de disseny. En aquest sentit, i com es veurà també més endavant, el disseny ha desenvolupat, o recollit d'altres disciplines, una sèrie d'eines comunicatives que li permeten traslladar aquest gran volum d'informació en càpsules de fàcil comprensió, eminentment visuals, i que posen especial èmfasi en l'experiència personal, les motivacions i les conductes de la persona; es troben en aquest grup, eines com el mapa de context de Sleeswijk Visser (2009), o l'user journey, eina molt popularitzada que dibuixa de forma visual la relació de l'usuari amb un artefacte concret sobre una línia temporal.

Resumint, durant el procés de recerca, la recol·lecció de dades en el projecte de disseny és àmplia $\mathrm{i}$ complexa, a la vegada que bàsica per al posterior desenvolupament del projecte. Sobretot per dues raons principals: la primera, perquè és la base conceptual que aportarà justificació a les decisions posteriors. I la segona, perquè és la font més essencial i primària per a definir nous reptes de disseny.

\subsubsection{Antropologia, etnografia i enfocaments afins aplicats al disseny}

Quan el disseny s'aproxima a la recerca de l'experiència i pretén buscar reptes de disseny en la quotidianitat, tal i com aboquen Sanders i Stappers (2012) o Sleeswijk Visser (2009), les eines de l'antropologia, i més concretament de l'etnografia, passen a ser valuoses per a la recerca del disseny. En referència a l'ergonomia, i la seva visió prospectiva pròxima al projecte de disseny, també són eines vàlides per a la seva recerca. Per a Buxó Rey, catedràtica d'antropologia cultural a la Universitat de Barcelona, UB, “el disseny ha d'ajudar a generar idees de contrast i conjectures racionalitzades que permetin articular els desitjos personals i omplir-los de contingut i en fer-ho així transformar la idea, els impulsos i l'activitat en propòsit” (Buxó Rey, 2012, p.20). Dit amb altres paraules, entendre la quotidianitat per a detectar evidències que es puguin convertir en reptes de disseny plens de contingut. 
En el món del disseny de serveis — vegeu 2.2.5.1 Service Design Thinking—, la recerca etnogràfica és bàsica pel procés de disseny, tal i com es pot llegir a les paraules d'Stickdorn i Schneider (2011), tant pel propi procés de disseny (omplint-lo de contingut), com per la necessitat de comunicació entre els diversos actors, ja que exemplifica les diverses visions existents sobre un àmbit:

“L'etnografia del disseny és una investigació qualitativa etnogràfica que s'emmarca en un context de disseny. Ofereix resultats que informen i inspiren processos de disseny, per exemple, processos de disseny de serveis. Ofereix material de referència sobre la vida quotidiana de les persones, les seves pràctiques, motivacions, somnis i inquietuds. Els resultats també poden ser útils per comunicar els resultats de la recerca a altres persones de l'equip del projecte que puguin tenir diferents antecedents i representen diferents disciplines (per exemple, tecnologia, màrqueting, comunicació, gestió, serveis al client). L'etnografia aplicada al disseny pretén explícitament generar material que comuniqui la informació de la recerca a un ampli grup d'interessats, per assegurar-se que la fonamentació del disseny s'entenen bé i s'accepta" Stickdorn i Schneider, 2011, p 109).

Per la seva banda, Crouch i Pearce (2012) presenten quatre metodologies diferents per a aquesta recerca de la quotidianitat, quatre metodologies que emmarquen com s'enfoca el projecte. Totes quatre estan relacionades amb la recerca humanista i treballen majoritàriament amb dades qualitatives, les anomenen respectivament, etnografia, relat, cas d'estudi i recerca en acció participativa. S'entén, però, que una participa de l'altra i que difícilment s'executen formes pures. Aquests autors, escullen aquestes quatre metodologies perquè consideren que estan ben establertes en la recerca social i que, a més a més, són adequades per a la recerca pel disseny. Segons escriuen, "les formes d'investigació etnogràfiques i narratives, on l'atenció se centra en experiències viscudes d'individus o grups de persones, s'ajusten bé a una perspectiva d'investigació interpretativa" (Crouch i Pearce, 2012, p. 63). Aquesta investigació interpretativa, encaixa perfectament amb la intenció del disseny tal i com s'entén en aquest treball, ja que precisament busca interpretar la realitat per a po- 
der definir reptes de disseny. Les altres dues, cas d'estudi i recerca en acció participativa, busquen més aviat la visió crítica. I també, aquesta mirada encaixa perfectament amb la intenció del projecte de disseny. Un cop més, la base conceptual de la recerca es repeteix, explorar la quotidianitat per a proposar futurs basats en el present $\mathrm{i}$ omplir aquests futurs amb solucions que responguin a les persones. A més a més, durant la recerca, les diverses metodologies es poden mesclar o combinar, segons es consideri necessari per cada situació.

En relació a l'etnografia, Monaghan i Just (2000) proposen una definició basada en la seva acció de recerca principal, l'observació: “l'etnografia es basa en la idea, aparentment simple, que per entendre allò que les persones realitzen, la millor manera és observar-les mitjançant la interacció íntima amb elles i durant un temps prolongat”" (Monaghan i Just, 2000, p.25). Tal i com expliquen Crouch i Pearce, l'etnografia és una disciplina que neix de l'antropologia, ciència que estudia els éssers humans, les seves experiències i pràctiques culturals. Tradicionalment, és una disciplina que investiga in situ, i elabora teories de forma empírica. Aquesta disciplina va agafar especial importància durant l'època colonial, quan investigadors es passaven mesos, fins i tot anys, convivint en les diverses cultures de les colònies. Part de la seva recerca, passa per l'anàlisi dels objectes i artefactes d'aquests pobles, que fan possible comprendre la seva visió del món. A la inversa, i aplicant-ho al disseny actual, la comprensió del món, guiarà al dissenyador a elaborar objectes i artefactes que encaixin amb el seu món, i responguin a les seves pràctiques culturals. Per a Crouch i Pearce, l'evolució de l'etnografia fora de l'antropologia té lloc sobretot en la intenció de la seva recerca, comparteixen mètodes, però d'alguna manera difereixen en la intenció, ja que “l'etnografia s'especialitza en les qüestions culturals a través de l'examen del comportament, el llenguatge o els artefactes culturals particulars del grup d'estudi". Per tant, per a l'etnografia és imprescindible treballar en una definició de cultura que es desenvolupa en allò que és comú en grups de persones, les diverses experiències viscudes, o la comprensió similar de certs temes. Aquesta definició de cultura permet identificar grups amb pràctiques culturals similars i que poden formar part d'una mateixa professió, d'una mateixa entitat, o per descomptat, d'una mateixa franja d'edat, compartir una mateixa llengua vehicular 
o una nacionalitat. En definitiva, que les persones poden formar part al mateix temps de múltiples grups culturals que construeixen la societat. (Crouch i Pearce, 2012, pp. 83-86). L'eina principal de l'etnografia tradicionalment ha sigut l'observació participant, és el cas quan la persona que du a terme la recerca s'introdueix com un "igual" en l'àmbit que està investigant. Per descomptat, altres opcions d'observació també són possibles, com seria l'observació no participant. Per exemple, si es vol fer recerca en la zona neonatal d'un hospital, l'investigador conviurà setmanes, en aquest espai per entendre de forma profunda els hàbits, usos i comportaments del cos mèdic i d'infermeria, així com de les famílies — vegeu 2.2.4.3 Estudi de cas-. Aquesta observació, també inclourà entrevistes per aprofundir en aspectes concrets, sobretot en la recerca del per què de les accions, així com la recol·lecció d'experiències; la informació es guardarà a través de filmacions, fotografies, escrits que constituiran el material de recerca. Aquesta observació formarà part d'un projecte de recerca definit i emmarcat en uns marcs culturals concrets, que seran l'estructura que permetrà parlar amb tranquil·litat a l'observador, un cop definida la pròpia subjectivitat cultural.

En qualsevol activitat d'observació, cal tenir en compte el paper de la persona que l'està duent a terme i com afecta la seva presència a l'entorn observat. És a dir, les persones no actuen igual quan se senten observades, o quan saben que formen part d'una investigació. Tot i així, el repte és obtenir informació rellevant. "Això no significa que les observacions no siguin útils com a dades de recerca, sinó simplement que és important contextualitzar les observacions tant en l'orientació teòrica dels investigadors com en les seves perspectives pràctiques" (Crouch i Pearce, 2012, p. 94); aquesta contextualització inclou informació espacial i temporal, no s'extreuen les mateixes evidències de l'observació dels recorreguts, les actituds i els comportaments de les persones del metro de les 8 del matí d'un dia feiner, que de la mateixa observació a les 12 del migdia d'un dissabte. Per a Monaghan i Just (2000), “sembla ser que l'observació participant constitueix la forma més efectiva de comprendre en profunditat les altres visions del món i interactuar amb elles, i en ocasions ens fa interioritzar-nos en les nostres pròpies preconcepcions i creences" (Monaghan i Just, 2000, pp.27-28). És a dir, que per poder observar de forma útil i pertinent pel projecte, és 
necessari conèixer-se un mateix, amb les idees preconcebudes que emmarquen l'observació. Només sent coneixedor del propi marc cultural, és possible contrastar-lo amb aquell observat.

Per a Monaghan i Just, “el diàleg és la columna vertebral de l'etnografia. [...] Finalment la clau de l'èxit etnogràfic és ser allà, disposat a observar, a rastrejar la informació, a aprofitat els esdeveniments espontanis" (Monaghan i Just, 2000, p. 40). Segons aquests autors, el "descobriment casual" és allò que dona especial valor a l'etnografia, és el què l'omple de "força i flexibilitat", ja que consideren que altres mètodes d'investigació deductius, com l'enquesta o la investigació científica, no són capaços d'afrontar el cas inesperat (Monaghan i Just, 2000, p. 33). El dissenyador, pot adoptar eines de l'etnografia per dibuixar l'encaix cultural i les seves pràctiques en cada individu, encara que no formi part d'una recerca etnogràfica real, i pot desvelar en la seva observació desitjos, necessitats o problemàtiques que es traduiran en el repte de disseny. L'èxit de l'observació etnogràfica té lloc quan es descobreixen accions, actituds, motivacions o interaccions amb l'entorn i l'artefacte, que es poden traslladar en comprendre necessitats no satisfetes.

Per altra banda, Crouch i Pearce introdueixen noves pràctiques etnogràfiques, com per exemple l'etnografia crítica que "té com a objectiu explorar qüestions de poder i la marginació dels grups socials, desitjant aconseguir un canvi i justícia socials" (Crouch i Pearce, 2012, p.91), i obre les portes a membres de minories o de grups marginats. Aquests autors també parlen de l'autoetnografia, on precisament la cultura investigada és la pròpia de l'investigador.

Les tasques de recol·lecció de dades en un procés d'observació etnogràfica també han d'estar ben dissenyades, tant a nivell d'esforços com de temps; "l'etnògraf no es llença al camp sense preparar-se" (Monaghan i Just, 2000, p. 35). En fases inicials són dades més genèriques, observacions preliminars, però s'han d'anar concretant a mesura que avança el projecte. La quantitat de dades obtingudes pot ser immensa, i la tasca d'ordenació i treball amb aquestes dades és també molt important per a què posteriorment siguin útils i no es perdi informació per incapacitat de treballar-hi. Alguns exemple són deixar espai a les 
notes per poder apuntar opinions i comentaris de l'observador, més enllà de la descripció més “objectiva" d'allò que observa; establir una codificació temàtica des de l'inici o definir àmbits d'observació concrets. Tot plegat són decisions metodològiques a tenir en compte.

En resum, i en paraules de Crouch i Pearce "una perspectiva etnogràfica ajuda a identificar aquelles característiques de l'objecte dissenyat, del sistema i del treball del dissenyador que requereixen una comprensió de les pràctiques culturals i socials" (Crouch i Pearce, 2012, p.101). Des del món del disseny i la seva pròpia experiència com a investigadora etnogràfica, Christy Harper (2018) explica com es desenvolupa la recerca etnogràfica de la següent manera:

\footnotetext{
“Típicament el que passa és una barreja d’observació i entrevista. És possible que tingueu moments d'observació veritable, trobareu nous artefactes, explorareu un nou entorn i conduireu entrevistes semiestructurades. El més important, tindreu una rara oportunitat de mirar el món d'una altra persona. De tota manera, sigui quin sigui el repte, sigui el que anomenis mètode, tot allò realment important és el què pots aprendre i la història que pots compartir". Christy Harper, 2008
}

Harper (2008), de la mateixa manera que Sleeswijk Visser (2009), també es preocupa en el fet de compartir allò après, és a dir, les dades recollides de la recerca. Una bona manera de fer-ho, és un altre dels mètodes proposats per Crouch i Pearce (2012) en relació a la recerca: el relat, com a eina bàsica per explorar experiències viscudes. I, segons Harper (2008), una bona manera de comunicar. En aquest sentit, Crouch i Pearce expliquen com "les investigacions basades en el relat es relacionen amb la gent i busquen escoltar, enregistrar i comprendre les seves experiències de vida com a històries". (Crouch i Pearce, 2012, p.105). No només aquestes eines, sinó també d'altres com la comunicació per email o els blogs poden proveir de dades a l'investigador, que construirà un document amb format de comunicació de la recerca. El relat és útil també per explicar situacions complexes ja que pot fer ús dels esdeveniments claus per construir la història, de manera, que el relat fa servir històries per construir-se, a la vegada que explica històries (Crouch i Pearce, 2012, pp. 104-117). 
De la mateixa manera que l'eina natural de l'etnografia és l'observació; per a la recerca del relat, l'eina natural és l'entrevista. Això no significa que una i altra eina es facin servir indistintament o de forma complementària en cada un dels mètodes de recerca. En una entrevista, “l'objectiu de l'investigador és copsar les experiències i perspectives dels participants en la investigació de manera que s'apropin al màxim a la realitat d'aquestes experiències" (Crouch i Pearce, 2012, p.112). En referència als focus groups, entrevistes a grups reduïts, que permeten "proporcionar perspectives diferents sobre una experiència comuna són valuoses si interessa obtenir diverses perspectives i opinions sobre un determinat tema, objecte o sistema dissenyat" (Crouch i Pearce, 2012, p.114).

En qualsevol situació on es té contacte amb les persones, cal estar atent de ser sempre respectuós i comportar-se de manera que les persones amb qui s'està treballant se sentin còmodes, i mai amenaçades o intimidades. Sobretot, en temes conflictius, com per exemple dins l'àmbit laboral, on la gent pot pensar que s'està posant en dubte la qualitat de la seva feina. En aquest sentit, diversos autors aconsellen apel·lar precisament a les històries personals, tant com una forma de trencar al gel, ja que en general, a la gent li agrada explicar històries, com per arribar a opinions i impressions de la persona amb més agilitat. Així ho proposa, també, el Design Thinking, en les seves recomanacions per a la realització de l'entrevista ${ }^{26}$.

Fer entrevistes requereix per part de l'entrevistador d'unes qualitats empàtiques que l'ajudin a saber quan callar, quan insistir, quan mantenir l'entrevista dins del tema, o quan deixar que l'entrevistat surti del camí preestablert. Les dades que s'obtenen de l'entrevista, també són moltes i complexes, de la mateixa manera que ho eren les dades de l'observació. En aquest cas, el primer pas serà transcriure l'entrevista per després treballar sobre text. Caldrà codificar l'entrevista per temàtiques (codificació que és transversal per a tota la recerca) i del treball amb aquestes dades haurien de sorgir els conceptes i les evidències

26 Vegeu, per exemple el portal designkit.org/methods que facilita la consultora Ideo, on es poden trobar eines com Compartir relats inspiradors, l'entrevista, o la tècnica dels Cinc per què? (última consulta 23 d'agost de 2019) 
que es traslladaran al projecte ${ }^{27}$. Per altra banda, Crouch i Pearce (2012) fan una sèrie de recomanacions en referència a les preguntes. Ells aposten per un tipus d'entrevista semi estructurada que deixi oberta la possibilitat de la sorpresa. Com s'ha comentat uns paràgrafs més amunt, l'esdeveniment inesperat és un punt valuós per a la recerca etnogràfica. Per aconseguir-ho, a més a més, les preguntes han d'oferir a l'entrevistat la possibilitat d'explicar-se, per tant, han de ser un tipus de preguntes que convidin al relat, més que no pas que convidin a respostes tancades de sí o no. Tot plegat són recomanacions habituals, però molt útils quan es tracta d'introduir-te en el món de l'entrevista. El dissenyador, sense formació específica al respecte, segurament realitzarà entrevistes en més d'una ocasió, i per tant és interessant que es prepari bé i que en conegui qüestions bàsiques per a al seva realització.

En resum, i en paraules de Crouch i Pearce (2012) en referència al relat:

\begin{abstract}
"La investigació narrativa permet a l'investigador comprendre com els individus i els grups donen sentit als esdeveniments $i$ accions de la seva vida i s'adapta especialment a l'estudi de les identitats i les subjectivitats humanes. [...] El relat és una estratègia per emmarcar processos complexos de manera que es converteixin en processos més accessibles, com en el cas d'un relat de sistemes o en un relat de temps i d'espai, que mostra allò que succeeix en un determinat període de temps o en un espai particular." (Crouch i Pearce, 2012, p.120-121)
\end{abstract}

En definitiva, el relat és útil per a diverses qüestions, però sobretot, com a eina de comunicació d'entrevistes i observacions, com també com a eina especialment adient per a traslladar comportaments i subjectivitats humanes.

Un tercer enfocament de la recol·lecció d'informació que presenten Crouch i Pearce, és la recerca basada en casos d'estudi. En aquest cas, enfoca els seus esforços en unitats delimitades que serveixen com a punt de partida. Un cas d'estudi, pot formar part d'una

27 Vegeu, per exemple El Método Lingüístico: técnicas de obtención de información de Fran Elejabarrieta (1997), per ampliar la informació en referència a les entrevistes i el tractament de les dades recollides 
recerca més àmplia, i a través d'un cas concret, aprofundir coneixement. Les limitacions que emmarquen el cas d'estudi poden ser temporals i espacials, o referir-se a accions, esdeveniments, processos o activitats concretes. Per exemple, una limitació temporal podria ser limitar la recerca a un horari concret, com pot ser l'hora punta del matí, o a una temporada concreta, com pot ser durant les festes de Nadal. Limitacions espacials poden fer referència sobre el lloc on ocorren les accions, per exemple un bany públic o el bany de la llar. Per a Crouch i Pearce, el treball en casos d'estudi pot ajudar en recerques molt àmplies on es poden distribuir les tasques per equips que es dedicaran a casos d'estudi concrets. Les limitacions que emmarquen cada cas concret a estudiar han de quedar definides des del principi de la recerca, i precisament aquesta és una de les principals característiques que el diferencien dels enfocaments etnogràfics i de relat, ja que els límits d'aquests últims són més oberts, al contrari que en el cas d'estudi, on els límits són tancats. Per altra banda, les eines utilitzades per a la recerca de casos d'estudi són compartides amb la resta, és a dir, que segons el cas en concret, seran pertinents entrevistes, observació, elaboració de diagrames, material fotogràfic o tot allò que faci falta per a la recollida de dades. Resumint, la recerca a partir de casos d'estudi permet dividir una recerca, delimitar cada dimensió de la quotidianitat a estudiar (temps, espai, acció, artefacte, etc.) per abordar-les per separat i sumar-les posteriorment després en un mapa complet. També, en altres ocasions, l'estudi d'un cas concret, pot ser el punt de partida per a un nou enfocament de la investigació. Segons les característiques de cada dimensió, l'enfocament de la recerca serà diferent i per tant també les eines utilitzades (Crouch i Pearce, 2012, p.123-128). Per altra banda, aquestes diverses dimensions del cas concret, podrien adequar-se fàcilment a la distribució per variables que planteja l'anàlisi del sistema persona/màquina ergonòmic, que en aquest cas pretén un anàlisi holístic a partir de les divisions de les variables —vegeu subapartat 2.2.2.1 Sistema Persona/Màquina-.

El cas d'estudi com a enfocament metodològic per a la recerca és un bon exemple on la recol·lecció de dades pot ser realitzada de formes molt diverses. Fins al moment, s'ha parlat de la recol·lecció de dades qualitatives argumentant que permeten una profunditat de recer- 
ca superior i, sobretot, perquè són més adequades per a la investigació de les motivacions i les raons de les persones. Tot i així, l'enquesta, com a eina per excel·lència de la recerca quantitativa, permet recollir dades en relació a les perspectives de grans grups de persones o poblacions; i és molt adequada principalment en dos moments del procés de disseny, en un estat inicial del projecte per ajudar a enfocar-lo de manera genèrica, i en estats avançats del projecte per a la verificació de decisions preses. Sigui com sigui, en una recerca es combinen totes les eines necessàries per a obtenir la informació que es considera pertinent: "quan les paraules i les narracions poden afegir significat i riquesa a les dades numèriques, els números poden afegir claredat i precisió a les dades qualitatives" (Ary, Jacobs i Sorensen, 2010, a Crouch i Pearce, 2012, p.130).

De la mateixa manera que és necessària la preparació per a les entrevistes, també ho és la preparació per a les enquestes, que sempre han de tenir uns objectius de recerca perfectament definits. Una de les principals diferències és que les enquestes necessiten arribar a un gran número de gent. En general, per tant, la majoria de vegades l'enquesta la realitza la persona de forma autònoma, sense l'investigador a qui preguntar, i això significa que tant l'estructura de l'enquesta, com l'elaboració de les preguntes, com les possibles respostes s'han d'ajustar perfectament a qui, en principi, contestarà. És necessari controlar el canal per on arriba l'enquesta, saber a qui va destinada, controlar el vocabulari utilitzat i la complexitat de les preguntes, controlar contradiccions o preguntes amb respostes impossibles. En definitiva, tenir un control elevat de qualsevol de les qüestions que poden sortir malament. Posteriorment, les dades obtingudes caldrà processar-les de forma estadística, fet que pot resultar força complex i requerir d'especialistes.

Finalment, l'última proposta de Crouch i Pearce per a la recol·lecció de dades qualitatives és el què ells anomenen recerca en acció participativa (Crouch i Pearce, 2012, pp. 144157). En aquest cas, fan referència a processos col·lectius de recerca d'informació, és a dir, a processos col·lectius de disseny, com anomenen Sanders i Stappers (2012) disseny generatiu - vegeu apartat 2.3.1 Disseny generatiu-. Aquests autors coincideixen en un tipus de recerca que inclou tots els actors implicats en l'objecte de disseny com a partici- 
pants d'aquest procés. Això implica, entre d'altres coses, una sèrie de canvi de rols, per exemple del propi dissenyador, com s'ha vist en apartats anteriors. Per a Crouch i Pearce (2012) la clau que diferencia aquest tipus d'enfocament és una voluntat explícita de repensar i redefinir les accions de l'objecte de disseny; és a dir, de redefinir la interacció entre la persona i l'artefacte o entorn. Per aquesta raó, aquests autors consideren que és una opció potencialment més crítica que la resta, ja que està en la seva raó de ser el replantejament des de la base. A més a més, afegeixen que és un tipus de recerca que es focalitza en un cas concret i aporta solucions per a aquest cas concret, independentment que, després, aquestes solucions siguin extrapolables de forma genèrica per a casos similars. És a dir, que "l'objectiu de la recerca en acció és desenvolupar solucions pràctiques i rellevants als problemes identificats" (Crouch i Pearce, 2012, pp. 144) i aquest procés es desenvoluparà de forma especialment iterativa.

Per a Crouch i Pearce (2012) un dels principals arguments per a dur a terme aquest tipus de recerca —argument amb el qual coincideixen altres autors, entre ells Sanders i Stappers (2012) - , és que la participació dels diversos actors implicats, en facilita la seva identificació, i el fet de sentir-se partícip és especialment adequat en processos de disseny complexes on, per exemple, hi ha diversos grups d'actors molt diferenciats compartint un mateix espai. A més a més, és un enfocament que se centra en l'acció humana, fins al punt, que "el disseny en sí, es pot entendre com una forma de recerca en acció" (Crouch i Pearce, 2012, pp. 157).

En relació a la recerca pel disseny, i com es posiciona l'usuari dins del procés de recerca, Elizabeth Sanders elabora un mapa de doble entrada per a classificar en aquest sentit diverses metodologies de disseny. Aquest mapa va evolucionant, la versió de 2012 que apareix a la publicació "Convivial Toolbox" que elabora Sanders conjuntament amb Pieter Jan Stappers, és la que apareix a la figura 27.

El mapa pretén fer visible l'estudi de les persones com a usuaris de productes, serveis i ambients a la indústria i a la pràctica de les dues últimes dècades (Sanders i Stappers, 2012). Es divideix en dos eixos, l'eix horitzontal que defineix la mentalitat i diferencia la 


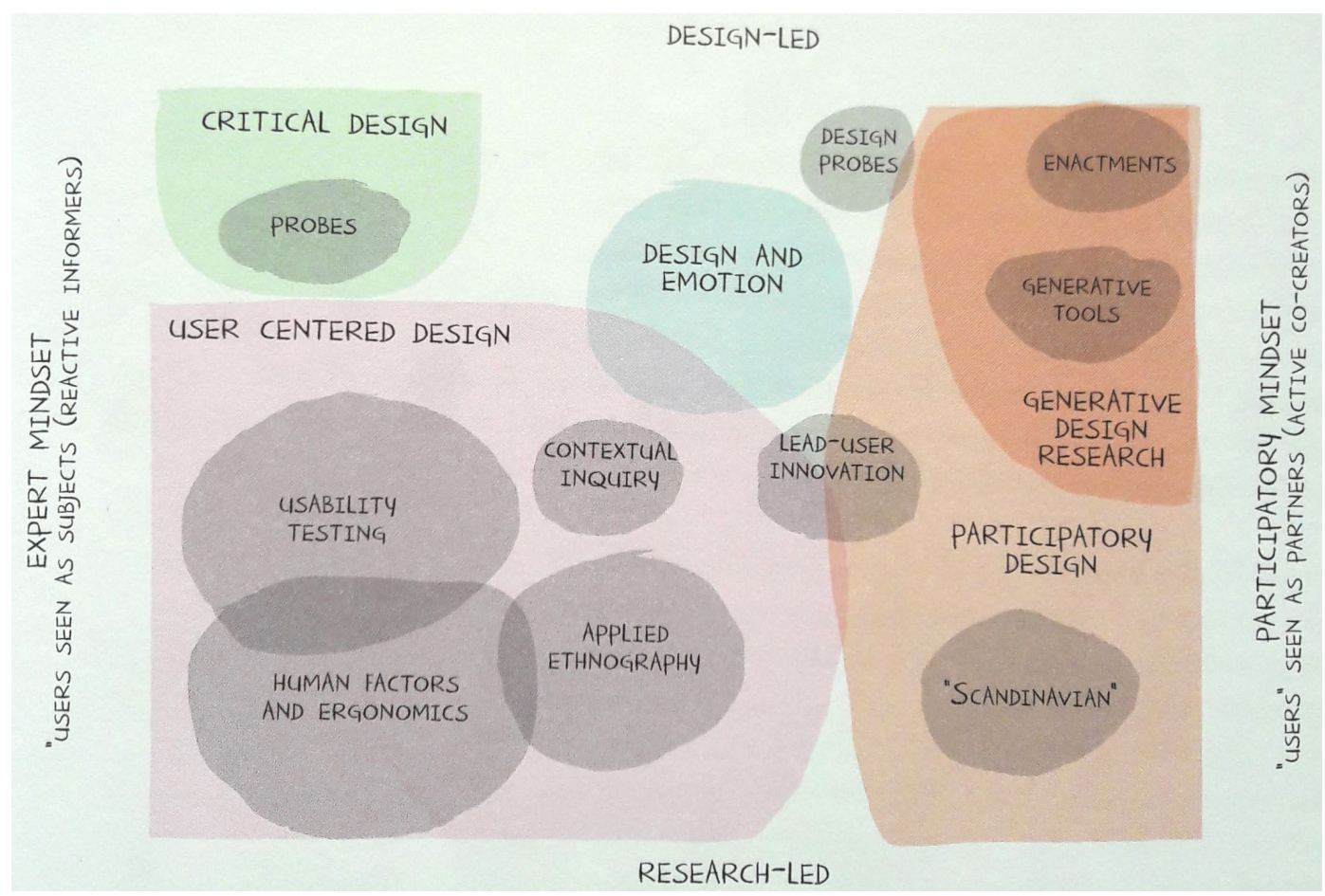

Fig. 27 Mapa sobre la recerca en Disseny (Sanders i Satppers, 2012 p. 19)

recerca segons tingui una mentalitat d'expert (que l'usuari tingui un paper de subjecte), o una mentalitat participativa (que l'usuari tingui un paper d'actor). En l'eix vertical, que defineix l'enfocament, es fa distinció entre un enfocament cap a la recerca més teòrica, amb més tradició i duta a terme per psicòlegs, antropòlegs, sociòlegs i enginyers, el tipus de recerca que s'ha vist en paràgrafs anteriors, recerca sobre el disseny; i un enfocament cap el disseny, més recent, i en certa manera, més pràctic, que és comparable a la recerca que en paràgrafs anteriors s'ha caracteritzat com a recerca pel disseny.

També, Faste i Faste (2012) parlen de la diferència entre el disseny entès com un tipus de recerca, i la recerca en disseny entesa com a part del procés de la pràctica del disseny. Sota aquesta segona visió que concorda amb la visió de Sanders i Stappers, Faste i Faste (2012) proposen tres enfocaments diferents, un d'ells és l'enfocament que agafen Sanders i Stappers amb el seu treball al voltant del disseny generatiu. Per Faste i Faste (2012), es tracta d'un treball de recerca al voltant d'unes tasques estètiques per donar forma a un 
element, en el qual el dissenyador participa realitzant prototips de formes i experiències de manera iterativa per poder determinar la utilitat i usabilitat de l'element en qüestió. Aquest tipus d'aproximació ha de tenir lloc necessàriament en un context de pràctica de disseny en el món real i involucra eines com l'storyboard, la pluja d'idees, el prototipatge físic o interactiu, etc.

La zona més gran del mapa de Sanders i Stappers — vegeu figura 27-, és la zona lila situada a baix a l'esquerre que correspon a la recerca centrada en l'usuari, és la que té més literatura i més volum. És la zona on es treballa amb la intenció que els productes i serveis s'ajustin a les necessitats dels usuaris. Aquesta part, correspondria a un segon tipus de recerca que dibuixen Faste i Faste (2012) orientada empíricament i basada en l'observació directa del món físic a través de recerca qualitativa observant la gent en context per identificar necessitats i emmarcar oportunitats, la qual consideren que podria ser sinònima de recerca etnogràfica. La tercera línia de recerca que proposen Faste i Faste (2012) es basa en la participació en un enfocament crític, especulatiu o pel contrari teòric que inclou l'exploració i la intervenció en el discurs i la pràctica cultural; que en certa manera correspon a la taca blava de la part superior esquerre, que Sanders i Stappers anomenen Critical Design. També com s'ha vist, Crouch i Pearce (2012) distribueixen els diversos mètodes de recerca comentats a través de la participació més o menys directa i implicada de l'usuari.

El disseny participatiu ocupa la zona taronja a la dreta de la figura. Aquesta zona engloba també el disseny generatiu, que fa referència a l'apoderament de la persona per generar i promoure alternatives a una situació present. El fet de concretar amb el concepte eines generatives és perquè fa referència a la creació d'un llenguatge de disseny compartit que fan servir, dissenyadors i altres experts per comunicar-se visualment entre sí de forma directa; és a dir, una manera per explorar idees, somnis i revelacions (Sanders i Stappers, 2012).

Com es pot veure al mapa, el disseny generatiu i la recerca associada, formen part del disseny participatiu. Sanders i Stappers (2008) coincideix amb altres autors citant l'origen d'aquests processos als països escandinaus, i tradueix l'antic concepte de disseny participatiu pel nou concepte codesign, en l'era de l'activitat CO. El punt de partida és la creença 
que aquell a qui li afecten les decisions de disseny, hauria de tenir la possibilitat de dir-hi alguna cosa. Sanders i Stappers (2008) recupera un article de Nigel Cross de 1972 on comenta la gran revolució que suposarà el fet de fer participar a l'usuari en el procés de generació d'idees, tot i que també comenta que encara falten molt anys perquè això passi i que cal preparar-ho bé.

La proposta d'aquest treball, que accepta l'ergonomia com un dels puntals del projecte de disseny, és dotar d'aquesta visió participativa als mètodes i eines que l'acompanyen, de manera que els factors humans i l'ergonomia, així com a l'anàlisi d'usabilitat, que en aquest mapa de doble entrada apareixen a baix a l'esquerre, es traslladin a una posició enfocada al disseny (és a dir, a la part superior), i guiada per l'usuari entès com a membre integrant de l'equip (és a dir a la part dreta). Es considera que aquest canvi aportaria a l'ergonomia una renovació metodològica d'acord amb el segle XXI, i convertiria part de la disciplina en una font d'innovació i visió prospectiva.

\subsubsection{Conclusions}

En definitiva, en aquest apartat es fa un breu recorregut en relació a possibles enfocaments de la recerca en el projecte de disseny, centrant-se en la recerca realitzada a l'inici del projecte. Cada un d'ells, tot i que són afins i comparteixen eines, té unes característiques pròpies que el fa més o menys adequats en cada cas concret. A l'iniciar el projecte, és necessari establir els marcs de treball i sota quines perspectives i expectatives treballa el projecte, per poder enfocar la recerca d'informació de forma coherent i eficaç, i evitar, tant com sigui possible, la recol·lecció de dades supèrflues i irrellevants per al projecte. Un cop realitzades les diverses activitats de recerca per a l'obtenció d'informació, caldrà fixar aquesta informació de manera que sigui pràctic poder treballar amb ella. L'ús de fitxes conceptuals o diversos tipus de mapes, són maneres visuals i àgils de fixar la informació. A més a més, caldrà transcriure entrevistes i passar a net les notes de camp de qualsevol observació. Les dades han de quedar ben documentades, de manera que si cal recórrer a elles de nou, es puguin localitzar sense problemes. 
A més a més, un cop les dades estan emmagatzemades de forma coherent i entenedora, es pot començar a treballar amb elles. El primer pas serà codificar la informació. Aquest procés es caracteritza per a la classificació de les dades per temàtiques. Es tracta d'una classificació oberta que cal estructurar de manera concreta per a cada recerca, i que, a part, evolucionarà amb el propi projecte. S'anomena codificar perquè s'elabora un llibre de codis per a classificar les dades que servirà durant tot el projecte, $i$ que es farà servir en tots els tipus de dades, siguin fruit, per exemple, de l'observació o de les entrevistes. Per altra banda, aquest llibre de codis serà utilitzat per tots els membres participants d'aquesta fase de forma homogènia. Sanders i Stappers (2012) proposen diversos nivells per a la classificació de les dades, resulta interessant aquesta classificació perquè ja ordena les dades pensant amb les fases posteriors on l'objectiu principal serà la detecció d'evidències —vegeu al proper apartat 2.4.3 i la figura 29 Esquema DIKW-.

Resumint, les fases d'anàlisi inclouen, per una banda, la recol·lecció de dades pertinents, habitualment a través de mètodes propis de la recerca etnogràfica, però no només; i per l'altra, la classificació, ordenació, emmagatzematge i codificació de les dades obtingudes.

\subsubsection{Les fases argumentatives}

En aquest treball, quan es parla de les fases argumentatives es fa referència al procés mitjançant el qual la informació i les dades recol·lectades durant un procés de recerca són treballades de manera que es converteixen en arguments per a la presa de decisions del projecte de disseny, és a dir, premisses de disseny que formaran part del brief. Els arguments que es defineixin durant aquest procés es recolzaran en les dades en pro de la coherència projectual. Per altra banda, les fases argumentatives conduiran al dissenyador a identificar reptes de disseny, fruit de les necessitats no satisfetes, dels desitjos o de les problemàtiques recollides amb cura durant el procés de recol·lecció de dades; aquest repte encapçalarà el brief, com es veurà en l'últim apartat d'aquest capítol, 2.4.4 Elaboració d'un brief de disseny. 
Aquest és un moment crític del projecte de disseny i una de les fases que requereix més pensament lateral, visió àmplia i innovadora, i on el dissenyador ha de demostrar que té una lectura del món que l'envolta que li permet posicionar-se en el futur. Saber allunyar-se d'obvietats, saber llegir entre línies, i posicionar-se empàticament amb cadascun dels actors que participen de l'artefacte, són característiques que han de guiar al dissenyador durant aquestes fases. El pas entre la recerca i el disseny és precisament el pont conceptual que cal construir. Un pont conceptual que porta al dissenyador des del passat o el present (on es fa la recol·lecta de dades), fins al futur (on esdevindrà l'artefacte dissenyat).

Sanders i Stappers (2012) plantegen la gran diversitat de formats que poden tenir les dades recol-lectades com un dels primers problemes amb els quals es pot trobar el dissenyador immers en un procés de recerca. El procés de codificació que es planteja durant l'apartat anterior és un procediment que ajuda a ordenar tot el material obtingut perquè sigui més manejable, procura que no es perdi informació durant el procés d'anàlisi, i en fa possible la seva recuperació si en algun moment es volgués recórrer a les dades originals.

\begin{tabular}{|c|c|c|}
\hline $\begin{array}{l}\text { WHAT } \\
\text { PEOPLE }\end{array}$ & $\begin{array}{l}\text { USER-CENTERED } \\
\text { DESIGN RESEARCH }\end{array}$ & $\begin{array}{l}\text { GENERATIVE } \\
\text { DESIGN RESEARCH }\end{array}$ \\
\hline Say & $\begin{array}{l}\text { Transcripts } \\
\text { Questionnaire data } \\
\text { Interview notes }\end{array}$ & $\begin{array}{l}\text { Transcripts } \\
\text { Questionnaire data } \\
\text { Interview notes }\end{array}$ \\
\hline Do & $\begin{array}{l}\text { Photos } \\
\text { Videotapes } \\
\text { Observation notes }\end{array}$ & $\begin{array}{l}\text { Photos } \\
\text { Videotapes } \\
\text { Observation notes }\end{array}$ \\
\hline Make & & $\begin{array}{l}\text { Image collages } \\
\text { Cognitive maps } \\
\text { 3-D models } \\
\text { Workbook data of many forms } \\
\text { Transcripts of stories told about the artifacts } \\
\text { Annotated photographs from the participants } \\
\text { Observations of people's behavior during the workshops }\end{array}$ \\
\hline
\end{tabular}

Fig. 28 Comparativa de les dades recollides segons diversos enfocaments metodològics. Sanders i Stappers, 2012, p. 199) 
La diversitat de formats pot incloure des de notes de camp, fotografies, vídeos o àudios d'entrevistes, fins a documentació d'una recerca en fonts secundàries, mapes conceptuals o petits prototips fruit del treball amb els usuaris. A més a més, aquesta informació pot ser molt diferent a nivell de profunditat, si es tracta d'un esdeveniment esporàdic o genèric, $\mathrm{o}$ per exemple si es tracta d'informació eminentment subjectiva, tot i pretendre un to objectiu. Segons aquests autors, la problemàtica s'accentua quan se segueix un procés de disseny generatiu com el que proposen ells, ja que es treballa amb elements físics amb els diversos actors del projecte.

Sanders i Stappers, en la seva proposta, es basen en el convenciment que la persona actua segons tres nivells de consciència: allò que diu, allò que fa, i allò que construeix. Aquests tres nivells els resumeixen en Dir/Fer/Construir, i cada un proporciona diferents tipus de dades, tal i com es pot observar a la figura 28 (Sanders i Stappers, 2012, p. 198-199). En aquest esquema, Sanders i Stappers també distingeixen entre la recollida de dades a partir d'un procés clàssic de disseny centrat en l'usuari, i la recollida de dades a partir d'un procés de disseny generatiu com el que defensen ells. Segons aquests autors, la divisió Dir/Fer/Construir només té lloc quan l'usuari participa activament del procés de disseny i construeix models, és a dir, crea material de recerca, ja que en el disseny centrat en l'usuari, aquest és observat i analitzat, però no construeix res. Si es dur a terme un procés de disseny generatiu, el material recol·lectat augmenta enormement, i també la seva disparitat, i per tant, també augmenta la complexitat per al tractament de les dades obtingudes. El dissenyador que vol treure informació útil per al projecte ha d'aprendre a treballar amb aquesta gran quantitat de dades en formats diferents i ha d'aguditzar la capacitat d'observació i visió crítica per a detectar les evidències que el fan avançar. Quan Sanders i Stappers parlen de facilitador, en lloc de dissenyador, també és en el sentit que els usuaris necessiten un acompanyament per a construir de forma útil, de manera que els collages, els mapes mentals o els prototips bàsics, entre d'altres, estiguin plens de contingut i siguin viables per a l'extracció d'informació. D'aquesta manera, faciliten, encara que només sigui en part, l'enorme tasca del tractament de dades i l'extracció d'evidències, conclusions i premisses de disseny. 
Com ja s'ha dit, un dels punts més complexes del procés projectual és, doncs, l'aprofitament de les dades recollides, és a dir, com aquestes dades es converteixen en informació útil pel projecte. Per això, resulta especialment interessant l'aportació de Sanders i Stappers per a l'estructuració del pont conceptual que explica com el dissenyador treballa amb les dades per definir el repte de disseny. Aquests autors, elaboren un quadre que visualitza aquest procés inspirat en la proposta d'Ackoff (1989) i el seu esquema DIKW (Data, Information, Knowledge, and Wisdom ${ }^{28}$ ). En aquesta classificació hi ha diversos elements especialment interessants i que ajuden a ordenar la recerca, a la vegada que n'estructuren el procés, tal i com es pot veure a la figura 29 .

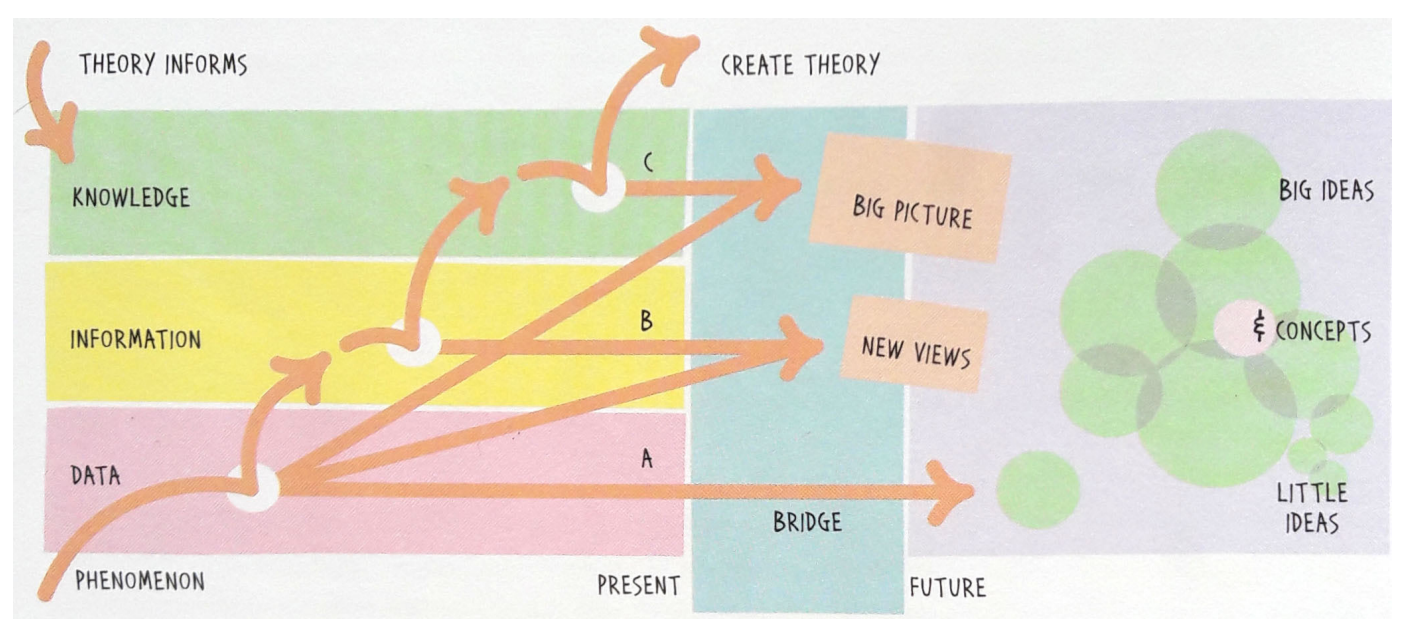

Fig. 29 Esquema DIKW del salt entre el fenomen i el futur dissenyat. Sanders i Stappers, 2012, p. 204)

Com proposen Sanders i Stappers (2012), el punt de partida és un fenomen (phenomenon), un fet o una acció que té lloc a la realitat, i que també anomenen evidència. L'únic element que es pot guardar del fenomen és precisament la dada (data), que poden ser notes, fotografies, vídeos, entrevistes, etc. La dada ja ha sofert un procés de selecció, per exemple, en el moment que l'investigador escull un o altre enquadrament per fer una foto, però encara no es pot parlar d'interpretació. Les dades es poden emmagatzemar, classificar i ordenar.

28 Traducció pròpia: Dades, Informació, Coneixement i Saviesa 
La interpretació de les dades és el procés que fa saltar de nivell i arribar a la informació (information). "L’investigador tria activament el significat mitjançant la interpretació, mentre que les dades són típicament físiques i tenen molts aspectes, les interpretacions són simbòliques —-sovint verbals— i sovint s'escullen dins d'un marc de classificació" (Sanders i Stappers, 2012, p. 201). A aquest nivell, la informació es treballa a través de definir patrons i elaborar conceptes, i precisament aquest patrons i conceptes agrupats en una visió nova del fenomen són la base per fer el salt al següent nivell, el de coneixement (knowledge).

El coneixement és genèric i es dedueix de l'abstracció d'allò individual que és a la vegada la seva base, "si encertem elaborant una teoria exitosa, es podran predir esdeveniments futurs" (Sanders i Stappers, 2012, p. 201), que, el cap i a la fi, és la màxima del disseny: el reconeixement de l'actualitat per la configuració del futur en base a unes premisses actuals que considera certes, tal com ja afirmava Jones (2a ed. 1992). És a dir, allò que s'anomena coneixement, es construeix a partir de la informació que s'ha elaborat amb les dades que fan visible un fenomen.

Finalment, Sanders i Stappers proposen un nivell superior, fora de l'esquema en sí, que anomenen saviesa (wisdom), amb aquesta paraula volen fer referència a les premisses que guien al dissenyador sobre com fer ús del coneixement del qual disposa i que el duen a tenir una visió global del problema (big picture), l'única manera d'arribar a la cúspide de la piràmide de Lluis Arnal —vegeu 2.4.1 El procés Projectual一.

Per la seva banda, Sleeswijk Visser (2009) també recull aquest esquema, i afegeix que el nivell de saviesa és on el dissenyador aplica el coneixement també d'altres àmbits que no són pròpiament els de la recerca. Per això, a aquest nivell, la visió és definitivament més àmplia (Sleeswijk Visser, 2009, p.29).

El pas del fenomen viscut, fins a la creació de teories que s'observa en l'esquema de Sanders i Stappers (2012), és la base conceptual del projecte de disseny, és la base que ha de sostenir i argumentar la presa de decisions posteriors durant el desenvolupament del producte. Per això, és important que el dissenyador tingui la capacitat de recollir dades, de tre- 
ballar-les, codificar-les i definir evidències (insights) — vegeu el subapartat següent 2.4.3.1 Extracció de conclusions. Els insights - que van més enllà de l'observació objectiva d'allò que està passant. Perquè el procés d'anàlisi de dades sigui profitós, cal tenir sempre presents les diverses capes de contingut de cada acció de l'usuari.

Tot i així, cal tenir present el problema de l'objectivitat, i considerar que no existeix en estat pur, i menys encara quan es treballa sobre la vida quotidiana sobre la qual, qualsevol persona, també el dissenyador o l'ergonomista, té models preestablerts. "Es tracta de models establerts pel costum, per les modes, per les nostres capacitats mimètiques o per les imposicions d'altri" (Martí Font, 1999, p. 210). Martí Font recorre a Edward de Bono per explicar per què fem ús d'aquests models preestablerts:

\footnotetext{
“[...] en primer lloc, perquè en el procés comunicatiu és més fàcil explicar una situació si em serveixo de models preestablerts que si en creo d'específics; en segon lloc, perquè en la interpretació del món exterior, davant diverses opcions possibles, la més fàcil és el model preestablert; i en tercer lloc, perquè en reconeixement de situacions es pot establir el model a partir d'una o de poques dades, la qual cosa és, quasi de manera invariable, un model arquetípic o preestablert" (De Bono a Martí Font, 1999, p. 210)
}

Tal com s'ha vist en el subapartat 2.4.2.1 Recol·lecció de dades pel projecte de disseny, l'experiència de la quotidianitat és una font d'informació essencial en l'època de l'experiència d'usuari, i és important ser conscient dels propis models preestablerts quan es du a terme la recerca. Aquesta és la clara tendència no només del disseny, sinó també de molts altres àmbits, entre ells, per exemple, el món de l'educació.

És en l'observació de la quotidianitat on esdevenen els fenòmens que es convertiran en dades. Més enllà d'aquests fenòmens, caracteritzats fonamentalment com a accions (fruit de l'experiència d'usuari), hi ha una altra sèrie de qüestions que acabaran conformant les diverses dimensions de l'artefacte, és aquí on el sistema d'anàlisi que proposa l'ergonomia esdevé una eina valuosa, ja que proposa l'aproximació a les diverses dimensions des de les seves cinc variables (finalitat, acció, persona, màquina i entorn) tal i com es veurà en el capítol III. 
Davant de tal complexitat, és interessant que existeixi una coordinació del projecte forta i amb capacitat de visió global. Martí Font (1999), a final del segle XX, ja considera que el dissenyador té les capacitats per assumir aquesta coordinació, però afegeix que necessita comptar amb especialistes que assumeixen funcions específiques. Per a Martí Font, el dissenyador "és capaç de dominar totalment l'immens inventari de tècniques i de coneixements culturals necessaris per abordar el grau de complexitat, i les seves conseqüències, conegudes o desconegudes, de les societats contemporànies" (Martí Font, 1999, p. 233). Aquest autor, doncs, també atorga al dissenyador un paper de mediador cultural pròxim a les persones, més enllà dels coneixements tècnics i tecnològics que se li suposen. En el mateix sentit, Robert i Brangier (2009) consideren a l'ergonomista també capacitat per assumir aquesta coordinació des de la visió global enfocada al futur que predica la seva proposta d'ergonomia prospectiva — apartat 2.2.2.3 Ergonomia Prospectiva-.

\subsubsection{Extracció de conclusions. Els insights}

L'extracció de conclusions és l'activitat que acaba amb la fase d'anàlisi de dades, una primera pedra col·locada cap a la definició del repte de disseny. És el principi de la construcció d'un pont que ha de superar la distància entre la recerca, que parla de la situació present o passada i on s'han recollit unes dades que pretenen ser útils per les premisses de disseny, i el propi disseny, que parla sobre el futur i visualitza un producte o servei que hauria de millorar en algun sentit la situació present. La qualitat de les conclusions, més enllà de l'habilitat del dissenyador, també depèn de la qualitat de la recerca, fins i tot, durant l'anàlisi es pot descartar informació per irrellevant. Per a Martí Font, la recerca prèvia és essencial i, "si bé no ens garanteix mai un resultat acceptable, sí que possibilita la disminució de probabilitats de fracàs" (Martí Font, 1999, p. 230). La intenció d'aquestes paraules és posar sobre la taula la importància de l'argumentació ben fonamentada, per tant, construïda sobre unes dades i una informació fiable, fet que obliga a desenvolupar una recerca sistemàtica 
i rigorosa, en base a les premisses de la recerca social i científica. Aquí entren en joc, com s'ha vist anteriorment, les diferències de plantejament entre la recerca pel disseny i la recerca sobre el disseny; la segona estructurada i metòdica enfocada al desenvolupament de coneixement, i la primera, epistemològicament menys estricta i enfocada a construir una base argumentativa i conceptual a l'objecte de disseny. Martí Font, també comenta la possibilitat de prendre decisions "incompletes, errònies o ineficaces" (Martí Font, 1999, p. 230), encara que sorgeixin de dades rigoroses. És a dir, que una bona recerca és necessària, però no assegura una bona extracció de conclusions. Per aquest autor, "en qualsevol cas el que cal reduir al mínim possible és la intervenció de l'atzar, tot i acceptar que aquest no és mai eliminable del tot” (Martí Font, 1999, p. 230).

Per a Sanders i Stappers (2012), la qualitat de les conclusions també depèn del nivell d'anàlisi de les dades d'on s'extreuen aquestes conclusions, "si no ha tingut lloc cap anàlisi o si aquesta anàlisi ha sigut pobra, existeix el risc que les idees obtingudes siguin superficials" (Sanders i Stappers, 2012, p. 222). És a dir, cal tenir molt en compte que l'extracció de conclusions marcarà la tendència cap a un projecte continuista sense millores aparents de la realitat, o cap a un projecte innovador fruit de la comprensió oculta (no bàsica o superficial) de la realitat, o qualsevol de les opcions entre els dos extrems. El dissenyador és qui posa el límit a les seves intencions i és qui ha de saber detectar el seu grau de compromís amb la exhaustivitat de la recerca i la pròpia intenció de desvelar conclusions que guiïn cap a la innovació, entesa de forma àmplia. Per aconseguir-ho, o facilitar-ho, el disseny s'abasteix de tècniques i eines creatives que han de guiar en aquest procés; i l'ergonomia, que per tradició no està avesada a processos creatius d'aquest abast, por recórrer a aquestes eines i traçar un pont entre disciplines amb gran afinitat. Seguint l'esquema DIKW de Sanders i Stappers - vegeu figura 29-, com més avancis en aprofundir i treballar les diverses fases d'aproximació a la idea (dada, informació coneixement i saviesa), més probabilitat existeix que sorgeixin idees significatives al llarg del procés. Per aquests autors, és important que el dissenyador no perdi en cap moment la intenció de tenir una visió global del tema sobre el qual versa la recerca. 
Per a Sanders i Stappers, la formulació de conclusions inclou, també, la seva comunicació. El fet d'haver de comunicar el resultat de la recerca, obliga a analitzar les dades i extreure'n conclusions. Per fer-ho, proposen diverses estratègies lligades, sobretot, a les possibilitats econòmiques i temporals del client. En el seu cas, tractant-se d'una recerca desenvolupada amb disseny generatiu, la proposta és extreure les conclusions també amb la participació dels usuaris, sempre hi quan sigui possible. Es planteja una activitat que pot durar més d'un dia estructurat com a taller de creativitat, i es preveuen conclusions més riques per la diversitat de visions. Treballar les dades significa agrupar i descartar buscant evidències que converteixi la informació en possibilitats de disseny, ja que l'objectiu principal per a l'extracció de conclusions és poder delimitar problemàtiques, necessitats i desitjos dels usuaris, que es puguin convertir en reptes de disseny.

Així doncs, l'objectiu principal de l'extracció de conclusions és l'elaboració d'un mapa de les activitats que s'estan analitzant, on apareguin necessitats, desitjos i problemàtiques de les persones, conceptualitzades a través del concepte d'evidència (insight). En aquest treball, es tradueix el concepte insight pel terme evidència, fent referència a un fenomen existent que sense la mirada del dissenyador estava oculta, però un cop es desenvolupa una recerca, el fenomen passa a ser evident, es pot descriure i treballar-hi per convertir-lo en un repte de disseny. Formulat d'una altra manera, les evidències fruit de la recerca, són observacions, opinions, desitjos o necessitats de l'usuari sorgides de la interacció de la persona amb l'entorn que porten implícites possibilitats de disseny i que el dissenyador/ investigador ha sabut treure a la llum.

L'insight és un terme que prové de la psicologia, una mostra més de com el disseny (igual que l'ergonomia) s'apropia d'allò que li interessa d'altres disciplines i ho adapta a les seves necessitats. Per a la psicologia l'insight és sinònim de solució, és la idea que desencalla una problemàtica quan la persona en visualitza la solució. Es pot definir com "la solució sobtada a un problema llarg i molest, un reconeixement sobtat d'una nova idea o una comprensió sobtada d'una situació complicada acompanyada d'un moment Aha!" (Jung-Beeman, Collier \& Kounios, 2008, p. 20, a Hill i Kemp, 2016, p. 7). Una altra definició que 
obvia la informació relacionada amb la resolució de problemes: “un canvi en la mentalitat o un canvi en el pensament [...] que va acompanyat d'un moment Aha! quan és positiu o d'un moment Uh-oh! quan és negatiu" (Klein i Jarosz, 2011, p. 338 a Hill i Kemp, 2016, p. 7). Com expliquen Hill i Kemp (2016), el moment Aha és el moment que se sol representar amb una bombeta encesa sobre el cap. El moment Uh-oh!, és el moment que permet entendre alguna problemàtica complexa, per exemple quan de cop l'alumne aguditza la visió espacial i entén la representació dièdrica. Aquests autors també classifiquen el moment Uh-oh! De forma negativa, reconeixent que l'evidència a vegades es fonamenta en argumentacions errònies $\mathrm{o}$ amb problemes d'inferència, descriu la causa/efecte de forma errònia, o evidencia un insight que ja és conegut per la gran majoria de persones i, per tant, el seu valor és escàs i s'allunya de la intenció creativa i innovador que pretén el disseny.

O sigui, que en realitat els insights també poden aportar claredat a un problema, no només representar-ne la solució absoluta, i en aquesta definició és on encaixa amb l'insight que proposa el desenvolupament del projecte. És a dir, una evidència que aporta claredat, o expectatives de solució, a alguna qüestió de la quotidianitat.

També és interessant veure com Hill i Kemp (2016), fruit d'un experiment amb diverses persones, classifiquen els insights en tres grans blocs: (1) intel·lectuals, (2) pràctics i (3) personals. Els primers, els intel·lectuals, fan referència a la connexió entre temes dispars que permeten entendre un concepte concret. És a dir, que la persona busca recursos en la seva memòria explícita; aquí podríem fer un paral·lelisme en la recerca de referents del projecte de disseny, o en l'experiència del dissenyador. Els segons, els pràctics, fan referència a la resolució d'un problema que requereix certa manipulació manual del tipus travar una porta que constantment es tanca amb el corrent d'aire; que anirien relacionats amb activitats de prototipatge. Finalment, els tercers, els personals, fan referència a la reflexió al voltant de la pròpia vida o en relació a la seva mentalitat. És a dir, relacionat amb com enfocar aspectes vitals concrets, o el compromís de canviar hàbits; relacionats, per tant, amb les expectatives i desitjos de les persones. Aquesta classificació obre la porta a molts diferents tipus d'evidències, i mostra de manera clara la necessitat que el dissenyador tingui una mirada àmplia quan observa la quotidianitat. 
Finalment, Hill i Kemp (2016), a través de l'experiment que duen a terme, també identifiquen el moment en el qual les persones experimenten l'evidència. És comú pensar que les idees ens venen el cap quan menys ens ho esperem, com deia la definició de més amunt de manera "sobtada". Aquesta situació correspon a un moment en el qual s'està duent a terme alguna tasca de baixa carga cognitiva, com per exemple dutxar-se, caminar $\mathrm{o}$, fins i tot, conduir. Però no només. L'estudi conclou que part de les persones també experimenten el moment Aha!, quan n'estan buscant la solució activament. En definitiva, s'hauria de considerar que la recerca que du a terme el dissenyador, l'ha d'ajudar a desenvolupar moments Aha!, sigui durant el treball amb les dades i la informació, o sigui tornant cap a casa, però que necessita, per al bon desenvolupament del projecte, rescatar un insight, o una evidència, o diverses, que donin cos al projecte.

També des del món de la psicologia, on l'insight s'associa directament a la solució, Salvi, Bricolo, Bowden, Kounios i Beeman (2016) es pregunten per què és tan difícil argumentar solucions fruit de l'insight si poden oferir propostes similars a les solucions fruit d'un procés de reflexió actiu. Segons aquests autors, "alguns problemes són difícils de resoldre perquè els conceptes rellevants no s'associen de forma clara i, per tant, només s'activen dèbilment per la presentació del problema" (Salvi et al., 2016, p. 53). Més que fixar-nos en com s'arriba a la solució, i entenent que des del disseny l'insight no és la solució, sinó la base on sustentar-ne una, la reflexió de Salvi és interessant per la seva afirmació que els conceptes que defineixen un problema a vegades no es relacionen de forma clara. En aquest sentit, i amb la intenció de crear ponts de relació entre conceptes, és bàsic el procés d'anàlisi basat en establir relacions que conclou amb l'extracció de conclusions. El disseny també aporta eines per a desenvolupar aquest procés de forma àgil i, habitualment, visual. El Manual Thinking n'és un exemple —vegeu apartat 2.3.3 Manual Thinking-.

A la seva descripció del Design Thinking, Tim Brown (2009) també parla de l'insight, el defineix, i expressa la necessitat que sigui fruit d'un procés de recerca qualitatiu. Les fases del Design Thinking inicien el procés de disseny amb una fase d'empatia on es recol·lectarà la informació, seguida d'una fase de definir, on es concretaran els insights — vegeu 2.3.1 Design Thinking-. Brown qualifica l'insight com "una de les fonts clau del pensament en disseny, 
i no sol provenir de piles de papers amb dades quantitatives que mesuren exactament el que ja tenim i ens diuen el que ja sabem. Un millor punt de partida és sortir al món i observar les experiències reals de viatgers, patinadors i infermeres tal com improvisen el camí del seu dia a dia" (Brown, 2009, pp. 40-41). Per a Brown, els insights s'han de detectar observant aquest dia a dia de les persones, per poder trobar, gràcies al seu comportament i accions, "pistes inestimables sobre el seu ventall de necessitats insatisfetes". (Brown, 2009, p. 41). Per a Brown, guru del Design Thinking empresarial, la idea bàsica del procés es "convertir necessitats en demanda", per tant, el concepte és tan senzill com “esbrinar què vol la gent i després donarlos-hi” (Brown, 2009, p. 39), i per aconseguir-ho, el primer pas és detectar aquests desitjos, o necessitats, i expressar-los a través de l'insight.

Revisant opinions diverses sobre el procés d'identificació d'insights, si una cosa queda clara, és que és un concepte complicat d'entendre, i un dels moments crítics del procés de disseny. Es recull l'exemple del bloc Designthinking . $\mathrm{Gal}^{29}$ perquè exemplifica de forma força clara com s'amaga el verdader insight, o l'evidència que aporta valor al projecte. A través d'un article, Marcos Saavedra explica com, en gairebé tots els casos, a la pregunta "Per què un apicultor porta un vestit tant aparatós per recollir la mel?", la resposta és "perquè no el piquin les abelles". Tanmateix, el verdader per què és que l'apicultor es protegeix amb el vestit per poder recollir la mel. Per tant, l'insight ha de ser la intenció o voluntat de recollir la mel. En el desenvolupament del projecte, posar els esforços en protegir l'apicultor de les picades de les abelles, o posar els esforços en desenvolupar un sistema per a recollir la mel, desemboquen en propostes de disseny infinitament diferents. Com ja s'ha dit abans, el compromís del propi dissenyador amb l'exhaustivitat i la intenció innovadora és qui posarà més o menys valor a cada evidència, sempre tenint en compte que l'insight, o l'evidència, no són la solució, sinó la base des d'on construir-la.

Per tot plegat, una bona extracció de conclusions fruit de l'observació, i de la recerca en general, és un moment important i clau del projecte.

29 Visiteu el bloc https://designthinking.gal/que-son-los-insights/ per a llegir l'article complet "Qué son los insights?" (última visita 17/06/2020) 


\subsubsection{El repte de disseny}

En aquest moment del treball cal fer una distinció important perquè no sorgeixin dubtes al respecte. En tot moment, quan es fa referència a la recerca en disseny, es pretén una recerca inicial del projecte, en molts casos prèvia a l'encàrrec, prèvia al repte de disseny i prèvia al brief.

En general, són equiparables els moments que marquen l'inici del projecte de Martí Font (1999), quan parla de l'encàrrec o autoencàrrec; el moment de Cross (2003) quan inicia la recerca de solucions; o el moment tradicional de l'inici d'un projecte amb la recepció d'un brief. En tots aquests casos, el repte de disseny marca l'inici del procés de disseny inclòs dins l'encàrrec — vegeu figura $30 \mathrm{amb}$ la comparativa- .

També són equiparables els moments d'inici de la recerca de Sanders i Stappers en el fuzzy front end, la recerca de Hekkert i van Dijk a través de l'exploració del context futur, o fins i tot les fases d'empatia i definició del Design Thinking, ja que totes elles se situen en un moment previ, i pretenen començar el projecte definint el repte de disseny. En aquests casos l'acotació inicial del projecte és molt més àmplia, molt més oberta i procura no definir l'artefacte sorgint del procés, que tant pot acabar en un objecte, com en un servei o una aplicació pel mòbil. Aquest treball, es preocupa especialment d'aquest tipus de recerca, sense oblidar, però, que en qualsevol projecte de disseny existeix recerca, i que per tant, d'alguna manera, les reflexions elaborades al voltant de la recerca i els seus processos són traslladables a altres fases amb el projecte més avançat.

El cas del doble diamant és un cas paradigmàtic ja que en el seu primer esquema el punt de sortida se situa en un problema, en canvi en l'esquema actualitzat del 2019 el punt de sortida és un repte. Un canvi de nomenclatura que el posiciona dins els mètodes actuals i que el connecta amb les teories sobre el disseny que es veuen a continuació, així com la intenció actual d'un disseny molt més transversal i multidisciplinari. El primer esquema, acaba el primer diamant amb el design brief, que s'adiu a la intenció de la recerca que 
proposa aquest treball; en canvi, l'esquema renovat elimina el concepte de brief — vegeu apartat 2.3.2 Doble Diamant-.

Dit això i tornant al repte de disseny, la seva definició resumeix totes les tasques fetes durant la recerca i proposa un objectiu sobre el qual treballar. Aquest objectiu esdevé de l'evolució dels diversos insights (evidències) fruit de la recerca. Una fase de recerca pel disseny desenvolupada dins del fuzzy front end, pot desembocar en més d'un repte. És a dir, si la recerca s'ha iniciat en la investigació de la quotidianitat acotat de forma temporal o emmarcat en un context, però sense un encàrrec (o autoencàrrec) concret, l'aspiració de l'investigador és que les possibilitats de desenvolupar un projecte siguin múltiples i variades, per tant, també el repte de disseny ho hauria de ser, és a dir, hi hauria d'haver diversos reptes possibles.

Sigui quin sigui el repte de disseny i de quin grau de definició gaudeixi, el repte ha de predisposar a l'acció. Aquests reptes no apareixen del no res, ni es pretén que siguin només fruit de l'instint i la creativitat, sinó que són fruit de la recerca i responen a les conclusions que defineixen les necessitats, problemàtiques i desitjos de les persones, és a dir, responen a les evidències observades. Traslladar aquestes conclusions al format repte que predisposi a l'acció és el pas previ a la definició del brief de disseny. Cal fer esment, que la definició de reptes de disseny no només s'ha de limitar a la recerca de problemàtiques i a la seva solució. Polanyi, recorrent a Plató, posa en dubte la viabilitat de treballar a partir de la recerca de solucions als problemes, en el sentit que "cercar la solució d'un problema és un absurd; ja sigui que sàpigues el que estàs buscant, i després no hi ha problema; o que no saps el que estàs buscant, i no es pot esperar trobar res" (Polanyi, 1966, p.22). Al llarg d'aquest treball, s'ha fet esment en diverses ocasions de l'estreta relació del disseny amb la recerca de solucions, tanmateix, és interessant tenir en compte que aquesta és només una de les possibilitats que poden configurar el repte, però que n'hi ha d'altres com el compliment de desitjos o satisfacció d'expectatives de l'usuari, més lligats a l'experiència, que també poden resultar molt enriquidors, i sobretot, innovadors ja que projecten futur sense tenir implícit un problema previ.

Alguns autors, com per exemple Sanders i Stappers (2012) anomenen aquesta etapa la fase de conceptualització: "Conceptualització és on es fabriquen les noves idees, conceptes i 
Fig. 30 Comparativa dels diversos moments de l'inici del projecte en contrast amb el moment del repte, i les seves diverses nomenclatures
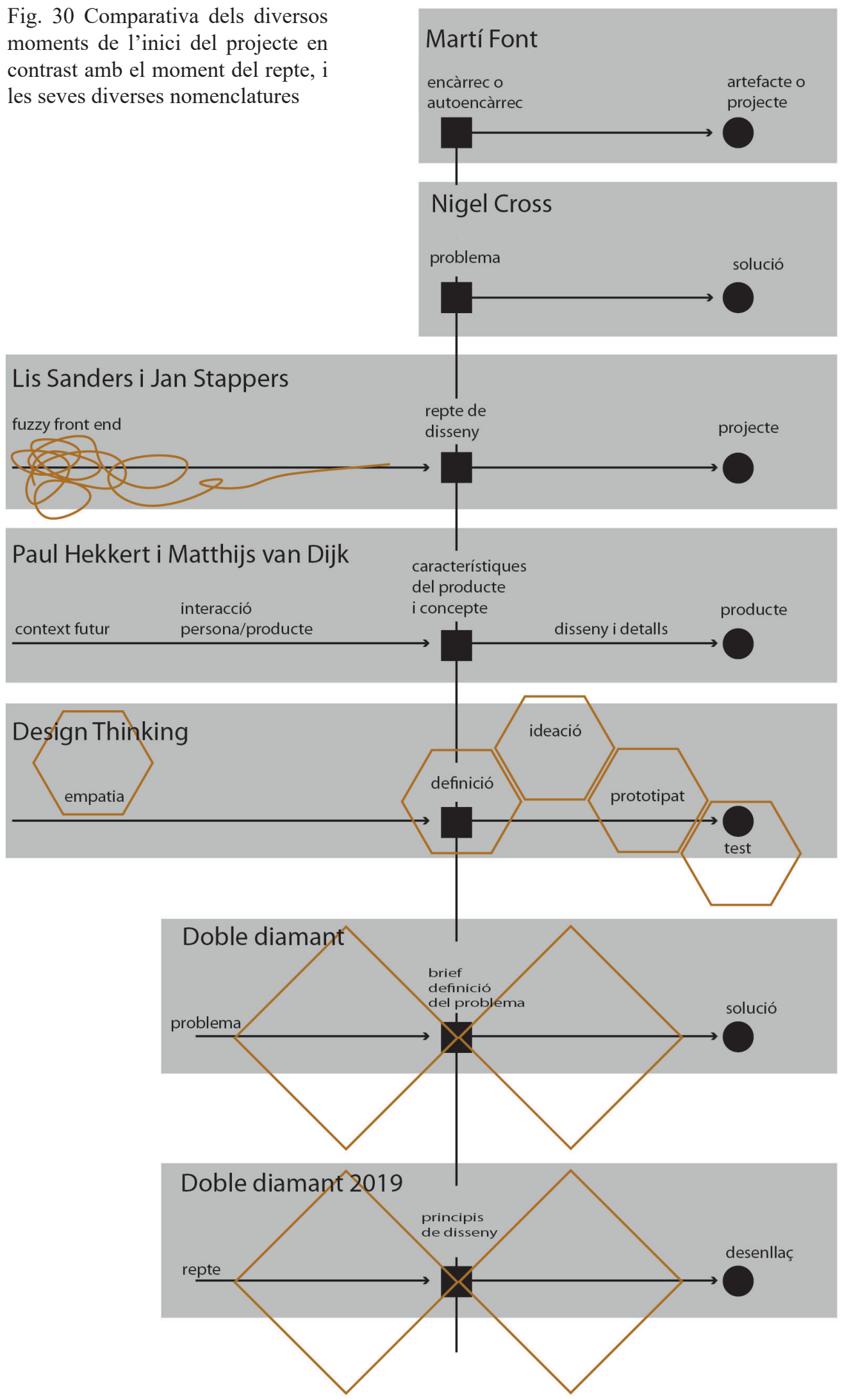
solucions, i des de fa temps es reconeix com la part central del disseny" (Sanders i Stappers, 2012, p. 255). Per dur a terme aquesta part tant important i que marca el punt de partida per al desenvolupament del projecte, també es treballa amb eines creatives que han d'ajudar al dissenyador a visualitzar un futur possible, per exemple, com treballen Hekkert i van Dijk (2011) la definició de reptes de disseny a partir de la configuració de l'entorn futur i la interacció prevista entre l'usuari i aquest entorn — vegeu apartar 2.2.4.1—.

Com afirmen diversos autors, entre ells Sanders i Stappers (2012), mentre es treballa amb les dades recol·lectades de la recerca poden aparèixer petites idees que ja comencen a enfocar un repte de disseny. Per a Cross (2003), que focalitza les fases del disseny cap a la solució, considera que és un procés que evoluciona en paral·lel: mentre estàs esforçant-te per entendre o interpretar les dades de la recerca, ja projectes futur, encara que sigui de forma poc precisa. Tot i així, Cross (2003), també considera que aquestes idees inicials han ser vagues, per deixar la possibilitat que n'apareguin d'altres, i no caure en l'error de creure que la primera visualització de solució és la bona, pel simple fet d'haver sigut la primera. Un bon repte de disseny projecta futur i permet la visualització de respostes difuses que solucionen el repte, encara que siguin molt vagues, el dissenyador ha d'intuir que hi ha recorregut quan es posa a treballar sobre un repte de disseny.

Sanders i Stappers (2012) també dibuixen a la part dreta del seu esquema DIKW — vegeu figura 29- com les tasques d'anàlisi de les dades ja impliquen la configuració d'idees per a la definició del repte de disseny, però l'aspiració és evolucionar aquestes petites idees a través de més dedicació i treball amb les dades per assolir grans idees, fruit de la visió global de la situació. Per aquests autors, "l'objectiu de la conceptualització es acabar amb un o diversos conceptes rellevants (és a dir, propostes per futurs productes, interaccions, o escenaris d'ús) que encaixin amb les evidències fruit de la recerca així com amb altres restriccions que poden existir (per exemple, solucions que encaixin amb el nínxol de mercat del client)" (Sanders i Stappers, 2012, p. 256). Això que ells anomenen conceptes rellevants, precisament fa referència a la possibilitat que es puguin definir diversos reptes de disseny o "oportunitats de disseny". La visió global que descriuen com el punt final 
del procés, "resumeix tot allò après durant la recerca, l'anàlisi i l'exploració inicial de les oportunitats de disseny. Comunica una comprensió del context actual i de les futures situacions d'ús. Esbossa un visió de futur, i connecta els aprenentatges del passat." (Sanders i Stappers, 2012, p. 260).

La definició del repte de disseny és una tasca complicada que requereix de certa experiència en aquest tipus de processos. És la combinació d'allò que resulta interessant pel dissenyador i les conclusions extretes de la recerca i que es preveu amb possibilitats de desenvolupament. Ha de ser un concepte prou ampli com per treballar possibilitats de solució, i prou concret com per no iniciar un nou procés de recerca des del fuzzy front end. És a dir, ha de visualitzar solucions sense concretar-les, ja que és un moment, on la resolució del projecte encara està per definir.

Les visions de Cross i Sanders, en cert punt, són contradictòries. Cross inicia el procés de disseny a partir d'un problema, però com a tal considera que aquest problema sempre estarà mal definit. De fet, aquest concepte és la base que estructura tota la metodologia projectual, ja que, segons aquesta visió, la intenció del disseny obvia el problema mal definit perquè s'enfoca en la solució. En canvi, Sanders pretén comprendre el context i aprendre del passat i el present per projectar el futur. Cross posa en dubte que la comprensió del present sigui especialment rellevant, ja que assumeix que el problema de disseny (el repte) sempre estarà mal definit, i amb el desenvolupament del projecte, s'anirà delimitant i entenent millor, però entendre'l, mai serà l'objectiu, ja que la disciplina està enfocada a la solució, no al problema.

De fet, la psicologia recolza la teoria de Cross quan aborda el tema dels problemes ben i mal definits. En la seva tesi doctoral, Ovington (2016) es recolza de les teories de Gick i Lockhart (1995), Dominowski (1995) i Davidson i Sternberg (2003), entre d'altres, per afirmar com els problemes ben definits, precisament per estar ben definits, tenen un objectiu clar, i la seva solució és relativament senzilla, si més no basada en aprenentatges previs, de manera que la seva solució és una qüestió d'habilitat i coneixement; per exemple, solucionar una suma. Per tant, és un tipus de solució allunyada de la creativitat, ja que no és nova i se solucionarà a través de processos analítics conscients. 
En canvi, els problemes mal definits comencen amb una representació del problema esbiaixada i no tenen un recorregut clar cap a la solució. Només l'aplicació del pensament creatiu i d'estratègies innovadores guiaran en el camí per poder abordar el problema. En aquest grup hi inclou la gran majoria de problemes que ens trobem al dia a dia (Ovington, 2016, p. 4). En aquesta línia definida per la psicologia, els problemes de disseny que defineix Cross, queden clarament emmarcats dins dels problemes mal definits.

A més a més, el problema mal definit segurament necessitarà ser observat des de diferents angles i aportar una informació externa que caldrà anar definint a mesura que avança el projecte (és a dir, que no existeix un full de ruta inicial que mostri de forma clara el recorregut). Fins i tot, en ocasions, si el problema és realment complex, caldrà reestructurar esquemes inicials per poder-lo observar des d'una altra perspectiva (Ovington, 2016, p. 5). Per altra banda, la psicologia també considera que la resolució d'aquest tipus de problema va lligada als insights sobtats (els moments Aha) que s'han vist a l'apartat anterior — vegeu 2.4.3.1. Extracció de conclusions. Els insights-.

Així doncs, en psicologia es defineix una distinció entre la resolució de problemes a través d'un insight, que anomena moment Aha, per als problemes mal definits; o la resolució de problemes de forma analítica, que pressuposa uns coneixements suficients, per als problemes ben definits. Segons aquesta visió, el disseny es trobaria entremig, ja que pretén aportar "solucions" de forma analítica basant-se en insights.

Les característiques dels problemes mal definits, segons Cross (2003, p. 22) són les següents:

1. No existeix una formulació definitiva del problema.

2. Qualsevol formulació del problema pot contenir inconsistències

3. Les formulacions del problema depenen de la solució

4. La proposta de solucions és una forma d'entendre el problema

5. No existeix una formulació definitiva al problema

Resumint, aquest autor està considerant que el disseny està clarament enfocat a la recerca de solucions a partir d'un repte de disseny plantejat, que de forma genèrica anomena problema. 
Tot i així, com s'ha vist en paràgrafs anteriors, per a diversos autors el projecte comença abans que el problema. Cross, no es preocupa del procés previ a l'evidència del problema (encara que sigui mal definit); mentre que Sanders hi dedica gran part de la seva teoria.

Avançant una mica més en el projecte, un cop superada la recerca inicial fruit del problema, Cross, des de una visió més clàssica del procés de disseny i més pròxima a l'enginyeria, denomina al repte de disseny resum o plantejament (Cross, 2003). En aquest cas, planteja el repte de disseny com una possibilitat de producte llençada a l'aire. És a dir, per aquest autor, els plantejaments vagues d'un problema, desencadenen un procés de disseny. Tanmateix, la descripció que en fa encaixa amb la intenció del repte de disseny que es considera en aquest treball, la principal diferència és que no és fruit de la recerca, si més no, de la recerca intencionada, estructurada i metodològica de la qual s'ha estat parlant al llarg dels diversos apartats seguint la intenció del fuzzy front end proposat per Elizabeth Sanders i els seus autors afins. Per a Cross (2003), el repte de disseny inclou "una meta, algunes restriccions dins de les quals s'ha d'aconseguir arribar a la meta, i alguns criteris amb els quals es pugui reconèixer una solució òptima" (Cross, 2003, p. 20). En realitat, aquesta descripció seria més pròxima al brief de disseny que es veurà a l'apartat 2.4.4, on ja apareixen restriccions i criteris, que en aquest treball s'anomenaran premisses projectuals. A part de ser interessant incloure la visió de Cross per poder fer una referència a una visió de l'estructura projectual més tradicional, també fa observacions interessants en referència, per exemple, al repte de disseny, perquè més enllà d'incloure què ha de tenir el seu resum, deixa clar que "no s'especifica quina en serà la solució" (Cross, 2003, p. 20). Deixa obert el procés de disseny per a que es configuri una solució que pot ser totalment inesperada per la persona que ha plantejat el repte, de la mateixa manera que el repte de disseny proposa una intenció projectual sense plantejar tampoc com s'hi dona resposta.

Per a Cross, la base del repte és la definició de problemes mal definits, que en definitiva, i com es veurà a continuació, és la definició d'un repte de disseny basat en una observació i que planteja una incògnita de futur, donant la possibilitat de desvelar la incògnita de maneres molt diferents. No s'han de confondre els problemes mal definits, amb la seva falta 
d'argumentació durant el procés de desenvolupament. És a dir, que el problema mal definit també s'ha de sustentar en l'observació de la quotidianitat.

Resumint, sota el concepte de repte de disseny s'entén un moment clau en el desenvolupament del projecte perquè tanca la fase de recerca prèvia. El repte de disseny es basa en les evidències detectades durant la recerca i l'observació de la quotidianitat, posiciona el punt de partida del projecte, per tant, predisposa a l'acció, ja que ha de permetre entreveure cert recorregut de desenvolupament creatiu. El repte de disseny és fruit de les necessitats, desitjos i problemàtiques detectades, per tant, hauria d'estar fortament lligat amb les persones. Una bona recerca pot proporcionar diversos reptes de disseny, per tant, pot donar pas a diversos projectes. I finalment, el repte de disseny marca la intenció del projecte, per tant, és un concepte que no es pot oblidar al llarg del seu desenvolupament.

Per altra banda, tot projecte conviu amb una sèrie de restriccions que l'emmarquen i el posicionen en societat. Aquestes restriccions poden venir definides pel dissenyador mateix, fruit de les seves creences, aptituds i habilitats; poden venir definides per l'encàrrec, fruit de les creences o possibilitats de qui el fa; poden venir definides per l'observació i l'anàlisi realitzat durant la recerca inicial, o també, per una barreja de tot plegat. Aquestes restriccions, més enllà del repte de disseny, han de ser directrius a seguir durant el desenvolupament del projecte. Aquestes restriccions s'anomenaran en aquest treball premisses de disseny o premisses de projecte i són part bàsica i essencial pel projecte. Es desenvoluparan amb profunditat al capítol III, però com a element fruit, en part, de la recerca, es considera oportú introduir-ne la seva existència per concloure aquest apartat. 


\subsubsection{Elaboració d'un brief de disseny}

Aquest últim apartat del capítol II apareix com a tancament de la secció dedicada a la base analítica del disseny, entenent que el procés de recerca, anàlisi de dades i extracció de conclusions ha d'acabar amb una proposta de projecte que, en aquest cas, ve definida per un brief de disseny elaborat pel propi equip de disseny que inclou un repte de disseny $i$ una sèrie de premisses projectuals, basades $i$ argumentades per la recerca, que cal respectar al llarg del desenvolupament del projecte. El tractament que es fa a aquest document anomenat brief, es veurà en l'apartat corresponent del capítol III, per ara, en aquest punt es fa un repàs sobre el concepte genèric de brief de disseny.

En essència el brief de disseny és un document de comunicació que, en principi, implica un encàrrec entre un dissenyador (o equip de disseny) i la part que llença aquest encàrrec. No existeix un format únic ni concret, ni una fórmula estricta, en part per la gran varietat del propi projecte de disseny, però sí que el brief sol incloure una sèrie de temes que es veuran al llarg d'aquest apartat seguint el guió de Peter L. Phillips que ha dedicat la seva vida professional a la indústria del disseny, la gestió i el desenvolupament corporatiu, i fruit de la seva experiència, i a través del Design Management Institute, realitza conferències i cursos sobre com crear el brief de disseny. Per a Phillips (2005) el brief de disseny és "una descripció per escrit d'un projecte que requereix algun tipus de disseny" (Phillips, 2005, p. 1). Una definició molt genèrica però que permet englobar la gran varietat de formats $i$ temàtiques que pot incloure aquest document, això sí, sempre relacionat amb un projecte $\mathrm{i}$ amb el disseny. Per tant, sembla fàcil considerar que el document ha d'incloure informació útil pel dissenyador i pel projecte.

Per a Phillips, la meta del brief és ser tan complet i útil com sigui possible, independentment de la seva longitud o del seu format (Phillips, 2005, p. 1). Fent ús de la raó de ser del disseny, tot i les discrepàncies existents — vistes en capítols anteriors- sobre el fet 
de resoldre problemes, afirma que "si el disseny és una disciplina per resoldre problemes, llavors un gran disseny hauria de començar amb una comprensió profunda del problema que ha de ser resolt i el millor lloc on trobar-ho és un gran brief de disseny" (Phillips, 2005, p. 12). És a dir, que el brief ha d'explicar i incloure tot allò que es pugui comunicar en referència al problema. És, per tant, un document fruit d'una recerca prèvia que permet explicar coses al voltant d'un tema.

Zarney (a Phillips, 2005) descriu una sèrie d'elements inflexibles que han de quedar definits en el brief de disseny. Per aquest autor, aquests ingredients comencen amb la limitació temporal, és a dir, que el dissenyador necessita saber de quan temps disposa per tenir el projecte acabat. Un altre element inflexible està relacionat amb els condicionants tècnics $i$ requisits productius, i, per acabar, tenir coneixement del pressupost disponible. En definitiva, una sèrie de qüestions allunyades de les característiques de l'artefacte que s'han vist al llarg d'aquest treball relacionades amb característiques més intrínseques — tornant al sistema persona/màquina, característiques relacionades amb la finalitat, la persona, l'acció, l'entorn i la màquina-, però que restringeixen i emmarquen al projecte, a la vegada que el connecten amb la realitat empresarial. En aquest sentit, un bon brief de disseny pot actuar com a contracte, ja que s'hi descriuen acords que cal respectar en la relació entre el dissenyador i qui llença l'encàrrec. Resulta interessant el concepte d'elements inflexibles que es traslladarà a la proposta d'aquest treball com a premisses de disseny, tot i que aquestes últimes tenen un abast diferent, ja que sí que es dirigeixen al projecte en sí.

A nivell de projecte, Phillips (2005) presenta els següents apartats que hauria d'incloure qualsevol brief de disseny:

- Visió general del projecte i antecedents: una introducció que presenti el projecte, els seus principals valors, "ha de ser ric en contingut i a la vegada suficientment concís com per ser un resum executiu" (Phillips, 2005, p. 36). És una part essencial ja que ha de quedar clar a l'inici del document, de què s'està parlant.

- Revisió de la categoria: Phillips entén la categoria, com la indústria on s'inclou el projecte, i en certa manera en el seu posicionament. L'autor cita l'exemple de McDo- 
nald's que aparentment se situa dins la categoria de menjar ràpid, però que en els seus inicis formava part de la categoria d'entreteniment, ja que allò que transmetia al client era que es tractava d'un lloc per passar l'estona amb la família on, a més a més, es podia menjar. (Phillips, 2005, p. 36-41). En aquest sentit, aquesta part del brief està relacionada amb el compromís que se li suposa al dissenyador durant la recerca, anàlisi i conclusions — vegeu 2.4.3.1. Extracció de conclusions. Els insights-. I està clarament relacionat amb el posicionament sociocultural que se li exigeix des de les premisses projectuals que es veuran en el capítol III, al definir la proposta per a la metodologia de recerca i anàlisi.

- Revisió del públic objectiu: un altre punt essencial que ha de quedar clarament descrit en el brief, en tots els seus diversos nivells, "cada un dels grups de públics objectiu té necessitats molt diferents, i els dissenyadors han d'entendre cada una d'aquestes necessitats" (Phillips, 2005, p. 42). De fet, si recapitulem la importància que atorguen a la persona el Design Thinking en general, i concretament els exemples vistos en apartats anteriors com la proposta d'Elizabeth Sanders i el disseny generatiu, o la clau de la innovació a través del context i de la interacció que es proposa des de la TUDelft, el què Phillips descriu com a públic objectiu, és en aquests altres casos la raó de ser del propi projecte. Com es veurà en el capítol III, el pes de l'ergonomia apareix a nivell de persona a l'hora de definir les premisses projectuals.

- $\quad$ Carpeta de l'empresa: segons Phillips, un apartat molt important quan el disseny es realitza des d'una empresa externa, ja que pretén descriure l'empresa que posarà el producte al mercat, així com les seves activitats. El disseny ha de respectar els valors i filosofia d'aquesta empresa, així com comprendre el posicionament i la reputació de la marca. El projecte que descriu el brief ha d'encaixar entre els productes ja existents d'aquesta marca (Phillips, 2005, p. 43-45).

- Objectius comercials i estratègies de disseny: per a Phillips aquí és on va inclosa la descripció del problema de disseny, és essencial i bàsic que quedi ben definit abans d'iniciar el projecte perquè "proporciona enfocament i claredat per a l'etapa de desenvolupament del concepte de disseny” (Phillips, 2005, p. 47). És a dir, aquí va descrita la raó de ser del projecte. 
- $\quad$ Abast, temps i pressupost del projecte (fases): en aquest apartat, Phillips descriu les diverses accions que es duran a terme per a la realització del disseny, quant de temps inclouen i la distribució del pressupost. Tornant a la simbiosi del brief de disseny amb un contracte, en aquest apartat es descriu l'abast del projecte i, en certa manera, educa a les persones que són alienes al procés de dissenyar i, per tant, no reconeixen els esforços i necessitats que implica, perquè mostra les accions i activitats de cada fase de disseny. En aquest sentit es poden descriure en temps i materials accions de caire metodològic, com la realització d'entrevistes i enquestes, les necessitats del prototipat, o dels diversos testos que es volen dur a terme. (Phillips, 2005, p. 48-52). Per tant, aquí és on descriuria l'abast, temporització i pressupost per a la fase d'anàlisi, amb una descripció de les accions concretes a realitzar.

- Preguntes a investigar: un apartat a completar amb aquella informació que no es disposa en el moment de l'elaboració del brief, però que es considera necessària per al desenvolupament del projecte, per tant, l'àmbit de la recerca.

- Apèndix: un últim apartat optatiu, però que pot incloure tot allò important que no està clar on ha d'anar col·locat, com per exemple fotografies, informes, o altres documents d'interès. (Phillips, 2005, p. 55).

Per a Phillips, aquest plantejament del brief tant extens va lligat amb una intenció educativa a través del qual el dissenyador "comunica les seves necessitats com a professional de disseny de forma eficaç en termes que els socis comercials que no hi estan relacionats ho puguin entendre" (Phillips, 2005, p. 58). Per aquest autor, tot el temps que dediques a realitzar el brief, te l'estalvies en el desenvolupament del projecte multiplicat pels malentesos que es poden donar per la falta d'entesa inicial. Com descriuen Dewulf, Wewer i Brezet (2012) "conté tota la informació essencial: què, per què i com en relació al projecte" (Dewulf et al., 2012, p. 458)

En essència, doncs, el brief de disseny és un document escrit on s'especifica un encàrrec i en el qual, en major o menor mesura s'especifiquen unes premisses de disseny a respectar, així com una sèrie de restriccions, és a dir, que es plantegen un objectius a aconseguir 
seguint unes pautes. A més a més, emmarca la relació del producte amb l'empresa que el durà al mercat i especifica qüestions de desenvolupament del projecte, com pressupostos i temporització.

També cal tenir en compte que el brief no és un document definitiu, sinó que el dissenyador, després de treballar-hi, si han sorgit controvèrsies o hi ha dubtes, parla amb el client per elaborar un contrabrief que solucioni aquestes problemàtiques.

La visió de Phillips és una visió basada en la relació entre l'empresa i el client, on l'empresa és qui vol desenvolupar un nou producte, i el client és el dissenyador o l'equip de disseny, siguin ambdós membres de la mateixa organització o no. Tanmateix, hi ha una altra visió que s'aproxima més a la idea de brief que es vol desenvolupar en aquest treball, i que està relacionada amb la necessitat del propi dissenyador d'establir unes premisses de disseny fruit d'una fase de recerca. En aquest sentit, el brief es considera el document que recull les conclusions de la recerca transformades en un repte de disseny i en unes premisses projectuals. Com s'ha vist en apartats anteriors — vegeu 2.4.3.2 El repte de disseny-, les diverses propostes metodològiques situen l'inici del projecte a partir del brief, en aquest cas, la tasca de recerca s'ha dut a terme des de fora del projecte de disseny. En canvi, altres metodologies aposten per començar el projecte abans del brief, és en aquesta segona opció que encaixa i té sentit el document brief que es planteja en aquest treball.

En el seu model projectual, Martí Font (1999), tot i situar l'encàrrec (el brief) com al punt de partida del projecte, també parla de la hipòtesi de treball que "per una banda, recull tota la informació ordenada i sintetitzada amb què culmina la fase anterior del projecte $i$, per altra banda, defineix l'acció projectual fins arribar a una representació vàlida per a la projectació d'un artefacte nou" (Martí Font, 1999, p. 241). Aquesta definició de la hipòtesi de treball es correspon a la definició de repte de disseny, segons s'entén en aquest treball, acompanyada, de la "informació ordenada i sintetitzada de la recerca", que es tradueix en les premisses de disseny o de projecte. Dos elements que es convertirien en el brief de disseny. 


\subsubsection{Conclusions}

Al llarg d'aquest apartat, s'han revisat conceptes relacionats amb la metodologia del projecte, que a nivell de disseny està molt analitzada. El projecte, i com aquest es desenvolupa, és un element essencial per aquesta disciplina, ja que s'explica a ella mateixa a través del seu resultat (productes, espais, etc.) i a través de la seva metodologia. Des de fa anys, el disseny s'esforça per traslladar la metodologia tant als propis dissenyadors, com als aprenents de dissenyadors, com a persones alienes a la disciplina, però que li reconeixen certes virtuts que volen traslladar als seus propis camps — tal com ha fet el Design Thinking-.

El fet de disposar d'una metodologia de projecte —no una única, sinó una entre diverses-, fa possible que el disseny es reconegui com a tal, tot i obtenir resultats tan diferents. Existeixen diverses propostes projectuals, tal i com s'ha vist en els diferents apartats d'aquest treball, però totes tenen certs elements en comú, entre ells, una fase de recerca i de recopilació d'informació que ha de servir de base conceptual a la resta de fases de desenvolupament del projecte. També hi ha diferències en la forma d'enfocar aquesta recerca i en quin moment del projecte es posiciona. Per aquest treball, es considera especialment interessant situar l'inici de la recerca en un moment fora del projecte de disseny en sí, acceptant la proposta de Sanders i Stappers (2008) del fuzzy front end. Aquest tipus de recerca és especialment empàtica i es relaciona amb l'experiència de les persones, per això, les seves eines de treball són afins a l'etnografia i l'antropologia, posicionant a la persona en el centre de la investigació. És a dir, un tipus de recerca basada en dades qualitatives, i que pot realitzar-se amb més o menys participació de la persona.

Observar, entrevistar, esquematitzar, són activitats que recullen una gran quantitat d'informació que cal analitzar i treballar perquè sigui útil pel projecte. Tal com s'ha vist al llarg d'aquest apartat, és un moment complicat de la recerca i, a més a més, no només complicat, sinó clau per al desenvolupament del projecte, ja que les evidències resultants de la recerca es convertiran en reptes de disseny i premisses projectuals. En aquest procés d'anàlisi —tal 
i com s'ha vist en l'apartat 2.4.3 Les fases argumentatives-, el dissenyador ha de voler allunyar-se d'obvietats, ha de saber llegir entre línies i ha de posicionar-se empàticament per definir una projecció de futur traslladada en format de repte de disseny. I aquestes conclusions, repte i premisses de disseny, han de comunicar-se a través d'un document escrit que s'anomena brief de disseny. Aquest document, trasllada la recerca i les seves conclusions, en un format comprensible per persones alienes a la recerca que s'encarregaran de desenvolupar el projecte. Tal i com s'explica en l'apartat corresponent — vegeu apartat 2.4.4-, el brief es considera l'encàrrec entre el dissenyador i aquell que encarrega el disseny.

Fins aquí el capítol II d'aquest treball, que fa una revisió general de la recerca en el projecte de disseny i en l'ergonomia, posicionant diversos ingredients necessaris per comprendre l'abast i el mètode d'aquesta recerca. A partir de la suma d'aquests ingredients, es fa una proposta de metodologia de recerca que es pot veure en el capítol següent. 
CAPÍTOL III

\section{PROPOSTA PER A UNA METODOLOGIA DE RECERCA}




\subsection{Introducció}

En el capítol II, sota el títol "Revisió general de la recerca en el projecte de disseny", es pretén dibuixar un context genèric sobre com el disseny enfoca una tasca que li és pròpia: la recerca. Tot i veure pinzellades sobre qüestions de recerca en general, els esforços d'aquest treball se centren en la recerca sobre la quotidianitat de les persones. És a dir, de les actituds, maneres de fer o activitats del dia a dia que relacionen a les persones amb el món que les envolta: espais i objectes tal i com s'ha vist a través d'autors com Sanders i Stappers (2012), o Hekkert i van Dijk (2011). Aquesta relació amb l'entorn, es caracteritza durant el capítol anterior dibuixant un context genèric en relació a la usabilitat i l'experiència d'usuari, i com diferents disciplines (i especialitats dins d'aquestes disciplines) enfoquen el concepte d'interacció. Apareixen l'ergonomia i el disseny com a dues disciplines que guien un procés projectual basat en les persones. És a dir, que ergonomia i disseny comparteixen la seva principal raó de ser: construir un món adequat a las limitacions, desitjos i característiques humanes.

Aquesta raó de ser és immensa i complexa, per això aquest treball es concentra només en una part del projecte, però que es considera essencial i clau per al desenvolupament de bones propostes: la definició d'un bon repte de disseny i la recerca que el precedeix. És a dir, s'aposta per formular bones preguntes per poder obtenir bones respostes.

Perquè el disseny es pugui treure definitivament l'etiqueta de simple embellidor, i quedar-se situat en una disciplina que configura el món en tots els seus estrats i dimensions, es considera que és bàsic dissenyar a partir de plantejaments basats en realitats observades i amb un fonament social i participatiu. Es considera que aquesta és la manera més eficaç d'apartar-se de projectes sense fonamentació, que creen necessitats inexistents, que danyen el planeta (i per tant a la persona), que només persegueixen fins econòmics o de notorietat, que no tenen en compte la gran diversitat de mides, proporcions i habilitats cognitives de les persones, o que, simplement, no s'adeqüen a les necessitats del context. 
Ergonomia i disseny, tal i com s'entenen en aquest treball, comparteixen una meta i és en aquest punt de connexió d'on sorgeix la idea d'una metodologia de recerca que aprofiti les virtuts sistèmiques de l'ergonomia i les virtuts creatives del disseny per construir una metodologia que pretén ser una guia en el desenvolupament de la recerca, principalment, la recerca inicial que desemboca en un brief, però que també ha de poder funcionar en el desenvolupament de la recerca a l'inici del projecte, o en qualsevol altre moment que el projecte requereixi una recerca estructurada.

Una de les principals raons de ser d'una recerca estructurada i ben fonamentada és minimitzar el risc del nou producte, entenent que, si aquest està ben recolzat per les conclusions de la recerca, té més possibilitats de ser un producte encertat. Per altra banda, com que cada projecte és diferent, les seves necessitats de recerca també ho són. El projecte té moltes facetes que són diferents i poden evolucionar, per això la metodologia s'estructura de forma clara, però té la capacitat de funcionar aplicant el mapa sencer o només una part, i per altra banda també pot variar el focus segons necessitat del projecte. A més a més, aquesta àmplia gama de possibilitats, obliga a fer un pas previ per a plantejar i estructurar la recerca abans de dur-la a terme.

Aquesta metodologia per a la recerca, vol actuar en certa manera, com ha actuat el Design Thinking explicant el procés de disseny, aproximant-lo i fent-lo comprensible per persones alienes al món creatiu i com a eina per a la docència. És a dir, aquesta metodologia també vol explicar el procés de recerca i pretén ser una eina per a la docència, tant de l'ergonomia aplicada al disseny, com pel propi projecte de disseny on l'alumne comença sense una ruta marcada, oferint un esquema rigorós i d'abast adaptable al temps i la dedicació disponibles. En definitiva, es pot considerar un mapa de la interacció amb diversos punts clau on parar-se. Com a metodologia de recerca pel disseny, es considera una aportació valuosa que complementa el projecte. Pretén ajudar al dissenyador a incloure les diverses dimensions que configuren la interacció de la persona amb artefactes que li faciliten la consecució dels seus objectius. És a dir, aquesta metodologia pretén ser una visió exhaustiva i sistèmica de tot allò que envolta el projecte, de manera que, si s'agafa pràctica en el seu ús, la recerca es 
converteix en un procés més àgil i eficaç. I tot això gràcies a la visió global del món que té l'ergonomia. En realitat, tant el disseny com l'ergonomia són disciplines expertes en manllevar eines i mètodes d'altres disciplines que li són útils per al projecte. Per exemple, com s'ha vist extensament en el capítol anterior, eines relacionades amb la sociologia, l'etnografia o l'antropologia, però també la informàtica, la enginyeria o la biologia. Per tant, una metodologia de recerca pel disseny i l'ergonomia ha de poder suportar i ordenar la gran quantitat d'informació dispar que pot rebre segons li reclami el propi projecte, $\mathrm{i}$ ha de poder acceptar la informació en diversos formats, fruit de les eines pròpies de cada disciplina de suport. En principi, la metodologia que es presenta, és capaç de treballar amb informació dispar, per una banda, perquè la seva intenció ja és precisament aquesta — tenir un mapa genèric de tot allò relacionat amb el projecte-, i per l'altra banda, perquè es tracta més aviat d'una estructura organitzativa, o un marc d'actuació. En resum, la metodologia vol agrupar una recerca més experiencial fruit de l'observació i altres processos etnogràfics, i una recerca més tècnica, com per exemple qüestions antropomètriques o relacionades amb els materials.

L'ergonomia té un caire científic, sempre busca establir lleis i protocols d'actuació en base a informació veraç, científicament contrastada i estadísticament treballada. Un clar exemple és l'antropometria, ciència que estudi les dimensions i proporcions humanes. L'antropometria treballa a partir de taules antropomètriques que recullen les mides preses a la població $i$ les organitza en percentils. És, per tant, informació estadística que el dissenyador, o l'ergonomista, han de saber aplicar al projecte per dimensionar espais i objectes d'acord amb les mides de les persones i els diversos paràmetres antropomètrics (abast, ajust, folgança, etc.). L'ús de dades antropomètriques veraces valida la presa de decisions projectuals, ofereix suport científic que justifica la presa de decisions, i així és com el disseny se sustenta de forma argumentada. Per tant, una metodologia de recerca també ha de ser capaç de recollir informació científica, validar-ne la idoneïtat i posar-la a disposició del projecte com a suport per a la presa de decisions, o fins i tot com a premissa de projecte. I tot això, tenint en compte que cada projecte de disseny és únic; i sense oblidar, que el projecte de disseny és 
una projecció d'un futur desitjat, i que per tant, les dades actuals podrien ser diferents quan el projecte ja és una realitat.

Aquesta metodologia neix de la necessitat docent de traslladar estructura metodològica relacionada amb el disseny i l'ergonomia, i de veure com les dues disciplines són molt més afins del què es consideren habitualment, sobretot si es recull de l'ergonomia la seva branca prospectiva descrita per Robert i Brangier (2009) — vegeu 2.2.2.3 Ergonomia prospectiva—. Per tant, aquesta metodologia neix de la mescla de dues disciplines, ergonomia i disseny, que es mesclen en la formació del dissenyador. Habitualment en una relació on l'ergonomia és una part del projecte de disseny i, en general, es limita a aportar al projecte informació dimensional de la persona. Però si s'observen les dues disciplines com a disciplines amb capacitat prospectiva, la seva relació canvia. Per una banda, el coneixement divers (científic, tècnic i social), la creativitat, les habilitats instrumentals, la sensibilitat, i, també, la capacitat de recerca són considerats fonaments bàsics en la formació d'un dissenyador. A l'alumne se li ensenya un recorregut de diverses fases que ha d'anar completant de forma iterativa i relacional per avançar en el projecte, prendre decisions i fer una proposta coherent amb una recerca prèvia. Una part d'aquest coneixement científic i tècnic que se li suposa és, precisament, l'ergonomia, sobretot en el seu vessant dimensional. Però, ¿què passa quan l'ergonomia per sí sola té capacitat per configurar projectes i fer propostes d'artefactes que responguin a necessitats humanes? Les dues disciplines poden compartir espai, ja que l'aplicació del mètode diagnòstic de l'ergonomia també és un gran instrument per a l'estimulació de la creativitat, ajuda a generar conceptes i a elaborar estratègies, gràcies a la seva capacitat de contextualitzar idees, com s'ha vist en el capítol anterior, una part important de les preocupacions ergonòmiques són qüestions relacionades amb el context. D'aquesta manera, ergonomia i disseny s'alineen en intenció projectual i es poden mesclar en una relació profitosa per al projecte. La intenció de la proposta que es presenta en aquest capítol és, precisament, configurar aquesta relació profitosa entre ambdues disciplines específicament durant la recerca implícita en qualsevol projecte.

Amb el convenciment que una bona recerca prèvia contribueix al bon desenvolupament 
del projecte, ja que permet fonamentar-lo sobre una base sòlida formada per una sèrie de premisses de projecte fruit de les conclusions extrets de dades recollides de forma rigorosa i analitzades de forma sistemàtica, aquesta metodologia proposa un recorregut des de la preparació de la recerca fins a l'elaboració d'un brief que inclogui un repte de disseny i un número sense determinar de premisses projectuals ponderades segons importància. Gràcies a la bona recerca inicial, aquest repte i les seves premisses haurien de respondre a les necessitats, desitjos i problemàtiques humanes i s'haurien de poder argumentar a través de les dades de la recerca, que en realitat són qui emmarquen la raó de ser del projecte.

Per tant, tot i que resulta complicat definir què significa una bona recerca, així com definir què significa un bon repte de disseny, i encara més complicat decidir si la metodologia funciona, es considera un èxit si la metodologia pot contribuir en:

1. Una planificació inicial exhaustiva de les necessitats del projecte amb la definició dels diversos actors participants i fruit del recorregut traçat per les cinc dimensions del projecte, basat en el sistema persona/màquina de l'ergonomia —vegeu apartat 3.6.1 Fase Organitzar-

2. Un desenvolupament de la recerca fluid que reculli dades pertinents pel projecte i un anàlisi de les dades des d'una perspectiva creativa que doni pas a evidències enriquidores pel projecte — vegeu apartat 3.6.2 Fase Buscar-

3. L'estructuració d'una base argumentativa per a la presa de decisions del projecte a través de premisses projectuals — vegeu apartat 3.7 Pont entre divergència i convergència: l'anàlisi-.

4. Una presa de decisions argumentada on s'accepten i es descarten recorreguts projectuals possibles — vegeu apartat 3.8.1 Fase Definir-.

5. L'elaboració d'un brief de disseny argumentat que inclogui un repte de disseny coherent amb la recerca, amb intenció innovadora, i que col·loqui la persona per davant d'altres requisits existents — vegeu apartat 3.8.2 Fase Comunicar-. 
En definitiva, és impossible assegurar un resultat de la recerca exitós, ja que al llarg del recorregut apareixen infinitat d'elements que poden dificultar el procés, o simplement perquè no s'han donat una sèrie de circumstàncies ideals. En paraules de Blessing i Chakrabarti (2009):

"Si bé una metodologia hauria d'ajudar a realitzar un procés d'investigació més ben planificat i planer, i augmentar així les possibilitats d'obtenir resultats vàlids i útils, aquests resultats no es poden garantir: la naturalesa d'una metodologia és heurística, més que algorítmica. Cada investigador té els seus antecedents i interessos personals, fent que cada procés de recerca sigui únic. Una metodologia només pot donar suport a aquest procés. El resultat pot ser millor i el tema pot ser més uniforme, més rigorós i més fiable, però, per descomptat, també es pot aconseguir una bona solució sense una metodologia (normalment amb algun cost) $i$ es pot obtenir un resultat deficient tot $i$ aplicar una metodologia (per exemple, per falta de coneixements especialitzats en el camp d'estudi o per falta de reflexió). S'ha d'utilitzar una metodologia de manera flexible i oportunista per adaptar-se a les particularitats del tema de recerca i a qualsevol via interessant que pugui sorgir" (Blessing i Chakrabarti, 2009, p. 14).

L'estructura metodològica proposada consta de les següents cinc fases, que també es poden veure representades a la figura 31 :

1. ORGANITZAR · Plantejament i estructuració de la recerca

L'inici de la recerca ve donada per una hipòtesi que suposa possibilitats de disseny vagues i sense concretar. Amb aquesta hipòtesi es treballa per plantejar i estructurar la recerca de manera que s'obtinguin dades pertinents pel possible projecte. S'agafa com a esquema bàsic les cinc dimensions de l'artefacte — vegeu apartat 3.4-

\section{BUSCAR $\cdot$ Recerca}

Les diverses tasques plantejades durant la fase anterior, es duen a terme. Fruit d'això, es pot donar el cas que apareguin nous camins, o que sigui necessari modificar coses. 
3. ANALITZAR · Treball amb les dades i extracció de conclusions

Les dades fruit de la recerca s'organitzen, codifiquen i analitzen de forma transversal per a la detecció d'evidències (insights) que signifiquen el primer pas cap al repte de disseny.

4. DEFINIR · Definició del repte de disseny i de les premisses projectuals

El repte de disseny, que pot ser més d'un, és l'objectiu a solucionar pel projecte i les premisses projectuals són les diverses restriccions a tenir en compte. En aquesta fase, les cinc dimensions tornen a ser importants perquè cada una d'elles s'ha de veure representada per premisses de disseny aportant, així, una visió global al projecte

\section{COMUNICAR · Comunicació: brief}

El brief és el document que agrupa el repte de disseny i les premisses de forma comprensible per una persona aliena al procés de recerca. En principi, el propi dissenyador, o un equip de disseny que desenvolupi el projecte.

L'estructura metodològica es proposa de forma seqüencial, amb una fase rere l'altre, tal i com es pot observar a la figura 31 , amb les fletxes de la dreta que marquen el salt d'una fase a la següent. Però també es pot donar el cas, que fruit del treball en una fase, es decideixi tornar a la fase anterior, o fins i tot replantejar l'estructura de la recerca, o que s'avanci en paral·lel a través de diverses fases. De la mateixa manera, que pot succeir que, fruit del brief, s'obrin noves hipòtesis inicials de recerca de les oportunitats de disseny, circumstància que fins i tot pot ser desitjable, ja que aporta continuïtat al projecte. Per tant, són necessàries les fletxes de l'esquerre que marquen la possibilitat de redefinir fases anteriors.

Les eines utilitzades per al desenvolupament de la recerca són les pròpies del disseny i l'ergonomia, així com de la recerca antropològica i la sociologia, eines de desenvolupament creatiu i d'observació de la quotidianitat que s'han anat comentant al llarg del capítol II. No són unes eines estàtiques o concretes, sinó que segons el cas, se n'utilitzen unes o unes altres. També és veritat que, principalment, es tracta d'eines i tècniques de recerca qualitativa com, per exemple, l'entrevista i l'observació. Tot i així, se'n proposen algunes que es 


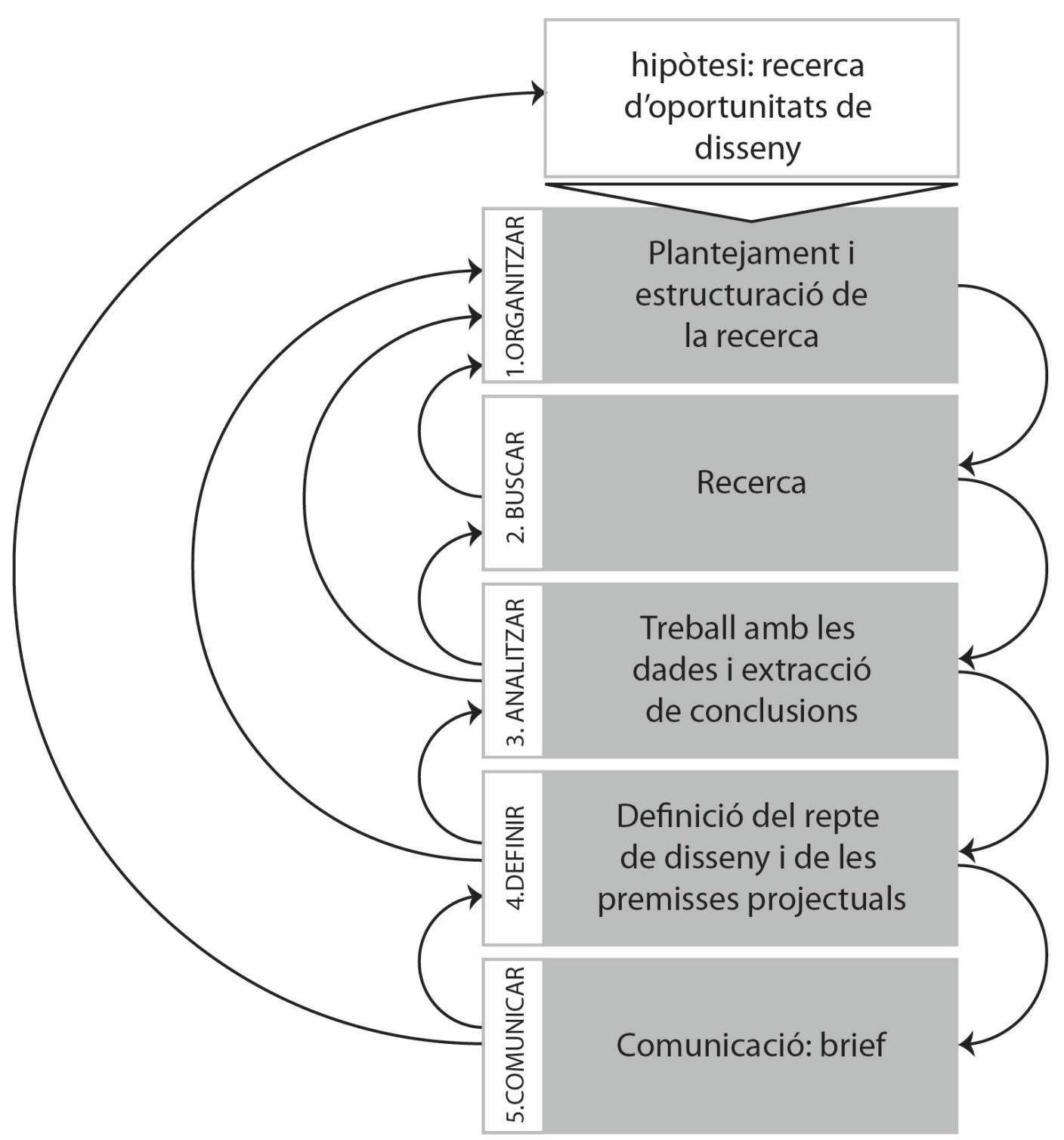

Fig. 31 Esquema de les fases de la metodologia de recerca

consideren adequades per a cada una de les diverses fases de la metodologia, i aquestes es traslladen en forma de fitxa de treball, com s'aniran veient al llarg d'aquest capítol.

Per altra banda, per ajudar a formalitzar l'estructura i a organitzar les necessitats de recerca, també s'aporten una sèrie de fitxes de treball que s'endinsen en cada una de les dimensions. L'abast i temporització de la recerca vindrà donada per les necessitats del projecte, i en conseqüència, les fitxes també es treballaran de forma més o menys exhaustiva. 
Com ja s'ha comentat, és complicat definir l'èxit de la proposta. Una possibilitat és enfocar-se a uns millors resultats, però això no és mesurable, en el sentit que no es pot saber quins resultats s'haurien obtingut a través d'altres metodologies. Només un experiment aplicant metodologies diferents sobre una mateixa hipòtesi de treball, podria mostrar alguna evidència. Tot i així, i sempre que es desenvolupés per persones diferents, aquestes evidències només podrien ser parcials. I, si es desenvolupés per les mateixes persones, la pròpia experiència ja viscuda en la mateixa hipòtesi de treball, també n'invalidaria les evidències. És a dir, que l'avaluació de la proposta difícilment pot estar enfocada cap al resultats, tot i que sí que es desitgen uns reptes de disseny creatius (allunyats de les obvietats) i fonamentats (recolzats en la recerca), i aquests dos conceptes serien, doncs, els conceptes a valorar en relació a les propostes.

Per altra banda, també es pot avaluar el propi funcionament de la metodologia en ús. En aquest sentit és necessari conèixer l'opinió d'aquells que l'han fet servir com a estructura per a la recerca. Si es tracta de persones avesades al desenvolupament de projectes i a la seva recerca implícita, la seva pròpia experiència prèvia hauria de ser útil per poder comparar si, per exemple, aquesta metodologia els ha facilitat la feina, els ha ajudat a ser més exhaustius o els ha obert portes que no solien tenir en compte. A la vegada que també poden opinar sobre si consideren que els resultats són satisfactoris. Tot plegat, es veurà en el capítol IV Aplicació de la metodologia (cas pràctic).

\section{2 Àmbits d'aplicació i idoneïtat}

El principal àmbit d'aplicació, tal i com es planteja el desenvolupament de la recerca, és la investigació que ha d'aportar un repte de disseny. És a dir, una fase prèvia a la definició del projecte, que de forma genèrica posa sobre la taula el Design Thinking amb la seva fase d'empatia. Això no significa, que com a metodologia de recerca pel disseny, disciplina que es desenvolupa en constant procés de recerca, la metodologia no es pugui utilitzar en altres estrats dels projecte més avançats. 
En tot cas, la proposta per una metodologia de recerca vol ajudar en la fase d'investigació del projecte de disseny posant especial interès en l'experiència d'usuari i tot allò que té a veure amb la persona, com a premissa projectual. Dins de les diverses branques del disseny, aquesta metodologia està pensada pels àmbits que tracten objectes i espais, és a dir que estan relacionats amb la materialitat, i en com s'organitzen, és a dir els serveis. Queda fora del seu àmbit, l'anàlisi de productes digitals, pàgines web o aplicacions per mòbil $\mathrm{o}$ tauletes; és a dir, que en aquest treball es parla d'interacció com a relació que s'estableix entre la persona, els artefactes físics i els seus continents. És també un mètode que ajuda a estructurar el procés de disseny en les seves fases inicials, i és per això que es presenta adequat com a eina de treball dins de l'aula, en escoles de disseny, sobretot quan es presenta a l'alumne una hipòtesi de treball oberta que el propi alumne ha de concretar i convertir en un projecte. Com per exemple podria ser el treball a partir de la hipòtesi següent: les activitats desenvolupades dins del bany de la llar són múltiples $i$ variades, i sovint compartint espai, el disseny pot aportar artefactes que millorin la usabilitat de l'espai i l'eficiència de les activitats que s'hi duen a terme, millorant així, l'experiència d'usuari. Aquesta hipòtesi de treball és oberta, i el primer que caldrà fer per encarar el projecte i poder prendre decisions sobre el repte de disseny, serà iniciar una recerca dels usos del bany a les llars actuals, i de les necessitats, desitjos i problemàtiques de les persones que els fan servir.

Com a eix vertebrador de l'anàlisi sempre hi haurà la persona, per això, entre altres coses, l'ergonomia serveix com a base de la proposta. Se'n recull la seva manera d'organitzar el món dissenyat: el sistema Persona/Màquina, que permet ordenar sistemes senzills i complexes, i es prenen de referència les seves cinc dimensions: finalitat, acció, persona, entorn i artefacte, per vestir l'estructura de la proposta. Per qüestions de gènere i per aproximar el sistema al disseny, ja des d'un principi s'ha substituït la paraula home — terme utilitzat tradicionalment per anomenar el sistema Home/Màquina-, per la paraula persona que engloba a tothom. Però a més a més, per al seu ús a la proposta la màquina se substitueix per l'artefacte, recollint la paraula genèrica utilitzada per Martí Font (1999) en referència al producte. D'aquesta manera, s'aparten les connotacions excessivament tècniques de la 
màquina, per una paraula que pot convertir-se en qualsevol cosa: artefacte, que segons defineix el Gran Diccionari de la Llengua Catalana és un "objecte produït pel treball de l'home".

Per altra banda, està en el cor de l'ergonomia vetllar per l'adaptació del món artificial (o dissenyat) a la persona, i no a l'inrevés, buscant que les tasques es realitzin de forma eficaç, segura i confortable i es respectin les característiques, les limitacions i les necessitats de les persones. De l'ergonomia també se'n recullen els principis de disseny que ajuden en el guiatge a través de la presa de decisions, uns principis que s'han anat veient al llarg del seu apartat corresponent — vegeu apartat 2.2.2 Enfocament des de l'Ergonomia—.

Fruit de la recerca i de l'anàlisi de les dades obtingudes, es definiran una sèrie de premisses projectuals que vetllaran per a la bona usabilitat i experiència d'usuari, tema clau en el desenvolupament d'aquest treball, ja que és allà on es mostra si encaixen les decisions preses respecte l'artefacte i els requisits marcats per la persona. Com es veurà més endavant en l'organització de les diverses dimensions de l'artefacte, les variables de Persona són les que han de prevaler en la presa de decisions i en la definició de les premisses projectuals, però les variables d'Acció són les que caracteritzen la usabilitat i experiència d'usuari desitjades.

S'invita a combinar eines d'anàlisi objectives i subjectives. Les característiques objectives relacionades amb l'observació directa i amb el registre de les accions, en general relacionat amb dades quantitatives. Formen part d'aquesta observació els protocols ergonòmics, l'anàlisi biomecànic, el recompte d'encerts i errors, el càlcul del temps necessari per a la realització de les accions, etc. Per altra banda, les característiques subjectives estan relacionades amb eines provinents de disciplines com l'etnografia i la sociologia, com les entrevistes, les opinions dels usuaris en referència a la satisfacció, la qualitat percebuda, les expectatives, el confort, l'esforç econòmic, etc., en general relacionat amb dades qualitatives. La incògnita és ¿com es poden observar tota aquesta sèrie de qüestions si s'està parlant d'una fase de recerca prèvia a la definició del projecte? La resposta a aquesta incògnita és que, tot i ser una fase prèvia, sempre es parteix d'una hipòtesi que amaga possibilitats de 
disseny, ja que de forma instintiva o per experiència pròpia, es reconeixen possibilitats de millora. És a dir, pensar que es pot començar una recerca completament des de zero és una fal·làcia, sempre hi haurà, per molt vague que sigui, una hipòtesi inicial. Amb l'anàlisi de dades obtingudes de la recerca, s'arribarà a conclusions que es convertiran en premisses projectuals. Per exemple, una premissa de servei dels supermercats Bonpreu, és que mai pot haver-hi més de dues persones esperant per ser atès a caixa. Per tant, quan una persona es col·loca a la cua i té dues persones per davant, la persona que està a la caixa demana per megafonia que algú més acudeixi a cobrar. Això, mantenir el temps d'espera per sota de dues persones a caixa, és una premissa projectual en referència al servei de cobrament d'aquesta cadena de supermercats que està clarament relacionada amb la intenció d'oferir una bona experiència d'usuari al client, a qui, com és ben sabut, no li agrada esperar, i menys, per pagar.

Amb aquesta metodologia, es busca un recorregut guiat que acabi amb un brief de projecte que expliqui quina relació hi ha d'haver entre l'usuari i l'objecte o l'espai, és a dir que expliqui quina interacció es vol aconseguir entre la persona i el món. Així les propostes de disseny queden obertes a qualsevol tipus de solució tal i com expliquen a Hekkert i van Dijk a VIP (2011) — vegeu apartat 2.2.4.1—. El brief resultant és el punt de partida de les solucions, és el punt de partida per al desenvolupament del projecte de disseny. És a dir, es treballa una metodologia que permeti desxifrar on hi ha les oportunitats de disseny, sobre quins punts es pot incidir, què es pot millorar o canviar en benefici de la persona enfocat des de diversos punts de vista. Per tant, és adequat per a l'anàlisi de productes o espais existents, així com per l'anàlisi d'activitats que comporten l'ús d'artefactes o la interacció amb altres persones, amb la intenció de detectar aquelles parts que són millorables a nivell d'usabilitat i experiència d'usuari. Sota aquest punt de vista, aquesta metodologia recull la proposta del disseny de serveis, el qual dona importància a la divisió de fases per a una millor detecció d'oportunitats — vegeu apartat 2.2.5.1 Service Design Thinking—.

Per altra banda, les diverses fases de l'anàlisi es treballen amb eines que conviden a la participació directa dels diversos actors implicats en l'ús de l'objecte o espai, sempre que 
això sigui possible. La metodologia recull eines àmpliament utilitzades en disseny — vegeu apartat 2.3.6 Eines - i s'ajusta a la tendència de fer partícip a l'usuari del procés, que comença en la fase d'anàlisi. Forma part de la tendència dels processos participatius descrits per Elizabeth Sanders — vegeu apartat 2.3.4 El disseny generatiu—. Aquí també el disseny de serveis proporciona casos d'èxit relacionats, per exemple, amb els serveis públics i els processos participatius desenvolupats per exemple des de la consellaria de Joventut de Catalunya per millorar els usos i serveis del Carnet Jove, o l'intent de procés participatiu per a definir la nova distribució de l'avinguda Diagonal de Barcelona, o l'exemple de l'ajuntament de Sant Quirze del Vallès per a la millora del seu servei d'atenció ciutadana — vegeu apartat 2.2.5.3 Estudi de cas-.

La metodologia proposada no pretén aportar solucions de disseny sinó ajudar a definir bons reptes de disseny, per tant ajudar a detectar punts de millora, de modificació, o fins i tot, de noves possibilitats.

No pretén ser una proposta tancada sinó una guia de possibilitats que cal escollir segons convingui al projecte. Per això una preparació inicial de les tasques a realitzar sempre serà imprescindible i necessària tal i com es pot veure a la primera fase de la proposta, anomenada Organitzar — vegeu figura 31—. En aquesta mateixa figura, també es pot observar com la proposta, tot i està plantejada de forma seqüencial, es basa en la idea de iteració, que permet depurar el repte fins al brief projectual, on les premisses queden definides com a directrius del projecte.

Per altra banda, aquesta metodologia de recerca també vol definir un context d'ús i d'experiència per ajustar característiques socioculturals, econòmiques i tecnològiques, així com temes relacionats amb les tendències i les expectatives de valor, ja que pretén ser una metodologia d'abast ampli.

S'entén el procés de disseny de manera pròxima a la proposta del Doble Diamant que proposa el British Council, sobretot per la seva referència a les diverses fases de divergència i convergència, que es van iterant al llarg del procés. Cal tenir en compte que les fases de divergència es caracteritzen per la recopilació d'informació i l'elaboració de preguntes, són 
fases on s'acumula material (entrevistes, observació, referents), és el moment d'obrir la ment, de proposar, és l'hora de la pluja d'idees, i de tenir múltiples preguntes. Les fases de convergència, en canvi, són aquells moments on es prenen decisions, quan es tria el camí a seguir i quan es proposen respostes. Les decisions preses sempre han de ser raonades $\mathrm{i}$ el màxim de testejades possible, tant a través de prototips, entrevistes o simulacres, com a través de requeriments tècnics, econòmics o socioculturals. Saber definir i proposar solucions concretes (no preconcebudes) és un dels moments més crítics del procés de disseny. La metodologia que es proposa en aquest treball, pretén ser una ajuda per a la fase inicial, per definir l'àmbit de treball i les premisses a respectar.

El fi últim d'aquesta metodologia és ajudar al dissenyador en la seva proposta de futur, entenent que precisament aquesta és la tasca del dissenyador: fer propostes de futur basant-se en uns criteris que el mateix dissenyador ha definit gràcies a les conclusions extretes de la recerca, entenent que un bon plantejament inicial, ajudarà de forma exponencial el bon desenvolupament de la recerca.

Per tant, a partir d'una hipòtesi inicial...

- com més ben plantejada estigui la recerca, més informació pertinent pel projecte es podrà recollir

- com més informació pertinent es tingui, més probabilitat hi haurà de treure bones conclusions

- com més encertades siguin les conclusions extretes de les dades recollides, més encertades seran les premisses projectuals

- com més encertades siguin les premisses projectuals, més ben definit estarà el repte de disseny

- com més ben definit estigui el repte de disseny, més encertades seran les propostes de disseny

- com més encertades siguin les propostes de disseny, millor encaixaran amb l'usuari i l'entorn 
- com millor encaixin amb usuari i entorn, millor compliran amb les expectatives d'ús i aportaran una millor experiència d'usuari

Tot això, però, tenint en comte que la metodologia no deixa de ser, només, una guia estructural adaptable a cada projecte que, sobretot, marca uns àmbits d'interès per a la reflexió, de manera que si es creu pertinent incloure'n el resultat, s'inclou, però que si es considera que per un projecte en qüestió hi ha algun dels àmbits que no és pertinent, es deixa fora. Blessing i Chakrabarti (2009) citen a un experiment desenvolupat per Fricke a principi dels anys noranta del segle passat en referència a la necessitat que el projecte de disseny es pugui desenvolupar de manera flexible metodològicament parlant. "El DRM [fent referència a la metodologia de recerca en disseny, DRM] no s'ha d'interpretar com un conjunt d'etapes i mètodes de suport que s'han d'executar de manera rígida i lineal. Els efectes negatius de fer-ho són ben coneguts per l'aplicació de metodologies de disseny. Fricke, per exemple, va observar que els dissenyadors que van intentar seguir pas a pas una metodologia de disseny d'una manera rígida, van produir dissenys de menys qualitat que els que van seguir un enfocament dirigit per objectius, però flexible" (Blessing i Chakrabarti, 2009, p. 17). Tenint en compte aquest precedent, aquesta metodologia, dins de la seva estructura pretén mantenir-se adaptable a les necessitats i desitjos de cada projecte i dissenyador, tot i que, com ja s'ha comentat abans, la possibilitat de valorar els resultats de disseny d'un procés en comparació amb els resultats d'un altre procés és poc viable, perquè, en principi és complicat saber si els resultats haurien sigut els mateixos canviant les persones de cada grup o canviant el repte.

La fase de recerca, acaba amb un brief on s'estableixen les intencions de disseny. És un document d'anada i tornada que pot ser des d'una frase, fins a un plec de condicions; és a dir, pot ser molt senzill o molt complex, però sempre ha de complir amb uns mínims informatius que expliquin quina és la interacció desitjada i quines premisses projectuals han de prevaler en la proposta. Cal que el brief s'entengui bé i no inclogui contradiccions. Es formularà donant per tancada la fase de recerca i iniciant la fase de desenvolupament. Tot $\mathrm{i}$ 
així, dins del propi procés de disseny, que és eminentment iteratiu, sempre es podrà tornar enrere i revisar-lo.

Resumint, la metodologia que es proposa, ha de ser útil per a la fase inicial de recerca que desemboca en un brief de projecte, que al seu torn desencadena en un projecte de disseny. La metodologia pretén guiar al dissenyador en aquesta fase de manera que pugui argumentar les premisses projectuals que marcaran el desenvolupament del projecte. Aquestes premisses col·locaran a la Persona, la seva experiència, i la seva interacció amb l'artefacte i el continent, com a eix central de la recerca, i la faran partícip del desenvolupament, sempre que sigui possible.

\subsection{Objectius}

\section{Objectiu principal}

L'objectiu principal d'aquesta metodologia de recerca per a les fases prèvies del projecte de disseny és guiar i acompanyar la recerca a través d'una estructura metodològica amb la intenció d'aconseguir recerques de disseny més rigoroses i efectives. Amb aquest acompanyament, es pretén que el dissenyador estigui més ben preparat per afrontar una recerca que forma part de la seva disciplina, i que això l'ajudi a generar conceptes —a l'identificar cap on van les coses i què ens fa pensar en elles - i a generar estratègies - al contextualitzar les idees-.

\section{Objectius generals de la recerca}

A través d'aquest acompanyament es pretén:

- La identificació de reptes de disseny que, en algun sentit, millorin la relació de la persona amb el món que l'envolta i que afavoreixin projectes de disseny més útils i innovadors - conceptes-. 
- La identificació de les premisses projectuals que emmarcaran el projecte al llarg del seu recorregut — contextualització-.

\section{Objectius per a la metodologia de recerca}

Per assolir aquests objectius genèrics, aquesta metodologia es proposa:

- Proporcionar una estructura de recerca dividida en fases seqüencials i iteratives que ajudi a desenvolupar la recerca de forma coherent amb la hipòtesi inicial

- Proporcionar una guia per a aconseguir una recerca rigorosa

- Proporcionar una visió àmplia i holística del fenomen investigat

- Ajudar a desenvolupar una argumentació sòlida tant del repte de disseny com de les premisses projectuals a través de les dades obtingudes

- Oferir eines, tècniques i mètodes que ajudin en l'obtenció de dades pròximes a la persona

- Oferir eines, tècniques i mètodes per a l'anàlisi de les dades i per l'extracció de conclusions

- Oferir eines, tècniques i mètodes per a la comunicació de la recerca a través d'un brief projectual

\section{Fites pel dissenyador}

Perquè la metodologia sigui efectiva i proporcioni el suport i acompanyament desitjats, es proposa que el dissenyador (o l'investigador) en les diverses accions que es duen a terme, assoleixi diverses fites al llarg del recorregut de la recerca:

- L'elaboració d'un pla de recerca amb les accions a realitzar i la seva temporització

- La definició del context d'ús

- La identificació de l'abast de la recerca 
- La definició del sistema investigat i la descripció de les seves dimensions

- La recol·lecció d'informació, el tractament de dades i la seva anàlisi

- L'extracció de conclusions de la recerca

- La definició d'uns objectius de projecte

- La definició d'un ideal d'interacció

- La definició de requisits relacionats amb la persona

- La definició de requisits relacionats amb l'entorn

- La definició de requisits relacionats amb l'artefacte o el servei

- L'elaboració de prioritats projectuals

- La definició de reptes de disseny

- L'elaboració d'un plec de premisses projectuals que es respectin al llarg del desenvolupament del producte

\subsection{Esquelet de la proposta}

L'esquelet de la proposta es determina acceptant com a certs, o més encertats, alguns dels plantejaments pel desenvolupament del projecte que s'han anat veient al llarg del capítol II, així com els diversos enfocaments en relació al pes del projecte. És important tenir un esquelet, entre d'altres coses, per poder definir el mètode de treball i saber en tot moment en quin estat es troba la recerca. A més a més, això també permet explicar-ho a terceres persones si fos necessari, per exemple a un client i així justificar les tasques realitzades. L'esquelet identifica les fases i aporta estructura de forma genèrica.

En primer lloc, cal definir el punt d'inici de la recerca. En aquest sentit, s'accepta com a encertat el fet de situar el punt d'inici de la recerca en base a una hipòtesi vague, que bàsi- 
cament mostra que existeix la possibilitat d'aportar algun element de millora. Aquest és un punt d'inici afí al fuzzy front end d'Elizabeth Sanders. Situar el punt d'inici de forma tant oberta ofereix la possibilitat de definir reptes de disseny des d'una recerca molt inicial, buscant arguments en la quotidianitat de les persones i intentant desxifrar, en el seu dia a dia, necessitats, problemàtiques i desitjos. Per altra banda, dificulta la recerca en el sentit que si no s'estructura bé i se'n delimita l'abast, es pot caure fàcilment en una recerca inabastable i sense sentit, o al contrari, el gran abast encega el dissenyador i no és capaç de separar-se de les obvietats. Tot i aquestes possibilitats, s'aposta per la bona argumentació d'una recerca inicial forta, i per tant es manté el focus en el fuzzy front end.

Tanmateix, l'esquelet de la proposta és fàcilment adaptable a un punt més avançat del projecte, quan aquesta recerca inicial ja està realitzada i arriba a mans del dissenyador un encàrrec amb un repte de disseny. Aquest encàrrec, tal i com marca Martí Font (1999) és el punt de partida d'una sèrie de processos, entre els quals també es troba la recerca, que desemboquen en la formalització d'un artefacte (Martí i Font, 1999, p. 102).

Tant si es tracta d'un inici a partir d'una hipòtesi vaga com si l'inici és fruit d'un encàrrec amb un repte de disseny més definit, l'estructura d'aquesta metodologia comença organitzant la recerca que cal dur a terme, ja que s'aposta per planificar cada un dels passos abans de dur-los a terme.

Per altra banda, també es recullen com a certes les afirmacions al voltant de la complexitat del món actual, tal i com afirma, per exemple, en Donald Norman (2010). Per superar aquesta complexitat, es proposa una estructura de recerca que sigui a la vegada flexible i holística. És a dir, que es pugui adaptar a cada situació, i que sigui capaç d'englobar tots els àmbit necessaris per a cada projecte en concret.

A més a més, vol ser una estructura que permeti posar a la Persona com a beneficiari de la reflexió, i així prevalguin les decisions que afavoreixen el benestar i la qualitat de vida i contribueixen per a un entorn favorable i sostenible. 
Per a donar resposta a aquests objectius es considera que la base metodològica de l'ergonomia ofereix una visió àmplia de la realitat, amb un component sistèmic que en relaciona les diverses parts amb una relació de causa/efecte, afegint un factor més a tenir en compte: totes les dimensions són importants perquè unes depenen de les altres. És a dir, que es recull l'esquema del sistema persona/artefacte i els seus cinc grups de variables: persona, artefacte, acció, finalitat i entorn — veure apartat 2.2.2.1 Sistema Persona/Màquina—, com a base estructural i transversal. És a dir, les cinc dimensions estan presents al llarg de les diverses fases de la recerca.

Per altra banda, el fet d'incloure el sistema persona/artefacte com a eix transversal de la recerca, fa possible que aquesta proposta de metodologia es pugui reconèixer com a pròpia també des de l'ergonomia, i, per tant, s'ofereix una eina que col·labora en la visió més prospectiva de la disciplina, ja que seria útil en els processos projectuals que descriuen Robert i Brangier (2009) — vegeu apartat 2.2.2.3 Ergonomia prospectiva —.

Les variables del sistema passen a anomenar-se dimensions de l'artefacte, i pretenen descriure totes les facetes a tenir en compte a l'hora tant de fer recerca, com de prendre decisions. De cada dimensió, i fruit del procés de recerca, s'elaboraran unes premisses projectuals que han d'actuar com a directrius durant el procés de desenvolupament. Aquestes dimensions recorren el projecte de forma horitzontal - vegeu figura 32- i van evolucionant segons la informació disponible a cada fase de desenvolupament. És a dir, al principi la informació serà molt més genèrica, i a mesura que s'avanci, la informació serà molt més concreta i precisa.

Per verificar que les cinc dimensions del sistema persona/artefacte poden donar suport a les diverses necessitats del projecte de disseny, s'han avaluat les necessitats projectuals del disseny per contrarestar-les amb les possibilitats de resposta del sistema, tal i com es veurà a l'apartat 3.5 Les dimensions de l'artefacte.

Així doncs, el marc metodològic no només s'estructura a través de cinc fases, sinó que les dimensions del projecte actuen com a quadre de doble entrada. 
Per altra banda, és important afegir que les dimensions es relacionen unes amb les altres dins d'un sistema superior que és el motiu de la recerca. Això significa, que no són illes aïllades, sinó unes depenen de les altres. Des d'aquest treball s'aposta perquè la dimensió de la Persona sigui la principal, la que ha de prevaler, però es podria donar el cas que per altres circumstàncies haguessin de prevaler, per exemple, les dimensions d'Artefacte o les d'Entorn. L'estructura es manté, però el focus principal es distribueix diferent.

L'esquelet de la proposta és l'estructura base que acompanya la recerca, començant pel plantejament de cinc fases consecutives, que poden repetir-se si la recerca ho reclama, i que, habitualment, també poden transcorre en paral·lel. Tot i així, l'esquema es manté seqüencial perquè una fase necessita l'anterior per poder-se desenvolupar.

\begin{tabular}{|c|c|c|c|c|c|}
\hline & 1. ORGANITZAR & 2. BUSCAR & 3. ANALITZAR & 4. DEFINIR & 5. COMUNICAR \\
\hline \multirow[t]{2}{*}{$\begin{array}{c}\text { hipòtesi: recerca } \\
\text { d'oportunitats de } \\
\text { disseny }\end{array}$} & $\begin{array}{l}\text { Plantejament i } \\
\text { estructuració de } \\
\text { la recerca }\end{array}$ & Recerca & $\begin{array}{l}\text { Treball amb les } \\
\text { dades i extracció } \\
\text { de conclusions }\end{array}$ & $\begin{array}{l}\text { Definició del repte } \\
\text { de disseny i de les } \\
\text { premisses projectuals }\end{array}$ & Comunicació: brief \\
\hline & pla de recerca & dades & insights / evidències & $\begin{array}{l}\text { repte de disseny i } \\
\text { premisses projectuals }\end{array}$ & brief \\
\hline
\end{tabular}

Fig. 32 Esquema de les fases de la metodologia de recerca i les fites aconseguides a cada fase

Com s'ha vist en la introducció d'aquest apartat, aquesta metodologia de recerca es planteja a través de cinc fases: organitzar, buscar, analitzar, definir i comunicar. Si es col·loca sobre l'esquema de divergència i convergència proposat pel doble diamant —vegeu apartat 2.3.2-, es pot identificar una fase de divergència formada per la fase Organitzar i la fase Buscar, un canvi de rasant format per la fase Analitzar, i una fase de convergència formada per les fases Definir i Comunicar. De manera que l'esquema quedaria com un diamant amb les puntes arrodonides. De fet, encaixa millor amb l'esquema de J.C. Jones (2a ed. 1992), divergència, transformació, convergència, però per Jones aquest esquema és el projecte sencer, i en canvi aquí, aquest esquema només fa referència a la recerca, i en aquest cas, allò que es transformen són les dades, en informació útil pel projecte. 
A cada fase es realitzen unes tasques i fruit d'aquestes tasques s'obté un resultat —vegeu figura 32-. Tot i així, cal insistir que la gran majoria de vegades les fases no es desenvoluparan de forma seqüencial pura, sinó que es solaparan entre elles o s'anirà endavant i enrere per recuperar elements que queden poc clars. També és veritat, però, que unes fases depenen de les altres i que amb més o menys deteniment s'ha de passar per cada una d'elles.

El resultat obtingut de cada fase, són les diverses fites que el dissenyador ha de voler assolir.

La fase Organitzar és la fase de plantejament necessària, per una banda, per posicionar el coneixement inicial sobre el tema, i per l'altra, per organitzar i estructurar la recerca. Posicionar el coneixement inicial significa ser conscient del coneixement propi o de l'equip respecte el tema que es vol tractar, i establir prioritats de recerca. És a dir, el plantejament inicial és el que marca el punt de partida del projecte treballant a partir de la hipòtesi —una declaració instintiva que afirma com el disseny pot actuar per al bé de la persona en certa direcció o en certa unitat funcional-. A més a més, cal que sorgeixi un pla de recerca on es plantegi com aquesta recerca es durà a terme, qui s'encarregarà de cada acció, una temporització, com s'organitzaran les dades, amb quin tipus de suport es recolliran, així com uns objectius per saber què cal observar, en definitiva un marc d'actuació per restringir l'abast d'una recerca que podria ser infinit.

De la fase Buscar, la fase de recerca d'informació, en sorgiran les dades, que poden concretar-se a través de fotografies, entrevistes, diaris de camp... en principi, totes recollides de fonts d'informació primàries, buscant l'experiència i el contacte directe amb l'usuari, així com la seva participació, i fent ús d'eines de l'etnografia i l'antropologia, com per exemple, l'observació i l'entrevista, o també fruit processos col·laboratius. A través d'aquesta recerca de fonts primàries s'obté un tipus d'informació que ha de concloure amb el repte de disseny. Idealment, la recollida d'informació inicial ha de tenir lloc a la vida real, a través de la pròpia participació de l'investigador en processos o entrevistes amb els actors implicats, o que fan ús de l'artefacte. Es recull la intenció empàtica de comprensió de la persona dels processos de disseny centrat en les persones. 
Tot i així, hi ha una segona part de recerca, que segurament necessitarà buscar informació de fonts secundàries, sobretot allò que està relacionat amb qüestions tècniques. Tornant a l'exemple de l'antropometria, cert és que seria ideal realitzar un estudi antropomètric dels usuaris reals de l'artefacte. Per exemple, si s'estan dissenyant els punts de caixa d'un supermercat, seria ideal tenir les dades antropomètriques de les treballadores i treballadors que estaran atenent la caixa, perquè així les decisions dimensionals es basarien en dades reals. Tot i així, la tasca d'elaborar unes taules antropomètriques rigoroses, prenent mides de forma normalitzada i realitzant el treball estadístic posterior és tan extens, costós i laboriós, que disposar d'aquestes dades és complicat per la gran majoria de projectes. Per tant, es recorre a taules antropomètriques ja existents que s'aproximin a les persones usuàries tan com sigui possible. Per això, la recerca no només pot ser de fonts primàries, sinó que necessita inevitablement, i degut a la complexitat del món, recórrer a fonts secundàries.

De la fase Analitzar, en sorgiran les evidències o insights, que tal i com s'ha vist al subapartat 2.4.3.1 són el pas previ per a la definició del repte de disseny. De totes maneres, abans d'arribar a les evidències hi haurà una sèrie de tasques a realitzar amb les dades, per entendre-les i elaborar un mapa de la situació existent, l'elaboració de la Persona arquetip, l'elaboració d'un o diversos user journey maps, o la codificació d'entrevistes i notes de camp. En definitiva, el treball amb les dades és part essencial del procés de recerca per poder extreure conclusions encertades. És a dir, tota la informació recollida s'emmagatzema i analitza, es comparen visions per temàtiques i s'extreuen conclusions de recerca que es converteixen en evidències projectuals: els insights. De totes les evidències projectuals detectades, s'escullen aquelles que deixen marge per a la millora, o la innovació. Cal tenir en compte, tal i com diuen Crouch i Pearce que "els dissenyadors, els investigadors i els usuaris, interactuen tots amb objectes i sistemes en un context cultural i material que emmarca com s'entén el món” (Crouch i Pearce, 2012, p. 54). És a dir, que tant les dades observades, com les evidències i conclusions fruit de l'anàlisi sempre van acompanyades de la pròpia visió del món que té aquell que observa, i aquell que actua. Per altra banda, cal tenir en compte que l'anàlisi de les dades ens permet veure on han quedat buits de conei- 
xement necessaris, per exemple, tal i com diuen Blessing i Chakrabarti, en la definició de les tasques que es duen a terme en la realitat observada: "L'anàlisi de les dades empíriques revelen les característiques típiques o la definició insuficient del problema i mostra que una definició insuficient que té lloc a la fase d'investigació de les tasques, habitualment es converteix en una despesa de temps més elevada que té lloc en fases posteriors del procés degut a la necessitat de fer modificacions" (Blessing i Chakrabarti, 2009, p. 16). La detecció de buits de coneixement, enviarà a l'investigador a buscar més dades, i així successivament fins que es consideri acabat, o fins que la limitació temporal o de recursos hi posi fi. Per això, és important una bona planificació, per evitar avançar i retrocedir en massa ocasions, la iteració és positiva perquè permet depurar informació, però si se n'abusa, no s'avança.

De la fase Definir, en sorgiran el repte de disseny i les premisses projectuals. És, per tant la culminació de tota la feina feta fins al moment i és on dibuixarà el futur desitjat. El repte de disseny és l'encàrrec que predisposa a l'acció, el punt de partida del projecte. I les premisses de disseny, són tots aquells elements que cal tenir en compte per desenvolupar el projecte, dels quals se'n parlarà més detingudament a l'apartat 3.8.1 Fase Definir.

Finalment, de la fase Comunicar, en sorgirà el brief de disseny. És important elaborar un document que transmeti de forma independent el resultat de la recerca, és a dir, un document que conté el repte de disseny, les premisses projectuals, i tota aquella altra informació que es considera pertinent per al desenvolupament del projecte. Aquest document, ha de funcionar per sí sol perquè no sempre hi haurà els responsables de la recerca al costat per poder-ho explicar. A més a més, i independentment del seu punt d'inici, el projecte ha fet un salt de concreció, ha d'haver avançat en coneixement de la situació, en problemàtiques detectades, en definició de desitjos, en principis inviolables, i en principis desitjables. La fase de recerca ha de sustentar l'argumentari per a la presa de decisions posterior. Tot plegat, en un brief de disseny que marca l'inici del desenvolupament del projecte.

Fins aquí, l'esquelet està organitzat de forma seqüencial en el seu eix horitzontal, tot i que els resultats de cada fase es dibuixen a l'eix vertical sota de cadascuna d'elles amb les fites 


\begin{tabular}{|c|c|c|c|c|c|}
\hline \multirow[b]{2}{*}{$\begin{array}{l}\text { hipòtesi: recerca } \\
\text { d'oportunitats de } \\
\text { disseny }\end{array}$} & 1. ORGANITZAR & 2. BUSCAR & 3. ANALITZAR & 4. DEFINIR & 5. COMUNICAR \\
\hline & $\begin{array}{l}\text { Plantejament i } \\
\text { estructuració de } \\
\text { la recerca }\end{array}$ & Recerca & $\begin{array}{l}\text { Treball amb les } \\
\text { dades i extracció } \\
\text { de conclusions }\end{array}$ & $\begin{array}{l}\text { Definició del repte } \\
\text { de disseny i de les } \\
\text { premisses projectuals }\end{array}$ & Comunicació: brief \\
\hline \multicolumn{6}{|l|}{ ENTORN } \\
\hline \multicolumn{6}{|l|}{ ACCIÓ } \\
\hline \multicolumn{6}{|l|}{ FINALITAT } \\
\hline \multicolumn{6}{|l|}{ PERSONA } \\
\hline \multicolumn{6}{|l|}{ ARTEFACTE } \\
\hline & pla de recerca & dades & insights / evidències & $\begin{array}{l}\text { repte de disseny i } \\
\text { premisses projectuals }\end{array}$ & BRIEF \\
\hline
\end{tabular}

Fig. 33 Esquema de les fases de la metodologia de recerca, resultat de cada fase, amb l'aplicació de les dimensions

a assolir pel dissenyador. Ara falta incloure-hi el sistema persona/artefacte i les seves cinc dimensions que es distribuiran a l'eix vertical tal i com es pot veure a la figura 33.

Com que l'eix vertical i horitzontal s'entrecreuen com a quadre de doble entrada, des de la fase Organitzar ja es comença a distribuir la informació segons cada dimensió, de manera que d'una forma visual es pot observar on estan els principals buits de coneixement, què té més pes i com s'organitzen, des d'un principi, les diverses dimensions del projecte.

La recerca s'ha de plantejar de manera que les dades que se n'extreguin siguin realistes i útils. Cal recollir dades que recolzin la hipòtesi inicial i ajudin a desenvolupar-la per poder concretar un repte de disseny argumentat. A partir de la informació recol·lectada, es dibuixa una descripció de la situació existent que ha de permetre analitzar-la i detectar-hi punts conflictius i encertats, tal i com proposa el disseny de serveis a través del service blueprint o a través d'un user journey map. Amb un mapa ben dibuixat, que significa entendre la situació existent, i focalitzant els esforços sobre un repte en concret, el dissenyador pot descriure la situació futura desitjada, començant per les intencions de l'usuari i les accions que vol que es desenvolupin per aconseguir-les, com vol que se senti, i com els artefactes i l'entorn han de configurar-se perquè aquestes accions es realitzin de manera fluida i satisfactòria. 
Aquesta situació desitjada es convertirà en el repte de disseny i el desenvolupament del projecte, fora de l'abast d'aquest treball, el dissenyador s'esforçarà per aconseguir que la situació desitjada es faci realitat. Blessing i Chakrabarti (2009) parlen de la comprensió de la situació existent a través d'una sèrie de factors que els serviran per descriure la situació futura desitjada. En el treball d'aquesta descripció, els investigadors podran detectar quin dels factors té més possibilitats de desenvolupar-se i serà en aquesta direcció que s'actuarà i s'enfocarà el projecte. (Blessing i Chakrabarti, 2009, p. 16). Per aquests autors, és molt important l'ús de la visualització del futur desitjat; en aquest treball, es recull aquesta eina perquè permet configurar de manera visual i descriptiva les diverses premisses de disseny que es vulguin incloure. És una manera de sortir de l'espai teòric immers en dades i la seva anàlisi, i introduir-se en un espai aplicat on el dissenyador, en principi, se sent molt més còmode.

Tornant a l'esquelet de la metodologia, la intenció de combinar els eixos vertical i horitzontal és que en cada fase hi hagi una estructura que interpel·li al dissenyador en cada una de les dimensions, de manera que la recerca i l'anàlisi no es deixi res pel camí o, si més no, es deixi menys coses que si no tingués un estructura amb el projecte dividit en dimensions. Com ja s'ha comentat anteriorment, saber si aquesta estructura de doble entrada és útil i organitza la recerca tal i com pretén, caldrà revisar-ho a través de la satisfacció del dissenyador que l'ha utilitzat.

\subsection{Les dimensions de l'artefacte}

Des de l'experiència de l'ús del sistema persona/màquina i la seva descripció teòrica —vegeu subapartat 2.2.2.1—, se li reconeix la virtut de l'anàlisi exhaustiva i holística d'un fenomen, que l'ergonomia utilitza bàsicament pels seus exàmens preventius i correctius. A més a més, observa la realitat de forma sistèmica, on les accions tenen conseqüències, i tot està interrelacionat. En aquests dos sentits, sembla una proposta perfecte per servir de base 
a qualsevol intenció d'anàlisi i recerca d'algun tipus de fenomen o situació.

En essència, l'ergonomia descriu un sistema entre dos elements que es relacionen de forma causal, la persona i la màquina. En algunes descripcions del sistema, també s'hi inclou l'entorn, definint el sistema persona/màquina/entorn. En qualsevol cas, en aquest treball interessa la visió holística dels fenòmens i la relació que s'estableix entre els elements que formen aquest fenomen. En aquest sentit, es desconstrueix el sistema en les seves cinc variables —-finalitat, acció, persona, entorn i artefacte—, que passen a anomenar-se dimensions i d'alguna manera s'equiparen, suprimint el binomi, de manera que el sistema, en principi, s'adaptarà a cada situació. Es tracta, doncs, de cinc dimensions relacionades entre sí de forma dependent, unes depenen de les altres. A més a més, cada dimensió inclou una sèrie de variables que són les que completen la visió holística de forma exhaustiva. Les variables, com a tal, són elements mesurables, per tant són els elements que permeten descriure similituds i diferències. A través de la recerca, les dimensions es van omplint de contingut, i aquest contingut, al ser analitzat pot convertir-se en premisses de disseny. La dependència entre dimensions obliga al dissenyador a posicionar-se, ja que en algun moment ha de donar prioritat a unes premisses o a unes altres.

Això vol dir, per exemple, que la presa de decisions sobre qüestions relacionades amb la persona, afectaran la configuració de l'artefacte; o també, que certa premissa irrenunciable de la dimensió d'entorn, afecta directament en les decisions de tipus de material de l'artefacte. Sovint les dependències entre variables de les dimensions poden entrar en conflicte, una variable pot contradir-ne un altra; i és aquí on entren en joc les premisses projectuals ordenades per prioritat — vegeu apartat 3.8 Fases de convergència-, per si, donat el cas, cal renunciar a alguna premissa, o modificar-la.

De forma genèrica, es pot dir que les variables de finalitat són tradicionalment les primeres premisses a definir, i les que guien l'objectiu perseguit pel projecte, però no únicament. Actualment, l'experiència d'ús és tant o més important que la finalitat de l'artefacte, i aporta valor d'estima, un tipus de valor que no és material o de mercat, sinó que té a veure amb les expectatives i amb l'emotivitat o afectivitat que pot generar un producte. 
Per altra banda, cal tenir sempre present que les característiques i capacitats de la persona són inqüestionables ja que són la raó de ser de tota la reflexió. Aconseguir artefactes i sistemes que acompanyin a les persones en el desenvolupament de la seva vida diària, sense que sigui nociu ni per la persona mateixa, ni pel medi ambient, ja que sense aquest segon, la persona tampoc pot sobreviure.

Finalment, les variables d'entorn, entre d'altres coses, posicionen l'artefacte en un sistema sociocultural concret, i en descriuen el context mediambiental.

Per avaluar l'eficiència del sistema i contrastar la seva capacitat d'abastar les necessitats d'un projecte de disseny, es realitza una aproximació teòrica a través d'un mapa conceptual —vegeu figura 34-. El mapa relaciona les cinc dimensions, amb les seves variables i amb les premisses de disseny que poden resultar-ne. A més a més, posiciona àrees de rellevància en relació a cada dimensió per acabar de completar-ne la visió global. De forma genèrica, es col·loquen les preguntes a les quals dona resposta cada dimensió i es distribueixen temes cabdals pel projecte. Per exemple, relacionat amb la dimensió d'entorn — que respon a les preguntes quan? i on?-, s'hi troben enllaçats temes cabdals com les condicions econòmiques i la societat i la cultura. A més a més, la dimensió queda emmarcada per les tendències, l'estètica o el posicionament del projecte, dibuixant un mapa genèric dels elements que estructuren la dimensió Entorn. És a dir, aquest mapa conceptual és la base estructural de la proposta organitzada a través de les dimensions.

Tanmateix, tota aquesta informació distribuïda de forma visual, es trasllada al llarg d'aquest apartat a través de les descripcions de cada dimensió. A més a més, també es trasllada a les fitxes de treball, que són una eina per al desenvolupament de la recerca.

La fitxa de treball és l'eina de recerca, és a dir, és l'eina que guia al dissenyador en la recerca. Cada dimensió té la seva fitxa que interpel·la al dissenyador amb preguntes o qüestions a tenir en compte — vegeu figures de 36 a 40 - 


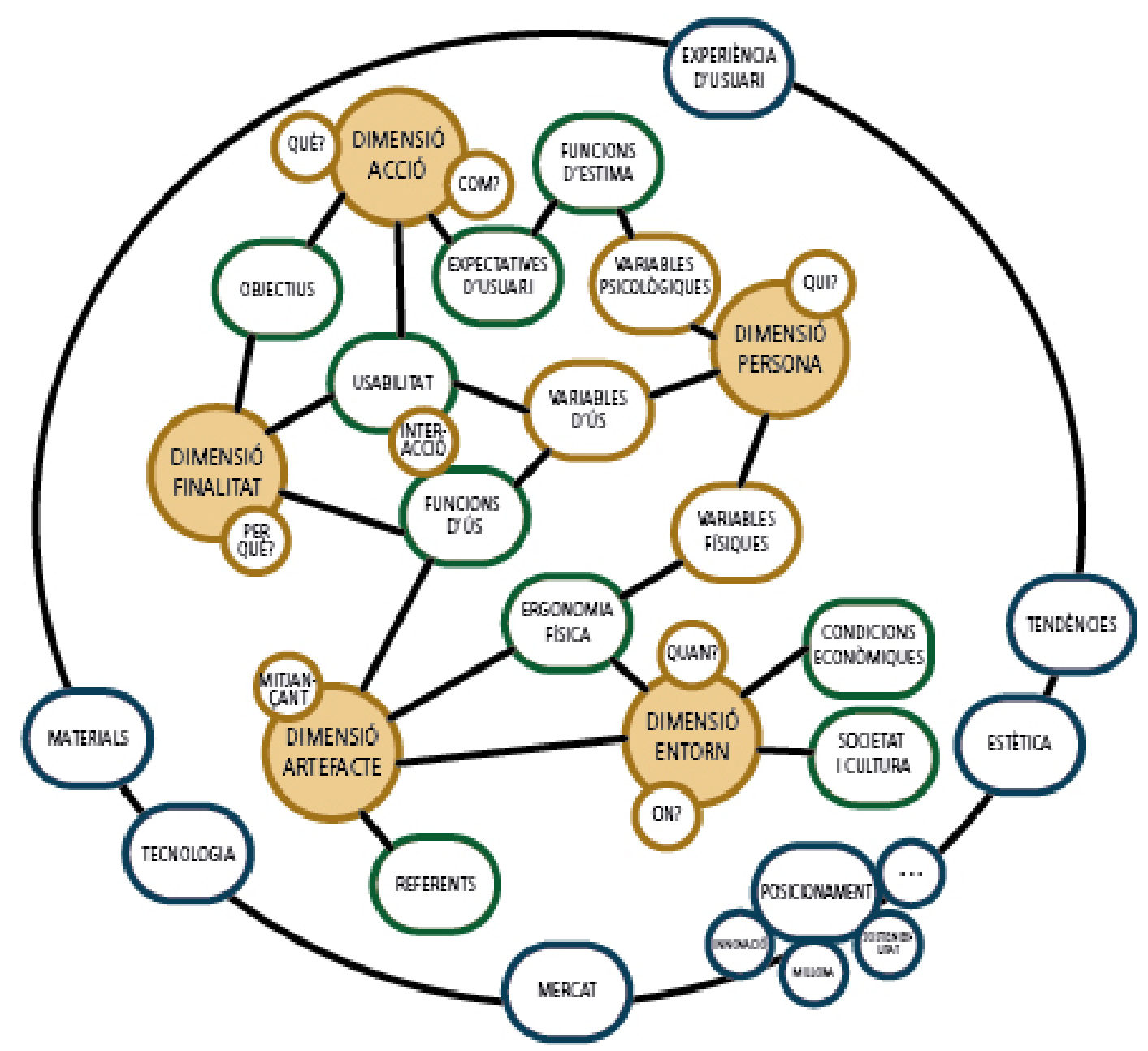

Fig. 34 Mind map de la distribució de les necessitats del projecte de disseny entre les cinc dimensions del sistema $\cdot$ Realitzat amb les eines del Manual Thinking

\section{Dimensió Acció}

La dimensió Acció — vegeu fitxa corresponent a la figura 36 - està formada per una sèrie de variables que responen a les preguntes què? i com? Defineixen les diverses accions, seqüències d'accions i tasques que realitzen persona i artefacte, així com de quina manera es comuniquen una i altre.

Per descomptat, les accions definides cal contrastar-les amb les variables de Persona, per no incórrer en cap demanda que pugui ser nociva per la persona, que pugui provocar lesions, o simplement que exigeixi un esforç tant físic com mental innecessari. 
Entre d'altres aspectes, les variables d'acció defineixen les seqüències de comunicació entre la persona i l'artefacte. És a dir, defineixen l'existència o la necessitat d'interfícies, botons o mecanismes mecànics que permetin assolir els objectius definits en les variables de finalitat. És per tant, la dimensió que defineix la interacció. Per aquesta variable és imprescindible tenir en compte la diversitat funcional de les persones en tots els sentits, i procurar prendre decisions pròximes al disseny universal.

En aquest sentit, també defineix les accions i les respostes de cada una de les parts quan es realitza una acció; i per tant, també té un paper en la definició de la usabilitat, concepte que defineix la facilitat d'ús de l'artefacte. Això significa que es defineix la capacitat de control i maneig que s'atorga a la persona. Aquí cal tenir en compte un cop més les capacitat de les persones per atorgar-li accions que pugui realitzar sense incórrer en errors innecessaris. És a dir, hi ha accions com el càlcul i la comparativa de dades que realitza millor una màquina que una persona; i al contrari, quan succeeix una excepció, la persona té molta més capacitat per actuar i trobar solucions que la màquina enfront els fets inesperats. Per tant, quan es defineix el control i el maneig, cal atorgar a cadascú les accions que més s'ajusten a les pròpies virtuts i capacitats, tal com s'ha vist en l'apartat corresponent en referència a autors com Sanders i McCormick (7a ed. 1993) o Tillman et al. (3a ed. 2016) — vegeu subapartat 2.2.2.1 Sistema persona/màquina—.

Per a definir la usabilitat es necessiten premisses projectuals que n'assegurin eficiència, efectivitat i satisfacció. Recuperant l'exemple de les caixes del supermercat, la premissa de no haver d'esperar més de dues persones a la cua per pagar també és un exemple de definició per a la variable de satisfacció de la usabilitat. En algun moment, s'ha decidit que el màxim han de ser dues persones, i no tres, o quatre. Aquest nivell de precisió de la premissa projectual és difícil d'assolir a l'inici del projecte, ja que les variables i les dimensions solen tenir descripcions força genèriques, ara bé, en estadis més avançats, les premisses de disseny han d'aspirar a ser requisits amb una clara intenció de millora tan precises com sigui possible.

Relacionada amb l'anterior, una de les variables més interessants d'aquesta dimensió és la variable que defineix qui fa què. Aquest és un concepte que treballen Tillman et al. (3a ed. 
2016), en aquesta obra s'explica com en algun moment cal prendre decisions sobre qui executarà les accions definides. Per exemple, una porta que cal obrir per passar. Aquesta acció d'obrir la porta serà executada per la persona (moure el pany, empènyer o estirar i passar), o serà executada per l'artefacte (un sensor detecta la presència d'una persona i executa unes ordres que fan que la porta s'obri automàticament i la persona passa). La decisió sobre qui fa què afecta enormement a l'artefacte i està molt relacionat amb la capacitat tecnològica del moment.

La dimensió Acció també inclou les variables de moment d'ús. És a dir, que defineix els diversos estadis de l'artefacte en relació a les accions que

Per a la descripció de la dimensió Acció es podrien fer servir les preguntes següents:

Quines accions es realitzen per assolir l'objectiu?

Qui fa què?

Quines accions requereixen els canvis d'ús de l'artefacte?

Quan puc dir que les accions són eficaces? Eficients? Satisfactòries? Què defineix la usabilitat de l'artefacte? cal executar per a aconseguir el propòsit de l'artefacte. També cal tenir en compte què passa quan l'artefacte està en repòs, guardat, apagat, plegat, etc., altres moments d'ús que s'allunyen de les accions que defineixen la seva raó de ser. I també en altres situacions com per exemple si cal executar tasques de manteniment, o com es faciliten les accions de reparació. Per exemple, un vehicle tan ha d'estar dissenyat per poder-lo conduir, com perquè el mecànic pugui accedir al motor.

Dins de l'ergonomia, la part de biomecànica, que analitza moviments i esforços humans, és la part que posa el focus sobre la persona i els seus moviments. Per exemple, a nivell esportiu hi ha molts estudis que busquen l'optimització de moviments per a millorar les marques personals. Això, traslladat a la vida diària, ajuda a definir moviments nocius o saludables, així com les accions que suposen més o menys esforç. En aquest sentit, l'ergonomia laboral ha elaborat una sèrie de protocols normalitzats — com per exemple, els mètodes d'avaluació postural OWAS o REBA—on s'analitzen postures i moviments que poden servir de guia pel disseny d'artefactes i espais. 


\section{Dimensió Persona}

La dimensió Persona — vegeu fitxa corresponent a la figura 37- està formada per una sèrie de variables que responen a les preguntes qui? Defineix com a persona clau a l'usuari principal de l'artefacte, sistema o servei. Aquest és principalment l'element que marcarà les premisses de disseny, però no només, perquè la definició dels moments d'ús dibuixen una sèrie d'altres actors que tenen relació amb l'artefacte, es tracta dels usuaris secundaris, com poden ser el personal tècnic o de manteniment, personal de neteja, venedors, etc. que també han de poder interactuar amb l'artefacte de manera satisfactòria. És a dir, tant important és que l'usuari accedeixi al paper de vàter de forma còmode $\mathrm{i}$ el talli sense problemes, com que la persona de manteniment pugui canviar-ne el rotlle de forma àgil.

Per a la descripció de la dimensió Persona es podrien fer servir les preguntes següents:

Qui és l'usuari?

Quins paràmetres antropomètrics cal tenir en compte? Amb quins percentils cal treballar? Quin esforç físic o cognitiu s'està exigint?

Quines exigències posturals cal tenir en compte? Com s'estructura el procés de comprensió de l'objecte? Quins desitjos o pors, necessitats o problemàtiques té l'usuari?

De la persona, es tenen en compte dos grans blocs, per una banda les seves característiques físiques, i de l'altra les seves característiques psicològiques i cognitives. Tant les primeres, com les segones queden descrites des de l'ergonomia, que busca conèixer el funcionament del cos humà i les seves capacitats per definir premisses que promoguin decisions que beneficiïn la persona. En relació a les característiques físiques, es defineixen variables relacionades amb la fisiologia, l'antropometria (paràmetres i percentils), la biomecànica, la postura o l'esforç. En qualsevol dels casos, durant la fase Organitzar, cal identificar molt bé quins elements són necessaris. Per exemple, per dissenyar unes ulleres, a nivell antropomètric es necessitaran mesures com la distància entre els ulls, o la distància entre les orelles i els ulls. Però no serà necessari fer esment de la llargada del peu. És important incidir en aquest aspecte, ja que 
la recerca d'aquest tipus de dades de fonts pròximes, actuals i fidedignes no sempre resulta senzill, per tant, molt millor optimitzar esforços.

En relació a les característiques psicològiques i cognitives es defineixen variables relacionades amb la capacitat de comprensió, la percepció o el coneixement tàcit. Per exemple, dins dels principis del bon disseny proposats per Donald Norman (1990), la topografia natural formaria part del control dels elements — vegeu apartat 2.2.2.5 Ergonomia cognitiva一. Aquí també hi entren temes relacionats amb la comunicació de l'artefacte i conceptes de semiòtica de l'artefacte, en relació a la persona.

Per descomptat, tant les característiques físiques com les psicològiques vindran definides a través de conceptes de diversitat funcional, i es procurarà que les premisses projectuals $\mathrm{i}$ les decisions preses siguin el més pròximes possible al disseny universal.

Un altre tipus de variables que formen part de la dimensió Persona, són les variables que defineixen les característiques socioculturals. Aquestes, estan especialment relacionades amb la dimensió Entorn, que també es preocupa de la societat. En definitiva, aquí apareixen aquest grup de variables per posar èmfasi en el fet que qualsevol artefacte o servei, es posiciona en societat $\mathrm{i}$ això implica una sèrie de qüestions a tenir en compte relacionat amb les característiques del propi usuari, com pot ser per exemple la percepció del color i quins significats implícits comporta.

Per altra banda, es pretén fer partícip als diversos actors tant com sigui possible, per tant, també es definiran les expectatives dels usuaris, així com els seus desitjos o pors, les necessitats o les problemàtiques, fruit o bé de la recerca etnogràfica, o bé, de la participació directa en la recerca dels diversos actors implicats, tal i com defensen Sanders i Stappers (2012).

\section{Dimensió Finalitat}

La dimensió Finalitat — vegeu fitxa corresponent a la figura 35- està formada per una sèrie de variables que responen a la pregunta per a què?, i inclou objectius, metes, fins i propòsits relacionats amb l'artefacte. També està estretament relacionada amb les funcions 
d'ús, és a dir amb la utilitat que el seu ús proporciona a l'usuari. És a dir, en general funcions relacionades amb la utilitat.

Dins de la dimensió Finalitat es troba l'objectiu principal de l'artefacte, la raó de ser de la seva funció, allò pel qual ha sigut dissenyat. En principi, l'objectiu principal es convertirà en una premissa irrenunciable. Un plat servirà per exemplificar els diversos nivells de funcions; com a objectiu principal, es pot descriure el de contenir menjar durant un àpat.

Aquesta dimensió, també inclou altres tipus d'objectius, funcions secundàries que complementen la funció principal. Cal vigilar aquí de no sobredimensionar les funcions secundàries perquè podrien afegir complexitat innecessària a l'artefacte, tal i com explica Don Norman (1990) quan descriu els cinc principis per al bon disseny amb l'objectiu que l'artefacte sigui utilitzable i comprensible en referència a les prestacions que hauria d'incloure. Aquests objectius secundaris també poden ser diferents metes a assolir, en el cas que l'artefacte, sistema o servei formés part d'una solució a terminis. En referència a l'exemple del plat, es podrien afegir com a objectius secundaris, o funcions accessòries, que el plat inclogués una zona on deixar els coberts o una divisió per diverses tipologies d'aliments.

També formen part de la dimensió Finalitat els fins que es volen assolir amb la utilització de l'artefacte, és a dir, no directament la seva funció principal, sinó allò que aporta més enllà de l'objectiu concret. En vista de què es fa servir un artefacte. Seguint amb l'exemple del plat, es podria descriure com a fi, el fet de facilitar l'alimentació de les persones. L'objectiu principal és contenir el menjar, però forma part d'una finalitat superior que és facilitar l'alimentació. A aquest nivell es pot veure, com diverses cultures han donat resposta a aquesta necessitat de formes diferents. A Europa, majoritàriament amb el plat, però a Àsia hi juga un paper molt Per a la descripció de la dimensió Finalitat es podrien fer servir les preguntes següents:

Quin és l'objectiu o finalitat de l'artefacte?

Que vol aconseguir l'usuari?

Què volen aconseguir els

diversos actors implicats? important el bol. 
Els propòsits encara van una mica més enllà i són difícilment comprovables. Són intencions futures que es podrien descriure com l'empremta que es vol deixar amb l'artefacte. Per exemple, el propòsit del plat podria ser millorar l'alimentació. Aquest propòsit és difícilment comprovable, però es podria convertir amb la premissa projectual de fomentar la bona alimentació, que sí que es podria traslladar a nivell de disseny en una decoració que dividís el plat de forma coherent entre proteïnes, hidrats i greixos. O en mantenir unes dimensions reduïdes perquè la gent no mengi massa quantitat.

Finalment, la dimensió Finalitat recull les evidències establertes en l'anàlisi d'usabilitat, que correspon a la dimensió Acció, ja que forma part de les tasques executades amb l'artefacte. Aquest concepte s'inclou dins dels protocols ergonòmics i pretén ser quantificable a nivell d'eficiència, eficàcia, satisfacció, capacitat d'aprenentatge, etc. —vegeu apartat 2.2.2.2. Usabilitat i experiència d'usuari-. Per exemple, perquè el plat sigui efectiu, la persona ha de poder traslladar menjar amb suc sense que aquest vessi per la vora del plat. Si es realitzen proves i de cada 10 viatges, 3 regalima el suc, potser cal modificar la forma del plat. El grau d'exigència cal definir-lo prèviament, és a dir, quants errors es consideraran acceptables?

\section{Dimensió Entorn}

La dimensió Entorn — vegeu fitxa corresponent a la figura 38 — està formada per una sèrie de variables que responen a les preguntes quan? i on? Defineix les variables que estan relacionades amb el lloc on majoritàriament es farà servir l'artefacte i en el moment que es farà servir. És a dir, es tracta d'una dimensió que defineix si es tracta d'un element d'ús públic o privat, si és interior o si estarà a l'aire lliure. Aquests són una sèrie de variables que tenen un pes important en l'elecció de materials, formes i configuració, etc., per tant en la dimensió de l'artefacte.

Per altra banda, és una dimensió que posiciona el producte en societat, en descriu el posicionament sociocultural i econòmic, així com de quines tendències forma part. També el po- 
siciona dins d'un sistema; per exemple, tornant al plat, les seves dimensions no han de superar unes mides concretes, ja que si ho fa, ja no entra al rentaplats. La detecció dels sistemes propis de l'artefacte, tant per sobre com per sota, poden aportar informació valuosa que es pot convertir en premisses projectuals.

Finalment, tenir en compte, que en la gran majoria dels casos serà un producte que sortirà al mercat, per tant és necessari conèixer-ne les seves característiques.

Per a la descripció de la dimensió Entorn es podrien fer servir les preguntes següents:

Quines qüestions ambientals cal tenir en compte: Ilum, temperatura, aigua, humitat? Quines qüestions socioculturals i econòmiques cal tenir en compte?

De quines tendències forma part?

\section{Dimensió Artefacte}

La dimensió Artefacte - vegeu fitxa corresponent a la figura 39- està formada per una sèrie de variables que responen a la qüestió mitjançant. Defineix les variables que estan relacionades directament amb la configuració de l'artefacte, sistema o servei. Tot i que moltes decisions d'aquesta dimensió es prendran durant el desenvolupament del producte, hi ha una sèrie de característiques que es poden preveure i definir com a premisses desitjables ja que responen a qüestions que depenen d'altres dimensions. Per això, la dimensió Artefacte apareix l'última, perquè és la que recull els requisits de totes les altres dimensions i procura donar-los resposta. Sempre que sigui possible, ho farà. Però en altres ocasions, les pròpies premisses de l'artefacte poden entrar en conflicte amb les premisses de les altres dimensions, aquí és quan entren en joc el pes de les prioritats. També és possible, que no es pugui donar resposta a certes premisses per falta de recursos tècnics, o econòmics, entre d'altres. Un cop més, entren en joc el pes de les prioritats.

En primer lloc, en aquesta dimensió es defineixen les funcions tècniques de l'artefacte, és a dir tot allò que forma part de la seva configuració, divisió de les diverses peces, dimensions, estructura interna i externa, etc. Això inclou també, la descripció de les zones practicables, 
les parts fixes i mòbils, la inclusió de ferramentes, etc. Per exemple, en el projecte d'una maleta, una premissa de la funció tècnica podria ser la inclusió de rodes. En el desenvolupament del projecte es decidirà quin tipus de roda, de quina mida o quantes, de moment, com a premissa projectual apareix que la maleta ha de tenir rodes.

També es defineixen una sèrie de característiques físiques desitjables, per exemple, en referència al pes, la resistència o la ductilitat dels materials, així com característiques relacionades amb els acabats, la qualitat de les superfícies o l'estètica.

Un altre grup de variables defineix la pertinença de l'artefacte a una família, i també configura diferents tipologies de l'artefacte. Per exemple, si es tracta d'una làmpada de peu, o si forma part d'una família de làmpades on també s'hi inclouen l'aplic

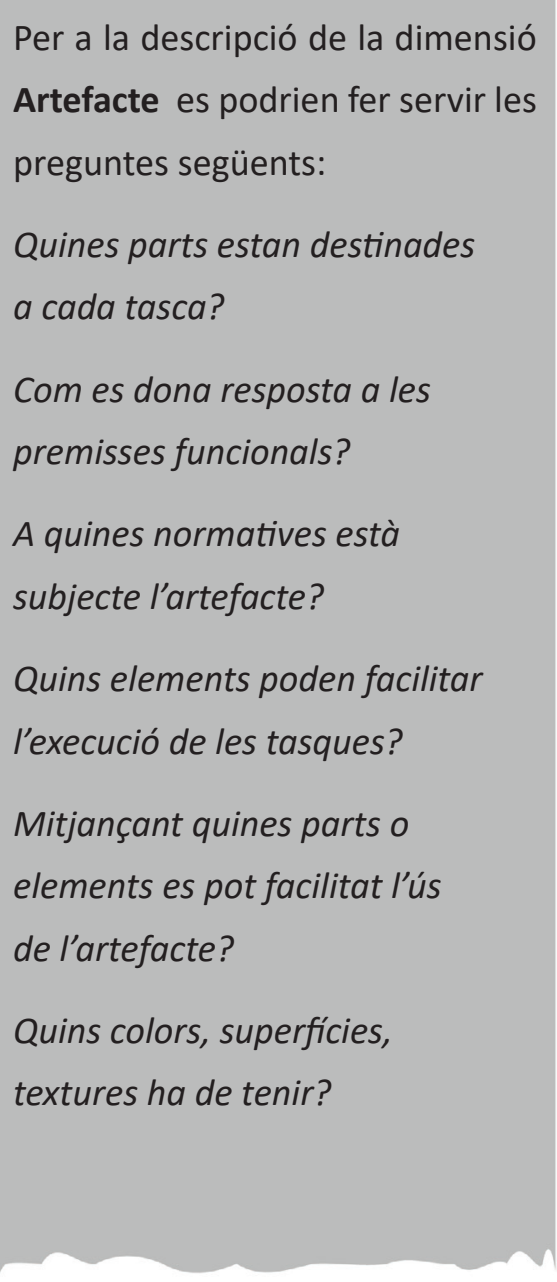
de paret, la de sobretaula i la làmpada penjant. $\mathrm{O}$ si simplement, l'artefacte forma part d'una família amb ventall de dimensions, com podria ser la cafetera express, on podem trobar l'opció d'una tassa, dues, tres, etc. dins de la mateixa configuració d'artefacte. Aquest aspecte es converteix fàcilment en premissa de disseny, i vindria donat per un anàlisi dels desitjos i necessitats de l'usuari.

Naturalment, des de la dimensió Artefacte també es tenen en compte les funcions accessòries, que són aquelles que recolzarien les funcions secundàries definides a la dimensió Finalitat. També inclouen, però, altres funcions accessòries pròpies de la configuració de la màquina $\mathrm{i}$ que no tenen perquè ser del coneixement de l'usuari. Per exemple, elements que puguin ser necessaris per a l'equilibri de l'artefacte, però no tenen res a veure amb el seu ús. 
Per altra banda, aquesta dimensió també és la que preveu aspectes nocius i riscos per la persona i elabora premisses de disseny que n'impedeixin l'execució.

Cal fer especial esment que la dimensió Artefacte sempre respon a les característiques i capacitats de la persona.

Fins aquí la descripció de les diverses dimensions i com s'estructuren les variables que en formen part. Un cop més, cal fer esment de la interdependència entre una i altra dimensió, ja que les premisses projectuals que defineix una dimensió afecten la presa de decisions d'una altra dimensió. De fet, aquesta estructura sistèmica de causa/efecte dona valor a l'ús de les dimensions per l'observació de la quotidianitat, ja que mostra la realitat com un tot, i no com a parts independents, les decisions de disseny tenen conseqüències, tant pel propi artefacte, com per la seva relació amb el món. Per exemple, quan l'anàlisi d'usabilitat executat des de la dimensió Acció ha comprovat que el plat no serveix per traslladar menjars amb suc ja que s'esdevenen massa errors, ha provocat una modificació de l'artefacte per assegurar que una de les funcions (objectius) descrites en la dimensió Finalitat es faci realitat. L'estructura d'anàlisi ha de contribuir en l'elaboració d'una anàlisi extensa i profunda, per aconseguir que les premisses de disseny siguin el més clares, precises, i sobretot encertades, possibles; i que no es contradiguin unes a les altres

Com ja s'ha dit, les diverses dimensions dibuixen l'eix horitzontal, transcorren per les files, a l'eix vertical s'hi troben les diverses fases del projecte, que transcorren per les columnes, i que es descriuen en els apartats següents, fins a l'elaboració del brief de projecte.

Després de la taula amb la informació més rellevant de cada dimensió, s'inclouen les cinc fitxes de treball corresponents. Aquestes fitxes són l'eina de treball inicial per començar a treballar en la recerca. És a dir, la fitxa serveix perquè el dissenyador tingui una guia d'elements a tenir en compte, una espècie de check list però amb espais per omplir i fer una prospecció inicial. Això significa que no és un document final, sinó una eina de treball.

Cada fitxa es divideix en dues zones, la zona superior és explícita per cada fitxa, la zona inferior predisposa per a l'organització de les necessitats — vegeu figures de 35 a 39—. 
Taula 3 Resum de les variables de cada dimensió

\begin{tabular}{|c|c|}
\hline $\begin{array}{l}\text { Les dimensions } \\
\text { del projecte } \\
\text { Les dimensions depenen } \\
\text { unes de les altres }\end{array}$ & $\begin{array}{l}\text { Les variables de finalitat guien la intenció del projecte } \\
\text { Les caracteristiques i capacitats de la persona son inqüestionables } \\
\text { L'experiència d'ús (dimensió Acció) aporta valor a l'artefacte } \\
\text { Les variables d'artefacte defineixen la configuració, la innovació } \\
\text { Les variables d'entorn posicionen l'artefacte }\end{array}$ \\
\hline $\begin{array}{l}\text { Dimensió Finalitat } \\
\text { Tot allò relacionat amb } \\
\text { l'objectiu de l'artefacte } \\
\text { o servei }\end{array}$ & $\begin{array}{l}\text { Objectiu principal per a què es dissenya? } \\
\text { Objectius secundaris allò que complementa i amplia l'objectiu principal } \\
\text { Metes què aporta més enllà dels objectius concrets? Visió genèrica de la finalitat } \\
\text { Propòsits intencions, quin és l'objectiu a llarg termini? Com contribueix al } \\
\text { bé comú? }\end{array}$ \\
\hline $\begin{array}{l}\text { Dimensió Persona } \\
\text { Tot allò relacionat amb les } \\
\text { caracteristiques, } \\
\text { limitacions i possibilitats } \\
\text { humanes }\end{array}$ & $\begin{array}{l}\text { Defineix l'usuari principal, però també usuaris secundaris com personal } \\
\text { tècnic o de manteniment } \\
\text { Defineix les característiques físiques de les persones: antropometria, } \\
\text { capacitat d'esforç, equilibri, postura } \\
\text { Defineix les característiques psicològiques i cognitives: capacitat de } \\
\text { comprensió, coneixement tàcit, percepció } \\
\text { Defineix les característiques socioculturals } \\
\text { Reconeix la diversitat funcional } \\
\text { Descriu els desitjos, necessitats i problemàtiques de les persones }\end{array}$ \\
\hline $\begin{array}{l}\text { Dimensió entorn } \\
\text { Tot allò relacionat amb el } \\
\text { que envolta l'artefacte }\end{array}$ & $\begin{array}{l}\text { Defineix el lloc on habitualment s'utilitzarà l'artefacte: públic o privat, in- } \\
\text { terior o exterior, ... } \\
\text { Defineix el seu posicionament sociocultural: tendències, gustos, costums } \\
\text { Defineix el seu posicionament dins d'un sistema superior o si forma part } \\
\text { d'un subsistema. Defineix el posicionament en el mercat }\end{array}$ \\
\hline $\begin{array}{l}\text { Dimensió Acció } \\
\text { Tot allò relacionat amb } \\
\text { les activitats i les tasques }\end{array}$ & $\begin{array}{l}\text { Defineix moments d'ús: emmagatzematge, repòs, ús, manteniment, repara- } \\
\text { ció. Defineix conceptes d'usabilitat } \\
\text { Defineix seqüencies de comunicació amb l'artefacte (interfícies, botons, } \\
\text { mecanismes, etc.) } \\
\text { Defineix la capacitat de control i maneig }\end{array}$ \\
\hline $\begin{array}{l}\text { Dimensió Artefacte } \\
\text { La resposta de l'artefacte } \\
\text { a totes les necessitats, } \\
\text { problemàtiques i desig de } \\
\text { la resta de dimensions }\end{array}$ & $\begin{array}{l}\text { Defineix les funcions tècniques de l'artefacte } \\
\text { Defineix les parts i mecanismes: zones practicables, fixes o mòbils, peces } \\
\text { Defineix característiques físiques: pes, resistència, materials, acabats, es- } \\
\text { tètica, etc. } \\
\text { Defineix tipologies i famílies, i capacitat d'adaptació } \\
\text { Defineix funcions accessòries } \\
\text { Prevé aspectes nocius i riscos per la persona }\end{array}$ \\
\hline
\end{tabular}




\section{DIMENSIÓ FINALITAT}

\section{Objectiu principal}

Respon a la pregunta, amb quina finalitat? Quina activitat humana facilita?

Altres funcions

Més enllà de complir amb l'objectiu principal, quines altres funcions inclou? Quines subfuncions complementen la funció principal?

\section{Propòsits i metes}

Com contribueix a la societat? Quina empremta vols deixar?

\section{Què necessito per traslladar aquestes variables a l'informe de disseny?}

Les variables de finalitat van llistades mitjançant objectius del projecte. Defineixen els objectius que sempre cal tenir presents. Em falta alguna informació per a completar aquesta llista d'objectius?

On i com trobo la informació necessària?

Quan estarà acabat aquest apartat? 


\section{DIMENSIÓ ACCIÓ}

\section{Accions realitzades}

Quines accions es realitzen per aconseguir els objectius definits? La informació de l'storyboard serà útil per descriure-les

\section{Experiència d'usuari i funcions d'estima}

Expectatives d'ús, valor d'estima

Moments d'ús, desús, repòs

Quines accions tenen lloc en cada un dels diversos moments d'ús?

Seqüencies de comunicació

Com es comuniquen l'artefacte i la persona? Hi ha botons? Interfícies? Mecanismes?

Qui fa què?

Qui executa les accions, la persona, l'artefacte?
Capacitat de control i maneig

\section{Què necessito per traslladar aquestes variables a l'informe de disseny?}

Les variables d'acció es plantegen mitjançant l'stroryboard (fent referència a l'experiència d'usuari) i es concreten mitjançant les taules d'usabilitat.

Em falta alguna informació per a completar la llista d'accions?

On i com trobo la informació necessària? 


\title{
DIMENSIÓ PERSONA
}

\author{
Variables físiques \\ Antropometria, postura, biomecànica, esforç físic, diversitat funcional
}

Variables psicològiques

Capacitat sensitiva, de reacció. Comprensió de l'artefacte. Percepció. Capacitat d'aprenentatge. Diversitat funcional

Variables socioculturals

Quines caracteristiques cal tenir en compte?

\section{USUARI ARQUETIP}

\section{Per a qui és?}

Nom:

Edat:

Estudis:

Foto:

Gustos / oci: Música, cine, sèries, esports...

Somnis:

Expectatives:

Per què fa servir aquest artefacte?

Per què no voldria fer-lo servir mai?

\section{Altres usuaris}

Manteniment, neteja, compra... altres requeriments

especials?

\section{Què necessito per traslladar aquestes variables a l'informe de disseny?}

Les variables de persona són moltes i molt diverses. És imprescindible dibuixar esquemes antropomètrics i definir percentils, així com reflexionar sobre postures adquirides y els esforços requerits. Pot haver-hi més d'un usuari arquetip.

Em falta alguna informació per a completar les variables de persona?

On i com trobo la informació necessària?

Quan estarà acabat aquest apartat? 


\section{DIMENSIÓ ENTORN}

\section{On i quan s'utilitza l'artefacte?}

Més enllà d'estar situat en els serveis d'un centre comercial, cal especificar alguna cosa més?

\section{De quin sistema forma part? De quin} subsistema?

Què cal tenir en compte que sigui extern al propi artefacte? Normatives?

\section{Condicionants econòmics}

En quin rang de preu està l'artefacte? Posicionament de mercat, és un producte de luxe? És un producte bàsic?

\section{Condicionants socioculturals}

Quines qüestions cal tenir en compte? Com es posiciona l'artefacte en societat? És conegut? Fa falta explicar com funciona? Fa falta explicar-ne alguna norma d'ús? Forma part d'alguna tendència? Un moodboard pot ajudar-te a emmarcar-lo.

\section{Espai}

Cal tenir en compte algun element? Temperatura, humitat, vibracions, soroll, il/luminació? Espai públic o privat? Interior o exterior?

\section{Què necessito per traslladar aquestes variables a l'informe de disseny?}

Les variables d'entorn posicionen l'artefacte en relació amb tot allò que l'envolta i que pot tenir influència sobre la seva configuració.

Em falta alguna informació per a completar la llista d'elements a tenir en compte?

On i com trobo la informació necessària?

Quan estarà acabat aquest apartat? 


\title{
DIMENSIÓ ARTEFACTE
}

\author{
Funcions tècniques \\ Què inclou? Rodes, portes, tancaments? És autoportant? Plejable? Va fixat a algun lloc? Té peces fixes o mòbils?
}

Característiques físiques

Pes, resistència, materials, acabats, estètica

\section{Funcions accessòries}

Quins complements té? S'hi poden afegir altres funcions? És personalitzable? Forma part d'una familia?

Referents i antecedents

\begin{tabular}{|l||l||l|}
\hline Referents formals & Referents funcionals & \\
& & \\
& & \\
\end{tabular}

Què necessito per traslladar aquestes variables a l'informe de disseny?

Les variables d'artefacte configuren l'objecte i han de respectar les premisses definides en totes les altres variables, posant a la persona en primer terme.

Em falta alguna informació per a completar la definició de l'artefacte?

On i com trobo la informació necessària?

Quan estarà acabat aquest apartat? 


\subsection{Fases de divergència}

Com s'ha vist al llarg del treball, les fases de divergència estan caracteritzades per la descoberta. Per tant, en el procés de recerca formaran part d'aquest grup les fases Organitzar i Buscar, a través de les quals s'organitza la recerca i s'omple de contingut necessari pel projecte.

\subsubsection{Fase Organitzar}

La fase Organitzar és un pas inicial i imprescindible que ha de permetre organitzar la recerca, bàsicament, en dos sentits. Per una banda, plantejar-la conceptualment, saber-ne l'objectiu, l'abast, la intenció inicial i en quin àmbit pretén contribuir. Per l'altra banda, estructurar les accions a dur a terme, temporitzar-les i repartir responsabilitats. Fruit d'aquesta fase, sorgeix el pla de recerca, que fa referència a la recerca en general; i el pla d'acció inicial, que fa referència a directament a la fase següent, la fase Buscar.

En resum, amb la fase Organitzar s'haurien d'aconseguir els següents objectius:

1. Refermar la hipòtesi inicial del projecte

2. Posicionar el coneixement inicial de l'equip sobre l'àmbit de la recerca i distribuir responsabilitats

3. Establir prioritats de recerca i els seus objectius

4. Definir el tipus de recerca, els mètodes i, de forma genèrica, el resultat esperat

5. Delimitar un marc d'actuació per definir l'abast de la recerca i el seu context

6. Organitzar, estructurar i temporitzar la recerca fins a l'elaboració del brief

7. Recollir aquesta informació (punts 1-6) en el pla de recerca 
8. Elaborar un pla d'acció inicial per la fase Buscar amb els responsables de les accions que es decideixin dur a terme, el material necessari, la definició de com es realitzaran i la seva temporització, així com el format de les dades i el seu emmagatzematge

El pla de recerca té una fitxa com a ajuda per a la seva elaboració — vegeu figura 40-. En aquesta fitxa apareixen els ítems principals a tenir en compte per plantejar i estructurar la recerca. Com qualsevol altra fitxa, és un document de treball, no un document final. Per al treball en equip, l'exercici de posar-se d'acord per omplir les fitxes assenta les bases del projecte i posiciona a tothom en el mateix punt de sortida. Si es treballa individualment, el fet de plantejar certes preguntes i haver-ne d'escriure les respostes, també assenta les bases del projecte. Així doncs, el primer pas és refermar allò que se sap del projecte i posar-ho per escrit.

El primer punt és la hipòtesi de treball, una frase assertiva que aporta projecció de futur que ha de guiar la recerca, com a mínim en els seus passos inicials, fins que es pugui revisar i afinar. La hipòtesi és la raó de ser de la recerca. Aquesta hipòtesi serà molt vaga si es treballa des d'un enfocament preliminar, i serà més concreta si es treballa des d'un encàrrec. També és interessant descriure els objectius de la recerca i establir prioritats. La intenció del pla de recerca, a part de temporalitzar les fases, és posicionar-la en context i refermar-ne l'abast. No és el mateix una hipòtesi inicial per millorar l'experiència de pagament al supermercat, que una hipòtesi inicial per millorar l'experiència de compra en general. L'abast de les dues hipòtesis és molt diferent. Fins i tot, es podria afinar més, i restringir la situació en millorar l'experiència de pagament al supermercat en hora punta. El focus de la recerca i la intenció varien en els tres casos, i per tant, també les accions que caldrà desenvolupar per recollir informació pertinent pel projecte.

La fitxa també inclou un espai per especificar el tipus de recerca que es vol dur a terme i quins mètodes es volen fer servir, així com els resultats que se n'esperen. Tot plegat de forma genèrica, perquè s'acabarà de concretar a través del pla d'acció inicial que especifica les accions a realitzar per a la fase Buscar. 
PLA DE RECERCA

hipòtesi:

objectius de la recerca:

prioritats de recerca

abast i context: delimita l'espai, els horaris, les accions,... estableix restriccions

tipus de recerca, mètodes i resultats esperats

estructura i temporització de la recerca

\begin{tabular}{|c|c|c|c|c|}
\hline $\begin{array}{l}\text { ORGANITZAR } \\
\text { pla de recerca }\end{array}$ & $\begin{array}{l}\text { BUSCAR } \\
\text { dades }\end{array}$ & $\begin{array}{l}\text { ANALITZAR } \\
\text { insights } \\
\text { evidències }\end{array}$ & $\begin{array}{l}\text { DEFINIR } \\
\text { repte de disseny } \\
\text { i premisses } \\
\text { projectuals }\end{array}$ & $\begin{array}{l}\text { COMUNICAR } \\
\text { BRIEF }\end{array}$ \\
\hline data de finalització & data de finalització & data de finalització & data de finalització & data de finalització \\
\hline
\end{tabular}

Fig. 40 Fitxa Pla de recerca 


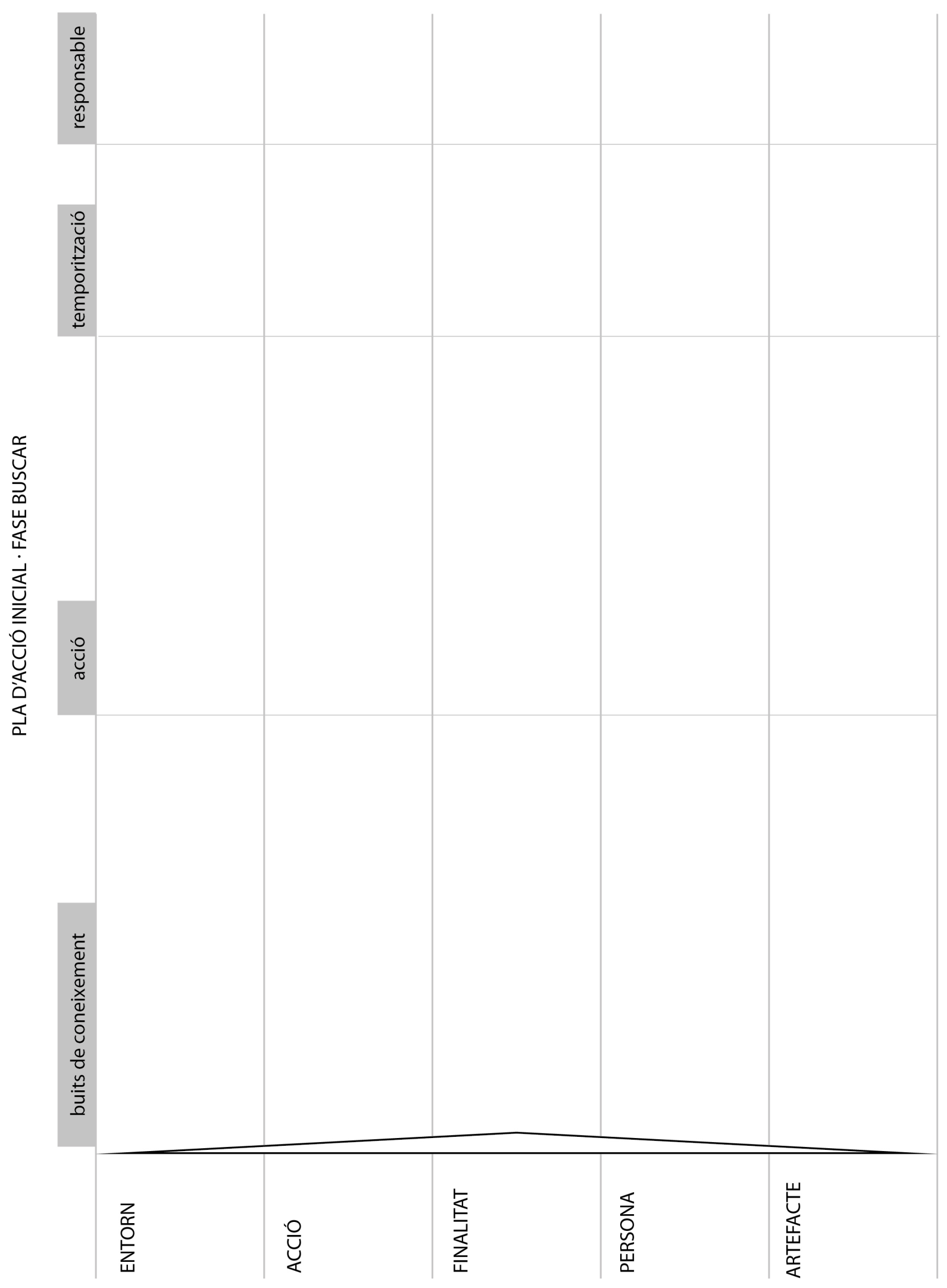


Finalment, i no menys important, la fitxa inclou un espai per a la temporització de les fases. Un altre apartat imprescindible és organitzar la recerca de forma temporal, des de la data de lliurament del brief com a punt final i avançant enrere per distribuir les diverses fases en el temps. Per definir la temporització, és necessari tenir present certs moment d'iteració per solucionar algun contratemps que pugui sorgir, tot i que habitualment, el temps mai és tant com es voldria.

Per a preparar i estructurar concretament la fase Buscar, el primer pas és definir quin coneixement es té, de quines dades es disposa i de quines no. És a dir, quina informació imprescindible, es considera necessària, però no es disposa d'ella. Aquests buits inicials, revisats a través de cada dimensió, marcaran el punt de partida de la recerca.

En l'esquelet de la metodologia per la recerca es veu com a la columna Organitzar ja s'hi creuen les cinc files amb cada dimensió. Aquesta estructura permet avançar per cada una de les dimensions, desxifrant el coneixement existent i els buits de coneixement. Per al primer, caldrà afegir com verificar la informació; en els buits de coneixement, s'hi afegirà on es pot trobar la informació pendent. Es tracta de decidir què es necessita saber, què és pertinent. En funció de la complexitat del sistema, l'abast de les variables de cada dimensió i la relació entre elles, també serà diferent. També hi ha un fort component temporal que delimita l'abast de la recerca i que cal tenir sempre present.

La casuística és infinita, per això és necessària una estructura flexible i adaptable a cada situació. En principi, però, es marcaran dos punts de partida possibles. Per una banda, la intenció de millorar en algun aspecte algun artefacte, sistema o servei existent. Per altra banda, la marcada intenció cap a la innovació, és a dir per al desenvolupament d'un artefacte, sistema o servei inexistent fins el moment. Un cop més, la intenció inicial pot veure's modificada, però marcarà des d'un principi l'observació i recerca d'informació, i també la detecció d'evidències, desitjos i necessitats de les persones. Això està relacionat amb la piràmide d'habilitats que presenta Arnal (2017) amb les diferents maneres d'afrontar els problemes del dissenyador — vegeu apartat 2.4.1 El procés projectual一. És a dir, que l'enfocament de les preguntes a respondre són molt diferents si allò que es vol és resoldre un 
problema, qüestionar i redefinir el problema, descobrir el problema o fer-lo rellevant. Tot i que la metodologia es pot aplicar en qualsevol dels casos, en principi, la intenció d'aquest tipus de recerca des del fuzzy front end, és descobrir el problema.

En qualsevol cas, un dels objectius d'aquesta fase és definir, entre d'altres, aquest tipus de qüestions conceptuals, ja que d'alguna manera cal emmarcar i definir l'abast del projecte. Si és un treball en equip, com sol ser habitual, és imprescindible posar-se d'acord amb aquests aspectes de manera que tothom tingui clar com enfocar la recerca i no apareguin problemes de base —això, es veurà reflectit en el pla de recerca一.

Per tant, un pas imprescindible és haver definit el sistema de forma global, és a dir la seva envergadura i complexitat, què engloba, i si existeixen restriccions inicials d'algun tipus —-per exemple temporal o de recursos-. Aquí s'entén el sistema de forma genèrica, inclou l'artefacte i el servei del qual pot formar part, és el primer pas per a emmarcar l'abast del projecte. Per fer-ho cal tenir en compte el seu origen, l'encàrrec o autoencàrrec, cap on es vol dirigir, és el punt clau per definir la dimensió de l'artefacte que marcarà la tendència de les evidències, i la direcció i pes de les premisses.

Per exemple, es pot definir el sistema segons les accions de l'usuari. És a dir, com es relaciona amb l'artefacte. Què es vol que la persona faci? Com es vol que la persona interaccioni? Aquesta seria la visió que plantegen Hekkert i van Dijk (2011), tal i com s'ha vist a l'apartat 2.2.4.1. Experiència d'usuari. Metodologia sorgida a la Universitat Tècnica TUDelft.

També es pot definir el sistema segons l'objectiu fruit de la relació de l'usuari amb l'artefacte. És a dir, què es vol aconseguir? És un artefacte per? Aquesta seria una visió clàssica del disseny de producte, i el seu principi racionalista de "la forma segueix la funció".

Una tercera possibilitat és definir el sistema segons la Persona, fruit d'una aproximació empàtica on el dissenyador és capaç de desxifrar problemàtiques, desitjos i necessitats de la persona. Aquesta seria la visió del disseny generatiu que proposen Sanders i Stappers (2012). Definir el sistema segons la dimensió Artefacte és una altra possibilitat, en aquest cas es 
parlaria d'un tipus de projecte on el material de l'artefacte, o els processos de fabricació, són el punt clau de la reflexió. Per exemple, projectes de recerca aplicada on es busquen possibilitats d'aplicació d'un material com podria ser les possibilitats d'aplicació del grafè. Finalment, l'última possibilitat és definir el projecte segons les característiques de l'entorn. Això seria propi de projectes on les característiques ambientals marquessin el desenvolupament del projecte, o també projectes que volen donar resposta a certes tendències existents. Sigui quin sigui l'origen de la recerca, i es posi el pes en una o altra dimensió, sempre, indiscutiblement, caldrà respectar la persona i prendre decisions per defensar i millorar-ne el benestar.

Un cop definit el sistema, i tenint clar el posicionament inicial sobre el tema, es poden establir les prioritats de recerca i a partir d'aquí, elaborar el pla d'acció on s'especifica qui porta a terme les accions - entrevistes, observació, recerca de referents, recerca de fonts secundàries, etc.-, quan i com es realitzen aquestes accions, i no menys important quin material s'aconsegueix amb la realització d'aquestes accions. És a dir, a part del contingut, quin format tindran les dades recol·lectades — fotos, àudios, esbossos, textos, etc.- En conseqüència, el pla d'acció també ha de tenir en compte on i com s'emmagatzemen les dades, si per exemple, es comparteix tot en un drive al núvol, i amb quin arbre organitzatiu es guarda.

Aquest pla d'acció prepara la recerca per a la fase següent, la fase Buscar, es pot treballar a través de la seva fitxa - vegeu figura 41-, per organitzar les diverses accions que es duran a terme per a recol-lectar la informació necessària. En principi, com més definida sigui la hipòtesi de treball, més precisa serà la recerca d'informació. Molt probablement, amb una hipòtesi inicial vaga, la recerca s'iniciarà amb una observació i unes entrevistes més o menys genèriques. De totes maneres, i com ja s'ha dit uns paràgrafs més amunt, les accions a desenvolupar també estan relacionades amb l'enfocament que prengui la recerca en general. En qualsevol cas, aquesta fitxa distribueix les necessitats d'informació i les accions a desenvolupar, així com el responsable d'aquestes accions i la seva temporització a través de les cinc dimensions del projecte. 


\subsubsection{Fase Buscar}

Gràcies a la fase Organitzar ha quedat definit el procés d'actuació i s'ha decidit com recollir la informació: entrevistes, observació, recerca bibliogràfica, etc. Depenent de la informació necessària serà adequat fer servir una o altra tècnica per obtenir informació - vegeu apartat 2.4.2.1 Recol·lecció de dades pel projecte de disseny-. És el punt de partida de la fase de recerca pròpiament dita, el resultat d'aquesta fase és, per tant, un seguit de dades.

Una part bàsica de la recollida de dades és com es guarden i es preparen per al seu anàlisi. L'envergadura marcarà la necessitat més i menys metòdica del procés, però en qualsevol cas, cal organitzar la informació de manera que sempre sigui recuperable, i per tant, fàcilment localitzable.

Per altra banda, cada dimensió té una forma pròpia, tot i que no exclusiva, per a la recollida de dades, en moltes ocasions, però, els mètodes de recerca també variaran si es tracta de la definició de nous reptes de disseny, o de la revisió d'artefactes i reptes de disseny existents, és a dir, si la recerca és més concreta o més inicial. Aquestes eines de recerca estan manllevades d'altres disciplines tal i com s'ha vist extensament en el capítol II, sobretot en referència a les eines i mètodes de l'etnografia, ja que es pretén una aproximació empàtica a l'àmbit de recerca. A les escoles de disseny, es reclama a l'alumne que realitzi aquestes accions de recerca, que sigui ell mateix qui surti a buscar informació allà on sigui necessari pel projecte i que ho faci de forma vivencial, apartant-se de recursos digitals que necessitarà per complementar la recerca. És a dir, s'aposta per la pròpia recol·lecció de dades amb el convenciment que, fent-ho així, el dissenyador serà capaç de descobrir les evidències que el portaran a definir un bon repte de disseny.

Per exemple, la forma pròpia de recollida de dades de la dimensió Acció, és l'aproximació etnogràfica, l'empatia i sobretot l'observació. Amb el projecte més avançat, o en el cas de la revisió d'un artefacte o servei ja existent, també li són propis protocols d'anàlisi d'usabilitat, i definició de l'experiència d'usuari. Recuperant la intensió de la dimensió Acció cal 
dir que és la dimensió que té a veure amb les activitats i les tasques que l'usuari executa dins de la unitat funcional que es vol millorar, respon a les preguntes què? i com? Aquesta unitat funcional pot tenir més o menys envergadura, però ajuda a delimitar l'abast de la recerca. Per exemple, una unitat funcional pot incloure l'activitat de rentar-se les mans en un bany públic. Al seu torn, aquesta activitat inclou diverses accions: mullar-se les mans, posar-hi sabó, esbaldir-les i eixugar-les. A partir la dimensió Acció, i a través de l'observació, es descriurà com es duen a terme aquestes accions, si són certes i sempre ocorren o si la gran majoria de persones se salta el sabó o l'eixugar-se. Caldrà observar també, de forma més precisa com es desenvolupen les accions, com s'accionen els artefactes, si tenen accionament mecànic o si l'aigua surt gràcies a l'avís d'un sensor que detecta la presència de les mans, quanta estona s'hi dedica, si falla alguna cosa, i quantes vegades falla, o vessa. També caldrà apartar una mica la mirada de l'activitat de rentar-se les mans en sí, i observar estratègies de les persones, què fan amb les bosses que porten o si es treuen els anells, on ho deixen, etc. O també és interessant establir seqüències d'accions: mullar, sabó, fregar esbaldir / sabó, mullar, fregar, esbaldir, eixugar.

El resultat de l'observació són, en principi, fotografies i notes de camp on s'apunta tot allò observat. Cal incloure, per a la seva posterior anàlisi, dia, lloc i hora de l'observació, així com qualsevol altra informació tècnica rellevant que es consideri oportuna. Tot aquest material es farà servir en la següent fase Analitzar, per a l'elaboració del mapa d'accions de l'usuari, l'user journey map.

Com s'ha vist a l'apartat anterior, la dimensió Persona és una dimensió complexa ja que té tres branques molt marcades. Per una banda, tot allò que té a veure amb consideracions subjectives relacionades amb els raonaments i els perquès de les persones, així com les seves expectatives, necessitats i grau de satisfacció, que fa referència a les variables psicològiques. Per una altra banda, tot allò que té a veure amb les variables físiques, punt estretament lligat amb l'ergonomia clàssica que inclou antropometria, esforç físic, postura, etc. I, finalment, les variables d'ús, estretament lligades amb la dimensió Acció que parla de formes i costums d'utilització. 
Les eines pròpies de la dimensió Persona per a les seves variables psicològiques, són els processos $\mathrm{col} \cdot$ laboratius que permeten indagar en els raonaments i perquès de les persones, o també, si no s'inclou a l'usuari en el procés de disseny, les entrevistes són la font més directa d'informació, o les enquestes. Cada una d'aquestes eines és vàlida per obtenir informació de l'usuari que ajudi a completar la pregunta qui? Tot el material obtingut en relació a la persona, es concretarà durant l'anàlisi de dades en un, o diversos, usuaris arquetip a través de l'eina Persona.

Com en qualsevol altre pas de la recerca, abans de fer-lo, cal preparar-lo bé, també és el cas de les entrevistes. En aquest sentit, es proposa una fitxa de preparació per a l'entrevista -vegeu figura 42- que recupera les necessitats informatives del pla d'acció inicial, d'aquesta manera, les temàtiques a discutir amb l'usuari venen marcades per les necessitats de la recerca, tot i que també és recomanable deixar fluir la conversa cap a altres temàtiques, és necessari tenir un guió predefinit.

Sempre és important tenir en compte com es guarda la informació recol·lectada, però en el cas de les entrevistes és especialment important. Idealment, les entrevistes sempre han d'estar enregistrades — previ consentiment de l'entrevistat — i transcrites per poder treballar amb el seu contingut de forma més efectiva. Durant la fase Analitzar es codificaran i se n'extrauran insights, però prèviament és recomanable elaborar un fitxa resum de cada una de les entrevistes amb la informació més rellevant — vegeu figura 43-. Aquesta fitxa es divideix en dues parts, la primera part és informació tècnica amb dades estadístiques i demogràfiques, així com dades de la pròpia entrevista (dia, hora, lloc de realització), o per exemple altres tipus d'informació, com si la persona ha sol·licitat l'anonimat. També està bé, sempre que la persona entrevistada ho accepti, tenir-ne una foto. I és recomanable especificar per què aquesta persona s'ha considerat adequada per a ser entrevistada, és a dir, quins característiques té que la fan interessant pel projecte.

L'altra part d'aquesta fitxa cal omplir-la just acabar l'entrevista amb les sensacions del moment, i allò que l'entrevistador pot recordar com a més rellevant i remarcable, tant sobre qüestions de contingut — què ha dit remarcable—, com sobre qüestions observades — tant 
de l'espai on s'ha fet l'entrevista, si és pertinent pel projecte, com de la pròpia persona entrevistada-, com també, sobre reaccions que hagi pogut tenir en referència a alguna pregunta, si s'ha molestat, si li ha fet gràcia, etc. ${ }^{30}$

En definitiva, aquesta fitxa actua com a resum de l'entrevista sencera, i en descriu el to i aquells elements més importants, de manera que no faci falta llegir-la tota per saber cap a quina direcció van les respostes de l'usuari i què ha dit de rellevant; no treu, però, la necessitat d'analitzar l'entrevista sencera en algun moment.

La segona gran branca de la dimensió Persona és la branca relacionada amb les variables físiques, és a dir quines necessitats antropomètriques cal tenir en compte, quines postures són sanes i cal promoure o quines postures són nocives i cal evitar. També es té en compte els esforços que suposen les diverses accions que l'artefacte i l'entorn obliguen a fer a l'usuari per aconseguir els seus objectius. Per exemple, i tornant a l'exemple del rentamans, a nivell postural es podria observar si la persona ha d'inclinar-se gaire per arribar al raig d'aigua o com ha d'allargar el braç per arribar fins al sabó. En un ideal d'execució, al qual s'aspira en el projecte, les accions realitzades seran sanes gràcies a la bona configuració de l'artefacte. Però per configurar aquest artefacte adequadament, cal recolzar-se en les taules antropomètriques, decidir els usuaris i buscar les mides que englobin més persones en un ús saludable. A més a més, no s'ha d'oblidar la diversitat funcional o la possibilitat que les persones vagin en cadira de rodes, per tant, l'alçada de la pica ha de donar resposta a la gran varietat de dimensions possibles, incloses, en un bany públic, les dimensions dels infants. Aquesta part estrictament ergonòmica requereix o bé recerca bibliogràfica de taules antropomètriques i posturals, o bé la recerca aplicada d'amidaments propis. També a nivell cognitiu, cal fer recerca bibliogràfica en referència a fonts d'informació oficials (Institut

30 En xarxa es poden trobar recursos amb tècniques i recomanacions per al desenvolupament de les entrevistes pel projecte de disseny, ja que en processos de disseny pròxims al Design Thinking, l'entrevista és una de les eines amb més importància. Vegeu per exemple els recursos en línia de la D.School associada a Stanford http://dschool.stanford.edu/ (última visita 2/07/2020) o els recursos en línia d'Ideo http://www.designkit.org/ (última visita 2/07/2020) 
Nacional de Seguretat i Higiene en el Treball, INSHT, Institut Nacional d'Estadística, INE, les normes ISO o les normes tècniques).

Les variables físiques de la dimensió Persona són bàsiques per la configuració de l'artefacte, $i$ en depenen directament les variables de la dimensió Acció, tanmateix són un tipus de variables que no solen aparèixer al principi del projecte perquè encara és aviat per definir concretament quines dades de les variables físiques són necessàries.

Finalment, l'última gran branca de la dimensió Persona són les variables d'ús. Aquí hi entren qüestions socioculturals que afecten el comportament de la persona, per exemple, en el cas del bany públic, qüestions relacionades amb la intimitat i la seguretat, la divisió dels banys entre gèneres, etc. En aquest sentit, part de la informació per a aquestes variables també seria extreta de les entrevistes i l'observació, tot i que es podria buscar suport en altres fonts secundàries, com per exemple estudis de tendències o normatives vigents.

En resum, la dimensió Persona s'endú gran part dels esforços de la recerca, perquè un dels seus objectius principals és poder elaborar un bon usuari arquetip que expliqui i respecti les seves necessitats, desitjos i problemàtiques; entendre la persona, és clau per al bon desenvolupament del projecte. Part de la informació recollida per a aquesta dimensió serà informació que s'utilitzarà per configurar l'usuari arquetip, i part de la informació es convertirà en premisses de disseny, tal i com es veurà en les fases Analitzar i Definir.

La dimensió Finalitat és la dimensió que descriu els objectius del projecte i respon a la pregunta per què? Per tant, és una dimensió que es va concretant fruit de la definició del repte de disseny. És a dir, en projectes molt oberts, la dimensió Finalitat serà molt vaga; i en projectes més concrets, la Finalitat tindrà ja certs objectius descrits. És una dimensió que en la fase del projecte Buscar no té encara gaire pes, i es concretarà de forma important en la fase Definir. Tot i així, fruit de l'observació plantejada i fruit de les accions dels usuaris o les seves necessitats i estratègies d'ús, es pot donar el cas que apareguin funcionalitats que no s'havien considerat, en aquest cas la dimensió Finalitat pot incloure aquestes noves casuístiques per ampliar-ne la recerca. 


\section{L'ENTREVISTA}

\section{PLA D’ACCIÓ INICIAL}

On tinc els principals buits de coneixement? Quins experts em poden ajudar a enfocar el projecte? Amb qui puc contrastar la meva idea inicial?

\section{OBJECTIU DE L'ENTRVISTA}

Què vull saber? Quina informació vull aconseguir? Per què em servirà aquesta informació? Em permetrà avançar en el repte de disseny les respostes obtingudes? Quin tipus d'entrevista és el més adequat?

\section{STAKEHOLDERS}

Quines característiques té la persona ideal? Per què és ideal? Edat, interessos, feina, afició, producte similar, ????

Qui és aquesta persona: CONTACTA-HI

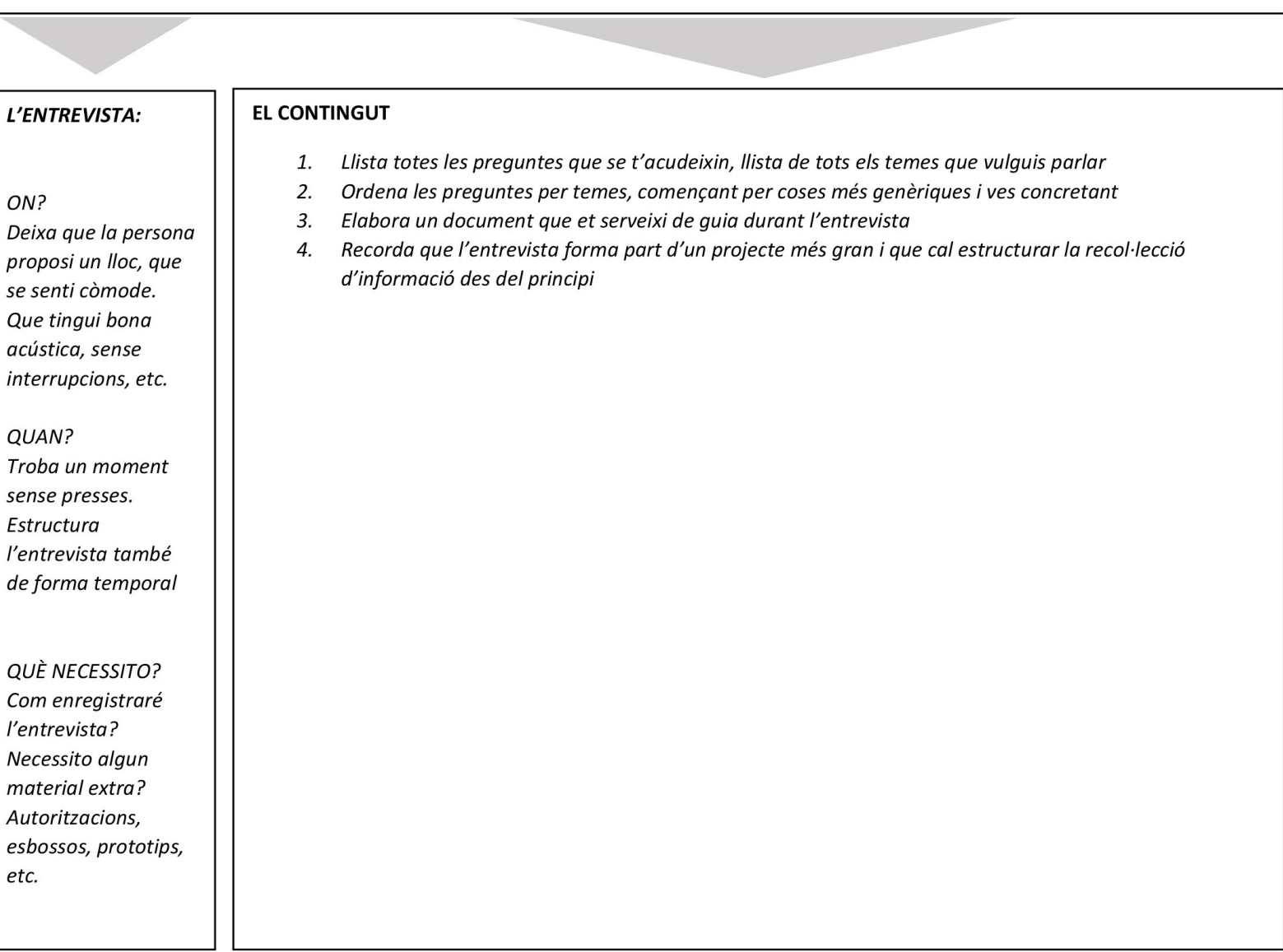




\section{Fitxa entrevista}

\section{informació bàsica i sensacions post-entrevista}

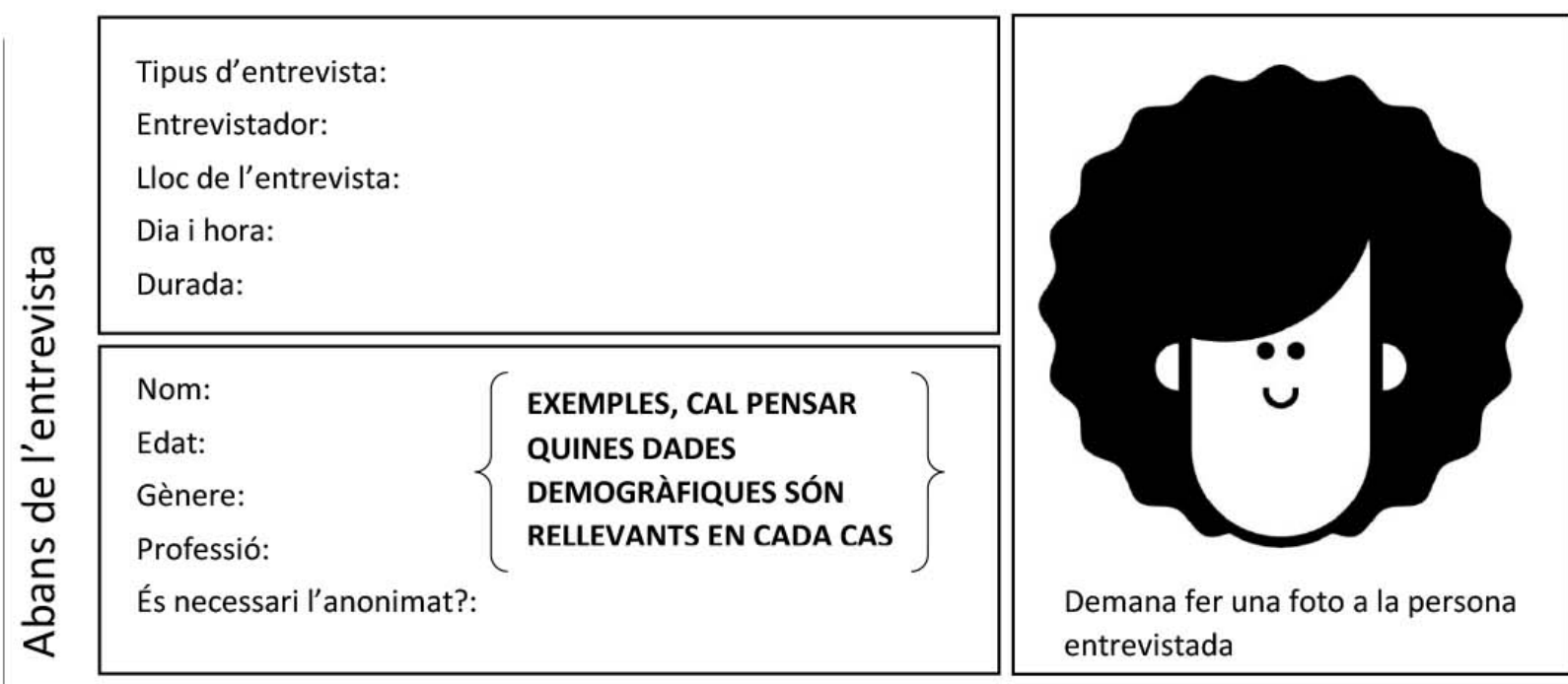

Per què l'he escollit per entrevistar-la? Quines caracteristiaues la fan la persona adeauada?

Què ha dit que sigui remarcable? Requisits, motivacions, necessitats, desitjos, etc.

Quines observacions ha fet que siguin remarcables? Alguna qüestió nova?

Quines reaccions ha tingut que siguin remarcables?

*Girl face by Oksana Latysheva des de Noun Project @ Creative Commons 
Els objectius, metes i propòsits inclosos en la dimensió Finalitat delimiten el projecte i en canalitzen els esforços, però en aquesta fase del projecte rarament estan clars, sinó que, més aviat, es concretaran a la fase Definir fruit de la recerca realitzada a les altres dimensions.

La dimensió Entorn, que respon a les preguntes quan? i on?, també té diverses branques diferenciades com ja s'ha vist en la dimensió Persona, i cada una no menys important que l'altra. Per una banda, hi ha una sèrie de variables relacionades amb el lloc on es troba l'artefacte i per tant, qüestions com si és un espai públic o privat, interior o exterior, així com qüestions de llum, temperatura i so, entren a formar part de les qüestions observables. És a dir, que amb l'observació que s'ha plantejat com a eina adequada per a la dimensió Acció, també es poden tenir en compte aquesta sèrie d'elements i introduir-los a les notes de camp, ja que tenen el seu pes tant en la satisfacció de l'usuari, com en la configuració de l'artefacte, i, per descomptat, de l'espai. Per altra banda, hi ha una sèrie de qüestions relacionades amb temes socioculturals, sobretot en relació a les tendències, gustos i costums. Per això, en relació a la dimensió Entorn, és adequat fer una recerca d'informació relacionada amb el què està passant a la societat. L'objectiu d'aquesta recerca és l'encaix del producte amb les tendències del moment, $\mathrm{o}$ amb les tendències que es poden preveure. Per exemple, i tornant al bany, en un moment on la necessitat d'higiene i desinfecció s'ha convertit en un tema de salut pública, potser cal afegir esforços en aconseguir que els banys públics es converteixin en una zona real de higiene i desinfecció. Per això es planteja la utilització d'una fitxa d'anàlisi de tendències — vegeu figura 44-, perquè durant la fase Buscar sorgeixin tendències on es podria encabir la hipòtesi de treball.

La fitxa de tendència inclou una zona per a descriure la tendència i les paraules clau que la qualifiquen. A continuació, inclou un espai per localitzar projectes que formin part de la tendència que s'està investigant, ja que és la manera de confirmar que es tracta d'una tendència que afecta diversos àmbits, com més nous siguin els projectes, millor, per assegurar que la tendència és actual. I finalment, inclou una predicció de futur a nivell social, tecnològic i de mercat, per refermar l'abast de la tendència.

Les tendències són interessants pel projecte perquè permeten presentar-lo en societat acom- 
panyat d'altres projectes d'àmbits diferents que persegueixen mateixes metes i propòsits. Per exemple, una tendència pot ser el consum responsable. En aquest sentit, projectes de tot tipus i d'àmbits diferents poden sumar-se a la tendència, i així ho pot fer també el disseny d'un bany d'un centre comercial. Aquesta tendència es pot convertir en la fase Definir, en una premissa projectual, de manera que durant el desenvolupament les decisions es prendran tenint en compte el consum responsable. En el moment actual, i enmig de la pandèmia pel covid-19, les tendències de consum o certs valors sembla que poden canviar per quedar-se. El disseny com a configurador del món futur cal que estigui ben atent per veure com va evolucionant tot ${ }^{31}$.

Finalment, l'última branca de la dimensió Entorn fa referència a la relació de l'artefacte dins del sistema del qual forma part. A aquesta branca es comporta en certa manera com la dimensió Finalitat, ja que en aquesta fase del projecte, si la hipòtesi és molt vaga, encara costa definir les necessitats informatives i on trobar-ne les dades. Tot i així, hi ha qüestions que sí que es poden tenir en compte. Per exemple, tornant a l'exemple del bany, es podria observar com la unitat funcional es relaciona amb altres unitats funcionals pròximes. És a dir, com es relaciona el sistema per rentar-se les mans amb el sistema de l'inodor, o amb el sistema que l'acull, un centre comercial, un museu o una estació. Per sota, trobarà altres subsistemes com el sabó que fa servir o el sistema per eixugar les manes i si cal abastir-los de material i amb quina freqüència. Per tant, per obtenir aquesta informació altra vegada es recorre a les eines de l'observació i les entrevistes, aquestes últimes també als treballadors encarregats del manteniment de les instal·lacions.

Per tant, el resultat de la fase Buscar en relació a la dimensió Entorn, seran també fotografies, notes de camp, entrevistes, un estudi de tendències i un mapa que relacioni els diversos sistemes implicats en la recerca.

31 Com a exemple de recull de tendències existeix l'Euromonitor International, que observa què passa a la societat $\mathrm{i}$ cada any presenta les 10 tendències de consum per a l'any següent. A més a més, constantment està publicant articles que expliquen tot tipus de qüestions relacionades amb la societat —vegeu més informació a https://blog.euromonitor.com/ (última visita 02/07/2020) —. 


\section{ANÀLISI DE TENDÈNCIES}

\section{TENDÈNCIA:}

\section{Descripció de la tendència}

Què és o què significa?

Causes i conseqüències

\section{Paraules Clau}

\section{Exemples reals}

Qui? Quan? On? Per què? Com?

Qui? Quan? On? Per què? Com?

Qui? Quan? On? Per què? Com?

Impactes que es preveuen

Efectes socials

Resposta del mercat

Recerca tecnològica 
Per acabar, i en relació a la dimensió Artefacte, que respon a la preposició mitjançant, la recerca sí que serà majoritàriament fora del context d'ús, ja que es basarà en la recerca de referents funcionals, estètics o conceptuals, així com la recerca d'antecedents —altres unitats funcionals iguals dissenyades amb antelació-. Aquesta recerca d'informació també pot dedicar-se a investigar materials, processos productius, sistemes organitzatius o avenços tecnològics que puguin ser útils per a la hipòtesi plantejada. Per tant, aquesta dimensió, aportarà recursos digitals, enllaços, fotos i descripcions. En algun cas, es farà en persona, llavors, la informació aportada, seran notes de camp, fotos i entrevistes, com ja s'ha comentat en dimensions anteriors. En el moment del projecte inicial, encara és aviat per concretar més qüestions de l'artefacte, però si el projecte ja està en estadis més avançats, la dimensió Artefacte inclou qüestions directament relacionades amb la seva configuració, les parts que pugui tenir, les parts practicables, etc. És a dir, aquesta dimensió inclou característiques com modular, portàtil, autoportant, fixat a la paret, etc.

En resum, la fase Buscar s'encarrega de recopilar informació pertinent pel projecte posant especial interès en la informació obtinguda de fonts directes a través de l'observació, les entrevistes o l'experiència directa del usuaris. També inclou una part de recopilació de dades de fonts secundàries, sobretot en la branca de variables físiques de la persona i en la dimensió Artefacte. Aquesta necessitat d'informació estarà marcada pel pla d'acció inicial plantejat a la fase Organitzar. Cal dir, però, que segurament en algun moment caldrà tornar a la fase Buscar per recopilar informació que no s'havia tingut en compte o que, fruit de l'anàlisi, ha aparegut com a necessària. Sigui com sigui, i amb quin format estigui, tota aquesta gran quantitat de dades obtingudes cal emmagatzemar-les, codificar-les i preparar-les per a l'anàlisi — vegeu l'apartat 2.4.2.2 Antropologia, etnografia i enfocaments afins aplicats al disseny-. És a dir, cal posar-ho tot a punt per a poder començar amb la fase Analitzar que es descriu a l'apartat següent. 


\subsection{Pont entre divergència $i$ convergència: fase Analitzar}

Dins de l'esquema de divergència i convergència, Jones (2a ed. 1992) hi col·loca una fase de transformació. Aquesta fase de transformació es recupera conceptualment per aquest treball per configurar una fase que es troba entre la divergència i la convergència i que, precisament, transforma les dades recol·lectades durant la fase Buscar en informació útil per a la recerca. A través de l'anàlisi d'aquestes dades se n'extreu la informació rellevant i es converteixen en unitats informatives preparades per a la fase Definir, durant la qual s'assentaran les premisses projectuals i el repte de disseny. De moment, però, en aquesta fase, es tracta de transformar les dades en brut, en dades netes i presentables. Fins al moment, la recerca s'havia mantingut amb una intenció objectiva, és a dir, la selecció de dades observades o les entrevistes pretenien mantenir l'objectivitat. Però a partir de la fase Analitzar, agafa pes la intenció del dissenyador, la seva mirada i la seva capacitat d'entendre i llegir entre línies per visualitzar un futur.

Els principals objectius per la fase Analitzar són els següents: .

1. Codificar transcripcions de les entrevistes, les notes de camp i altre material existent

2. Extreure conclusions d'aquestes dades a través de la formulació de necessitats i d'insights

3. Elaborar l'usuari (o usuaris) arquetip

4. Elaborar mapes d'accions de l'usuari, l'user journey map

5. Elaborar un mapa conceptual de la situació existent

6. Revisar si falta alguna informació i plantejar com aconseguir-la

7. Revisar la hipòtesi de treball inicial i concretar-la

La fase Analitzar no cal que comenci amb la fase Buscar acabada, ja que hi ha una sèrie de tasques farragoses que es poden anar fent, sobretot el tema de la transcripció i codificació de les entrevistes i les notes de camp. Com s'ha vist a l'apartat corresponent — vegeu 2.4.2.1 Recol·lecció de dades pel projecte de disseny—, la codificació de les dades serveix 
per unificar-ne criteris de manera que es puguin comparar les explicacions de diverses entrevistes de forma àgil. Amb la codificació es fa relativament senzill localitzar les parts que comparteixen temàtica.

La gran majoria d'esforços per analitzar dades i extreure'n informació es destinen en la formalització de dos elements: l'usuari arquetip i el mapa d'accions. També, i no amb menys importància, a la detecció d'insights, evidències projectuals —vegeu 2.4.3.1 Extracció de conclusions. Els insights-.

Per tant, en aquesta fase tenen especial rellevància les dimensions Persona i Acció, ja que se'n definirà un part important. Les altres fases prenen rellevància en la detecció de necessitats, com es veurà una mica més endavant.

Fruit de tota la informació recol·lectada es formalitza un, o diversos, usuaris arquetip, que exemplificaran a l'usuari a qui va destinat el projecte. Altre cop és una eina manllevada de processos creatius com el Design Thinking o afins, i també és una eina molt utilitzada pel màrqueting. Aquest usuari arquetip és en realitat un perfil fictici que representa un grup d'usuaris particular. Tot i ser fictici, no ha de ser inventat, ja que la informació que inclou ha de sortir de les dades de la fase Buscar. Per fer-ho, cal contrastar evidències extretes de les entrevistes i agrupar-les segons interessos comuns dels diversos usuaris per crear perfils viables. En un projecte, es poden tenir diversos usuaris arquetip però no haurien de ser més de cinc o sis, ja que és poc viable donar resposta a gaires perfils. És important que l'usuari arquetip es converteixi en un plafó visual, on hi hagi una foto de la persona i tingui un nom, i on es recullin les principals característiques de l'usuari, de manera que la informació abstracte es converteixi en desitjos i necessitats de persones reals -en aquest cas, representades per un usuari arquetip-. Cada Persona, tal com s'anomena l'usuari arquetip en àmbits creatius, pot aportar característiques molt diferents d'una mateixa unitat funcional, això permet als equips de disseny definir i contrastar els diferents grups d'interès que puguin existir. Per a l'elaboració dels diversos usuaris arquetip es proposa una fitxa de treball per configurar la Persona - vegeu figura 45-, no es tracta d'un model pel plafó Persona, sinó una eina de treball per a elaborar el perfil. En aquesta fitxa apareixen els principals 
conceptes a tenir en compte. Són d'especial rellevància les qüestions psicològiques com les motivacions i les renúncies, és a dir, què fa que aquesta Persona utilitzi l'artefacte i per què deixaria d'utilitzar-lo, o també, quines expectatives té en relació amb l'ús de l'artefacte.

Hi ha una sèrie d'eines útils per ajudar a extreure aquest tipus d'informació psicològica d'entre les dades de les entrevistes. Tot i així, des d'un principi cal focalitzar-se amb aquesta intenció, per ajudar és útil fer servir un mapa d'empatia - vegeu figura 46-, pensaments, creences o sentiments no es poden observar directament, sinó que cal aguditzar la capacitat d'anàlisi i en moltes ocasions saber llegir entre línies. Aquest mapa ajuda a entendre allò que les persones volen exactament dels productes o serveis per poder-ho adaptar a les seves necessitats. Tal com indica el seu nom, pretén posar-se a la pell de les persones, conèixer el seu entorn, comprendre la visió del món i els seus desitjos i necessitats ${ }^{32}$.

Un altre tema cabdal de la fase Analitzar és formalitzar un mapa d'accions de l'usuari; per fer-ho, es recull una de les eines principals del disseny de serveis, l'user journey map —vegeu apartat 2.2.5.1 Service Design Thinking-. Tal i com s'ha vist, aquest mapa posiciona sobre una línia temporal el recorregut de l'usuari en l'ús de l'artefacte o servei. A través de moments clau, es divideixen les diferents accions realitzades i es caracteritzen segons les sensacions i estats d'ànim que provoquen a l'usuari, de manera que es promou la detecció del punts més conflictius de la interacció entre la persona, l'entorn i l'artefacte. De la mateixa manera que amb l'eina Persona, es tracta d'elaborar un recorregut fictici, però no inventat, ja que ha de ser fruit de l'observació i les entrevistes desenvolupades a la fase Buscar. Finalment, aquesta fase ha de tenir una llista d'insights fruit de l'anàlisi de les dades en general. Com s'ha vist en el capítol corresponent — vegeu 2.4.3.1 Extracció de conclusions. Els insights-, aquest element són les evidències fruit del treball amb les dades. És a dir, el treball d'anàlisi que es realitza per a elaborar les Persones i el mapa d'accions, així com el treball de codificació de les dades en general, té, en principi, una segona conseqüència:

32 Cal recordar, un cop més, que la xarxa és plana d'eines útils en el desenvolupament de l'anàlisi i que es pot recórrer a aquests recursos segons les necessitats del moment. En aquest treball, només se'n recullen algunes que es consideren especialment rellevants. 

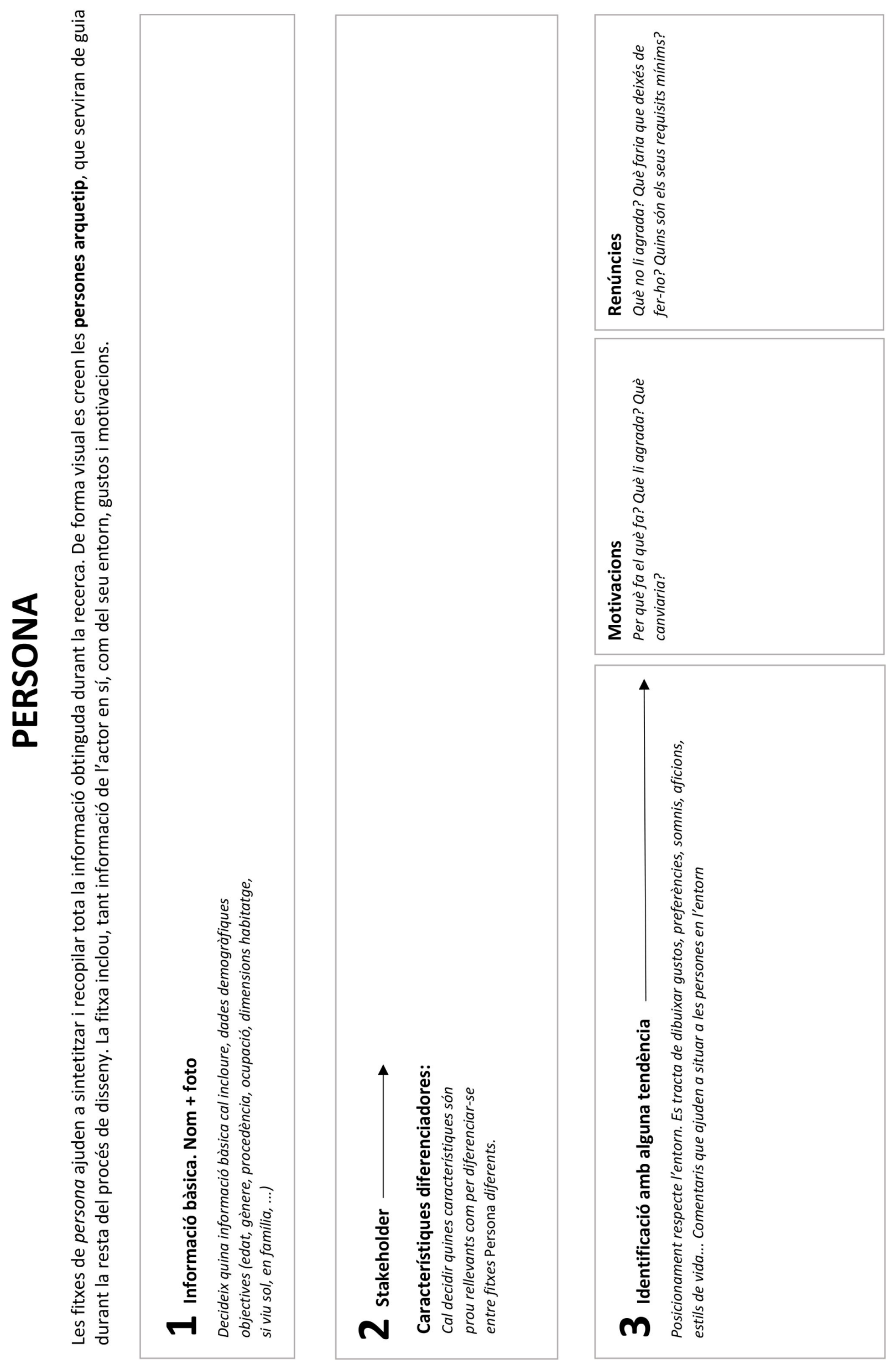

Fig. 45 Fitxa per a l'elaboració de l'usuari arquetip agrupat sota el concepte Persona 


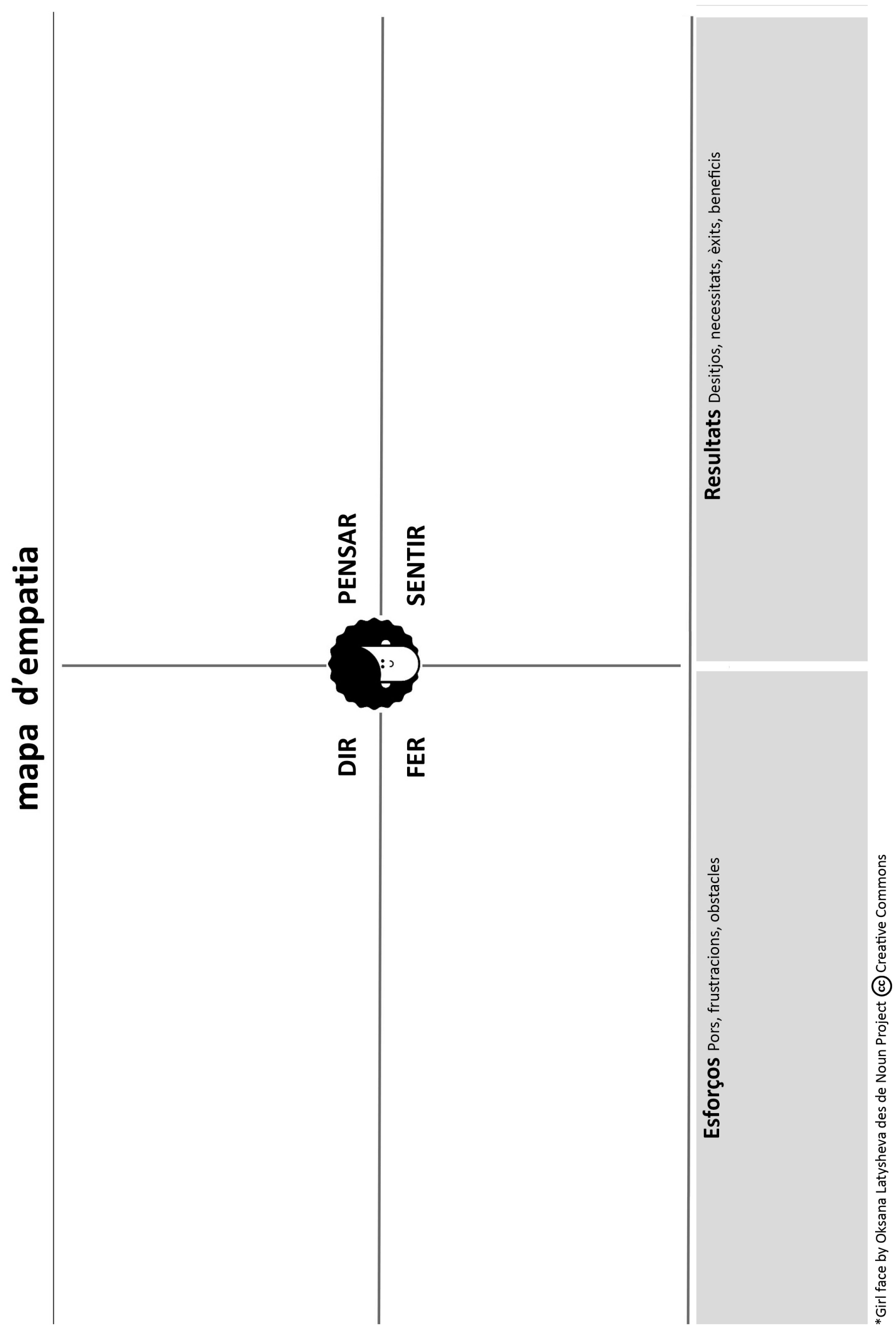


la detecció de certes necessitats. Les necessitats poden aparèixer fruit de qualsevol de les dimensions, per això es recomana, un cop més, recórrer l'esquema amb cada una de les dimensions per veure quines necessitats s'han pogut detectar en cada una d'elles i fer una anàlisi exhaustiva i holística. Per a la tasca d'elaboració d'insights es recomana l'ús de la fitxa corresponent —vegeu figura 47-. Aquesta fitxa, precisament comença amb la detecció de necessitats: requeriments humans, físics, emocionals en referència a la dimensió Persona. Requeriments funcionals, fruit dels objectius de les accions, del per què del projecte, fent referència a la dimensió Finalitat. Requeriments en relació a les tasques i les accions que es realitzen, per exemple especificant-ne el modus —més ràpid, de forma àgil, eficaç, etc.—, que fan referència a la dimensió Acció. Requeriments en relació a l'espai i a la seva distribució, relacionats amb el medi o relacionats amb les tendències i el posicionament sociocultural, fent referència a la dimensió Entorn. I finalment, requeriments relacionats amb l'artefacte, en la seva configuració — personalitzable—, en qüestions de material — resistent al vandalisme- o qualsevol altre necessitat específica de la dimensió Artefacte. Part d'aquestes necessitats, fruit de l'anàlisi de les dades recollides a la fase Buscar, es convertiran en insights. Gran part de les necessitats detectes es convertiran a la fase següent, o bé en premisses projectuals, o bé en reptes de disseny.

Tornant a la fitxa per a l'elaboració d'insights, té una primera part on especificar les necessitats detectades. Les necessitats es recomana expressar-les amb verbs perquè en realitat són desitjos futuribles, més que no pas amb substantius que porten directament a la solució. Seguint amb l'exemple del bany públic, una necessitat podria ser rentar-se les mans sense tocar cap artefacte. El següent pas que proposa la fitxa és convertir les necessitats en insights, -tenint en compte que no tenen una correspondència 1 a 1 -, a través d'una frase curta i afirmativa que expressi una possibilitat, per exemple, porcions de sabó automatitzades. Finalment, la fitxa proposa convertir els insights en possibilitats de disseny a través de la pregunta com podria? —una altra de les tècniques típiques del Design Thinking-. Seguint amb l'exemple, com podria proporcionar les unitats de sabó necessàries per a desinfectar les mans en cada rentada? 
En definitiva, la redacció de necessitats, insights i preguntes com podria?, són maneres de treballar amb les dades per extreure'n conclusions. Com ja s'ha comentat, la xarxa és plena d'eines i tècniques que ajuden a treballar amb les dades. Aquesta és una de les aportacions del Design Thinking, la capacitat de plantejar el projecte de disseny a través d'activitats aparentment petites i senzilles. Per poder-ho plantejar així, elabora documentació on s'expliquen cada una d'aquestes eines ${ }^{33}$, i habitualment són recursos oberts.

Per acabar, i fruit de tot aquest anàlisi, l'equip de disseny ha d'estar en disposició d'elaborar un mapa conceptual de la situació existent. És a dir, un mapa visual que inclogui les principals evidències detectades distribuïdes segons les accions i moments clau de la interacció en relació amb els diversos usuaris. Amb aquest mapa, es podrà definir allà on es vol posar el focus de la contribució i per tant, on es col·locarà el repte de disseny.

Per tancar la fase Analitzar, falta un últim procés de reflexió a través del qual es depura la hipòtesi de treball que fins al moment ha guiat la recerca. En aquest moment, depurar significa focalitzar-la, ja que es disposa d'informació suficient perquè deixi de ser tant vaga i comenci a ser més concreta. A més a més, fruit de les necessitats plantejades, pot ser que faci falta fer un pas cap a la fase Buscar, per acabar de complimentar informació que no s'havia tingut en compte.

En qualsevol cas, un cop les dades estan transformades en informació pertinent ja es pot passar a les fases de convergència que, com ja s'ha comentat, són fases de presa de decisions.

33 Vegeu per exemple l'àrea de recursos de la Universitat Oberta de Catalunya http://design-toolkit. recursos.uoc.edu/ (última visita 02/07/2020), o també l'àrea de recursos de Ideo per a familiaritzar-te amb el Design Thinking https://designthinking.ideo.com/resources (última visita 02/07/2020). 


\section{INSIGHTS}

\section{Identificar necessitats segons cada dimensió}

Requeriments humans, físics, emocionals, tot allò que la persona vol aconseguir. Les necessitats s'expressen millor amb verbs perquè són desitjos, futuribles, etc. no amb substantius, que ens oferirien solucions.

\section{Converteix les necessitats en insights i escull els més significatius}

Possibilitats expressades en frases curtes i afirmatives

3 Converteix els insights en possibilitats de disseny... Com podria?

Fig. 47 Fitxa per a la localització de necessitats a través de les dimensions 


\subsection{Fases de convergència}

En aquesta proposta per a una metodologia de recerca, la convergència engloba dues fases, la fase Definir i la fase Comunicar. Tal i com es veurà a continuació, la fase Definir és la fase on es prenen les decisions pel projecte, s'estableixen premisses de disseny i es defineix el repte. La fase Comunicar s'encarrega de traslladar aquesta informació en un format que pugui ser comprès per persones externes a la recerca, s'ha escollit el brief de disseny com a element de comunicació.

\subsubsection{Fase Definir}

La fase Definir és una fase especialment creativa, ja que és el moment de prendre decisions i d'enfocar el projecte. Per fer-ho es planteja treballar a dos nivells, per una banda en la definició de premisses projectuals per a cada una de les dimensions, i per l'altra en la configuració d'un futur desitjat que exemplifiqui aquestes premisses. Tot i així, cal tenir present que es tracta d'una fase més de la recerca, o sigui que no es pretenen solucions, sinó la caracterització de les solucions a través de les premisses. Precisament, com que no es pretenen solucions, el futur desitjat pot plantejar qüestions aparentment inabastables i que suposarien un vertader repte de disseny.

També en aquesta fase es defineix el repte de disseny, que planteja un desafiament per al dissenyador. Aquest repte sorgeix de la hipòtesi plantejada i es concreta a través de les necessitats. En definitiva, el repte de disseny és la conclusió de tot el recorregut realitzat fins al moment, d'alguna manera, el concepte es fa tangible ja que el repte predisposa a la transformació de la idea en un artefacte que la representi.

Per tant, per a la fase Definir es plantegen els següents objectius:

1. Concretar la recerca prenent decisions que descartin i escullin el camí a seguir 
2. Elaborar un llistat de premisses projectuals per a cada una de les dimensions

3. Plantejar un futur desitjat com a caracterització conceptual del repte

4. Concretar el repte de disseny

Tenint en compte que les propostes de solució que es generaran posteriorment, depenen de la formulació del repte de disseny, aquesta és una fase crítica de la recerca. L'equip de disseny ha de saber escollir les idees que plantegin una problemàtica, desig o necessitat real, que siguin rellevants i que ofereixin un abast abastable — per exemple, d'acord amb les restriccions temporals i de recursos-, i que no sigui ni massa vague, ni massa concret. Per a l'elaboració de les premisses de disseny, es proposa seguir l'esquema de les dimensions i transformar les necessitats detectades en premisses de disseny. En aquest cas, però, es tracta d'escollir aquelles que es consideren més adequades per a enfocar el repte, i concretar-les fins allà on es consideri oportú, recordant que no es tracta d'aportar solucions sinó de caracteritzar la solució. És a dir, per a un bany públic en relació a la unitat funcional de rentar-se les mans les premisses de disseny en configuraran la solució. Les premisses relacionades amb la persona, per exemple, aportaran dimensions i podrien concretar-se a través de la identificació de percentils: l'altura de treball de la pica ha de proporcionar un accés còmode al percentil 5 i al 95 masculí i femení, així com tenir en compte l'accés amb cadira de rodes $i$ als infants a partir de 7 anys. La solució per aquesta premissa, podria ser piques a diverses alçades, graons que facilitin l'accés dels infants, o la recerca d'una altura que acontenti els diversos rangs antropomètrics, però això, ja forma part de la solució, i per tant, del procés de desenvolupament del projecte.

Les premisses de disseny formen part de l'argumentari que aporta solidesa a la presa de decisions, ja que aporten condicionants que ajuden a refermar la solució. Per exemple, la dimensió Entorn, aporta condicionants relacionats amb les tendències i el posicionament sociocultural de l'artefacte, per tant, podria aportar un condicionant a nivell de preu de mercat: una premissa de disseny fruit de les expectatives de l'usuari que marquin el preu de venda l'artefacte ha de sortir al mercat amb un preus de venda entre 100 i 150 euros. 


\section{REPTE DE DISSENY}

\section{Hipòtesi de treball}

Hipòtesi de treball que ha guiat el procés de recerca fins al moment

Necessitats + insights

Quines són les principals necessitats detectades?

Quines evidències tenen recorregut de projecte?

\section{Principals restriccions}

Quines restriccions emmarquen el projecte?

Temporals, de recursos, per espai, etc.

Valora i escull

\section{Repte de disseny}

Redacció del repte de disseny. És recomanable començar la frase amb un verb que expressi possibilitat del tipus crear, definir, adaptar, etc.

Qüestions a les quals volem donar resposta

Principals qüestions a solucionar formulat a través de preguntes que predisposin a l'acció 


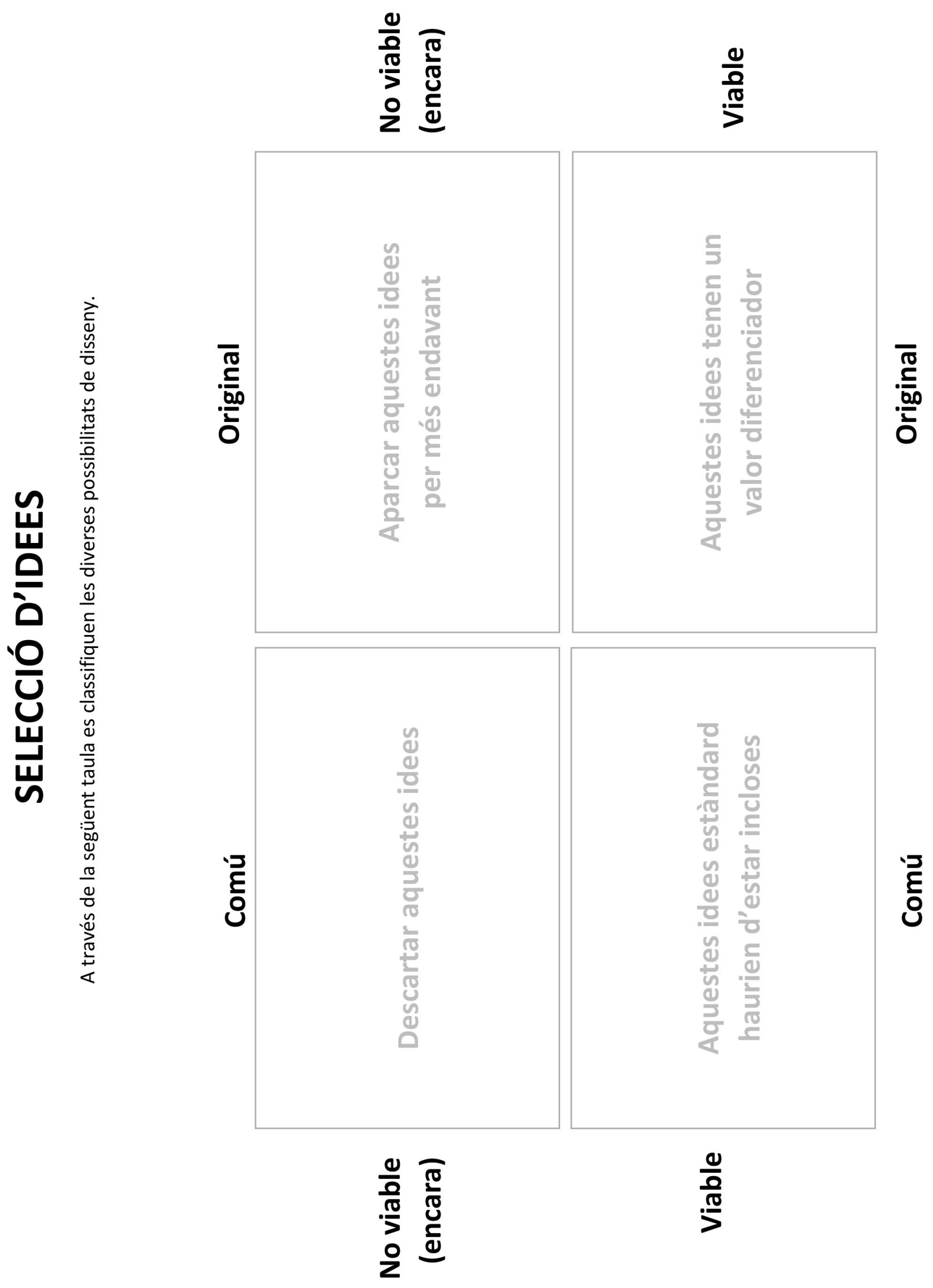


Cada dimensió té les seves premisses de disseny, Finalitat, Persona, Acció, Entorn i Artefacte aportaran premisses que poden entrar en conflicte entre elles, o contradir-se. Per tant, una de les tasques a realitzar durant la configuració de premisses de disseny és establir prioritats. En principi, a la fase Organitzar s'han definit les línies genèriques de la recerca i per tant també les seves prioritats. Per descomptat, hi ha certes premisses que haurien de ser inviolables, sobretot relacionades amb el manteniment de la salut de les persones, però moltes d'altres formen part dels criteris de disseny. Dins de cada dimensió, cal establir prioritats estratègiques per deixar clar per on es pot començar a renunciar si en algun moment fa falta fer-ho. Aquestes prioritats quedaren ben definides a la fase de Comunicació, ja que durant el desenvolupament del projecte, l'equip que el dugui a terme sàpiga quines són les premisses projectuals més importants.

Una ajuda per a la redacció de premisses de disseny és la projecció del futur desitjat. És una eina creativa que s'allunya de la teoria i es capbussa a la part aplicada a través de l'imaginari, sempre tenint en compte que és una proposta conceptual i que no pretén ser una solució, sinó una eina més de treball. Aquesta projecció del futur inclou les accions que es consideren ideals, configurades de forma ideal, fent ús d'artefactes que permeten dur a terme les accions en un entorn idoni. És a dir, que el futur desitjat també configura les cinc dimensions. És adequat formalitzar el futur desitjat a través d'esbossos, ja que és una forma directa de comunicar i el 2D és capaç de suportar qualsevol idea.

Finalment, la fase Definir ha de concretar el repte de disseny, repte que encapçalarà el brief i serà l'objectiu a complir durant el projecte. Per tant, un bon repte de disseny és cabdal per un bon projecte de disseny. La seva definició es pot treballar a través de la fitxa corresponent — vegeu figura 48 - Cal tenir en compte que el repte de disseny hauria d'estar plantejat en termes relacionats amb la dimensió Persona, ja que es pretén que el disseny li faciliti el seu dia a dia, més que no pas sota termes relacionats amb la tecnologia o l'artefacte. Focalitzar el repte en termes humans, dirigeix el projecte cap a problemàtiques, desitjos i necessitats humanes. Per altra banda, com ja s'ha dit en diverses ocasions, el repte ha de ser suficientment ampli i obert com per tenir diverses solucions possibles, o fins i tot, a través 
de la seva resolució, descobrir noves àrees d'interès. I ha de ser suficientment acotat com perquè el tema sigui manejable, és a dir, que de cop no es torni al punt de partida inicial amb la hipòtesi de treball vaga.

Precisament, la fitxa comença posicionant la hipòtesi inicial que ha guiat la recerca, és una manera de no perdre el fil i mantenir present l'objectiu, per vague que sigui. A continuació es demana que es revisin les principals necessitats i els principals insights detectats al llarg de la fase Analitzar. No es tracta de col·locar-los tots, sinó d'escollir aquells que es considera instintivament que poden tenir recorregut. A més a més, es demana que s'incloguin les principals restriccions del projecte perquè l'elecció del repte s'adeqüi a les possibilitat de resolució existents. Una restricció habitual és el temps del qual es disposa per a plantejar la solució. En principi, a la fase Organitzar s'han treballat aquestes restriccions, però també en poden aparèixer de noves fruit de la recerca i l'anàlisi de les dades, que segurament es presenten en format premissa de disseny. Contrastant aquests dos grups —necessitats/insights i restriccions-, i valorant la seva capacitat projectual, cal escollir quina és la millor opció per esdevenir el repte de disseny. Un cop més l'experiència i la capacitat de visió futura del dissenyador l'ajudaran a escollir de forma més adequada. De totes maneres, hi ha eines com el $\mathrm{DAFO}^{34} \mathrm{o}$ el mapa de selecció d'idees, que estan pensades precisament per ajudar en aquest sentit — vegeu figura 49-. Aquesta fitxa de treball contrasta les idees a partir de dos supòsits la seva viabilitat i la seva originalitat. En principi, els reptes de disseny que visualitzen solucions de disseny viables i originals, són les idees més interessants per escollir, ja que són les que aporten més valor diferenciador.

Un cop escollida l'opció que es considera més adequada cal redactar el repte de disseny. La resta d'opcions, de moment, quedaran aparcades.

Es recomana que la redacció del repte de disseny es faci a través d'una frase que expressi possibilitat, per exemple, utilitzant verbs inicials que conviden al projecte: crear, definir,

34 El DAFO divideix la zona de treball en quatre parts Debilitats, Amenaces, Fortaleses i Oportunitats, diferenciant si són d'origen extern o intern. D'aquesta manera es pot valorar el possible recorregut del projecte amb els seus punts forts i punts febles 
adaptar, etc. A més a més, el repte de disseny pot incloure algunes de les premisses de disseny principals de cada dimensió. Per exemple dissenyar un bany públic universal que respecti el medi ambient i faciliti la desinfecció i higiene personal a través d'una zona de rentar mans preparada per a diversos productes de neteja personal. Aquest repte és obert i ampli en algun sentit, i molt més restrictiu en d'altres. És a dir, en relació amb la dimensió Artefacte, el repte estableix com a premissa que el disseny ha d'incloure diversos productes de neteja personal, això és una restricció força concreta, tot i que la manera de solucionar-ho és plena de possibilitats.

En definitiva, la fase Definir, és la fase que escull el camí a seguir tant a través del repte de disseny com a través de les premisses que n'han de guiar la resolució. Amb aquesta fase, es tanca el procés de recerca i ja només falta preparar la informació per poder-la comunicar de forma unívoca i comprensible.

\subsubsection{Fase Comunicar}

La fase Comunicar conclou el procés de recerca amb l'elaboració d'un brief de disseny. Com s'ha vist a l'apartar corresponent — vegeu apartat 2.4.4 Elaboració d'un brief de disseny-, es tracta d'un document escrit que serveix per comunicar un encàrrec de disseny. En aquest treball es pren aquesta definició com a certa i s'utilitza el brief com a document de tancament de la recerca que conté el repte de disseny i les seves premisses, i que per tant, predisposa a començar un projecte de disseny.

Per altra banda, i tal com s'ha vist al llarg del capítol II, existeix certa preocupació per a la comunicació entre els equips de recerca i els equips de disseny, que poden ser el mateix o diferents. Per exemple, Sleeswijk Visser (2009) es preocupa especialment d'aquest tema. Sigui, com sigui, està clar que el brief ha de comunicar de forma unívoca un repte de disseny i les seves premisses, de manera que les propostes de solució siguin el més encertades possible. Per donar resposta a aquesta preocupació, aquesta última fase s'anomena comunicar. 
Fent una mica de resum, al llarg de la recerca, s'ha fet la distinció entre aquells projectes amb intenció cap a la innovació, que neixen d'un principi molt difós, i a mesura que la recerca avança es van destriant opcions i evidenciant aspectes que acabaran per definir un repte de disseny. Aquest seria el cas que descriuen Sanders i Stappers (2012) quan parlen del fuzzy front end. També, IDEO quan presenta el seu Disseny Centrat en l'Usuari amb open source a través del seu portal Design $\mathrm{Kit}^{35}$. Són mètodes que conviden a l'observació de les persones en el seu context i quotidianitat, i que permeten detectar reptes -o oportunitats— de disseny, que en principi estaven força ocultes pel dia a dia de la persona.

L'altre gran grup, serien aquells projectes que venen amb un encàrrec definit prèviament, com planteja Martí Font (1999) amb al punt de partida de l'encàrrec o autoencàrrec. De totes maneres, també en aquest cas, la recerca que planteja aquesta metodologia té sentit, ja que qualsevol projecte comença amb una fase de recerca. En aquest cas, la hipòtesi inicial serà més tancada, i pot ser que ja es pugui considerar repte de disseny. Per tant, la recerca s'encarregarà de definir les premisses que l'han d'acompanyar en el desenvolupament del projecte, a la vegada que revisar el repte inicial per si fa falta afinar-lo una mica més.

Per tant, l'objectiu de la fase Comunicar és el següent:

1. Traslladar la informació resultant de la fase Decidir a un document escrit que s'anomenarà brief

I els objectius del brief són els següents:

1. Expressar el repte de disseny de forma unívoca

2. Identificar els usuaris principals i secundaris

3. Posicionar el projecte en el context

4. Acompanyar el repte de disseny de les premisses projectuals de cada dimensió necessàries per emmarcar el repte

35 Es pot descarregar el document en diversos idiomes a https://www.designkit.org/resources/1 (última visita $02 / 07 / 2020$ ) 


\section{EL BRIEF}

\section{Per què em serveix el brief?}

- El brief de projecte serveix com a punt de partida per començar l'etapa de disseny i és un document que mostra un enfocament clar sobre tot allò que requereix el projecte

- Cada brief és diferent, segons les caracteristiques del projecte

- És clau saber establir i definir les prioritats que han de guiar el desenvolupament del projecte. Prioritats que han de ser punt de referència $i$ consulta

\section{Evitar}

Cal evitar contradiccions i repeticions. Vigilar que la informació no sigui massa genèrica, és a dir, poc concreta o que serveixi per qualsevol projecte. Cal ser concís i precís i evitar literatura supèrflua

\section{REPTE DE DISSENY}

Frase breu que predisposa a l'acció: un desafiament que necessita una resposta

\section{Breu descripció}

Descripció clara i concisa del projecte amb les característiques que li donen especial valor, allò diferenciador

\section{Identificació dels usuaris}

A qui va destinat el projecte? A qui puc considerar usuari (ho compra, ho fa servir, etc.)? Què volem que les persones facin/pensin/sentin? Usuaris arquetip / Persona

\section{Relació del projecte amb l'entorn}

Descriure el context en què s'emmarca. D'on surt el projecte? Es tracta de saber on colllocar el projecte, com s'articula en relació a l'entorn. És un projecte innovador? És una millora? És una revisió? Explica l'aire del projecte en general

Fig. 50 Fitxa per a l'elaboració del brief. Primera pàgina amb el repte de disseny i qüestions genèriques 
Requeriments del projecte fruit de l'anàlisi. Priorització numèrica d'imprescindibles (1), desitjables (2) i renunciables (3).

\begin{tabular}{|c|c|c|}
\hline Tipus de requeriments & Llistat de requeriments & Priorització \\
\hline $\begin{array}{l}\text { DEFINICIÓ DE L'ARTEFACTE } \\
\text { Punt de partida per a la } \\
\text { priorització }\end{array}$ & & \\
\hline $\begin{array}{l}\text { DIMENSIÓ ACCIÓ } \\
\text { Requeriments de tasques } \\
\text { Qui fa què? Com es succeeixen } \\
\text { les accions? Quins esforços i } \\
\text { postures es reclamen a l'usuari? } \\
\text { Quines variables per a la } \\
\text { usabilitat són acceptables? }\end{array}$ & $\begin{array}{l}\text { a. } \\
\text { b. } \\
\text { c. } \\
\text { d. } \\
\text {.. }\end{array}$ & \\
\hline $\begin{array}{l}\text { DIMENSIÓ PERSONA } \\
\text { Requeriments físics i psicològics } \\
\text { Quins percentils són adequats? } \\
\text { Antropomètricament, què cal } \\
\text { tenir en compte? Com es } \\
\text { defineix la biomecànica? } \\
\text { A nivell cognitiu, què és } \\
\text { acceptable? Quins requeriments } \\
\text { aporta el disseny universal? }\end{array}$ & $\begin{array}{l}\text { a. } \\
\text { b. } \\
\text { c. } \\
\text { d. } \\
\text { a. }\end{array}$ & \\
\hline $\begin{array}{l}\text { DIMENSIÓ FINALITAT } \\
\text { Requeriments funcionals } \\
\text { Explica la funcionalitat, objectius, } \\
\text { fins i propòsits, el per a què de } \\
\text { l'artefacte }\end{array}$ & $\begin{array}{l}\text { a. } \\
\text { b. } \\
\text { c. } \\
\text { d. } \\
\text { a. }\end{array}$ & \\
\hline $\begin{array}{l}\text { DIMENSIÓ ENTORN } \\
\text { Requeriments de posicionament } \\
\text { Socioculturalment on se situa? } \\
\text { Quins frames el recullen? } \\
\text { Quines implicacions ambientals } \\
\text { cal tenir en compte? }\end{array}$ & $\begin{array}{l}\text { a. } \\
\text { b. } \\
\text { c. } \\
\text { d. } \\
\text { a. }\end{array}$ & \\
\hline $\begin{array}{l}\text { DIMENSIÓ ARTEFACTE } \\
\text { Requeriments tècnics } \\
\text { Requeriments específics } \\
\text { relacionats amb la tècnica, } \\
\text { materials, processos de } \\
\text { fabricació, estètica, etc. }\end{array}$ & $\begin{array}{l}\text { a. } \\
\text { b. } \\
\text { c. } \\
\text { d. } \\
\text { a. }\end{array}$ & \\
\hline
\end{tabular}

Fig. 51 Fitxa per a l'elaboració del brief. Segona pàgina 
5. Valorar les premisses de disseny segons prioritat

6. Comunicar les idees projectuals de forma comprensible i que no es presti a errors

Per a l'elaboració del brief es presenta una fitxa de treball — vegeu figures 50 i 51 - per ajudar a organitzar-lo, una eina de treball que permet estructurar-ne el contingut. Aquesta fitxa consta de dues pàgines, la primera recull la informació més rellevant i que presenta el projecte a grans trets. La segona recull les premisses de disseny distribuïdes per dimensions. Com sempre, es tracta d'una fitxa de treball, no d'un document final per presentar.

El primer pas per a l'elaboració del brief és especificar el repte de disseny que s'ha escollit a la fase Definir. El repte sol ser una única frase que inclou els principals objectius i les principals restriccions de la proposta.

A continuació, es demana una breu descripció d'allò que dona sentit al repte. Es plantegen de forma clara les principals característiques del projecte, allò que li aporta valor i el diferencia dels altres. Amb aquesta descripció s'emmarca el projecte i es dibuixen prioritats, es poden incloure, per exemple, les premisses de disseny irrenunciables de cada una de les dimensions.

A continuació, s'identifiquen els usuaris. Aquí s’inclouen els usuaris arquetip, així com els usuaris secundaris que cal tenir en compte, i es fa una breu introducció a l'experiència d'usuari que es vol proporcionar. Amb aquesta introducció es dona rellevància a la dimensió Persona, sobretot de les variables psicològiques d'aquesta dimensió.

Finalment, es descriu la relació del projecte amb l'entorn. Per una banda, quina és la seva meta, és a dir, pretén ser un projecte especialment innovador?, es tracta d'una millora?, quin és l'aire del projecte en general? Per una altra banda, com s'introdueix el projecte en societat, per tant, si forma part d'alguna tendència i quin és el seu posicionament sociocultural.

El brief té una segona part, que pot ser més o menys extensa. En aquesta part, s'inclouen les premisses de disseny que es considerin oportunes per a cada una de les dimensions, i amb informació més o menys específica. És a dir, els requeriments del projecte fruit de les 
fases prèvies. Cal tenir en compte que hi ha conceptes que poden ser compartits entre dues dimensions, en aquest cas, no cal repetir la informació, ja que és important que les premisses siguin clares i úniques. No estarà millor o pitjor, si una premissa està en una dimensió o en una altra, sinó que la intenció és fer un recorregut exhaustiu de les diverses dimensions que configuren l'artefacte. Per tant, és important que la premissa hi sigui, però és superflu si està en una $\mathrm{o}$ altra dimensió.

A més a més, es proposa jerarquitzar les premisses segons prioritat, organitzar el desenvolupament del projecte segons premisses imprescindibles i premisses renunciables. És a dir, existeixen premisses essencials que aporten diferenciació al projecte i a les quals no es pot o no es vol renunciar, però també n'hi ha d'altres que són desitjables, però no imprescindibles pel projecte. Es tracta de posicionar-les, de manera que durant el desenvolupament del projecte sigui més àgil decidir per on es pot començar a renunciar. La intenció sempre és complir amb l'ideal descrit per totes les premisses, però la gran majoria de vegades això no és possible. Aquesta priorització ve caracteritzada per les fases Analitzar i Decidir, que han anat configurant el repte de disseny, però en última instància és el dissenyador qui posarà més o menys importància a certs elements del projecte.

La priorització de les premisses es classifica segons les diverses dimensions, cada una amb la seva priorització:

- Dimensió Acció · Requeriments de tasques

- Dimensió Persona $\cdot$ Requeriments físics i psicològics

- Dimensió Finalitat · Requeriments funcionals

- Dimensió Entorn · Requeriments de posicionament i ambientals

- Dimensió Artefacte $\cdot$ Requeriments tècnics

Així doncs, el brief de disseny recull tota la feina feta en les fases anterior i la comunica a un equip de disseny que desenvoluparà el projecte. Si es tracta de la mateixa persona, també és important deixar per escrit el repte de disseny, les seves característiques més importants i les premisses de disseny prioritzades. Cal tenir en compte, que el brief es 
convertirà a partir d'aquest moment, en un document de consulta per assegurar que es compleixen tots els requisits tal i com es descriuen. Tanmateix, no té perquè ser un document final inamovible. En recerques inicials, el repte de disseny i les seves premisses poden ser encara vagues, així que el primer pas serà iniciar una nova recerca, tornar a començar per la fase Organitzar i continuar per les fases Buscar, Analitzar i Definir, buscant configurar el projecte i avançar en la proposta.

Amb aquesta fase, es tanca la proposta d'una metodologia de recerca pel projecte de disseny que pretén aprofitar l'anàlisi diagnòstic de l'ergonomia a través del seu sistema persona/màquina com a estructura de recerca, $\mathrm{i}$ fer ús de les eines $\mathrm{i}$ tècniques provinents del disseny focalitzat en la quotidianitat de les persones per configurar reptes de disseny innovadors, així com unes premisses projectuals que emmarquin aquest repte.

La intenció és que la metodologia col-labori en una recerca exhaustiva amb el convenciment que una bona recerca comporta bons reptes, i que bons reptes comporten bons projectes i solucions encertades per a millorar el dia a dia de les persones.

\subsection{Esquema general de la proposta}

Com s'ha pogut veure al llarg d'aquest capítol la metodologia es planteja a través d'una estructura de treball que organitza les fases en l'eix horitzontal —això li permet seguir un recorregut temporal— i les dimensions del projecte en l'eix vertical — que pretén profunditat i exhaustivitat d'anàlisi- . De manera que es va avançant per les fases i sempre estan presents les cinc dimensions del sistema persona/artefacte: acció, finalitat, persona, entorn i artefacte. Per al seguiment d'aquest recorregut es proposen una sèrie de fitxes de treball que ajuden a concretar aspectes de cada una de les fases, ja que ofereixen una guia de conceptes i elements a tenir en compte. La metodologia aposta per a l'observació de la quotidianitat, i per això les fitxes estan enfocades en aquesta direcció i amb la intenció que la dimensió Persona tingui notorietat en el complex món de relacions projectuals. 
Es considera que la feina amb fitxes de treball és útil per a una aproximació àgil a les tasques que s'aniran desenvolupant al llarg de la recerca. Les fitxes actuen com a punt de partida per a les accions de recerca. No són documents finals, ni eines de treball estàtiques, sinó eines estructurals que marquen el recorregut. A part de les fitxes d'elaboració pròpia, com per exemple les fitxes per cada dimensió que defineixen la proposta, també s'inclouen fitxes de treball d'eines d'ús comú en processos creatius. Aquesta metodologia no pretén ser un recull d'aquestes eines i tècniques de recerca obertes, ja existeixen reculls molt ben elaborats amb recursos ben explicats i d'accés lliure. Per aquest treball, s'ha seleccionat alguna d'aquestes eines i s'ha traslladat en format fitxa per a la seva utilització en el desenvolupament de la recerca ${ }^{36}$. Tenint en compte que cada projecte és únic, i que cada recerca té les seves pròpies necessitats, es convida a qualsevol que pugui fer ús de la metodologia a utilitzar les eines que consideri més adequades per a millorar la recerca d'informació, per l'anàlisi de dades, per l'extracció de conclusions i per l'elaboració del brief. El valor de la proposta no recau en la utilització de certes eines, sinó en una estructura dibuixada a través de les dimensions.

Per tancar aquest capítol, i amb ell la presentació de la metodologia de recerca, s'inclou un mapa general del recorregut amb les diverses fites a aconseguir a cada fase i les eines que es proposen com a adequades que es pot veure a la figura 52 .

36 Vegeu índex de figures per a recuperar les fonts originals de les eines que no són d'elaboració pròpia 
ESQUEMA GENERAL DE LA METODOLOGIA

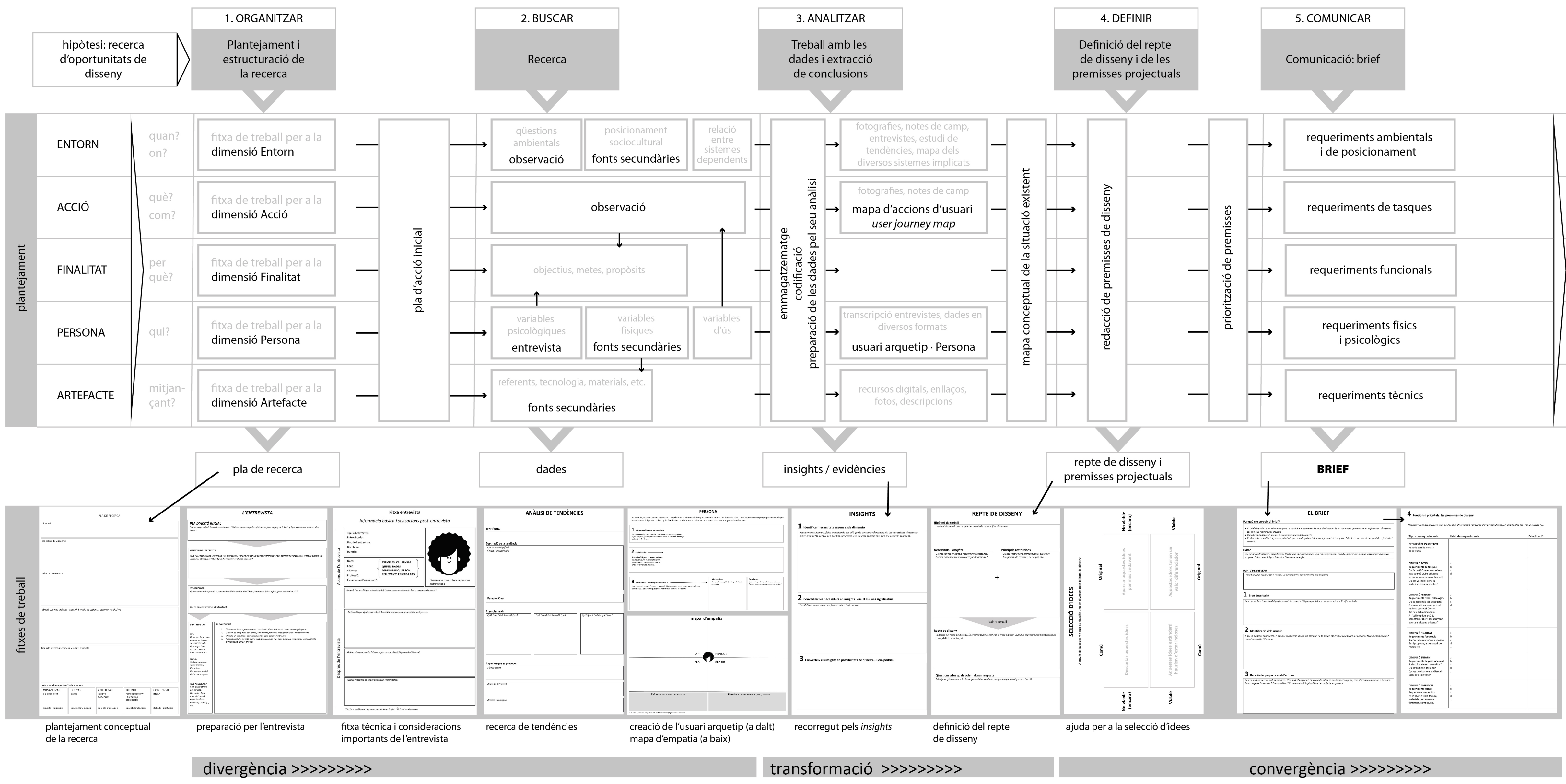



CAPÍTOL IV

\section{APLICACIÓ DE LA METODOLOGIA (CAS PRÀCTIC)}




\subsection{Planificació i temporització}

Es planteja l'aplicació de la metodologia en l'àmbit docent com a un exercici dins del marc de l'assignatura de Disseny per a l'Entorn i l'Hàbitat del quadrimestre de primavera de 4t curs, una assignatura optativa que forma part de l'itinerari de Disseny per a Entorn i Ús del grau en Enginyeria en Disseny Industrial i Desenvolupament de Productes de la Universitat Jaume I de Castelló de la Plana.

Tal com escriu el director del grau en Enginyeria Tècnica en Disseny Industrial, Raúl Izquierdo, a la presentació del grau que apareix a la web (www.uji.es, visitada el 20/06/2020), aquesta universitat va implantar aquest grau l'any 1990 amb la intenció "d'implicar els factors tècnics amb valors estètics en la formació de l'enginyer o enginyera i unir els imperatius productius (processos de fabricació, materials, disseny automatitzat, etc.) amb els aspectes formals i creatius determinants en una cultura del disseny". És per tant, un grau en enginyeria amb llarg recorregut, que inclou formació en disseny a l'enginyer apostant per un perfil de professional molt interessant i amb moltes possibilitats de desenvolupament, i més en els temps actuals, quan de forma generalitzada se li reconeix al disseny un factor afegit d'innovació. Tanmateix, el perfil tècnic de l'alumnat s'allunya d'un perfil més humanista del disseny que es transmet en escoles que inclouen el grau en Disseny en la branca de les Humanitats, les quals posicionen els seus esforços en la comprensió de la persona i la societat. Es tracta de dues visions de la disciplina que es complementen una a l'altra a partir de les seves particularitats. Per tant, l'aplicació de la metodologia en una enginyeria és un repte major, ja que els alumnes estan poc avesats a processos creatius humanistes allunyats del desenvolupament tècnic. Tot i així, els objectius són comuns en ambdós enfocaments, "perfilar els objectes que ens envolten amb la finalitat de millorar la qualitat de vida de la societat" (Raúl Izquierdo des de la presentació del grau a www.uji.es), per tant, és encertat aplicar la metodologia en aquest àmbit i en aquesta assignatura, que, tal i com indica el seu nom, es preocupa especialment de l'entorn. 
Es planteja la realització de l'exercici durant sis setmanes (del 19 de febrer al 25 de març) que representen cinc jornades lectives, ja que la setmana cinc és festiva. L'exercici acaba amb una presentació pública dels briefs projectuals i les propostes conceptuals del disseny a la setmana 7, que correspon a l'1 d'abril.

Es planteja un treball en equip que desenvolupi una recerca a partir del plantejament d'una hipòtesi vaga per arribar a concretar un repte de disseny i unes premisses projectuals fruit d'aquesta recerca. Es planteja una iteració en el procés per focalitzar i delimitar el repte.

Les tasques es divideixen en hores lectives i hores de treball autònom:

- Durant les hores lectives (5 sessions de 3 hores, amb un total de 15 hores), es dona prioritat a les explicacions pertinents de cada pas i de l'estructura d'anàlisi, es plantegen les tasques i es duen a terme - això permet acompanyar cada grup en el desenvolupament de les tasques-, es posen en comú les conclusions buscant especialment l'argumentació de les decisions. La major part de l'exercici té lloc dins de l'aula.

- Durant les hores de treball autònom en grup i individual (un total de 10 hores de dedicació), es realitzen algunes tasques que no es poden dur a terme dins de l'aula —com per exemple, les entrevistes-, s'acaben d'analitzar, reflexionar i revisar les tasques que s'han realitzat dins de l'aula, es prenen decisions i es prepara el material de comunicació.

Es pressuposen les següents habilitats transversals fruit dels estudis que estan cursant:

- Certa destresa manual en el traçat d'esbossos i croquis

- Capacitat de síntesi, observació crítica i de treball en equip

- Capacitat de planificació per a la comunicació oral i escrita, així com l'elaboració de documentació de suport

Com a punt de partida es planteja la següent hipòtesi de treball:

A través de la recerca es poden plantejar projectes que millorin la usabilitat i l'experiència d'usuari de la cantina de l'Escola Superior de Tecnologia i Ciències Experimentals de la UJI 
Es proposa un cronograma dividit en dues fases — vegeu taula 4-, una primera fase més llarga de recerca, a través de la qual es busca l'apropament a l'usuari i al seu entorn de forma empàtica, i una segona fase de presa de decisions, a través de la qual es pretén aplicar habilitats d'anàlisi i síntesi ${ }^{37}$. Les cinc dimensions del projecte guien el desenvolupament de la recerca. Degut a la pandèmia del Covid-19 i el conseqüent confinament de la població, les últimes dues sessions no es poden realitzar de forma presencial. Es decideix transmetre la informació pertinent a l'alumnat perquè pugui treballar de forma autònoma durant la sessió corresponent al 25 de març, durant la qual es defineixen les premisses de disseny que inclou el brief i es depura el repte de disseny si així es considera oportú.

Finalment, tampoc es pot realitzar una presentació pública dels resultats, i s'acorda que els estudiants facin arribar les seves propostes en format digital.

Per altra banda, i fora del procés de recerca en sí, es demana a l'alumnat que faciliti tota la documentació generada al llarg de les sessions. També es demana a l'alumnat que contesti una enquesta per a la valoració del seu grau de satisfacció amb la proposta i amb la feina que han desenvolupat. Tot aquest material es fa servir per a valorar el desenvolupament de la pràctica.

\subsubsection{Objectius}

L'aplicació de la metodologia es planteja com un pas més per definir-ne la capacitat d'aplicació, per tant es plantegen els objectius següents:

- Utilització d'un mètode d'anàlisi guiat a través de tasques i fitxes de treball

37 En el moment de dur a terme l'aplicació de la metodologia a l'aula, encara no s'havia desenvolupat l'estructura en cinc fases — organitzar, buscar, analitzar, definir i comunicar — que es presenta en el capítol anterior. Precisament, és una organització més elaborada fruit del treball realitzat a l'aula i la seva posterior avaluació a través de la qual s'arriba a la conclusió que cal definir millor les fases que implica la recerca. Dins de l'aula, i tal com mostra la taula 4, s'estructuren dues fases, una que s'anomena recerca i investigació, que inclou les posteriors fases d'organitzar, buscar i analitzar; i una altra que s'anomena presa de decisions, que inclou definir i comunicar. 
- Testeig sobre la comprensió del mètode de forma autònoma

- Testeig sobre la capacitat del mètode per ordenar la recerca

- Testeig sobre la capacitat del mètode per treballar en l'elaboració de premisses projectuals

- Testeig de la recerca organitzada a través de les cinc dimensions del sistema persona/ artefacte

- Detecció d'incongruències i aspectes de millora

- Detecció de virtuts i aspectes per potenciar

- Recollir l'opinió d'alumnes avesats en recerca projectual, i poc avesats en processos de desenvolupament creatiu afins al Design Thinking

Taula 4: Cronograma per a l'aplicació de la metodologia de recerca dins l'assignatura

\begin{tabular}{|c|c|c|}
\hline \multirow{3}{*}{ 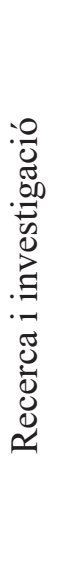 } & Dc $19 / 02$ & $\begin{array}{l}\text { Presentació } \\
\text { Observació de la cantina i plasmació de l'observació en un mapa d'ac- } \\
\text { cions de l'usuari - user journey map-. En referència majoritària- } \\
\text { ment a la dimensió Entorn }\end{array}$ \\
\hline & Dc $26 / 02$ & $\begin{array}{l}\text { Fixació d'objectius d'una hipòtesi de treball per grup } \\
\text { Recollida d'informació a través d'entrevistes a usuaris de la cantina. } \\
\text { En referència majoritàriament a les dimensions Acció i Persona }\end{array}$ \\
\hline & Dc $04 / 03$ & $\begin{array}{l}\text { Treball amb les dades recopilades amb les entrevistes. Detecció de } \\
\text { necessitats i insights. } \\
\text { Definició del repte de disseny (primera iteració) }\end{array}$ \\
\hline \multirow{3}{*}{ 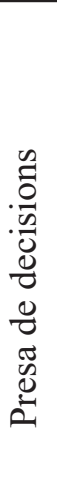 } & Dc $11 / 03$ & $\begin{array}{l}\text { Pla d'acció de la investigació: establir quina informació és necessària } \\
\text { per a la presa de decisions respecte l'artefacte } \\
\text { Treball amb les fitxes de dimensió: entorn, finalitat, persona, acció i } \\
\text { artefacte }\end{array}$ \\
\hline & Dc $25 / 03$ & $\begin{array}{l}\text { Fixació del repte de disseny (segona iteració) i fixació de les premis- } \\
\text { ses de disseny } \\
\text { Elaboració del brief }\end{array}$ \\
\hline & Dc $01 / 04$ & $\begin{array}{l}\text { Comunicació: presentació pública del brief i presentació de la propos- } \\
\text { ta conceptual }\end{array}$ \\
\hline
\end{tabular}




\subsubsection{Definició del projecte}

Es defineix el projecte adaptat a les limitacions temporals, espacials i temàtiques de l'assignatura. Es preveu l'assistència de 19 alumnes, per tant, una quantitat molt idònia per al desenvolupament de l'activitat, ja que és un grup de persones controlable i que es poden repartir en grups de 3 o 4 alumnes. Cada grup treballarà una única proposta. També es té en compte el grau de dedicació establert en hores de treball dins i fora de l'aula, que sumen un total de 25 hores.

El punt de partida del projecte és una hipòtesi de treball vaga i pròxima al seu dia a dia.

Es descarta el treball autònom, i es considera oportú incloure part de teoria conceptual referent als conceptes i a la metodologia del projecte.

Com a presa de contacte amb l'exercici s'elabora un document que explica a grans trets de què va i com s'enfoca - vegeu figura 53-. A més a més, es crea un conjunt de documentació que explica el recorregut que es durà a terme i els principals conceptes que s'utilitzen, per exemple què s'entén per premisses de disseny, què s'entén per brief, què s'entén per insight, etc. ja que es considera que són termes que no s'utilitzen habitualment. Per tant, es planteja un recorregut del projecte força guiat i acompanyat durant les cinc sessions previstes, tant a nivell de metodologia del projecte, com a nivell de tasques concretes per dur a terme. Per tant, es planifiquen sessions de teoria i pràctica combinada.

S'inicia el projecte amb una hipòtesi de treball vaga i que forma part de l'experiència de cada alumne, ja que són usuaris habituals de la cantina de la seva Escola i es proposa, a partir de l'observació, que cada grup defineixi una hipòtesi de treball més concreta, sobre la qual treballaran la resta de dies.

Seguidament, es treballen les entrevistes, per ampliar l'abast de l'experiència pròpia i avaluar l'encert d'aquesta primera hipòtesi de treball. A partir d'aquí es treballa amb cada dimensió per focalitzar la recerca i l'anàlisi de forma més exhaustiva, amb la intenció de convertir la hipòtesi de treball en un repte de disseny concret, fonamentat en la recerca i que 


\section{LA INVESTIGACIÓN EN EL PROYECTO DE DISEÑO}

Definición de premisas de diseño

Inclusión de las premisas en un brief de diseño

Las dimensiones del proyecto: investigación y toma de decisiones

\section{El ejercicio}

Fig. 53 Resum presentació de l'exercici a l'aula pels alumnes de

Disseny per l'Entorn i l'Hàbitat
Las premisas de diseño son normas decididas por uno mismo a tener en cuenta en el desarrollo del proyecto.

Por ejemplo, una premisa puede ser "respetar un precio de compra ajustado". Esta premisa implica que cuando se tomen decisiones alrededor del producto, se van a priorizar aquellas que cuesten menos, y se cambiarán formas, piezas, para respetar las premisas preestablecidas.

El brief de diseño es el documento que delimita el proyecto y recoge las premisas de diseño a respetar. Este documento puede provenir del cliente, pero también lo puede elaborar el mismo diseñador.

El proyecto de diseño abarca muchas dimensiones de la realidad, distintas perspectivas desde donde observar el proyecto, y cada una de estas dimensiones define sus propias premisas. Las premisas resultantes no son independientes ni están aisladas, sino que se relacionan y dependen unas de las otras. Un buen producto empieza con la definición de premisas bien argumentadas y contrastadas, con una base de investigación sólida.

Para conseguir unas premisas de diseño sólidas hay que llevar a cabo una investigación ordenada y bien estructurada, para ello se divide el proyecto en cinco dimensiones: finalidad, acción, persona, entorno y artefacto. Desde cada dimensión se va a reflexionar sobre las necesidades del proyecto, se buscará información pertinente y se tomarán decisiones que acabarán definiendo las premisas. Para ello, se utilizarán herramientas del diseño, preparadas para el ejercicio de la creatividad y la observación exhaustiva del entorno.

Este ejercicio en concreto se trabajará en la cantina de la facultad. Se trabajará en grupos pequeños, y cada equipo va a elaborar, al final del ejercicio, un brief de premisas proyectuales que definirán una ficticia reforma del espacio, de sus funciones, de su distribución o de alguno de los elementos que se encuentran en él.

El ejercicio se divide en una primera fase de investigación, y una segunda fase de toma de decisiones. La primera hace referencia a la realidad existente, la segunda hace referencia al futuro deseado. 
predisposi a la resolució d'un problema, necessitat o desig de les persones que conviuen a la cantina. Aquesta segona fase de la recerca es planteja a través de fonts d'informació secundàries. A partir de les fitxes i de la informació recopilada, es planteja gràcies a l'anàlisi, la seva transformació en premisses de disseny. Finalment, es demana traslladar tota la informació en un document que expliqui el repte de disseny i proposi un primer esbós conceptual de la proposta.

L'estructura que es planteja és una suma de continguts que avancen per anar concretant aspectes del repte de disseny, començant per l'observació de l'entorn, la fixació d'una finalitat, una reflexió sobre les activitats i tasques de les persones, la fixació de l'usuari arquetip i finalment, com tot això es trasllada a l'artefacte. Per tant, la metodologia apareix adaptada per un recorregut més guiat del que seria habitual — vegeu l'esquema genèric del plantejament conceptual de l'exercici a la figura 54-.

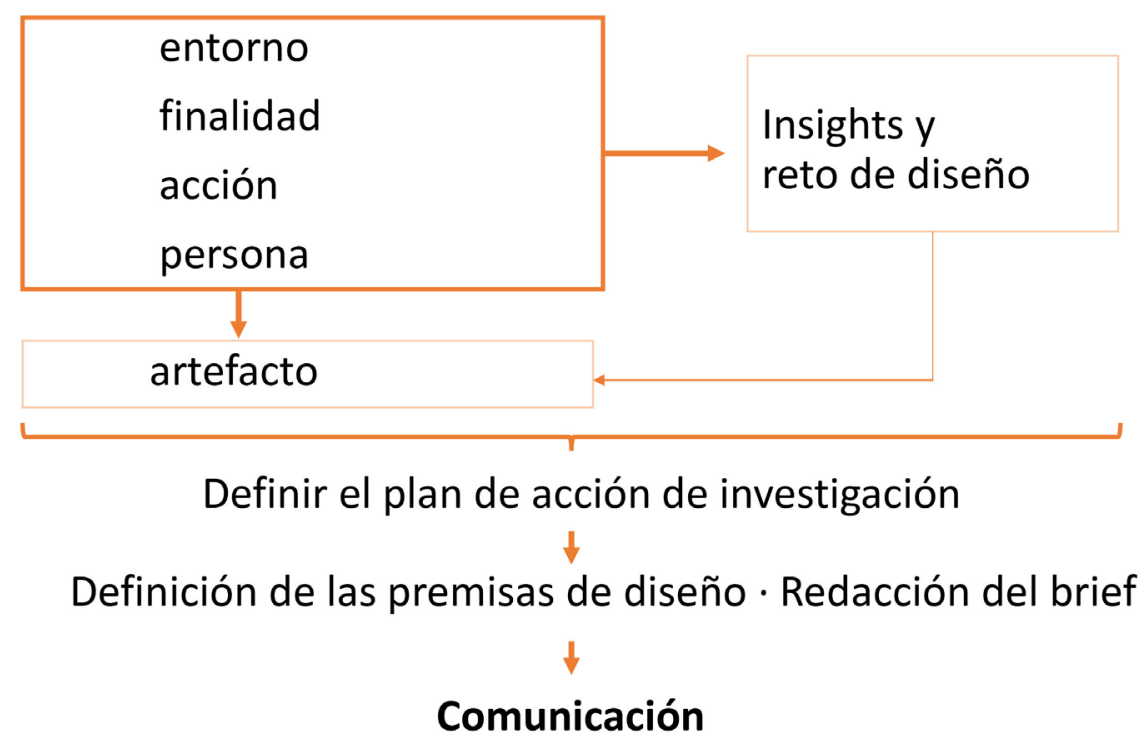

Fig. 54 Esquema del plantejament de l'exercici desenvolupat a l'aula

En aquest esquema s'observa com hi ha quatre dimensions predominants que desemboquen a la dimensió Artefacte, que a més a més, es veu condicionada pels insights i el repte de disseny definits gràcies a les dades extretes de l'observació i les entrevistes. A continuació, 
es planteja una segona fase de recerca a través de les fitxes de les dimensions, per aconseguir informació que es considera necessària per a la concreció de les premisses de disseny i la redacció del brief. Tot plegat, acaba en una fase de comunicació. Perquè l'exercici no quedi només en un àmbit teòric i per donar la possibilitat d'elaborar una solució al repte, encara que sigui de forma molt bàsica, es demana als estudiants que incloguin algun esbós de la proposta que tenen plantejada.

Resumint, es planteja un exercici que no tracta tota les dimensions de l'artefacte de la mateixa manera, sinó que planteja com unes depenen de les altres de forma prefixada, tal i com es pot observar a l'esquema de l'exercici de la figura 52. En canvi, com s'ha vist a la presentació de la metodologia al llarg del capítol III, sí que es tracten totes per igual, com es veu de forma clara a l'apartat 3.4 Esquelet de la proposta. Aquest canvi és degut, en part, a la realització d'aquest exercici, tal i com es veurà en el capítol V $\cdot$ Resultats. Per altra banda, l'estructura plantejada per a l'exercici està adaptada a les possibilitats temporals i d'abast disponibles, entenent que l'estructura de recerca ha de ser un esquelet adaptable a les múltiples situacions possibles.

\subsubsection{Avaluació de la metodologia}

Per poder avaluar la metodologia es plantegen dos blocs:

- Per una banda la satisfacció dels estudiants s'avalua a través d'una enquesta amb els formularis de google que contesten 18 dels 19 estudiants que participen en el projecte, de la qual s'analitzen els resultats al capítol V Resultats. A part de la satisfacció, l'enquesta també inclou preguntes sobre el seu grau de coneixement d'eines i mètodes projectuals, així com de la seva opinió sobre l'ús de les eines tractades durant l'exercici.

- Per una altra banda, es vol avaluar la qualitat de la recerca desenvolupada, dels reptes de disseny plantejats i de les propostes finals. En aquest sentit es realitza una valoració personal dels resultats. Aquesta valoració es planteja amb un argumentari docent que 
es revisa a l'apartat 5.3.3 Els brief resultants. Com ja s'ha comentat amb anterioritat, valorar la proposta a través dels seus resultats té certa controvèrsia ja que no és possible valorar resultats partint de la mateixa hipòtesi inicial però desenvolupant-se a través d'una metodologia diferent. És a dir, els resultats es valoren en absolut i sense comparar amb possibles resultats fruit d'altres processos. En aquest sentit, una valoració docent, avesada a avaluar resultats sembla una valoració encertada, i més tractant-se d'un exercici de classe.

\subsection{Treball de camp}

S'inicia l'exercici al 19 de febrer. Hi assisteixen 19 alumnes (12 nois i 7 noies), i es formen cinc grups de treball:

- Equip 1: 3 nois i 1 noia

- $\quad$ Equip 2: 4 nois

- Equip 3: 1 noi i 3 noies

- $\quad$ Equip 4: 4 nois

- $\quad$ Equip 5: 3 noies

L'assistència es manté estable durant el desenvolupament de tot l'exercici.

L'estructura i temporització de les sessions és la que es mostra a la taula 5, tot i així, com ja s'ha dit, degut al confinament de la població a mitjan març, la sessió 5 i la comunicació no es poden realitzar de forma presencial. 
Taula 5: Cronograma i distribució de tasques de l'alumnat i del professorat amb temporització

\begin{tabular}{|c|c|c|c|}
\hline $\begin{array}{l}1 \\
\text { Dc } \\
19 / 02\end{array}$ & $\begin{array}{l}\text { TASCA: Observació } \\
\text { Per grups, baixar a la cantina: dibuixar les } \\
\text { diverse parts i definir-ne la finalitat. } \\
\text { Esquematitzar l'ús actual i distribució. } \\
\text { Esquematitzar accions dels usuaris de l'espai } \\
\text { TASCA: Mapa d'accions d'usuari } \\
\begin{array}{l}\text { Focalitzar-se en una seqüència d'accions } \\
\text { concreta. Dibuixar i descriure moments } \\
\text { clau de l'experiència d'usuari }\end{array}\end{array}$ & $\begin{array}{l}\text { Explicació de l'exercici: } \\
\text { Presentació general de les diverses } \\
\text { tasques que es duran a terme } \\
\text { Acompanyament en l'observació } \\
\text { Explicació de la tasca: exemple } \\
\text { Acompanyament en el desenvolupa- } \\
\text { ment de la tasca } \\
\text { Tancament i explicació del pròxim dia }\end{array}$ & $\begin{array}{l}15^{\prime} \\
1 \mathrm{~h}\end{array}$ \\
\hline $\begin{array}{l}2 \\
\text { Dc } \\
26 / 02\end{array}$ & $\begin{array}{l}\text { COMUNICACIÓ: Visualització dels di- } \\
\text { versos mapes d'accions d'usuari } \\
\text { Comentari dels punts més importants } \\
5 \text { grups x } 5 \text { minuts = } 25 \text { minuts } \\
\text { TASCA: Fixació d'objectius previs i ela- } \\
\text { boració d'una hipòtesi de treball } \\
\text { TASCA: Elaboració d'una entrevista per } \\
\text { a la recopilació d'informació dels usuaris. } \\
\text { Informació pertinent respecte la hipòtesi i } \\
\text { els objectius definits. } \\
\text { TASCA: Entrevista entre grups i com- } \\
\text { panys de classe (entre } 1 \text { i } 2 \text { entrevistes per } \\
\text { grup) } \\
\text { TASCA: Revisió de les preguntes } \\
\text { TASCA FORA D'AULA: Realització de } \\
\text { mínim una entrevista per membre del } \\
\text { grup (3 o } 4 \text { entrevistes), i preparació de la } \\
\text { informació per a poder treballar-la el } 4 \text { de } \\
\text { març }\end{array}$ & $\begin{array}{l}\text { Explicació de la tasca } \\
\text { Explicació: com preparar les dades re- } \\
\text { collides per a poder extreure'n informa- } \\
\text { ció vàlida }\end{array}$ & $\begin{array}{l}10 \\
20 \\
10 \\
20\end{array}$ \\
\hline
\end{tabular}




\begin{tabular}{|c|c|c|c|}
\hline $\begin{array}{l}3 \\
\text { Dc } \\
04 / 03\end{array}$ & $\begin{array}{l}\text { TASCA: treball amb les dades extretes de } \\
\text { les entrevistes. Elaboració d'insights } \\
\text { TASCA: Definició del repte de disseny } \\
\text { COMUNICACIÓ: el repte de disseny de } \\
\text { cada grup }\end{array}$ & $\begin{array}{l}\text { Explicació de les dimensions: exemple. } \\
\text { Presentació del mapa conceptual } \\
\text { Anàlisi de l'actualitat / projecció del fu- } \\
\text { tur desitjat: explicació dels Insights } \\
\text { Acompanyament en la realització de la tasca } \\
\text { Explicació del repte de disseny } \\
\text { Tancament i explicació del pròxim dia }\end{array}$ & $\begin{array}{l}45^{\prime} \\
10^{\prime} \\
20^{\prime} \\
30 \\
10^{\prime}\end{array}$ \\
\hline $\begin{array}{l}4 \\
\text { De } \\
\text { 11/03 }\end{array}$ & $\begin{array}{l}\text { TASCA: pla d'acció de recerca } \\
\text { TASCA: treball amb les diverses dimensi- } \\
\text { ons, complementació de fitxes } \\
\text { TASCA FORA L'AULA: omplir d'infor- } \\
\text { mació les dimensions segons plantejament } \\
\text { organitzat a classe }\end{array}$ & $\begin{array}{l}\text { Preparació per a la recerca d'informa- } \\
\text { ció: què haig de saber } \\
\text { Anàlisi de l'actualitat / projecció del fu- } \\
\text { tur desitjat: elaboració de fitxes } \\
\text { - Persona arquetip i requisits antro- } \\
\text { pomètrics } \\
\text { - Referents i requisits tècnics } \\
\text { - User journey desitjat } \\
\text { Tendències i mapa del sistema de } \\
\text { l'artefacte } \\
\text { Objectius i propòsits } \\
\text { Explicació del treball a realitzar fins al } \\
25 \text { de març }\end{array}$ & $\begin{array}{l}15^{\prime} \\
30^{\prime} \\
45^{\prime} \\
15^{\prime}\end{array}$ \\
\hline $\begin{array}{l}5 \\
\text { Dc } \\
25 / 03\end{array}$ & $\begin{array}{l}\text { Portar les dimensiones fetes (5 fitxes) } \\
\text { TASCA: elaboració del brief i de les pre- } \\
\text { misses de disseny de cada dimensió }\end{array}$ & $\begin{array}{l}\text { Explicació: el brief del projecte }+ \text { pre- } \\
\text { misses de disseny i priorització } \\
\text { Exemple } \\
\text { Revisió de les dimensions i acompa- } \\
\text { nyament en l'elaboració de premisses }\end{array}$ & $2 \mathrm{~h}$ \\
\hline $\begin{array}{l}6 \\
\text { Dc } \\
01 / 04\end{array}$ & $\begin{array}{l}\text { COMUNICACIÓ: Presentació pública } \\
\text { del brief de disseny, amb argumentació per } \\
\text { a la presa de decisions. } \\
5 \text { grups x } 10 \text { minuts }=50 \text { minuts }\end{array}$ & Comentaris & $\begin{array}{l}\mathrm{h} \\
30\end{array}$ \\
\hline
\end{tabular}




\subsubsection{Sessió 1: Observació i mapa d'accions d'usuari}

Punt de partida de l'exercici, per tant es fa un plantejament general sobre com es desenvoluparà, quines tasques es realitzaran i com es tancarà l'exercici. Es prepara una presentació amb diapositives que van guiant el recorregut. Primer una breu introducció sobre metodologia del projecte, les fases de divergència i convergència i com es poden visualitzar amb el doble diamant del British Council. A més, s'hi suma el garbuix del fuzzy front end de Sanders i Stappers (2008) — vegeu figura 55 — . En el moment de portar a la pràctica l'exercici, l'esquema metodològic de la proposta d'aquest treball que es pot veure a la figura 52 encara no està formalitzada. L'estructura amb les fases i les dimensions interactuant com un quadre de doble entrada, tot i que conceptualment existeix i és com es prepara l'exercici a l'aula, encara no està formalitzat. Per tant, per explicar als alumnes com es desenvoluparà la recerca i, sobretot, per explicar on es posiciona metodològicament l'exercici, es recorre a alguns dels esquemes existents que s'han vist al capítol II, és a dir, es recorre als referents metodològics que es consideren més adequats: el doble diamant del British Council (2004) i el garbuix de Sanders i Stappers (2008), que s’uneixen en un únic esquema. Amb aquest esquema es pretén mostrar la metodologia del projecte de forma visual, de manera que els alumnes identifiquin les fases del projecte que ens disposem a desenvolupar.

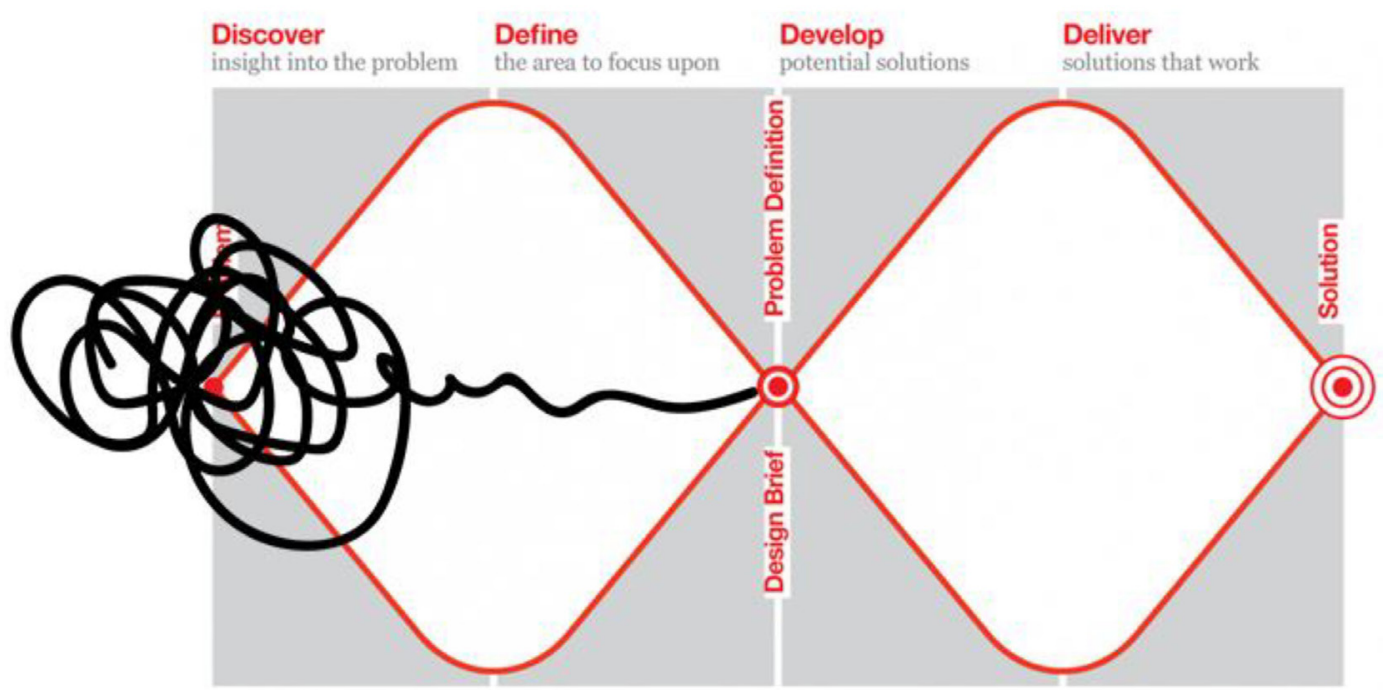

Fig. 55 Esquema tradicional del doble diamant del Design Council amb el garbuix de Sanders i Stappers (2008) per exemplificar el recorregut de l'exercici 
Amb aquest esquema es pot explicar com l'exercici comença i acaba en el primer diamant, és a dir, a partir d'un inici difús, vague i sense concretar — tal com mostra el garbuix—, s'anirà recollint informació per poder-la analitzar, extreure conclusions, i acabar el procés amb un brief, que inclogui un repte i unes premisses de disseny, procés que correspon a les fases de Descobrir i Definir el primer diamant, una fase de divergència i una de convergència.

Tal i com s'ha vist en l'apartat anterior, la hipòtesi inicial és la següent:

A través de la recerca es poden plantejar projectes que millorin la usabilitat i l'experiència d'usuari de la cantina de l'Escola Superior de Tecnologia i Ciències Experimentals de la UJI

És a dir, es tracta d'una hipòtesi de treball que recull la possibilitat de projectes que millorin l'experiència a la cantina, però queda totalment oberta l'especificació del tipus de projecte resultant, de manera que els alumnes, en el desenvolupament de l'exercici, hauran de decidir on focalitzen la seva proposta, així com concretar si es tracta d'un producte físic, d'una aplicació, una redistribució de l'espai o d'una estratègia, com a exemple de les múltiples possibilitats de proposta.

Com a primera activitat, es planteja l'observació de la cantina, posant especial èmfasi en l'observació del què fan les persones i de com ho fan, així com de la delimitació de l'entorn. Per poder treure el màxim profit d'aquesta observació, es donen algunes directrius sobre com realitzar-la i es demana que s'escriguin notes de camp i que es faci un esquema de l'espai que inclogui els accessos, el posicionament del mobiliari, la senyalització, una zonificació d'activitats i els recorreguts de les persones durant l'observació; es tracta d'observar en general, però fixant-se en qüestions relacionades amb l'experiència de l'ús i en la configuració de l'espai per veure com les persones assoleixen els seus propòsits al entrar a la cantina. L'observació té lloc a les 16 h i dura aproximadament una hora. Durant aquesta estona hi ha poc moviment a la cantina, petits grups d'estudiants que recullen un cafè o que xerren tranquil·lament en una taula, alguna persona sola, així com personal de la cantina netejant la zona de taules. 
Es retorna a l'aula i s'introdueix el mapa d'accions de l'usuari, l'user journey map, una eina visual per plasmar l'experiència d'usuari. Es tracta de mostrar el recorregut temporitzat d'un usuari en la realització d'una activitat. Cada grup escull, l'usuari que li resulta més interessant d'entre de cada una de les observacions dels membres de l'equip. Cal incloure els objectes que utilitza, les persones amb qui interactua i els recursos de disseny que guien la seva activitat. És important, plasmar en el mapa d'usuari els seus sentiments i allò que pensa, ja que és la manera de visualitzar els elements crítics i quins punts podrien suposar una oportunitat de disseny — vegeu 2.2.5.1 Service Design Thinking—.

Per concloure la sessió, es revisen els passos fets i es planteja la propera sessió, que començarà amb una presentació de cada grup del seu mapa d'accions d'usuari. S'obre la possibilitat de reproduir l'observació en altres moments d'ús de la cantina, per exemple a primera hora del matí, o durant el servei de menjador del migdia, on les dinàmiques són molt diferents que les observades a primera hora de la tarda.
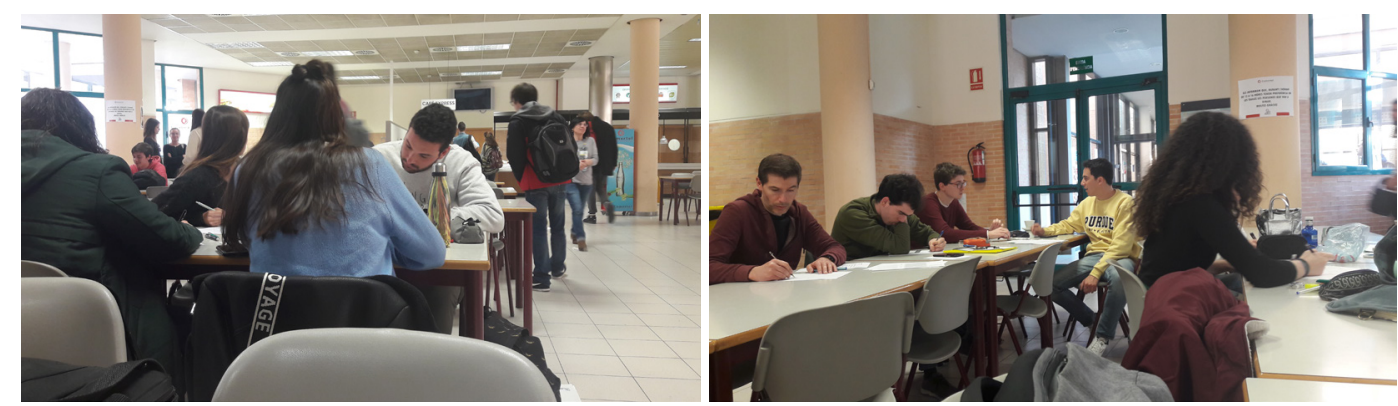

Figs. 56 i 57 Alumnes a la cantina desenvolupant l'observació

A la figura 58 es pot veure una mostra del mapa d'accions d'usuari resultant, elaborat per l'equip número 3. En aquest mapa es desenvolupa com una persona de 21 anys entra a la cantina per prendre un cafè. En el seu recorregut es visualitza com, tot i no haver-hi gaire gent, cal fer cua. També és un moment crític el moment de trasllat del cafè a una taula. Tot $\mathrm{i}$ així, l'usuari està satisfet en general perquè li agrada el cafè que es pren i assoleix l'objectiu que s'havia proposat inicialment. 


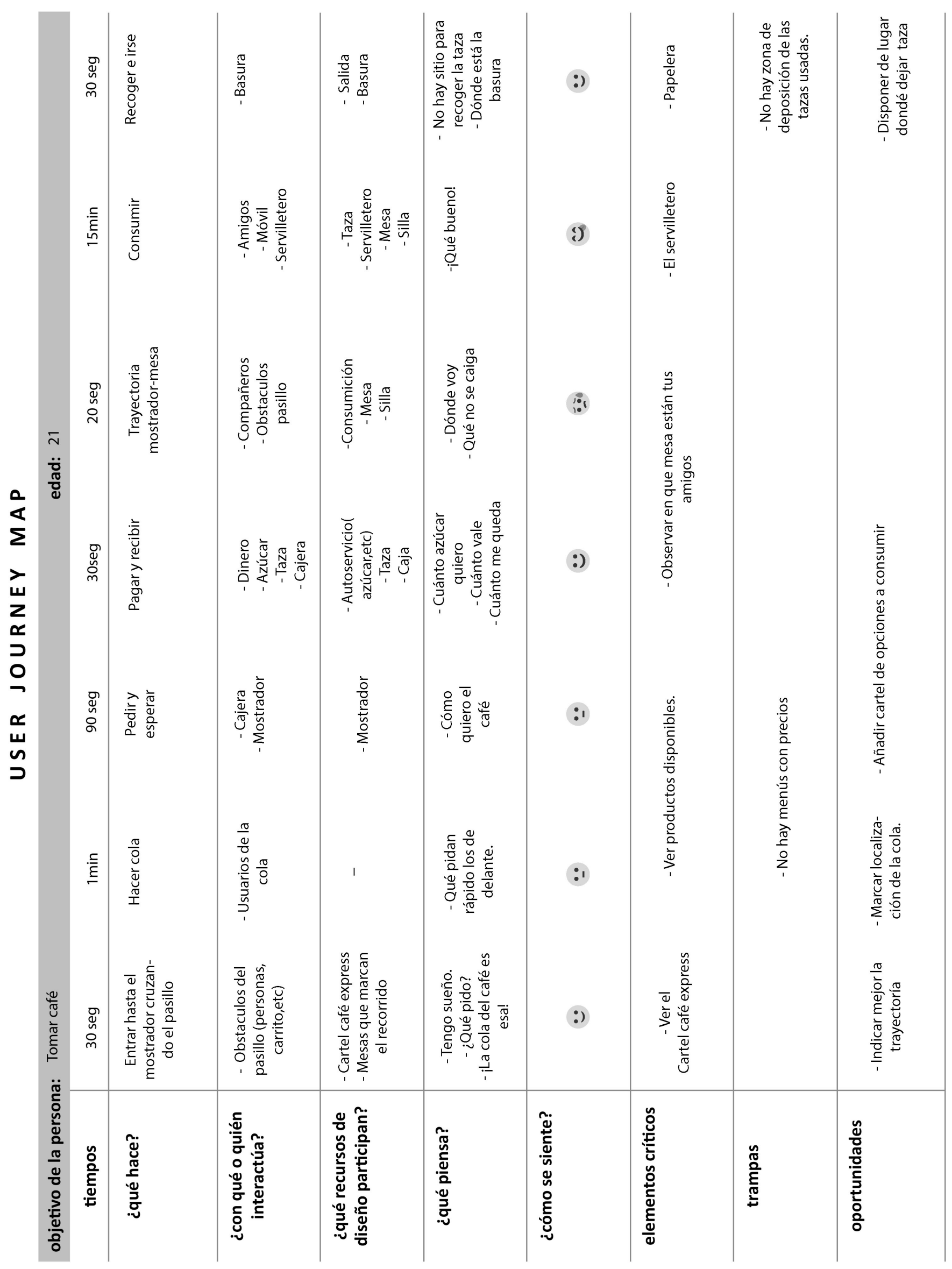

Fig. 58 Mapa d'accions d'usuari elaborat per l'equip número 3 


\section{LA HIPÓTESIS}

Descripción breve del ámbito de trabajo

¿Qué elementos críticos, trampas y oportunidades son más relevantes del User Journey Map

\section{Necesidades y deseos}

Convierto estos elementos en necesidades y deseos

\section{Restricciones y limitaciones}

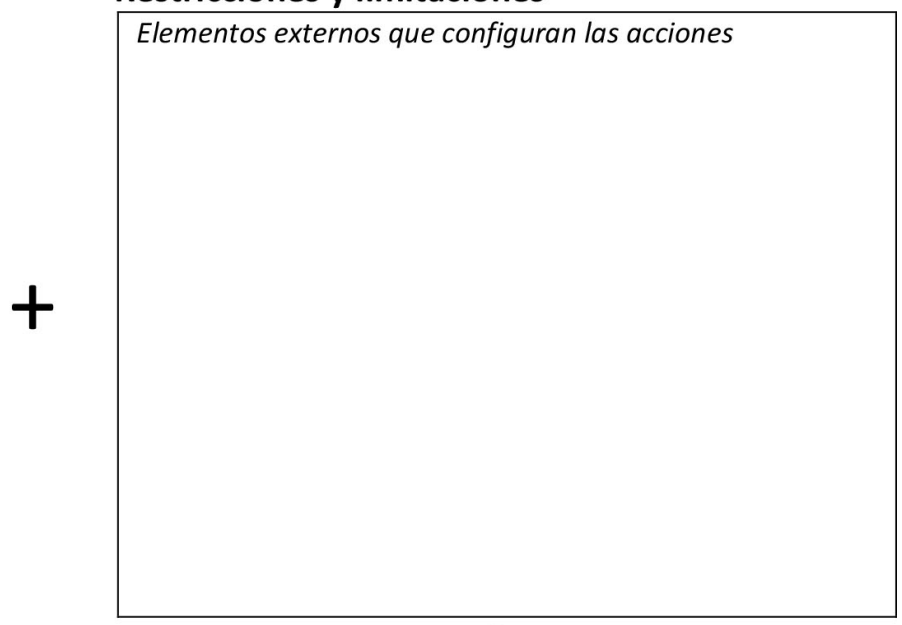

Redacción de la hipótesis

Hipótesis

Redacción declarativa

\section{¿A qué vamos a dar respuesta? Objetivos}




\subsubsection{Sessió 2: Hipòtesi i entrevistes}

La segona sessió es desenvolupa íntegrament dins l'aula. Comença amb les presentacions dels mapes d'accions d'usuari que ha elaborat cada grup i que han preparat per a la seva projecció. A continuació es comença a treballar amb les dades per poder elaborar una hipòtesi de

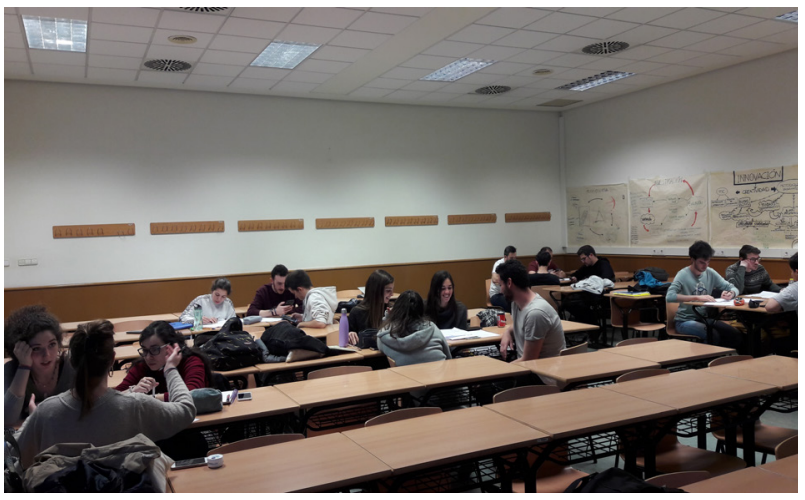

Fig. 61 Alumnes treballant per equips dins l'aula treball per cada grup. Grups amb dos mapes d'accions, cal que es posin d'acord sobre quin resulta més interessant o quin ofereix més oportunitats de disseny tenint en compte les restriccions temporals i d'accés a la informació.

L'elaboració de la hipòtesi es treballa a partir d'una fitxa de treball — vegeu figura 59—, com es pot comprovar, la fitxa és molt similar a la fitxa presentada en el capítol anterior pel repte de disseny — vegeu figura 48-. Aquesta modificació, es deguda a les conclusions extretes a partir de l'aplicació de la metodologia dins l'aula, tal i com s'explica a l'apartat 5.3.1 La caracterització del repte de disseny.

Si apareixen diverses hipòtesis i cal escollir-ne una, es proposa la fitxa per a la selecció d'idees — vegeu figura 49-. A l'equip 5, per exemple, li resulta útil passar les diverses opcions que tenen sobre la taula pel sedàs d'aquest quadre. Al contrastar les propostes a través dels conceptes de comú, original, viable o no viable, escullen convençudes el camí a seguir. En canvi, altres grups escullen la proposta sense necessitat de fer servir aqueta eina. Amb les hipòtesis plantejades de cada grup, es passa a parlar de les entrevistes. Es fa una breu introducció teòrica sobre l'entrevista, com enfocar-la i com dur-la a terme per treure'n el màxim profit; en aquest moment, s'ha delimitat l'abast de la hipòtesi inicial genèrica a partir de la informació observada durant la primera sessió de treball i cada grup té una nova 
hipòtesi més concreta, tot i que encara oberta a infinitat de possibles solucions.

Es plantegen entrevistes curtes de màxim 10 minuts per controlar el volum de dades resultant. Els objectius d'aquestes entrevistes són bàsicament tres:

- Entendre la persona per poder crear un usuari arquetip amb els seus requisits i les seves motivacions

- Descobrir els desitjos i les necessitats al voltant de la hipòtesi de treball de cada grup

- Explorar què fa la persona entrevistada que pugui resultar interessant en relació als usos de la cantina

Amb aquests objectius genèrics, cada grup ha de preparar la seva pròpia entrevista, objectius, temes i preguntes que necessitin per obtenir informació rellevant al voltant de la seva hipòtesi. La preparació de l'entrevista es realitza amb el guió d'una fitxa de treball — vegeu figura 60 - , que comença a partir de la hipòtesi de treball i la definició d'uns objectius. A continuació realitzar una pluja d'idees de preguntes que es podrien fer. En aquesta pluja d'idees cal que hi participin tots els membres de l'equip, ja que cada un ha d'aportar la seva visió de la hipòtesi. Un cop tenen cert volum de preguntes, cal excloure les preguntes repetides i ordenar-les de més genèriques a menys. Seguidament, es recomana convertir les preguntes en temes a tractar, de manera que les entrevistes puguin fluir com una conversa, més que a través de pregunta i resposta directes. La intenció ha de ser que l'entrevistat expliqui la seva experiència en la realització de l'activitat escollida, es busquen històries i arguments, i es pretén fugir de respostes monosil·làbiques de sí i no. Per acabar de preparar l'entrevista, la fitxa planteja reflexionar sobre qui és la persona adequada per respondre les preguntes, quan i on es podrà dur a terme, i quin material es necessita — per exemple, el mòbil carregat per poder enregistrar l'entrevista-. Per verificar que les entrevistes estan ben plantejades, es realitza un simulacre entre grups, que permet observar si la cadència de temes és correcta i si tal i com es formulen les preguntes s'aconsegueix la informació desitjada. També es presenta la fitxa tècnica de l'entrevista per recollir les primeres impressions just acabada l'entrevista — vegeu figura 43-. 


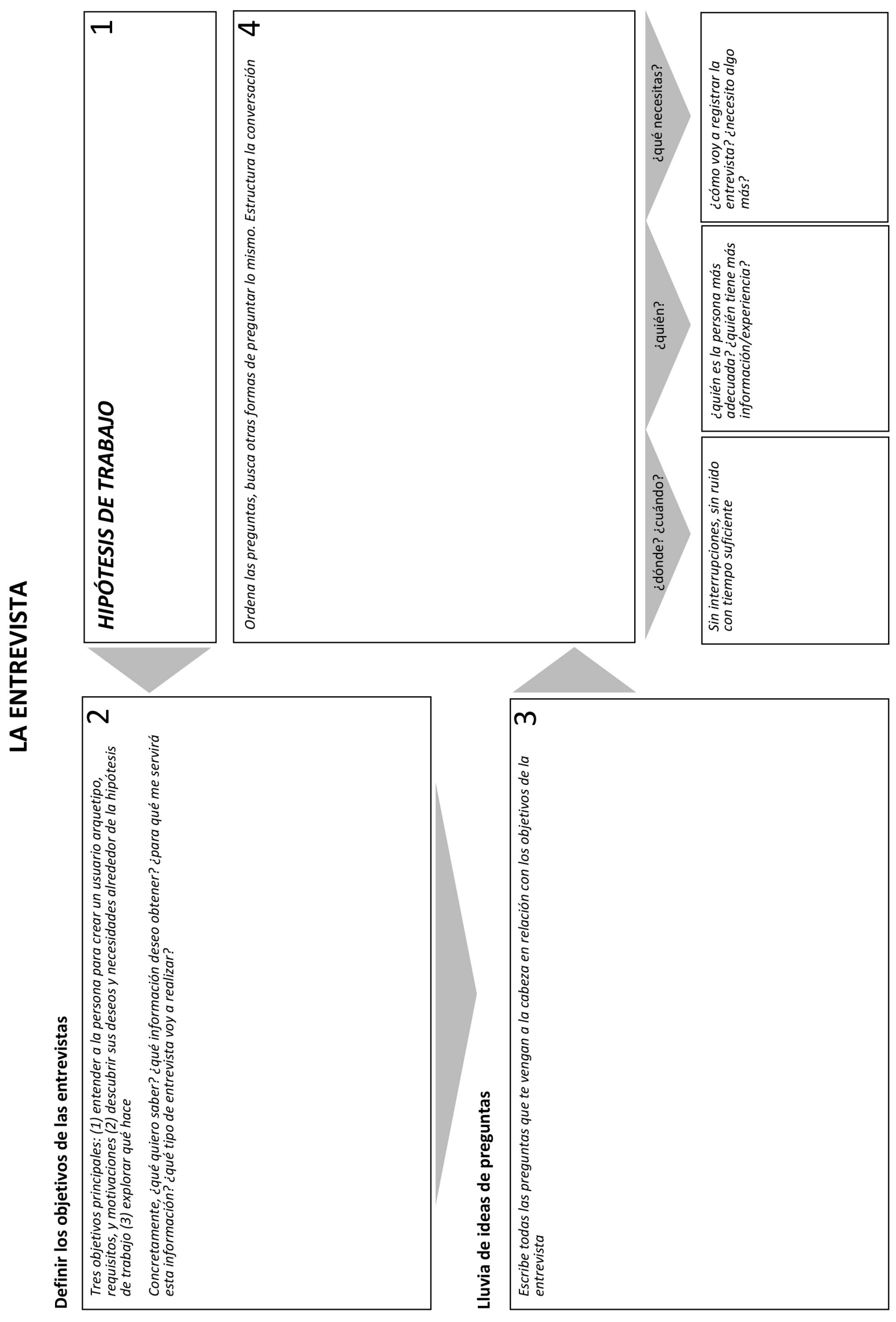

Fig. 60 Fitxa per a la preparació de les entrevistes 


\section{RETO DE DISEÑO}

Hipótesis de trabajo fruto de la observación

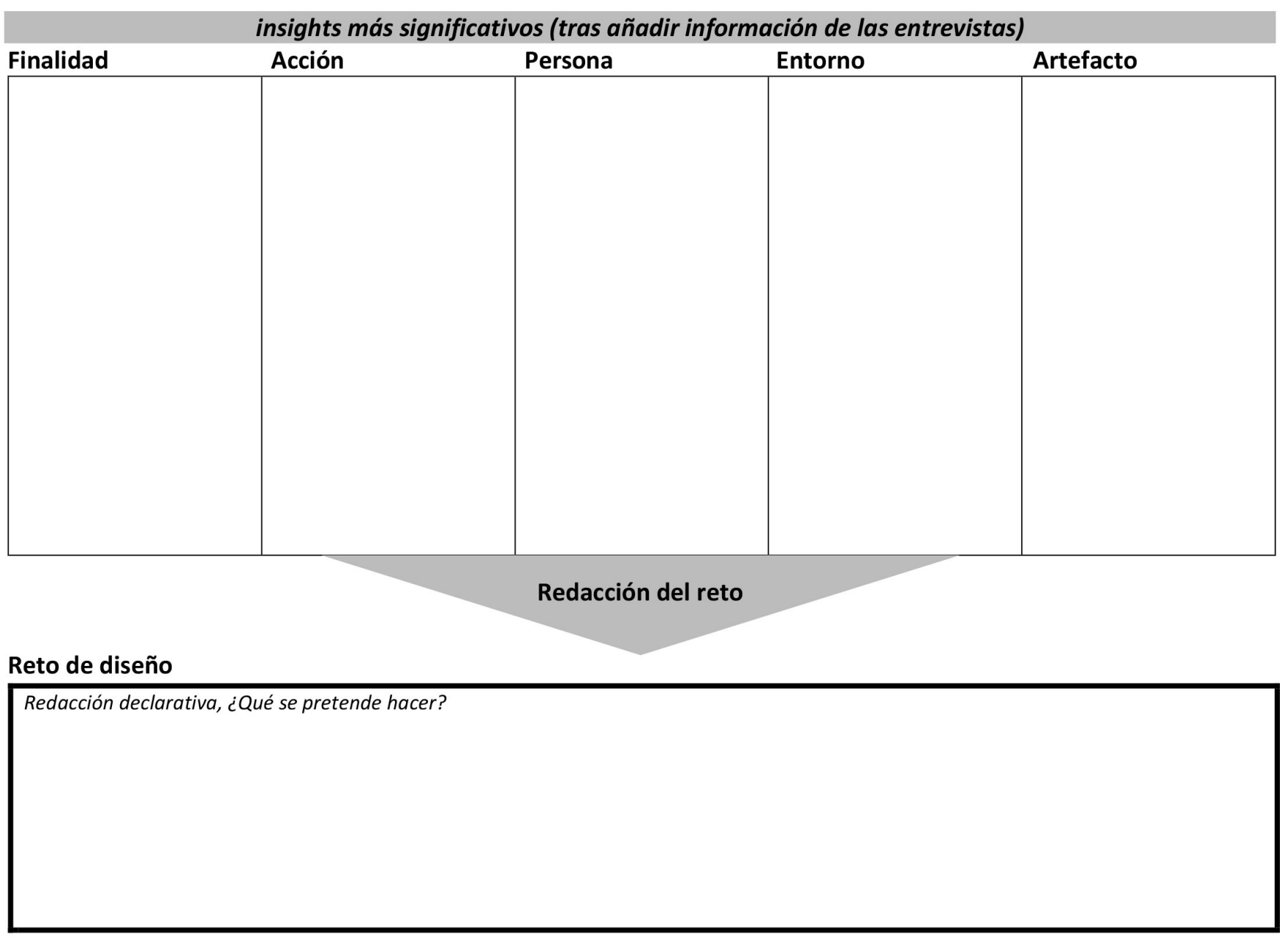

Objetivos: cuestiones a las cuales quiero dar respuesta 
Per altra banda, també s'explica com guardar i codificar la informació resultant de les entrevistes. S'explica com les temàtiques de les entrevistes no només són els temes en sí, sinó que hi ha un altre grup de temes més amagats com els valors que porten les persones a actuar d'una manera o d'una altra, les activitats associades a l'activitat principal, qüestions de comportament propi de cada persona, etc.

L'encàrrec per la propera setmana és dur a terme com a mínim dues entrevistes, transcriure-les i codificar-les per poder treballar amb les dades recopilades a la tercera sessió.

\subsubsection{Sessió 3: Dimensions $i$ insights}

La tercera setmana comença amb la introducció de les cinc dimensions i què implica cada una d'elles. La intenció és ordenar tota la informació acumulada fins al moment seguint l'estructura de les dimensions. Cada grup té la informació de l'observació del primer dia de cada membre del grup, notes de camp i potser alguna fotografia. També té la informació recuperada a través de les entrevistes, que pot haver aportat algun concepte o alguna idea nova. A més a més, des de la presentació de l'activitat dues setmanes enrere, l'alumne té temps d'haver observat i reflexionat, i per tant d'aportar també informació nova. En resum, amb les cinc dimensions presentades al capítol III — vegeu apartat 3.5 Les dimensions de l'artefacte - es planteja organitzar la informació i així desfer la possible ambigüitat que comporta la complexitat de qualsevol tasca, encara que sigui aparentment simple, com prendre un cafè a la cantina de la universitat.

Per organitzar aquesta informació es planteja una tasca relativament ràpida, 30 minuts per repartir la informació en un mapa de dimensions molt genèric: una pàgina amb cinc zones marcades, una per cada dimensió. Un cop la informació ja està organitzada, se'n planteja l'anàlisi. Es tracta d'identificar necessitats que amaguen evidències informatives, els insights — vegeu subapartat 2.4.3.1 Extracció de conclusions. Els insights - per a cada una de les dimensions; i finalment convertir aquestes evidències amb preguntes Com podria...?, 
que aproxima els conceptes cap a oportunitats de disseny. Tot aquest procés ha d'acabar amb un repte de disseny final. Aquestes tasques s'acompanyen de la fitxa insights — vegeu figura 47-, i d'una fitxa per a la definició del repte de disseny — vegeu figura 62 - En aquesta fitxa, es recupera la hipòtesi de treball que fins al moment ha guiat el grup, aquesta hipòtesi es contrasta amb els insights més significatius de cada dimensió que s'han treballat durant la primera part de la sessió. Aquí el grup ha d'aplicar les habilitats d'anàlisi i síntesi per identificar la proposta que es preveu amb més recorregut, que es mostra amb possibilitats de solució de forma viable i actual. Quan la proposta s'ha escollit, cal redactar-la en format repte de disseny, és a dir, incloure en aquesta definició les principals restriccions que embolcallen el repte. Un últim apartat de la fitxa, deixa espai per escriure els objectius, aquelles qüestions a les quals es vol donar resposta.

Per acabar la sessió, es fa una posada en comú, perquè cada equip conegui els projectes dels companys.

\subsubsection{Sessió 4: Repte de disseny i projecció de futur}

La quarta sessió pretén transformar el repte de disseny en el futur desitjat per poder emmarcar el projecte i omplir de contingut real cada una de les dimensions. És a dir, plantejar un futur ideal i organitzar una nova etapa de recerca per convertir aquest futur ideal en realitat. Fins al moment s'han treballat totes les sessions sobre informació de recerca fruit de l'observació, les entrevistes i la pròpia experiència, ara es tracta de plantejar un pla de recerca de fonts secundàries per poder caracteritzar el repte de disseny. És important la paraula caracteritzar perquè no es tracta de fer una proposta, sinó de caracteritzar aquesta proposta. És a dir, descriure les accions que haurien de tenir lloc, les qualitats dels artefactes, la il·luminació de l'entorn... totes les característiques que es poden descriure perquè es recolzen en informació fruit de la recerca. Per exemple, es pot definir com a premissa que les taules i cadires han de ser robustes i resistents per un ús continuat i diari, però amb això no s'estan 

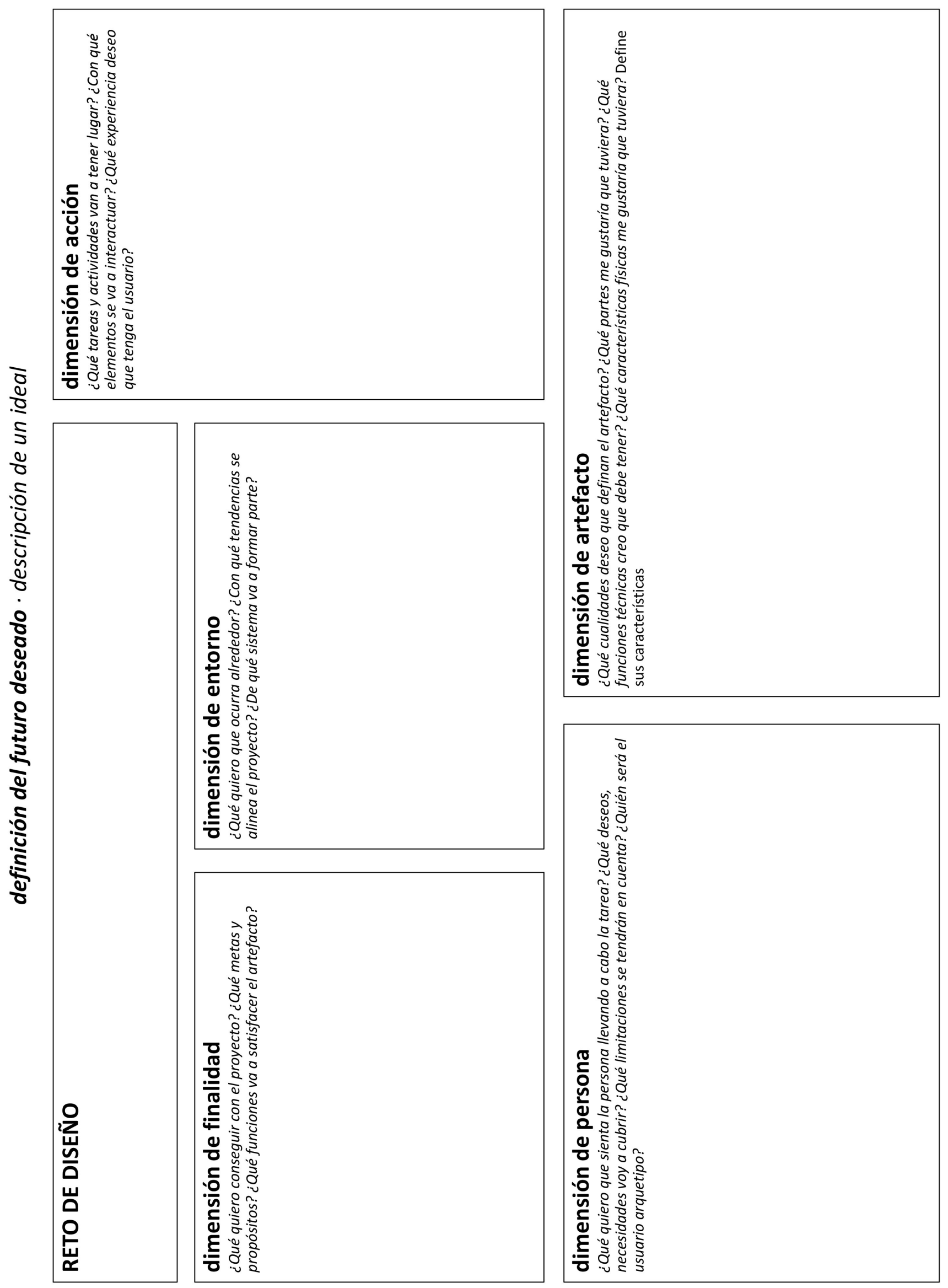
definint ni materials, ni gruixos, ni especificacions constructives, només característiques formals que poden actuar com a premisses de disseny incloses en el brief.

El futur desitjat es treballa a través d'una fitxa — vegeu figura 63 - que distribueix la pàgina en les cinc dimensions. Es tracta de fer volar la imaginació sense restriccions, ja que en el proper pas ja es tornarà a treballar sobre un futur plausible. Aquesta fitxa té una cara posterior en blanc per poder dibuixar aquest futur, i que no quedi només en descripció escrita, sinó que també es treballi en representació en 2D a través d'un prototipat bàsic.

Per acabar la sessió, cal elaborar el pla de recerca final, per a fer-ho es treballa amb les fitxes de cada dimensió — vegeu figures 35 a 39-, on es descriu la informació coneguda, i també inclou una part amb la informació que falta, on es pot localitzar i qui s'encarrega de fer-ho. Per a la pròxima sessió cal dur les fitxes de dimensió ben acabades, amb la informació localitzada, és a dir, amb detalls de referents, qüestions antropomètriques, novetats organitzatives o propietats materials que puguin ser d'interès per a la solució del repte.

Fins aquí la quarta sessió, durant la qual a través de la iteració i de la plasmació del futur desitjat, es pretén depurar i definir les premisses projectuals que acompanyaran el repte de disseny en el brief, document que es pretén elaborar durant l'última sessió de treball.
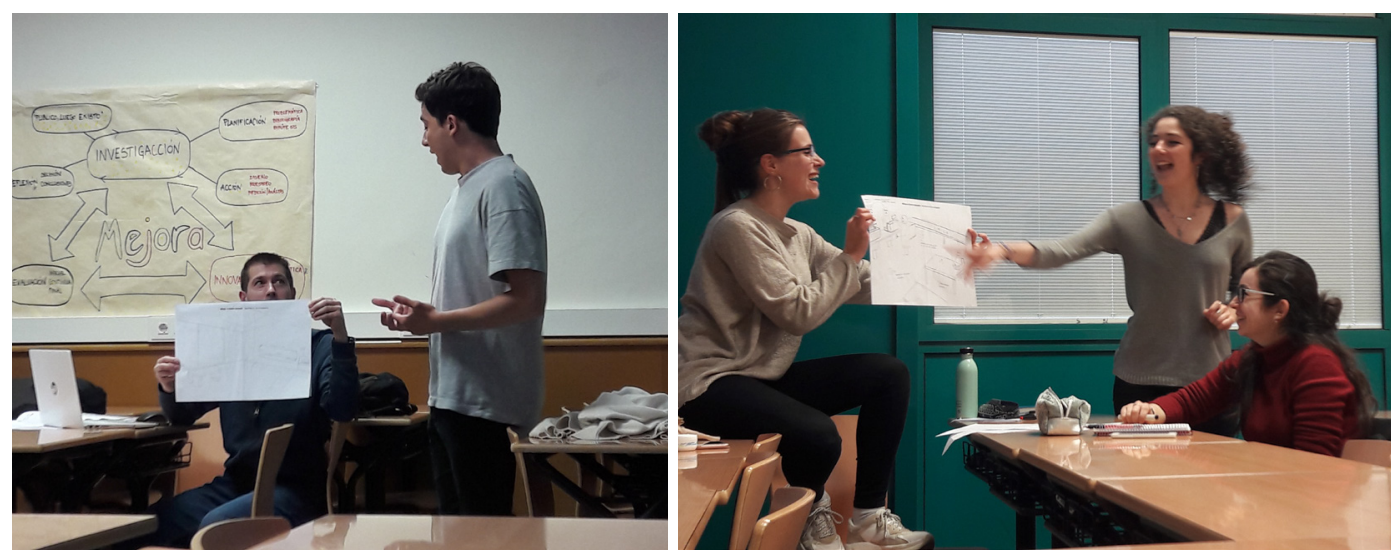

Fig. 64 Alumnes presentant el futur desitjat 


\subsubsection{Sessió 5 (confinada): Premisses de disseny prioritzades}

Com ja s'ha comentat, l'última sessió prevista pel 25 de març ja no es pot realitzar de forma presencial. Així que es facilita la informació en format pdf a través de l'aula virtual i els grups treballen de forma autònoma l'última setmana. Els objectius són dos: per una banda elaborar un brief de disseny que inclogui el repte i les premisses projectuals; i per l'altra, preparar la comunicació del projecte.

Una aposta important que inclou aquesta metodologia de recerca és el fet de prioritzar les premisses de disseny, tal i com es descriu en l'apartat corresponent — vegeu apartat 3.8.2 Fase Comunicar-, on es descriu com la priorització de les premisses pot agilitzar la presa de decisions posterior, durant el desenvolupament del projecte. Tal com recull la fitxa per a l'elaboració del brief — vegeu figures 50 i 51 -, les premisses de cada dimensió es categoritzen segons siguin (1) imprescindibles, (2) desitjables i (3) renunciables. Cada premissa pot anar categoritzada amb qualsevol dels tres qualificatius, això depèn de les prioritats que atorgui el dissenyador en l'elaboració del brief.

Al llarg de la setmana, i fins 1'1 d'abril, cada equip ha de preparar un document d'entrega per mostrar el treball realitzat i un vídeo on s'expliqui el brief que s'ha plantejat.

\subsubsection{Comunicació}

La comunicació estava prevista en format de presentació oral, on cada equip comunicava el resultat de la seva recerca, el repte de disseny i la seva caracterització. La intenció també era poder comentar els resultats entre els diversos equips. Finalment, però, es realitza l'entrega d'un document final per equip a través de l'aula virtual que ha d'incloure:

1. El repte de disseny i una justificació que recolzi amb la recerca el perquè d'aquest repte

2. El plantejament de l'usuari arquetip, per qui està pensat el repte de disseny? 
3. Les premisses de disseny de cada una de les dimensions (prioritzades)

4. Esbossos de les primeres propostes

Es demana un document visual que inclogui el recorregut traçat durant les setmanes de treball que conclou amb el brief. A més a més, es demana que facin arribar un vídeo on expliquin el projecte com a substitució de la comunicació oral.

Tots els grups entreguen puntualment la documentació sol·licitada.

Per cuses alienes, l'exercici no pot concloure com estava previst, però tot i el confinament, els alumnes acaben de recopilar la informació i entreguen les conclusions de la seva recerca. De poder ser, s'hauria fet un tancament conjunt agraint la seva participació i la dedicació mostrada. 


\section{CAPÍTOL V}

\section{RESULTATS}




\section{$5.1 \quad$ Introducció}

En aquest capítol es plantegen exposar els resultats obtinguts en l'aplicació de la metodologia com a exercici dins de l'aula durant el semestre de primavera del curs 19/20, en el marc de l'assignatura de Disseny per a l'Entorn i l'Hàbitat, de la UJI, Castelló, des del seu plantejament a partir d'una hipòtesi de treball vaga, fins a la presentació d'un brief de disseny. Com es pot veure en els capítols corresponents — vegeu capítol III Proposta per a una metodologia de recerca i capítol IV Aplicació de la metodologia (cas pràctic)—, la metodologia aplicada difereix en estructura de la metodologia que es proposa en el capítol III, la qual ja té una estructura definida. Quan es realitza l'exercici dins les aules de l'UJI, tot i que conceptualment la metodologia existeix, encara no s'ha plasmat en un esquema visual que guia durant la recerca — vegeu figura 52-, per tant, es fa ús d'un altre esquema més senzill que marca el recorregut perquè l'alumne sàpiga en quin punt del procés es troba —vegeu figura 54-. És precisament l'aplicació de la metodologia dins l'aula que permet evolucionar-la i definir-la fins a l'esquema general de les cinc fases i les cinc dimensions.

Com a resultat, s'inclou també una mostra de l'anàlisi a través de les cinc dimensions que es du a terme a l'assignatura d'Ergonomia a ESDi, Sabadell, també durant el semestre de primavera del curs 19/20, tot i que en aquest cas el plantejament no és sencer com a metodologia, sinó que només es tracta del treball amb les fitxes de les cinc dimensions per a l'anàlisi d'una unitat funcional dins d'un bany públic, però es considera que és pertinent afegir també el resultat d'aquesta anàlisi, perquè permet contrastar certs punts, sobretot en referència a la caracterització del repte a través de les premisses de cada dimensió. A més a més, el treball amb les fitxes de les dimensions cal verificar-lo en diversos escenaris ja que ha de poder adaptar-se sense problemes a situacions diverses.

Per altra banda, també es revisen les enquestes realitzades els alumnes de la UJI un cop acabat l'exercici, que permet avaluar el grau de satisfacció de l'alumnat amb les tasques realitzades i els resultats obtinguts. 
Tal i com s'ha comentat al llarg del treball els resultats que cal comentar en relació a aquest exercici són de dos tipus: els resultats en sí del treball resultant i la satisfacció de l'alumnat en l'ús de la metodologia. En aquest cas, especialment la seva satisfacció en relació a l'estructuració de l'anàlisi a través de les cinc dimensions recollides dels diversos sistemes persona/màquina de l'ergonomia.

\subsection{Desenvolupament de l'exercici i reptes}

En general, els resultats obtinguts en l'exercici a les aules de la UJI són satisfactoris, tot i que relativament creatius, és a dir, no hi ha reptes especialment innovadors. Les tasques s'han anat desenvolupant sense complicacions i de forma fluida. El cinc equips han realitzat el recorregut pautat $\mathrm{i}$ han treballat seguint les recomanacions de les fitxes arribant a la definició d'un repte de disseny més o menys concret i a unes premisses projectuals que l'acompanyen, tanmateix, només dos, dels cinc equips se'ls reconeix un repte de disseny amb recorregut projectual.

Es detecten els següents punts conflictius:

- Resulta confós per alguns alumnes entendre l'evolució de la hipòtesi al repte de disseny

- Resulta complicat per alguns alumnes caracteritzar una proposta conceptual, sense enfocar-se en descriure la proposta que s'està plantejant.

- Resulta complicat per alguns alumnes decidir un repte i descartar altres problemàtiques trobades

- En general, el recorregut resulta repetitiu i poc àgil

- La proposta es mou en una esfera conceptual i teòrica i això resulta complicat per alguns alumnes

I els següents punts encertats:

- L'observació és una bona eina per iniciar una recerca, obre molts camins

- Les cinc dimensions plantegen un bon escaneig de la situació 
- Les fitxes ajuden a focalitzar les activitats, però cal entendre-les com una eina de treball

- La metodologia s'adapta a diversos nivells de profunditat i concreció

En relació al material final entregat de cada equip com a comunicació, es poden fer les observacions següents:

Fruit de l'observació inicial, els equips 1 i 2 plantegen una nova distribució de la cantina en general per aconseguir millores d'experiència d'usuari a través d'adequar els espais als diversos usos que s'hi poden trobar. És a dir, divideixen zones per menjar, treballar, descansar, etc.

L'equip 1 realitza un projecte sòlid en el sentit que està ben estructurat, però les seves premisses són genèriques i assumeixen poc risc, sembla ser que, a partir d'una hipòtesi acceptable, ha sigut difícil aprofundir per convertir-la en un repte ben definit i creatiu. Es valora positivament el plantejament de tres ambients (zona d'estudi, zona menjador i zona d'oci), tot i que no ho acaben de caracteritzar - treballen amb la mateixa idea des del primer dia, però aprofundeixen i concreten poc-- és significatiu, per exemple, que necessitin posar cartells per diferenciar les zones, sense confiar en què el propi disseny de les mateixes guiarà les persones a dirigir-se segons les seves necessitats — vegeu el seu plafó de presentació a la figura $65-$.

L'equip 2 ha intentat englobar massa problemes i focalitzar-se en donar-hi resposta, més que no pas comprendre l'usuari de forma més precisa, per poder detectar evidències més abastables. Així que, tot i realitzar un anàlisis exhaustiu i plantejar premisses concretes, al final la gran quantitat d'informació de la fase inicial i els múltiples camins possibles a seguir, els impedeix concretar un repte de disseny. Per aquesta mateixa raó, la seva proposta pretén englobar molt i queda difusa.

Els equips 3 i 4 se centren al voltant del servei de menjador, com s'estructuren les cues, el pagament o la distribució del menjar en sí.

L'equip 3 realitza una bona anàlisi i sap definir bones premisses. El repte de disseny està ben definit i pot servir com a brief i punt de partida d'un projecte. El repte està ben justificat 


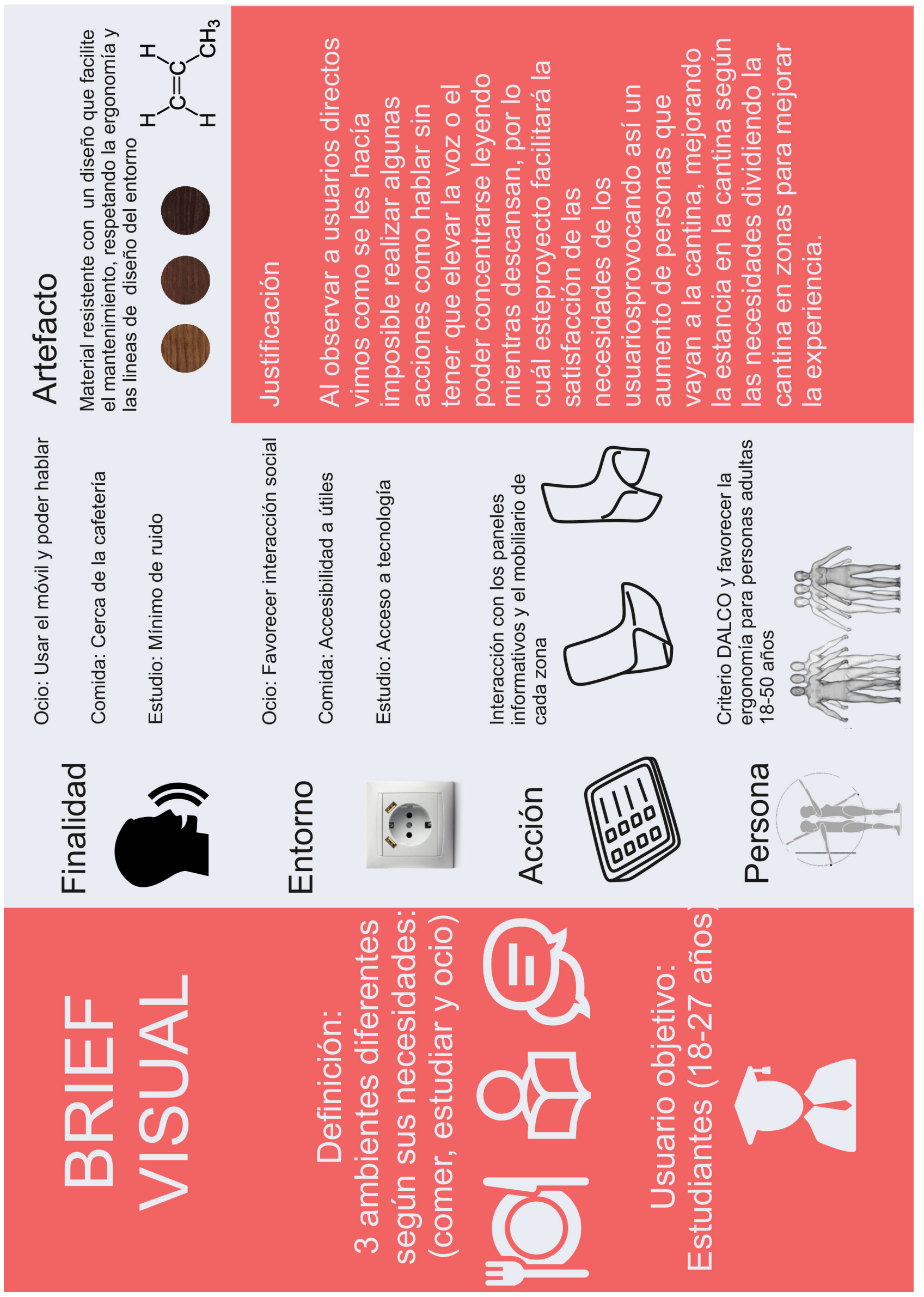



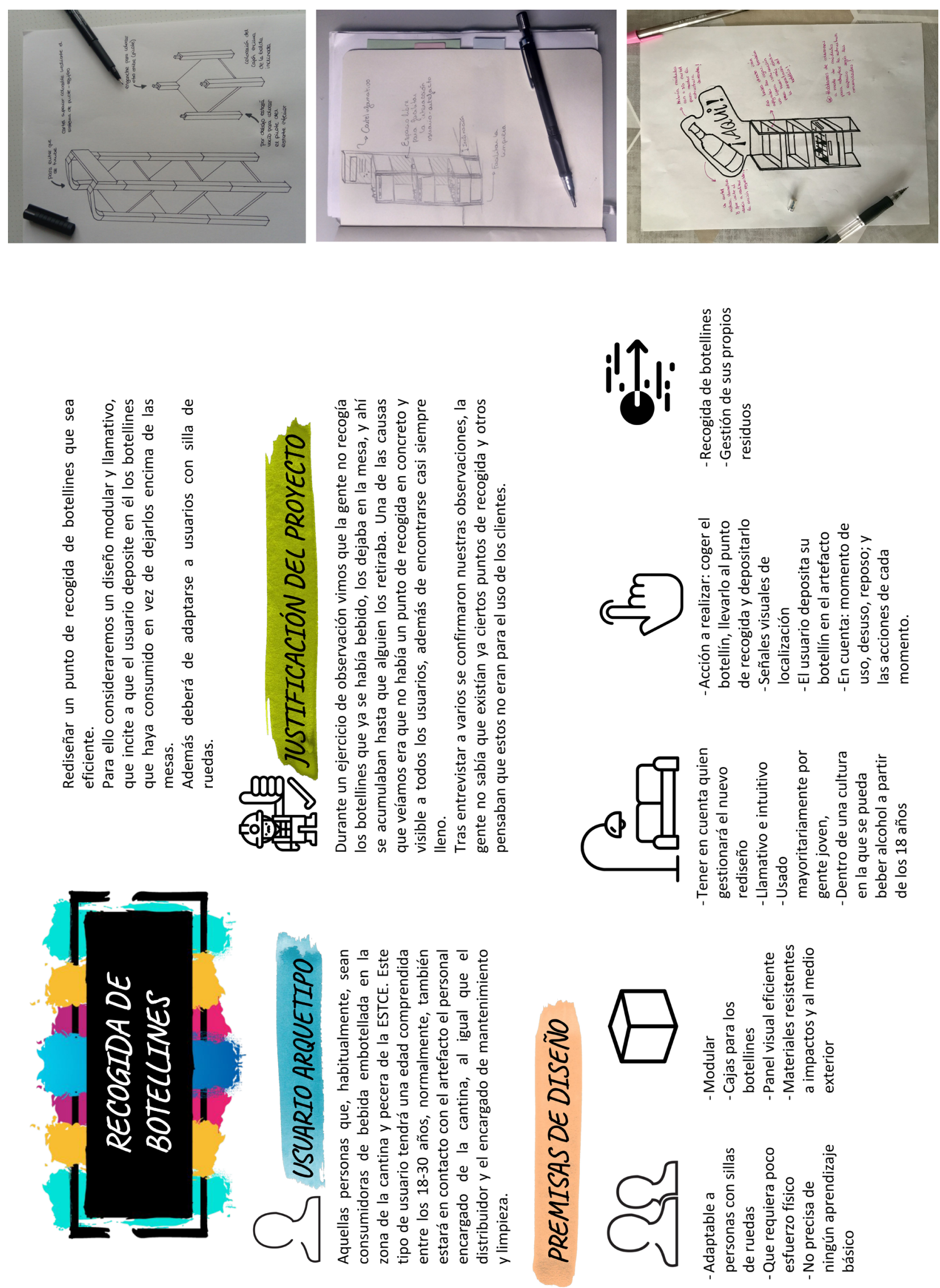
a través de les evidències extretes de l'observació. Dibuixen un bon usuari arquetip amb desitjos i expectatives, així com informació sobre perquè deixaria d'anar a la cantina. Les premisses de disseny estan ben travades. En general, s'observa una bona comprensió de la metodologia.

L'equip 4 ha trobat moltes dificultats per mantenir-se en l'anàlisi sense llençar-se a proposar solucions, així és com acaben presentant un brief a través de la proposta de solució, més que plantejant la caracterització del repte de disseny.

Finalment, l'equip 5, tot i no realitzar una observació i anàlisi especialment profundes, sap localitzar un insight efectiu, d'abast relativament petit i per tant tractable, i això li permet focalitzar el projecte de forma molt més coherent i plantejar un repte de disseny que té recorregut projectual — vegeu el seu plafó de presentació a la figura 66-.

Més enllà del resultats concrets de cada grup, l'aplicació de la metodologia en un àmbit docent com a exercici limitat en el temps es considera una pràctica necessària i per tant satisfactòria. Ha permès observar certs passos especialment conflictius, així com també valorar algunes virtuts.

Amb aquesta pràctica, es demostra que la metodologia és adaptable a diversos requisits temporals, que significaran diversa envergadura i profunditat d'anàlisi, però també es fa palès que, en algunes parts, necessita que s'expliquin alguns conceptes, com per exemple, és difícil transmetre que el resultat final del procés és un brief de disseny amb les respectives premisses a respectar, i no una proposta. Potser l'intent de facilitar la tasca de definició del brief a través de la caracterització d'una solució dibuixada, enlloc de millorar aquest problema, l'ha empitjorat. Per tant, en properes ocasions no es promocionarà aquest fet.

El recorregut de l'anàlisi és elevat i permet aprofundir bastant, i es considera que l'alumne, en aquest sentit, sí que s'ha sentit recolzat per l'estructura de les dimensions.

Com que es detecta certa confusió entre els conceptes d'hipòtesi i repte, per a la proposta de metodologia que es presenta en el capítol III, se suprimeix la definició de cap hipòtesi, directament es defineix un repte de disseny, que es pot afinar gràcies a les iteracions en 
la recerca. La hipòtesi només es manté com a recurs per iniciar la recerca en algun àmbit concret.

És cert que la proposta es mou en una esfera conceptual i teòrica, per això cal valorar prèviament el coneixement metodològic de l'alumne. A la proposta final de la metodologia, l'esquema estructural pot ser més senzill o més complicat segons es desitgi, amb la intenció de poder funcionar amb alumnes de primer, per exemple.

En resum, s'avalua una recerca guiada a través de les cinc dimensions (finalitat, acció, persona, artefacte $\mathrm{i}$ entorn), en aquest sentit les 7 setmanes de treball han resultat suficients per avaluar la idoneïtat del treball amb les dimensions. Tanmateix, es revisa per a la proposta plantejada al capítol III, com es presenten i s'articulen les cinc dimensions en el desenvolupament de la metodologia de recerca.

Per altra banda, la part final de l'exercici corresponent a l'elaboració del brief s'ha hagut de realitzar sense acompanyament directe dins de l'aula a causa del confinament, per tant, els equips han treballat de forma autònoma tant el brief com la seva comunicació final. Com ja s'ha dit, és difícil saber si els reptes i les premisses serien gaire diferents d'haver pogut realitzar la cinquena sessió de forma presencial on precisament es tractava d'assentar aquests conceptes en una última iteració. Tot i així, revisant el material de treball, per exemple, les fitxes de les dimensions omplertes, es pot veure com hi ha grups que tenen informació no inclosa en la documentació final, que ha quedat més superficial; hi ha força diferència entre equips. Per tant, potser sí que es podria afirmar, que el confinament ha afectat als documents finals de presentació. En qualsevol cas, ha sigut impossible realitzar una presentació pública amb comentari i debat posterior dels diversos equips participants. 


\subsection{Anàlisi de l'aplicabilitat de la metodologia}

\subsubsection{La caracterització del repte de disseny}

La metodologia que es presenta en aquest treball, és una metodologia de recerca que ha de guiar al dissenyador en el desenvolupament d'un repte de disseny encertat i d'unes premisses de disseny que emmarquin el projecte. Aquesta metodologia agrupa les dimensions del projecte provinents del sistema Persona/Màquina de l'ergonomia, la visió d'un inici de projecte marcat per la confusió de Sanders i Stappers, així com la creença que una recerca desenvolupada amb rigor i coherència permetrà extreure unes conclusions vàlides i valuoses per la configuració del projecte. D'alguna manera, es busca alleugerir el pont entre el concepte i la idea que pot suposar un punt conflictiu en el desenvolupament del projecte. En aquest sentit, es planteja confiar en la recerca de manera que l'observació guiada de la realitat, esdevingui un punt clau d'aquest pont. La metodologia sortint, planteja que aquesta observació guiada es realitzi segons una estructura basada en les cinc dimensions: persona, acció, finalitat, entorn i artefacte. Martí Font (1999) situa la construcció de la hipòtesi com "la clau de volta de tota l'activitat projectual", ja que "es tracta de l'estadi del projecte on es configura la idea del què serà més endavant una nova entitat material" (Martí Font, 1999, p. 228). Aquest autor anomena hipòtesi al concepte que des d'aquest treball s'anomena repte. És molt interessant observar com per a Martí Font, una hipòtesi de partida és la clau per desenvolupar un projecte coherent, i que a més a més, és la hipòtesi que visualitza la possibilitat de solució a través de la configuració de la idea. Les premisses projectuals pretenen configurar aquesta idea a través d'informació vàlida per al desenvolupament del projecte. Per a Martí Font, “aquesta configuració prèvia a l'existència de l'artefacte apareix més o menys formalitzada, més o menys clara, en la ment del dissenyador" (Martí Font, 1999, p. 228). En realitat, aquest és un dels problemes que mostra la metodologia, com es pot prevenir la formalització de l'artefacte, durant el procés de recerca? És a dir, no 
prevenir la formalització mental de l'artefacte sortint, perquè això és el que, en definitiva, guia al dissenyador a través del seu instint, però sí com prevenir que aquesta formalització es caracteritzi fora de la recerca. Les cinc dimensions pretenen caracteritzar l'artefacte sense concretar-lo, talment com si s'anessin donant pistes d'una endevinalla que cal tenir en compte per desvelar la resposta, per exemple en el joc d'endevinar personatges, amb el qual a través de preguntes i respostes sí/no es configura un personatge. Aquestes preguntes i respostes serien les premisses de disseny. Quan es tenen totes les peces, llavors es desvela el personatge que en aquest cas seria l'artefacte.

Per tant, tot i que es considera molt útil l'ús de la metodologia de recerca en un projecte de disseny, el fort enfocament cap a la solució dels alumes, en dificulta la seva aplicació. Això s'ha pogut observar de forma molt marcada en algun dels grups de treball de l'assignatura de Disseny per a l'Entorn i l'Hàbitat. En canvi, des d'una assignatura apartada del projecte de disseny en sí, com és l'assignatura d'Ergonomia a ESDi, els alumnes estan més disposats a la recerca, sense proposta projectual, ja que l'enfocament ja és diferent des d'un principi. En aquest sentit, es considera que l'explicació inicial al voltant de la metodologia del projecte ha d'estar enfocada explícitament en aclarir aquesta diferenciació, entre recerca i desenvolupament, entre repte de disseny i proposta. A la figura 67 es pot observar l'anàlisi realitzat per un alumne a través de les cinc dimensions sobre un rentamans públic, a través de la informació de la fitxa, es configuren les premisses que s'inclouran en el brief.

La informació sortint d'aquesta recerca és informació vàlida per traslladar a un equip de disseny que desenvolupi un rentaments per un poliesportiu i que tingui en compte característiques diferenciadores dels infants. Per exemple, a característiques físiques de la dimensió Persona, l'alumne dibuixa un esquema de les dimensions d'ergonomia dinàmica que necessita tenir en compte, no en sap la resposta, ja que tot just és un primer pas de la recerca, però ja es reflexiona sobre informació que necessitarà conèixer, de manera que la fitxa de la dimensió està exercint un dels seus principals objectius: oferir a la recerca una visió àmplia des de diverses dimensions que afecten la configuració de l'artefacte.

En resum, la metodologia i amb ella el treball a partir de les cinc dimensions funciona 

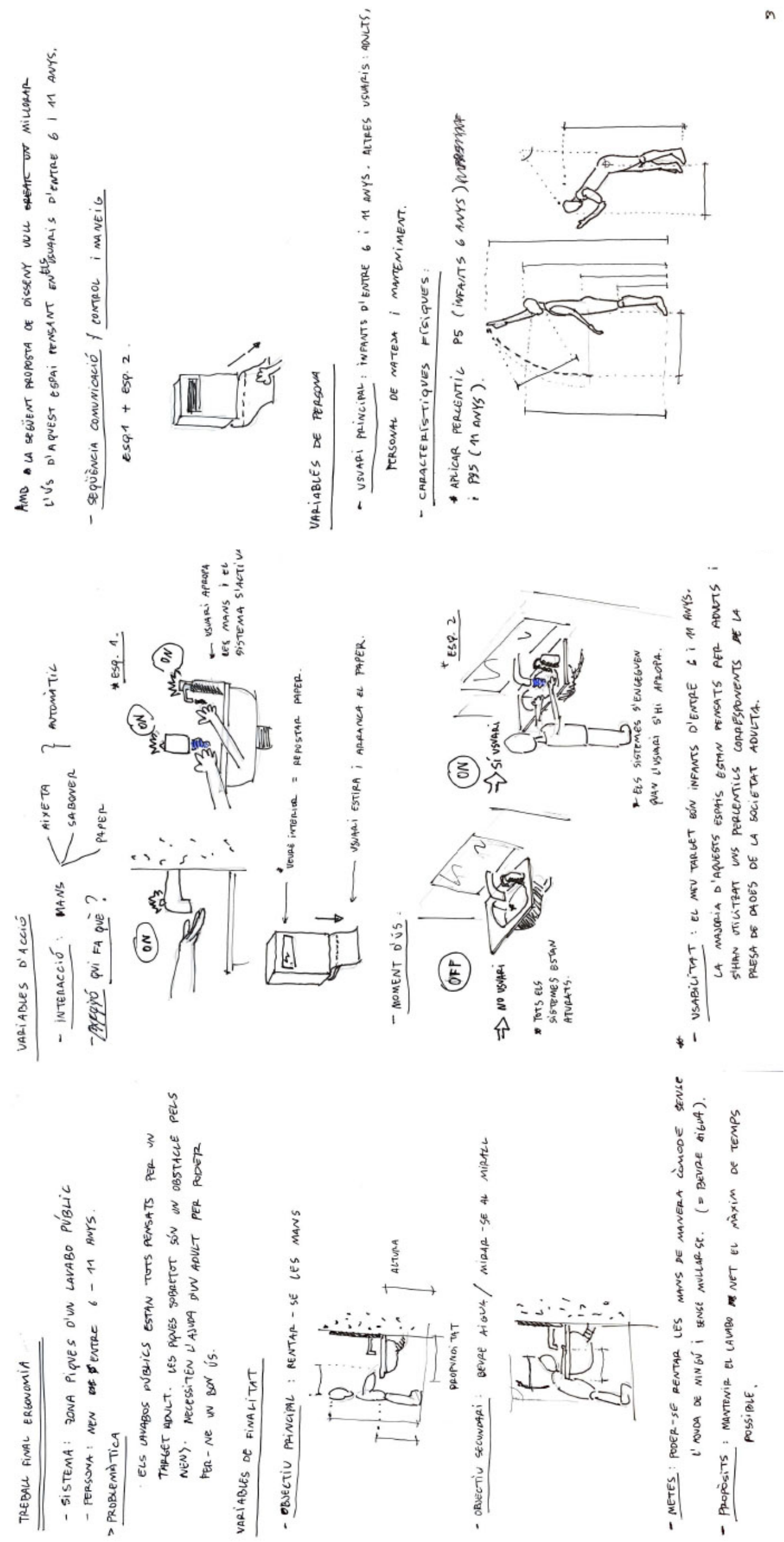

Fig. 67 Recerca i establiment de característiques a través de les cinc dimensions d'un rentamans públic 


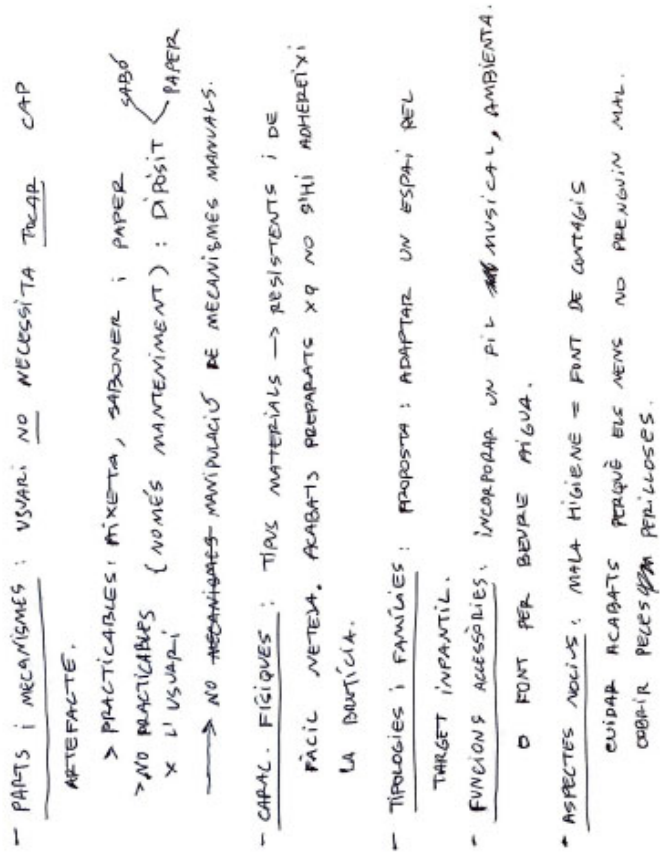
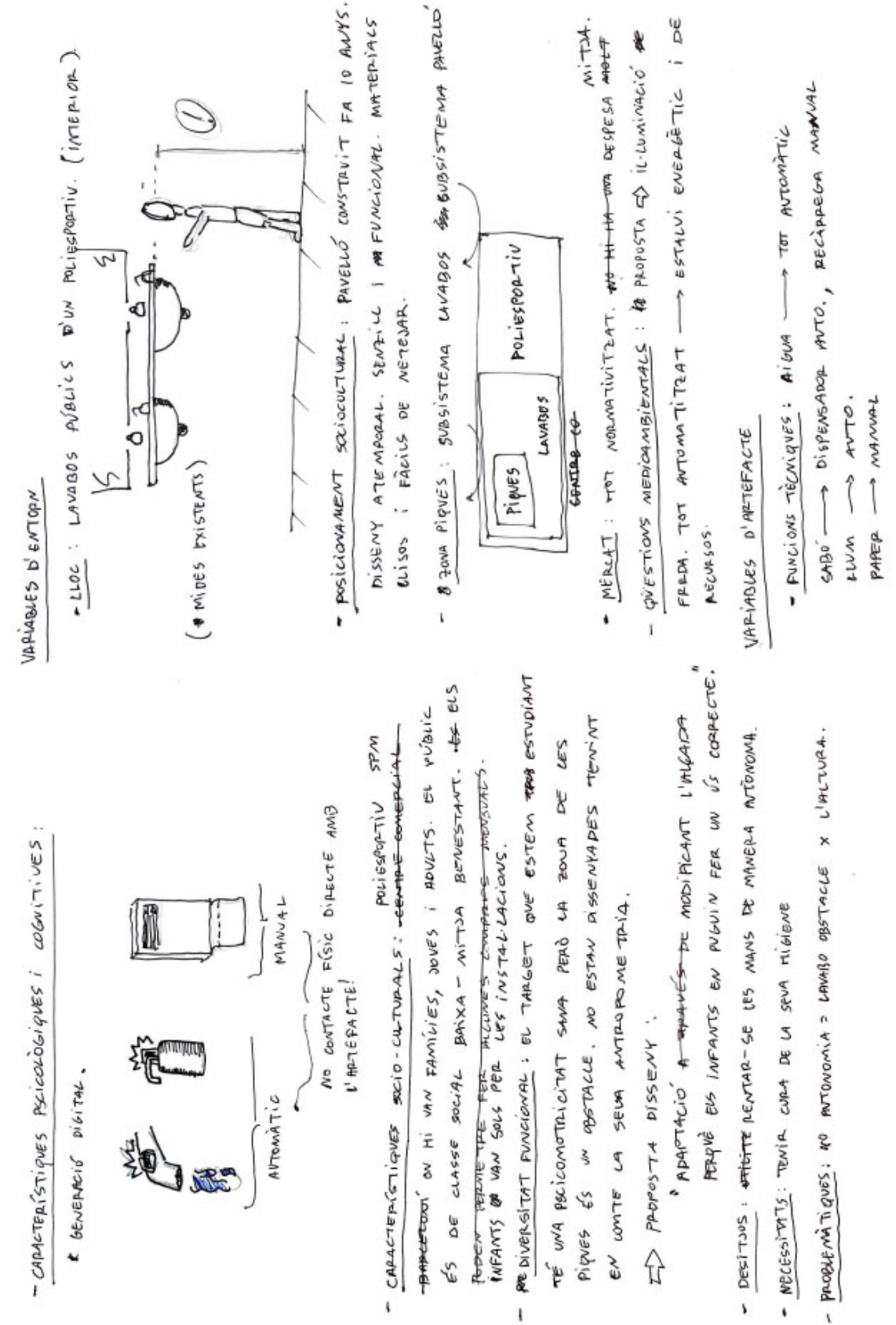
molt millor quan l'alumne es focalitza en modus de recerca i caracterització de l'artefacte. I resulta més complicat, quan l'alumne es focalitza en la solució, ja que perd l'observació empàtica i la recerca de necessitats, desitjos i problemàtiques de les persones que faran ús de l'artefacte.

La metodologia es planteja amb una estructura adaptable a diverses necessitats de recerca, tot i així, es pressuposen certes habilitats adquirides amb els estudis de disseny. Per exemple, la metodologia busca l'aproximació empàtica a l'usuari i l'observació d'un conjunt de tasques que configuren una unitat funcional, més gran o més petita. Ambdues eines requereixen cert aprenentatge, per tant, si l'alumne mai ha tingut contacte amb aquest tipus d'eines o tot just acaba de començar els estudis, li cal un esforç extra d'adaptació i comprensió.

\subsubsection{Les enquestes}

Un cop acabada la pràctica a l'assignatura de Disseny per a l'Entorn i l'Hàbitat a la UJI, es realitza una enquesta per a conèixer el grau de satisfacció del desenvolupament de l'exercici, així com els seus coneixements de metodologia del projecte, que 18 dels 19 alumnes contesten de forma anònima al llarg del mes d'abril. Que siguin més o menys conscients de la metodologia que fan servir i del nom d'aquesta metodologia, no és especialment significatiu si en reconeixen les dinàmiques. Tot i així, es pot observar, per exemple, que només 2 dels 19 alumnes que contesten l'enquesta són conscients de fer servir metodologia de codesign, en contraposició a 9 alumnes que no la coneixen o no són conscients d'utilitzar-la. La majoria d'alumnes tampoc fan servir el doble diamant, tot i que 6 d'ells admeten conèixer-lo. Amb el Design Thinking passa una mica el mateix, tot i que en aquest cas 6 alumnes reconeixen utilitzar-lo. En canvi, els alumnes són plenament conscients de l'ús del disseny universal i del disseny centrat en les persones amb 14 i 13 respostes afirmatives respectivament. És a dir, els alumnes d'aquesta aula no són conscients de conèixer les metodologies de disseny que serveixen de base per a la proposta d'eines a utilitzar en la metodologia de 
recerca a través de les cinc dimensions. Per tant, en aquest context, és necessari explicar molt bé cada pas, per què serveix i on ens permet arribar.

Quan es pregunta concretament pel coneixement i l'ús d'eines utilitzades, les respostes són més repartides, predomina el "haver-la utilitzat alguna vegada", per exemple en el cas de l'entrevista -10 respostes —, l'observació contextual -8 respostes—, o la definició d'un repte de disseny — també 8 respostes- I destaquen com a eines mai utilitzades, el mapa d'accions d'usuari $\_8$ respostes, l'elaboració d'insights $— 14$ respostes—, i l'estructura en cinc dimensions - 13 respostes-. És a dir, que les principals eines utilitzades, excepte l'entrevista, eren desconegudes pels alumnes. Com era de suposar, l'estructuració de la recerca a partir de les cinc dimensions, és majoritàriament desconegut per l'alumne, ja que aquesta és precisament la proposta principal de la metodologia, tot i així uns altres 5 alumnes contesten que l'havien fet servir alguna vegada; fet que és possible, ja que es tracta de la configuració del sistema persona/màquina de l'ergonomia, per tant, podien haver-ne fet ús, si més no de forma similar, amb antelació.

També és cert, que tot i fer servir eines desconegudes fins al moment, a la pregunta si consideren que han sigut útils per a la bona definició del projecte, per al mapa d'accions d'usuari, contesten que bastant o molt útil, 14 alumnes; per a l'elaboració d'insights, 11 alumnes; i, per l'estructura en cinc dimensions, també 11 alumnes. Tot i que en aquest últim cas, un alumne contesta que ha sigut poc útil. Aquest alumne, expressa la seva opinió general al final de l'enquesta afirmant que "s'ha sentit perdut en algunes tasques i que ha tingut la sensació de tornar enrere. De la mateixa manera que no ha sentit una evolució de la investigació, ja que premisses que tenia clares al primer dia, no les ha modificat o ha canviat d'opinió". Per tant, aquest ha sigut un alumne a qui no se li ha sabut transmetre la utilitat de cada pas, ni el per què de les eines utilitzades; sembla, amb les seves respostes, que no ha sabut aplicar la recerca d'insights, ja que ha quedat satisfet amb el primer plantejament de projecte. Ha faltat transmetre, que cal una mirada crítica sobre les pròpies idees preconcebudes i que el procés d'iteració serveix per replantejar aspectes que es consideren definitius. 
En relació a l'estructuració de la fase de recerca, es pregunta si creuen que una bona estructuració ajuda a tenir més informació vàlida per a determinar el repte de disseny. Tots els alumnes menys un, estan d'acord amb aquesta informació, 7 d'ells totalment d'acord. Tots els alumnes sense excepció consideren important la fase inicial de recerca en un projecte de disseny, 13 dels quals totalment d'acord. En canvi, al preguntar concretament per l'estructura a partir de les cinc dimensions, ja hi ha una mica més de disparitat. Al preguntar si s'han sentit còmodes treballant amb les dimensions, 13 dels alumnes responen afirmativament, però la majoria — 8 d'ells—, només parcialment d'acord. Al preguntar si ha sigut fàcil ordenar la informació en cada una de les dimensions, 10 alumnes responen afirmativament, però cap d'ells hi està totalment d'acord, i dos alumnes hi estan totalment en contra. O sigui, que cal revisar com es trasllada el contingut de cada fitxa de dimensió. Els requadres de les fitxes inclouen una breu explicació sobre quina informació es pretén col·locar en l'espai corresponent, la majoria de vegades, aquesta descripció es realitza a través de preguntes. Això és així per intentar obrir la mirada del dissenyador i que se senti interpel·lat. És veritat, però, que en ocasions es veuen respostes molt directes a la pregunta sense una reflexió superior o sense adaptar una pregunta genèrica al cas concret que s'està investigant. De fet, tot i mantenir l'estructura de les fitxes, segons per quina recerca, val la pena adaptar-ne aquestes preguntes, per ajudar a l'alumne a enfocar millor.

Preguntant en relació a la satisfacció, 15 alumnes estan satisfets tant amb les premisses de disseny resultants del procés d'investigació, com del repte de disseny definit, com del desenvolupament general de la recerca fins a la definició del repte. En els tres casos es manté l'estructura de 8 alumnes que gairebé estant del tot d'acord amb l'afirmació, ja que han votat una nota de 5 sobre 6.

Així doncs, en general els alumnes estan satisfets amb l'exercici i consideren que la pràctica ha sigut útil per al seu desenvolupament personal, ja que la majoria reconeix la utilitat de les eines per a una bona definició del projecte i considera que les continuarà fent servir en futures ocasions. A més a més, també la gran majoria se sent satisfeta amb els resultats. És 
veritat, però, que hi ha certs punts conflictius que s'han intentat solucionar amb la proposta de la metodologia per la recerca que es presenta en el capítol III.

\subsubsection{Els briefs resultants}

A continuació s'inclouen alguns dels briefs resultants de la recerca, presentats a través de la fitxa de treball corresponent — vegeu figures 50 i 51-, abans de traslladar-se als documents de comunicació.

Com es pot observar a la figura 68 , on es pot veure el brief de l'equip 2, la descripció breu que es demana a l'inici del brief, coincideix amb la hipòtesi inicial de l'exercici, és a dir, millorar l'experiència d'usuari en l'ús de la cantina. Per tant, en aquest equip ha faltat treballar els insights de forma més precisa per aconseguir trobar una evidència que desemboqui en un repte, o també, ha faltat decisió a l'hora d'escollir el camí. És a dir, han volgut donar resposta a les queixes de tots els usuaris amb qui han parlat — com es pot veure a la part 3 - Justificació del projecte, a la figura 68-, i ho han inclòs tot en les premisses de disseny — vegeu figura 69-. Per tant, es tracta d'un projecte enorme, inabastable en un exercici de cinc sessions lectives, de manera que les premisses són molt irregulars, hi ha premisses molt concretes com que el menú estigui en tres idiomes; i premisses molt genèriques, com que al client no li importi passar estona a la cantina, premissa classificada com a prescindible. També aporten premisses que fan referència a persones amb diversitat funcional, aportant una perspectiva de disseny universal. S'aprecia una tasca realitzada amb ordre, i cada una de les premisses té un sentit que es recolza en alguna opinió expressada per usuaris, més que no pas en l'observació de la recerca, tal i com es pot veure en el material que faciliten del desenvolupament del projecte. El futur imaginat d'aquest grup és una cantina completament diferent, grans finestrals, taules modulars, plantes penjant del sostre, i un servei de restauració totalment reestructurat. En definitiva, és un treball que demostra, per una banda, la capacitat d'abast de la metodologia, ja que interpel·la en molts sentits i per 
tant s'obre moltes possibilitats; però per altra banda, aquesta mateixa virtut es pot tornar en contra si no es treballa bé el procés de convergència, i el repte de disseny queda difuminat. En contraposició a aquest exemple, es pot observar el brief de l'equip 5 -vegeu figures 70 i $71-$. Aquest grup ha definit un repte de disseny clar i concret, i sobretot abastable temporalment, de manera que el brief resultant, pot ser un punt de partida per un projecte. En aquest cas, l'equip 5 pretén redissenyar un punt de recollida de les ampolles de cervesa eficient, i que inciti als usuaris a fer-lo servir, ja que durant l'observació han vist que les taules estan plenes d'ampolles sense recollir. El pas de l'observació al repte, demostra un bon treball d'insights i de concreció de la idea, ja que la seva hipòtesi preliminar era la gestió de la recollida d'ampolles, que es va definir en el repte del redisseny del punt de recollida. Aquest equip, a més a més, tenia diversos insights i finalment es va quedar amb el considerava més viable i innovador, fent ús del quadre de selecció d'idees. En resum, és un bon exemple de com els diversos passos ajuden a la convergència.

Les seves premisses inclouen diversos usuaris, clients i treballadors responsables de la recollida, i a part de l'objectiu principal marcat com a la recollida de les ampolles, tenen unes metes en referència a la conscienciació del usuaris sobre la necessitat de mantenir els espais nets i sobre com tractar els tipus de residus — totes dues premisses, però, considerades com a prescindibles-. Per altra banda, degut a l'envergadura del repte, poden concretar premisses de l'artefacte com que sigui modular, o que tingui rodes, requeriments tècnics valuosos per al projecte. En definitiva, un brief ben estructurat i que es recolza en la recerca i les entrevistes, amb unes premisses que caracteritzen l'artefacte que l'equip ha visualitzat, sense definir-lo.

Finalment, es mostra el brief de l'equip 3 -vegeu figures 72 i 73 -. Aquest equip es preocupa especialment del servei de menjador. També es tracta d'un repte de força envergadura, però en aquest cas és més focalitzat que el brief presentat per l'equip 2, sobretot perquè una de les premisses que tenen és la de mantenir elements preexistents tant com sigui possible. De manera que, tot i caracteritzar un brief que remodela tot el servei, les premisses estan més treballades i aporten informació valuosa per el desenvolupament del projecte. 
En general, aquest brief és el més ben treballat dels tres que es mostren, sobretot per la coordinació que s'observa entre dimensions. És molt interessant la premissa que el model sorgint del procés de disseny sigui traslladable a altres cantines, demostrant capacitat de visualitzar el recorregut del propi projecte. Aquest equip ha realitzat una bona feina de conjunt i el seu principal valor està en haver sabut aprofitar les cinc dimensions per caracteritzar el repte. En aquest cas, el repte de disseny ha quedat més genèric, però la bona feina feta a través de les dimensions i les premisses acaben configurant un repte que es veu ben travat per al seu desenvolupament. 


\section{Descripción breve}

Descripción clara y conciso del proyecto con las coracteristicas que le dan valor, aquelio que le diferencia de los artefactas parecidos Se busca la mejora de la experiencia del usuario para mejorar la satisfacción del cliente, con ello conseguiremos un mayor consumo de los productos de la cafetería.

\section{Identificación de los usuarios}

¿A quién wo destinado el proyecto? ¿Quién es el usuario arquetipo?

Va destinado a los usuarios diarios de la cafeteria (estudiantes, profesorado y personal de mantenimiento), cuyo objetivo es un consumo rápido para seguir con sus tareas y desconectar durante unos minutos del trabajo.

\section{Justificación del proyecto}

¿Qué observaciones han desencadenado el proyecto? ¿Por qué tiene sentido? ¿Qué problemática, deseo o necesidad pretende solucionar? Los usuarios nos han hecho llegar el descontento generalizado por la cantidad de tiempo que se tarda en atender a los usuarios, la falta de información de los precios y del proceso de compra en la barra, la mala distribución del espacio útil y la mala estetica seguida.

Se va a llevar a cabo una remodelación del espacio que suponga una mejora tanto en eficiencia como en calidad del servicio, también mejorar la experiencia del usuario mediante la remodelación estética del entorno y la mejora de distribución del espacio. 


\section{Funciones y prioridades, las premisas de diseño}

Requerimientos del proyecto fruto del anáissis previo, del estudio de usuaria, del andilisis de referentes, etc. Priorización numérico de imprescindibles: imprescindible (1), deseable (2), prescindible (3)

\begin{tabular}{|c|c|c|}
\hline Tipo de requerimiento & Listado de requerimientos & Priorización \\
\hline $\begin{array}{l}\text { Básicos del proyecto } \\
\text { RETO DE DISENOO "Mejorar la experiencia } \\
\text { durante la estancia en la cafeteria" }\end{array}$ & $\begin{array}{l}\text { a. Que el cliente salga satisfecho. } \\
\text { b. Que el servicio sea eficiente. } \\
\text { c. Que el personal de servicio esté contento }\end{array}$ & $\begin{array}{l}\text { Aqui todos deberian } \\
\text { ser } 1 \\
1 \\
1 \\
1\end{array}$ \\
\hline $\begin{array}{l}\text { DIMENSIÓN de FINALIDAD } \\
\text { Requerimientos funcionales Objetivo } \\
\text { principal, objetivos secundarios, } \\
\text { metas y propósitos ¿Qué objetivos } \\
\text { debe cumplir? ¿Para que sirve? }\end{array}$ & $\begin{array}{l}\text { a. Que el cliente recomiende el bar } \\
\text { b. Que el cliente no le importe pasar el tiempo en la cafeteria } \\
\text { c. Que se facilite el trabajo del servicio } \\
\text { d. Que el cliente consuma asiduamente }\end{array}$ & $\begin{array}{l}1 \\
3 \\
2 \\
2\end{array}$ \\
\hline $\begin{array}{l}\text { DIMENSIÓN de ENTORNO } \\
\text { Requerimientos de posicionamiento } \\
\text { Como sistema o subsistema, ¿qué } \\
\text { premisas debe cumplir? } \\
\text { Estéticamente, ¿qué premisas definen el } \\
\text { artefacto? Socioculturalmente, } \\
\text { ¿dónde se sitúa? }\end{array}$ & $\begin{array}{l}\text { a. Que haya un espacio vegetal } \\
\text { b. Espacios amplios que faciliten la circulación de los usuarios } \\
\text { c. Que la disposición del espacio transmita tranquilidad } \\
\text { d. La distribución de las mesas permita sentarse a más gente. }\end{array}$ & $\begin{array}{l}2 \\
1 \\
2 \\
2\end{array}$ \\
\hline $\begin{array}{l}\text { DIMENSı́́N de ACCIÓN } \\
\text { Requerimientos de experiencia de uso } \\
\text { Requerimientos relacionados con las } \\
\text { tareas y acciones, ¿cómo deseamos } \\
\text { que se lleven a cabo? ¿Cómo es la } \\
\text { interacción usuario/artefacto? ¿Cuáles } \\
\text { son las secuencias de uso definidas? } \\
\text { ¿Qué premisas aseguran una buena } \\
\text { usabilidad? ¿Hay que tener en cuenta } \\
\text { distintos momentos de uso? }\end{array}$ & $\begin{array}{l}\text { a. Que se pueda pagar rápidamente. } \\
\text { b. Generar un sitio para depositar tazas usadas } \\
\text { c. Identificar las papeleras claramente } \\
\text { d. Que la puerta se abra hacia las dos sentidos }\end{array}$ & $\begin{array}{l}1 \\
2 \\
1 \\
1\end{array}$ \\
\hline $\begin{array}{l}\text { DIMENSIÓN de PERSONA } \\
\text { Requerimientos del usuario } \\
\text { Limitaciones fisicas y cognitivas, } \\
\text { ergonomia, antropometria. Valores, } \\
\text { deseos. }\end{array}$ & $\begin{array}{l}\text { a. Que el mend está en valenclano, castellano e ingles. } \\
\text { b. Carteleria legible a } 5 \mathrm{~m} \text {. como mínimo. } \\
\text { c. Que el pavimento sea abotonado para que dirija a la persona hacia } \\
\text { la barra. }\end{array}$ & $\begin{array}{l}1 \\
1 \\
2\end{array}$ \\
\hline $\begin{array}{l}\text { DIMENSıÓN de ARTEFACTO } \\
\text { Requerimientos técnicos } \\
\text { ¿Qué partes y mecanismos podemos } \\
\text { definir? ¿Qué caracteristicas fisicas } \\
\text { podemos definir? Peso, resistencia, } \\
\text { color, materiales, acabados... } \\
\text { ¿Forma parte de alguna familia? } \\
\text { ¿lncluye accesorios? } \\
\text { ¿Qué aspectos nocivos hay que prever? }\end{array}$ & $\begin{array}{l}\text { a. Las mesas deben ser modulables } \\
\text { b. Las sillas deben ser de fácil apilamiento } \\
\text { c. Que la barra pueda garantizar múltiples filas. }\end{array}$ & $\begin{array}{l}2 \\
2 \\
2\end{array}$ \\
\hline
\end{tabular}




\section{EL BRIEF}

1 Descripción breve

Descripción clara y concisa del proyecto con las caracteristicas que le dan valor, aquello que le diferencia de los artefactos parecidos

Rediseñar un punto de recogida de botellines que sea eficiente.

Para ello consideraremos un diseño modular y llamativo, que incite a que el usuario deposite en él los botellines que haya consumido en vez de dejarlos encima de las mesas.

Además deberá de adaptarse a usuarios con silla de ruedas.

\section{Identificación de los usuarios}

\section{¿A quién va destinado el proyecto? ¿Quién es el usuario arquetipo?}

Aquellas personas que, habitualmente, sean consumidoras de bebida embotellada en la zona de la cantina y pecera de la ESTCE. Este tipo de usuario tendrá una edad comprendida entre los 18-30 años, normalmente, también estará en contacto con el artefacto el personal encargado de la cantina, al igual que el distribuidor y el encargado de mantenimiento y limpieza.

\section{Justificación del proyecto}

¿Qué observaciones han desencadenado el proyecto? ¿Por qué tiene sentido? ¿Qué problemática, deseo o necesidad pretende
salucianar?
Durante un ejercicio de observación vimos que la gente no recogía los botellines que ya se había bebido, los dejaba
en la mesa, y ahí se acumulaban hasta que alguien los retiraba. Una de las causas que veíamos era que no había un
punto de recogida en concreto y visible a todos los usuarios, además de encontrarse casi siempre lleno.
Tras entrevistar a varios se confirmaron nuestras observaciones, la gente no sabía que existían ya ciertos puntos de
recogida y otros pensaban que estos no eran para el uso de los clientes.




\section{Funciones y prioridades, las premisas de diseño}

Requerimientos del proyecto fruto del andilisis previo, del estudio de usuario, del análisis de referentes, etc. Priarización numérica de imprescindibies: imprescindible (1), deseoble (2), prescindible (3)

\begin{tabular}{|c|c|c|}
\hline Tipo de requerimiento & Listado de requerimientos & Priorización \\
\hline $\begin{array}{l}\text { Basicos del provecto } \\
\text { RETO DE DISENO }\end{array}$ & $\begin{array}{l}\text { a. Hacer visible el punto de recogida } \\
\text { b. Concienciar a la gente en recoger sus residuos } \\
\text { c. Limpiar el espacio de cantina, pecera y terraza de botellines } \\
\text { que se quedan por encima de las mesas } \\
\text { d. Aumentar la capacidad de recogida en el redisefio }\end{array}$ & $\begin{array}{l}\text { Aqui todas deberian } \\
\text { ser } 1\end{array}$ \\
\hline $\begin{array}{l}\text { DIMENSION de FINALIDAD } \\
\text { Requerimientos funcionales } \\
\text { Objetivo principal, objetivos } \\
\text { secundarios, metas y propósitos } \\
\text { ¿Qué objetivos debe cumplir? ¿Para } \\
\text { qué sirve? }\end{array}$ & $\begin{array}{l}\text { a. Recogida de botellines } 1 \\
\text { b. Facilitar las tareas a los trabajadores } 2 \\
\text { c. El usuario gestione sus propios residuos } 1 \\
\text { d. Concienciar a la gente sobre cómo tratar cada tipo de residuo } \\
\text { e. Concienciar sobre los espacios limpios } 3\end{array}$ & \\
\hline $\begin{array}{l}\text { DIMENSIÓN de ENTORNO } \\
\text { Requerimientos de posicionamiento } \\
\text { Como sistema o subsistema, ¿qué } \\
\text { premisas debe cumplir? } \\
\text { Estéticamente, ¿qué premisas definen } \\
\text { el artefacto? Socioculturalmente, } \\
\text { ¿dónde se sitúa? }\end{array}$ & $\begin{array}{l}\text { a. Tener en cuenta quien gestionará el nuevo rediseño, sea una } \\
\text { empresa externa o la propia que lleva la cantina } 1 \\
\text { b. Estéticamente, que sea llamativo e intuitivo } 1 \\
\text { c. Socioculturaimente, va a ser usado mayoritariamente por } \\
\text { gente joven, que suele ser más intuitiva } \\
\text { d. Dentro de una cultura en la que se pueda beber alcohol a } \\
\text { partir de los } 18 \text { años }\end{array}$ & \\
\hline $\begin{array}{l}\text { DIMENSION de ACCION } \\
\text { Requerimientos de experiencia de uso } \\
\text { Requerimientos relacionados con las } \\
\text { tareas y acciones, ¿como deseamos } \\
\text { que se lleven a cabo? ¿Como es la } \\
\text { interacción usuario/artefacto? ¿Cuáles } \\
\text { son las secuencias de uso definidas? } \\
\text { ¿Que premisas aseguran una buena } \\
\text { usabilidad? ¿Hay que tener en cuenta } \\
\text { distintos momentos de uso? }\end{array}$ & $\begin{array}{l}\text { a. El usuario se siente realizado al retirar el botellin } 3 \\
\text { b. La acción realizada debe ser: coger tu botellin, llevario al } \\
\text { punto de recogida y depositarlo } 1 \\
\text { c. El artefacto manda señales visuales de localizacion } 1 \\
\text { d. El usuario deposita su botellin en el artefacto } 1 \\
\text { e. Tener en cuenta el momento de uso, desuso, reposo y las } \\
\text { acciones que tienen lugar en cada uno de estos momentos } 1\end{array}$ & \\
\hline $\begin{array}{l}\text { DIMENSION de PERSONA } \\
\text { Requerimientos del usuario } \\
\text { Uimitaciones fisicas y cognitivas, } \\
\text { ergonomia, antropometria. Valores, } \\
\text { deseos. }\end{array}$ & $\begin{array}{l}\text { a. Adaptable a personas con sillas de ruedas } 1 \\
\text { b. Que requiera poco esfuerzo fisico } 1 \\
\text { c. Fácil percepción visual y comprension a simple vista } 2 \\
\text { d. No precisa de ningün aprendizaje básico } 1 \\
\text { e. Usado principalmente por gente joven } 3 \\
\text { f. Tener en cuenta el personal distribuidor de botellines } 2\end{array}$ & \\
\hline $\begin{array}{l}\text { DIMENSION de ARTEFACTO } \\
\text { Requerimientos tecnicos } \\
\text { ¿Que partes y mecanismos podemos } \\
\text { definir? ¿Qué caracteristicas fisicas } \\
\text { podemos definir? Peso, resistencia, } \\
\text { color, materiales, acabados... } \\
\text { ¿Forma parte de alguna familia? } \\
\text { ¿lncluye accesorios? } \\
\text { ¿Que aspectos nocivos hay que } \\
\text { prever? }\end{array}$ & $\begin{array}{l}\text { a. Modular } 1 \\
\text { b. Con ruedas para facilitar su transporte con sistema de } \\
\text { frenado } 2 \\
\text { c. Cajas para los botellines } 1 \\
\text { d. Panel visual eficiente } 1 \\
\text { e. Materiales resistentes a impactos y al medio exterior } 1\end{array}$ & \\
\hline
\end{tabular}




\section{EL BRIEF}

1. Descripción breve, descripción clara y concisa del proyecto con las caracteristicas que le dan valor, aquello que le diferencia de los artefactos parecidos

El proyecto propone un rediseño completo de la zona de comidas de la cantina, incluyendo todo el recorrido del usuario desde que elige qué comer hasta que se sienta. Implica mejorar la dinámica del servicio, tanto diferenciando distintos platos del menú como agilizando el pago de lo que se lleva el consumidor y facilitando la atención al personal. También facilita y organiza el recorrido de los consumidores hasta las zonas de asiento $\mathrm{y}$, además, debe tener en cuenta las medidas de todos los posibles usuarios y su accesibilidad.

2. Identificación de los usuarios, ¿A quién va destinado el proyecto? ¿Quién es el usuario arquetipo?

El proyecto va destinado a todo aquellos usuarios que hacen uso de las instalaciones de la UJ y tienen la necesidad de utilizar el servicio de venta de comida.

Usuario arquetipo principales: Estudiantes/Profesorado

Nombre: Rubén

Edad: 22

Estudios: Ingeniería de Diseño Industrial y desarrollo de producto.

Expectativas: un buen servicio, de manera rápida y ordenada, que le permita comer en poco tiempo y disfrutar del descanso entre clases.

Por qué utiliza la cantina: queda cerca de las aulas donde tiene clases, la comida según el menú puede estar buena, suele encontrarse con sus amigos de otras clases alli.

Por qué dejaría de utilizar la misma: El servicio se torna muy lento o hay una fila muy larga, no hay lugar en las mesas para que se siente acompañado por sus amigos, no le gusta el menú que hay para elegir ese día, quiere comprar un bocadillo o medio menú pero tiene que hacer la misma fila que los que elegirán el menú completo.

Usuarios secundarios:

Trabajadores de mantenimiento

Trabajadores de la cafetería como cajeras, camareras y cocineras.

3. Justificación del proyecto, ¿Qué observaciones han desencadenado el proyecto? ¿Por qué tiene sentido? ¿Qué problemática, deseo o necesidad pretende solucionar?

Algunas de las observaciones más importantes del servicio actual que justifican el proyecto son:

- Confusión a la hora de elegir los platos.

- Confusión y demoras por unificación de las filas.

- Incertidumbre respecto a la disponibilidad de lugares.

- Hay un descontento general con el servicio pero la ubicación de la cantina hace que se mantengan los clientes.

Algunos de los deseos del equipo de diseño que se quieren cumplir son:

- Se estudiará una forma de autopago para favorecer la fluidez de los usuarios.

- Los materiales facilitarán la limpieza.

- Facilitar la experiencia desde la selección del plato hasta el momento de pago.

- Que el diseño actual pueda ser aprovechado en su mayoría.

Algunas de las necesidades a las que hacer frente son:

- Separar visiblemente los diferentes tipos de platos: primeros, segundos, postres, etc.

- Diferenciar las filas según lo que se vaya a consumir para disminuir tiempos de espera.

- Mejorar la señalización y la información hacia los consumidores.

- Agilizar los sistemas de pago. 


\section{Funciones y prioridades, las premisas de diseño}

Requerimientos del proyecto fruto del and́isis previo, del estudio de usuario, del and́lisis de referentes, etc. Priorización numérica de imprescindibles: imprescindible (1), deseable (2), prescindible (3)

\begin{tabular}{l} 
Tipo de requerimiento \\
Basicos del proyecto RETO DE DISENo \\
\hline Dimensión de FINALIDAD \\
Requerimientos funcionales Objetivo \\
principal, objetivos secundarios, metas y \\
propósitos \\
¿Qué objetivos debe cumplir? ¿Para qué \\
sirve? \\
\hline Dimensión de ENTORNO \\
Requerimientos de posicionamiento \\
Como sistema o subsistema, ¿qué \\
premisas debe cumplir? \\
Esteticamente, ¿qué premisas definen el \\
artefacto? Socioculturalmente, \\
¿dónde se sitúa?
\end{tabular}

Listado de requerimientos

Priorización

a. Agilizar el proceso de selectión y pago de la comida.

b. Que se facilite la selectión de los diferentes platos

(19 plato, $2^{9}$ plato, postre y bebida

c. Que se diferencien las filas para las distintas consumiciones.

a. Debe de reducir el tiempo de colas

b. Debe permitir el autoservicio de comida.

c. Debe permitir el autoservicio del pago.

d. Debe mostrar el precio final sin necesidad de comunicarse con el personal.

a. Debe poder comercializarse y utilizarse tanto en la cantina de la Ull como

en cualquier otra.

b. Debe cumplir con reglamentaciones de higiene, de manipulación de 1 alimentos, etc.

c. Su precio debe ser accesible para empresas como Living Food.

d. Debe soportar altas temperaturas (hasta $40^{\circ} \mathrm{C}$ ), niveles de humedad altos (hasta el 100\%), vibraciones prowocadas por otros electrodomesticos y máquinas.

e. Su diseño y señalización no debe generar controversia en relación al contexto sociocultural donde se inscribe.

f. La estética del artefacto debe ser clara y entendible, similar a antecedentes, para su fácil interpretación y comprensión.

\section{DIMENSIÓN de ACCIÓN}

Requerimientos de experiencia de uso Requerimientos relacionados con las tareas y acciones, ¿como deseamos que se lleven a cabo? ¿Cómo es la interacción usuario/artefacto? ¿Cubles son las secuencias de uso definidas?

¿Que premisas aseguran una buena usabilidad? ¿Hay que tener en cuenta distintos momentos de uso?

a. Debe incorporar otros tipos de pagos existentes.

b. El artefacto debe favorecer tanto los momentos de uso (venta al público, cobrar, hacer cafte, servir,...) como los de desuso

(mantenimiento y limpiera).

c. El artefacto debe poseer una visualización sencilla e intuitiva.

DIMENSIÓN de PERSONA

Requerimientos del usuario Limitaciones fisicas y cognitivas, ergonomia, antropometria. Valores, deseos.

a. Las zonas deben estar adaptadas a todo tipo de usuarios, sillas de ruedas, deficiencias visuales, etc.

b. Debe haber diferencias claras entre las zonas y recorridos para cualquier tipo de usuario.

c. Debe facilitar la interacción usuario-artefacto a la hora de hacer pedidos o pagar.

\section{DIMENSIÓN de ARTEFACTO}

Requerimientos técnicos

¿Qué partes y mecanismos podemos definir? ¿Que caracteristicas fisicas podemos definir? Peso, resistencia, color, materiales, acabados..

¿Forma parte de alguna familia?

¿lncluye accesorios?

¿Que aspectos nocivos hay que prever? a. Las pantallas deben cumplir con la altura recomendada por reglamentaciones de inclusion y discapacidades.

b. La dimensión de botones $y$ comandos debe ser la recomendada por reglamentaciones de inclusión.

c. Debe funcionar con un sistema de tarjetas recargables que hagan más rápido el pago.

d. Debe poseer un sistema de escaneo de bandeja que interprete el precio del consumo según la cantidad de platos.
2 


\subsection{Reflexions finals}

Fins aquí la presentació de resultats fruit de l'exercici desenvolupat en el marc de l'assignatura de Disseny per a l'Entorn i l'Hàbitat a la UJI. Els resultats són satisfactoris perquè els cinc equips han treballat des de l'observació fins al brief i la seva comunicació de forma compromesa i assolint els diversos objectius plantejats. En general, s'ha entès la proposta i les tasques s'han desenvolupat de forma fluïda. Els resultats es presenten des de diverses perspectives; per una banda, la caracterització del repte de disseny a través de les premisses projectuals amb la dificultat de definir reptes enlloc de solucions, i per l'altra, el recorregut en sí realitzat a partir de certes eines de recerca. Els briefs resultants del procés de recerca, que inclouen el repte i les premisses, i com la informació que conté el brief es trasllada en un document de comunicació. Finalment, la satisfacció de l'alumnat en l'ús de la metodologia i la percepció d'utilitat en el marc d'un projecte que es presenta a través de les respostes anònimes d'una enquesta un cop s'ha donat l'exercici per acabat. Aquestes respostes són de gran valor per a la concreció de la metodologia que es presenta al capítol III.

És cert, que els resultats tenen diverses qualitats, però aquest fet és un avantatge per a poder identificar els punts fluixos i forts de la proposta, que es percep més feble en l'aplicació de les eines, que no pas en l'estructura plantejada. És a dir, s'han posat en pràctica tres facetes de la proposta, el seu esquelet — de l'observació al brief-, les cinc dimensions per ordenar-lo, i l'ús de certes eines per arribar d'un punt a l'altre, i cada una d'aquestes facetes es veu representada en els resultats d'una manera o altra, tal com s'ha vist al llarg d'aquest capítol.

Els resultats més satisfactoris es detecten en l'organització de l'observació a través de les cinc dimensions, tot i que hi ha qüestions a polir, tal i com es veu en el capítol posterior — vegeu capítol VI · Conclusions_- es confirma l'exhaustivitat de la proposta. L'alumnat també facilita tot el material elaborat al llarg de les setmanes, és a dir, les fitxes de treball 
que han anat complementant. Aquestes fitxes són útils per veure l'evolució dels equips i com avancen en el desenvolupament del repte de disseny. En aquest sentit, la proposta metodològica treballada en aquest cas ha resultat repetitiva, tal i com es comenta en el capítol de Resultats. Per avaluar els resultats del brief, cal revisar també el camí seguit fins a la definició del repte i les seves premisses, ja que és important que tot allò que apareix en el document final sigui fruit del procés seguit, per tant, d'alguna manera s'hauria de poder traçar el recorregut de cada una de les premisses del brief des de l'inici de la recerca, i se n'hauria de poder justificar la seva inclusió a través del treball de reflexió i argumentació realitzar al llarg de tot el procés. La metodologia pretén ser un punt de suport en l'argumentació projectual, per tant la traçabilitat de l'origen de les premisses és desitjable.

Finalment, cal fer una reflexió en relació a les eines utilitzades per el desenvolupament de la recerca. Com ja s'ha dit, són eines manllevades de processos creatius o de l'aproximació etnogràfica a la realitat existent. És a dir, eines com l'entrevista o el mapa d'accions d'usuari, són eines reconeixibles i traslladables a altres processos creatius. Per aquest exercici se n'han escollit unes quantes i s'han traslladat a format fitxa per a la seva aplicació. L'ús d'aquestes eines també forma part de la metodologia utilitzada dins de l'aula, i l'encert o desencert del seu ús forma part dels resultats avaluables, ja que per a cada ocasió cal buscar les eines més adequades. Algunes, com l'observació i les entrevistes, sempre formaran part d'un procés de recerca; d'altres, com el quadre de selecció d'idees, es podrà fer servir quan es consideri oportú. L'ús de de les eines escollides i si la seva aplicació ha resultat satisfactòria, tota la documentació resultant del procés de recerca es converteix en evidències útils per a l'avaluació d'aquest procés i dels mètodes desenvolupats. 


\section{CAPÍTOL VI}

\section{CONCLUSIONS}


L'objectiu principal d'aquesta investigació era configurar una metodologia de recerca pel projecte de disseny, principalment de producte, però també d'espais i serveis, entesos com a unitats funcionals entorn a activitats. Des d'un inici s'accepta com a certa l'afirmació que tot projecte de disseny inclou una fase de recerca, i per tant, una metodologia que guiï en aquest procés és pertinent. Tot i així, es posa especial èmfasi en una fase de recerca molt inicial, que comença amb una hipòtesi de treball molt vaga i que acaba amb un brief argumentat a través d'unes premisses de disseny resultat de l'anàlisi de les dades obtingudes en la recerca.

Els ingredients utilitzats per a l'elaboració de la metodologia es veuen descrits al llarg del capítol II, anomenat Revisió general de la recerca en el projecte de disseny. S'entén que una metodologia d'aquest tipus necessita tres grans grups d'ingredients. Per una banda, un punt focal per a qualsevol recerca que es desenvolupi; per una altra banda, unes eines que acompanyin en el seu desenvolupament; i, finalment, una base analítica que permeti extreure conclusions.

Així doncs, es planteja un punt focal al voltant de la usabilitat i l'experiència d'usuari perquè aquest és un dels punts que comparteixen l'ergonomia i el disseny en el seu desenvolupament del projecte, i perquè s'accepta que si s'aconsegueix dibuixar l'experiència d'usuari desitjada, la resta d'elements es podran anar configurant per facilitar-la. Tanmateix, i amb la intenció que la recerca sigui exhaustiva i ordenada, es recull l'anàlisi del sistema persona/màquina que té una visió global de la realitat i, sobretot, entén les relacions causa/ efecte de cada una de les parts que configuren el sistema.

També es revisen certes eines, tècniques i mètodes que es consideren interessants per al desenvolupament de la proposta, buscant aquelles que posen l'èmfasi en una aproximació empàtica a l'usuari, i que formen part de la tendència creativa al voltant del Design Thinking i metodologies afins, i per tant, es posa especial atenció sobre tècniques manllevades de l'etnografia que aposten per un apropament empàtic. 
I finalment, es fa una aproximació a la base analítica del disseny perquè es considera necessari per argumentar les diverses fases de la metodologia de recerca, així com les fites que cal aconseguir amb cada fase.

Tots aquests ingredients estructuren una proposta que es posa en escena en un exercici de classe a l'assignatura de Disseny per a l'Entorn i l'Hàbitat a la UJI, del qual se'n pot veure el recorregut al capítol IV · Aplicació de la metodologia (cas pràctic). Al llarg del capítol s'explica com es desenvolupa l'exercici en les sessions setmanals, quines eines s'utilitzen i com es planteja el salt de l'observació al repte. Els resultats més rellevants i que exemplifiquen millor la variabilitat de resultats obtinguts durant l'exercici de classe es poden veure al capítol $\mathrm{V} \cdot$ Resultats. La metodologia es posa en pràctica a les aules de la UJI en un moment on encara no té l'esquema general que es pot veure a la figura 52, on apareixen els ingredients ordenats en cinc fases i cinc dimensions. Els ingredients sí que estan clars, però falta acabar d'ordenar-los. L'exercici realitzat amb els alumnes de la UJI és clau per acabar d'elaborar aquest esquema. També són clau altres exercicis d'envergadura més reduïda que es duen a terme en altres centres universitaris, com l'exercici desenvolupat a la classe d'Ergonomia a ESDi, Sabadell —vegeu 5.3.1 La caracterització del repte de disseny-, que permet afinar les fitxes de les dimensions. Tot plegat, els diversos ingredients i la posada en pràctica de la recerca guiada a través de les dimensions, acaba configurant la proposta de metodologia per a la recerca que es presenta al capítol III · Proposta per a una metodologia de recerca.

Al llarg del capítol VI · Conclusions, es pot llegir el per què de les modificacions que s'han realitzat un cop analitzats els resultats i les evidències fruit de la posada en pràctica de la metodologia, o d'alguna de les seves parts. Al llarg d'aquest capítol, es pretenen veure els punts crítics i encerts, les limitacions de la metodologia i les futures línies d'aplicació.

Per enfocar aquesta avaluació es recuperen les paraules de Martí Font (1999) quan afirma que per avaluar un mètode "cal fer sempre una doble avaluació: avaluació constant del procés i avaluació individual dels mètodes aplicats — com a instruments de presa de de- 
cisió - en aquell. Així es fa evident en la seva importància, la necessària distinció entre els mètodes concrets i les seves situacions concretes d'aplicació i la metodologia com a ciència del mètode" (Martí Font, 1999, p. 150). És a dir, que per una banda cal observar el procés de l'aplicació de la metodologia, i per l'altra, cal observar els mètodes i les eines utilitzades, i tot plegat contrastar-ho amb el context en el qual s'ha aplicat. Mètodes i eines, apareixeran com a més o menys encertades segons les circumstàncies del projecte.

Una altra preocupació és avaluar els projectes sortint, i intentar definir si són bons, o, més aviat, si són encertats i idonis, i si es pot considerar que aporten innovació. Com ja s’ha comentat en diverses ocasions, no és possible avaluar els projectes per comparativa, perquè cada situació és diferent i irrepetible, per tant, s'ha decidit comentar-ne el resultat a través de l'anàlisi del seu desenvolupament i a través d'una avaluació docent, que es pot veure en el capítol V—vegeu apartat 5.3.3 Els briefs resultants-, en el qual s'exposen els resultats de l'experiment. Sí que és important, però, prestar atenció al recorregut argumentatiu de la proposta, és a dir, que les decisions que es van prenent sempre estiguin argumentades i recolzades per les dades de la recerca i la seva anàlisi.

\subsection{Punts crítics i encerts}

Es recuperen els objectius de la posada en pràctica de la metodologia — vegeu apartat 4.1.1-, per identificar els punts crítics i els encerts de l'experiment desenvolupat amb els alumnes de Disseny per a l'Entorn i l'Hàbitat, ja que aquests objectius plantegen la viabilitat de la proposta.

Com a mètode general de recerca $i$ anàlisi guiat a través de certes tasques establertes $i$ amb l'ajuda de fitxes de treball, la proposta és viable. Tanmateix, cal afinar la comunicació cap als alumnes perquè interioritzin els diversos passos i no se sentin perduts. Aquesta és una qüestió docent que forma part de la metodologia del projecte en general, és a dir, com s'ensenya a dissenyar. I dins d'aquesta tasca que ocupa uns estudis sencers, cal ensenyar a fer 
recerca i a prendre decisions projectuals. Cada escola i facultat té la seva manera de fer i focalitza esforços de manera diferent.

La metodologia de recerca que es presenta en aquesta tesi, tant pot suposar una manera molt diferent de desenvolupar l'inici del projecte, com pot suposar una manera pròxima si la metodologia del projecte ja inclou l'aproximació etnogràfica en la recerca. En qualsevol cas, la intenció és que la metodologia de recerca formalitzada a través de cinc fases i cinc dimensions sigui viable en qualsevol dels casos, i que la diferència d'aplicabilitat principal recaigui en l'explicació més o menys metòdica de les eines a utilitzar per avançar en la recerca.

En aquesta direcció, les enquestes realitzades als alumnes revelen certa incomprensió de la metodologia desenvolupada, concretament dos alumnes consideren que els passos realitzats han resultat repetitius. Per tant, alumnes a qui no s'ha sabut traslladar el per què de cada pas i el recorregut a realitzar. En aquesta posada en pràctica han fallat les iteracions cap a una major definició de les premisses i de la informació de cada dimensió. Aquesta falta de comprensió de la iteració s'ha traduït, a la proposta final de la metodologia, en unes fases més seqüencials, que deixen la iteració segons es consideri oportú. És a dir, la iteració hi ha de ser perquè és positiva per la definició del projecte i l'avaluació constant del procés que s'està realitzant, però a la metodologia que es proposa, ja no es marca a través de les eines que es fan servir sinó que es defineixen cinc fases amb un títol que indubtablement marca en quin moment de la recerca es troba l'investigador (organitzar, buscar, analitzar, definir i comunicar). A la pràctica això es tradueix amb un inici a partir de les fitxes de dimensions que començaran sent més genèriques i que gràcies a la recerca i les tasques desenvolupades a cada fase es podran anar concretant segons les pròpies necessitats del projecte. L'esquema de recerca es converteix en un mapa que posiciona on et trobes en cada moment.

Per altra banda, està clar que la metodologia no té capacitat de funcionar de forma autònoma des d'un principi. Cal explicar-la, i cal que les persones que la desenvolupin tinguin certs coneixements d'eines de desenvolupament creatiu pròxim al Design Thinking, ja que les eines en sí, són manllevades d'aquestes propostes: tant l'observació, com l'enfocament 
empàtic de les entrevistes, o l'anàlisi a través d'insights, són eines comuns en aquest tipus de propostes. Tot i així es considera que els resultats de l'experiment són satisfactoris i que, tot i que algun alumne s'ha sentit perdut i ha necessitat més explicacions, al final les coses han anat sortint i l'exercici s'ha desenvolupat correctament i, per tant, es considera que la metodologia sí que té capacitat per ordenar la recerca, per contribuir en l'elaboració de premisses projectuals i per definir un repte de disseny. A més a més, també es considera que les cinc dimensions aporten amplitud a la recerca, tot i que, directament, no aporten profunditat. En aquest sentit, tal com s'ha vist en la recerca realitzada per un alumne d'Ergonomia d'ESDi, la capacitat d'aprofundir ha sigut superior en alumnes que no s'han focalitzat en la solució. Aquest fet, també és observable amb el resultat de l'equip 5 de la UJI, que ha sabut identificar un insight encertat que els ha permès desenvolupar la recerca de forma molt més enfocada. Altres equips participants de l'exercici a la UJI, amb reptes de disseny molt amplis, com la remodelació general de la cantina, no han pogut focalitzar, per falta de temps i recursos al tractar-se d'un exercici de classe limitat en el temps, i les seves premisses són molt més genèriques. En aquest sentit, i tal com s'ha comentat en el capítol V, s'intueixen diferents els resultats fruit d'un exercici aillat en el context d'una assignatura més àmplia — com és el cas de l'exercici desenvolupat a Disseny per a l'Entorn i l'Hàbitat de la UJI-, i els resultats fruit d'un exercici final en una assignatura que ha estat desenvolupant certes habilitats d'observació ergonòmica al llarg de les 15 setmanes lectives —com és el cas de l'exercici d'anàlisi a partir de les cinc dimensions desenvolupat a Ergonomia a ESDi-, però uns i altres no són millors o pitjors, sinó que responen a circumstàncies diferents. Segons Martí Font (1999) “molt sovint l'adequació d’un mètode pot variar segons el moment de la seva aplicació $i$, donada aquesta circumstància, no hem d'avaluar el mètode com a bo o dolent sinó com a oportú o inoportú” (Martí Font, 1999, p. 150). Així doncs, es prenen aquestes paraules i s'intentarà concloure aquesta tesi a través de l'argumentació de la idoneïtat de la metodologia en diverses circumstàncies i contextos. Tot i que, enlloc de considerar-la oportuna o inoportuna, es traduirà amb més o menys acompanyament en el seu desenvolupament. La necessitat d'explicar més o menys cada fase i les seves eines associades també forma part de la capacitat d'adaptació pretesament buscada. 
La iteració que es plantejava per aconseguir més profunditat no ha funcionat, és precisament aquesta iteració que els alumnes han vist com a una activitat repetitiva. Cal dir, però, que també és significatiu que en el moment de la iteració final, centrada en la cinquena sessió, ja no es pot realitzar de forma presencial, i és probable, que aquest fet hagi disminuït la concreció de les premisses. És observable, la quantitat d'informació de les fitxes que no s'ha traslladat al brief.

Per altra banda, es considera un encert el fet d'organitzar qualsevol recerca pel projecte, ja que és una activitat que cal fer, que argumenta el projecte i que, per tant, és positiu realitzar-la de forma metòdica. Aquesta és una de les principals raons de ser d'aquest treball, per això una metodologia amb un esquelet $\mathrm{i}$ unes fases. Tanmateix, com que és necessari que la recerca s'adapti a qualsevol circumstància, per definir l'envergadura d'aquesta recerca i definir-ne la intenció, s'estableix una fase de preparació — vegeu 3.6.1 Fase Organitzar — que no ha tingut lloc amb l'exercici desenvolupat a la UJI. Aquesta fase assenta les bases de la recerca en qüestió i en defineix el tarannà a través del Pla de recerca, així com posa d'acord a tots els membres de l'equip amb les tasques a realitzar a través del Pla d'acció inicial, on també s'acorden una sèrie de qüestions pràctiques sobre com, per exemple, cal emmagatzemar les dades. Aquest Pla d'acció inicial, ja es desenvolupa a través de les dimensions, de manera que, enlloc d'aparèixer les dimensions per ordenar la informació de la recerca, es fan servir les dimensions des del principi. Se suposa que aquest canvi, també millora la sensació de repetició innecessària, i més tenint en compte que es defineixen certes eines com a més idònies per a cada dimensió, però es deixa oberta la possibilitat d'utilitzar altres eines segons es consideri oportú.

Un cop superat el simulacre a les aules de l'UJI, es considera que la fase Organitzar és cabdal per al bon desenvolupament de la recerca. Per exemple, es considera encertat iniciar una recerca amb l'observació, que pot ser més o menys participativa i que pot durar més o menys en el temps; definir quan es durà a terme l'observació, on, amb quines persones, així com decidir què es vol observar, es considera que pot millorar la recerca de forma exponencial. I, per altra banda, evitarà que els alumnes es perdin durant el desenvolupament 
de la recerca, perquè ells mateixos hauran decidit com fer-ho, de la mateixa manera que fa el disseny generatiu — vegeu apartat 2.3.4- desenvolupant la recerca amb els usuaris, en aquest cas, els usuaris són els alumnes —o altres dissenyadors- que fan servir la metodologia per la fase de recerca. En resum, una de les accions que s'han dut a terme en la proposta final és travar un millor esquelet, perquè la proposta sigui més adaptable a cada circumstància, tant del projecte en sí, com dels equips que desenvolupen la recerca. Això no treu, però, que continuï sent necessari explicar-ne les fases, la distribució per dimensions i les eines per a dur-la a terme.

\subsection{Limitacions de la metodologia}

Per tant, una de les principals limitacions de la metodologia és que necessita ser explicada, i això en condiciona la seva aplicabilitat, ja que necessita un acompanyament inicial. És, per tant, ideal per desenvolupar-se en un àmbit docent, on un professor pot acompanyar l'alumne en la recerca. És ideal per assignatures que posen l'èmfasi en aquesta fase del projecte de disseny — la recerca—, i que aposten per una bona base conceptual que recolzi la presa de decisions en relació a l'artefacte. També és cert, però, que un cop coneguda, no cal desenvolupar-la sencera, sinó que se'n poden fer servir algunes de les seves parts. Tot i que no és desitjable, se sap que l'usuari sempre adapta l'artefacte segons li convé, per tant, també pot adaptar una metodologia segons li convé. En aquest sentit, es considera que les parts més valuoses de la proposta són, precisament, les fitxes de les cinc dimensions i la definició d'un repte de disseny amb les premisses prioritzades, que en són, de fet, les aportacions principals. També és interessant l'esquelet amb les fases i l'estructuració de les eines proposades — vegeu figura 52-, que es presenta com un desplegable que es pot imprimir i penjar a la paret com a guia, per no perdre en cap moment la noció de la fase on es troba la recerca. 
Per altra banda, una altra limitació és també l'habilitat en l'ús de les eines que s'utilitzen al llarg de la recerca. Com s'ha vist en les enquestes dels alumnes de Disseny per a l'Entorn i l'Hàbitat, desconeixien les principals eines utilitzades, fet que suposa un esforç extra per a desenvolupar la metodologia. Tot i així, són eines genèriques de processos creatius afins al Design Thinking i se'n poden trobar descripcions en línia amb facilitat, així com d'altres eines que no s'inclouen en aquest treball que poden resultat molt útils, sobretot, a les fases Analitzar i Definir, com poden ser mapes conceptuals de tot tipus per ordenar i visualitzar les dades, o per ajudar a descartar i a escollir. L'ús de les eines ha de ser l'adequat, per tant, és recomanable que la persona que acompanya en la recerca, tingui suficients recursos com per recomanar una o altra eina a cada pas. O també, que s'utilitzin eines adequades que ja se solen utilitzar.

Finalment, també comentar que la proposta es mou en una esfera força conceptual i teòrica, per això cal valorar prèviament el coneixement que l'alumne té sobre metodologia del projecte i si està avesat a fer servir una sèrie de conceptes teòrics que acompanya qualsevol projecte de disseny. En aquest sentit, s'ha pogut comparar a l'apropar l'Ergonomia a alumnes de primer curs, assignatura que s'ha impartit a l'escola LCI de Barcelona, que aquest aprenentatge transversal aporta recursos intrínsecs a l'alumne acostumat a projectar i que l'alumne de primer encara no té. Per altra banda, els alumnes de quart, han desenvolupat ja les seves pròpies eines i maneres de fer, i pot ser que siguin més reticents a modificacions que s'aparten del camí preestablert, tanmateix, una circumstància que no s'ha observat amb els alumnes de Disseny per a l'Entorn i l'Hàbitat. És a dir, difícilment es troben circumstàncies ideals, i per tant, un cop més, cal apostar per una metodologia adaptable a les circumstàncies que puguin sorgir.

Aquest fet, s'ha intentat tenir en compte per a la proposta final presentada al capítol III, a través d'un esquema estructural que pugui funcionar de forma molt senzilla, pràcticament només a través de les cinc fases i les cinc dimensions; i de forma molt més complexa, a través de les cinc fases, les cinc dimensions, les fitxes de treball, les iteracions, les propostes d'eines i mètodes, etc. 
En resum, es considera que en aquesta tesi es proposa una metodologia adaptable a circumstàncies molt diverses, treballant de forma exhaustiva en un projecte durant sis mesos, o de forma ràpida en un taller de tres dies. En aquest sentit, emula també les característiques del Design Thinking quan apareix com a mètode trencador en un procés creatiu. Aquesta metodologia pot servir també, en un àmbit empresarial, per desenvolupar una recerca per trobar nous productes. I en aquest moment, les circumstàncies seran les mateixes, serà necessari una persona que acompanyi l'equip en el desenvolupament de la recerca, i serà necessari explicar-ne l'esquelet —-fases i dimensions_-, així com les diverses eines a utilitzar per desenvolupar-la.

Així doncs, queden contestades les preguntes d'investigació. Es pot confirmar que l'estructura d'anàlisi ergonòmica a través del sistema persona/màquina pot contribuir positivament en les fases de recerca del projecte de disseny; a la vegada que es pot confirmar, que l'ergonomia pot beneficiar-se d'eines, tècniques i mètodes del disseny. Per tant, sí que és possible estructurar una metodologia de recerca amb la intenció de detectar reptes de disseny innovadors i beneficiosos per la persona, tot i que aquests qualificatius atorgats al repte no apareixeran de forma sine qua non, sinó que caldrà que l'equip de disseny que dugui a terme la recerca s'esforci per aconseguir-los.

I finalment, d'una metodologia de recerca se'n pot valorar en part l'eficàcia, l'eficiència i la satisfacció. De moment, se n'ha valorat la satisfacció a través de les enquestes, i el resultat ha sigut satisfactori, tot i que no extraordinari. Algunes persones han considerat que la proposta era poc eficient, perquè donava moltes voltes abans d'arribar a l'objectiu, per tant es malgastava un recurs tant important com el temps, de manera que l'aspecte de la eficiència s'ha convertit en un dels principals punt a millorar. Tot i així, ha resultat ser una metodologia eficaç, ja que tots els equips participants de l'exercici han assolit l'objectiu d'elaborar un brief de disseny amb premisses prioritzades i comunicar-lo a través d'una presentació oral i escrita. 


\subsection{Futures línies de treball}

Les futures línies de treball que es plantegen, per una banda, estan relacionades amb la seva aplicabilitat i, per l'altra, estan relacionades en afinar les eines utilitzades en cada fase i dimensió, que implica, entre d'altres coses, revisar les fitxes de treball per aconseguir el punt adequat de generalitat i concreció necessaris per adaptar-se a circumstàncies molt diverses. És a dir, a nivell d'aplicabilitat, la metodologia té llarg recorregut com a mètode d'innovació docent en assignatures d'ergonomia aplicada al disseny. Resulta molt interessant el fet de poder transformar una assignatura tradicionalment teòrica i feixuga, en una assignatura de recerca, on precisament, a través de la recerca, es van tractant tots els factors implicats en l'anàlisi ergonòmica. Aquest fet és possible gràcies a la utilització del sistema persona/ artefacte com a guia en el recorregut de les diverses fases. Si en aquestes circumstàncies la metodologia funciona $\mathrm{i}$ en resulten reptes de disseny creatius i innovadors, caldrà donar la raó a Robert i Brangier en relació a la capacitat de l'ergonomia de configurar projectes prospectius. També es considera la possibilitat de funcionar en assignatures projectuals d'estudis en disseny, però també és cert, que aquests tipus d'assignatura normalment estan focalitzats en la solució, o simplement, la distribució de pesos en les diverses fases del projecte no recauen especialment en la recerca, per tant, tot i que aplicable — perquè la metodologia és adaptable a diferents temporitzacions i necessitats-, segurament no es pugui desplegar amb tota llibertat.

En un futur més llunyà, també existeix la intenció de traslladar la metodologia a l'empresa, per contribuir en la definició de reptes de disseny. Però per arribar aquí primer cal realitzar la segona línia de treball que queda oberta: afinar les eines proposades per cada fase i dimensió, així com la seva posada en escena. Cal continuar treballant en el contingut de les fitxes, revisar-les i ajustar-les perquè puguin funcionar en qualsevol recerca sense necessitat d'adaptacions. I, per descomptat, la metodologia ha de ser visualment atractiva, per tant, els seus esquemes i les seves fitxes necessiten treballar-se gràficament, ja que de moment, aquesta tasca encara no s'ha dut a terme. 


\section{BIBLIOGRAFIA}


Arnal , L. (Juny, 2017). People \& Purpose. Comunicació presentada al congrés de la Barcelona Design Week 2017. Organitza Barcelona Centre de Disseny, BCD. [Assistent]

Associació Espanyola de Normalització i Certificació. (2000). Procesos de diseño para sistemas interactives centrados en el operador humano (UNE-EN ISO 13407)

Bjögvinsson, E., Ehn, P. i Hillgren, P-A. (2012). Design Things and Design Thinking: Contemporary Participatory Design Challenges. Design Issues, 2 (3), pp. 101-116. Recuperat de https://www.mitpressjournals.org/doi/10.1162/DESI_a_00165

Blessing, L.T. i Chakrabarti, A. (2009). DRM, a Design Research Methodology. Londres: Springer-Verlag.

Brent, P. (2005). The KaosPilots and The Contemporary Higher Education Sector. Oslo: HEDDA Program. Instittute of Educational Research, Faculty of Education. Recuperat de https://pdfs.semanticscholar.org/399e/b63e4651b89569e8d91e3a980696de0b5d09.pdf

Brown, T. (2009). Change by Design. Nova York: HarperCollins Publishers

Bustamante, A. (1995). Diseño Ergonómico. En la prevención de la enfermedad laboral. Madrid: Ediciones Diaz de Santos

Bustamante, A. (2008). Ergonomía para diseñadores. Madrid: Editorial Mapfre SA

Buxó Rey, M.J. (2012). Etnografia i innovació cultural: dissenyar i emprendre. Revista d'etnologia de Catalunya, 38, pp. 20-23

Buxó Rey, M.J. (2016). Tecnopaisajes, identidades y diseños culturales. Barcelona: Edicions de la Universitat de Barcelona

Craouch, Ch. i Pearce, J. (2012). Doing Research in Design. Londres: Bloomsbury Academic

Cross, N. (2001). Designerly Ways of Knowing: Design Discipline Versus Design Science. Design Issues, 17 (3). Recuperat de http://users.metu.edu.tr/baykan/arch467/Readings/ Cross01.pdf

Cross, N. (2003). Métodos de diseño: Estrategias para el diseño de productos. Mèxic: Editorial Limusa. Grupo Noriega Editores

Cross, N., Dorst, K. i Roozenburg, N. (1992). Research in Design Thinking. Delft: Delft University Press

De Bono, E. (1992). El Pensamiento Creativo. El poder del pensamiento lateral para la creación de nuevas ideas. Barcelona: Edicions Paidós Ibérica

Design Council (2013). Design for public good. Recuperat de https://www.designcouncil. org.uk/sites/default/files/asset/document/Design\%20for\%20Public\%20Good.pdf

Design Museum (2010). Cómo diseñar una silla. Barcelona: Editorial Gustavo Gili 
Dewulf, K., Wever, R. i Brezet, H. (2012). Greening the Design Brief. A Matsumoto, M. et al. (eds.) Design for Innovative Value Towards a Sustainable Society (pp. 457-467). Springer Science + Business Media Dordrecht

Dorst, C. (2003). The problem of design problems. A E. Edmonds, i N. Cross (Eds.), Expertise in Design, Design Thinking Research Symposium 6 Creativity i Cognition Studios Press, pp. 135-147

Elejabarrieta, F. (1997). El Método Lingüistico: técnicas de obtención de información. Barcelona: Universitat Autònoma de Barcelona

Espejo, R. (2005). La abducción y el conocimiento tácito: un diálogo entre C. S. Peirce y M. Polanyi. (Tesi doctoral, Universidad de Chile). Recuperat de http://repositorio.uchile. $\mathrm{cl} / \mathrm{handle} / 2250 / 108835$.

Fallan, K. (2010). Design history. Understanding theory and method. Gran Bretanya: Bloomsbury Academic

Faste, T. i Faste, H. (2012). Demystifying 'design research': design is not research, research is design. Boston: IDSA. Simposium Educació

Garcia, A.M. (febrer 2011). Ergonomía participativa: metodología. Comunicació presentada a la Jornada Tècnica: Los trastornos musculoesqueléticos (TME): estrategias para una prevención eficaz. Madrid. Recuperat de https://www.insst.es/-/jornada-los-trastornos-musculoesqueleticos-tme-estrategias-para-una-prevencion-eficaz

Genís Domenech, M.S. (2010). Creación de un protocolo para la mejora del puesto de trabajo mediante la Ergonomía Participativa. (Tesi doctoral, Universitat Politècnica de València). Recuperada de https://riunet.upv.es/bitstream/handle/10251/8537/tesisUPV3350.pdf? sequence $=1 \&$ isAllowed $=\mathrm{y}$

Gibbons, S. (14 gener 2018). Empathy Mapping: The First Step in Design Thinking. [article web]. Recuperat de https://www.nngroup.com/articles/empathy-mapping/

Gibbs, J. (2005). Diseño de interiores. Guia útil para estudiantes y profesionales. Barcelona: Editorial Gustavo Gili

Gothelf, J. (2017). Lean vs. Agile vs. Design Thinking. What you really need to know to build high-performing digital product teams. EUA: Gothelf Corp

Harper, Ch. (15 juliol 2018). Best practices for ethnographic research, lessons learned in the wild. [article web] Recuperat de https://uxdesign.cc/best-practices-for-ethnographic-research-lessons-learned-in-the-wild-ceb5bfc3bf

Hekkert, P. i van Dijk, M. (2011) Vision in Product Design: Handbook for Innovators. Amsterdam: Bis Publishers

Henao-Cálad, M., Uribe Ochoa, B. i Diez Gaviria, A.C. (2016). El conocimiento tácito grupal, motor del conocimiento Organizacional. Red Pilares 
Herrera Batista, M.A. (11 novembre 2010). Investigación y diseño: reflexiones y consideraciones con respecto al estado de la investigación actual en diseño.[article web] Recuperat de http://www.nosolousabilidad.com/articulos/investigacion_diseno.htm\#biblio

Hill, G. i Kemp, S. (2016). Uh-oh! What Have We Missed? A Qualitative Investigation into Everyday Insight Experience. The Journal of Creative Behaviour, 52 (3), 201-211.

Hollnagel, E. (1997). Cognitive ergonomics: it's all in the mind. Ergonomics, 40 (10), pp. $1170-1182$

Hollnagel, E. (2001). Extended cognition and the future of ergonomics. Theoretical Issues in Ergonomics Science, 2 (3), pp. 309-315.

Huber, L. i Veldman, G.J. (2015). Manual Thinking. The tool for managing creative teamwork. Barcelona: Zahori de ideas

IDEO (2012). Design Thinking for Educators. Recuperat de https://designthinkingforeducators.com/

Institut Nacional de Seguretat i Higiene en el Treball. (198+). NTP226: Mandos: Ergonomía de diseño y accesibilidad. Recuperat de https://www.insst.es/documents/94886/327166/ ntp_226.pdf/b762a795-e5d7-4eaa-9b7f-ad23f2f187cb

Institut Nacional de Seguretat i Higiene en el Treball. (199+). NTP 296: El grupo de discusión. Recuperat de https://www.insst.es/documents/94886/327166/ntp_296.pdf/3ff05a00-c12a-4380-a6f5-9b4033fb23e0

Institute of Design School at Stanford (2009). Bootcamp bootleg. Stanford: Stanford University. Recuperat de https://dschool.stanford.edu/resources/design-thinking-bootleg

Ivergård, T. i Hunt, B. (2a ed. 2009). Handbook of Control Room Design and Ergonomics. A perspective for the Future. Nova York: CRC Press. Taylor \& Francis Group

Jones, J.C. (2a ed. 1992). Design Methods. EUA: John Wiley \& Sons, Inc.

Jordan, P.W. (1998). An introduction to usability. Londres: Taylor \& Francis

Kimbell, L. (2011). Rethinking Design Thinking: Part I. Design and Culture, 3 (3). Recuperat de http://goo.gl/Gs8iWJ

Kuan, C. i Fabricant, R. (2019). User Friendly. How the hidden rules of design are changing the way we live, work, and play. Londres: Penguin Random House UK

Kumar, R. (3a ed. 2011). Research Methodology. A step-by-step guide for beginners. Londres: Sage Publications

Laplace, J. (1985). La psicologia ergonòmica. Barcelona: Oikos-Tau SA

Loranger, H. (28 gener 2018). Usability Test, Even When You Know the Answer. [article web]. Recuperat de https://www.nngroup.com/articles/test-when-you-know-answer/ 
Mañá, J. (1973). El diseño industrial. Barcelona: Edicions Grammont. Salvat.

Martí Font, J.M. (1999). Introducció a la metodologia del disseny. Barcelona: Edicions de la Universitat de Barcelona

Maturana, H. i Varela, F. (1972). De máquinas y seres vivos: una teoría sobre organización biológica. Santiago de Chile: Editorial Universitaria

McCormick, E.J. (1980). Ergonomía. Factores humanos en ingeniería y diseño. Barcelona: Gustavo Gili

Milton, A. i Rodgers, P. (2013). Métodos de investigación para el diseño de producto. Barcelona: Blume

Monaghan, J. i Just, P. (2000). Social \& Cultural Anthropology: a very short introduction. Oxford: Oxford University Press

Mootee, I. (2014). Design Thinking para la innovación estratégica. Lo que no te pueden enseñar en las escuelas de negocios ni en las de diseño. Barcelona: Ediciones Urano, SAU

Neville, A., Stanton, M. i Harvey, C. (2a ed. 2014). Guide to Methodology in Ergonomics. Designing for Human Use. Nova York: Taylor \& Francis

Nielsen, J. (3 gener 2012). Usability 101: Introduction to Usability. [article web]. Recuperat a https://www.nngroup.com/articles/usability-101-introduction-to-usability/

Nielsen, J. (24 desembre 2017). A 100-year view of User Experience. [article web]. Recuperat a https://www.nngroup.com/articles/100-years-ux/?lm=the-design-of-everyday-things\&pt $=$ book

Nielsen, J. (1993). Usability Engineering. Oxford: Elsevier

Nielsen, J. (24 abril 1994). 10 Usability Heuristics for User Interface Design. [article web]. Recuperat de https://www.nngroup.com/articles/ten-usability-heuristics/

Nogareda, S. (coor.) (5a ed. 2008). Ergonomía. Madrid: Institut Nacional de Seguretat i Higiene en el Treball. Ministeri de Treball i Immigració

Norman (28 febrer 2018). Don Norman: The Term UX. [vídeo a la web]. Recuperat de https:/www.nngroup.com/articles/definition-user-experience/

Norman, D. (1990). La Psicología de los objetos cotidianos. Madrid: Nerea

Norman, D. (2010). Living with complexity. Londres: The MIT Press

Ovington, L. (2016). Who has insights? The who, where, and when of the Eureka moment. (Tesi doctoral, School of Psychology, Charles Sturt University). Recuperat de https://pdfs. semanticscholar.org/4de7/58621516f4e3c95c1d4fa9fb1f8de29761cc.pdf

Partheeban, K. (2 març 20117). Introduction to Heuristic Evaluation [Article a la web]. Recuperat de https://uxdesign.cc/introduction-to-heuristic-evaluation-658705606518 
Phillips, P.L. (2005). (cómo crear) el brief de diseño perfecto. Barcelona: Divine Egg Publicaciones

Polanyi, M. (2009 [1966]). The tacit dimension. Chicago: The University of Chicago Press Ricard, A. (2012). Casos de diseño. Barcelona: Ariel

Rinaldi, A. (2016). Il Design per l'usabilità e per la user experience di sistemi, prodotti e servizi. Revista Italiana di Ergonomia, 11/12, pp. 15-27

Robert, J.M. i Brangier, E. (2009). What Is Prospective Ergonomics? A Reflection and Position on the Future of Ergonomics. A Karsh, B. (Ed.): Ergonomics and Health Aspects, HCII 2009, LNCS 5624, pp. 162-169. Springler-Verlag Berlin Heidelberg

Robert, J.M. i Brangier, E. (2012). Prospective ergonomics: origin, goal and prospects. Work 4, pp, 5235-5242. Recuperat de https://www.academia.edu/26071190/Prospective_ ergonomics_origin_goal_and_prospects

Robert, J.M. i Brangier, E. (Agost, 2015). Prospective Ergonomics for the Design of Future Artefacts: recommendations and methods. Comunicació presentada a 19è Congres Triennal de la AIE. Melbourne. Recuperat de https://iea.cc/congress/2015/1715.pdf

Saavedra, M. (26 setembre ?). Qué son los insights. [article a blog]. Recuperat de https:// designthinking.gal/que-son-los-insights/

Salvendy, G. (ed.) (4a ed. 2012). Handbook of Human Factors and Ergonomics. New Jersey (EUA): John Wiley \& Sons, Inc. Recuperat de https://kuliahdianmardi.files.wordpress. com/2016/03/handbook-of-human-factors-and-ergonomics-fourth-edition-2012.pdf

Salvi, C., Bricolo, E., Bowden, E., Kounios, J. i Beeman, M. (2016). Insight solutions are correct more often than analytic solutions. Thinking and Reasoning. 22 (4), pp. 443-460. Recuperat de https://www.ncbi.nlm.nih.gov/pmc/articles/PMC5035115/

Sanders, E. (2002). From User-Centered to Participatory Design Approaches. Design and Social Sciences. J.Frascara (Ed.). Taylor \& Francis Books Limited. Recuperat a http:// www.maketools.com/articles-papers/FromUsercenteredtoParticipatory_Sanders_\%2002. pdf $01 / 01 / 2020$

Sanders, E. i Stappers, P.J. (2008). Co-creation and the new Landscapes of Design a CoDesign. [Prepint per CoDesign, Taylor \& Francis]. Recuperat a https://naaee.org/sites/default/ files/preprintdraft.pdf

Sanders, E. i Stappers, P.J. (2012). Convivial Toolbox. Generative research for the front end of design. Amsterdam: Bis Publishers

Sanders, M.S. i McCormick, E.J. (7a ed. 1993). Human Factors in Engineering and Design. Nova York: McGraw-Hill Publishing. 
Sevilla Zapater, M.J. (2014). Ergopar. Un procedimiento de Ergonomía participativa para la prevención del riesgo ergonómico de origen laboral. Espanya: ISTAS-CCOO. Recuperat de http://ergopar.istas.net/recursos/

Sleeswijk Visser, F. (2009). Bringing the Everyday Life of People into Design. (Tesi doctoral TUDelft). Recuperat a https://repository.tudelft.nl/islandora/object/uuid\%3A3360bfaadc94-496b-b6f0-6c87b333246c el 06/08/2019. ISBN 978-90-9024244-6

Stanton, N.A., Young, M.S. i Harvey, C. (2a ed. 2014). Guide to Methodology in Ergonomics. Designing for Human Use. Nova York: CRC Press - Taylor \& Francis Group

Stickdorn, M. i Schneider, J. (2011). This is Service Design Thinking. Basics-Tools-Cases. Hoboken, New Jersey: John Wiley \& Sons

Thoelen, A. i Cleeren, S. (ed.) (2015). Public Service Design. A guide for the application of service design in public organisations. Brussel-les: SPIDER. Designvlaanderen. Recuperat de https://www.servicedesignmaster.com/wordpress/wp-content/uploads/2016/10/ Public-Service-Design.-A-guide-for-the-application-of-service-design-in-public-organizations..pdf

Tillmann, B., Fitts, D.J., Woodson, W.E., Rose-Sundholm, R. i Tillman, P. (3a ed. 2016). Human factors and Ergonomics Design Handbook. USA: McGraw-Hill Education

Tschimmel, K. (2012). Design Thinking as an effective Toolkit for Innovation. A: Proceedings of the XXIII ISPIM Conference: Action for Innovation: Innovation from Experience. Barcelona

TUDelft Collegerama (13 març 2009). Elizabeth Sanders: IO_Contextmapping/Exploring Co-creation on a Large Scale [arxiu de vídeo]. Recuperat de https://collegerama.tudelft.nl/ Mediasite/Play/35a0ffdf188342f7a7b39c0e212d531d

Turienzo, R, (2016) El pequeño libro de la motivación. Barcelona: Alienta Editorial 


\section{ÍNDEXS \\ DE TAULES I FIGURES}




\section{Taules}

Taula 1 - Comparativa entre ergonomia correctiva, preventiva i prospectiva. Robert, J.M. i Brangier, E. (2009). What Is Prospective Ergonomics? A Reflection and Position on the Future of Ergonomics. A Karsh, B. (Ed.): Ergonomics and Health Aspects, HCII 2009, LNCS 5624, pp. 162-169. Springler-Verlag Berlin Heidelberg

Taula 2 - Mostra del resultat de l'exercici de redisseny d'un comandament a distància aplicant principis ergonòmics. Taula d'elaboració pròpia. Fotos $\mathrm{i}$ esbossos realitzats pels alumnes Jan Isern, Edgar Martos i Cintia Vizcaíno a Ergonomia de 3r curs del Grau Universitari en Disseny, menció de Producte, a l'Escola Superior de Disseny ESDi, Sabadell, el curs 2019/2020.

Taula 3 - Resum de les variables de cada dimensió. Elaboració pròpia

Taula 4 - Cronograma per a l'aplicació de la metodologia de recerca dins l'assignatura. Elaboració pròpia

Taula 5 - Cronograma i distribució de tasques de l'alumnat i del professorat amb temporització. Elaboració pròpia

\section{Figures}

Figura $1 \cdot$ Plantejament inicial de la recerca. Elaboració pròpia

Figura 2 - Variables del sistema Persona / Màquina. Elaboració pròpia

Figura 3 - Esquema metodològic a ViP. Hekkert, P. i van Dijk, M. (2011) Vision in Product Design: Handbook for Innovators. Amsterdam: Bis Publishers. Pàg. 119

Figura 4 - Evolució de les disciplines en disseny. Sanders, E. i Stappers, P.J. (2012). Convivial Toolbox. Generative research for the front end of design. Amsterdam: Bis Publishers. Pàg. 17

Figura 5 - Treball amb el personal d'infermeria i prototipatge 2D i 3D de les habitacions. (TUDelft Collegerama, 2009) 
Figura 6 - Mostra d'un service blueprint. Autor Brandon Schauer. Copyright i termes de llicència CCBY-SA 2.0. Recueperat de https://designforservice.wordpress.com/2009/03/17/service-panel-blueprint/

Figura $7 \cdot$ Horaris Sustainability Jam Barcelona $2012 \cdot$ Drassana Studio i Claro Partners. Material propi

Figura 8 - Esquema sobre la relació entre la persona i l'artefacte. Elaboració pròpia

Figura 9 - Design Thinking per la d.school, Institut Hasso-Plattner Model de 6 fases. Recuperat a https://hpi-academy.de/en/design-thinking/what-is-designthinking.html

Figura 10 - Design Thinking per la d.school. Model de 5 fases. Recuperat a http://thinkingofdesign.blogspot.com/2017/08/mits-steve-eppinger-on-designthinking.html

Figura 11 - IDEO (2012). Design Thinking for Educators. Pàg. 15. Recuperat de https://designthinkingforeducators.com/

Figura 12 - Doble Diamant del Design Council. Recuperat de https://abeldb. com/en/reports/design-process-the-double-diamond/

Figura 13 - Doble Diamant del Design Council - Revisió 2019. Recuperat de https://www.designcouncil.org.uk/news-opinion/what-framework-innovation-design-councils-evolved-double-diamond el 20/06/2020

Figura 14 - Mostra del mapa i les etiquetes autoimprimibles. Huber, L. i Veldman, G.J. (2015) Manual Thinking. The tool for managing creative teamwork. Barcelona: Zahori de idees. Pàg.152. Fotografia pròpia del manual

Figura 15 - Representació del procés de codisseny. Sanders, E. i Stappers, P.J. (2008). Co-creation and the new Landscapes of Design a CoDesign. [Prepint per CoDesign, Taylor \& Francis]. Recuperat a https://naaee.org/sites/default/ files/preprintdraft.pdf

Figura 16 - Estructuració del projecte per al disseny d'una educació transformacional. Taller del 19 al 21 de juny de 2017. Organitza Coperfield (Barcelona) per Kaospilot. Material facilitat en el taller.

Figura 17 • Fase d'ideació · GovJam 2015 Barcelona. Foto pròpia

Figura 18 · Fase de prototipat · GovJam 2015 Barcelona. Foto pròpia 
Figura 19 · Piràmide de Maslow segons Turienzo, R, (2016) El pequeño libro de la motivación. Barcelona: Alienta Editorial. Figura d'elaboració pròpia

Figura 20 - Piràmide d'habilitats presentada per Arnal, L. (Juny, 2017). People \& Purpose. Comunicació presentada al congrés de la Barcelona Design Week 2017. Organitza Barcelona Centre de Disseny, BCD. [Assistent]. Figura d'elaboració pròpia

Figura 21 · Model "Ideale" versió "Gigante Lusso", 1930. Recuperat de www. lapavoni.com

Figura 22 - A l'esquerre, esbós per a la cafetera original; a la dreta, una cafetera actual de la marca. Comparant-les es veu amb claredat les poques modificacions viscudes. Imatge recuperada de http://torneartdesign.blogspot.com/2014/03/ los-autores-y-sus-obras-bialetti-y-la.html en data 14/06/2019

Figura 23 - Model "Dedica EC 685.M" i molinet de cafè, de DêLonghi, recuperat de www.delonghi.com

Figura 24 - Model "INICIA" de Krups per a Nespresso, recuperat de www. nespresso.com

Figura 25 - Esquema del procés projectual amb punt d'inici i punt final. Martí Font, J.M. (1999). Introducció a la metodologia del disseny. Barcelona: Edicions de la Universitat de Barcelona. Elaboració pròpia

Figura 26 - Mapa de context Sleeswijk Visser, F. (2009). Bringing the Everyday Life of People into Design. (Tesi doctoral TUDelft). Recuperat de https:// repository.tudelft.nl/islandora/object/uuid\%3A3360bfaa-dc94-496b-b6f0$6 c 87 b 333246 c$

Figura 27 - Mapa sobre la recerca en Disseny Sanders, E. i Stappers, P.J. (2012). Convivial Toolbox. Generative research for the front end of design. Amsterdam: Bis Publishers.

Figura 28 - Comparativa de les dades recollides segons diversos enfocaments metodològics. Sanders, E. i Stappers, P.J. (2012). Convivial Toolbox. Generative research for the front end of design. Amsterdam: Bis Publishers.

Figura 29 - Esquema DIKW del salt entre el fenomen i el futur dissenyat. Sanders, E. i Stappers, P.J. (2012). Convivial Toolbox. Generative research for the front end of design. Amsterdam: Bis Publishers. 
Figura 30 - Comparativa dels diversos moments de l'inici del projecte en contrast amb el moment del repte, i les seves diverses nomenclatures. Basat en:

1. Martí Font, J.M. (1999). Introducció a la metodologia del disseny. Barcelona: Edicions de la Universitat de Barcelona.

2. Cross, N. (2003). Métodos de diseño: Estrategias para el diseño de productos. Mèxic: Editorial Limusa. Grupo Noriega Editores.

3. Sanders, E. i Stappers, P.J. (2008). Co-creation and the new Landscapes of Design a CoDesign. [Prepint per CoDesign, Taylor \& Francis]. Recuperat a https://naaee.org/sites/default/files/preprintdraft.pdf

4. Hekkert, P. i van Dijk, M. (2011) Vision in Product Design: Handbook for Innovators. Amsterdam: Bis Publishers.

5. Institute of Design School at Stanford (2009). Bootcamp bootleg. Stanford: Stanford University. Recuperat de https://dschool.stanford.edu/resources/ design-thinking-bootleg

6. Doble diamant, recuperat de https://www.designcouncil.org.uk/

Figura 31 - Esquema de les fases de la metodologia de recerca. Elaboració pròpia

Figura 32 - Esquema de les fases de la metodologia de recerca i les fites aconseguides a cada fase. Elaboració pròpia

Figura 33 - Esquema de les fases de la metodologia de recerca, resultat de cada fase, amb l'aplicació de les dimensions. Elaboració pròpia

Figura $34 \cdot$ Mind map de la distribució de les necessitats del projecte de disseny entre les cinc dimensions del sistema $\cdot$ Realitzat amb les eines del Manual Thinking. Elaboració pròpia

Figura $35 \cdot$ Fitxa dimensió Finalitat. Elaboració pròpia

Figura 36 · Fitxa dimensió Acció. Elaboració pròpia

Figura $37 \cdot$ Fitxa dimensió Persona. Elaboració pròpia

Figura $38 \cdot$ Fitxa dimensió Entorn. Elaboració pròpia

Figura 39 - Fitxa dimensió Artefacte. Elaboració pròpia

Figura $40 \cdot$ Pla de recerca. Elaboració pròpia

Figura $41 \cdot$ Pla d'acció inicial · Preparant la Fase Buscar. Elaboració pròpia

Figura 42 - Fitxa per a la preparació de l'entrevista. Elaboració pròpia 
Figura 43 - Fitxa tècnica pel resum de l'entrevista amb la informació més rellevant. Elaboració pròpia. Imatge: Girl face by Oksana Latysheva des de Noun Project @ Creative Commons

Figura $44 \cdot$ Fitxa per a la detecció de tendències on es pot encabir la hipòtesi de treball. Elaboració pròpia, inspirada en material de We Question Our Porject de la GovJam 2015

Figura 45 - Fitxa per a l'elaboració de l'usuari arquetip agrupat sota el concepte Persona. Basat en eines de Institute of Design School at Stanford (2009). Bootcamp bootleg. Stanford: Stanford University

Figura 46 - Mapa d'empatia per a ajudar en la configuració psicològica de l'usuari arquetip. Basat en l'esquema de Gibbons, S. (14 gener 2018). Empathy Mapping: The First Step in Design Thinking. [article web]. Recuperat de https://www.nngroup.com/articles/empathy-mapping/. Imatge: Girl face by Oksana Latysheva des de Noun Project @Creative Commons

Figura $47 \cdot$ Fitxa per a la localització de necessitats a través de les dimensions i per a l'elaboració d'insights. Elaboració pròpia

Figura $48 \cdot$ Fitxa per a la definició del repte de disseny. Elaboració pròpia

Figura 49 - Fitxa per a la selecció d'idees que pot ajudar a escollir el repte de disseny més adequat. Basat en eines de Institute of Design School at Stanford (2009). Bootcamp bootleg. Stanford: Stanford University

Figura 50 - Fitxa per a l'elaboració del brief. Primera pàgina amb el repte de 287 disseny i qüestions genèriques. Elaboració pròpia

Figura 51 - Fitxa per a l'elaboració del brief. Segona pàgina amb les premisses 288 prioritzades i organitzades per dimensions. Elaboració pròpia

Figura 52 Esquema general de la metodologia. Elaboració pròpia

Figura 53 - Resum presentació de l'exercici a l'aula pels alumnes de Disseny 301 per l'Entorn i l'Hàbitat, curs 2019/2020, del grau en Enginyeria en Disseny Industrial i Desenvolupament de Productes de la Universitat Jaume I de Castelló de la Plana. Elaboració pròpia

Figura 54 - Esquema del plantejament de l'exercici desenvolupat a l'aula de Disseny per l'Entorn i l'Hàbitat, curs 2019/2020, del grau en Enginyeria en Disseny Industrial i Desenvolupament de Productes de la Universitat Jaume I de Castelló de la Plana. Elaboració pròpia 
Figura 55 - Esquema tradicional del doble diamant del Design Council amb el garbuix de Sanders i Stapper (2008) per exemplificar el recorregut de l'exercici. Muntatge propi a partir de:

1. Doble Diamant del Design Council. Recuperat de https://abeldb.com/en/ reports/design-process-the-double-diamond/

2. Sanders, E. i Stappers, P.J. (2008). Co-creation and the new Landscapes of Design a CoDesign. [Prepint per CoDesign, Taylor \& Francis]. Recuperat a https://naaee.org/sites/default/files/preprintdraft.pdf

Figures 56 i 57 - Alumnes de Disseny per a l'Entorn i l'Hàbitat, curs 2019/2020, del grau en Enginyeria en Disseny Industrial i Desenvolupament de Productes de la Universitat Jaume I de Castelló de la Plana a la cantina desenvolupant l'observació. Fotos pròpies

Figura 58 - Mapa d'accions d'usuari elaborat per l'equip número 3. Exercici de classe a Disseny per a l'Entorn i l'Hàbitat, curs 2019/2020, del grau en Enginyeria en Disseny Industrial i Desenvolupament de Productes de la Universitat Jaume I de Castelló de la Plana

Figura 59 - Fitxa per a la definició d'una hipòtesi de treball. Elaboració pròpia

Figura 60 - Fitxa per a la preparació de les entrevistes. Elaboració pròpia

Figura 61 - Alumnes de Disseny per a l'Entorn i l'Hàbitat, curs 2019/2020, del grau en Enginyeria en Disseny Industrial i Desenvolupament de Productes de la Universitat Jaume I de Castelló de la Plana, treballant per equips dins l'aula. Foto pròpia

Figura 62 - Fitxa per a la definició del repte de disseny. Elaboració pròpia

Figura 63 - Fitxa per a la definició del futur desitjat. Elaboració pròpi

Figura 64 - Alumnes Disseny per a l'Entorn i l'Hàbitat, curs 2019/2020, del grau en Enginyeria en Disseny Industrial i Desenvolupament de Productes de la Universitat Jaume I de Castelló de la Plana presentant el futur desitjat. Fotos pròpies

Figura 65 - Plafó amb la proposta de l'equip 1. Elaborat per l'equip 1 a Disseny per a l'Entorn i l'Hàbitat, curs 2019/2020, del grau en Enginyeria en Disseny Industrial i Desenvolupament de Productes de la Universitat Jaume I de Castelló de la Plana

Figura 66 · Plafó amb la proposta de l'equip 5. Elaborat per l'equip 5 a Disseny per a l'Entorn i l'Hàbitat, curs 2019/2020, del grau en Enginyeria en Disseny Industrial i Desenvolupament de Productes de la Universitat Jaume I de Castelló de la Plana 
Figura 67 - Recerca i establiment de característiques a través de les cinc dimensions d'un rentamans públic. Elaborat per l'alumne Jan Isern a Ergonomia de $3 r$ curs del Grau Universitari en Disseny, menció de Producte, a l'Escola Superior de Disseny ESDi, Sabadell, el curs 2019/2020

Figura 68 - Part genèrica del brief de l'equip 2. Elaborat per l'equip 2 a Disseny per a Entorn i l'Hàbitat, curs 2019/2020, del grau en Enginyeria en Disseny Industrial i Desenvolupament de Productes de la Universitat Jaume I de Castelló de la Plana

Figura 69 - Part de les premisses del brief de l'equip 2. Elaborat per l'equip 2 a Disseny per a Entorn i l'Hàbitat, curs 2019/2020, del grau en Enginyeria en Disseny Industrial i Desenvolupament de Productes de la Universitat Jaume I de Castelló de la Plana

Figura 70 - Part genèrica del brief de l'equip 5. Elaborat per l'equip 5 a Disseny per a Entorn i l'Hàbitat, curs 2019/2020, del grau en Enginyeria en Disseny Industrial i Desenvolupament de Productes de la Universitat Jaume I de Castelló de la Plana

Figura $71 \cdot$ Part de les premisses del brief de l'equip 5. Elaborat per l'equip 5 a Disseny per a Entorn i l'Hàbitat, curs 2019/2020, del grau en Enginyeria en Disseny Industrial i Desenvolupament de Productes de la Universitat Jaume I de Castelló de la Plana

Figura 72 - Part genèrica del brief de l'equip 3. Elaborat per l'equip 3 a Disseny per a Entorn i l'Hàbitat, curs 2019/2020, del grau en Enginyeria en Disseny Industrial i Desenvolupament de Productes de la Universitat Jaume I de Castelló de la Plana

Figura 73 - Part de les premisses del brief de l'equip 3. Elaborat per l'equip 3 a

Disseny per a Entorn i l'Hàbitat, curs 2019/2020, del grau en Enginyeria en Disseny Industrial i Desenvolupament de Productes de la Universitat Jaume I de Castelló de la Plana 